The Status and Distribution of Birds in Missouri

By

Mark B. Robbins

University of Kansas Biodiversity Institute, Lawrence, Kansas 


\title{
The Status and Distribution of Birds in Missouri
}

\author{
By \\ Mark B. Robbins \\ University of Kansas Biodiversity Institute, \\ Lawrence, Kansas
}




\section{(1) $(1) \Theta$}

This work is licensed under a Creative Commons Attribution-NonCommercial-NoDerivatives 4.0 International (CC BY-NC-ND 4.0).

\section{You are free to:}

- Share - copy and redistribute the material in any medium or format

- Adapt - remix, transform, and build upon the material

\section{Under the following terms:}

- Attribution - You must give appropriate credit, provide a link to the license, and indicate if changes were made. You may do so in any reasonable manner, but not in any way that suggests the licensor endorses you or your use.

- NonCommercial - You may not use the material for commercial purposes.

- NoDerivatives - If you remix, transform, or build upon the material, you may not distribute the modified material.

No additional restrictions - You may not apply legal terms or technological measures that legally restrict others from doing anything the license permits.

The licensor cannot revoke these freedoms as long as you follow the license terms.

3rd party content belongs to the original sources as indicated and is not governed by the $\mathrm{CC}$ license. Their terms of use may vary. 
To Kathy 



\section{Contents}

vii List of Figures

viii List of Tables

1 Introduction

1 History of Missouri Ornithology

3 Missouri Physical Environment

4 Natural Communities of Missouri

9 Summary of the State List

10 Format and Relative Abundance Definitions for Species Accounts

\section{Species Accounts (orders, families)}

Anseriformes

21 Anatidae (swans, geese, and ducks)

Galliformes

48 Odontophoridae (New World quail)

48 Phasianidae (pheasant, grouse, prairie-chickens, turkey)

Phoenicopteriformes

52 Phoenicopteridae (flamingo)

Podicipediformes

52 Podicipedidae (grebes)

Columbiformes

56 Columbidae (pigeons, doves)

Cuculiformes

59 Cuculidae (cuckoos, roadrunner, ani)

Caprimulgiformes

61 Caprimulgidae (nighthawk, nightjars)

Apodiformes

64 Apodidae (swifts)

65 Trochilidae (hummingbirds)

Gruiformes

69 Rallidae (rails, gallinules, coot)

74 Gruidae (cranes)

Charadriiformes

77 Recurvirostridae (stilt, avocet)

78 Charadriidae (plovers)

82 Scolopacidae (curlews, godwits, dowitchers, woodcock, snipe, sandpipers, and phalaropes)

103 Stercorariidae (jaegers)

105 Lariidae (gulls, terns, skimmer)

Gaviiformes

121 Gaviidae (loons) 


\section{Procellariiformes}

123 Hydrobatidae (storm-petrel)

\section{Ciconiiformes}

123 Ciconiidae (stork)

Suliformes

124 Fregatidae (frigatebird)

125 Phalacrocoracidae (cormorants)

126 Anhingidae (anhinga)

Pelecaniformes

127 Pelecanidae (pelicans)

128 Ardeidae (herons)

136 Threskiornithidae (ibises,spoonbill)

Cathartiformes

139 Cathartidae (New World vultures)

Accipitriformes

141 Pandionidae (Osprey)

142 Accipitridae (kites, eagles, hawks)

Strigiformes

156 Tytonidae (Barn Owl)

156 Strigidae (owls)

Coraciiformes

161 Alcedinidae (kingfisher)

Piciformes

162 Picidae (woodpeckers)

Falconiformes

169 Falconidae (falcons)

Psittaciformes

174 Psittacidae (parrot)

Passeriformes

175 Tyrannidae (flycatchers)

186 Laniidae (shrikes)

189 Vireonidae (vireos)

193 Corvidae (jays, nutcracker, magpie, crows, raven)

198 Alaudidae (lark)

198 Hirundinidae (swallows)

203 Paridae (chickadees, titmouse)

205 Sittidae (nuthatches)

207 Certhiidae (creeper)

208 Troglodytidae (wrens)

213 Polioptilidae (gnatcatcher)

214 Regulidae (kinglets)

215 Turdidae (bluebirds, solitaire, thrushes)

222 Mimidae (catbird, thrashers, mockingbird)

224 Sturnidae (starling) 
225 Bombycillidae (waxwings)

226 Passeridae (Old World sparrows)

227 Motacillidae (pipits)

229 Fringillidae (fringillid finches)

238 Calcariidae (longspurs)

240 Passerellidae (towhees, sparrows)

260 Icteriidae (Yellow-breasted Chat)

261 Icteridae (blackbirds, meadowlarks, orioles, cowbirds, grackles)

273 Parulidae (wood-warblers)

302 Cardinalidae (Piranga, cardinal, grosbeaks, buntings, Dickcissel)

\section{Acknowledgments}

\section{Literature Cited}

\section{Figures (maps and photographs)}

1. Divisions of the terrestrial Natural Communities, 4

2. Vegetation at the time of European settlement, 5

3. Current forest cover in Missouri, 6

4. Section of rivers surveyed for riparian-inhabiting species, 15

5. Smew, 45

6. Broad-tailed Hummingbird, 67

7. Sandhill Cranes, 75

8. Whooping Cranes, 76

9. Wilson's Plover, 80

10. Dunlin flock, 90

11. Hybrid sandpiper, 93

12. Parasitic Jaeger, 104

13. Ivory Gull, 106

14. Ross's Gull, 109

15. Mew Gull, 111

16. Iceland Gull, 114

17. Black Skimmer, 120

18. White Ibis flock, 137

19. Swainson's Hawk, 152

20. Aberrant Red-bellied Woodpecker, 164

21. Aberrant Red-bellied Woodpecker, 165

22. Crested Caracara, 170

23. Gyrfalcon, 172

24. Gray Kingbird drawing, 185

25. Fork-tailed Flycatcher, 187

26. Gray-headed Junco, 260

27. Hooded Oriole, 267

28. Western Tanager, 305 


\section{Tables}

Table 1. Breeding species that have increased in abundance and distribution during the past 25 years, 12

Table 2. Breeding species that have decreased in abundance and distribution during the past 25 years, 13

Table 3. Migrant and winter species that have increased in abundance and/or distribution during the past 25 years, 14

Table 4. Migrant and winter species that have declined in the past 25 years, 14

Table 5. Target species for riparian surveys, 16

Table 6. Riparian data. River along with reference to data in eBird checklists, 17 
Primarily as a result of climate change, there have been striking changes in the status and distribution of birds in Missouri since the last treatise on this subject (Robbins and Easterla 1992). This has been particularly evident in those species that are now wintering in larger numbers and farther north in the state (Table 3). Many migrants that winter in the southern United States and northern Central America are now arriving earlier in spring and lingering later in fall (Brinkley 2016; see Species Accounts). In addition to the considerable change in the status and distribution of birds in the state over this short time span, there has been an extraordinary upheaval in avian nomenclature and taxonomy as a result of genetic data that offer new insights into avian relationships (Chesser et al. 2017). Thus many scientific names and the linear arrangement of species have dramatically changed since Robbins and Easterla (1992). The advent of eBird (ebird.org) has revolutionized how observations are reported, stored, retrieved, and documented (Iliff et al. 2011). This has resulted in a massive increase in observations that are helping document rapid changes in the avifauna (see comments under the eBird section below).

Finally, because of electronic publishing and open access, the format of such works as this revision has greatly facilitated immediate access to information. Now observers can access this information digitally on their mobile devices and no longer have to carry a book or wait until getting home from the field to ascertain the significance of an observation. Moreover, revision updates can be done in a more-timely manner at relatively little cost, particularly with the inclusion of more colored photographs, reducing the negative impact of a paper-based product. The format of this work follows Robbins and Easterla (1992), with data inclusion through mid-January 2018. Please send comments and corrections to me at the following email address: mbrobbins@ku.edu.

\section{History of Missouri Ornithology}

Historical documentation of Missouri's birdlife began during the late eighteenth century and the early nineteenth century. The earliest accounts typically mentioned only game and conspicuous species and were confined to the main conduits through the state, the Missouri and Mississippi rivers. Thomas Say was the first trained ornithologist to visit the state when in 1819 he accompanied the Long Expedition, which traveled up the Mississippi River from the mouth of the Ohio River and then up the Missouri River. While stationed at Bellefontaine, St. Louis, 21-23 June 1819, Say collected the first Lark Sparrow known to science (Say 1823). While in the state, Say also made several references to Common Raven, a species that has been extirpated from Missouri since the early 1900s.

In the spring of 1834, Thomas Nuttall and John Townsend traveled upstream on the Missouri River to the Kansas City area. On 28 April 1834, as they traveled overland from Independence to Westport in Jackson County, they collected a sparrow that was eventually described as Harris's Sparrow (Harris 1919a). At nearly the same time (spring 1834), John James Audubon, Edward Harris, and John Bell passed through the state via the Missouri River, and it was then that a third and final species was described to science from specimens collected in Missouri. While in the vicinity of St. Joseph, Buchanan County, Bell collected a new vireo on 6 May 1834 that Audubon named in his honor, the Bell's Vireo. 
The first bird list for the state was produced by Hoy (1865) after exploration of western Missouri in 1854, under the auspices of the Smithsonian Institution. Unfortunately, the whereabouts of the material collected on that expedition remains a mystery, as it apparently was never catalogued at the Smithsonian. In 1874, W.E.D. Scott spent the spring and early summer in the vicinity of Warrensburg, Johnson County (Scott 1897).

The title of father of Missouri ornithology should certainly be bestowed upon Otto Widmann. Widmann arrived in St. Louis in 1867 but was preoccupied with business until early 1875 , when he began recording bird observations. Over the next half century he made detailed observations of the state's avifauna. One notable achievement of his was the discovery and description of the nest and eggs of the now-extinct Bachman's Warbler (Vermivora bachmanii) from along the St. Francis River in the "bootheel" of Missouri (Widmann 1897). By 1902 he had nearly completed a book on the state's birds, but, while he was away in Germany, a fire destroyed the manuscript and all his notes! Fortunately, he rewrote the manuscript, which remains indispensable to our knowledge of the status and distribution of birds in Missouri during that period (Widmann 1907). In the same year that Widmann's treatise was published, Edward Woodruff spent the spring of 1907 in the shortleaf pine (Pinus echinata) region of the state in Shannon and Carter counties (Woodruff 1907, 1908). The timing of Woodruff's visit was critical, as within a few short years the entire region was deforested. Woodruff's specimens are deposited at the American Museum of Natural History, New York.

The Audubon Society of Missouri (ASM) was formed in 1901 by thirteen people, but shortly thereafter came a hiatus in meetings and business. The organization resumed in 1933 and has been continuously active ever since. The society's publication, The Bluebird, is the primary journal in which status and distribution information on the state's birds is published. Observations began to be summarized in seasonal surveys in 1962. Observations for the St. Louis area have mostly appeared for nearly a hundred years in the Webster Groves Nature Study Society's Nature Notes.

Another landmark publication was that of Harry Harris (1919b), who summarized records for the Kansas City area, and an update for that region was Rising et al.'s (1978) Birds of the Kansas City Area. Bennitt's (1932) Check-list of the Birds of Missouri was a compilation that was primarily based on Widmann's (1907) and Harris's (1919b) works, but included some new information. Unfortunately, many of the new observations that were included are highly dubious, and many of the subspecific determinations are suspect or are based on taxa that are no longer recognized (see comments in Comfort 1972, Robbins and Easterla 1992). Summaries for the St. Louis area included Wilhelm (1958) and Anderson and Bauer (1968). The Webster Groves Nature Study Society's (1995) publication Birds of the St. Louis area, where and when to find them provided an update on those accounts and included a more critical evaluation of records. Contributions of individual observers from the 1930s through 1991 were encapsulated in Robbins and Easterla, Birds of Missouri (1992), which was the first modern comprehensive summation of Missouri's avifauna. Further clarifying the distribution of the breeding component of the avifauna from 1986 through 1992 was the publication of the Missouri Breeding Bird Atlas (Jacobs and Wilson 1997). 
The Missouri Bird Records Committee (MBRC), under the auspices of the Audubon Society of Missouri, was established in October 1987 and charged with evaluating and archiving all unusual observations. The Committee's decisions, with basic data about each record, have been published annually beginning in 1989; these are accessible in the March issue of The Bluebird and are archived on the Audubon Society of Missouri's web site, www.mobirds.org. The official state list, maintained by the MBRC, can also be accessed on that website.

\section{Missouri Physical Environment}

\section{Relief}

Compared to the Appalachian and Rocky Mountains, Missouri has relatively little relief. The lowest point, 250 feet $(76 \mathrm{~m})$ above sea level, is in Dunklin County in the region of the state that is often referred to as the "bootheel." In contrast, the highest point is in the east-central Ozarks, on Taum Sauk Mountain, Iron County, where the elevation reaches 1,772 feet $(537 \mathrm{~m})$. Collier (1955) and Rafferty (1982) graphically presented the topography of the state. Via Google Earth, satellite imagery now provides extraordinary detail of the state's relief and vegetation.

\section{Climate}

Due to Missouri's location in the center of the country, multiple climatic factors affect precipitation and temperature. Warm, moist air from the Gulf of Mexico, cold, dry air from the Arctic, and warm, dry air from the west all influence the state's climate. During spring and summer, about two-thirds of the state's precipitation arrives via the Gulf air mass. There is a gradient in rainfall in Missouri from the humid, warm southeastern corner ("bootheel") to the drier northwestern corner. Annually, the southeast receives about 50 inches $(125 \mathrm{~cm})$, whereas the northwest receives only about 35 inches $(89 \mathrm{~cm})$. This gradient is most pronounced during the winter when the southeast averages about 12 inches $(30 \mathrm{~cm})$ and the northwest only 3 inches $(7 \mathrm{~cm})$. In summer the rainfall gradient is reversed with the northwest averaging about 4 inches $(10 \mathrm{~cm})$ more annually than the southeast.

Differences in temperature are roughly on the same order as precipitation. On average the date of the first killing frost is in mid- to late October in the northern tier of counties, but not until a month later in the southeast. In spring, along the Iowa border, the average last killing freeze occurs in the third week of April, versus about the third week of March in the southeast. During January the average daily maximum and minimum temperatures in the north are $40^{\circ} \mathrm{F}$ and $16^{\circ} \mathrm{F}$, respectively, compared to $48^{\circ}$ and $28^{\circ} \mathrm{F}$, respectively in the southeastern corner. Differences between these two areas are less dramatic during the warmest month of the year, July, when the daily average maximum and minimum for the extreme north are $90^{\circ} \mathrm{F}$ and $65^{\circ} \mathrm{F}$, respectively, compared to $92^{\circ} \mathrm{F}$ and $71^{\circ} \mathrm{F}$ for the southeastern part of the bootheel. 


\section{Natural Communities of Missouri}

For depicting bird distribution in Missouri, six divisions of the state's natural communities were adopted from Thom and Wilson (1980). These divisions (fig. 1), which were beautifully illuminated with photographs by Nelson (2005), are described below. Although these natural divisions have been relabeled and further dissected (Nigh and Schroeder 2002), avian distribution is adequately depicted using the Thom and Wilson (1980) convention. It should be underscored that these faunal communities were based on the natural vegetation that existed at the time of European settlement (fig. 2). The dramatic influence of humans on these communities preceded the arrival

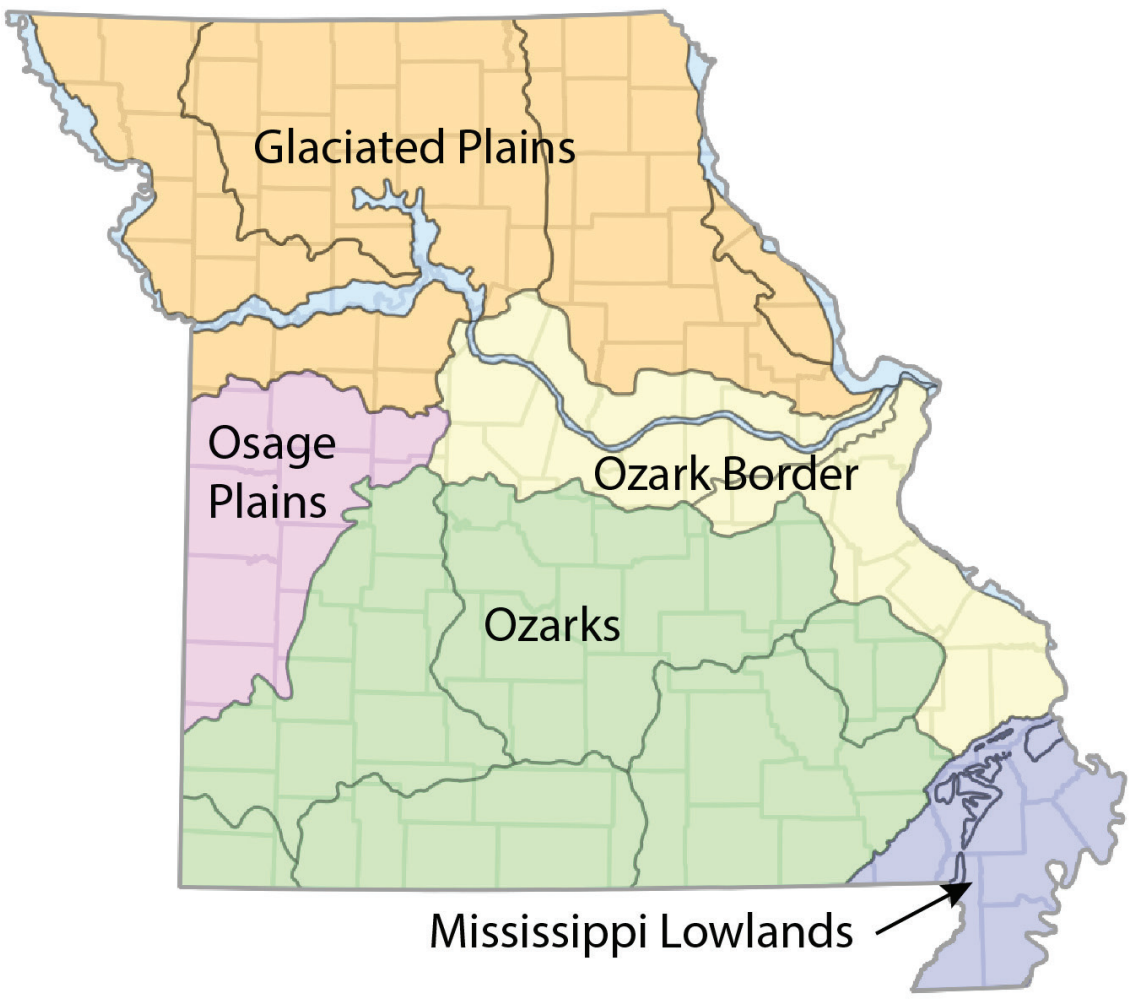

Fig. 1. Divisions of the terrestrial Natural Communities. Modified from Thom and Wilson (1980).

of Europeans by a minimum of 14,000 years, and thus both the fauna and the flora were already heavily impacted at the time of European arrival. For example, it is now widely appreciated that humans who had been on the landscape for thousands of years had greatly modified the environment with fire (Stewart 2002). When Europeans arrived, about 70 percent of the state was covered in forest with the remaining 30 percent mostly in tallgrass prairie (fig. 2); however, much of the state was a mixture of prairie, 


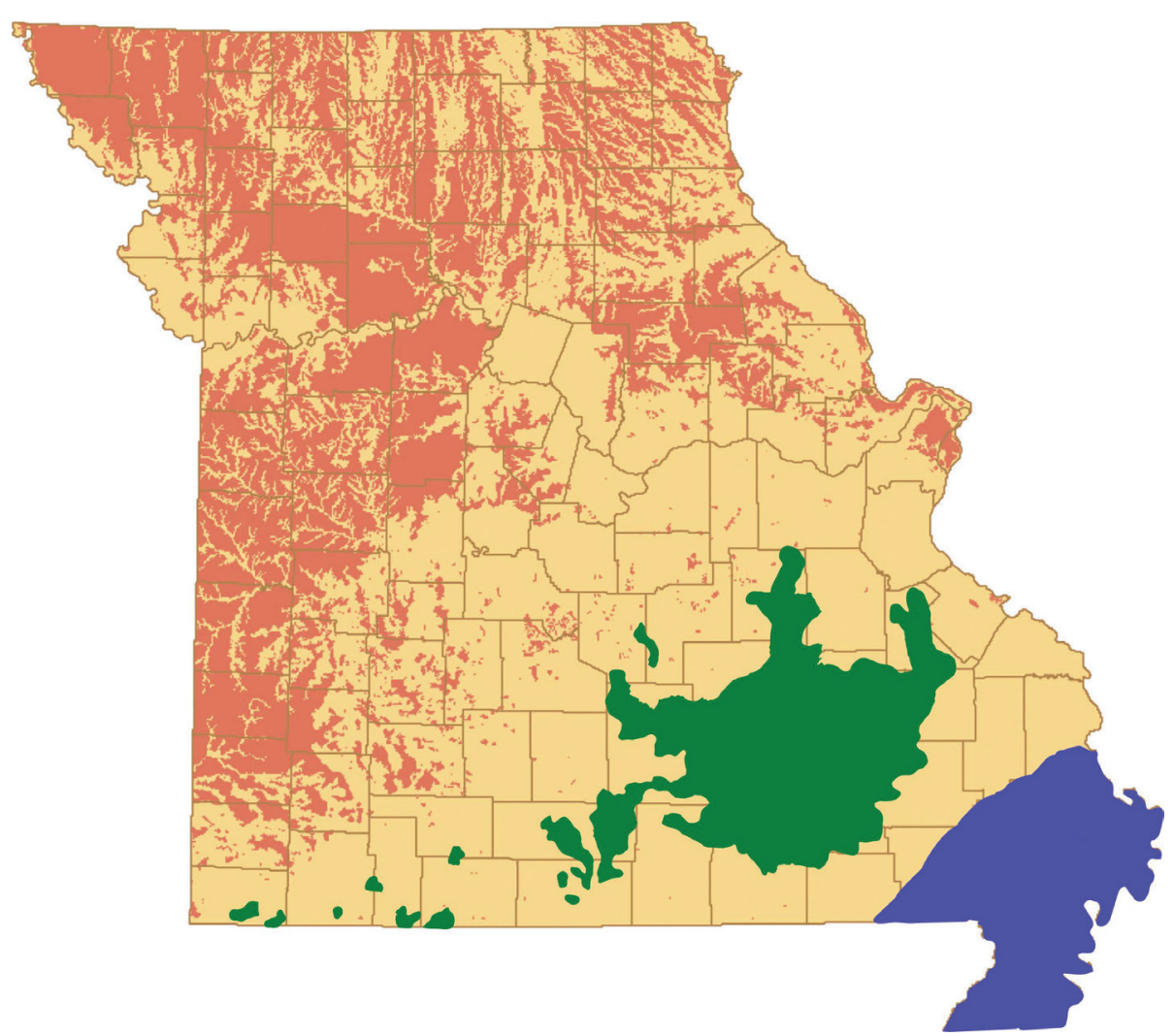

Fig. 2. Vegetation at the time of European settlement. Prairie (reddish brown), oak-hickory dominated forest ( $\tan$ ), shortleaf pine (green), and swamp, bottomland forest (blue). Modified from Schroeder (1981), Liming (1946), and Thom and Wilson (1980), respectively.

savanna, woodland, and forest (Nigh and Schroeder 2002). Most of Missouri's forest was removed between 1890 and 1920, with an estimated 50 percent of the original forest left by 1937 (Mayes 1937). At present, about 30 percent of the state is covered with regenerated forest (fig. 3). Of the original estimated 14 to 15 million acres of tallgrass prairie, less than 90,000 acres remain and are highly fragmented. North of the Missouri River it was estimated that 10,400 square miles of tallgrass prairie was present at the time of European arrival. Now only a few small, remnant patches remain there. Most of the remaining tallgrass prairie is in the Osage Plains, where it is highly dissected, with the largest patches less than 2,500 acres.

Glaciated Plains: This division covers roughly the northern third of the state. The gently rolling hills that characterize this entire zone were formed during the Nebraskan and Kansan Glacial periods (between ca. 1,800,000 and 600,000 years ago) of the Pleistocene epoch. This region is dissected by narrow river drainages that flow mostly north to south in the western and central sections, whereas drainage in roughly the eastern third 


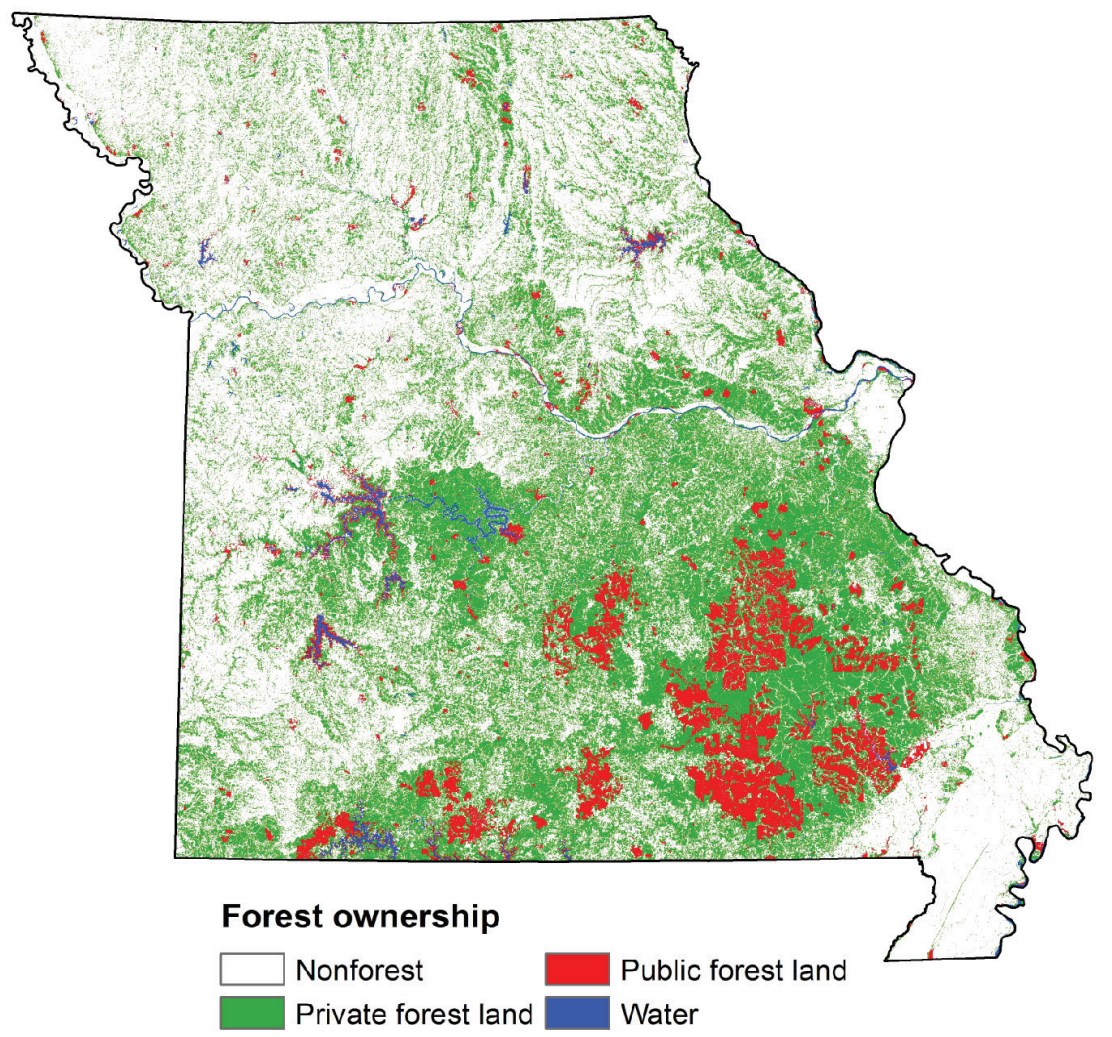

Fig. 3. Current forest cover in Missouri, based on National Land Cover Database 2011 (Homer et al. 2015).

is primarily to the southeast into the Mississippi River floodplain. The Grand and Chariton rivers, both channelized, are the two major tributaries to the Missouri and Mississippi rivers in this region. Soils are mostly composed of loess, glacial till, and alluvium.

The tallgrass prairie dominated the European presettlement landscape of the Glaciated Plains, with over half of the state's original 18,500 to 23,000 square miles (an estimated 15 million acres) of prairie present in this region (Schroeder 1981). Today, virtually all the prairie in the Glaciated Plains has been converted to agriculture (Google Earth), or, if still in grassland, it is now planted with non-native fescue. During the past two decades even non-native grassland/pasture has been planted in corn or soybeans. Because of the loss of Bison and fire suppression, succession has resulted in more woodland present now than at presettlement (Rafferty 1982).

Within this natural community, there is a gradual cline in increased rainfall from the west to east, as reflected in the composition of the avifauna. The northwestern corner of this region receives less precipitation than any other section of the state, and it is there where Western Meadowlark primarily breeds and where western Great Plains spe- 
cies, such as Burrowing Owl and Lark Bunting, have vagrantly bred. In general, as one moves eastward across this zone, open country birds decrease whereas woodland species increase. In addition to Western Meadowlark, the following species are primarily restricted in this region either year-round or during the summer: Ring-necked Pheasant, Vesper Sparrow, Rose-breasted Grosbeak, and Bobolink. Several other species that are widespread during the summer in Missouri reach their greatest abundance in this region: Red-headed Woodpecker, Northern Flicker, House Wren, American Robin, Gray Catbird, Brown Thrasher, and American Goldfinch. Because of the near total loss of prairie in this division, many prairie-inhabiting species that were once abundant are now present in only a small fraction of their former numbers - e.g., Upland Sandpiper, Grasshopper and Henslow's sparrows - or have been extirpated, e.g., Greater Prairie-Chicken.

Osage Plains: The flora and fauna of the Osage Plains region are very similar to those of the Glaciated Plains, but because this region was not glaciated it is comparatively flat. In presettlement Missouri, over 70 percent of this division was covered in tallgrass prairie (Schroeder 1981). The vast majority of the prairie has been plowed, although the estimated 70,000 acres of prairie remaining in the state, all of which is highly fragmented, is found in this natural division. Of the fewer than 60,000 acres of high quality prairie left in the state, most of it is in this region. The eastern and southern part of this natural division interdigitates with the Ozarks, and there is now more forest in this region for the same reasons mentioned for the Glaciated Plains.

The following species reach their greatest abundance in this natural division: Northern Harrier, Red-tailed Hawk, Scissor-tailed Flycatcher, Loggerhead Shrike, Bell's Vireo, Northern Mockingbird, Grasshopper and Henslow's sparrows, Dickcissel, and Eastern Meadowlark.

Ozark Border: As the name implies, this community represents a transition in relief and biota from the adjoining natural divisions (fig. 1). The area covers about 13 percent of the state. The dominant vegetation is upland oak-hickory forest. Prior to settlement, less than 10 percent of this region was prairie, mostly in the northern and western sections. No avian species are restricted to this division, and because of the large-scale opening of much of the Ozarks, differences in species' abundance between this and the Ozark division are likely minimal.

Ozarks: This is a high and deeply dissected plateau that is the eroded remnants of an ancient mountain range. As a result, the topography is generally rugged and relatively dramatic. Like most of the area south of the Missouri River, this region was never glaciated. The present second-growth Ozark forest is fairly uniform in maturity, since the entire region was logged in a relatively short period, between the late 1800s and early 1900s. In the European presettlement state, the western portion would have been interspersed with tallgrass prairie and open savannah-like woodland (largely because of anthropogenic burning). As one would expect, forest-inhabiting species reach their greatest abundance in this region of the state, e.g., Red-bellied and Pileated woodpeckers, Eastern Wood-Pewee, Red-eyed and Yellow-throated vireos, Tufted Titmouse, White-breasted Nuthatch, Wood Thrush, several warbler species, and both Pirangas. 
There are two distinct subdivisions within this physiogeographic zone. The first is dominated by shortleaf pine (Pinus echinata), primarily found in the southeastern portion of the Ozarks (Fig. 2; Liming 1946; Kucera 1961). Like the rest of the Ozark forest, the pinewoods were almost entirely logged in the late 1800's and early 1900's, and due to fire suppression most of the remaining stands now have a dense deciduous understory. The last colony of Red-cockaded Woodpeckers disappeared a few months after the last sizable stand of pine was cut in 1946 near Round Spring, Shannon County. As mentioned above in the History of Missouri Ornithology section, it is fortunate that E. Woodruff $(1907,1908)$ spent the spring of 1907 in the core area as it was being logged. His observations document the loss of this unique avifauna: the woodpecker, Brown-headed Nuthatch, and Bachman's Sparrow. Only the Pine Warbler still inhabits the remnants of this zone, but almost certainly it is present in much reduced numbers given the extent of degradation and loss of pine.

The other subdivision of note from an ornithological perspective is typically referred to as the White River Cedar Glades (Kucera 1961; reproduced in Robbins and Easterla 1992) located in the southwestern section of the Ozarks along the Arkansas border. Extensive limestone glades once characterized this subdivision, but like glades across the entire Ozark plateau, many have now disappeared as a result of a reduction in fire that enabled vegetation succession. An herbaceous flora with scattered eastern red cedar (Juniperus virginianus) dominates the thin-soiled glades. Whereas no bird species is unique to this subdivision, the following likely reach their highest densities there: Greater Roadrunner, Prairie Warbler, Field Sparrow, Blue Grosbeak, and Painted Bunting. It is possible that Bewick's Wren was most common in this habitat prior to European settlement.

Mississippi Lowlands: This natural division comprises about 5 percent of the state and has been greatly modified with nearly 95 percent of the forest converted to agriculture (Fig. 1; Nigh and Schoeder 2002). It once was covered with cypress/tupelo-dominated swamps with a mixture of deciduous forest on higher ground, and savanna/ prairie was present on sandy soils. Prior to the past quarter of a century, the primary crops were cotton and soybeans, but today a relatively large percentage of acreage is planted in rice. This region averages the highest precipitation and temperatures in Missouri. The swampy, tall forests were once home of the now-extinct Ivory-billed Woodpecker, as well as species that formerly bred in the state but are now extirpated as breeders, e.g., Anhinga and Swallow-tailed Kite. It was in dense understory and edge of swampy woodland and forest that the extinct Bachman's Warbler once bred. Many swamp-dwelling species that still breed elsewhere in the state were once most abundant in this region, such as the Prothonotary, Swainson's, Cerulean, Northern Parula, and Yellow-throated warblers. Today, Mississippi Kite, Black-necked Stilt, and Fish Crow are more common and widespread here than in any other region of the state. Species that were formerly local in the region when it was forested now obtain their highest abundances in the Mississippi Lowlands: Killdeer, American Kestrel, Horned Lark, Common Yellowthroat, Red-winged Blackbird, Common Grackle, and the introduced European Starling and House Sparrow. 
Missouri and Mississippi River Floodplain: Both rivers and their floodplain vegetation have been greatly modified since the arrival of Europeans. Along the Missouri, especially in the northwestern corner of the state in Atchison and Holt counties, wet prairie was the dominant vegetation, whereas the lower part of the river would have been heavily forested (Schroeder 1981). Because of the steep topography on the Missouri side of the Mississippi River from the Iowa border south to Cape Girardeau, the banks and the bluffs there too would have been heavily forested, not unlike today. The flat, broad floodplain below Cape Girardeau would have been dominated by swamps and cypress-tupelo forest that are now almost entirely gone.

Both rivers have been heavily leveed and channelized, and the upper Mississippi River from St. Louis north has several locks and dams, all of which have greatly affected the width and flow of these two great rivers. As a result of these anthropogenic processes, it has been estimated that the Missouri River lost 50 percent of its original surface area between 1897 and 1972, with greater than 90 percent loss of islands between 1879 and 1954 (Funk and Robinson 1974). Thus a multitude of riparian species has been negatively affected. Where forest remains, such species as Warbling Vireo, American Redstart, and Yellow Warbler reach their greatest densities in the state. The only region in the state where the threatened Least Tern now breeds is along the ephemeral large sandbars in the lower Mississippi River south of Cape Girardeau. It is likely that the threatened Piping Plover once bred on sandbars in the Missouri River from the Kansas City area to the northern border of the state.

\section{Summary of the state list}

A total of 423 species have been documented for the state during historical times, with four of these (Greater Prairie-Chicken, Red-cockaded Woodpecker, Common Raven, Brown-headed Nuthatch) now extirpated and another five that are extinct (Eskimo Curlew, Passenger Pigeon, Ivory-billed Woodpecker, Carolina Parakeet, and Bachman's Warbler). Another twelve species are listed as provisional; that is, more evidence is needed for full acceptance. Two species, Purple Sandpiper and skua sp., formerly treated as hypothetical (i.e., provisional) by Widmann (1907), Harris (1919b), and Robbins and Easterla (1992; see comments therein), were removed, as the Missouri Bird Records Committee concluded that the evidence was too sketchy for inclusion even on the provisional list (Rowe 2009).

A total of 197 species have been recorded breeding in the state since European settlement. Four of these are now extinct and another ten species are extirpated as breeders in Missouri. Since Robbins and Easterla's (1992) compilation, eight species have been documented breeding for the first time in the state. Between 160 and 165 species likely breed annually in the state. Species totals for the top five natural groups (family level) that breed annually or almost annually in the state are as follows:

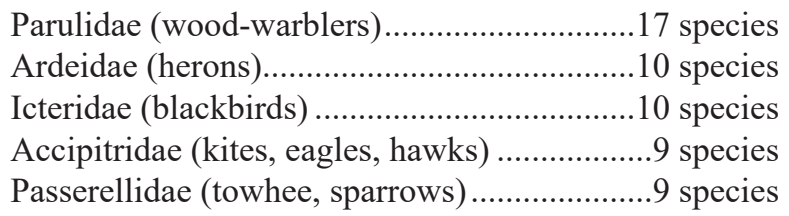


Species documented breeding for the first time in Missouri since Robbins and Easterla (1992), excluding reintroduced populations:

Black-bellied Whistling-Duck

Fulvous Whistling-Duck

Ruddy Duck

Sandhill Crane

Eurasian Collared-Dove

Inca Dove

White-winged Dove

Black-throated Green Warbler

\section{Format and Relative Abundance Definitions for the Species Accounts}

The order and family names precede all groups. Each species account begins with the English and scientific names. Taxonomy and nomenclature follow the North American Classification Committee (http://www.americanornithology.org/content/ north-american-classification-committee). Below the species' name is a status statement, using the criteria below, followed by the level of documentation and a brief description of the species' habitat. Finally, where appropriate, details of a species' status and distribution are presented by season. If the migration status is the same as another season, summer or winter, only the breeding or wintering status is provided. For example, Eastern Wood-Pewee, a species that is common during migration and the breeding season, is given the status of common summer resident.

\section{Relative Abundance Criteria}

Common: Encountered daily in relatively large numbers, more than 10 individuals/ day in appropriate habitat. Examples: Northern Cardinal at all seasons; White-rumped Sandpiper only during spring migration.

Uncommon: Observed on most days in relatively low numbers, 1-10 individuals/day; occasionally seen in relatively large numbers. Example: Hairy Woodpecker.

Rare: More than 15 records total or during a season; infrequently recorded and usually found in small numbers. Examples: Whimbrel; White-rumped Sandpiper in fall.

Casual: 5-15 records total or during a season; sporadically reported. Examples: Bohemian Waxwing; Cinnamon Teal in fall.

Accidental: 1-4 records total or during a season; a vagrant. Examples: Golden-cheeked Warbler; American Redstart in winter.

Extirpated: Formerly occurred in the state and/or at a particular season, but no longer recorded. Examples: Red-cockaded Woodpecker; Swallow-tailed Kite as a breeder.

Extinct: Species no longer exists. Examples: Ivory-billed Woodpecker, Carolina Parakeet. 


\section{Documentation}

The following criteria are used to document a species' occurrence in the state. Where a specimen is extant, it takes precedence over all other categories of documentation. The Missouri Bird Records Committee (MBRC) was established in October 1987 and has reviewed the vast majority of unusual records since then. As mentioned above, an annual report is published in the March issue of the Audubon Society of Missouri's Bluebird.

Specimen: The earliest extant specimen with full data was given the highest priority when choosing a specimen for documentation. For specimen deposition, see abbreviations for institutions under Specimen Data.

Photograph: Published photograph(s) or one or more that are deposited in VIREO (a photographic, archival collection at the Academy of Natural Sciences at Drexel University, Philadelphia), the MBRC files, and/or in an eBird checklist. Photos mentioned in the seasonal component either appear in one of the following or were seen by the author: eBird, MBRC files, and/or the Bluebird.

Sight Record(s): For sight records only, acceptance to the official state list requires independently acceptable written descriptions from at least two independent parties.

Provisional: Records that lack any of the above three criteria but are deemed acceptable based on a single documentation are placed in the provisional category. Examples: Black-backed Woodpecker, Violet-green Swallow. This category is also used for species whose identification is not in doubt but their provenance is uncertain. This group includes Barnacle Goose, Mute Swan, and American Flamingo. In the species accounts, provisional species' names are enclosed in brackets.

\section{Habitat}

A brief statement of habitat follows the Documentation line. This statement provides the primary habitat(s) in which the species is found. If breeding or wintering habitat differs from that of migration, it is so stated.

\section{Seasonal Definitions}

The four seasons, beginning with spring and ending in winter, have been arbitrarily defined as follows:

Spring: 21 February through 31 May. The basis for the initiation of the period in February is that a broad spectrum of birds begin migration at that time through Missouri, e.g., waterfowl, shorebirds, longspurs, sparrows, blackbirds.

Summer: 1 June through 31 July. Dates follow the North American Birds Summer seasonal definition. A breeding species is termed a summer resident and a non-breeding species is classified as a summer visitant. Some species may be both, e.g., a rare summer visitant and a casual summer breeder.

Fall: 1 August through 13 December. Initiation date follows North American Birds Fall seasonal definition, but the arbitrary ending date of 13 December is used to coin- 
cide with National Audubon Society's CBC dates (see below). Many species observed in early to mid-December are late fall migrants.

Winter: 14 December through 20 February. The beginning of the winter period is based on the onset of the National Audubon Society's Christmas Bird Count period. The definition of resident vs. visitant is arbitrary. If a bird spends most of the winter it is considered a resident, otherwise it is considered a visitant. Moreover, this definition is imprecise for those low-density species where most individuals spend a short period vs. a few individuals that may spend the entire winter. For example, with Plegadis sp. (White-faced/Glossy ibis), most records are of birds that were present for only a short period, but there are now records of birds that spent the entire winter. In those instances, the following convention is used for indicating winter status: visitant/resident.

\section{Breeding Bird Survey Data}

The North American Breeding Bird Survey (BBS) data set was used as an indication of the relative abundance and population trends across the natural divisions of the state. These roadside counts, which involve making a total of 50 three-minute stops every half mile along a predetermined route, were initiated in Missouri in 1967 (https://www.pwrc.usgs.gov/bbs/). A total of 80 routes have been established in Missouri with at least a few routes in each physiographic region. Approximate locations of Missouri routes are viewable at http://www.pwrc.usgs.gov/bbs/RouteMap/Map.cfm.

There has been considerable variability in the number of times each route has been conducted as well as observers. Moreover, a number of routes have been reconfigured for various reasons.

Although a number of biases have long been acknowledged in the methodology, there still is considerable debate on how these data should be analyzed. Thus BBS population trends should be viewed with caution. Only those trends that are highly significant statistically are mentioned in species accounts and used for supporting inclusion in Tables 1-2.

Table 1. Breeding species that have increased in abundance and distribution during the past 25 years. See individual Species Accounts for details.

\begin{tabular}{|l|l|}
\hline Wild Turkey & Bald Eagle \\
\hline Eurasian Collared-Dove & Cooper's Hawk \\
\hline Sandhill Crane & Red-shouldered Hawk \\
\hline Black-necked Stilt & Pileated Woodpecker \\
\hline Double-crested Cormorant & Western Kingbird \\
\hline Great Blue Heron & Scissor-tailed Flycatcher \\
\hline Great Egret & Fish Crow \\
\hline Black Vulture & Eurasian Tree Sparrow \\
\hline Osprey & Chipping Sparrow \\
\hline Mississippi Kite & \\
\hline
\end{tabular}


Table 2. Breeding species that have decreased in abundance and/or distribution during the past 25 years. See individual Species Accounts for details.

\begin{tabular}{|l|l|}
\hline Northern Bobwhite & Horned Lark \\
\hline Ring-necked Pheasant & Bewick's Wren \\
\hline Greater Prairie-Chicken & House Sparrow \\
\hline Common Nighthawk & House Finch \\
\hline Eastern Whip-poor-will & Bachman's Sparrow \\
\hline Chimney Swift & Grasshopper Sparrow \\
\hline Upland Sandpiper & Song Sparrow \\
\hline Red-headed Woodpecker & Eastern Meadowlark \\
\hline Northern Flicker & Western Meadowlark \\
\hline Eastern Kingbird & Dickcissel \\
\hline Loggerhead Shrike & \\
\hline
\end{tabular}

\section{Breeding Bird Atlas}

As mentioned in the history section, the Missouri Breeding Bird Atlas (BBA) project was undertaken to assess the breeding distribution of birds in the state from 1986 through 1992 (Jacobs and Wilson 1997). That effort involved more than 400 volunteer birders who contributed more than 21,000 hours and provided a baseline for replication of this type of effort in the future.

\section{Christmas Bird Count Data}

This long-term data set was used to provide the backbone for the status and distribution of birds from 14 December to 5 January. Those dates correspond with the official National Audubon Society's Christmas Bird Count (CBC) period. Coverage across the state is sparse, with few counts in any one physiogeographic region. Current count locations can be accessed at: http://audubon.maps.arcgis.com/apps/View/index. html?appid=3dcefef 2 f4654a94960fc3c8d1cfcc6d

Several of the long-term counts are now conducted within or near metropolitan areas and thus have the greatest observer effort. As a result, those counts routinely record absolute high counts for many species, but not necessarily the highest numbers/effort. In order to reduce this bias, high counts for passerines and a few non-passerines (ones that typically do not congregate, such as raptors) are standardized by presenting results based on party hours. For example, the CBC high count for Red-shouldered Hawk on the 28 December 1996, Mingo count was 42 (0.6). That is, a total of 42 individuals were recorded during that $\mathrm{CBC}$ with 0.6 individuals/party hour or 6 individuals/10 party hours. Because waterfowl often congregate, especially at northern counts where often most water may be frozen, party hours are not expressed for that group of birds. 
Table 3. Migrant and winter species that have increased in abundance and/or distribution during the past 25 years. See individual Species Accounts for details.

\begin{tabular}{|l|l|}
\hline Black-bellied Whistling Duck & Glossy Ibis \\
\hline Snow Goose - winter & White-faced Ibis \\
\hline Ross's Goose - winter & Roseate Spoonbill \\
\hline Greater White-fronted Goose - winter & Black Vulture - winter \\
\hline Canada Goose & Turkey Vulture - winter \\
\hline Trumpeter Swan - winter & Swallow-tailed Kite \\
\hline Inca Dove & Eastern Phoebe - winter \\
\hline White-winged Dove & Sedge Wren - winter \\
\hline American Coot - winter & Hermit Thrush - winter \\
\hline Killdeer - winter & Gray Catbird - winter \\
\hline American Woodcock - winter & American Pipit - winter \\
\hline Wilson's Snipe - winter & Lesser Goldfinch \\
\hline Bonaparte's Gull - winter & Smith's Longspur - winter \\
\hline Neotropic Cormorant & Chipping Sparrow - winter \\
\hline American White Pelican & Vesper Sparrow - winter \\
\hline Brown Pelican & Savannah Sparrow - winter \\
\hline Great Blue Heron - winter & Indigo Bunting - winter \\
\hline White Ibis & Dickcissel - winter \\
\hline
\end{tabular}

Table 4. Migrant and winter residents that have declined during the past 25 years. See individual Species Accounts for details.

Evening Grosbeak

Rusty Blackbird

\section{Ebird, Unpublished Field Notes and Literature}

As mentioned above, the advent of eBird has resulted in an avalanche of observational data (Iliff et al. 2011). Although there are fairly effective and frequently-adjusted software filters, and much quality-control effort by eBird reviewers, many records within that data set still remain questionable. Because of the magnitude of that data set, I focused on reviewing a subset of records by querying high counts and early and late dates. That review precipitated many questions, and I am deeply grateful to Missouri eBird reviewer Josh Uffman for assisting in clarifying records. Even though the use of eBird has become ubiquitous, some highly qualified observers have not entered their observations, especially prior to the past few years. Some of those observers were contacted to obtain unpublished and non-digitally archived observations. 
Twelve years of data on passerine spring migration through the migrant "trap" at Forest Park, St. Louis are presented in pertinent species accounts (Korotev 1990). For that data set, only the main migratory period is presented for each species, that is, early and late dates for that period are excluded. For example, although Korotev observed Blackpoll Warblers from 19 April through 31 May, the mean number of birds/hour was calculated for the dates of 30 April through 26 May, which is the primary period of passage for Blackpolls. Field notes of the late Floyd Lawhon were deposited at the St. Joseph Museums in October 2016. Finally, since the publication of Birds of Missouri (Robbins and Easterla 1992), an attempt was made to review pertinent journals.

\section{Riparian Data}

Even prior to the publication of Birds of Missouri (Robbins and Easterla 1992) it was recognized that many breeding species that primarily inhabit riparian areas were not being adequately sampled via standard road-based survey protocols, such as the BBS and BBA (Robbins 1989). Thus, beginning in 1992, river-based surveys were initiated to provide a better relative abundance assessment of birds inhabiting difficult-to-access riparian habitats (e.g., Robbins et al. 1992; Robbins et al. 2010b). Most of these river-based surveys were conducted in southern Missouri with an emphasis on the Ozarks (fig. 4), and thus a number of rivers in the northern half of the state remain unsampled. Moreover, even for those rivers that were surveyed from 1992 through 2005, all need to be resampled to determine if major changes have occurred since the original baseline assessments.

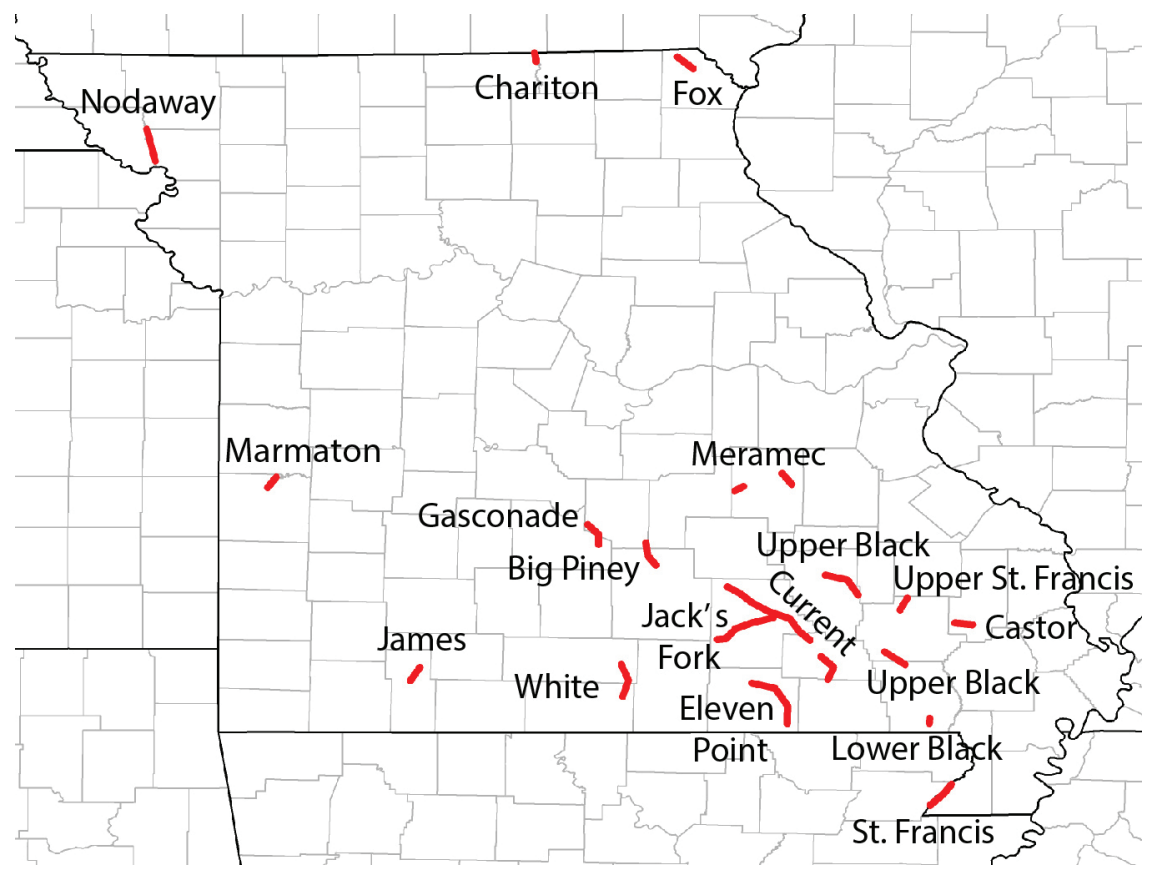

Fig. 4. Section of rivers surveyed for riparian-inhabiting species. 
Each survey began at $0600 \mathrm{hr}$ (DST) with ending times varying due to water flow rates and the distance traveled. However, with the exception of the Nodaway River, all surveys were completed by no later than late morning. Adult individuals heard and/ or observed were tallied for 19 target species (Table 5). Some of these species, such as Yellow-billed Cuckoo and Yellow-throated Warbler, breed in a variety of habitats, but have sizable populations in riparian habitat. Data also were recorded for a few non-riparian inhabiting species, such as Worm-eating Warbler, because this protocol facilitated access to populations that are not normally accessible. With the exception of three species (Belted Kingfisher, Northern Rough-winged and Bank swallows), we estimated that at least $90 \%$ of each species' tally was based on singing individuals presumed to be territorial males. All surveys were conducted under the same weather criteria used in the BBS; that is, no surveys were conducted during high winds or rain. Surveys were conducted from 19 May to 9 June to coincide with maximum singing rates of territorial males and to minimize inflation of numbers from late migrants or fledged young (Table 6). In the species accounts, data are expressed as the total number of birds per route with the mean number of individuals/river mile in parentheses, e.g., for Eastern Phoebe, 31 (3.3), 31 May 2002, Jack's Fork River; a total of 31 individuals were counted with an average of 3.3 birds/river mile on that section (Table 6) of the Jack's Fork River on 31 May 2001. Checklists in eBird can be viewed by inserting the checklist number from Table 6 at the end of the following: ebird.org/ebird/ view/checklist/checklist number. See Robbins et al. (2010b) for recommendations for survey protocol and potential biases associated with this technique.

\section{Table 5. Target species for riparian surveys.}

\begin{tabular}{|l|}
\hline Yellow-billed Cuckoo \\
\hline Yellow-crowned Night-Heron \\
\hline Red-shouldered Hawk \\
\hline Belted Kingfisher \\
\hline Acadian Flycatcher \\
\hline Willow Flycatcher \\
\hline Eastern Phoebe \\
\hline Warbling Vireo \\
\hline Northern Rough-winged Swallow \\
\hline Bank Swallow \\
\hline Louisiana Waterthrush \\
\hline Prothonotary Warbler \\
\hline Swainson's Warbler \\
\hline Hooded Warbler \\
\hline American Redstart \\
\hline Cerulean Warbler \\
\hline
\end{tabular}




\begin{tabular}{|l|}
\hline Northern Parula \\
\hline Yellow Warbler \\
\hline Yellow-throated Warbler \\
\hline
\end{tabular}

Table 6. Riparian data. River along with reference to data in eBird checklists.

\begin{tabular}{|l|l|}
\hline \multicolumn{1}{|c|}{ River } & \multicolumn{1}{|c|}{ eBird checklists } \\
\hline Black; upper & $\mathrm{S} 16884730, \mathrm{~S} 16884763, \mathrm{~S} 16881898$ \\
\hline Black; lower & $\mathrm{S} 16881364$ \\
\hline Big Piney & $\mathrm{S} 16857922, \mathrm{~S} 16858014$ \\
\hline Castor & $\mathrm{S} 16881731$ \\
\hline Chariton & $\mathrm{S} 16856409$ \\
\hline Current & $\mathrm{S} 16896079, \mathrm{~S} 16895998, \mathrm{~S} 16895878$, \\
& $\mathrm{S} 16896186, \mathrm{~S} 16884916, \mathrm{~S} 16908419$, \\
& $16908492, \mathrm{~S} 16900414, \mathrm{~S} 16900463$, \\
& $\mathrm{S} 16900383, \mathrm{~S} 16900581, \mathrm{~S} 16900516$, \\
\hline Sleven Point & $\mathrm{S} 168965777, \mathrm{~S} 16896229, \mathrm{~S} 16884825, \mathrm{~S} 16896591, \mathrm{~S} 16896803$ \\
\hline Fox & $\mathrm{S} 16856805$ \\
\hline Gasconade & $\mathrm{S} 16857506, \mathrm{~S} 16857825$ \\
\hline Jack's Fork & $\mathrm{S} 16897481, \mathrm{~S} 16897611, \mathrm{~S} 16898098$, \\
\hline James & $\mathrm{S} 16897689$ \\
\hline Marmaton & $\mathrm{S} 16872240, \mathrm{~S} 16872285, \mathrm{~S} 16872328$, \\
\hline Meramec & $\mathrm{S} 16872475, \mathrm{~S} 16872595$ \\
\hline Nodaway & $\mathrm{S} 16863137$ \\
\hline White River & $\mathrm{S} 16857296, \mathrm{~S} 16857130$ \\
\hline St. Francis; upper & $\mathrm{S} 1688007, \mathrm{~S} 16880105, \mathrm{~S} 16880207$, \\
\hline St. Francis; lower & $\mathrm{S} 16880335, \mathrm{~S} 16880441, \mathrm{~S} 16880520$ \\
\hline & $\mathrm{S} 16862221, \mathrm{~S} 16862963$ \\
\hline & $\mathrm{S} 16881517$ \\
\hline & $\mathrm{S} 16860774, \mathrm{~S} 16861479$ \\
\hline & \\
\hline
\end{tabular}

\section{Specimen Data}

Online access to the majority of collections that hold Missouri specimen material is now available via VertNet (VertNet.org). Abbreviations of collections where specimens are referred to more than once in the Species Accounts include Academy of Natural Sciences at Drexel University, Philadelphia (ANSP); American Museum of Nat- 
ural History, New York (AMNH); Bell Museum of Natural History, Minneapolis/St. Paul (BM); California Academy of Sciences, San Francisco (CAS); Carnegie Museum of Natural History, Pittsburgh (CM); Central Methodist College, Fayette, Missouri (CMC); Central Missouri State University, Warrensburg (CMSU); Chicago Academy of Science (CHAS); Field Museum of Natural History, Chicago (FMNH); Museum of Comparative Zoology, Harvard University (MCZ); Museum of Vertebrate Zoology, Berkeley (MVZ); Saint Louis Science Center (STSC); San Diego Natural History Museum (SDNHM); United States National Museum of Natural History, Smithsonian Institution (USNM); University of California, Los Angeles (UCLA); University of Kansas Biodiversity Institute, Lawrence (KU); University of Michigan Museum of Zoology, Ann Arbor (UMMZ); University of Missouri-Columbia (MU); and Western Foundation of Vertebrate Zoology, Camarillo, California (WFVZ). See comments in Robbins and Easterla (1992) concerning reliability of data associated with some specimens in the University of Missouri-Columbia collection.

\section{Species Account Abbreviations}

\section{Observers' initials and corresponding names that appear about ten or more times in the Species Accounts.}
CA - Connie Alwood
KA - Kathleen Anderson
RA - Richard Anderson
$\mathrm{SA}$ - Steve Addinall
BB - Brett Benz
$\mathrm{CB}$ - Chris Barrigar
CBo - Catherine Bonner
$\mathrm{CBu}$ - Charles Burwick
DB - David Becher
DB1 - David Blevins
HB - Harold Burgess
JB - John Bollin
JVB - Jack Van Benthuysen
LB - Lisa Berger
MB - Mike Beck
$\mathrm{MBr}$ - Mike Brady
TB - Tim Barksdale
JCa - Jeff Cantrell
JC - James F. Comfort
JEC - James Earl Comfort
WC - William Cunningham
RD - Ryan Douglas
SD - Steve Dilks
BE - Bill Eddleman
JE - Joe Eades
DE - David Easterla
TE - Todd Easterla
RF - Robert Fisher
AF - Andrew Forbes
BG - Bill Goodge
KG - Kirby Goslee
LG - Leo Galloway
MG - Matt Gearheart
RG - Ron Goetz
$\mathrm{CH}$ - Chris Hobbs
JHam - John Hamilton
JHa - Jim Haw
JHy - Jeff Hayes
JH - Jack Hilsabeck
KH - Kelly Hobbs
LH - Larry Herbert
MH - Mark Haas
BJ - Brad Jacobs
NJ - Nanette Johnson
TJ - Tim Jones
AK - Andrew Kinslow
JK - Jon King
SK - Steve Kinder
PK - Peter Kondrashov
RK - Randy Korotev
BL - Bob Lewis
FL - Floyd Lawhon 
LR - Larry Rizzo

MR - Mark Robbins

TR - Tommie Rogers

AS - Al Smith

BS - Bruce Schuette

$\mathrm{GSa}$ - Greg Samuel

GS - Greg Swick

SS - Scott Schuette

MT - Mike Thelen

JU - Josh Uffman

DW - Doug Willis

EW - Edge Wade

LW - Linda Williams

PW - Phil Wire

WW - Walter Wehtje

NY - Neal Young

\section{Localities frequently mentioned in the Species Accounts, listed in alphabetical order.}

$\mathrm{CA}=$ Conservation Area

$\mathrm{Co}=$ County

NWR=National Wildlife Refuge

$\mathrm{SP}=$ State Park

Bean Lake CA, Platte Co.

Ben Cash CA, along St. Francis River, Dunklin Co.

Big Oak Tree SP, Mississippi Co.

Bigelow Marsh, north of Bigelow, Holt Co.

Bilby Ranch Lake CA, Nodaway Co

BK Leach CA, Lincoln Co.

Bob Brown CA, Holt Co.

Bradford Farm, Columbia, Boone Co.

Brickyard Hill CA, Atchison Co.

Busch CA, St. Charles Co.

Clarence Cannon NWR, Pike Co.

Columbia Bottom CA, St. Charles Co.

Cooley Lake CA, Clay Co.

Duck Creek CA, Stoddard, Wayne, and Bollinger cos.

Eagle Bluffs CA, Boone Co.

Forest Park, City of St. Louis.

Fountain Grove CA, Livingston and Linn Cos.

Four Rivers CA, Vernon Co.

Grand Pass CA, Saline Co. 
Hi Lonesome Prairie CA, Benton Co.

Horseshoe Lake, Buchanan Co.

Independence, Jackson Co.

Kansas City, Jackson Co.

Lake Contrary, Buchanan Co.

Lake Wappapello, Wayne Co.

Loess Bluffs NWR (formerly Squaw Creek), Holt Co.

Marais Temps Clair CA, St. Charles Co.

Maryville Sewage Lagoons (SL), Nodaway Co.

Mingo NWR, Stoddard/Bollinger cos.

Montrose CA, Henry Co.

Otter Slough CA, Stoddard and Butler cos.

Riverlands Migratory Bird Sanctuary, St. Charles Co.

Roaring River SP, Barry Co.

Rosecrans Airport, St. Joseph, Buchanan Co.

Schell-Osage CA, Vernon Co.

Smithville Lake, Clay Co.

Stockton Lake, Cedar, Dade, and Polk Cos.

Sugar Camp Scenic Drive, 8 road miles through Mark Twain National Forest, Barry Co.

Swan Lake NWR, Chariton Co.

Taberville Prairie CA, St. Clair Co.

Table Rock Lake, Taney Co.

Ted Shanks CA, Pike Co.

Ten Mile Pond CA, Mississippi Co.

Thomas Hill Reservoir, Randolph and Macon cos.

Thompson River Wetlands, Livingston Co.

Tower Grove Park, City of St. Louis.

Tucker Prairie, Callaway Co.

Weldon Spring CA, St. Charles Co.

Weston Bend SP, Platte Co.

\section{Miscellaneous abbreviations:}

ad: adult

BBA: Missouri Breeding Bird Atlas, 1986-1992 (Jacobs and Wilson 1997)

BBS: Breeding Bird Survey

CBC: Christmas Bird Count

eBird: ebird.org

imm: immature

ML: Macaulay Library, Cornell Laboratory of Ornithology

MBRC: Missouri Bird Records Committee

m. ob.: many observers

NAMC: North American Migration Count 


\section{Species Accounts}

\section{Order Anseriformes \\ Family Anatidae: swans, geese, and ducks}

\section{Black-bellied Whistling-Duck (Dendrocygna autumnalis)}

Status: Rare transient and summer visitant; accidental summer resident; accidental winter visitant.

Documentation: Specimen, see below under Summer.

Habitat: Marshes, ponds, lakes.

Spring: All records except one are from the western half of the state from late Apr through May. Earliest dates: 1, photos, 10 Apr 2017, Ritter Springs Park (S. and W. Slatkavitz); 1, 23-29 Apr 2011, Mosby Flats (m. ob.); 2, photos, 24 Apr - 3 Jun 2017, BK Leach (m.ob); 2, 26 Apr 2003, Loess Bluffs (SD et al.). High counts: 18, 22 Apr 15 June 2009, southwest of Sedalia, Pettis Co. (WW, B. Viernes).

Summer: Most Jun and Jul records are from the western half of the state. There are now two nesting records, both in Wood Duck houses: photos, 2 Jul - 28 Aug 2010, near Napolean, Lafayette Co. (Burns et al. 2010; young failed to fledge; 2 ducklings preserved, KU 117242); photos, Aug-Oct 2017, ducklings observed with adults on 25 Sept, northeast of Otter Slough (M. Wilburn, S. Kendrick).

Fall: Records span from the beginning of the period until late Nov, with a dramatic decrease in frequency after Aug, with one Sep, one Oct, and three Nov records. Latest dates: 1, 24 Nov 2011, Eagle Bluffs (m. ob.); 8 (5 of which were shot by hunters; vouchers deposited at Eagle Bluffs and Four Rivers), 21 Nov 2011, Eagle Bluffs (fide V. Bogosian); 4, 11 Nov 1939, Loess Bluffs (E. and D. Cole, refuge manager; Rising et al. 1978; first MO record). High count: 18, 18-25 Oct 1989, west of Portage des Sioux, St. Charles Co. (J. and H. Belz, J. Schneithorst).

Winter: There are two records: a single bird that associated with domestic waterfowl from 5-18 Jan 1985, Cape Girardeau may have been an escapee (V. Moss et al.). The other record is of a group of ten $(2 \mathrm{ad}, 8 \mathrm{imm})$ that were first found at Riverlands on 26 Sep 2017 (P. Moffett et al.), with 6 lingering until 27 Dec.

Comments: Beginning in Texas in the late 1970s (Lasley and Sexton 1988), this species increased dramatically throughout the southern Great Plains and Midwest. Additional breeding could be encouraged in Missouri by creating Wood Duck houses with slightly larger diameter holes.

\section{Fulvous Whistling-Duck (Dendrocygna bicolor)}

Status: Rare transient and summer visitant in the southeast, casual elsewhere; accidental summer resident in southeast. 
Documentation: Specimen: female, captured in teal trap, 17 Apr 1953, Loess Bluffs (W. Boyd; St. Joseph Museum, St. Joseph, Missouri 73.1.36).

Habitat: Marshes, rice fields, ponds, lakes.

Spring: There are seven spring records, four from the southeast corner. Earliest date: 1, appeared after major dust storm on 3 Mar 1935 (present for almost 3 weeks), Knox City, Knox Co. (Musselman 1935). High count: 11, 9 May 2008, Mingo (SD).

Summer: All but three records from the southeast. There is a single breeding record: 2 adults with 2 young, 20 Jun 2006, Stoddard Co. (R. Meade, B. Brooks, M. Scheperle, K. McMullen). High count: 21, photos, 11 Oct 2003, rice fields near Dexter, Stoddard Co. (JE et al.), with a number of these present from at least late Jun through 17 Oct (m. ob.).

Fall: Aside from the above Sep through mid-Oct 2003 observations near Dexter, there are only two other records: 3 (1 collected; USNM 120308), "fall 1890", near New Madrid, New Madrid Co. (Sparks 1891; original locality of "New Albany" was in error and later corrected by Sparks in the same volume); 4, photos, 13-16 Aug 2009, near Caruthersville, Pemiscot Co. (D. Bosler, CB).

\section{Snow Goose (Anser caerulescens)}

Status: Common transient and winter resident; accidental summer resident. Has increased dramatically over past 50 years and now is abundant statewide.

Documentation: Specimen: female, 10 Dec 1966, near Mound City (KU 117541).

Habitat: Marshes, lakes, rivers, harvested cornfields.

Spring: Migrants begin augmenting winter populations in mid-to-late Feb, with peak now in early to mid-Mar. Large concentrations are encountered in early Apr with smaller flocks regularly seen through the third week of Apr. With the spring hunting season, initiated in 2009, groups consisting of crippled and sick birds are seen into summer. The species is now common across the entire state. High counts: estimated 1,425,000, 10 Mar 2008, Loess Bluffs (refuge data): 1,292,000, 7 Mar 2011, Loess Bluffs (refuge data); 582,000, 15 Mar 2015, Pershing SP (PM); 500,000, 15 Mar 2013, Fountain Grove (PM, BJ); 250,000, 4 Mar 2007, Monroe and Audrain cos. (P. Harrison).

Summer: Quite unexpectedly, a pair with young was observed in early Jun 1998, Bigelow Marsh (R. Lee). The pair that bred may have been sick or injured. As a result of the spring hunting season birds are routinely seen during the summer in a number of areas.

Fall: The initial, relatively small flocks begin to appear in late Sep, with large concentrations appearing by late Oct. High counts: in west: 460,000, 3 Dec 2007, Loess Bluffs (refuge data); 440,000, 23 Nov 1987, Loess Bluffs (refuge data); in east: 150,000 200,000, 24 Nov 2002, Otter Slough (BRe).

Winter: This species is more frequently wintering in immense flocks. During the height of the winter, in mid-Jan, large numbers temporarily move south. High counts: 
950,000, 18 Dec 2015, Loess Bluffs CBC; 603,100, 18 Dec 2012, Loess Bluffs CBC; 583,000, 17 Dec 2014, Loess Bluffs CBC; 110,000, 22 Jan 2000, Swan Lake (H. Lambert-Doherty);

Comments: During the past 50 years this species has increased dramatically, and huge concentrations now can be observed statewide, although the species is more abundant in the non-forested western part of the state.

\section{Ross's Goose (Anser rossii)}

Status: Uncommon transient and winter resident. Has increased dramatically over the past 50 years.

Documentation: Specimen: male, 25 Apr 1974, Bigelow Marsh (KU 117897).

Habitat: Marshes, lakes, rivers, harvested cornfields.

Spring: This species has the same migration schedule as the Snow Goose. Wounded or sick birds are seen lingering into summer. High counts: in west: 6,250, 29 Feb 2012, Loess Bluffs (C. Woods); 1,800, 15 Mar 2015, Pershing SP (PM); in east: 88, 23 Feb 2014, BK Leach (MT); 70, 1 Mar 2014, Duck Creek (MH).

Summer: With the spring hunting season, injured birds are now routinely seen with Snow Geese in the summer.

Fall: Birds begin appearing at the same time as Snow Geese with peak typically in late Nov. Earliest dates: 1, 14 Oct 1975, Maryville SL (DE); 7, 17 Oct 2009, Riverlands (BR). High counts: 624, 28 Nov 2006, Loess Bluffs (DE); 440, 23 Nov 1987, Loess Bluffs (refuge data).

Winter: Found statewide wherever there are flocks of Snow Geese. High counts: 200, 14 Dec 1987, Loess Bluffs (refuge data); 110, 15 Dec 2011, Big Oak Tree CBC; 59, 18 Dec 2012, Loess Bluffs CBC.

Comments: Although the first definite record for the state was not until Oct 1963, near Mindenmines, Barton Co. (fide RA, Bluebird 31:30), the species undoubtedly occurred well before then, as the first Nebraska record was in 1922 (Tate 1966). This species has increased dramatically over the past 50 years. Hybrids between Snow and Ross's are frequently encountered. The uncommonly recorded Ross's blue morph is thought to be the result of hybridization with a blue morph Snow Goose (Jonsson et al. 2013). It has been seen on several occasions in the state.

\section{Greater White-fronted Goose (Anser albifrons)}

Status: Common transient; uncommon to locally common winter resident; accidental summer visitant. Has increased dramatically over past 50 years, especially the past 20 years, statewide.

Docmentation: Specimen: female, 26 Mar 1968, Maryville (KU 117584).

Habitat: Marshes, lakes, rivers, harvested cornfields. 
Spring: Much more common in the west, where thousands can be seen from late Feb through the third week of Mar. Less common in east, but now even there a few thousand may be encountered. Numbers decrease by the end of Mar, but hundreds are still observed through mid-Apr, and rarely into early May. Mid-to-late May records are mostly of injured birds from spring hunting season. High counts: in west, 120,000, 25 Feb 1997, Loess Bluffs (refuge data); 34,550, 10 Mar 2008, Loess Bluffs (refuge data); in east, 3,000, 3 Mar 2007, BK Leach (JE).

Summer: There are several summer records, as far south as Otter Slough, that involve injured birds that presumably were casualties of spring hunts.

Fall: The species is considerably less common in fall than in spring in western Missouri. The earliest arrivals are typically in late Sep, with peak in late Oct/early Nov. A few thousand at a single locality may linger through the end of the period. Earliest dates of birds that clearly were not sick or injured birds that oversummered: 1, $11 \mathrm{Sep}$ 1992, L. Taneycomo (JHy); 12, 13 Sep 1970, Loess Bluffs (FL). High counts: 11,500, 19 Nov 2007, Loess Bluffs (refuge data); 9,100, 17 Nov 2008, Loess Bluffs (refuge data).

Winter: Now, with relatively mild winters, thousands of birds may overwinter north to the Iowa border and can be encountered in relatively large numbers (in the thousands) in the east. High counts across the state: 13,700, 16 Feb 2009, Loess Bluffs (refuge data); 7,407, 21 Dec 2011, Loess Bluffs CBC; 5,700, 17 Dec 2009, Big Oak Tree CBC; 5,130, 2 Jan 2000, Mingo CBC; 5,020, 30 Dec 2011, Clarence Cannon (JU).

Comments: As with other goose species, the Greater White-fronted Goose has increased dramatically during the past two decades, not only during migration but this species now overwinters in larger numbers statewide. The combination of milder winters and spring hunting (initiated in 2009) has resulted in wounded birds' surviving and now routinely appearing in late spring through the summer.

\section{Brant (Branta bernicla)}

Status: Casual fall transient; accidental spring transient and winter visitant.

Documentation: Specimen: male, 27 Nov 1956, Swan Lake (USNM 464454).

Habitat: Marshes, lakes, and rivers.

Spring: Only two records: 3, 3 Apr 1966, Little Prairie Lake, near Rolla, Phelps Co. (F. Frame and Mrs. Ollar); 1, 28 Mar 1970, Loess Bluffs (P. and L. Prevett).

Fall: There are now at least 13 records between early Oct and early Dec, with all but two occurring in the western half of the state. Most records are from hunters, with only two during the past 25 years. Earliest date: 1, 1 Oct 1958, Swan Lake (shot by hunter, fide DE). A report of 20, Nov 1987, Iron Co. that was included in Robbins and Easterla (1992) was considered questionable by the MBRC in Sep 2015. 
Winter: Only four records, all from the northwestern section: 1, photos, 4-19 Jan 1975, Pony Express CA, DeKalb Co. (FL et al.; photo in Robbins and Easterla 1992); 1, 2-4 Jan 1983, Pony Express CA (FL); 1, 20 Dec 1987, Loess Bluffs CBC (G. Shurvington, DE); 1, 19 Dec 2010, Lake Remembrance, Jackson Co. (A. Donner).

\section{[Barnacle Goose (Branta leucopsis)]}

Status: Provisional; provenance of all records uncertain.

Documentation: Specimen: ad female, taken by hunter, 1 Dec 1991, 5 miles E of Nevada, Vernon Co. No bands on neck or tarsi. Specimen deposited at USFWS training site in Glynco, Georgia; specimen photos in VIREO r08/15/001-2.

Habitat: Marshes, lakes, and rivers.

Spring: 1, 26 Mar 1950, Marais Temps Clair (m.ob.); 1, 25-26 Mar 1976, Loess Bluffs (LG et al.); 1, 29-31 Mar 2012, J.A. Reed CA (EW et al.); 1, photos, 28 May 1984, J.A. Reed CA (S. Cooper);

Fall: 2, 6 Nov 1977, Loess Bluffs (LG et al); 1, photos, 20-26 Oct 1980, Swan Lake (D. Graber); 1, 12-28 Nov 2007, Riverlands (JU).

Comments: This is a common bird in avicultural collections, and thus the origin of all records has been considered questionable. None of the birds reported in the state have been banded; however, during the past 30 years the Greenland population has steadily increased (Sherony 2008). Many birds on the East Coast are now considered to be of wild origin. All observations should be carefully documented, noting age and the presence/absence of neck and/or leg bands. Any birds that have been incidentally shot should be preserved, as provenance might be determined through stable isotope analyses.

\section{Cackling Goose (Branta hutchinsii)}

Status: Common migrant and locally common winter resident in west, uncommon migrant and winter resident in east.

Documentation: Specimen: sex undetermined, 10 Oct 1975, Maryville SL (KU 117585). Habitat: Marshes, lakes, rivers, harvested cornfields.

Spring: Much more common in the western half of the state. Migrants begin to appear during the latter half of Feb, with peak in early Mar. Smaller numbers are seen through Apr. Mid-May into summer records likely involve wounded birds. High counts: 125+, 4 Mar 2008, Pony Express CA (MR); 100, 5 Mar 2007, Muskrat Lake, Buchanan Co. (LL). Latest dates: 1, 18 May 2012, Holt Co. (DE); 1, 27 Apr 2011, Grand Pass (EW et al.).

Fall: The first individuals begin to appear in late Sep. Peak typically is at the end of Nov. Earliest dates: 5, 18 Sep 2011, Maryville SL (DE); 15, 4 Oct 2008, Winfield Lock and Dam, Lincoln Co. (SS). High counts, in west: 1,006, 28 Nov 2014, Maryville SL: 
1,000, 7 Dec 2007, Maryville SL (DE); in east, both at Riverlands by JE: 60, 12 Dec 2007; 24, 26 Nov 2006.

Winter: Locally common winter resident in west, less abundant in east. High counts: in west: 2,726, 15 Dec 2012, Maryville CBC; 1,000, 1 Jan 2012, Maryville SL (DE); in east: 278, 17 Dec 2009, Columbia CBC; 55, 29 Dec 2005, Clarence Cannon CBC; 50+, 23 Dec 2005, Riverlands (BR).

Comments: Although the Cackling Goose has been recognized as a species by various waterfowl experts for decades, it was not elevated to species status by the AOS until 2004 (Banks et al. 2004). As a result, the status of the species is still being clarified in Missouri. The species has dramatically increased during the past forty years in North America (Butcher and Niven 2007). Mlodinow et al. (2008) provided a good summary of the status and identification of the Cackling Goose complex. Of the four currently recognized subspecies of Cackling Goose, only nominate hutchinsii has been documented in Missouri; this form has long been known as "Richardson's Goose" by hunters and wildlife managers.

\section{Canada Goose (Branta canadensis)}

Status: Common permanent resident. Has increased dramatically over the past 50 years. Documentation: Specimen: male, 8 Dec 1947, Holt Co. (KU 490250).

Habitat: Marshes, lakes, rivers, harvested fields.

Spring: Migrants peak in late Feb and early Mar, with large numbers through Mar. The largest concentrations are seen at Swan Lake. High counts: ca. 50,000-70,000, recorded annually during peak in late Feb at Swan Lake (K. Granneman, pers. comm.); 25,000, 6 Mar 2010, Loess Bluffs (refuge data).

Summer: Prior to and during European settlement this goose bred along the Missouri and Mississippi rivers, but by the 1890s it had become rare (Widman 1907, McKinley 1961). Birds continue to breed in the rocky bluffs along the Missouri River between Jefferson City and St. Charles, with local residents having recollections of birds breeding in this area at least as far back as the 1920s (Johnson 1975). As a result of reintroductions from captive stock that began in the late 1940s and early 1950s, the species is a common breeder statewide.

Fall: Migrants begin appearing by mid-Sep, with peak in mid-to-late Nov. During peak over 100,000 are recorded at Swan Lake. High Swan Lake counts: 150,000, Nov 1978; 150,000, 4 Nov 1988 (K. Granneman).

Winter: Common throughout the period in most of the state. Apparently as a result of the warm winters, migrants are much less common during migration and winter in the southeastern part of the state when compared to over 20 years ago. Wintering birds in that region are thought to be mainly residents, and those birds are augmented by migrants when it becomes quite cold to the north (fide BE). High counts: 132,100, 
19 Dec 1976, Swan Lake; 127,950, 18 Dec 1977, Swan Lake; 109,000, 1 Jan 2012, Maryville SL (DE).

Comments: Taxonomy and nomenclature are complicated and still require further study. The permanent-resident subspecies in Missouri, both historically and presently, is B. c. maxima (Giant Canada Goose); however, as a result of reintroductions that involved populations attributable to $B$. c. moffitti, birds that are present year round are genetically an admixture of maxima and moffitti (Mowbray et al. 2002). Genetic work is needed to confirm which of the other six currently recognized subspecies (following Mowbray et al. 2002) occur during migration and winter in Missouri. Presumably, the bulk of the non-resident Canadas that migrate through and winter in the state, especially the eastern part, are of the subspecies interior, but confirmation is needed. See comments under Cackling Goose, which was officially split from Canada Goose in 2004 (Banks et al. 2004).

\section{[Mute Swan (Cygnus olor)]}

Status: Provisional; status uncertain.

Documentation: Sight records only; see below

Habitat: Ponds, lakes, and marshes.

Records: This aggressive swan was introduced to North America from the Old World. There is a sight record of a marked bird of unknown feral origin: imm and ad, 6 Jan to 9 Feb 1985, below Winfield Dam, Lincoln Co. (RG et. al.). The immature was banded as a cygnet the previous Jul at Eagle, Wisconsin. There are a number of other records of single birds of unknown origin. Efforts should be made to eradicate all individuals to insure that this species does not have a negative impact on other marsh-dwelling species.

\section{Trumpeter Swan (Cygnus buccinator)}

Status: Uncommon transient and locally common winter resident; accidental summer resident; former common transient statewide and summer resident in north.

Documentation: See below.

Habitat: Marshes, lakes, and rivers.

Spring: The winter population begins leaving by mid-Feb, and by early Mar the large population in the St. Louis area along the Mississippi River is greatly reduced. On the west side of the state, the wintering population is augmented by migrants in late Feb, and most have left there by the end of Mar. A few individuals are rarely seen into the first week of May. High counts: 1,088, 6 Feb 2017, Loess Bluffs (refuge data); 863, 24 Feb 2016, Loess Bluffs (refuge data). Latest dates: 1, 17 May 2013, Eagle Bluffs (B. Warrick); 1, 2-17 May 2015, Riverlands (m. ob.).

Summer: The first nesting attempt in over one hundred years was of a pair with 3 young, Jun-Jul 2005, near Livingston/Carroll Co. line (SK, M. Carlton). At least one of the pair was an offspring from the Iowa reintroduction program. The presumed same pair returned in 2006 but was unsuccessful; however, in 2007 young fledged. 
Fall: Swans begin to reappear by the end of Oct and continue to increase until water freezes in the northern half of the state. Earliest dates: ad, photos, 18 Sep 2016, Loess Bluffs (T. Nagle); 1, 15 Oct 2014, Loess Bluffs (refuge data); 2, 24 Oct 2013, Riverlands (D. Marjamaa); 1, 24 Oct 2014, Loess Bluffs (M. Stewart, C. Entriken). High counts, both at Riverlands: 1,069, 21 Nov 2017 (PL); 650, 25 Nov 2014 (PL).

Winter: Birds began wintering in the state at several sites in 1991-2. Nine marked birds from the Wisconsin reintroduction (initiated in 1989) wintered in the state in 1993-4. There were additional reports in 1994-5 of birds that came from the Michigan, Wisconsin, and Minnesota reintroductions. In just over a decade later a few hundred birds wintered in the St. Louis area. It is now common in the north on both sides of the state, with greater than a thousand birds present at prime sites. High counts: 1,303, 19 Dec 2017, Loess Bluffs (refuge data); 1,022, 22 Dec 2016, Riverlands (PL); 960, 22 Jan 2014, Riverlands (L. Richter).

Comments: This swan was a common transient and bred across the northern part of the state until the $1850 \mathrm{~s}$, but shortly thereafter it ceased breeding as a result of excessive hunting (Widmann 1907, McKinley 1962). By the late 1890s it was a very rare migrant, and the last definite record was of a bird collected in Apr 1900 (Harris 1919b; specimen apparently no longer extant). This swan almost became extirpated in the lower 48 states, if not for a remnant, protected population at Red Rocks NWR, Montana.

The reintroduction program from the Red Rocks population was initiated at LaCreek NWR, South Dakota in the early 1960s and was highly successful. The first individuals documented in Missouri from that population were on 7 Dec 1978, when 3 of 6 individuals were illegally shot at Thomas Hill Reservoir (Burgess 1981). During the 1980s, swans began appearing from the Minnesota reintroduction program and by the early 1990s birds from other reintroduction programs began to winter in the state.

\section{Tundra Swan (Cygnus columbianus)}

Status: Rare transient and winter resident.

Documentation: Specimen: female, 28 Oct 1968, near Mound City, Holt Co. (KU 117594)

Habitat: Marshes, lakes, and rivers.

Spring: Migrants appear at the end of Feb, with the majority of observations during the first three weeks of Mar. High counts: 40, 13-19 Mar 1983, Springfield (CBo); 24, 23 Feb 2014, Riverlands (JM, CM). Latest dates: 3 immatures, 4-16 Apr 1984, Cooley Lake (H. Burgess, CH); 1, photos, 1 Apr 2013, Loess Bluffs (DW).

Fall: The first individuals appear at the end of Oct, with the majority of records during late Nov/early Dec. Earliest dates: 2, 25 Oct 2017, Riverlands (B. Prather); 3, 27-29 Oct 1968, Trimble (C. Blanchard); 1, photos, 2 Nov 2008, Loess Bluffs (JB). High counts: 18, 21 Nov 1985, Loess Bluffs (B. Heck); 17, 14 Nov 1968, Loess Bluffs (H. Burgess). 
Winter: This swan now regularly overwinters with large Trumpeter Swan flocks at Riverlands near St. Louis and is now often seen, at least in early winter, at Loess Bluffs. High counts, all at Riverlands: 84, 2 Jan 2017 (JM); 76, 19 Dec 2017 (PL et al.); 58, 23 Jan 2016 (CM).

Comments: A Whooper Swan (Cygnus cygnus), photos, was present at Fountain Grove from 3-15 Mar 1995 (M. Carlton et al.). This record likely involved an escapee as both Greylag and Bar-headed geese were present at the same time.

\section{Wood Duck (Aix sponsa)}

Status: Common transient and summer resident; locally common winter resident in southeast, rare elsewhere, but most observations are from the southern third of the state.

Documentation: Specimen: male, 5 May 1879, Charleston, Mississippi Co. (MCZ 42763).

Habitat: Wooded swamps, ponds, slow-moving streams and rivers.

Spring: A few migrants appear by the end of Feb, with a dramatic increase by midMar. Peak is typically in late Mar/early Apr. High counts: 450, 13 Mar 1991, Loess Bluffs (refuge data); 400, 27 Mar 2013, Eagle Bluffs (G. Connette); 340, 18 Mar 1993, Loess Bluffs (refuge data).

Summer: The most common breeding waterfowl in the state. The species is most common in the Duck Creek and Mingo areas, but it is common in oxbow lakes throughout the state. By early Jul large concentrations may be encountered, e.g., 330, 8 Jul 2012, Mingo (CB); 300, 5 Jul 1988, Swan Lake (KG).

Fall: The late summer concentrations, mostly composed of immatures, continue to increase through Aug, with large numbers observed into Oct, which may be composed of both young as well as migrants from the north. High counts, all from Loess Bluffs (refuge data): 1,520, 20 Oct 2008; 1,000, 19 Oct 1990; 748, 31 Oct 2005.

Winter: The species is much less common at this season at widely scattered sites, with most observations from the southern third of the state. Highest concentrations are at Mingo. High counts: 1,560, 18 Dec 2010, Mingo CBC; 1,000, 17 Dec 1963, Mingo CBC.

\section{Garganey (Spatula querquedula)}

Status: Accidental spring transient.

Documentation: photograph: adult male, 2-3 Apr 1994, Busch, St. Charles Co. (JVB, RA et al.).

Habitat: Marshes, ponds, lakes.

Record: The only other record: ad male, photos, 19-21 Apr 2013, near Sumner, Chariton Co. (A. Weiss et al.). 
Comments: In addition to both North American coasts, there are now a number of records for the interior including most states that surround Missouri, e.g., Kansas has five records (Thompson et al. 2011).

\section{Blue-winged Teal (Spatula discors)}

Status: Common transient; rare summer resident; rare winter resident in south, casual in northern third of state.

Documentation: Specimen: male, 4 May 1879, Charleston, Mississippi Co. (MCZ 42806).

Habitat: Marshes, ponds, lakes.

Spring: The first migrants arrive in early Mar, but it remains rare to uncommon until early Apr when large numbers arrive. Hundreds are often still present at northern refuges through the third week of May but drop off dramatically the last week. High counts: 50,000, 23 Apr 1967, Loess Bluffs/St. Joseph (FL); 20,100, 7 Apr 2009, Loess Bluffs (refuge data); 12,000, 11 Apr 1982, Loess Bluffs (FL); 12,000, 28 Mar 1988, Loess Bluffs (refuge data).

Summer: A low-density breeder, with at most a few pairs at prime refuge sites north of the Missouri River. The first documented breeding south of the river was when a pair with young was observed in May 1991, at Table Rock Lake Fish Hatchery (M. Braswell). Although there are numerous other observations south of the Missouri River, none was indicative of breeding. High counts: 180, undoubtedly involving late migrants, 2 Jun 2013, Loess Bluffs (MR); 43, 14 Jul 2010, Columbia Bottom (KA).

Fall: Migrants augment breeding birds by mid-Aug with large concentrations by early Sep. Peak is typically from late Sep/early Oct, with few birds remaining by the end of Oct. It is rarely seen after mid-Nov. High counts for early and late in season: 9,359, 2 Oct 2001, Loess Bluffs (refuge data); 7,850, 14 Oct 2005, Loess Bluffs (refuge data); 6,000, 20 Aug 1987, Swan Lake (P. Thomsen); 1,500, 2 Nov 1987, Swan Lake (P. Thomsen).

Winter: During the past two decades there has been a dramatic increase in this species lingering to the end of Dec, with small numbers overwintering in the southeast. Most records are from south of the Missouri River. High counts, both on Big Oak Tree CBC: 30, 16 Dec 2006; 14, 17 Dec 2009.

Comments: Hybrids between Blue-winged and Cinnamon teal are regularly seen in the western part of the state, less frequently in the east. High count of hybrids for a single locality: 3, 28 Apr - 12 May 2013, Loess Bluffs (DW et al.).

\section{Cinnamon Teal (Spatula cyanoptera)}

Status: Rare spring, casual summer and fall transient; accidental winter visitant.

Documentation: male, late Mar 1986, near Big Lake SP (D. Mead, D. Snipes; Saint Joseph Museum, St. Joseph, MO 89.1.646).

Habitat: Marshes, ponds, lakes. 
Spring: A few individuals and pairs are seen every spring in the west, and although it is now observed almost every spring in the east, it is much less frequently encountered there. Records span from early Mar through May, with peak in late Mar/early Apr. Earliest dates: 1 Mar 1977, Trimble (B. West); male, 7-20 Mar 1998, Swan Lake (SK). High counts: several observations involving two pairs in the northwest.

Summer: It is casual in summer with the following records, all single males: late May - 15 Jun 1982, Clarence Cannon (SD, BRe, K. Adams); 4 Jun 2000, Loess Bluffs (DE, JH); 5 Jul 2004, Riverlands (CM, JM); 4 Jun 2006, Eagle Bluffs (BG, EW, J. Gaston, A. Downing, S. Elbert); 2 Jun 2013, Loess Bluffs (MR).

Fall: There are eight fall records, all males, from early Aug to early Nov: 1, 7 Aug 2013, Clarence Cannon (CM); 2, 13 Aug 1983, Schell-Osage (J. Sowers et al.); 1, 5 Sep 1976, Schell-Osage (NJ, KH); 1, 27 Sept 2016, Longview Lake, Jackson Co. (K. Davis); 1, 9-15 Oct 1983, Mingo (BE); 2, 27 Oct 1971, Busch (JC); 1, 15 Oct 2011, Little Prairie CA, Phelps Co. (J. Decker); 1, 1 Nov 2005, Lake Contrary (LL).

Winter: There are three winter records of males: 7-27 Jan 1995, Lake Springfield, Greene Co. (GS, LR et al.); 13 Jan 2008, near Otter Slough (CB); shot by hunter, photos, 22 Dec 2016, Cape Girardeau Co. (L. and J. Jordan).

Comments: See remarks under Blue-winged Teal concerning hybrids.

\section{Northern Shoveler (Spatula clypeata)}

Status: Common transient; accidental summer resident; rare summer visitant in north, casual in south; uncommon winter resident.

Documentation: Specimen: male, 7 Apr 1920, Kansas City (UCLA 106724).

Habitat: Marshes, ponds, lakes.

Spring: Winter residents are augmented at the end of Feb with relatively large numbers, hundreds to low thousands, appearing during the latter half of Mar. Like Bluewinged Teal, peak is later than most waterfowl and typically occurs in early to midApr. In most years, numbers have drastically dropped off by early May, although occasionally hundreds may still be present in late May, e.g., 225, 23 May 2013, Loess Bluffs (MR). High counts, all from Loess Bluffs (refuge data): 34,950, 4 Apr 2009; 20,000, 14 Apr 1968 (FL); several high counts of ca. 15,000.

Summer: Late migrants are still present through early Jun, with small numbers remaining through the summer, primarily at northern refuges. There are a number of records for the southeastern corner. Harris (1921) mentioned probable breeding (families were observed) of this duck and Northern Pintail in Platte and Buchanan counties in 1921. A female with eight downy young were seen on 10 May 1986 in a marsh at the edge of Mound City (LG). Another female with brood was observed at Loess Bluffs in May 1988 (BJ). High counts: 58, 2 Jun 2013, Loess Bluffs (MR); 32, 2 Jun 2000, Loess Bluffs (DE). 
Fall: Migrants begin appearing by mid-Aug, with a dramatic increase by the beginning of Sep. Peak is in early to mid-Nov. Numbers drop off dramatically at the end of Nov. High counts: 19,894, 13 Nov 2006, Loess Bluffs (refuge data); 13,807, 19 Nov 2007, Loess Bluffs (refuge data); 10,000, 5-6 Nov 2013, Maryville SL (DE).

Winter: Relatively large numbers may be seen through Dec, but numbers across most of the state are reduced during Jan and most of Feb. High counts: 4,230, 28 Dec 2013, Mingo CBC; 1,560, 4 Jan 2013, Winfield Slough, Lincoln (CM); 1,360, 22 Dec 2012, Mingo CBC; 1,100, 14 Dec 2012, Four Rivers CBC.

\section{Gadwall (Mareca strepera)}

Status: Common transient; accidental summer resident in northwest; rare and local summer visitant statewide; uncommon winter resident with larger numbers in the south.

Documentation: Specimen: female, 25 Oct 1963, Duck Creek (MU 1581).

Habitat: Marshes, ponds, lakes, and flooded timber.

Spring: Common from late Feb through Apr. Peak is typically in late Mar. Relatively large concentrations may be seen at northern refuges through mid-May. High counts, all at Loess Bluffs (refuge data): 31,080, 7 Apr 2008; 17,445, 15 Mar 2006; 14,175, 26 Mar 2007. High count for late in season: 110, 23 May 2013, Loess Bluffs (MR).

Summer: The species is regularly found in small numbers statewide, but is most consistently found at Loess Bluffs. Late migrants often linger into early Jun. High counts, both at Loess Bluffs: 41, 2 Jun 2013 (MR); 37, 4 Jun 1996 (DE). After the first week of Jun only pairs and small numbers are observed, e.g., high count away from northwest corner: 7, 7 Jul - 4 Aug 2007, Otter Slough (SS, BJ, JE, PW). The most recent definitive breeding records were obtained in 1990, when two nests with eggs were found at Loess Bluffs (R. Bell). The species undoubtedly breeds more frequently than has been documented as pairs often are seen in summer in appropriate breeding habitat.

Fall: The first migrants arrive in mid-Sep. Peak is in late Oct/early Nov. Numbers remain high in the north until water freezes and forces birds south. High counts, all at Loess Bluffs (refuge data): 26,410, 4 Nov 1998; 25,700, 29 Oct 2007; 24,250, 22 Nov 2004.

Winter: Uncommon winter resident statewide where there is open water. High counts on CBCs: 15,000, 21 Dec 2015, Clarence Cannon; 8,650, 28 Dec 2013, Mingo; 6,000, 28 Dec 1965, Mingo.

\section{Eurasian Wigeon (Mareca penelope)}

Status: Casual transient.

Documentation: photograph: male, 30 Apr - 1 May 2011, Loess Bluffs (AS et al.).

Habitat: Marshes, ponds, and lakes. 
Spring: Including the above record there are seven records of males ranging from late Feb through the end of Apr. These include: photos, 20 Feb-2 Mar 2016, Clarence Cannon (D. Becher et al.); 23 Mar 1947, near Old Monroe, St. Charles Co. (K. Wesseling); 25-26 Mar 1950, Sugar Lake, Buchanan Co. (J. Bishop, M. Magner; erroneously attributed to 26 April in Rising et al. 1978; see Bluebird 17[4]:1 for correct data); 1 Apr 1959, Loess Bluffs (fide FL); shot by a hunter, 10 Apr 1905, St. Louis (Widmann 1907); and 25-26 Apr 1943, Marais Temps Clair (WC; Wilhelm 1958).

Fall: Only three records, all single males: 24 Oct 1985, St. Joseph (FL et al.); 10 Nov 1946, St. Charles Marsh, St. Charles Co.; 16 Nov 1991, Loess Bluffs (CH, TB). The St. Charles record was documented with a specimen (only head preserved), but apparently it disappeared from the MU collection between 1986 and 1988 (Robbins and Easterla 1992).

Comments: Observers should be aware of the possibility of Eurasian x American wigeon hybrids. A small amount of green around a Eurasian Wigeon's eye, however, is within normal variation and by itself is not a sign of hybridity.

\section{American Wigeon (Mareca americana)}

Status: Common transient; uncommon winter resident; rare summer visitant northwest, casual elsewhere in summer.

Documentation: Specimen: female, 27 Mar 1900, St. Louis (AMNH 436129).

Habitat: Ponds, lakes, and marshes.

Spring: Migrants begin appearing in late Feb, with peak in late Mar/early Apr. Small numbers regularly linger through May. High counts, both at Loess Bluffs: 4,000, 15 Mar 1983 (FL); 2,000, 14 Mar 1988.

Summer: There are now over 15 records for the northwestern part of the state without any evidence of breeding. There are scattered observations elsewhere with records even from the southeastern corner at Otter Slough: male, 22-28 Jul 2007 (JE, JU); male, 13 Jul 2009 (CB). High counts, all at Loess Bluffs: 12, 4 Jun 1967 (FL); 5, 4 Jun 1996 (DE); 4, 20 Jun 2013 (T. Gaines, L. Olpin).

Fall: Migrants begin appearing by late Aug and occasionally by mid-Sep relatively large concentrations may be observed, e.g., 500, 17 Sep 1967, Loess Bluffs (FL). However, typically large numbers are not widespread until mid-Oct, with peak in late Oct/early Nov. Concentrations in the hundreds of birds can be observed through Nov. High counts, Loess Bluffs (refuge data): 7,332, 25 Oct 2000; 6,000, 29 Oct 2007.

Winter: The largest concentrations are seen in the southeastern part of the state in winter. CBC high counts: 4,000, 27 Dec 1963, Mingo; 1,945, 30 Dec 1996, Big Oak Tree; 1,700, 28 Dec 1997, Big Oak Tree. 


\section{Mallard (Anas platyrhynchos)}

Status: Common transient and winter resident; locally rare to uncommon summer resident.

Documentation: Specimen: male, 25 Feb 1905, Bigelow (UCLA 14256).

Habitat: All bodies of water and harvested cornfields.

Spring: The most abundant duck during migration. Winter populations are augmented by migrants during the latter half of Feb. Peak is typically in mid-Mar, but numbers remain high into early Apr. By early May only small flocks are observed. High counts, Loess Bluffs (refuge data): 100,000, 12 Mar 1967 (HB); 81,030, 20 Mar 1998.

Summer: Late migrants are often seen into early Jun. Locally a low-density breeder throughout the state, with the highest concentrations at northern refuges. High counts during the core of the summer at a single site are typically $<30$ individuals. High counts, both at Otter Slough by CB: 104, 24 Jul 2009; 86, 27 Jul 2010.

Fall: Migrants reappear in Aug, but large numbers are not encountered until early Oct, with an impressive peak in late Nov. If the fall is mild, huge concentrations remain until water freezes. High counts: 250,000, 16 Nov 2014, Dunklin Co. (TJ); 193,300, 11 Dec 2006, Loess Bluffs (refuge data); 168,000, 18 Nov 1968, Loess Bluffs (HB); 160,000, 28 Nov 1963, Loess Bluffs (HB).

Winter: It remains quite common throughout the winter, especially in areas with open water. High counts: 210,000, 14-20 Dec 1958, Loess Bluffs (K. Krum); 94,000, 7-8 Jan 1963, Loess Bluffs (HB); 70,929, 19 Dec 1997, Four Rivers CBC.

\section{American Black Duck (Anas rubripes)}

Status: Uncommon transient and winter resident.

Documentation: Specimen: male, 9 Dec 1949, Holt Co. (KU 39026).

Habitat: Ponds, lakes, marshes, and flooded timber.

Spring: More frequently recorded in the eastern half of state, with peak in Mar. There are a few documented records for May: ad female, 24 May 1997, Eagle Bluffs (PM); 2, 14 May 2005, Boone Co. (PM, BJ, BG, AF); 1, 30 May 2005, Riverlands (JE, CM, JM). Several other May reports of this species may pertain to Mottled Duck.

Summer: The three nesting records listed in Robbins and Easterla (1992) likely pertain to Mottled Duck (see species account). To date, there is no definitive record for this species during Jun or Jul; thus any summer record should be carefully documented.

Fall: There are a few reliable observations from the second week of Aug with a gradual increase in numbers that peak in Nov. Earliest dates: 1, 11 Aug 2001, Riverlands (CM). High counts: all of $<10$ individuals for this season. A high count of ca. 850 from Loess Bluffs in 1962 that was included in Robbins and Easterla (1992) is now considered questionable. 
Winter: Observed in relatively small numbers across the state, with the highest numbers consistently reported from the southeast corner. $C B C$ high counts, all on Big Oak Tree: 85, 17 Dec 2009; 65, 17 Dec 2007; 60, 15 Dec 2006. Extraordinary high counts for the Mingo CBC during the early to mid-1960s are considered erroneous (fide BE).

Comments: In addition to the issue of confusion with Mottled Duck, observers should be aware that hybrids between American Black Duck and Mallard are common; in fact, upon close examination most, if not all (?), birds seen in the state exhibit signs of hybridization.

\section{Mottled Duck (Anas fulvigula)}

Status: Casual transient and summer visitant; provisional summer resident. Documentation: Specimen: ad male, 20 Nov 2009, Bob Brown (N. Giessman; MU 3612).

Habitat: Marshes and ponds.

Spring: Two documented records: 1, photos, 22-30 May 2014, near Hornersville Swamp CA (TJ); female, photos, 9-10 May 2015, Eagle Bluffs (BJ, CB et al.).

Summer: There is a single definite record for this period: male, photos, adjacent to Otter Slough, 2 Jun - 16 Jul 2009 (Robbins et al. 2010a). However, nesting records of American Black Duck during 1962 and 1973 at Loess Bluffs and Schell-Osage, respectively, likely pertain to Mottled Duck (summarized in Robbins and Easterla 1992). At that time observers were not aware of the possibility of Mottled Duck (Robbins et al. 2010a), even though the species was documented breeding at Cheyenne Bottoms, Barton Co., Kansas from at least 1963 to 1977 (Thompson et al. 2011).

Fall: In addition to the specimen above there are four additional fall records: female, photos, 13 Aug 2006, BK Leach (SS, JE; this record was brought to light after Robbins et al. 2010a); female, photos, 28-29 Aug 2011, Confluence SP (M. Andrews, JU); 1, 1 Sep - 30 Oct 2011, Otter Slough (CB); 1, photos, 11 Nov 2014, Loess Bluffs (M. Stewart).

Comments: It is likely that Mottled Ducks occurring in Missouri represent the subspecies maculosa of Texas and Louisiana, which is somewhat darker in plumage than nominate fulvigula of Florida. Observers should also be aware that hybridization with Mallard, already a major problem in the Florida population, may turn out to be an issue in the maculosa population as well. Thus any apparent Mottled Duck found in Missouri requires close scrutiny for signs of hybridity.

\section{Northern Pintail (Anas acuta)}

Status: Common transient; accidental summer resident in northwest; rare summer visitant; uncommon winter resident.

Documentation: Specimen: male, 25 Feb 1905, Bigelow Marsh (UCLA 14256).

Habitat: Marshes, ponds, lakes, rivers, and flooded timber. 
Spring: Migrants begin arriving in late Feb with peak typically during the third week of Mar. By mid-Apr numbers are greatly reduced and only small numbers are seen during May. High counts, all at Loess Bluffs (refuge data): 145,000, 25 Mar 1965 (HB); 24,050, 20 Mar 1998; 19,040, 13 Mar 2001.

Summer: Regularly seen in small numbers in the northwest, although there are only three documented breeding records. As with Northern Shoveler, Harris (1921) mentioned that a few pairs probably bred in Platte and Buchanan counties in 1921, but more precise documentation was not obtained until a family was seen during the summer of 1971 at Loess Bluffs (HB), and a hen was flushed from a nest containing nine eggs on 20 May 1990, Bigelow Marsh (DE). There are now several observations for even the southeastern corner of the state. High counts: 20, 4 Jun 1967, Loess Bluffs (FL); 15, 17 Jun 1973, Loess Bluffs (FL); 10, 16 Jun 2013, Otter Slough (GSa et al.).

Fall: Small flocks begin arriving during the latter half of Aug, and by early Sep thousands may be seen at refuges. Numbers continue to increase with peak in late Oct/early Nov. High counts: 86,500, 29 Oct 1998, Swan Lake (BO); 71,815, 13 Nov 2006, Loess Bluffs (refuge data).

Winter: Relatively large concentrations, in the thousands, are seen in Dec and again in Feb, but during the heart of winter it is uncommon. High counts: 25,245, 3 Feb 2011, Otter Slough (CB); 25,002, 18 Dec 2017, Big Oak Tree CBC.

\section{Green-winged Teal (Anas crecca)}

Status: Common transient; rare summer visitant in north, casual in south; common winter resident in south, rare in north.

Documentation: Specimen: female, 14 Nov 1965, near Forest City, Holt Co. (KU 51004). Habitat: Marshes, ponds, lakes.

Spring: Migrants begin arriving in late Feb with peak in late Mar/early Apr. By midMay it is rare, but regularly seen in small numbers through the end of the month. High counts: 25,000, 3 Apr 1966, Trimble/Loess Bluffs (FL); 22,200, 19-25 Mar 1967, Loess Bluffs (HB).

Summer: A rare but regular summer visitant in the northwestern corner, less frequent in other areas north of the MO River. It is casual in the southern half of the state, with most observations from Otter Slough. High counts: 10, 3 Jul 1990, Loess Bluffs (DE); two counts of 8 birds at Loess Bluffs in Jun.

Fall: Migrants begin to reappear in Aug, with large concentrations by the end of Aug/ early Sep. Numbers continue to increase until peak, typically in late Oct/early Nov. Relatively large numbers, in the hundreds/low thousands, may still be present through early Dec. High counts: 55,100, early Nov 1963, Loess Bluffs (HB); 27,212, 19 Nov 2007, Loess Bluffs (refuge data). 
Winter: Locally common in the south, much rarer in the north. As with almost all waterfowl, numbers vary considerably with the severity of the winter. High counts, both on the Four Rivers CBC: 7,200, 19 Dec 1997; 7,000, 14 Dec 2001.

Comments: The Palearctic nominate subspecies has not been recorded in Missouri, although it has been recorded from a number of areas in North America. Some authorities consider it as a separate species.

\section{Canvasback (Aythya valisineria)}

Status: Common transient and winter resident along Mississippi River; uncommon transient and rare winter resident elsewhere; casual summer visitant along Mississippi River, accidental elsewhere.

Documentation: Specmen: male, 25 Oct 1972, Maryville SL (KU 117699).

Habitat: Large rivers and lakes.

Spring: Migrants augment winter populations during the latter half of Feb/early Mar. Peak of migration is in Mar, with decreasing numbers in Apr. By May, only a few strays are observed, with occasional birds lingering until the end of the month. High counts along the Mississippi River, St. Louis: 5,000 - 10,000, early Mar 1963 (RA); 7,000, 5 Mar 1967 (JEC). High counts away from Mississippi River: 2,965, 25 Mar 1993, Loess Bluffs (refuge data); 2,000, 31 Mar 1974, Loess Bluffs (FL).

Summer: There are at least 10 records from the Mississippi River area at St. Louis and at least three observations for Loess Bluffs. High counts: 5, 1 Aug 1962, Loess Bluffs (HB) are presumed birds that oversummered, not extremely early migrants; 3 (2 males, 1 female), 4 Jun 1996, Loess Bluffs (DE).

Fall: The first migrants typically do not arrive until the last ten days of Oct, with large numbers appearing in Dec, especially on the Mississippi River. Earliest dates: 1, 3 Oct 1980, Loess Bluffs (FL); 3, 10 Oct 1977, Maryville SL (DE). High counts, along Mississippi River at Riverlands: 1,800, 8 Dec 2002 (PB); 500, 10-20 Nov 1992 (m.ob.); in west, Loess Bluffs (refuge data): 300, 23 Nov 2009; 220, 12 Nov 1998.

Winter: As with every other season, this species is most common along the Mississippi River, where impressive concentrations may be present. Typically, the largest numbers do not appear until there is widespread ice on the river upstream. It is much less common at this season in all other areas of the state. High counts: 5,000-6,000, second week of Jan 1975, Alton Dam (RA); 4,000, Jan 1995, Riverlands (RA et al.); 4,000, 30 Dec 2001, Riverlands (BR).

\section{Redhead (Aythya americana)}

Status: Uncommon transient; casual summer visitant; rare winter resident.

Documentation: Specimen: male, 24 May 1968, Bigelow Marsh (KU 117670).

Habitat: Marshes, lakes, rivers. 
Spring: Migrants begin arriving in the north with the opening of water. Peak is typically in mid-Mar. Only small numbers are seen after mid-Apr and it is rare in May; however, it is occasionally seen even during the last week of May. High counts: 1,200, 19 Mar 1939, Bean Lake, Platte Co. (WC); 1,000, 5 Mar 1967, St. Louis (JEC); 500, 1 Mar 1995, near Blairstown, Henry Co. (MR, SA, CH).

Summer: At least thirteen records, with the majority from the northwest. Although pairs have been seen on a few occasions at Loess Bluffs, there still is no evidence of breeding. There are no records for the southeast, but there are two for the southwest: male, entire summer 1996, L. Taneycomo, Taney Co. (JHy); 2, 3-4 Jun 2006, Greene Co. (D. Rising, J. Rives). High count: 3 pairs, 20 Jun 1990, Loess Bluffs (R. Bell).

Fall: The first arrivals typically appear in mid-Oct, with numbers increasing until peak in early to mid-Nov. Earliest dates: 1, 14 Aug 2004, Lewis and Clark SP (KM); 1, 1 Oct 2012, Smithville Lake (DW). High counts: 1,000, 12 Nov 1992, Smithville Lake (CH); 935, 16 Nov 2000, Swan Lake (H. Lambert-Doherty).

Winter: Compared to most other waterfowl, this species is scarce and only seen in small numbers, even in the southeastern corner. There have been years when either none or a total of a single bird has been recorded on the CBCs. High CBC counts: 150, 17 Dec 2014, Four Rivers; 75, 19 Dec 1997, Four Rivers; 46, 18 Dec 1998, St. Joseph.

\section{Ring-necked Duck (Aythya collaris)}

Status: Common transient; rare summer visitant; uncommon winter resident.

Documentation: Specimen: male, 3 Mar 1936, Rocheport, Boone Co. (MU 262).

Habitat: Marshes, lakes, rivers.

Spring: Migrants augment the winter population in late Feb. Peak is usually during the first half of Mar, but occasionally large concentrations, in the hundreds or low thousands, are observed through mid-Apr. Regularly seen into mid-May at northern refuges, it is rare thereafter. High counts: 7,500, 4 Mar 2012, Loess Bluffs (JB); several counts of 5,000 birds in early to mid-Mar at Loess Bluffs and Swan Lake.

Summer: A rare summer visitant statewide, with most observations of single birds at northern refuges. High counts: 8, 10 Jun 2012, Mingo (CB); 7, 27 Jun - 10 Jul 2007, Otter Slough (SS, BJ, JE, PW).

Fall: The first migrants begin to appear in late Sep, gradually building in numbers through Oct, with a major influx in early Nov. Peak is typically in mid-Nov. High counts: 10,000, 5-6 Nov 2013, Maryville SL (DE); 4,500, 27 Nov 1998, Loess Bluffs (MR); 4,180, 4 Nov 2003, Loess Bluffs (TR); 4,000, 3 Dec 2001, Swan Lake (SK).

Winter: This is one of the most common diving ducks at this season. Large rafts are occasionally seen on the Mississippi River and large concentrations are typically 
present in the bootheel at Mingo and Duck Creek. High counts from the Mingo CBC: 8,450, 28 Dec 2013; 7,171, 29 Dec 2001; 7,161, 27 Dec 1997; 6,338, 18 Dec 1993.

\section{Greater Scaup (Aythya marila)}

Status: Uncommon transient and winter resident; accidental summer visitant.

Documentation: Specimen: female, 10 Nov 1972, Maryville SL (KU 117879).

Habitat: Rivers, lakes, and marshes.

Spring: This species is less common than the Lesser Scaup at all seasons. Migrants augment wintering birds in late Feb, with most observations during Mar. The species is regularly seen in small numbers through mid-Apr and there are several records of single birds during the first half of May. High counts: 95, 13 Mar 2013, Maryville SL (DE); 85, 5 Mar 2004, Lake Jacomo (RM). Latest dates: male, 20-25 May 2012, Eagle Bluffs (RD, N. March, KA); female, 9-19 May 2001, Loess Bluffs (DE, KG, JH et al.).

Summer: Only one record: female, 7 Jun 1976, Bigelow Marsh (DE, MR).

Fall: The first migrants typically appear in late Oct with a dramatic increase in numbers in early Nov. Peak is usually in mid-Nov. If water remains open, relatively large numbers remain through the winter. Earliest dates, both at Maryville SL by DE: 1, 18 Oct 1986; 1, 20 Oct 1985. High counts: 140+, 9 Dec 2004, Lake Jacomo (KM); 61, 10 Nov 2013, Maryville SL (DE); 60, 16 Nov 1977, Maryville SL (DE).

Winter: Birds remain in north until water freezes. High counts, all at Lake Jacomo: 153, 2 Jan 2010, Lake Jacomo (MB); three observations of ca. 100 in early Jan 2000, 2003, 2006. This species may be much more common on the Mississippi River than observations indicate, as scaup are often at too great a distance to determine species, especially if birds are not observed in flight.

Comments: See remarks under Lesser Scaup concerning population trends.

\section{Lesser Scaup (Aythya affinis)}

Status: Common transient; rare summer visitant; uncommon winter resident.

Documentation: Specimen: 4 May 1879, Charleston, Mississippi Co. (MCZ 42744).

Habitat: Rivers, lakes, and marshes.

Spring: Much more common than Greater Scaup at all seasons, with the largest concentrations occurring on the Mississippi River. Birds begin arriving in Feb with the peak typically in late Mar, but large numbers, in the thousands, may be observed through the first half of Apr. Regularly seen through mid-May. High counts: 50,00070,000, during Mar 1963, St. Louis (RA); 20,000, 21 Mar 1965, Alton Dam (RA et al); 12,810, 21 Mar 2001, Loess Bluffs (refuge data).

Summer: Late migrants are regularly seen into the first week of Jun, afterwards usually only 1-2 birds remain and most of these may be injured or sick individuals. Although 
there are records that span the state, most are from the Loess Bluffs area. High counts: 7, 2 Jun 1995, Loess Bluffs (MR); 6 (male, 5 females), 2 Jun 2013, Loess Bluffs (MR).

Fall: The earliest migrants appear at the end of Sep. The species remains rare until about the third week of Oct. Peak occurs in mid-Nov, with relatively large numbers seen into Dec. High counts: 6,500, 5-6 Nov 2013, Maryville SL (DE); 6,000, 14 Nov 1970, Loess Bluffs (FL); 6,000, 6 Nov 1978, Browning Lake, Buchanan Co. (FL).

Winter: Relatively common at most open, large bodies of water, with the largest numbers on the Mississippi River. High count: 4,000-6,000, Jan 1995, Riverlands (RA et al.).

Comments: Both species of scaup have suffered severe declines since the early 1980s with record lows on the continent recorded in 1998. This is reflected in the Missouri data, as numbers seen on the Mississippi River at St. Louis are now greatly reduced compared to what was observed during the 1960s-1970s.

\section{Harlequin Duck (Histrionicus histrionicus)}

Status: Casual transient; accidental winter visitant.

Documentation: Specimen: sex?, female plumage, 3 Nov 1972, Maryville SL (KU 117695).

Habitat: Rivers, reservoirs, and lakes.

Spring: Single record: 1, collected (specimen not located), 21 Mar 1897, Montgomery Co. (E. Parker; Widmann 1907).

Fall: Three additional observations beside the above specimen record: 1, collected (specimen not located), 29 Oct, prior to 1884, St. Charles Co. (Widmann 1907). Hurter (1884) published a list of birds, which included the above record that he collected in the St. Louis area. The other two records: female, 22 Nov 1970, Little Dixie Lake, Callaway Co. (I. Adams, BG); ad male, photos, 24 Nov - 6 Dec 2010, Maryville SL (DE et al.).

Winter: Only one record: female, photos, 30 Jan - 6 Feb 1999, Riverlands (SD et al.).

Comments: In addition to the above records, Harris (1919b) listed two records for Jackson County (now within the Kansas City city limits) without specific dates: 1, on the Missouri River, at Eaton Tower; 1, shot in 1887, at Lake City.

\section{Surf Scoter (Melanitta perspicillata)}

Status: Rare transient; rare winter resident on Mississippi River, casual in winter elsewhere.

Documentation: Specimen: female, 19 Apr 1969, Maryville (KU 117607).

Habitat: Rivers, lakes, ponds.

Spring: Most frequently seen from late Feb through Mar, but there are a number of Apr and at least eleven May records. High counts: 8, photos, 24 Apr 2016, Little Prai- 
rie CA, Phelps Co. (B. Nelson et al.); 4, 6 May 1995, Riverlands (JVB). Latest dates: female, photos, 23 May 2013, Fellows Lake (GS, CBu); female, photos; 10-19 May 2003, Bethel Park, Boone Co. (J. Leonatti, C. Gerhardt et al.); female, photos, 12-14 May 1994, Mound City, Holt Co. (DE et al.); ad male, 11-13 May 2013, Riverlands (JM, CM, D. Sheets).

Fall: This scoter is far more numerous than the other scoters and is more consistently seen in fall than spring. Immatures comprise the majority of birds observed. The first individuals arrive in mid-Oct, with peak in late Oct/early Nov. Earliest dates: 1, 12 Oct 1986, Maryville SL (DE); 3 observations for 13 Oct. High count: 16, 15 Nov 2002, Riverlands (CM et al.).

Winter: At least thirteen records, all but one of single birds, spanning the entire period with most from the Mississippi River at St. Louis. High count: 6, 21 Dec 2006, Riverlands (RD, PW).

\section{White-winged Scoter (Melanitta fusca)}

Status: Rare transient and winter resident.

Documentation: Specimen: female, 25 Oct 1972, Maryville SL (KU 117553).

Habitat: Rivers, reservoirs, and lakes.

Spring: Less frequently recorded in spring than fall and winter. All records but three are during late Feb and Mar. Only Apr record: 1, 4 Apr 1977, St. Louis (F. Hallett). Two May records: 1, 30 May 1955, Alton Dam (RA); 1, 14 May 1991, Duck Creek (BL). High counts: 5, 1 Apr 2011, Fellows Lake (CBu); 3, 6-7 Mar 1953, Harbor Point, Mississippi River, St. Charles Co. (JEC, RA); 3, 6 Mar 2004, Riverlands (CM, JM).

Fall: As with the other scoters the initial birds do not appear before mid-Oct. Most records are concentrated in late Oct/early Nov and primarily involve immatures. Earliest dates: 2, 15 Oct 1977, Loess Bluffs (MR, TB); 1, 17 Oct 1970, Little Dixie Lake, Callaway Co. (I. Adams, BG). High counts, both from the Maryville SL by DE: 11, 28 Oct 2012; 10 imm, 3 Nov 1984.

Winter: Records span the entire period, with most from the Mississippi River. High counts: 7, 5 Jan 1987, Springfield (m. ob); 5, 14 Feb 1976, Labadie, Franklin Co. (D. Hays).

\section{Black Scoter (Melanitta americana)}

Status: Rare transient; casual winter resident along Mississippi River.

Documentation: Specimen: female, 20 Oct 1976, Maryville SL (KU 117599).

Habitat: Rivers, reservoirs, and lakes.

Spring: At least twelve records that span the period into mid-May, with no discernible peak. Records are widespread across the state. High count: 4, 4 Apr 2009, Riverlands 
(JE). Latest dates: female, 8-24 May 1993, Loess Bluffs (DE et al.); pair, 12 May 1981, Maryville (TE); imm, 11 Mar 2003, Big Lake SP (TR).

Fall: Regularly reported, the vast majority immatures, at the Maryville SL. The first birds appear at the end of Oct, with peak in early to mid-Nov. Few are seen in Dec. Earliest dates: 3, 16 Oct 1976, Chain of Rocks, Mississippi River (JE); 2, 22 Oct 2000, Lake Jacomo (CH). High counts: 27 (3 ad males, 24 female plumaged), 15 Nov 1977, Alton Dam (C. Spener et al.); 18, 11 Nov 2008, Riverlands (DR et al.).

Winter: There are at least twelve records that span the entire period, all of them along the Mississippi River at St. Louis: High counts: 7, 20 Dec 1950, Alton Dam (JVB); 3, 16 Dec 1994, Riverlands (DB et al.); 3 imm/females, 26 Dec - 18 Jan 2006-7, Riverlands (JU, DR).

\section{Long-tailed Duck (Clangula hyemalis)}

Status: Rare transient and winter resident.

Documentation: Specimen: female, 1 Dec 1968, 10 miles south of Gravois Mills, Morgan Co. (KU 117883).

Habitat: Rivers, reservoirs, and larger lakes.

Spring: Wintering birds and migrants are regularly seen through Mar with records throughout Apr and six May records from across the state. High count: 4, 15 Mar 2014, Lions Lake, Washington Co. (KA). Latest dates: male, 28 May 2005, Rosecrans Airport (LL); 1, 24 May 1985, Lake Jacomo (CH, RF); imm that molted into first-summer plumage, late Jan-24 May 1993, Riverlands (m. ob.).

Fall: Most records are from mid-Nov into early Dec. There are only two Oct records: ad male, 13 Oct 1999, Smithville Lake (MR); 1, 28 Oct 1981, Alton Dam (BRu). High count: 4, 21 Nov 1983, Greene Co. (N. Fay).

Winter: Most records are from the Mississippi River and the larger reservoirs. High counts: flock of 12, most of Jan 1950, Mississippi River at Portage Des Sioux, St. Charles Co. (m. ob.); 4, 21 Jan 1991, Table Rock Lake (PM, TB, M. Corder); 4, 15 Feb 1992, Smithville Lake (CH, RF, L. Moore).

\section{Bufflehead (Bucephala albeola)}

Status: Uncommon transient and local winter resident; accidental summer visitant.

Documentation: Specimen: male, 29 Mar 1969, Maryville (KU 117693).

Habitat: Lakes, rivers, and marshes.

Spring: Migrants begin appearing in late Feb with peak in late Mar. Relatively large flocks (50-100/day) are seen through mid-Apr, with only small flocks and single birds observed during the latter half of Apr into early May. High counts: 3,500, 24 Mar 1985, Loess Bluffs (FL); 750, 10 Mar 2012, Loess Bluffs (J. Hawkins); 400+, 31 Mar 2010, Maryville SL (DE). Latest dates: male, 24 May 1997, Chloe Lowry Marsh CA, 
Mercer Co. (SK, TM); 1, 23 May 2006, Riverlands (JU); female, 20 May 2002, Loess Bluffs (DE).

Summer: Two records, both at Riverlands: male 16-31 Jul 1992 (RA et al.); male, photos, 31 May-26 Jun 2014 (D. and M. Marjamaa et al.).

Fall: The initial migrants do not appear until the end of Oct, but shortly thereafter large numbers can appear with peak typically during the latter half of Nov. Earliest dates: 1, 1 Sep 2004, Loess Bluffs (LL); three observations for 18 Oct, all in the north. High counts: 381, 3 Nov 1991, east-central MO (PM, TB); 280, 22 Nov 2013, Smithville Lake (DW); 200+, 24 Nov 2003, Swan Lake (SK); 200+, 18 Nov 2008, Loess Bluffs (DE).

Winter: A locally uncommon winter resident on the Mississippi River and the larger reservoirs and lakes. High counts, all on CBCs: 163, 27 Dec 1997, Taney Co.; 161, 3 Jan 2004, Taney Co.; 108, 18 Dec 1993, Mingo.

\section{Common Goldeneye (Bucephala clangula)}

Status: Common transient and winter resident except the southern third of the state where uncommon; casual summer visitant.

Documentation: Specimen: male, 3 Feb 1968, 10 miles south of Gravois Mills, Morgan Co. (KU 117887).

Habitat: Rivers, lakes, and marshes.

Spring: The largest concentrations are encountered on the Mississippi River and the large reservoirs in the north at all seasons. Wintering birds begin to leave as soon as ice melts. This goldeneye is regularly seen in moderate concentrations (40-100 individuals) through Mar, with smaller flocks encountered through Apr, and it is rare by early May. High counts: 3,532, 12 Mar 2007, Loess Bluffs (refuge data); 1,720, 18 Mar 2008, Loess Bluffs (refuge data). Latest dates: female, 30 May - 1 Jun 2002, Loess Bluffs (DE, PK); 2 males, 27 May 2005, Riverlands (CM).

Summer: There are several records, some which involved injured birds, primarily along the Mississippi River: 1, 26 Jun 1939, St. Charles Co. (L. Ernst, W. Short); 1, 19 Jun 1993, Riverlands (K. Palmer); male and injured female, multiple dates during summer 2000, Riverlands (CM, F. Holmes, D. Herwig); male, multiple dates in Jun 2004, Riverlands (m. ob.); unmated male and female, photos, 23 May - mid-Jul 2006, Loess Bluffs (B. Lomas, N. Peterson); 2 males, 1 female, late May through at least 24 Jun 2012, Riverlands (JU, JM et al.); injured female, 26 Jun 2014, Lake Remembrance, Jackson Co. (MB).

Fall: Typically not seen until the end of Oct, with large numbers appearing at the end of the period. Earliest dates: 2, 29 Sep 1996, Lake of the Ozarks SP, Camden Co. (SA); 1, 11-15 Oct 2012, Smithville Lake (DW); many observations early Nov. 
Winter: Common in the northern half of the state along the two major rivers and on large reservoirs, much less common in the southern third of the state. High counts: 5,000, 13 Jan 2001, Riverlands (DR); 2,500, 19 Feb 1989, between mouth of Missouri River and Elsah, Illinois (RG); 2,500, Jan 1995, Riverlands (m. ob); 2,000, 20 Jan 2009, below Canton Dam (MR).

\section{Barrow's Goldeneye (Bucephala islandica)}

Status: Casual transient and winter visitant.

Documentation: Photograph: ad male, 12 Dec 2011, near Ectonville, Clay Co. (C. Anderson; photos of mounted specimen in MBRC files).

Habitat: Rivers and lakes.

Spring: There are four records: male, 29 Feb 1984, near Fayette, Howard Co. (C. Royall); 1, 14 Mar 1962, Fellows Lake (F. Shumate, P. Weber); $1^{\text {st }}$-year male, 29-30 Mar 1947, St. Charles Co. (JEC, K. Wesseling); male, 3 Mar 2003, Riverlands (E. McCullough).

Fall: Three of the four fall records are of shot birds: bird shot fall 1890 at New Madrid, New Madrid Co. (see Fulvous Whistling-Duck account concerning locality; Sparks 1891, Widmann 1907); another shot third week Nov 1918, on Missouri River above Kansas City (R. Holland); male at Lake Jacomo, 10 Dec 1972 (MM; Rising et al. 1978); and the shot bird mentioned under Documentation.

Winter: There are only five records: male, 20-21 Dec 1975, Lake Jacomo (m. ob.); female, 8 Jan 1977, Chain of Rocks, Mississippi River, St. Louis (Eades et al. 1978); male, 15 Jan 1973, present for over two weeks, Alton Dam (D. McClaren et al.); ad male, photos, 24-26 Jan 1999, Riverlands (BR, K. Lannert); ad male, 12-27 Jan 2001, Riverlands (CM et al.).

Comments: Care must be exercised involving reports of Barrow's, as hybrids between it and Common are not rare (Martin and Di Labio 1994). An adult male that exhibited hybrid characters was photographed, 26 Feb - 5 Mar 1994, Muskrat Lake, Buchanan Co. (LL, LG), and at the same locality the following year the presumed same bird, photos, was present from 24 Feb - 11 Mar 1995 (m. ob.). What may have been the same bird was seen at Wyandotte Co. Lake., Kansas on 27 Dec 1996 (LM).

\section{Smew (Mergellus albellus)}

Status: Accidental winter visitant.

Documentation: Photograph; fig. 5.

Habitat: Rivers and lakes.

Record: An adult male, photographed, 13 Jan - 5 Mar 2001, Riverlands (MG, RM et al.). The bird was thought to be of wild origin because it was not banded and the date was within the period of vagrancy for North American occurrences. 


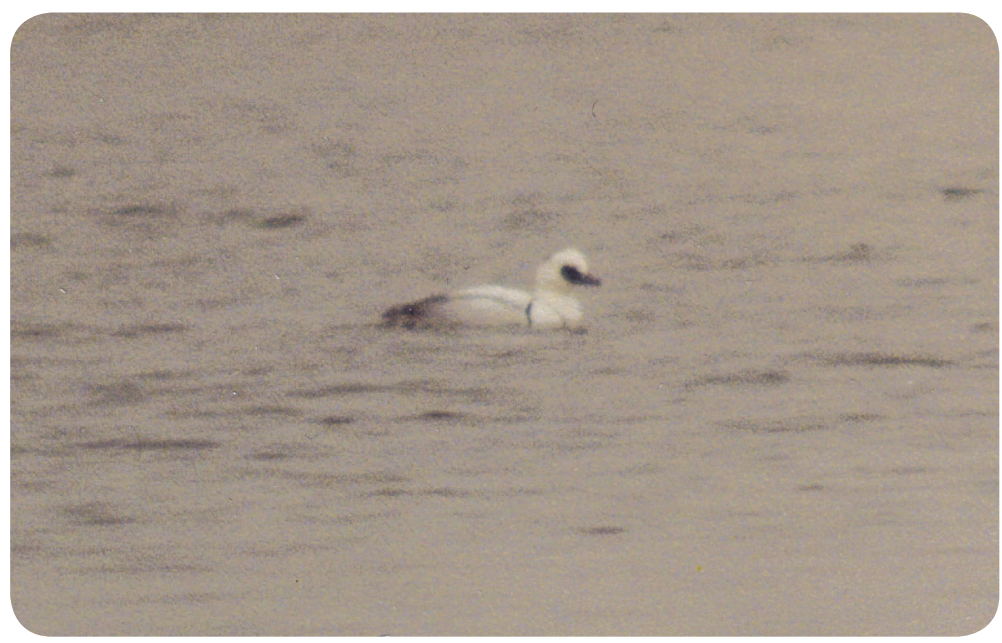

Fig. 5. Adult male Smew at Riverlands on 13 January 2001. Photo by Jim Malone.

\section{Hooded Merganser (Lophodytes cucullatus)}

Status: Common transient; locally common summer resident in southeast, rare elsewhere. Locally common winter resident in south, uncommon and local in north.

Documentation: Specimen: female, 8 Apr 1899, Kansas City (KU 39034).

Habitat: During the breeding season primarily found on oxbows, wooded marshes, slow moving rivers and streams; in migration and winter on lakes and rivers.

Spring: Migrants appear in late Feb and peak is generally in mid-Mar, with decreasing numbers through mid-Apr. Birds seen in late Apr and May are primarily summer residents. High counts, all from Loess Bluffs (refuge data): 578, 11 Mar 2009; 299, 28 Feb 2011; 214, 12 Mar 2007.

Summer: This merganser breeds throughout the state in small numbers with the largest concentrations at refuges. Not surprisingly, given that there has been considerable degradation and disappearance of wetlands, this species formerly was much more abundant, especially in the swamps of the Mississippi Lowlands (Widmann 1907).

Fall: Migrants begin appearing in early Oct, but large numbers are not observed until the end of Oct/early Nov. Large numbers remain at a few reservoirs, especially at Montrose Lake where warm water from a power plant keeps water from freezing. High counts: 2,200, 4 Nov 2000, Thomas Hill Reservoir (EW); 2,100, 1 Dec 2011, Montrose (MR); 600, 6 Nov 1991, Thomas Hill Reservoir (S. Hazelwood).

Winter: In most areas of the state only small numbers are observed; however, at the Montrose power plant in Henry Co. impressive concentrations are present annually throughout the winter: 2,643, 17 Dec 2011, Montrose CBC; 996, 14 Dec 2011, Mon- 
trose CBC; 940, 20 Jan 2003, Montrose (MR); 575, 16 Jan 2011, Montrose (MR, M. Andersen, JK); 550, 31 Jan 2010, Montrose (MR, M. Andersen, JK).

Comments: There are multiple observations in the state of hybrids between male Hooded Merganser and female Common Goldeneyes.

\section{Common Merganser (Mergus merganser)}

Status: Common transient and winter resident except in the southern third of the state where uncommon; casual summer visitant.

Documentation: Specimen: female, 20 Nov 1948, Saline Co. (KU 39036).

Habitat: Rivers and lakes.

Spring: Status and distribution is very similar to Common Goldeneye. The relatively large wintering concentrations leave the state in Feb/early Mar. Small numbers are seen into mid-Apr, but after that typically only 1-2 birds are encountered. High counts: 2,000+, 6 Mar 1978, above Alton Dam (TB); 1,607, 3 Mar 1994, Loess Bluffs (refuge data). Latest dates: female, 26 May 2004, Current River, below Round Spring (MR, B. Barber, A. Nyari); pair, 26 May - 16 Jun 2011, Horseshoe Lake (LL).

Summer: There are several records, some of which involved injured birds: 1, 29 Jun 1993, Riverlands (K. Palmer); male, 6 Jul 1995, Loess Bluffs (DE); 1, 4 Jun 1996, Nodaway River, Holt/Andrew Co. (DE); male, 2-4 Jun 2000, Loess Bluffs (DE, JH); 3 ad males, photos, 21 Jun - 20 Jul (1 bird) 2008, Riverlands (D. Clark, CA, A. Kirkpatrick, MT); male, probably injured, 15-17 Jul 2013, Edwin Pape Lake, Lafayette Co. (KA et al.).

Fall: The first migrants appear at the end of Oct, but large numbers are typically not seen until late Nov/early Dec. Earliest dates that may have involved injured birds: 1, 3 Aug 1958, Gravois Mills, Lake of the Ozarks (DE); female, 16 Aug - 7 Sep 2008, Riverlands (M. and D. Marjamaa, BR); 2, 8 Sep 1992, Stockton Lake (JHy); very few observations until the end of Oct. High count for Nov: 365, 27 Nov 2014, Smithville Lake (DW).

Winter: Except for severe winters when most water is frozen, this merganser is much more abundant along rivers and reservoirs in the northern two-thirds of the state. High counts: 7,000+, 23 Jan 2016, Truman Dam, Benton Co. (MR, CH); 3,000+, 29 Dec 1985, Stockton Lake (MR, FL); 3,000, 16 Jan 2011, Montrose (MR, M. Andersen, JK).

\section{Red-breasted Merganser (Mergus serrator)}

Status: Uncommon transient; casual summer visitant; rare winter resident.

Documentation: Specimen: female, 20 Nov 1948, Grand Pass, Saline Co. (KU 39038).

Habitat: Rivers and lakes.

Spring: Birds begin appearing in late Feb, with relatively large numbers seen along the Mississippi River, e.g., 100, 24 Feb 2004, Riverlands (JU). Numbers continue to increase with a peak in late Mar/early Apr. Smaller numbers continue to be seen 
through early May, although occasionally relatively large flocks may even be encountered in mid-May, e.g., 53, 15 May 1975, Alton Dam (JE). It is rarely seen after midMay, but there are at least six records at the end of May. High counts: 1,000+, 20 Mar 1993, Riverlands (DB et al.); 297, 10 Apr 1980, Thomas Hill Reservoir (TB); a few counts of 250 during Mar on both sides of the state.

Summer: There are at least ten records for the June-July period, all of females except for one male and female, 6 Jun 2017, Riverlands (T. Caraway, G. Gagnon). Records span the state except for the Mississippi Lowlands.

Fall: The first migrants are seen at the very end of Oct, but numbers increase quickly and peak is typically in mid-Nov. Few are seen after early Dec. Earliest dates: 14, 27 Oct 1980, St. Joseph (FL); 1, 29 Oct 1997, Thomas Hill Reservoir (EW). High counts: 250, 5 Nov 1991, Thomas Hill Reservoir (S. Hazelwood); 250, 9 Nov 2003, Smithville Lake (S. Bingham); 150, 12 Nov 1995, Smithville Lake (CH).

Winter: Small numbers are found primarily along the Mississippir River at St. Louis and at the larger reservoirs. With the recent mild winters more are being recorded. High counts: 20, 10 Jan 2017, Lake Jacomo (E. Hough); 17, 26 Jan 2003, Riverlands (B. Schindewolf); 13 (9 males, 4 females), 19 Jan 1998, Truman Lake (MR).

\section{Ruddy Duck (Oxyura jamaicensis)}

Status: Common transient, accidental summer resident, rare summer visitant; uncommon winter resident in south, rare in north.

Documentation: Specimen: female, 25 Nov 1972, Maryville SL (KU 117565).

Habitat: Marshes, lakes, and rivers.

Spring: By the end of Feb, large numbers may be seen. Peak is normally during early to mid-Apr, with substantial numbers still seen into early May. Small numbers are routinely seen to the end of May. High counts: 2,920, 29 Mar 2001, Swan Lake (H. Lambert-Dougherty); 1,680, 7 Apr 2009, Loess Bluffs (refuge data); 1,000, 22 Apr 2008, Maryville SL (DE).

Summer: Small numbers are routinely seen through the summer, particularly at northern refuges. There are three breeding records: Jun 2003, Loess Bluffs (Bell and Durbian 2004), 2005 Loess Bluffs (R. Bell) and two nests photographed 18 Jun - 29 Aug 2008, Little Creve Coeur Lake (R. Meade). High counts of non-breeding birds: 16-23, 17-19 Jul 2002, Little Creve Coeur Lake (MBr, MT et al.); 18 (males and females), 16 Jun 2002, Maryville SL (DE).

Fall: Migrants began appearing at the end of Sep, with numbers increasing through Oct with peak typically in early Nov. High counts: 5,100, 9 Nov 2011, Maryville (DE); 2,000, 16 Oct 2000, Swan Lake (H. Lambert-Doherty); 1,683, 3 Nov 2003, Loess Bluffs (refuge data); three observations of 1,200 between from 1 Nov to 3 Dec. 
Winter: With milder winters during the past two decades this duck has become an uncommon resident in the south, primarily at reservoirs and large lakes and along the Mississippi River as far north as St. Louis. During most winters it is sporadically encountered in only small numbers in the north and may be absent there during severe winters. High counts: 283, 26 Jan 2013, Lake Wappapello (CB); 250, 20 Dec 1997, Kansas City CBC; 184, 18 Dec 1998, Four Rivers CBC.

\section{Order Galliformes}

\section{Family Odontophoridae: New World quail}

\section{Northern Bobwhite (Colinus virginianus)}

Status: Common permanent resident.

Documentation: Specimen: male, 12 May 1879, Charleston, Mississippi Co. (MCZ 41688).

Habitat: Woodland edge, hedgerows, and grasslands with scattered cover.

Comments: While still relatively common, the bobwhite has suffered a dramatic decline during the past two decades as a result of the continued conversion of grasslands to cropland, the removal of hedgerows, and suburban sprawl. It is now at its lowest population in the state since the arrival of Europeans, with estimates of a 70-90\% decline between 1965 and1995 across the United States distribution (Brennan 1999). Not surprisingly, given that most of the area has been converted to agriculture, it is least common in the Mississippi Lowlands. It reaches its highest abundance in the Glaciated Plains, although even there it has suffered significant declines. There has been a long-term decline, and for the period 2003-2013 there has been 5.01\% annual decline in Missouri (BBS data).

The Northern Bobwhite is negatively affected during winters when there is prolonged snow and ice cover. For example, the population was depressed following the severe winters of 1976, 1978, and 1983. High CBC counts: 142 (2.8), 16 Dec 1989, Grand River; 137 (1.9), 17 Dec 1983, Springfield; 127 (2.5), 20 Dec 1997, Grand River; 113 (2.8), 18 Dec 1999, Grand River.

\section{Order Galliformes \\ Family Phasianidae: pheasant, grouse, prairie-chickens, turkey}

\section{Ring-necked Pheasant (Phasianus colchicus)}

Status: Introduced; uncommon permanent resident primarily in the northern half of the Glaciated Plains; rare and more local in the southern half of the Glaciated Plains and the Mississippi Lowlands; casual elsewhere.

Documentation: Specimen: female, 21 Feb 1963, Columbia, Boone Co. (USNM 488652).

Habitat: Typically in agriculture-dominated landscape with hedgerows and brush. 
Comments: This species was initially introduced by private landowners as early as the late 1890s (Cary 1984), followed by the release of birds in 1904 by the Missouri Department of Conservation (MDC). However, a more intense effort was not initiated until the 1920s-30s. Throughout this time frame, including up to the present, additional introductions have occurred that involved several subspecies. For example, MDC released birds at 23 targeted sites in 14 counties between 1987 and 2000. The species is principally found north of the Missouri River and in several counties in the Mississippi Lowlands (Hallet 1988).

Pheasant populations fluctuate considerably from year to year. Recently, drought has had a negative influence on populations, and when levees were breached as a result of high water in the upper Missouri floodplain (Atchison and Holt cos.) in 2011, pheasant populations were severely depressed in that area. Annually, during Apr, MDC cooperates with rural mail carriers to monitor pheasant populations, and another roadside index is conducted annually during Aug. In addition, harvest figures are recorded each year. All these indices continue to indicate that the pheasant population is highest in the northwestern portion of the Glaciated Plains and is lowest in the Mississippi Lowlands. The greatest populations have been recorded in the Loess Bluffs and Marais Temps Clair areas. There has been an annual decline of $2.66 \%$ for the period of 2003-2013 in Missouri (BBS data). High counts, all on CBCs: 358 (8.4), 2 Jan 1982, Orchard Farm CBC; 196 (4.0), 27 Dec 1980, Loess Bluffs; 176 (3.2), 20 Dec 1981, Loess Bluffs.

\section{Ruffed Grouse (Bonasa umbellus)}

Status: Based on reintroductions, now a very local, rare permanent resident in the Ozark and Ozark Border regions.

Documentation: Specimen: male, 28 Nov 1906, Monteer, Shannon Co. (AMNH 353377).

Habitat: Most common at the edge of forest clearings and forest borders in large continuous matrix of forest.

Comments: Only very small, precarious populations from reintroductions persist in a few east-central counties, primarily in Callaway, Montgomery, and Warren. Prior to the 1880 s, this grouse was "numerous in most wooded parts of Missouri," but by 1900 it was considered rare (Widmann 1907). There was a complete ban on hunting by 1905 , and apparently as late as 1930-34 the species still persisted in about nineteen localities:13 in the southeast and six in the northeast (Bennitt and Nagel 1937). Initial reintroductions began in the 1940s (see McKinley 1960a), but a larger-scale program commenced in 1959, when $>4,000$ birds from Ohio and Indiana were transplanted. By the late 1990s, it was apparent that the introductions had been mostly unsuccessful (Wade 2003). Populations that persist in the above counties are remnants of those introductions.

\section{Greater Prairie-Chicken (Tympanuchus cupido)}

Status: Natural populations are extirpated; only reintroduced populations remain in remnant prairie. Formerly, an abundant permanent resident in Glaciated and Osage 
plains. Apparently, when the population reached a peak and large tracts of the forested Ozarks and Mississippi Lowlands area were removed, the species even occurred in those regions. During that period the species was thought to have occurred in every county in Missouri.

Documentation: Specimen: egg set, 5 May 1896, Sand Ridge, Clark Co. (WFVZ 110268).

Habitat: Tallgrass prairie, suitable grassland, and adjacent cultivated fields.

Comments: Sadly, the native population is extirpated, and the species is maintained only through reintroductions; even those are not self-sustaining. The presettlement Missouri population has been estimated as high as one million (Wywialowski and Christisen 1989), but based on other estimates it may have been several million. However, as early as 1880 , this grouse had already been drastically reduced and was considered rare (Widmann 1907). By 1900, it was no longer of regular occurrence in the Kansas City area, where the last nesting record was 1891 (Harris 1919b). In 1940, Schwartz (1945) estimated the population to be about 12,000 birds, but by 1983, it was known to exist in only one core area north of the Missouri River (Cannon and Christisen 1984; Christisen 1985). In 1988, it was estimated that the northern population, primarily in Audrain Co. and the surrounding area, was between 150 and 200 birds (Wywialowski 1988). Between 1983 and 1988, the male population in the state was estimated to have declined by $36 \%$, with the total state population comprising only about 3,000 individuals in 1988. At that time, two-thirds of the state's population was restricted to Barton and Dade counties.

By the late 1990s, the native population was functionally extirpated, with populations continuing to decrease and disappear. Reintroduction programs by the MDC (400 birds released from 1993-7; hundreds released during the 2000s) and the Iowa Department of Natural Resources at the Kellerton Grasslands Bird CA (beginning in 1987, then hundreds released during 2012-2013), just across the border from Harrison County, Missouri, have been unsuccessful in restoring a viable population. Prior to these reintroductions there are a number of observations of birds away from core areas: 1, 5 May 1973, Bigelow Marsh (DE); 1, 4 Mar 1983, Loess Bluffs (KG); 1, 3 May 1984, Sullivan Co. (R. Thom); 1, 17 Aug 1991, northwest of Maryville (DE). The only record for the Mississippi Lowlands, long after the region had been drained and deforested, was of a single female taken at New Well, Cape Girardeau Co., 15 Nov 1939 (H. Bolen; SEMO 50).

\section{[Lesser Prairie-Chicken (Tympanuchus pallidicinctus)]}

Status: Provisional.

Specimen: see below.

Comments: Widmann (1907) treated the species as hypothetical based on the presence of about 30 individuals in a New York market (Fulton) that apparently originated from a dealer in Pierce City, Lawrence Co., Missouri. This was brought to light by G. Lawrence who published (1877) an account of having found the 30 specimens at the 
market. Two of the Lesser Prairie-Chicken specimens that Lawrence obtained and prepared are still extant (AMNH 45207, study skin; USNM 74007, mount; both from Jan 1877). In determining the provenance of these birds, Lawrence remarked "all I talked to said they had not noticed them before this winter."

The Lesser Prairie-Chicken was much more common and widespread in the late 1800 s than it is today; apparently large numbers occasionally wandered in winter to eastern Kansas (Goss 1891). Goss collected two specimens in Dec and Jan 1878-9 in Neosho County, Kansas (KU 71641-2), and four additional extant specimens (MCZ 187193-4, 25382, 331738) were taken during Jan and Feb 1881-1894, in Anderson, Lyon, and Miami counties (Thompson et al. 2011), all within 15-45 miles of the Missouri border. In view of this, it seems quite likely that the Lesser Prairie-Chicken specimens that Lawrence examined and preserved were indeed collected in the vicinity of Pierce City, Missouri, in January 1877.

\section{Wild Turkey (Meleagris gallopavo)}

Status: Common permanent resident.

Documentation: Specimen: male, 6 Dec 1871, St. Louis (STSC).

Habitat: Forest, woodland borders, and cultivated fields adjacent to woodland.

Comments: Now a common bird throughout the state. Prior to the 1880 s, it was a common resident, although presumably less common in the prairie-dominated Glaciated and Osage plains. By 1906, apparently, it was extirpated from northern Missouri and was present in only small numbers in the Ozarks and the swampland of the Mississippi Lowlands (Widmann 1907). The estimated population for the state in 1952 was $<2,500$ birds, but through habitat manipulation and reintroduction of birds from other parts of North America (e.g., Texas) the species began to recover (Lewis 1961). By 1984, the restoration program had been so successful that hunting was permitted in all counties. Major translocations into areas where there were no or few turkeys continued until 1987, when several thousand birds were released. Prior to reintroductions, the subspecies that was found in Missouri was M. gallopavo silvestris.

Wild Turkey harvest data indicate that the highest numbers obtained are in the western Ozarks (8,052 in 2016) and the lowest in the Mississippi Lowlands (562 in 2016). About 48,000 have been harvested during the 2014-2016 period (J. Isabelle, Missouri Department of Conservation, unpublished data).

The following high counts, mostly from CBC data, demonstrate how abundant the species has become statewide: 260 in a single flock, 8 March 1996, Daviess Co. (T. Maher); 293 (5.7), 15 Dec 2013, Meramec Spring CBC; 268 (4.3), 27 Dec 2012, Cole Camp CBC; 259 (3.2), 15 Dec 2007, Springfield CBC; 238 (3.9), 14 Dec 2014, Grand River. 


\section{Order Phoenicopteriformes \\ Family Phoenicopteridae: flamingo}

\section{[American Flamingo (Phoenicopterus ruber)]}

Status: Provisional.

Documentation: Photograph: 1, 13 May - 11 Jun 1965, Loess Bluffs (HB; photo in Bluebird 33:12).

Records and Comments: In addition to the above record, there is another observation of a single bird on 1 Sep 1959 at LaGrange, Lewis Co. (Harford 1959). The origin of both of these birds is in question; they likely were escapees.

\section{Order Podicipediformes Family Podicipedidae: grebes}

\section{Pied-billed Grebe (Podilymbus podiceps)}

Status: Common transient; uncommon winter resident south, rare north; uncommon local summer resident.

Documentation: Specimen: female, 5 May 1879, Charleston, Mississippi Co. (MCZ 41953).

Habitat: Found on virtually every type of body of water during migration; primarily breeds in marshes with relatively high water levels.

Spring: Migrants began appearing as soon as there is open water. Peak is usually in mid-Apr, and relatively large concentrations can be seen into May. High counts: 380 , 17 Apr 1980, near St. Joseph (FL); 250, 12 Apr 2016, Little Prairie CA (J. Hill, T. Goodwin).

Summer: Although there are scattered breeding records throughout southern Missouri, the bulk of the populations are north of the Missouri River. High counts of nests: 151, Jun 1997, Loess Bluffs (results from 1992-97 summarized in Hilsabeck and Bell 1999); 124, 2-8 Jun 1999, Loess Bluffs (JH); 52, 8-10 Jun 1993, Clarence Cannon (BJ, L. McFarland, S. Huddlemeyer).

Fall: Migrants begin to appear in early Sept, e.g., 115, 4 Sep 1975, Maryville SL (DE), with peak typically occurring in late Sep/mid-Oct. Large concentrations are still seen through early Nov, but rapidly drop off thereafter. High counts: 540+, 28 Sep 1974, St. Joseph/Maryville area (FL, MR); 500, 25 Oct 1947, Creve Coeur Lake (JEC); 312, 9 Oct 2017, Longview Lake, Jackson Co. (K. Davis).

Winter: A local and uncommon resident, primarily in the south. Generally, the highest concentrations are at Mingo. CBC high counts: 127, 15 Dec 2007, Mingo; 81, 27 Dec 1997, Mingo; 64, 28 Dec 1965, Mingo; 55, 16 Dec 1995, Springfield. 


\section{Horned Grebe (Podiceps auritus)}

Status: Uncommon transient; uncommon winter resident in south, casual in north; accidental summer visitant.

Documentation: Specimen: female, 28 Apr 1973, Maryville SL (KU 117700).

Habitat: Reservoirs, lakes, and less frequently marshes.

Spring: Early migration, typically in late Feb, is notable in the north when water opens. Numbers build throughout Mar, with peak in late Mar/early Apr. A few birds are still seen passing through in the first half of May. High counts: 573, 15 Mar 2014, Table Rock Lake SP (m. ob.); 500, 23 Mar 2011, Spring Arm, Bull Shoals Lake (Greater Ozarks Audubon); 362, 12 Mar 2016, Stockton Lake, Cedar Co. (DBl et al.); 250, 11-25 Mar 1990, Table Rock Lake (C. Lundberg). Latest dates: 1, alternate plumage, photos, 22 May 2015, Eagle Bluffs (C. Darr); 2,18 May 1968, Table Rock Lake (N. Fay); 2, alternate plumage, 18 May 2008, Nodaway Valley CA (MR).

Summer: Single record, most likely of a very late migrant: 1, photos, alternate plumage, 11 June - 5 July 2017, Table Rock Lake (C. Smith).

Fall: There are a few records for Aug, but most years the species is not detected until early Sep and it remains rare until late Sep. Numbers increase during Oct, reaching a peak in late Nov. Large numbers are still present at southern reservoirs in early Dec. Earliest dates: 1, 10 Aug 1968, Table Rock Lake (N. Fay); 2, 14-21 Aug 1977, Maryville SL (DE). High counts: 208, 7 Nov 2015, Stockton Lake (MR, CH); 200+, 1 Nov 2015, Smithville Lake (M. McKellar, M. Nemecek); 137, 25 Nov 2007, Stockton Lake (JE).

Winter: With mild winters during the past two decades, larger numbers are wintering in the southern large reservoirs; it typically is absent from north of the Missouri River from late Dec until late Feb. High counts, all on Table Rock Lake: 459, 1 Jan 1994, Taney County CBC; 400+, 18 Feb 1990 (DE, PM, JH); 414, 28 Dec 2013, Taney Co. CBC.

\section{Red-necked Grebe (Podiceps grisegena)}

Status: Rare transient; casual winter visitant.

Documentation: Photograph, see below.

Habitat: Reservoirs, lakes, rivers, and occasionally marshes.

Spring: There are eight records, all singletons, that range from early Mar through May. Earliest records: 1, 8-9 Mar 2012, Duck Creek (CB, B. Beck); 1, $13-20$ Mar 1993, Riverlands (DB et al.). Latest date: 27 May 1984, Marais Temps Clair (L. Barber, J. Ziebol).

Fall: There are at least 20 records, with most from late Oct through early Dec. Earliest and only Sep record: 1, early Sep 1954, near Buckner, Jackson Co. (F. Bart; Rising et al. 1978). High counts: four observations involving two individuals.

Winter: There are six records: 1, 1-3 Jan 1982, Lake Jacomo (H. Gregory et al.); 1, 1-17 Jan 1983, Fellows Lake (C. Bonner et al.); 2, 18 Dec 1987, Lake Wappapello 
(BRe, SD); 1, 6-17 Feb 1994, Thomas Hill Reservoir (TB, BG); 1, 3 Jan 2011, Columbia (RD et al.); 1, 7 Dec - 10 Jan 2012-3, Lake Jacomo (m. ob).

\section{Eared Grebe (Podiceps nigricollis)}

Status: Uncommon transient west, rare east; formerly accidental summer resident in northwest; casual summer visitant; rare winter visitant.

Documentation: Specimen: 4-egg clutch, 27 Jul 1898, Manning Lake, Atchison Co. (CM E10223; Robbins 2016).

Habitat: Marshes, ponds, lakes, and reservoirs.

Spring: This grebe is more frequently encountered in the western half of the state, especially the northwestern corner. It is regular in the east, but records are sparser with smaller numbers. The first migrants typically appear in early Mar, but larger numbers are not seen until late Apr, with peak during the first half of May. Earliest date of non-wintering birds: 2, 27 Feb 1999, Lake Jacomo (MB). The largest number encountered in the state followed several days of strong WSW winds in May 1978, when this grebe was observed on many medium to large-sized bodies of water in the northwest corner. On 12 May 1978, a minimum of 130 were counted at Loess Bluffs (J. Brady), and two days later 23 were present on the Maryville SL (MR, TB). High counts under more normal conditions: 39, 15 May 1981, Loess Bluffs (FL, MR); 28, 9 May 1999, Loess Bluffs (m.ob.). High count in east: 13, 6 Apr 2009, Long Branch Reservoir (PK).

Summer: Late migrants and lingering birds are occasionally seen through the first week of Jun in the northwest corner. There are the following extralimital records: latest Jun record, 1, 17 Jun 1973, Maryville SL (MR) and only Jul record, 1, 18 Jul 2005, Four Rivers (LL, SK, JH, TR). Historically, the species bred in at least the extreme northwestern corner of the state in the late 1800s, with documented breeding at Maryville on 29 May 1889 (FMNH 224) and at Manning Lake, Atchison Co. on 27 June 1898 (CM E10223; Robbins 2016). Given that it was recorded breeding in those two counties, it very likely also bred in at least Holt County as well.

Fall: Migrants begin appearing in late Aug and appear to peak in late Sep, with smaller numbers observed through Nov. One to two individuals are regularly seen into early Dec. Earliest dates: 1, 14-21 Aug 1977, Maryville SL (DE); 4, alternate plumage, 14 Aug 1999, Schell-Osage (RF). High counts, both by DE at Maryville SL: 23, 25 Sep 1985; 9, 2 Nov 1991. High count in east: 7, in basic plumage, 20 Aug 1994, Clarence Cannon (DB et al.).

Winter: Although there are about 20 records, all but four of these are of lingering migrants into the latter half of Dec. The following are the only records during the heart of the winter: 2,10 Feb 1991, Stockton Lake (TB); 1, alternate plumage, 31 Jan 1992, Mingo (BL); 2, 29 Dec - 4 Feb 1991-2, Smithville Lake (TB, RF, CH); 1, basic plumage, 2 Jan 1995, Duck Creek (K. Adams, S. Greenberg, R. Hitson). High count: 3, 19 Dec 2015, Smithville Lake CBC. 


\section{Western Grebe (Aechmophorus occidentalis)}

Status: Rare transient; casual summer and winter visitant.

Documentation: Specimen: male, 21 Oct 1976, Nodaway Co. Lake (KU 117539).

Habitat: Reservoirs, lakes, ponds, and marshes.

Spring: Of about 20 records, the majority are from the western half of the state. There are only a couple of Mar records, and one of these likely involved a bird lingering from the winter. The majority of records are during late Apr/early May. Earliest date: 1, 16 Feb - 20 Apr 2013, Riverlands (L. Barber, DB et al.). High counts: 4, 14-16 Apr 1990, Thomas Hill Reservoir (BG, I. Adams); 4, 26 Apr 1992, Smithville Lake (RF).

Summer: Excluding birds that lingered into the first few days of Jun, there are five records: 1, 26 Jun 1939, Alton Dam (L. Ernst, W. Short); 1, 11 Jun 1967, Loess Bluffs (HB, FL, JHam); 1, present most of Jun 1974, Pony Express Lake (R. Lainy et al.); 1, 4 Jun - 5 Jul 1999, Riverlands (P. Weber, CM); 1, 18-20 Jun 2007, Lee's Summit, Jackson Co. (RF, L. Cassebolt).

Fall: There are more records for the fall, with most from the western half of the state. There is a single Aug and only two Sep records. The majority of the records are from mid-Oct to mid-Nov, with a few into early Dec. Earliest dates: 1, 7 Aug 1996, O'Fallon (E. Klass); 1, 16-19 Sep 2011, Smithville Lake (DW, PK et al.). High counts: 9, 2 Nov 1996, Smithville Lake (RF); 6, 21 Oct - 7 Nov 1967, Forest Lake, Kirksville (R. Luker); 6, 24 Oct 1999, Smithville Lake (CH, JH, M. McKellar).

Winter: There are ten records, all singletons, for this period, scattered across the state.

Comments: Hybridization between this and the Clark's Grebe is not uncommon; a bird that was photographed at Thousand Hills SP on 23-24 Oct 2011 exhibited characters of both species (PK).

\section{Clark's Grebe (Aechmophorus clarkii)}

Status: Casual transient; accidental winter visitant.

Documentation: Photograph; see below.

Habitat: All records at reservoirs.

Spring: There is a single record: 1, 5 Mar 1994, Table Rock Lake (M. Mlodinow et al.).

Fall: Four records: 27 Nov - 10 Jan 1988-9 (RF, MM, L. Moore, DE et al.): 1, photos, 18 Nov 1990 - early Feb 1991, Table Rock Lake (TB, BRe et al.); 1, 23-24 Oct 1999, joined by a second on 14 Nov, Smithville Lake (J. and E. Zellmer, CH et al.); 1, 4-25 Nov 2009, Smithville Lake (DW, KM).

Winter: Besides the two birds that lingered from the fall there is one additional observation of an adult, 27 Dec 1997, Table Rock Lake (B. Brown, J. Fitzgerald).

Comments: See remarks under Western Grebe account. 


\section{Order Columbiformes \\ Family Columbidae: pigeons, doves}

\section{Rock Pigeon (Columba livia)}

Status: Introduced; common permanent resident.

Documentation: Specimen: 3 Jan 1963, Cape Girardeau (SEMSU 16).

Habitat: Cities, towns, rural buildings, bridges, rock quarries.

Comments: Presumably this pigeon was introduced with European settlement. High counts on CBCs: 2,618 (48.3), 14 Dec 2013, Columbia; 2,142 (15.2), 19 Dec 1992, Springfield.

\section{Band-tailed Pigeon (Patagioenas fasciata)}

Status: Accidental transient and winter resident.

Documentation: Photograph; see below.

Habitat: Both records were at feeders.

Records: Two observations: 1, 29 Mar - 20 Apr 1985, Kansas City (J. Seaman et al.); 1, photos, late Nov - 20 Feb 1983-4, Marshall, Saline Co. (H. Hoey at al.; Robbins and Easterla 1992). There are three Kansas records (Thompson et al. 2011).

\section{Eurasian Collared-Dove (Streptopelia decaocto)}

Status: Uncommon permanent resident.

Documentation: Photograph: multiple on eBird checklists.

Habitat: Towns, rural areas, stockyards, grain elevators.

Comments: This Old World dove, which apparently was introduced from India to New Providence in the Bahamas during the mid-1970s, subsequently spread to Florida (Smith 1987) and now is found across much of the United States. In Missouri, no later than Feb 1998 it was documented nesting at Delta, Cape Girardeau Co., with several additional observations elsewhere that same year. Within a couple of years it was found nesting at a number of localities across the state. The four on 3 Jan 2000 at Orchard Farm were the first on a Missouri CBC. In 2005, the species expanded greatly both in distribution and numbers, for example, 150+, 1 Oct 2005, St. Joseph stockyards (LL); 100+, 5 Nov 2006, Chillicothe, Livingston Co. (SK). Now it is widespread through the state. High counts: 180, 21 Dec 2011, near Lockwood, Dade Co. (GS et al.); 167, 6 Oct 2009, Dunklin Co. (TJ). High counts on CBCs: 148 (1.5), 16 Dec 2006, Springfield; 107 (1.2), 20 Dec 2014, Springfield; 97 (1.8), 17 Dec 2005, St. Joseph.

\section{Passenger Pigeon (Ectopistes migratorius)}

Status: Extinct; formerly an abundant migrant; apparently a local breeder and winter resident.

Documentation: Specimens: male and female, 17 Dec 1896, Attie, Oregon Co. (CHAS 15460; 15462; see McKinley 1960b for clarification of the locality). 
Habitat: Primarily in mature forest and woodland, but also in other habitats.

Comments: The following is summarized from McKinley's (1960b) extensive review of the literature. It was an abundant migrant through the state with several reports of flocks so enormous that they "darkened" the sky. Spring migration extended from Feb through May, with the largest numbers reported in late Mar and Apr. In the fall, huge flocks were reported as early as Sep, and numbers continued to increase at roost sites during Oct and Nov. Nesting and winter accounts are fewer with less detail; however, there were reports of large breeding colonies in a few areas of the state and of scattered breeding pairs. Apparently large winter roosts were primarily in the southern part of the state.

Immense numbers were still reported until the 1880 s, with one enormous winter roost still persisting in Ripley Co. in 1883-4. However, after that account, there were only occasional reports in the state, with no mention of any large concentrations. Apparently the last report in Missouri was at New Haven, Franklin Co., on 26 Sep 1902 (Dr. Eimbeck; Widmann 1907).

\section{Inca Dove (Columbina inca)}

Status: Casual transient and winter resident; accidental summer resident.

Documentation: Photograph: 1, at feeder, mid-Dec - 6 Feb 1987-88, Mound City (G. Rockwell, J. Wilson et al.; Robbins and Easterla 1992).

Habitat: In towns at feeders, grain elevators, open country with scattered trees.

Spring: Two records: 1, photos, 5 Mar - 3 Apr 1995, Columbia (G. Lamdeth et al.); 1, 12 Apr 2006, near Columbia (S. Pelc et al.).

Summer: A pair built a nest and laid two eggs on the late date of 2 Nov 2015 on a farm near Metz, Vernon Co. The hatchlings did not survive. The pair had apparently been present since at least late summer (BJ, photos of birds and nest) and again nested in 2016, but disappeared in the early spring of 2017 (BJ, pers. comm).

Fall: Besides the birds in Vernon Co., there are two records for this period: 1, 26 September 2013, Joplin (C. Pistole); 1, mid-to late Nov 2017, southwest of Buffalo, Dallas Co. (P. Hostetler et al.).

Winter: In addition to the above record there are the following for this season: 1 , photos, 1-29 Jan 2004, South Shores, St. Charles Co. (T. Bormann et al.); 1, photos, 6 Feb - 2 Mar 2006, Springfield (CBu, A. Daniels); 2, photos, 24 Dec - 5 Feb 2013-4, same site as the above Dallas Co. locality (GS et al.); 1, photos, 12 Dec - 22 Feb 20145, Holden, Johnson Co. (D. and V. Cowell, S.and D. Martin et al.).

\section{Common Ground-Dove (Columbina passerina)}

Status: Casual transient and winter visitant. 
Documentation: Specimen: male, 5 or 6 Oct 1981, near Rosendale, Andrew Co. (KU 117945).

Habitat: Open country with bushy hedgerows that border cultivated fields.

Fall: In addition to the above specimen record, there are the following records that span from early Oct through the end of the period: male, 9 Oct 1993, Horseshoe Lake (LL); 1, found shot, 16 Oct 1997, Plow Boy Bend CA, Montineau Co. (R. Thom; KU 88889); ad male, 9-11 Oct 2007, Kearney, Clay Co. (KM, LW, M. Gulick); 1, 29 Oct 1972, ca. 16-17 miles east of Columbia, Callaway Co. (I. Adams); 1, 5 Nov 2011, Otter Slough (K. Brunke); 1, photos, 24 Nov - 8 Jan 2011-12, Weldon Spring (MBr et al.).

Comments: There is a spring record of a ground-dove that was not identified to species: 30 Mar 2007, New Madrid Co. (R. Meade).

\section{White-winged Dove (Zenaida asiatica)}

Status: Rare transient and summer visitant; accidental summer resident in Mississippi Lowlands; casual winter visitant.

Documentation: Photograph: 1, 22-23 Apr 1994, Columbia (K. McCrory, PM, J. Wallace, $\mathrm{BG}$ et al).

Habitat: Most records are of birds in towns.

Comments: The first observation was on 9 Jul 1973 at Schell-Osage (J. Rathert et al.), but it was not until after 1994 that the species was detected with some regularity. It is now recorded almost annually. For example, there were five reports in the spring of 1999. Records span the entire state with most from mid-Apr through May. Breeding was confirmed at East Prairie, Mississippi Co., as early as 2005 (JE). The first Kansas documented nesting record was in 2001 just across the Missouri River in Atchison Co. (Thompson et al. 2011).

In addition to the birds at East Prairie that have been present year-round, there are six other winter records: 1, 30 Dec - 12 Jan 2008-9, St. Joseph (LL); 1, 9 Jan 2013, Cape Woods CA, Cape Girardeau (MH); 2, 14 Feb 2016, Dunklin Co. (K. Freeman); 1, 16 Dec 2017, Chillicothe (SK); 1, photos, 18 Dec 2017, Four Rivers CBC (D. and S. Martin, LB, CBu); 1, photos, 2 Jan 2018, Morgan Co. (anonymous).

\section{Mourning Dove (Zenaida macroura)}

Status: Common summer resident; common winter resident southeast, uncommon elsewhere.

Documentation: Specimen: male, 12 May 1879, Charleston, Mississippi Co. (MCZ 41831).

Habitat: Found in a variety of open habitats and woodland and forest edge, as well as towns and cities.

Spring: Migrants enhance wintering populations at the end of Feb and in early Mar. Numbers continue to increase until peak in mid-Apr. 
Summer: Based on BBS data, this dove is most common in the Mississippi Lowlands and least common in the Ozarks. By late Jul large concentrations are encountered in cultivated fields.

Fall: It is very common during Aug through mid-Sep when large flocks (in the hundreds or low thousands) are observed in cultivated fields with grain. By mid-Oct, numbers are much reduced.

Winter: As in summer, it is most common in the Mississippi Lowlands. High $C B C$ counts, all on Springfield: 1,478 (17.0), 18 Dec 2010; 1,425 (13.5), 20 Dec 1997; 1,425 (15.3), 16 Dec 2006. Other high count: 710, 17 Jan 2013, Dunklin Co. (TJ).

\section{Order Cuculiformes}

Family Cuculidae: cuckoos, roadrunner, ani

\section{Yellow-billed Cuckoo (Coccyzus americanus)}

Status: Common transient and summer resident; accidental winter visitant.

Documentation: Specimen: egg clutch, 21 Jun 1887, Kansas City (FMNH 21643).

Habitat: During migration virtually any wooded or forested area; most common during the breeding season in riparian forest.

Spring: Arrival time and peak can vary considerably from year to year. Typically, the first individuals are not detected until the very end of Apr with peak during the third week of May. However, there are some years when the first individuals are not seen until the second week of May, with peak towards the end of May. In exceptional years, such as 2017, the bulk of the breeders did not arrive until early June in at least the western part of the state. During more typical years, obvious migrants are routinely seen into early Jun. Earliest dates: 1, photos, 16 Apr 2013, southern Dunklin Co. (TJ); 1, 16 Apr 2015, Mississppi Co. (MH); 1, 17 Apr 1999, Busch (JM). During a very early spring, such as 2013, the first individuals were detected in the south at six sites between 27-30 Apr. High counts on river float surveys: 42 (3.4), 23 May 2003, Current River, Round Spring to Jerktail access (MR, B. Benz, M. Papes); 38 (5.5), 27 May 1999, St. Francis River, Dunklin Co. (MR, B. Barber, K. Zyskowski).

Summer: It is common throughout the state, with BBS data indicating that is is most common in the Ozarks (especially along rivers) and the Ozark Border. Numbers can vary considerably from year to year. BBS data indicate there has been an annual 3.22 $\%$ decline for the period of 2003-2013.

Fall: This cuckoo is common through the first three weeks of Sep, but numbers drop off considerably by the first of Oct. It is rare during the first two weeks of Oct and it is occasionally seen during the last two weeks of Oct. It is casual in early Nov. High count: 28, 2 Sep 2013, Dunklin Co. (TJ). Latest dates: 1, 10 Nov 1990, Loess Bluffs (S. Seltman); 1, 9 Nov 2009, near Ben Cash CA (TJ); 1, 3 Nov 2008, Ben Branch Lake CA, Osage Co. (EW); 2, 2 Nov 1969, one at Maryville, the other ca. 10 miles N of Maryville (MR). 
Winter: A single observation: 1, 15 Dec 1987, west of Parnell, Nodaway Co. (G. Shurvington).

\section{Black-billed Cuckoo (Coccyzus erythropthalmus)}

Status: Transient uncommon; summer resident uncommon north, rare south.

Documentation: Specimen: egg set, 20 May 1895, St. Louis (FMNH 7318).

Habitat: During migration found in a wide variety of habitats; during the breeding season it is most common in Salix-dominated riparian habitat (willows).

Spring: Very rarely encountered prior to early May. Peak is in mid- to late May, when a maximum of 2-3 birds/day may be observed. Migrants are often seen into the second week of Jun. Earliest dates: 1, photo and audio recording, 24 Apr 2016, east of Columbia, Boone Co. (BJ); 1, 25 Apr 1990, St. Louis Co. (DB); 1, 28 Apr 2013, Dunklin Co. (TJ); 2, 28 Apr 2016, Whetstone Creek CA (C. Joos). High counts: 7, 15 May 1977, Honey Creek CA, Andrew Co. (MR, DE); 5, 23 May 1973, near Maryville (MR).

Summer: This low-density and secretive cuckoo is more frequently encountered in northern Missouri. Within the Glaciated Plains, BBA (1986-92) data indicated the highest densities were in the northwestern corner; however, effort was greater in that area compared to elsewhere in that region. It is very rare in the Ozarks and there still is no confirmed breeding for the Mississippi Lowlands, although there are a couple of mid-summer observations of single birds in that region. It may reach its highest abundance in willow-dominated areas along the Mississippi and Missouri rivers. In particular, islands along the Mississippi River above St. Louis need to be surveyed.

Fall: Obvious migrants are seen away from breeding areas beginning at least as early as late Aug, with peak presumably during the first half of Sep. However, observations are too sparse to determine a precise peak. An occasional bird is seen during the first half of Oct. Latest dates: imm, 29 Oct 2016, Ritter Springs Park, Springfield (CBu, M. Owens, S. Martin, D. Martin et al.); 1, 23 Oct 2001, Shell-Osage (PM); 1, 21 Oct 1986, Howard Co. (C. Royall).

\section{Greater Roadrunner (Geococcyx californianus)}

Status: Rare permanent resident in southern Ozarks.

Documentation: Specimen: male, 14 Apr 1968, Fairy Cave, Stone Co. (KU 117684). Habitat: Most common in Ozark glades, but also on farms and in towns and small cities.

Comments: Since this species was first detected in Missouri on 19 Jun 1956, just north of Branson, Taney Co. (Brown 1963), it has spread slowly north and eastward in the Ozarks. The expansion was truncated by three consecutive severe winters in the late 1970s (Norris and Elder 1982a); prior to those winters the species had reached three counties (Cooper, Moniteau, Osage) that bordered the south bank of the Missouri River in the central part of the state. Since the Norris and Elder (1982a) compilation, the species has been recorded for the first time in the following counties, with year of first 
occurrence: Shannon (1997; PM); Wayne (1997; T. Draper); Madison (1998; D and B. Roe); St. Francois (1999; S. Vogel); Jefferson (2000; B. and C. Black); Washington (2007; R. Moore); Butler (2008; Greer family); Crawford (2009; R. Weisman); Cole (2009; KA). There is still no record for north of the Missouri River. High count: 5, including 3 counter singing, 9 May 2013, Eagle Rock/Roaring River SP (MR, CH, JB).

\section{Groove-billed Ani (Crotophaga sulcirostris)}

Status: Casual fall transient.

Documentation: Specimen: found dead (seen alive for ca. one week before death), 13 Nov 1950, Centertown, Cole Co. (D. Campbell; Tulenko 1950; MU 1247).

Habitat: Open habitats, with brush and thickets.

Records: There is a total of five records, all prior to 1980, from mid-Oct to late Nov: 1, photos (banded), 10 Oct 1978, Kansas City (M. Myers); 1, 11-16 Oct 1979, Kingdom City, Callaway Co. (K. Evans, J. Rathert et al.); 1, 9-11 Nov 1972, Columbia (D. Rickett et al.; Goodge 1972); 1, shot, 22 Nov 1973, Greenwood, Jackson Co. (Rising et al. 1978); and the above specimen record. The lack of records during nearly the past four decades is likely a reflection of the species' decline over most of its United States distribution.

\section{Order Caprimulgiformes Family Caprimulgidae: nighthawk, nightjars}

\section{Common Nighthawk (Chordeiles minor)}

Status: Common summer resident.

Documentation: Specimen: male, 6 May 1878, Charleston, Mississippi Co. (MCZ 46921).

Habitat: During migration seen in a wide variety of habitats; primarily breeds on flat rooftops with gravel; formerly, the principal nesting areas were prairies, cliffs, and rocky ledges.

Spring: The first individuals are typically not detected until the end of Apr with peak in mid-May. Migrant flocks are regularly seen through the first week of Jun. Earliest dates: 2, 22 Apr 2016, St. Genevieve (N. March); 3, 24 Apr 2016, Cape Girardeau (A. Gathman). High counts: 25, 13 May 1987, Ted Shanks (K. McMullen); "very large flocks", 25-27 May 1882, passing over St. Louis (Widmann 1907).

Extraordinarily early reports, Mar through early Apr, can be attributed to misidentifications of vocalizations of other species (e.g., E. Starling, Am. Woodcock), and a few likely were bats. Audio recordings and/or photos should be obtained of any nighthawks prior to the third week of Apr.

Summer: A common summer resident statewide with the largest concentrations in towns and cities. However, based on BBS data, which has obvious limitations for tracking population trends for this species, and comparison of BBA data for states that have 
conducted more than one atlas, it appears that this species has gone through dramatic declines during the past few decades in North America (summarized in Musher 2013).

A number of reasons have been suggested for this decline. One probable reason that may have contributed to the decline of breeding nighthawks within Missouri is the replacement of flat, gravel-topped roofs with rubber or tar during the past twenty-five years. Prior to settlement the species nested on bare ground in prairies, glades, rocky ledges, ridges, and cliffs along the two large rivers. By Widmann's time (1907) they were readily using building roofs.

Fall: The initial movement can be discerned by the second week of Aug. Despite the apparent decline of this species across much of its North American distribution (Musher 2013), large flocks can still be seen during the latter half of Aug and the first half of Sep. Peak is at the very end of Aug/early Sep. Hundreds/flock are observed through the third week of Sep, but by the second week of Oct usually only one or two individuals may be encountered. There are a number of Nov records. High counts: major movement, 28 Aug 1981: 1,000, St. Louis (MP); 1,000, between Jefferson City and St. Louis (J. Wilson); 820, 9 Sep 1985, Jefferson City (MP). Highest count in eBird, which may be a reflection of the decline of this species during the past few years: 450 , 3 Sep 2014, Webster Co. (GS et al.). Latest dates: 1, 27 Nov 1991, Greene Co. (B. Noble); 1, 24 Nov 1993, Tower Grove (J. Ziebol); 1, 21 Nov 1993, Little Blue Park, Jackson Co. (D. Arney).

Comments: Late fall nighthawks should be carefully scrutinized for the possibility of Lesser Nighthawk (Chordeiles acutipennis), as this species is regularly reported along the Gulf Coast (eBird).

\section{Common Poorwill (Phalaenoptilus nuttallii)}

Status: Accidental transient; former summer resident along the western border.

Documentation: Specimen: see below.

Habitat: Short grassland with rock outcrops.

Spring: A single, verified record: 1, found injured, 18 Apr 2002, Kansas City, Jackson Co. (B. Kluepfel; KU 94658).

Summer: There are reports of poorwill breeding along the extreme western edge of the state during the late 1800s and early 1900s. Apparently, H. Nehrling found the species nesting in 1885 in Lawrence Co. (Widmann 1907), and it was reported breeding in open areas of Swope Park, Dodson, and Grandview in Jackson Co. during the first two decades of the 1900s (B. Bush; Harris 1919b). Further demonstrating that the species' former breeding range extended farther east than it does today are specimens taken during summer from Douglas (1897; KU 6485), Leavenworth (1913; KU 76554), and Anderson (1925; KU 14565) counties in Kansas near the Missouri border. A single bird was flushed by a reliable observer at a prairie in Vernon Co., Missouri, during 
the summer of 1945 (WC). Presumably, the loss of prairie coupled with succession has played a role in the recession of the poorwill's easternmost breeding distribution.

Fall: A single record: ad male, photos, 21-22 Nov 2009, west of Maitland, Holt Co. (B. Shields, KG, DE).

\section{Chuck-will's-widow (Antrostomus carolinensis)}

Status: Uncommon summer resident in Ozarks, Ozark Border, and Osage Plains; rare in Glaciated Plains and Mississippi Lowlands.

Documentation: Specimen: egg set, 17 May 1900, Doniphan, Ripley Co. (WFVZ 100435).

Habitat: In open pine-oak or cedar-oak associations, but also in strictly deciduous woods, especially along bluffs and ridges.

Spring: In the south the first arrivals generally appear by mid-Apr, but in the north they do not appear until the end of Apr/early May. Earliest dates: 1, 4 Apr 1983, St. Louis (fide RK); 1, 9 Apr 2001, Shell Knob, Barry Co. (N. Rochovansky). High counts: 24, 4 May 2006, White River Trace CA, Dent Co. (R. Chapman); 18, 13 May 2006, Livingston Co. NAMC; 17, 13 May 2000, Boone Co. (McKenzie 2000); 16, 8 May 1999, Livingston Co. NAMC.

Summer: The highest densities are in the Ozarks and Ozark Border (BBA, eBird). It is less common in the Osage and Glaciated plains, where in the latter region it may reach its highest densities along ravines and ridges in the bluffs of the Mississippi and Missouri rivers. As expected it is largely absent from the Mississippi Lowlands (BBA, eBird). BBS data suggest there has been both a long- and a shorter-term decline, but trends may be unreliable because of small sample sizes.

This species apparently expanded its breeding range northward during the $20^{\text {th }}$ century. The first record for the Kansas City region was obtained on 3 May 1918 (Harris 1919b), and Harold Hedges considered in rare there by 1940, but common by the mid-1950s (Johnston 1960). High counts: 33, 9 Jun 2013, Sugar Camp Scenic Drive (DW); 32, 20 stops along 9.5 miles of road, 28 May 1989, Taney Co. (JHy, PMa); 15, 20 stops along 9.5 miles of road, 9 Jun 1989, Dallas Co. (JHy).

Fall: There are very few records of this nightjar after the first week of Sep. Latest dates: 1, 6 Oct 2012, Eagle Bluffs (RD, N. March, K. McCommis); 1, 30 Sep 2008, Springfield (E. and L. Akins); 1, 17 Sep 1994, Forsyth, Taney Co. (PMa).

\section{Eastern Whip-poor-will (Antrostomus vociferus)}

Status: Common summer resident except in the Mississippi Lowlands, where it is rare. Documentation: Specimen: female, 8 May 1887, St. Louis (USNM A06963).

Habitat: Open woodland and forest. 
Spring: The first birds arrive at the very end of Mar in the south and about a week later in the north. Earliest dates: 1, 23 Mar 1986, Buffalo, Dallas Co. (J. Hancock); 1, 24 Mar 2003, Jefferson Co. (MP); 1, 24 Mar 2007, Little Lost Creek CA, Warren Co. (JE). High counts based on nightjar surveys: 27, 23 May 1992, Brickyard Hill area (MR); 25, 28 May 1989, Taney Co. (JHy, PMa; see protocol details under summer); 18, 25 May 1993, Honey Creek area (MR); 22, 14 Apr 2016, Sugar Camp Scenic Drive (DB1 and B. Blevins); 21, 23 Apr 2016, Red Bridge Road, Christian Co. (DBl and B. Blevins).

Summer: This nightjar is more common and widespread than the Chuck-will's-widow, but there are areas in the Ozarks, such as in cedar-oak habitat associations, where the Chuck-will's-widow is more common. Like the Chuck-will's-widow, this nightjar is rarest in the Mississippi Lowlands. High counts: 20 stops, one every 0.5 mile, along 9.5 miles: 48, 9 Jun 1989, Dallas Co. (JHy). High count, not based on the nightjar protocol: 17+, 8 Jun 2001, Rebel's Cove CA, Putnam Co. (Robbins et al. 2001).

Fall: Individuals are regularly heard through the first half of Sep, but by the end of Sep into early Oct it is rare. Latest dates: 1, 10 Oct 1997, near Rogersville, Webster Co. (AK); 1, 10 Oct 2015, Pomme de Terre Lake SP (R. and A. Dupika); Widmann (1907) gives a late date of 10 Oct without year or locality.

Comments: Apparently this nightjar has declined in at least some areas of its North American breeding range, but long-term appropriate data are scarce. BBS data indicate both a long-term (1967-2013) and more recent (2003-2013) annual decline of $2.73 \%$ and $2.53 \%$, respectively, in Missouri.

\section{Order Apodiformes \\ Family Apodidae: swifts}

\section{Chimney Swift (Chaetura pelagica)}

Status: Common summer resident.

Documentation: Specimen: male, 29 May 1857, Independence (USNM A08317).

Habitat: During migration seen flying over all habitats; since settlement the species primarily uses chimneys and abandoned buildings for breeding and roosting. Prior to settlement, it primarily nested in tree cavities and cliffs.

Spring: The first arrivals are usually seen at the beginning of Apr in the south and often not until the second week of Apr in the north. Earliest dates: 1, 20 Mar 1963, Charleston, Mississippi Co. (JHa); 6, 29-30 Mar 2012, Dexter City Lake (CB). High counts: 3,500-4,000, 7 May 1967, Columbia (M. Entrikin); 2,000+, 22 Apr 1991, Columbia (PM).

Summer: This is a common, widespread species that is most numerous in towns and cities, where it uses chimneys and old buildings to nest and roost. Undoubtedly an unknown, but quite small, percentage of the population still uses natural tree cavities (Graves 2004). Presumably it is now more common and widespread than prior to set- 
tlement, when it likely was much less common in the prairie-dominated parts of the state. However, BBS data for the period 2003-2013 indicate a yearly decline of 5.09\%.

Fall: By early Aug, large concentrations may be observed, primarily in the evening, at breeding and roosting sites in towns and cities. Relatively large flocks are still observed into early Oct, with occasional large congregations seen into the third week of Oct, e.g., 1,000, 19 Oct 1971, St. Louis (JC). High counts: 3,000 - 4,000+, 28 Sep 1975, downtown Kansas City (N. Johnson); 2,200, 13 Sep 2012, Springfield (m. ob.). Latest dates: 1, 18 Nov 1986, Columbia (TB); 8, 6 Nov and 1, 8 Nov 1925, St. Louis (Widmann 1928). As Widmann (1928) chronicled, the Nov 1925 records were part of a major late departure of this species across the eastern United States.

Comments: There is a single observation by two reliable observers in Dec 1938, near Parkville, Platte Co. (WC; A. Shirling; Rising et al. 1978). Unfortunately, there are no details, so the possibility of Vaux's Swift (Chaetura vauxi) cannot be ruled out. In view of the fact that there are no unequivocal winter records of Chimney Swift north of South America, and that Vaux's has been documented wintering in Louisiana as early as 1937 (Lowery 1939) with Dec records as far north as Shreveport, Louisiana (Cardiff 2008), this observation very likely was of a Vaux's Swift.

\section{White-throated Swift (Aeronautes saxatalis)}

Status: Accidental transient.

Documentation: Specimen, see below.

Fall: There is a single record of a bird that was found emaciated on the wall of an elevator at a cement manufacturing plant on 7 Nov 1988, Cape Girardeau (T. Lambert, J. Glubeck; Wilson 1989; specimen preserved as a mount; deposited at SEMSU). There are a few eastern Kansas records of this swift, including two in Nov (Thompson et al. 2011), and it has been recorded at least twice in Arkansas (James and Neal 1986).

\section{Family Trochilidae: hummingbirds}

\section{Mexican Violetear (Colibri thalassinus)}

Status: Accidental summer visitant.

Documentation: Videotape; see below.

Summer: One that was at a feeder was videotaped, 24 Jun - 2 Jul 1993, Reynolds Co. (F. and H. Leeser). There are a number of records for this Neotropical hummingbird in the eastern United States. All large hummingbirds should be documented with photographs.

\section{Ruby-throated Hummingbird (Archilochus colubris)}

Status: Common transient; uncommon to locally common summer resident; accidental winter visitant.

Documentation: Specimen: female, 14 Aug 1913, Kansas City (KU 39089). 
Habitat: During migration seen almost anywhere; during the breeding season typically at the edge of woodland and forest, especially in areas where there are high densities of flowers; often common in towns and cities with flower plantings and feeders.

Spring: The first arrivals are seen at the beginning of Apr in the south, a few days later in the north. Peak is in early May. Earliest dates: three observations for 21 Mar. High counts: 30+, 26 May 1999, Hornesville Swamp CA, Dunklin Co. (MR, B. Barber, K. Zyskowski).

Summer: An uncommon to locally common summer resident; lowest densities are in the Glaciated Plains and Mississippi Lowlands. No appropriate data are available for assessing population trends in this difficult-to-monitor species.

Fall: By late Jul migrants are apparent, e.g., 84, 1 Aug 2006, Versailles, Morgan Co. (D. Dejarnette) with numbers increasing to the peak in early Sep. It remains common through much of Sep, with numbers dropping off dramatically after early Oct. Thereafter it is primarily observed at feeders. High counts: 200+, 5-6 Sep 1981, Lawrence and Barry cos. (KH); 200+, at feeders, 24 Aug 1991, Schell City, Vernon Co. (PM, TB); 75, banded at feeders, 12 Sep 2008, Cape Girardeau (C. Hutchison). Latest dates: imm female, photos and banded, 9-15 Dec 2002, Columbia (M. Jolly, T. Gordon); imm male, banded, 21 Nov - 4 Dec 2002, St. Louis Co. (B. Murray, L. Chambers); ad female, 1 Dec 2007, Jackson, Cape Girardeau Co. (L. Chambers, B. Bliese). A female-plumaged bird that was identified to Archilochus sp. was present 7 Nov -22 Dec 1994, south St. Louis Co. (J. Hammel, PS et al.); imm male, photos and banded, 19 Dec 2015, St. Louis (L. Chambers et al.).

Winter: Note that three of the above late fall birds lingered into the winter season.

Comments: Hummingbirds seen at feeders should be examined carefully for the possibility of other species; in particular, from about mid-October into winter, any hummingbird is as likely to be a western species as a Ruby-throated. Detailed photographs, and at times measurements taken while banding, may be required for identification.

\section{Black-chinned Hummingbird (Archilochus alexandri)}

Status: Accidental fall transient.

Documentation: Photographed and banded; see below.

Fall: A single record: imm female, photos and banded, 9-19 Dec 2004, Farmington, St. Francois Co. (L. and L. Chambers).

\section{Anna's Hummingbird (Calypte anna)}

Status: Casual fall transient and accidental winter visitant.

Documentation: Photographed and banded, see below. 
Fall and winter: There are eight records ranging from late Oct through early Feb, all of birds at feeders: ad male, photos, 29 Oct 1993 - 3 Jan 1994, Columbia (TB,PM); ad male, 16-24 Nov 1993, Platte City, Platte Co. (J. and H. Palmer, L. Moore, Jo Ann Garrett); imm male, photos, 24 Nov - 2 Feb 1994-5, Ozark, Christian Co. (J. and K. Ritzen, LR, PM, TB et al.); female, 3-10 Nov 1997, Lee's Summit, Jackson Co. (P. Chamberlin, CH, J. Garrett); imm male, photos, 14-19 Dec 1997, Des Peres, St. Louis Co. (F. Phillips et al.); probable female, photos, 31 Oct - 19 Nov 2015, Franklin Co. (D. Burke, L. Chambers); ad male, photos, 3 Dec - 18 Jan 2015-6, Springfield (LB, CBu et al); ad male, photos, 28 Nov - 6 Dec 2016, Howell Co. (V. Petkovic).

Comments: A bird seen at a feeder 25 Aug - 9 Oct 1984, St. Louis was very likely an Anna’s (P. Snetsinger, D. Jones).

\section{Broad-tailed Hummingbird (Selasphorus platycercus)}

Status: Accidental summer visitant.

Documentation: Photographed (fig. 6) and banded, see below.

Summer: A single record: ad male, photos and banded, 13-16 Jun 2008, Farmington, St. Francois Co. (BRe et al.).

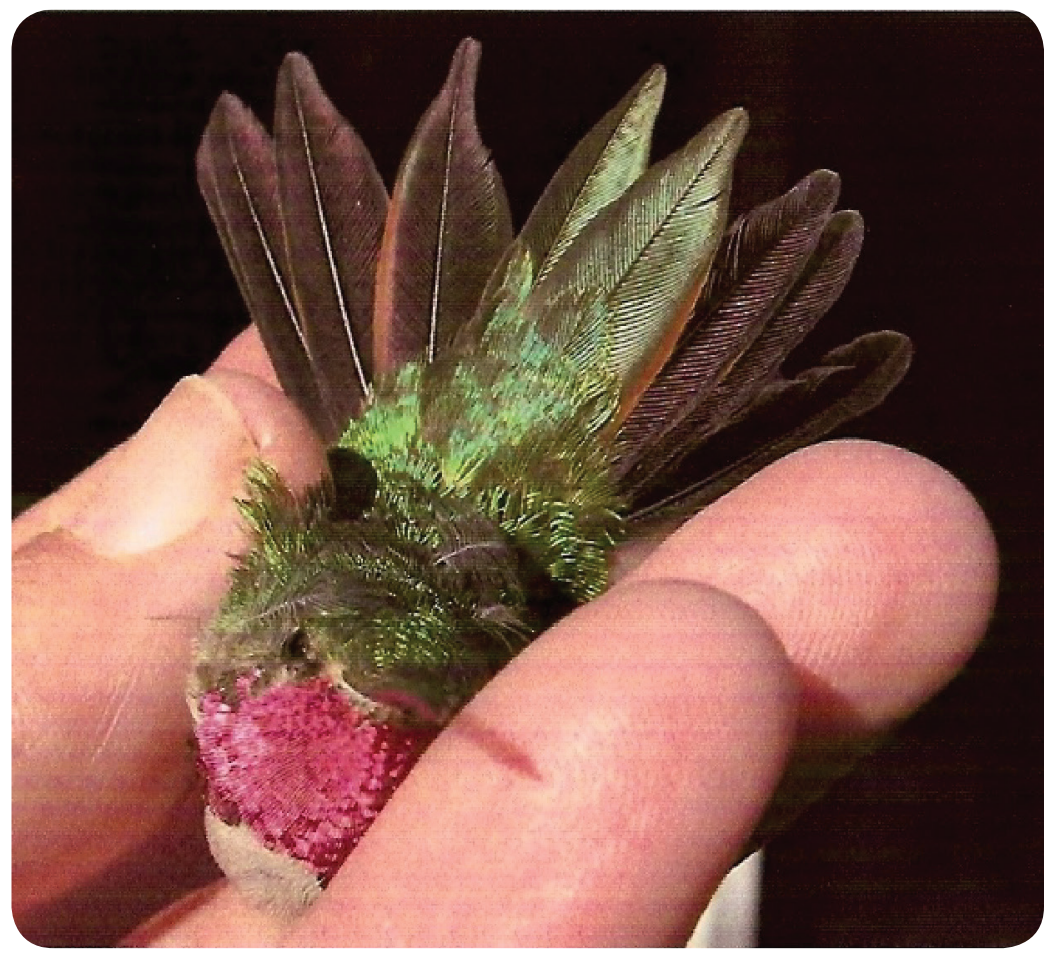

Fig. 6. Adult male Broad-tailed Hummingbird mist-netted in June 2008 at Farmington, St. Francois Co. Photo by Lanny Chambers. 


\section{Rufous Hummingbird (Selasphorus rufus)}

Status: Rare fall transient and winter resident.

Documentation: Specimen: male, 30 Jan 2004, St. Louis (KU 93085).

Fall and winter: Since the first record for the state in the fall of 1968, there has been a dramatic increase in the number of records, in part because of a major increase in people providing feeders and reporting unusual sightings. By the fall of 1999 , there were about 25 records of this species. It is now recorded almost annually, often with multiple records/fall. Records span from late Jul through the winter, with no discernible peak. Some individuals linger for months, and with heated feeders birds are lingering and overwintering on a regular basis. Earliest dates: ad male, photos, 22 Jul 2016, Taney Co. (J. Maxwell); ad male, photos, 25-31 Jul 1985, north of Corning, Atchison Co. (E. Wright); ad male, 1-3 Aug 1996, Fordland, Webster Co. (J. Sowers); ad male, 6-10 Aug 1996, Springfield (LR).

Comments: An adult female that was present 26 Oct - 23 Dec 1993, in Springfield was at least five years old when initially banded on 19 Dec 1989 in Pensacola, Florida. This same individual was recaptured in Bay Minette, Alabama on 2 Feb 1992 (McKenzie and Rizzo 1994). An adult female that was present 6 Oct - 24 Dec 2001, in St. Louis Co. had previously been banded as an adult in Nov 2000 in Metairie, Louisiana (A. McCormack, L. Chambers). A banded adult male, that was present from $26 \mathrm{Nov}$ 2014- 20 Jan 2015, Jackson, Cape Girardeau Co., reappeared 1 Nov 2015 and remained until 28 Jan 2016 (J. Nicholas, L. Chambers).

In addition to birds that have been positively identified as Rufous, there are $>30$ records of Selasphorus sp. that undoubtedly involved a vast majority that were Rufous. See Comments concerning identification under Allen's Hummingbird.

\section{Allen's Hummingbird (Selasphorus sasin)}

Status: Accidental fall transient.

Documenation: Photographed (see below), measured, and banded.

Fall: A single record of an imm male, 27 Nov 2008, Fenton, St. Louis Co. (L. and L. Chambers). Photos of the entire bird and tail spread appear on the cover and page 25 of Bluebird (36, 2009).

Comments: This species is exceedingly similar to Rufous Hummingbird; for unequivocal identification, measurements and photographs are a necessity. Even adult male Allen's may be virtually indistinguishable from some adult male Rufous, as a small percentage of Rufous may have extensive green in the back (McKenzie and Robbins 1999). Thus it is critical to document the width and shape of certain rectrices (Howell 2002).

\section{Calliope Hummingbird (Selasphorus calliope)}

Status: Accidental fall transient.

Documentation: Photographed and banded, see below. 
Fall: Two records of imm males that were both photographed and banded: ca. 10 Oct - 8 Nov 2002, Columbia (H. and KA; T. Gordon et al.); 12-29 Nov 2014, Ozark (GS et al.).

\section{Order Gruiformes}

\section{Family Rallidae: rails, gallinules, and coot}

\section{Yellow Rail (Coturnicops noveboracensis)}

Status: Rare transient.

Documentation: Specimen: sex?, 14 Apr 1901, Independence (KU 39057).

Habitat: Wet meadows, prairies, and grassy marshes.

Spring: Undoubtedly this rail is more common than the relatively few records indicate, as it is quite secretive, inconspicuous and difficult to flush. The first individuals have been detected in early Apr, with peak during the third week of the month. Although there are only a few May records, it likely is regular through at least the first week of May. Earliest date and only Mar record: 1, 27 Mar 1876, St. Louis (Hurter 1884). High counts: 7, flushed while burning wet prairie, 17 Apr 1979, Loess Bluffs (TB); 6, 13-14 Apr 1984, Tucker Prairie, Callaway Co. (TB, CH). Latest dates: 2, 16 May 1993, Loess Bluffs (PM); 1, 12 May 2017, Riverlands (L. Richter); 1, 10 May 2003, Bradford Farm (PM).

Fall: The earliest records are from the end of Aug, with peak at the end of Sep/early Oct. Earliest dates, both at Swan Lake: 1, 22 Aug 2012 (A. Fournier); 1, 27 Aug 2003 (J. Guthrie). High counts: 8, 27 Sep 2012, Swan Lake (J. Lehman); 4, 26 Sep 2012, Swan Lake (A. Fournier). Latest dates: 1, 28 Oct 1995, near Kingdom City, Callaway Co. (BJ et al.); several reports for 20-21 Oct across different areas of the state.

\section{Black Rail (Laterallus jamaicensis)}

Status: Casual transient; accidental summer visitant.

Documentation: Specimen: 1, killed by hail storm, 1 May 1933, Fayette, Howard Co. (Jenner 1934: CMC 460).

Habitat: Marshes, especially with spike-rush (Eleocharis), and wet meadows.

Spring: This rail is even more secretive than the Yellow Rail, but it does respond to playback of its vocalizations. There are now eleven records, nine since 1963, between late Apr and late May. Earliest dates: 1, 20 Apr 1963, Beverly Lake (T. Pucci); 1, 24 Apr - 2 May 1996, Grand Pass (J. Vogel). High counts: 2, calling midday, 26 May 1986, Bigelow Marsh (MR; ML 37378); 2, 3 - 13 May 2008, Bloomfield, Stoddard Co. (CB et al.).

Summer: A single record, 1, 17 Jul 1968, Swan Lake (L. Kline), but there is suitable breeding habitat across the Glaciated and Osage plains and the species breeds annually in Kansas (Thompson et al. 2011) and at least formerly in Illinois (Bohlen and Zimmerman 1989). 
Fall: There are three records: 1, 21 Sep 1963, near Ozark, Christian Co. (N. Fay); 1, tower kill, 23 Sep 1969, Cape Girardeau (R. Rowlett; USNM 564977); 1, heard, 9 Oct 2005, Swan Lake (TM).

Comments: The whereabouts of a Black Rail collected (no date given) by G. Rinker at Unionville, Putnam Co. is unknown (Widmann 1907).

\section{King Rail (Rallus elegans)}

Status: Rare transient and summer resident; accidental winter visitant.

Documentation: Specimen: egg set, 4 Jun 1888, Clark Co. (WFVZ 83921).

Habitat: Marshes and swamps, especially in cattail.

Spring: The initial migrants appear in early Apr, with peak in early May. Earliest dates: male, 26 Mar 1893, St. Louis (Florida Museum of Natural History 2988); 1, 31 Mar 1957, Swan Lake (DE, D. Snyder); 1, 2 Apr 1887, Fayette, Howard Co. (W.Wells). High counts: 8-12, throughout May 2006, Clarence Cannon (m. ob.); 4, 4 May 1983, Marais Temps Clair (D. Ulmer).

Summer: A rare breeder in marshes across the state. Recent highest densities have been found at Clarence Cannon: estimated 10-12 pairs, 1998 (D. Ellis); 5 broods, 1999 (R. Cantu), with confirmed breeding there and at nearby BK Leach in 2012. During the 1970s and 1980s, several pairs bred at Duck Creek, Mingo, Loess Bluffs, Ted Shanks, Marais Temps Clair, and Schell-Osage.

Fall: Most observations during Aug and early Sep are of breeding birds. Migrants recorded away from nesting sites are seen during Sep into the third week of Oct. High counts: 30, includes family groups, 27 Aug 1971, Loess Bluffs (HB); 5, 14 Sep 2002, Prairie Slough CA (JU). Latest dates: 1, 25 Oct 1898, Lake City, Jackson Co. (KU 39053); 1, 22 Oct 2000, Swan Lake (SK); 1, 17 Oct 1969, Loess Bluffs (FL).

Winter: A single record: ad, photos, 3 Jan 2010, Clarence Cannon (C. Chambers).

Comments: The King Rail has suffered large declines throughout much of its distribution as a result of the lost of wetlands (Cooper 2008). Between the 1780s and the 1980s, Missouri lost $>50 \%$ of its wetlands (Dahl 1990), so this rail was once much more common in the state. Widmann (1907) stated it was a "fairly common summer resident along the large rivers".

\section{Virginia Rail (Rallus limicola)}

Status: Uncommon transient; rare summer resident; rare winter resident at a single locality.

Documentation: Specimen: male, 6 May 1857, St. Louis (USNM A07057).

Habitat: Marshes, swamps, wet fields with emergent vegetation. 
Spring: A few early migrants are occasionally seen in early Mar, but it is not regularly observed until late Apr. Peak is typically in mid-May. Earliest dates: 2, 25-27 Feb 1986, Binder Lake, Jefferson City (D. Kurz, J. Wilson); 1, 22 Mar 2007, Loess Bluffs (PK). High counts: 30, 14 May 1967, Bigelow Marsh (DE, S. Hanselmann); a few counts involving 20-25 birds during mid-May.

Summer: This secretive bird appears to be a low-density breeder in marshes throughout the state. During the past two decades, either calling adults or young with adults have been heard and/or seen at McBaine water treatment plant, Boone Co. (continually since at least 2002; BG et al.); Riverlands (N. Rathenborg); Clarence Cannon (m. ob.); Loess Bluffs (DE); and Cloe-Lowry Marsh, Mercer Co. (J. Wilson et al.).

Fall: Migrants appear by early Aug, with an increase at the end of the month through late Sep/early Oct. It is very rare in Nov. Latest date, but see Winter: 1, 15 Nov 1972, Maryville (DE). High counts: 11, tower kill, 24 Sep 2009, Morgan Co. (WW); 9, 20 Sep 1969, Loess Bluffs (FL).

Winter: This species was unknown in Missouri during winter until it was discovered in dense cattails at the McBaine water treatment plant, Boone Co. in Dec 2000 (BG, J. Besser, S. Kubal, G. Richter). Since that time multiple individuals appear to be permanent residents. High winter counts at this site include: 18, 16 Dec 2017; 13, 16 Dec 2006; 12, 17 Dec 2005.

\section{Sora (Porzana carolina)}

Status: Common transient; rare summer resident and visitant; rare winter resident at a single locality, accidental winter visitant elsewhere.

Documentation: Specimen: male, 4 May 1879, Charleston, Mississippi Co. (MCZ 41920).

Habitat: Wide range of marsh vegetation and flooded fields with vegetation.

Spring: The first migrants typically are not detected until the end of Mar/early Apr, with peak in early to mid-May. Earliest dates away from Columbia wintering site: 1, 17 Mar 1986, Duck Creek (BRe); 1, 17 Mar 2012, Otter Slough (CB). High counts: 100+, 9 May 1972, Loess Bluffs (MR); 100, 14 May 1967, Loess Bluffs (DE, S. Hanselmann); 96, 10 May 1997, McBaine water treatment plant, Boone Co. (TB, G. Young).

Summer: This is an often overlooked, low-density breeding species that is primarily found in northern marshes, e.g., three nests, 24 May 1993, Loess Bluffs (BJ). Beginning in 2002 and continuing up to the present, this rail has been found breeding in small numbers (at most a few pairs) at the McBaine water treatment plant (BG et al.). There are only three Mississippi Lowlands breeding records: adults with young in Aug 2006, near Dexter, Stoddard Co. (JE); and two records during mid-Jul 2015 at separate Dunklin Co. sites (TJ). Intriguingly, one was heard calling, 12 Jun 1993, Bull 
Creek at Walnut Shade, Taney Co. (PMa). High count: 10, 11-12 Jul 2015, Columbia Bottom (JM, CM).

Fall: Migrants begin appearing by at least the second week of Aug and relatively large numbers (up to 50/site) may be seen by the end of the month. Peak appears to be during Sep/early Oct, when literally hundreds may be flushed at a single local. Standardized surveys during 2012-2015 across eleven publicly managed wetland properties determined that peak occurred in late Sep (Fournier et al. 2107). Aside from birds that may be permanent residents at the McBaine site, a few individuals are seen in early Nov. Latest dates: 1, photos, 24 Nov 2015, Otter Slough (N. Koch); 1, 15 Nov 2001, Swan Lake (SK). High counts: 400, during rice harvest, 11 Oct 2003, near Dexter, Stoddard Co. (JE); "hundreds estimated" 17 Sep 1999, Ten Mile Pond (BE); 140, 7 Sep 2000, Swan Lake (SK); 125, 14 Sep 2009, Swan Lake (SK). High count for late in season: 8+, 15 Nov 2006, near Clinton, Henry Co. (NY).

Winter: Since 2002, the species has been found wintering in low numbers at the McBaine site. There are the following records from elsewhere: 1, 13 Jan - 16 Feb 1992, Lake Taneycomo, Taney Co. (H. Simon, PMa); 1, 15 Dec 1994, near Clinton, Henry Co. (MR). CBC high counts at McBaine site: 12, 16 Dec 2017; 3, 16 Dec 2006.

\section{Purple Gallinule (Porphyrio martinica)}

Status: Rare spring transient and summer visitant in Mississippi Lowlands, casual elsewhere; accidental fall and winter visitant.

Documentation: Specimen: sex?, 9 May 1963, Beverly, Platte Co. (KU 117888).

Habitat: Marshes, swamps, flooded fields with vegetation.

Spring: A very rare migrant that is not recorded every year. Most records are from the bootheel region, but there are records scattered across the entire state. Records, all of single individuals, span from mid-Apr through the end of the period. Earliest dates: 1, photos, 14 Apr 2013, Springfield (M. Lohmeyer); 1, 18 Apr 1881, St. Louis (Hurter 1884); 1, 18 Apr 1981, Mingo (S. Sutter, R. Brundage).

Summer: Although there are a number of records, primarily during the first half of Jun, for the Mississippi Lowlands, there still is no definite breeding record even though it has been found breeding in adjacent Illinois (Bohlen and Zimmerman 1989) and in the Mississippi floodplain in northeastern Arkansas (James and Neal 1986). Intriguingly, at least four individuals were at Duck Creek, 8-22 Jun 1962 (E. Hartowicz). There is a single Jul record, 13 Jul 1963, Lake Contrary (FL), but none for Aug.

Fall: Only two records: 1, found injured within St. Charles, St. Charles Co., Oct 1951 (Comfort 1952); imm, photos, 8 Nov 1998, Springfield (B. Dyer, K. Johnson, LB, Z. Ellison).

Winter: Single record of a starving immature found in the Missouri River bottoms, Jackson Co., 30 Dec 1915 (Hoffman 1916). 


\section{Common Gallinule (Gallinula galeata)}

Status: Rare transient and summer resident.

Documentation: Specimen: egg set, 1 Jun 1893, Clark Co. (Yale Peabody Museum 129837).

Habitat: Marshes, swamps, and flooded fields with vegetation.

Spring: The first individuals appear during the latter half of Apr, with peak in midMay. Earliest dates: 2, 12 Apr 2003, McBaine water treatment plant (JU); 13 Apr, no year, Kansas City (Harris 1919b). High counts: 37, 22 May 2016, Mingo (CB);16+, 15 May 1985, Duck Creek (MR).

Summer: With the exception of the Duck Creek/Mingo area in the southeast, all breeding records are from along the Missouri River and at marshes in the north. The highest densities have been recorded at Loess Bluffs and the following nest high counts are from Hilsabeck and Bell (1999): 9 nests, Jun 1993; 7 nests, Jun 1996; 18 nests, Jun 1997.

Fall: Most observations are of breeding birds, with a number lingering until the first week of Oct. High counts: 36 (ad and young), 10 Aug 1998, Loess Bluffs (DE); 21, 6 Sep 2014, Loess Bluffs (M. Stewart); 18, 12 Sep 1999, Loess Bluffs (J. Zellmer). Latest dates: 1, photos, 2-4 Nov 2011, Busch (AS et al.); 1, 24 Oct 2010, Loess Bluffs (C. Foret); 3 observations for 23 Oct across multiple years.

\section{American Coot (Fulica americana)}

Status: Common transient; uncommon summer resident; uncommon winter resident in the Mississippi Lowlands, rare elsewhere.

Documentation: Specimen: male, 2 May 1909, Monteer, Shannon Co. (AMNH 354667).

Habitat: Utilizes virtually every body of water.

Spring: The first migrants are seen at the beginning of Mar and by the end of the month concentrations in the low thousands may be present. Tens of thousands are often present at a single site across the state during the first half of Apr, with large numbers seen into early May. If water levels are high and it is a late spring, a few thousand may be present at northern refuges through the third week of May, e.g., 5,500, 23 May 2013, Loess Bluffs (MR). When conditions are optimal at Loess Bluffs, a relatively large number may breed, e.g., 76 nests, late May 1990 (R. Bell). High counts, both at Loess Bluffs (refuge data): 37,280, 7 Apr 2009; 33,425, 2 Apr 1999.

Summer: Late migrants can number in the hundreds during the first week of Jun at northern refuges. The number of breeders varies considerably from year to year primarily depending on water levels and the presence of emergent marsh vegetation. Generally, greater numbers are present in years with high water levels. During more average years, scattered pairs breed across the state, with the largest numbers at Loess Bluffs. High count of nests: see Spring; 23 nests, 8-10 Jun 1993, Clarence Can- 
non (S. Huddlemeyer, L. McFarland). High counts, both at Loess Bluffs: 300 (many non-breeders), 18 Jun 1967, (FL); 300, 17 Jun 2013 (DW).

Fall: By late Aug migrants begin to appear and a few thousand may be present at a single site by the end of Sep. Peak is typically in late Oct/early Nov. High counts from Loess Bluffs (refuge data): 45,460, 20 Oct 2008; 42,130, 4 Nov 1998.

Winter: The number of birds present in the state varies considerably depending on the severity of the winter. During severe winters coots may be absent from the northern two-thirds of the state. Highest densities are typically encountered at refuges, such as Duck Creek/Mingo, in the southeastern corner. High counts on CBCs, both at Mingo: 4,245 (78.1), 29 Dec 2001; 2,890 (52.0), 27 Dec 1997.

\section{Family Gruidae: cranes}

\section{Sandhill Crane (Antigone canadensis)}

Status: Rare transient and winter resident; rare summer resident and summer visitant north, accidental in south.

Documentation: Specimen: male, 15 Apr 1974, near Rosendale, Andrew Co. (KU 117590).

Habitat: Harvested fields, primarily corn, and marshes.

Spring: Although it is reported more frequently during the past two decades than in prior years, it is still not recorded annually at this season. Birds occasionally appear at the end of Feb, but most observations of migrants are during Mar. Until the past two decades it was more frequently seen in the western half of the state, but now it is recorded almost as often in the east. High counts: 100, 15 Mar 1979, Reed CA, Jackson Co. (B. Eastman); 60, 4 Mar 2003, Mingo (NY); 39, 5 Mar 2010, Otter Slough (CB).

Summer: First breeding in the state may have occurred as early as 1991, as two birds were seen at Grand Pass in very early fall (M. McClure). Breeding was suspected there in 1994, as a pair was seen from late spring through summer (S. Hazelwood). Breeding was finally confirmed at that site in subsequent years (m. ob.). After a few years of suspected breeding, nesting was finally confirmed at Loess Bluffs in May 2006 (Lomas et al. 2006), Eagle Bluffs in 2011 (B. Heidi, E. Wood et al.), and Perry CA, Johnson Co. in 2013 (L. Olpin, T. Gaines). There have been a number of observations of single birds and presumed pairs at other localities without breeding confirmation.

Fall: Presumed migrants, birds seen away from potential nesting sites, have been recorded as early as Aug, but most records are not until mid-Oct through Nov. It is now regularly seen into early Dec. Earliest dates: 1, 10-17 Aug 1962, Loess Bluffs (HB et al.); 13, 19 Sep 2007, Poplar Bluff, Stoddard Co. (CB). High counts: 100, 4 Oct 1990, Terre du Lac, St. Francois Co. (H. Ferris); 54, 13 Nov 1998, Loess Bluffs (MR, PM, BJ); 50, 24 Oct 2015, Wright City, Warren Co. (T. Bahner); 48, 25 Nov 2012, Dunklin Co. (TJ). 
Winter: Prior to the early 1990 s, there were only seven winter records, but now the species is regularly recorded in winter at a few localities. A bird that could be unequivocally identified as the same individual because of a leg injury wintered for three consecutive winters (1993-6) near Columbia (PM, TB et al.). High counts: 42, 18 Feb 2002, Duck Creek (NY); 23, 18 Dec 2012, Loess Bluffs (m. ob.); 10, Dec-Jan 2013-4, Loess Bluffs (D. Welchert et al.); 9, 28 Jan 2012, Otter Slough (CB).

Comments: This crane was once very common in the state until near the end of the 1890s, when Widmann (1907) lamented that very few were recorded. Harris (1919b) listed a number of records from C. Danker who resided in Holt Co. in the northwestern corner. On 21 Mar 1916, Dankers related that he saw a flock of 90, and the following spring he saw "several small flocks". It remained quite rare until the 1990s when more migrants and wintering birds were observed, and, at least historically, it was documented breeding for the first time.

Recognition of subspecies is debated and attempting to label birds subspecifically in the field is problematic. Birds seen in the western half of the state are likely from populations that breed in the Canadian provinces west of Hudson Bay and migrate in large numbers through the Great Plains, whereas birds in the eastern Missouri may be from the population that breeds in Michigan, Minnesota, Wisconsin and southern Ontario that migrates southeastward through Illinois, Indiana, and Kentucky. As depicted in Gerber et al. (2014), Missouri lies between the two major migration corridors. At times, individuals of both populations may occur together; fig. 7.

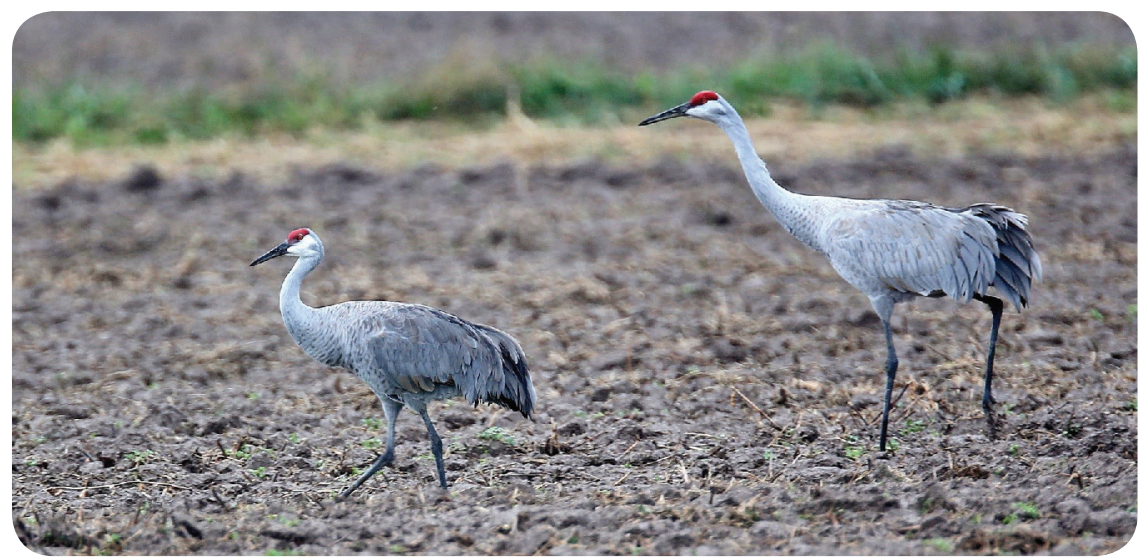

Fig. 7. Individuals from different Sandhill Crane populations (note size difference) in St. Charles County, 3 November 2016. Photo by Douglas Hommert.

\section{Whooping Crane (Grus americana)}

Status: Casual transient.

Documentation: Filmed: adult, 13-15 Oct 1958, Bigelow Marsh (m. ob.; single frame in Robbins and Easterla 1992).

Habitat: Marshes and agricultural fields, especially with corn. 
Spring: There is a single record for this season since the species almost became extinct in the early 1940s. Two individuals were seen flying over Independence on 29 Apr 1970 (KH, C. Huffman; Rising et al. 1978). Unbeknownst to each other, the observers independently saw the birds within a few minutes and miles of each other and immediately reported them. From the 1880s through 1913 there were a number of Mar records statewide, with at least two mid-Apr records (Hoy 1865, Widmann 1907, Harris 1919b).

Fall: In addition to the above Bigelow Marsh record, an immature was seen later the same fall, 30 Nov - 15 Dec 1958, Mingo (m. ob.). An adult, photos, 31 Oct 1996, was at the Aldrich arm, Stockton Lake, Polk Co. (K. Johnson). The three most recent records have been after very strong west winds: 8 , seen initially in flight and later in a field with Sandhill Cranes, 26 Oct 2010, near Rich Hill, Bates Co. (S. Miller, S. Ellis); ad and juv., photos, 21 Nov 2011, Newton Co. (JCa, B. Wylie et al.; fig. 8); 2, ad and juv., 15 Nov 2014, Aldrich area of Stockton Lake (DBl).

Comments: Today the wild population is about 300 birds. Given that the population continues to increase slowly, there are likely to be more records, especially if observers look for the species after strong westerly winds during late Oct and the first half of Nov.

Birds introduced during 2001 in Wisconsin, in an effort to establish a separate population, are free-flying and have been recorded recently in Missouri (Jan 2012, Mississippi County; May 2016, Eagle Bluffs) and adjacent Illinois.

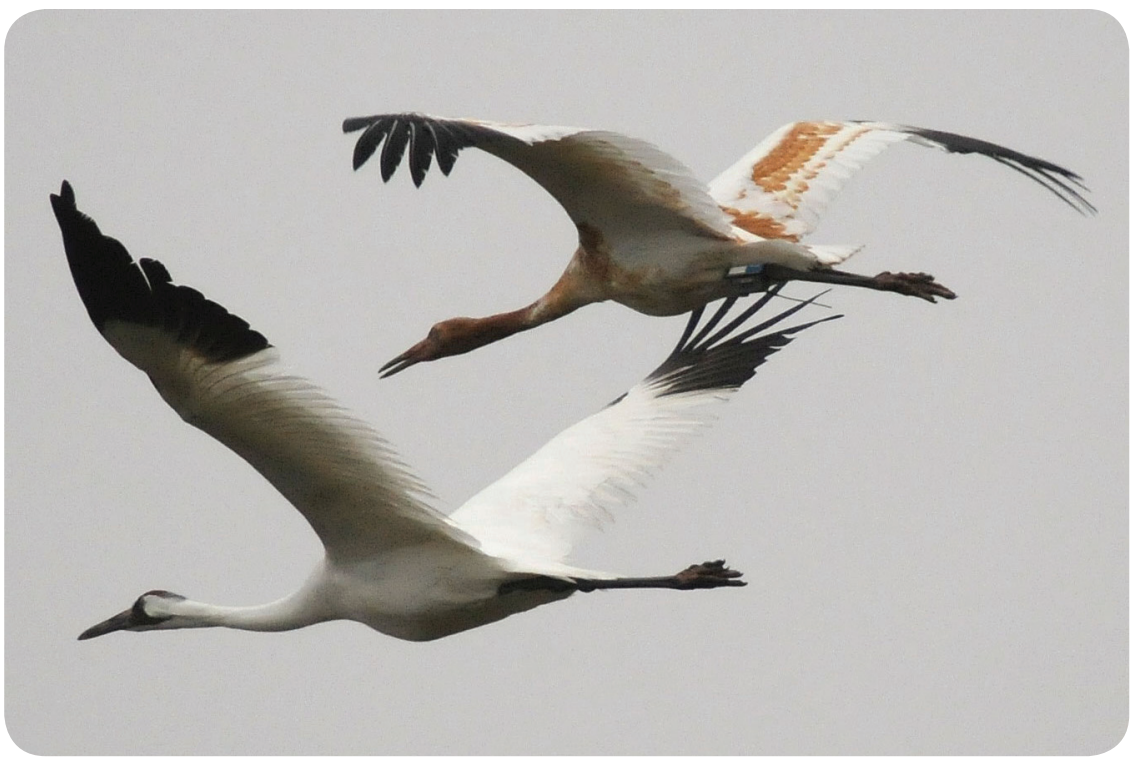

Fig. 8. Adult and juvenile Whooping Crane, 21 November 2011, Newton County. Photo by Becky Wylie. 


\section{Order Charadiiformes \\ Family Recurvirostridae: stilt, avocet}

\section{Black-necked Stilt (Himantopus mexicanus)}

Status: Locally common transient and summer resident in the rice fields of the Mississippi Lowlands, rare breeder along the Mississippi River to Pike County, accidental breeder in northwest; rare transient elsewhere in state.

Documentation: Photograph: see below.

Habitat: Breeds on rice field dikes, mudflats, and shoreline. During migration found in a wide variety of shallow-water habitats.

Spring: Migrants in the bootheel now begin appearing as early as late Mar, with large numbers observed in rice fields in this region by late Apr. Elsewhere in the state, it typically is not seen until mid-to late Apr. Earliest dates: 4, photos, 12 Mar 2013, Dunklin Co. (TJ); 4, 14 Mar 2012, Little River CA, Dunklin Co. (TJ); several, 17 Mar 2012, Otter Slough (CB). High counts, both in Dunklin Co. by TJ: 523, 23 Apr 2011; 410, 12 May 2015.

Summer: Since this stilt was first found breeding in rice fields in the bootheel in 1990 (Jacobs 1991; it had bred sporadically as close as Memphis, Tennessee, since 1982, L. Coffey), it has become locally common as a breeder in that section of the state. Subsequently, breeding was detected further north along the Mississippi River floodplain. A pair exhibiting distraction behavior was observed on 7 Jul 1993, Grand Tower Island, Perry Co. (T. Fink); pair with chicks, 4 Jul 2008, Perry Co. (JE); 32 ad, 4 Jul 2008, St.Genevieve Co. (JE); 27 ad, display behavior observed but area became inundated, Jun 2008, Columbia Bottom (m. ob); pair with 2 young, photos, 22 Jul 2010, Columbia Bottom (AS); ad with 4 downy chicks, 6 Jun 2012, BK Leach (CMc); and 2 ad with 2 young, 21 Jul 2012, Clarence Cannon (PL, MT, et al.). Likely unrelated to the Mississippi delta expansion was the first nesting in the northwestern corner, a pair with 3 young, 6 Aug 2010, west of Forest City, Holt Co (Robbins 2010). High counts: 400, 19 Jul 2015, Dunklin Co. (TJ); 295, 2 Jun 2009, southern bootheel (MR, PM, BJ).

Fall: Relatively large numbers (much reduced from earlier in summer) are seen in Aug, e.g., 150+, 25 Aug 2004, Otter Slough (NY), but by the second week of Sep numbers are drastically reduced. There are a few Oct observations from across the state. Latest dates and high count for late in season: 13-15, 30 Oct 1996, Skelton Training Site, Cole Co. (E. Young); 1, photos, 28-29 Oct 2012, Riverlands (AS, AR et al.).

Comments: The first record for the state was obtained when a single bird was observed on 23 Apr 1931 at Columbia (E. Thurston; Bennitt 1932).

\section{American Avocet (Recurvirostra americana)}

Status: Rare transient statewide, but more common at all seasons in the western half of the state; accidental winter resident. 
Documentation: Specimen: female, 7 May 1967, Bigelow Marsh (KU 117845).

Habitat: Mudflats, shoreline, flooded fields, lakes and reservoirs.

Spring: There are four Mar records, but the first migrants usually do not appear until early Apr, with peak in late Apr/early May. A few are seen into early Jun. Earliest dates: 2, 20 Mar 2012, Eagle Bluffs (G. Connette, PK); 1, 24 Mar 1977, Kansas City (J. Garrett). High counts: 100, 8 Apr 1894, near Stotesbury, Vernon Co. (T. Surber; Widmann 1907); 57, 1 May 2011, Loess Bluffs (MR, JK); 56, 16 Apr 2000, Four Rivers CA (MG); 55, 27 Apr 2008, Loess Bluffs (DE). Latest dates: there are several observations throughout Jun that likely represent late spring migrants and/or early fall migrants.

Fall: As mentioned above, late Jun records probably represent early fall migrants. Numbers increase during Jul and Aug, with the largest groups seen during mid- to late Oct. It is now regularly seen into the second week of Nov. High counts: 104, 26 Oct 1999, Swan Lake (EW et al.); 56, 27 Oct 1974, Loess Bluffs (FL); 50, 31 Oct 2004, Smithville Lake (JE, KM, DW). Latest dates: 1, 24 Nov 2008, Swan Lake (SK, M. Carlton, D. Fitchet); 1, 18-23 Nov 1998, Ten Mile Pond (B. Allen et al.).

Winter: A single record of an individual that was initially present from $27 \mathrm{Dec}-21$ Jan 2012-3 at Winfield Lock and Dam, Lincoln Co. (SS et al.; photos) and was presumed to be the same bird that was observed ca. 25 miles southeast at Riverlands on 18 Feb 2013 (BJ).

\section{Family Charadriidae: plovers}

\section{Black-bellied Plover (Pluvialis squatarola)}

Status: Uncommon transient; accidental winter visitant.

Documentation: Specimen: female, 27 Oct 1925, Jackson Co. (KU 39060).

Habitat: Mudflats, sandbars, flooded fields, edge of lakes.

Spring: A few migrants are seen as early as Mar with a gradual increase during Apr with peak in mid-May. Late migrants or oversummering birds are regularly seen into early Jun. Earliest dates: 1, 12 Mar 1994, St. Charles Co. (K. Lannert, CA, C. Lowe); 1, 15 Mar 1942, Platte Co. (WC); 2 observations for 23 Mar. High counts: 150, 16 May 1964, Loess Bluffs (DE, HB); 60, 14-20 May 1975, Loess Bluffs (HB); 59, 5 May 2011, Holt Co. (MR, M. Andersen). Latest date: 2, 12 Jun 1983, Overton Bottoms, Cooper Co. (P. Snetsinger, TB).

Fall: Southbound migrants are seen at the end of Jul with an increase through Aug; peak is typically at the end of Aug/early Sep. Small numbers are seen through Oct into early Nov; thereafter it is quite rare. Earliest dates: 1, 29 Jun 2008, Ten Mile Pond (JU); 1, 26 Jul 1992, near Urich, Henry Co. (V. Elsberry). High counts: 500, 1-15 Sep 1963, Loess Bluffs (HB); 42, 3 Oct 1984, Loess Bluffs (FL). Latest dates: 7, 6 Dec 1980, Loess Bluffs (J. Robinson); 1, 30 Nov - 1 Dec 2007, Riverlands (DR). 
Winter: A single record of an individual still mostly in alternate plumage, photos, 22 Dec 2012, Winfield Lock and Dam (AR, CMc).

\section{American Golden-Plover (Pluvialis dominica)}

Status: Common transient.

Documentation: Specimen: sex?, 19 Apr 1899, Buckner, Jackson Co. (KU 92227).

Habitat: Plowed fields, short-grass pastures, harvested agricultural fields, and mudflats.

Spring: Migrants are now being seen regularly in early Mar. By early Apr, thousands may be encountered statewide. It remains common until the beginning of May. Late migrants are regularly seen into Jun. Earliest dates: 21, 22 Feb 2014, Dunklin Co. (TJ); 1, 27 Feb 2011, Dunklin Co. (TJ); 1, 2 Mar 2001, Riverlands (CM, JM). High counts: 7,500, 21 Apr 1994, Grand Pass (G. Perrigo); 7,000, 5 Apr 2013, Dunklin Co. (TJ); 4,500+, 2 Apr 2011, Pemiscot Co. (TJ). The following observations could pertain to late spring or early fall migrants: 22, in alternate plumage, 8-16 Jun 1993, southeastern Stoddard Co. (K. Adams, BL, BRe); 1, 24 Jun 2000, Riverlands (m.ob.).

Fall: Presumed early southbound migrants are detected by mid-Jul (but see above), with a gradual increase during Aug. However, the largest numbers are not seen until early Oct when flocks numbering in the hundreds of individuals are seen foraging in recently harvested soybean fields across the state. Typically, after the first few days of Nov, only individuals or small groups are seen, with three early Dec observations. Earliest dates: 1, 13 Jul 2007, Winfield Dam (SS); 1, 13 Jul 2003, Donaldson Point (KA); 1, 20 Jul 2008, Columbia Bottom (BR, DR, DB). High counts: 600, 12 Oct 1980, Swan Lake (BG); 500, 17 Oct 1980, Loess Bluffs (FL). High count for late in season: 102, 1 Nov 2011, Loess Bluffs and Bob Brown (MR, JK). Latest dates: ad in mostly alternate plumage, 10 Dec 1999, Cooley Lake (R. Knotts); 1, photos, 2-3 Dec 2017, Clarence Cannon (J. Rurik, D. Bricmont, R. Mustell); 2, 1 Dec 1968, Loess Bluffs (FL).

\section{Snowy Plover (Charadrius nivosus)}

Status: Rare spring transient northwest, casual elsewhere; accidental summer visitant and fall transient.

Documentation: Specimen: male, of pair, 19 Apr 1968, near Bigelow (KU 117983; Easterla 1969).

Habitat: Mudflats and shoreline.

Spring: The first record for the state occurred in May 1962 at Loess Bluffs. It is now recorded nearly every year in the northwestern corner. Most records are between early Apr and early May. There are only three records for the eastern third of the state: 1, 27 Apr 1981, Thomas Hill Reservoir (TB, I. Adams); ad, photos, 22-23 Apr 2000, Little Creve Coeur Lake, St. Louis Co. (MT et al.); ad male, photos, 24 May 2008, Riverlands (CA, JE, JU). Earliest dates: 1, 25-26 Mar 1967, St. Joseph (FL, JHam); 2 other records from Loess Bluffs on 31 Mar. High counts: several records involving two birds, all from west. Latest date: see above Riverlands record. 
Summer and fall: There are three records for this period that may involve wandering birds and/or fall migrants: ad, photos, 25-27 Jun 2007, Eagle Bluffs (A. Downing, KA, S. Elbert); 1, 7-14 Jul 1968, Loess Bluffs (FL, HB); 1, 11 Aug 1963, Loess Bluffs (JHam).

\section{Wilson's Plover (Charadrius wilsonia)}

Status: Accidental transient.

Documentation: Photograph; fig. 9.

Habitat: Mudflats, shoreline.

Records and Comments: There are two records, both documented with photos. The first was of an ad male, 9 Jul 1995, Mound City, Holt Co. (CH, SA) and the second was of either a female or a male in non-alternate plumage, 4 May 2014, Riverlands (L. Beason, A. Smith, JM, CM, CA). There are now a number of records for the interior of North America, e.g., Kansas has two spring and one Jul record (Thompson et al. 2011).

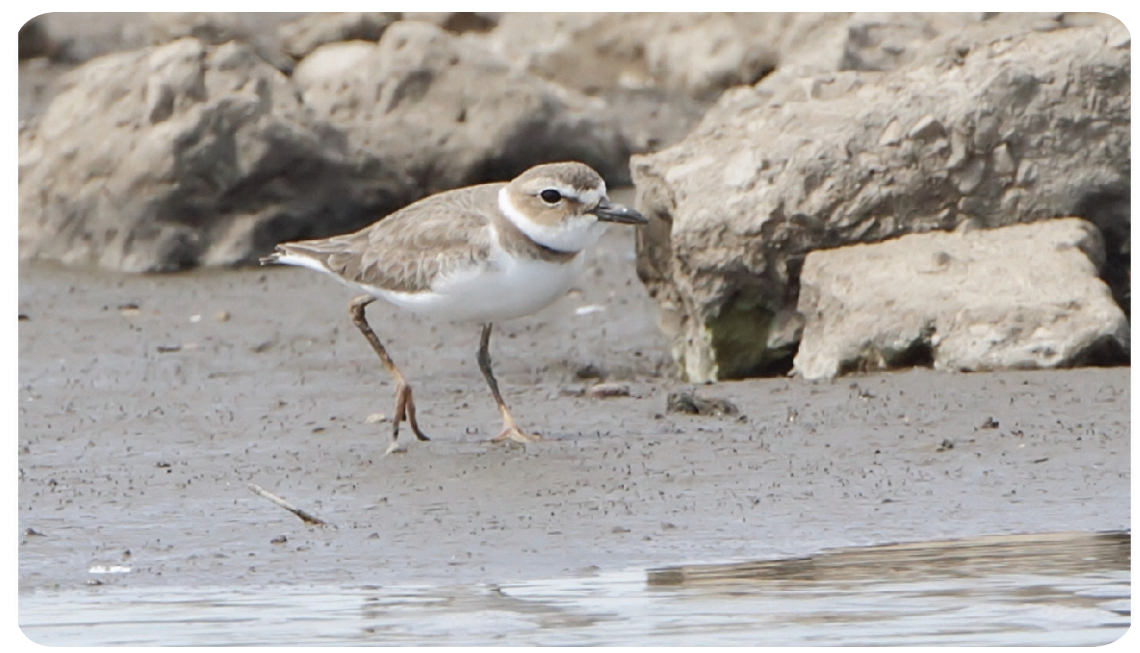

Fig. 9. The second record of Wilson's Plover for Missouri; 4 May 2014 at Riverlands.

Photo by Allen Smith.

\section{Semipalmated Plover (Charadrius semipalmatus)}

Status: Common transient.

Documentation: Specimen: male, 5 May 1879, Charleston, Mississippi Co. (MCZ 42251).

Habitat: Mudflats, shoreline, and bare flooded fields.

Spring: The first arrivals are in early Apr, with peak at the very end of Apr/early May. It is regularly seen into early Jun. Earliest date and only Mar record: 1, 21 Mar 1982, Creve Coeur Lake (C. Patterson); 1, 4 Apr 2011, Loess Bluffs (DW). High counts: 500, 27 Apr 1995, Loess Bluffs (m. ob.); 375, 9 May 1979, Loess Bluffs (TB); 318, 5 
May 2011, Holt Co. (MR, M. Andersen). Latest dates: 2, 16 Jun 2013, Eagle Bluffs (R. Stanton, G. Leonard); 1, 11 Jun 2011, Riverlands (JU).

Fall: There are a few records for early and mid-Jul, but this plover is not regularly seen until the final ten days of Jul. It is regularly encountered in small numbers throughout Aug into mid-Oct. It is rare during the latter half of Oct and there are only three Nov records. Earliest dates: 1, 4 Jul 2004, Riverlands (JU); 2, 8 Jul 2006, Ten Mile Pond (JE, JU, JM); 1, 9 Jul 2007, Caruthersville (SS, PW, BJ). High counts: 100, 8 Aug 2007, Settle's Ford CA (SS, BJ, PW); 50, 31 Jul 1988, Thomas Hill Reservoir (R. Brundage). Latest dates: 1, photos, 8 Nov 2004, Riverlands (JU); 1, 3 Nov 2002, Big Lake SP (TR); 1, 1 Nov 2011, Eagle Bluffs (G. Connette).

\section{Piping Plover (Charadrius melodus)}

Status: Rare transient.

Documentation: Specimen: male, 22 Apr 1967, near Bigelow (KU 117984).

Habitat: Mudflats, shoreline, and bare, flooded fields.

Spring: This plover is typically not encountered until the second week of Apr, but peak is at the end of Apr/early May. It is rarely seen during the latter half of May. Earliest dates: 2, 2 Apr 1977, Montrose (N. Johnson); 1, 10 Apr 2015, Loess Bluffs (DW). High counts: 18, 20 Apr - 1 May 1994, Loess Bluffs (MR); 16, 27 Apr 1995, Loess Bluffs (DE et al.). Latest date: 1, 27 May 1966, Loess Bluffs (DE).

Fall: Typically, the Piping Plover is not seen returning south until the end of Jul. It is regularly seen throughout Aug into early Sep. There are no late Sep records and only two Oct records. Earliest dates: 1, 1 Jul 1962, Duck Creek (D. Snyder); 1, 16 Jul 1992, Riverlands (T. and G. Barker). High counts: 5, 17 Aug 1969, Loess Bluffs (MR, R. Rowlett); 5, 18 Aug 1995, St. Charles Co. (BR); 5, 16 Aug 2002, Chillicothe wetlands, Livingston Co. (SK). Latest dates: 1, 27 Oct-5 Nov 1981, St. Joseph (FL); 1, 3 Oct 2004, Schell-Osage (CBu, LB, Z. Ellison).

Comments: A banded bird from the Great Lakes population was seen on 8 Aug 2010, at the Aldrich arm of Stockton Lake (CBu, M. Delong, GS). A banded adult male was photographed at Riverlands on 8 Sep 2016; this bird had been banded as an adult on 18 Jun 2015 on the Missouri River near Yankton, South Dakota (M. Friedrich, pers. comm.). It is likely this plover bred along the Missouri River in the state before channelization and dams, although there are no definitive records.

\section{Killdeer (Charadrius vociferus)}

Status: Common transient and summer resident; uncommon winter resident in south, rare and more sporadic in north.

Documentation: Specimen: male, 17 Jul 1818, Independence (MVZ 66672).

Habitat: Found in a wide variety of open, bare habitats, usually associated with water. 
Spring: Migrants begin to appear in mid-to late Feb in the south and about a week later in the north in most years. By late Mar it is very common statewide. High counts: 1,000, 21 Mar 2006, Lake Contrary (LL); 1,000, 3 Mar 2012, Dunklin Co. (TJ); 650 (extremely high number for this date and locality), 29 Feb 2012, Loess Bluffs (C. Wood, B. Sullivan). Eggs can be laid as early as mid-Mar: nest with 3 eggs, 12 Mar 2011, Wyatt, Mississippi Co. (W. Corse, MH); nest with 1 egg, 18 Mar 2012, Stoddard Co. (CB).

Summer and fall: Based on BBS data, this ubiquitous species is most common in the Mississippi Lowlands and least abundant in the Ozarks. Large concentrations that include adults and young are regularly seen from early Jul into Oct. Late nesting has been documented in Nov, both at Dexter City Lake by CB: juv., single neck band, 13 Nov 2009; newly hatched chick, photos, 2 Nov 2010. High counts during summer: 1,025, 8 Aug 2007, Settle's Ford CA (SS, BJ, PW); 350, 20 Jul 2009, Four Rivers (DW); 325+, 8 Jul 1994, Loess Bluffs (MR). High counts in late fall: 1,650, 1 Nov 2011, Loess Bluffs and Bob Brown (MR, JK); 400-500, 27 Nov 1953, Creve Coeur Lake (JEC); 500, 10 Nov 1984, Montrose (RF).

Winter: During mild winters this species is uncommon in the southern half of the state, especially the Mississippi Lowlands, but it is rare and local in the north. During severe winters this plover may be absent from much of the state and in greatly reduced numbers where present. High counts, both in Dunklin Co. by TJ: 800, 23 Dec 2012; 700, 30 Jan 2012. CBC high counts: 473 (12.4), 17 Dec 2009, Big Oak Tree; 445 (14.8), 17 Dec 2004, Big Oak Tree; 366 (8.1), 17 Dec 2011, Mingo.

\section{[Mountain Plover (Charadrius montanus)]}

Status: Provisional.

Documentation: Sight record only: see below

Records: A single bird was observed on 14 Mar 1953, at Prairie Lake, Buchanan Co., by several reliable observers (B. King et al.), but because this is the only record and there was no photograph or specimen it is treated as provisional.

\section{Family Scolopacidae: curlews, godwits, dowitchers, woodcock, snipe, sandpipers, and phalaropes}

\section{Upland Sandpiper (Bartramia longicauda)}

Status: Uncommon transient; uncommon summer resident in Glaciated and Osage plains.

Documentation: Specimen: egg set, 15 May 1896, Wayland, Clark Co. (WFVZ 102069).

Habitat: Short-grass prairies, fields, and pastures. During migration also occasionally observed on mudflats.

Spring: During both spring and fall this species is more common in the western half of the state. The first arrivals typically are observed in the southwest at the end of 
Mar, but not until the second week of Apr in the north. Peak is in late Apr/early May. Earliest dates: 1, 17 Mar 2007, near Hornesville, Dunklin Co. (BRe); 2, 20 Mar 1994, Swan Lake (BG). High counts: 20, 21 Apr 2012, Dade Co. (GSa et al.); 18, 25 May 1967, Ford City, Gentry Co. (DE, R. Rowlett).

Summer: With the accelerated conversion of prairie and pasture to cropland, this species continues to decrease in the Glaciated and Osage plains. It is more common in the western than the eastern half of the Glaciated Plains (BBS data, eBird). Outside the high density at the Grand River Grasslands near the Iowa border, the highest densities are found in the remaining prairie and pastures of the Osage Plains. Breeding occurs as far south as Jasper and Greene cos. where the Osage Plains and Ozarks interdigitate. It is absent or extremely rare in the Ozark Border and Ozarks, and it has not been recorded breeding in the Mississippi Lowlands. High counts: 74, 19 Jun 1994, Grand River Grasslands area (DE); 25, 13 Jun 2007, Hi Lonesome Prairie (SS, PW).

Fall: The initial southbound migrants begin to appear by mid-Jul. Peak is typically after a cold front from the northwest in early Aug, when relatively large numbers can be heard calling high overhead during day and night. It is regularly encountered through the first week of Sep, but by the end of the month it is rarely observed. There are only five Oct observations. High counts: 43, 3 Sep 2000, Rosecrans Airport (MR); 35, 19 July 1964, Amazonia, Andrew Co. (FL, E. Cole); 30, 20 Aug 1979, Kansas City International Airport, Platte Co. (S. Patti). Latest dates: 1, 8 Nov 1959, Sugar Lake, Buchanan Co. (FL); 1, 17 Oct 2015, Dunklin Co. (TJ); 1, 12 Oct 1991, King City, Gentry (JH); 2, 7 Oct 2000, Montrose (CH et al.).

Comments: As a result of excessive hunting and the conversion of prairie to cropland both in North America and on its wintering grounds in southern South America, this unique shorebird suffered immense declines during the latter half of the $19^{\text {th }}$ Century across its entire distribution (Houston et al. 2011). Widmann (1907) lamented that it was "greatly reduced, not one-tenth of the transient visitants of twenty years ago". He considered it to be a former "fairly common summer resident in the Ozark border and Prairie regions" of the state.

\section{Whimbrel (Numenius phaeopus)}

Status: Rare spring transient, casual in fall.

Documentation: Specimen: male, 16 May 1967, near Bigelow (KU 117643).

Habitat: Mudflats, flooded fields, and wet pastures.

Spring: There are four records for the first half of Apr, but almost all other observations are during the latter half of May into early Jun. Most observations are from the western half of the state. Earliest dates: 3, 31 Mar - 1 Apr 2007, Riverlands (CM, JM); 3, 11 Apr 2007, Riverlands (BJ); 1, 12 Apr 1975, Maryville SL (MR, DE). High counts: 16, 25 May 2004, Riverlands (CM); 3 observations of 13 individuals during late May. Latest dates: 1, 12 Jun 2009, Four Rivers (MDC personnel); 1, 3 Jun 1954, Missouri River, near St. Charles Co. (B. Dowling); 1, 2 Jun 2013, Loess Bluffs (MR). 
Fall: There are only five observations of presumed southbound single birds: 9 Jul 1977, Loess Bluffs (FL); 9 Jul 1988, near St. Joseph (K. Jackson, LG); 19 Jul 2015, Lincoln Co. (M. Taylor); 22 Aug 1995, St. Charles Co. (M. Treffert, D. Stegmann); 4 Sep 1949, St. Louis Co. (JVB).

\section{Eskimo Curlew (Numenius borealis)}

Status: Extinct. Formerly a common spring transient, especially in the western half of the state.

Documentation: Specimen: male, 16 Apr 1894, Vernon Co. (T. Suber; AMNH 752072; see below).

Comments: Widmann (1907) stated that it was formerly a very common migrant through western Missouri in late Mar through Apr. As late as 1894, a flock of 100 was observed on 16 Apr when T. Suber collected the above male. Apparently the last definitive record was of 10, 1 May 1902, Jasper Co. (W. Savage; Widmann 1907). A female was taken on 10 Apr 1871, St. Louis Co. (live mount; STSC, 4-6-50, J. Hurter 220). There were no fall records, as this species' primary fall route from the arctic breeding grounds was across Canada to Labrador, Newfoundland, and New England before making a transoceanic flight to South America (Gill et al. 1998). The last definitive record for the species was of a bird shot on Barbados on 4 Sep 1963 (ANSP 169796).

\section{Long-billed Curlew (Numenius americanus)}

Status: Casual transient west, accidental east. Formerly more common during spring and fall.

Documentation: Photograph; see below.

Habitat: Short-grass prairie, pasture, short grass strips at airports, flooded fields, and mudflats.

Spring: There have been only five observations since 1972: 1, 9 May 1992, Loess Bluffs (C. Fisher, D. Mead); 10, photos, 4 Apr 2008, rural Dade Co. (CBu); 1, 14 Apr 2008, Loess Bluffs (DW); 1, 6 May 2016, Loess Bluffs (N. Lewis); 2, photos, 9 May 2016, Riverlands (CMc, AR). Earliest date: 1, 31 Mar 1963, Loess Bluffs (FL). Latest date: 1, 28 May 1961, Loess Bluffs (S. Rositsky). High count, in addition to the Dade Co. observation: 6, 4 May 1968, Lake Contrary (FL). Prior to 1900, this curlew was common at this season when it was primarily observed in early Apr (Scott 1879; Hurter 1884, Widmann 1907).

Fall: Only two modern records: 1, 8 Jul 1972, Loess Bluffs (FL); imm, photos, 6 - 14 Sep 1996, St. Charles Co. Airport (T. Bormann, BR, JM et al.). Formerly, a common transient from Aug through Oct (Widmann 1907). Latest date: 4, 2 Nov 1917, on the Missouri River near Sibley, Jackson Co. (J. Guinotte; Harris 1919b).

\section{Hudsonian Godwit (Limosa haemastica)}

Status: Uncommon spring transient in west, rare in east; rare fall transient. 
Documentation: Specimen: female, 25 Apr 1965, Beverly Lake, Platte Co. (KU 117978).

Habitat: Mudflats and bare flooded fields.

Spring: Typically not seen until mid-Apr, with peak usually in early May. Small numbers are often seen through May into early Jun. Earliest dates: 1, 3 Apr 1979, Loess Bluffs (TB); 7-8, 11-12 Apr 2007, Riverlands (m. ob.); 6, 11 Apr 2011, Thompson River Wetlands (SK). High counts: 650+, 13 May 1979, Loess Bluffs (TB, R. Brundage, J. Rathert); 516, 13 May 2006, Loess Bluffs (DE); 400, 29 Apr 1956, Loess Bluffs (B. Stollberg). High count in east: 26, 12 Apr 2011, Dunklin Co. (TJ). Latest date: 2, 19 Jun 2001, Muskrat Lake (LL).

Fall: This godwit is much rarer in fall than spring, going unrecorded most falls. The bulk of the populations move across Canada to the eastern coast of North America and then south over the western Atlantic (Walker et al. 2011). Records occur in about the same frequency on both sides of the state. Observations span from early Jul through early Nov, with most from late Aug/early Sep. Earliest dates: 1, 5 Jul 2010, Thompson River Wetlands (SK); 3, 7 Jul 1964, Loess Bluffs (HB). High counts: 6, 8 Sep 2007, Riverlands (BR, M. Rowe, CA, C. Kirmaier); 5-6, 3 Sep 2008, St. Charles Co. (CM). Latest dates: 1, 5 Nov 2012, Swan Lake (SK); 1, 24 Oct 1971, Big Lake (FL, MR).

Comments: Female Hudsonian Godwits are much larger than males and are often not in the striking breeding plumage of males when passing through in spring; thus they are often mistaken for Marbled Godwits when at rest. In flight, however, the dramatic differences in wing pattern between the two species cannot be mistaken.

\section{Marbled Godwit (Limosa fedoa)}

Status: Rare transient; formerly common transient.

Documentation: Photograph: 2, 21 May 1990, Bigelow Marsh (DE; VIREO $\mathrm{x} 08 / 12 / 002)$.

Habitat: Mudflats and bare flooded fields.

Spring: This species is encountered more frequently in the west. The first migrants are not observed until early Apr. Peak is typically at the end of Apr. Occasionally, relatively large numbers (up to 20) are seen as late as the third week of May. Earliest dates: 1, 6 Apr 2008, Loess Bluffs (L. Olpin); 2, 10 Apr 1994, Loess Bluffs (MR); 1, 10 Apr 2004, Riverlands (DR). High counts: three observations involving 20 individuals from both sides of the state. Latest date: 1, 31 May 1981, Loess Bluffs (FL).

Fall: There are two late Jun records that presumably involved southbound migrants. Most observations are from early Jul through early Sep. Earliest dates: 3, 26 Jun 1966, Loess Bluffs (FL); 2, photos, 30 Jun 2014, Nodaway Valley CA (C. Crisler). High counts: 9, 8 Jul 1996, Swan Lake (B. Olson); 5, 18 Aug 2002, Horseshoe Lake (J. Rushin, JH). Latest dates: 1, 4 Oct 2016, Riverlands (CA); 1, 26 Sep 2005, Caruthersville (JE); 1, 20 Sep 1969, Loess Bluffs (FL). 
Comments: Even by Widmann's time (1907) this species had suffered severe declines as a result of excessive hunting and conversion of grassland to agriculture. Apparently it was a "fairly common transient" prior to the late 1800s. See identification comments on Hudsonian Godwit.

\section{Ruddy Turnstone (Arenaria interpres)}

Status: Uncommon transient.

Documentation: Specimen: female, 16 May 1967, Bigelow Marsh (KU 117805).

Habitat: Prefers rocky shoreline such as the base of dams, but it is seen most frequently on mudflats and occasionally in flooded fields.

Spring: This is one of the latest migrant shorebirds, and much more common in spring than fall. There are only two late Apr records and none for the first week of May, with the vast majority of observations occurring the third and the early part of the fourth week of May. Earliest dates: 3, 25 Apr 1995, Riverlands (B. McFall); 7, 30 Apr 1903, Missouri River, Jackson Co. (Harris 1919b). High counts: 72, 25 May 1994, Loess Bluffs (MR); 38, 29 May 1960, Loess Bluffs (FL et al.); several other observations of 30+ birds. Latest dates: 3, 23 Jun 1999, Riverlands (fide EW); 1, 15 Jun 1977, Chain of Rocks (JE); 17, 5 Jun 2009, Eagle Bluffs (BJ).

Fall: Turnstones return at the very end of Jul, with small numbers seen through early Sep. It is rarely seen after mid-Sep. Earliest dates: 1, 26 Jul 1992, near Urich, Henry Co. (V. Elsberry); 1, 26 Jul 2012, Lake Contrary (J. Phillips). High counts: 10, 10 Aug 2009, Swan Lake (SK); 5, 2 Sep 1979, St. Charles Co. (V. Bucholtz). Latest dates and only Oct records: 1, 20 Oct 1917, Missouri River, Jackson Co. (W. Andrews; Harris 1919b); 1, 19 Oct 2008, BK Leach (DR); 1, 10 Oct 1992, Fountain Grove (TM, SK).

\section{Red Knot (Calidris canutus)}

Status: Rare transient.

Documentation: Specimen: male, 7 May 1967, Bigelow Marsh (KU 118009).

Habitat: Mudflats, shoreline, and occasionally flooded fields.

Spring: There is a single late Apr and an early Jun record with all other observations between 11 and 26 May. It is detected very rarely at this season, with many years when the species is unrecorded despite heavy coverage of appropriate habitat. Apparently this has been the case historically, as Widmann (1907) and Harris (1919b) listed a total of only three records, all from the Kansas City area. There was not another record for the state until 1950 and between then and 1990 there were about a dozen spring records. Since then there have been the following observations: 1, 5 Jun 2003, Horseshoe Lake (DE, JH, PK, LL); 4, 25-26 May 2004, Riverlands (DR, JU); 1, 14-18 May 2012, Swan Lake (SK). Earliest date: 6, 24 Apr 1970, Loess Bluffs (FL). High counts: 30, 11 May 1980, Swan Lake (BG); 10, 19-20 May 1993, Horseshoe Lake (LL, L. Kenmark). 
Fall: There is roughly the same number of records for this season as for spring, despite the more intense observer coverage during spring. Most observations are concentrated at the end of Aug/early Sep. There are two Oct and one Nov records. Prior to 1990, there were eleven records for this season. The following have occurred since then: 1, 28 Aug 1994, Otter Slough (RF); 1, 10 Sep 2001, Sunshine Lake, Ray Co. (RF); 1, 29 Aug - 7 Sep 2002, Riverlands (JU, DR); 1, 8 Oct 2006, Bean Lake (DW); 1, 24 Aug - 9 Sep 2007, Otter Slough (CB, DR); 1, 26 Aug - 3 Sep 2007, Eagle Bluffs (BG et al.); 1, 19 Oct 2008, BK Leach (DR); 1, 20-24 Sep 2014, Aldrich Arm, Stockton Lake (DBl); juv., 20-24 Sep 2014, Riverlands (BR et al.). Earliest date: 3, 23 Aug 1988, Bonne Terre Marsh, St. Francois Co. (H. Ferris). Latest date: 1, 6-7 Nov 1981, Alton $\operatorname{Dam}(\mathrm{BRu})$.

Comments: The subspecies Calidris canutus rufa, which is the population that passes through Missouri, was officially listed as Threatened by the USFWS in January 2015.

\section{Ruff (Calidris pugnax)}

Status: Rare transient.

Documentation: Photograph: female, 6-7 May 1981, Big Lake (DE; Robbins and Easterla 1992).

Habitat: Mudflats, shoreline, and flooded fields.

Spring: There are fourteen records, all of single individuals, from late Mar to midMay, with most during late Apr/early May. Although twelve of the fourteen are from the western part of the state, this is likely an artifact of coverage as there are a number of records just to the east of the Missouri border (eBird). Earliest dates: 1, photos, 23 Mar 2015, Dunklin Co. (TJ); 1, photos, 29 Mar - 1 Apr 2006, near Bigelow (TR, RF, DE); male, photos, 1 Apr 2005, Loess Bluffs (TR). Latest date: female, photos, 24 May 2002, Lake Contrary (LL, T. Nagel, J. Rushin).

Fall: There are seven records ranging from mid-Jul through early Oct from both sides of the state. Earliest date: ad male, 14 Jul 1991, rice fields of Stoddard Co. (TB); ad female, 3 Aug 1992, Riverlands (RA). Latest date: 2, 7-10 Oct 1962, Busch (R. Laffey et al.).

\section{[Sharp-tailed Sandpiper (Calidris acuminata)]}

Status: Provisional; accidental transient.

Documentation: Sight record.

Habitat: Marshes, mudflats.

Records: There is a single record of an adult that was seen by multiple observers on 3-5 Aug 2013, Columbia Bottom (K. Hollinga, CA, DB, PL et al.). Since no photographs were secured, the MBRC decided to list the species as provisional until more concrete evidence of the species' occurrence in the state could be obtained. 


\section{Stilt Sandpiper (Calidris himantopus)}

Status: Uncommon to locally common transient in west, rare to uncommon in east during spring; common transient statewide in fall.

Documentation: Specimen: male, 7 Apr 1965, Horseshoe Lake, Platte Co. (KU 118996).

Habitat: Mudflats, flooded fields, and shoreline.

Spring: This sandpiper is much more common in the western half of the state. Very few are seen before late Apr, with peak in mid-May. It it regularly seen into early Jun. Earliest dates: 1, 29 Mar 2006, Loess Bluffs (TR); 1, 4 Apr 2013, Dunklin Co. (TJ); 3 records for 9 Apr. High counts: 1,200, 27 Apr 1995, Loess Bluffs (DE et al.); 1,012, 13 May 2006, Loess Bluffs (DE). High count in east: 100, 9 May 2003, Otter Slough (JU); 43, 13 May 2012, Dunklin Co. (TJ). Latest dates: two observations of single birds on 21 Jun that are presumed to be late spring migrants but may have been very early fall migrants.

Fall: The first fall migrants typically do not appear until early Jul. Peak is usually during late Aug/early Sep, but concentrations of $>100$ birds/day can be seen into mid-Oct. It is rarely seen from the end of Oct to mid-Nov. Earliest dates: 5, 2 Jul 1961, Loess Bluffs (FL); 4, 5 Jul 2008, Caruthersville (JE). High counts: 2,000, 1-15 Sep 1963, Loess Bluffs (FL, HB); 1,400, 28 Aug 1996, Swan Lake (B. Olson, BJ, D. Fitchett). High count late in season: 340, 17 Oct 2011, Loess Bluffs (MR, JK). Latest dates: 4, 16 Nov 1975, Loess Bluffs (E. Cole et al.); 12, 13 Nov 2003, Big Lake (TR).

Comments: See remarks under Dunlin regarding identification issues in the fall.

\section{Curlew Sandpiper (Calidris ferruginea)}

Status: Accidental transient.

Documentation: Photograph: see below

Habitat: Mudflats, shoreline, and flooded fields.

Records: There are two records: ad male, photos, 14-15 Jul 1998, Eagle Bluffs (D. Witten, T. Curtis, BG, PM et al.); 1, molting into alternate plumage, photos, 26-27 Apr 2008, Loess Bluffs (DW et al.).

\section{Red-necked/Little Stint (Calidris ruficollis/C. minuta)}

Status: Accidental vagrant.

Documenation: Photograph: see below.

Habitat: Mudflats, shoreline, and flooded fields.

Records: There are two reports during the same year of individuals that were very likely Red-necked Stints, but neither report eliminated the possibility of Little Stint: 1, in transitional plumage, photos, 28-30 Jul 2002, Lake Contrary (LL et al.; Lade 2002); 1, 20 Jul 2002, Ten Mile Pond (BRe). 


\section{Sanderling (Calidris alba)}

Status: Uncommon transient.

Documentation: Specimen: male, 15 May 1965, Bigelow Marsh (KU 117986).

Habitat: Mudflats, shoreline, and occasionally flooded fields.

Spring: There are only two Mar records and no observations for Apr until the middle of the month. Peak is during the second and third weeks of May. Occasionally seen into early Jun. Earliest dates: 6, 21 Mar 1902 (Harris 1919b); 6, 22 Mar 1940, Loess Bluffs (WC, A. Shirling). High counts: 150, 13 May 1979, Loess Bluffs (J. Rathert, R. Brundage, TB); 89, 23 May 2004, Riverlands (JU). Latest dates: 1, 9 Jun 2006, Eagle Bluffs (EW); 1, 6 Jun 1965, Loess Bluffs (FL).

Fall: The species does not appear until late Jul, with most observations concentrated between mid-Aug through mid-Sep. It is regularly seen in small numbers through midOct, but is rarely seen late Oct through Nov. Earliest dates: 3, 24 Jul 1979, Thomas Hill Reservoir (J. Rathert, BG); 1, 25 Jul 2012, Horseshoe Lake (K. Brink). High counts: 50, 1-15 Sep 1963, Loess Bluffs (HB); 40, 11 Sep 1968, Swan Lake (L. Kline). Latest dates: 1, 26 Nov 1978, St. Charles Co. (T. Parmeter); 3, 5-19 Nov 1992, Riverlands (JVB, RA); 1, 11 Nov 1967, Lake Contrary (FL).

\section{Dunlin (Calidris alpina)}

Status: Uncommon transient; rare winter visitant in the extreme southeastern corner, accidental winter visitant elsewhere.

Documentation: Specimen: female, 9 May 1964, Cooley Lake CA (KU 117912).

Habitat: Mudflats, shoreline, and flooded fields.

Spring: More common at this season than in fall. Outside the extreme southeastern corner of the state where birds have been consistently observed during Feb and Mar, there are only a few Mar records. Outside the bootheel, Dunlins are typically not seen until the last week of Apr, with peak in mid-May. The species is regularly seen at the end of May into the first week of Jun. Earliest dates away from the Mississippi Lowlands: 1, 15 Mar 2001, Lake Contrary (LL); 1, 22 Mar 2009, Riverlands (JU). High counts: 7,000, photos, 13 May 2012, Dunklin Co. (TJ; fig. 10); 1,726, 15 May 2006, Loess Bluffs (TR); 1,350-1,500, 21-23 May 2014, Dunklin Co. (TJ). Latest dates: 1, 14 Jun 2011, Swan Lake (SK); 1, 11 Jun 2004, Riverlands (JU).

Fall: The earliest southbound birds are normally not seen until the end of Jul and the species is encountered in only small numbers during Aug through early Oct. The largest concentrations are observed during the latter half of Oct and early Nov. It is rarely seen in early Dec with most records from the bootheel. Earliest dates: 1, alternate plumage, 10 Jul 2007, near Otter Slough (SS, BJ, PW); 1, alternate plumage, 14 Jul 2012, Osage River, Cole Co. (RD); 1, 16 Jul 2010, Thompson River Wetlands (SK, TM). High counts: 226, 11 Nov 2010, Dunklin Co. (TJ); 3 separate counts of 100 in late Oct/early Nov in the St. Louis region. 
Winter: Prior to 2009, there were only three observations for this period, but since then it has been encountered with increased regularity in extreme southern Dunklin County. Outside the southeastern corner there are the following observations of late migrants: 1, 22 Dec 1991, Aldrich CBC; 1, 17 Dec 1998, Four Rivers (MR). High counts, all from southern Dunklin Co. by TJ: 132, photos, 26 Dec 2009; 23, 23 Dec 2012.

Comments: See remarks under White-rumped Sandpiper for possible hybrid. Only the subspecies $C$. alpina hudsonia has been recorded, but western pacifica might occur in fall. During fall, juvenile Stilt Sandpipers are often confused with juvenile or basic-plumaged Dunlin. For example, a report of 750+ Dunlin, 25 Oct 1986, Rich Hill, Bates Co., likely pertained to juvenile Stilt Sandpipers.

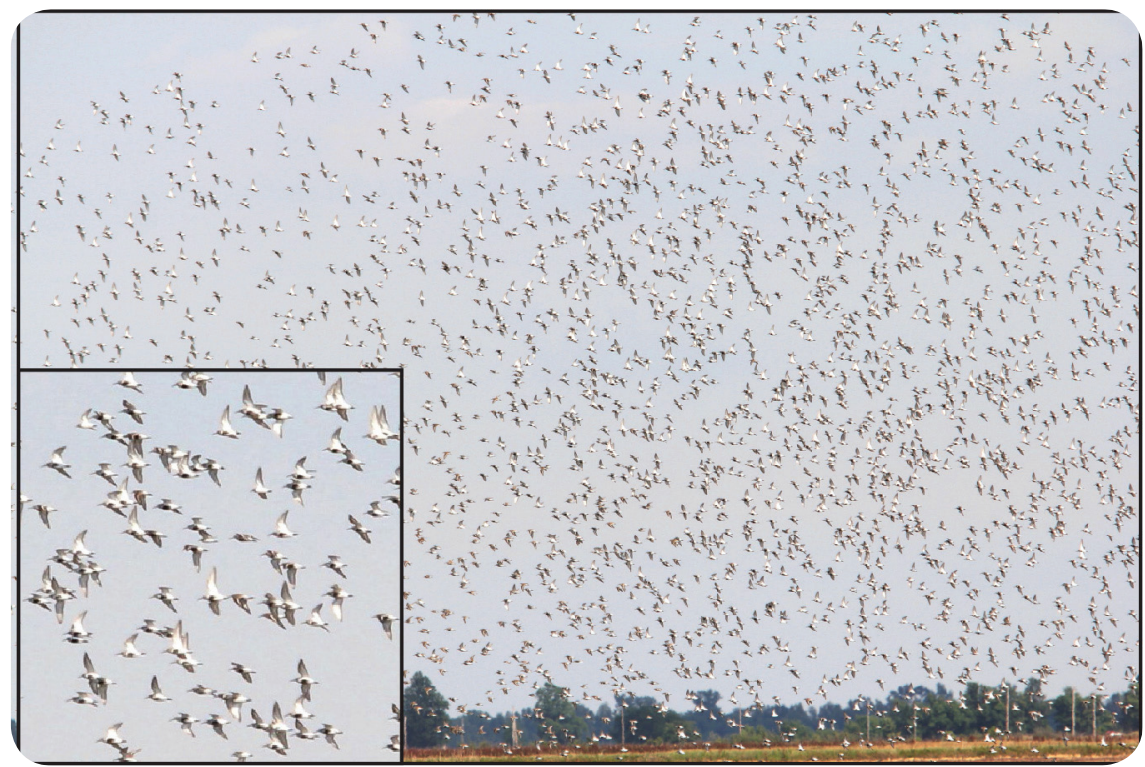

Fig. 10. Part of a flock of an estimated 7,000 Dunlin in Dunklin Co. on 12 May 2012. The largest concentration ever recorded in the state. Photo by Tim Jones.

\section{Baird's Sandpiper (Calidris bairdii)}

Status: Uncommon transient; accidental winter visitant.

Documentation: Specimen: male, 28 Mar 1968, Bigelow Marsh (KU 117784).

Habitat: Mudflats, shoreline, and flooded fields.

Spring: This sandpiper is more common in the western half of the state. The first individuals appear by mid-Mar, but relatively large numbers typically are not seen until the second week of Apr. Peak is usually in late Apr. By mid-May, only small numbers are observed. Earliest dates: 1, 4 Mar 1988, near St. Joseph (FL); 1, 5-9 Mar 2000, 
Eagle Bluffs (J. Leonatti, EW); 2, 8 Mar 2007, Grand Pass (BJ). High counts in west: 450, 21 Apr 1996, Eagle Bluffs (PM); 405, 27 Apr 2013, Bean Lake (JK); 270, 15 Apr 1994, Loess Bluffs (MR). High counts in east: 23, 17 May 1992, St. Charles Co. (CA et al.). Latest dates: several records for the first few days of Jun.

Fall: The first individuals returning south are seen in early Jul, but relatively large numbers are not seen until the end of Aug. Relatively large groups may be seen through mid-Oct, and now it is regularly reported into Nov. Earliest date: 3, 2 Jul 1961, Loess Bluffs (FL). High counts: 100, 1-15 Sep 1963, Loess Bluffs (HB, FL); 45, 26 Jul 2013, Webster Co. (GSa et al.); 30, 26 Aug 1992, Smithville Lake (RF). Latest dates: 1, 2 Dec 1997, Aldrich (MR); 1, 30 Nov 1968, Loess Bluffs (JH).

Winter: There are three records of late lingering migrants for this period: juv., 14 Jan 1996, Rock Port Sewage Lagoons, Atchison Co. (MR); 1, photos, 14 Dec 2006, Big Lake SP (BJ, AF); juv., photos, 24 Dec 2010, Smithville Lake (DW).

\section{Least Sandpiper (Calidris minutilla)}

Status: Common transient; rare winter visitant and winter resident.

Documentation: Specimen: male, 5 May 1879, Charleston, Mississippi Co. (MCZ 42408).

Habitat: Marshes, mudflats, shoreline, and flooded fields. This sandpiper prefers more grassy edge than other shorebirds and thus is less common on bare mudflat and flooded fields than other species.

Spring: The first migrants appear at the very end of Mar/early Apr. By late Apr it is common and peak is typically during the second week of May. It is regularly seen into early Jun. Earliest dates: there are a number of late Feb records that likely pertain to early migrants. High counts: 3,000, 13 May 2000, Loess Bluffs (DE, JH); 2,500, 15 May 2006, Loess Bluffs (TR, F. Durbian); 2,250, 12 May 2012, Boone Co. (m. ob.).

Fall: The first migrants appear at the end of Jun. By mid-Jul it is widespread and common. Peak is at the very end of July/early Aug. Although still common, numbers decrease from mid-Sep into the late fall. It is now regularly seen in small numbers through the end of the period. Earliest dates: several observations for 29 Jun. High counts: 1,000, 31 Jul 1988, Swan Lake (R. Brundage); 340, 20 Jul 1994, Loess Bluffs (DE); 300+, 7 Jul 2006, near Winfield Dam (CM); 250+, 7 Oct 2017, Winfield Dam (BR).

Winter: Prior to 1995, there were only two records for this period; now it is recorded annually. Most observations are of late-lingering fall or very early spring migrants, but there are several Jan records of birds that appeared to overwinter. High counts: 85, 18 Jan 2016, Hornesville Swamp area (TJ); 48, 23 Dec 2012, southern Dunklin Co. (TJ); several counts of $20+$ individuals. 


\section{White-rumped Sandpiper (Calidris fuscicollis)}

Status: Common spring, rare fall transient.

Documentation: Specimen: male, 15 May 1907, Jack's Fork River, Shannon Co. (AMNH 229422).

Habitat: Mudflats, shoreline, and flooded fields.

Spring: This is one of the later migrant shorebirds, with the first individuals not appearing until the end of Apr. Much larger numbers are encountered in the extreme western part of the state. By mid-May it is common with thousands seen at a single locality during the end of May into early Jun. Presumed northbound migrants are still observed in mid-Jun, e.g., 50, 15 Jun 2002, Four Rivers (MG). Earliest dates: 1, photos, 20 Apr 2017, Swan Lake (BJ); 1, 23 Apr 2011, Loess Bluffs (DW); several records for 24 Apr. High counts: 9,918, 13 May 2006, Loess Bluffs (DE); 5,000+, 17 May 1979, Loess Bluffs (TB).

Fall: This species is much less common in fall, with none detected most years, as the species' primary migration route, like those of the Hudsonian Godwit and the extinct Eskimo Curlew, is across eastern Canada and the northeastern United States before transoceanic passage to South America. Records span early Aug through late Oct, with most records from the St. Louis area. A few reports prior to 1980 are likely correct but lack details, whereas some that involved large numbers were clearly misidentifications. In addition, there have been editorial errors in the Bluebird that erroneously attributed Jun observations to Jul and Aug. Earliest dates: 1, 3 Aug 1980, Thomas Hill Reservoir (BG); 1, 5 Aug 1995, St. Charles Co. (G. and T. Barker). High count: 5 ad, 10 Sep 2011, Confluence SP (BR). Latest dates: 1, 31 Oct 2015, Winfield, Lincoln Co. (BR et al.); 3, photos, 10-12 Oct 2015, Eagle Bluffs (BJ).

Comments: What appeared to be a hybrid White-rumped x Dunlin was photographed on 21-22 May 2011, Loess Bluffs (DW; fig.11).

\section{Buff-breasted Sandpiper (Calidris subruficollis)}

Status: Rare spring transient in west, casual east; uncommon fall transient statewide. Documentation: Specimen: male, 8 Sep 1965, St. Joseph (KU 117609).

Habitat: Sod farms, mowed strips along airport runways, recently plowed fields, mudflats, and shoreline.

Spring: Much less frequently encountered during spring than in fall and not recorded every spring even in the extreme west. With the exception of two Apr records, the majority of observations are between the end of the first and the end of the third week of May. Earliest dates: 1, 9 Apr 1967, St. Louis (JEC); 1, 29 Apr 1956, Loess Bluffs (FL, S. Rositsky). High counts: 40, 19 May 1984, Camden Bottoms, Ray Co. (CH, MM); 30, 20 May 1967, near Bigelow (DE). Latest dates: 1, 2 Jun 2013, near Old Monroe, Lincoln Co. (DB); 1, 1 Jun 1969, Loess Bluffs (FL). In addition to the above two records there are only the following records for the heavily-covered St. Louis area: 2, 25 May 2004, Riverlands (DR); 6, 17 May and 1, 21 May 2013, Lincoln Co. (CM, JM). 


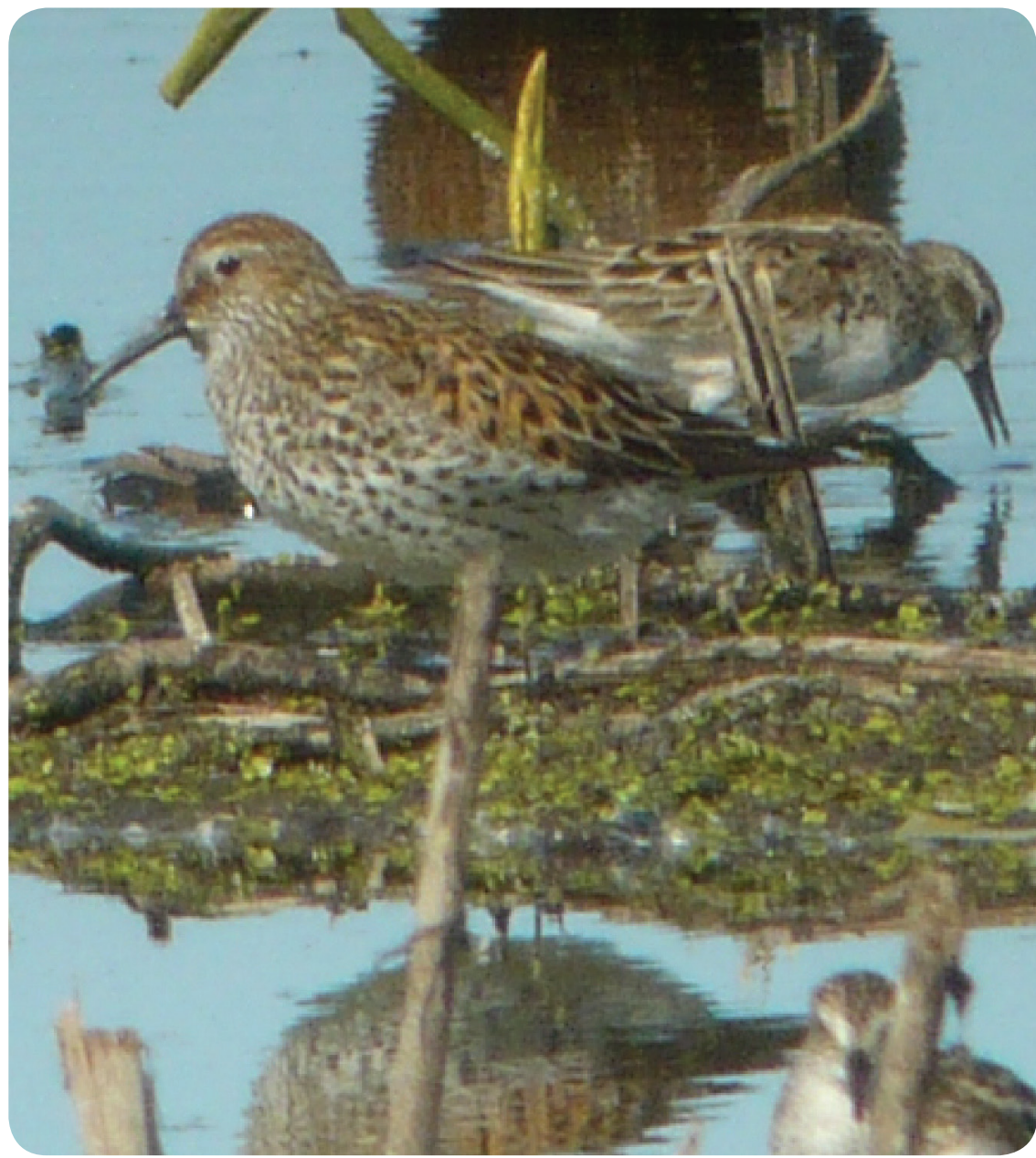

Fig. 11. A possible White-rumped Sandpiper x Dunlin hybrid, 21-22 May 2011, at Loess Bluffs N.W.R. Photo by Doug Willis.

Fall: Much more frequently recorded at this season than in spring. Most commonly recorded at sod farms and edge of airport runways. Adults begin to arrive at the end of Jul with a peak, mostly juveniles, during late Aug and early Sep. By the end of Sep it is rare. Earliest dates: 1, 20 Jul 1994, Loess Bluffs (DE); 1, 22 Jul 2013, Clarence Cannon (CA); 1, 24 Jul 1987, Schell-Osage (BJ); 18, 24 Jul 1994, Loess Bluffs area (MR, CH). High counts: 125-150, 29 Aug 2000, downtown Kansas City airport, Jackson Co. (K. Driggers, S. Reese); 90, 7 Aug 2007, Four Rivers (SS, BJ, PW). Latest dates: 1, 17-23 Oct 2011, Loess Bluffs (MR, JK, V. Austin); 1, 11 Oct 1947, Marais Temps Clair (K. Wesseling). 


\section{Pectoral Sandpiper (Calidris melanotos)}

Status: Common transient; accidental winter visitant.

Documentation: Specimen: female, 27 Apr 1963, Beverly Lake, Platte Co. (KU 41439).

Habitat: Mudflats, shoreline, and flooded fields.

Spring: Beginning in 2011, the first arrivals have been appearing in the rice fields in the extreme southeast in late Feb. Elsewhere they are not seen until early Mar. Large numbers are present by early Apr, with peak in late Apr/early May. It is regularly seen into early Jun. High counts: 6,500, 8 May 1979, Loess Bluffs (TB); 3,450, 5 May 2011, Holt Co. (MR, M. Andersen). Large number for early in season: 1,750+, $29 \mathrm{Mar}$ 1992, Otter Slough (BRe, BL). Earliest dates: 12, 19 Feb 2017, southern Dunklin Co. (TJ); 6, 21 Feb 2011, southern Dunklin Co. (TJ); 1, 23 Feb 2017, Grand Pass (BJ). Latest dates: 1, 15 Jun 1995, Mississippi Co. (J. Waldron); no.?, 15 Jun 2002, Four Rivers (MG).

Fall: Southbound migrants are seen as early as the end of Jun and by late Jul hundreds may be seen at a single locality. Peak is typically in late Aug, but the species remains common through early Oct. It is rare from late Oct through the end of the period. Earliest dates: no.?, 29-30 Jun 1991, rice fields in Stoddard Co. (TB, PM,BRe); 2,29 Jun 2006, Riverlands (JU). High counts: 4,507, 8 Aug 2007, Settle's Ford CA (SS, BJ, PW); 2,200, 13 Aug 1998, northern Atchison Co. (DE, JH). Latest dates: 3, photos, 11 Dec 2017, Otter Slough (GS); 1, 7-9 Dec 1987, Swan Lake (K. McMullen); 1, photos, 3 Dec 2017, Clarence Cannon (R. Mustell, T. Goodwin).

Winter: There are two records of late migrants for this period: 1, photos, 19 Dec 1997, Four Rivers CBC (MR, RM); 1, 14 Dec 2002, St. Joseph CBC (I. Lawhon, LL, et al.).

\section{Semipalmated Sandpiper (Calidris pusilla)}

Status: Common transient.

Documentation: Specimen: male, 29 May 1927, Grand Pass, Saline Co. (KU 39071). Habitat: Mudflats, shoreline, and flooded fields.

Spring: This is one of the most common shorebirds that migrate through the state. The first individuals typically do not appear until early Apr, with numbers increasing to a peak during mid-May. It is regularly seen, even in relatively large concentrations, into the second week of Jun. Earliest dates: 2, 14 Mar 2006, Muskrat Lake (LL); 2, 21 Mar 1976, Loess Bluffs (FL). High counts: 2,900, 13 May 2006, Holt Co. (DE); 2,500, 13 May 2000, Loess Bluffs (DE, JH); 2,400, 14 May 2012, Dunklin Co. (TJ). High count in Jun: 1,500, 1 Jun 1969, Loess Bluffs (FL).

Fall: Southbound birds begin to appear the second week of Jul and by the end of the month are widely seen, sometimes in relatively large numbers. It remains common through Aug into early Sep. It is regularly seen in much-reduced numbers in late Sep and the first week of Oct, but by mid-Oct it is very rare. There are reports, without 
details, by experienced observers as late as 18 and 19 Oct. Observations after mid-Oct likely pertain to Western Sandpiper, so photos and detailed descriptions are needed for that period. Earliest dates: 1, 3 Jul 2007, Nodaway Valley CA (SS); 1, 4 Jul 2012, Riverlands (JM). High counts: 2,500, 32 Jul 1988, Swan Lake (R. Brundage); 1,000, 1 Sep 1963, Loess Bluffs (HB, FL). Latest dates: see above and below.

Comments: Distinguishing Semipalmated from Western in the fall can be very difficult as the plumage is very similar and bill length and shape overlap between female Semipalmated and male Westerns (Veit and Jonsson 1984), thus some birds may not be identifiable.

\section{Western Sandpiper (Calidris mauri)}

Status: Rare spring transient, uncommon fall transient.

Documentation: Specimen: female, 11 Apr 1977, Bigelow Marsh (KU 117789).

Habitat: Mudflats, shoreline, and flooded fields.

Spring: This sandpiper is much less common in spring than during fall, and there are many more records for the western half of the state. The first individuals do not appear before early Apr, with peak at the end of Apr/early May. Typically, $<5$ individuals/ day are sparingly seen after the first week of May into early Jun. Earliest dates: no.?, 31 Mar 1963, near St. Joseph (FL); 1, 1 Apr 2011, Loess Bluffs (K. Diggers); 2, 4 Apr 2003, Loess Bluffs (TR). High counts: 20, 14 May 1994, Loess Bluffs (DE); 20, 29 Apr 2002, St. Joseph (LL); 12, 2 Apr 1977, Loess Bluffs (MR, DE). Latest records: 1, photos, 2 Jun 1999, Eagle Bluffs (J. Rathert, T. Curtis); 3, 29 May 2005, Thompson River Wetlands (SK).

Fall: It is much more frequently seen at this season than in spring across the state. The earliest individuals are seen at the beginning of Jul, but this sandpiper is not regularly observed until the latter half of Jul. The highest counts have occurred during late Jul and Aug. It is observed much less frequently from mid-Sep into Nov. Earliest dates: 1, 4 Jul 1940, Bean Lake (Newton 1942); 6, 7 Jul 2002, Cooley Lake (KM): 3, 8 Jul 1972, Loess Bluffs (FL). High counts: 55-60, 12 Aug 1988, Swan Lake (TB, W. Leitner); 50, 31 Jul 1988, Swan Lake (R. Brundage); 30+, 13 Aug 1995, St. Charles Co. (BR). Latest dates: 6, 28 Nov 2002, Otter Slough (DR); 1, 26 Nov 1975, Busch (JC); 1, photos, 19 Nov 2014, Pemiscot Co. (TJ). See comments under Fall for Semipalmated Sandpiper.

Comments: A color-banded individual seen on 18 May 1996 at Mound City had been banded earlier in the year in Ecuador (MR, K. Zyskowski). See Comments under Semipalmated Sandpiper.

\section{Short-billed Dowitcher (Limnodromus griseus)}

Status: Uncommon transient.

Documentation: Specimen: female, 17 May 1970, Bigelow Marsh (KU 117988).

Habitat: Mudflats, flooded fields and shoreline. 
Spring: Typically, this dowitcher does not appear until the end of Apr with peak during mid-May, which is about a week after the peak of Long-billed. It is regularly seen through May, but there is only one early Jun observation. Earliest confirmed date: 1, photos, 20 Apr 2015, Loess Bluffs (DW); a number of records for the last week of Apr. High counts: 701, 13 May 2006, Loess Bluffs (DE); 500, 13 May 2012, Eagle Bluffs (RD, G. Connette); 325, 7 May 1994, Loess Bluffs (DE); 300+, 11 May 1979, Loess Bluffs (DE, MR, TB). Latest date: 1, 1 Jun 2013, Otter Slough (JU, M. Paradise).

Fall: Southbound Short-billeds begin reappearing before Long-billeds; the first arrive at the very end of Jun. As in most shorebirds, adults are seen from late Jun through Jul, and when peak numbers are observed in mid-Aug it is a combination of adults and juveniles. There are no verified Oct or Nov records. Earliest dates: 4, 26 Jun 1966, Loess Bluffs (FL); 1, 28 Jun 2004, Riverlands (JM, CM). High counts: 35+, 14 Aug 1975, Loess Bluffs and Swan Lake (MR); 32, 23 Jul 2010, Dunklin Co. (TJ); 20, 11 Jul 2009, Otter Slough (CB). Latest dates: 1, 28 Sep 2014, Otter Slough (C. Wood); 2, 27 Sep 2008, Clarence Cannon (DR, SS).

Comments: More information is needed to clarify the mid-spring and mid-fall migration of this species. Only spring specimens exist, all of which are referable to the subspecies hendersoni. Separation of the two dowitcher species continues to be a problem; all records outside of the expected dates, as outlined here, should include voice description and photographs.

\section{Long-billed Dowitcher (Limnodromus scolopaceus)}

Status: Uncommon transient; casual winter visitant.

Documentation: Specimen: male, 25 Apr 1965, Beverly Lake, Platte Co. (KU 117808). Habitat: Mudflats, flooded fields and shoreline.

Spring: Migration is much more protracted for this dowitcher than the Short-billed, and Long-billed is considerably more common than Short-billed. Recently the species has been consistently detected during the last week of Feb in extreme southern Dunklin Co. Away from that region, the species is typically not observed until the beginning of the second week of Mar. By early Apr it can be seen in the hundreds, and thousands may be seen in a day at peak during late Apr/early May. By the beginning of the last week of May virtually all are gone. Earliest dates, all from southern Dunklin Co. by TJ: 2, 12 Feb 2017; 2, 19 Feb 2013; 2, 20 Feb 2011. Earliest date for outside the above region: 1, photos, 25 Feb 2017, Loess Bluffs (JK et al.). High counts: 5,800, 5 May 2011, Holt Co. (MR, M. Andersen); 4,200, 10 Apr 2011, Dunklin Co. (TJ); 3,240, 15 Apr 2012, Otter Slough (CB). High count for early in season: 600, 25 Feb 2012, southern Dunklin Co. (TJ). Latest dates: no definite records for the last week of May or early Jun.

Fall: Fall migration is initiated later than Short-billed, with Long-billed usually not detected until the end of Jul. From the end of Aug through the rest of the fall it outnumbers Short-billed. The largest numbers, juveniles, are usually observed during the 
third week of Oct when a few hundred/site may be observed. It is regularly seen into mid-Nov. Earliest dates: 1, id by voice, 8 Jul 1994, Loess Bluffs (MR); ad, 15 Jul 2007, Confluence SP (BR); 1, 18 Jul 2010, Clarence Cannon (DR); 6, 18 Jul 2010, St. Charles Co. (DR); 1-2, 19-20 Jul 2008, Four Rivers (MR, KM, DW, LW, L. Gilchrist). High counts: 330, 17 Oct 2011, Loess Bluffs (MR, JK); 250, 20 Oct 1963, Loess Bluffs (HB, FL); 230, 9 Oct 2016, Otter Slough (MR). Latest dates outside Mississippi Lowlands: 1, photos, 8 Dec 2000, Four Rivers (MR); 1, 4 Dec 2010, Confluence SP (BR, D. Marjamaa, M. Marjamaa, T. Bormann); 1, photos, 2-3 Dec 2005, Winfield Dam (CM, JM, JU et al.).

Winter: During the past several winters the species has been regularly observed in the Mississippi Lowlands until mid-Dec and again when early migrants appear as early as mid-Feb (TJ; eBird). The only report for this period outside that area is: 1, 19 Dec 1997, Four Rivers (MR, RM). Highest count: 350, photos, 5-18 Dec 2015, southern Dunklin Co. (TJ).

Comments: See remarks concerning identification under Short-billed Dowitcher.

\section{American Woodcock (Scolopax minor)}

Status: Uncommon summer resident, rare to uncommon winter resident in south.

Documentation: Specimen: female, 12 Mar 1894, Byrds Mill, Dunklin Co. (CHAS 15410).

Habitat: Moist areas that border forest and woodland and along wooded streams. During migration often encountered on brushy hillsides with creeks.

Comments: At all seasons this species appears to be most common in the Ozarks and Ozark border. The number of birds that actually overwinter is obfuscated by individuals that appear to return and begin displaying as early as late Jan. Few have been recorded on $\mathrm{CBCs}$, but some birds have recently been observed displaying in early and late Dec: 4 Dec 2012, Cole Co. (CB); 2, 22 Dec 2012, Bollinger Co. (A. Brant); 30 Dec 2011, Perry Co. (MH). Northernmost CBC record: 1, 16 Dec 2017, Smithville Lake (M. Nemecek, KM, S. Bingham).

The peak of spring migration appears to be in early Mar, with migrants still passing through during at least the first half of Apr. During fall, migrants peak during the latter half of Oct/early Nov. There are several high counts of $15+$ birds displaying during mid-Feb from the Columbia and St. Louis areas southward. Other high counts: 30, 17 Mar 2014, Busch and surrounding area (PL); 21, 1 Mar 2014, Maintz Wildlife Area, Cape Girardeau Co. (A. Gathman).

\section{Wilson's Snipe (Gallinago delicata)}

Status: Common transient; rare to locally uncommon winter resident.

Documentation: Specimen: female, 17 Oct 1893, Carthage, Jasper Co. (Bell Museum Natural History Museum 6068).

Habitat: Marshes, swamps, wet fields, and shoreline. 
Spring: As soon as ice begins thawing, usually in mid- to late Feb, migrants begin augmenting birds that have wintered. Numbers continue to increase until peak, usually in late Mar. Large numbers can be seen through most of Apr, and it is regularly seen in small numbers into the first two weeks of May. It is extremely rare the last ten days of May. High counts: 900, 3 Mar 2012, near Hornersville, Dunklin Co. (TJ); 800, 30 Mar 1991, Schell-Osage (PM, TB); 704, 19 Mar 2011, Dunklin Co. (TJ). Latest dates: 1, photos, 30 May 2011, Little River CA, Dunklin Co. (CB).

Summer: There are several sightings of birds during Jun, but no courtship behavior has been reported. Given that the species breeds in northern Iowa (Kent and Dinsmore 1996) and display behavior has been noted as far south as southern Illinois (Bohlen and Zimmerman 1989), it is conceivable that the snipe might breed in the state. There is a Jun observation that involved two birds: 10 Jun 1978, near Bigelow (DE, TB).

Fall: The first southbound migrants appear by mid-Jul, and by early Aug relatively large numbers are observed. Hundreds of individuals at a single locality can be observed through the end of Nov. Unless there is an early, hard freeze, birds are present across the state through the remainder of the period. Earliest dates: 1, 1 Jul 2010, Thompson River Wetlands (SK); 1, 7 Jul 1994, Loess Bluffs (JH). High counts: 708, 27 Nov 2013, Dunklin Co. (TJ); 250+, 16 Nov 2004, Pershing SP (SK); a few counts of 150/day from late Sep through Nov.

Winter: Status varies considerably from year to year depending on the severity of the winter. During mild winters, a few individuals may be present in the north, but during average years birds in the northern half of the state are scarce during mid-winter. During the past two decades much larger numbers have been recorded on a few CBCs. The highest concentrations are typically in the Mississippi Lowlands. CBC high counts: 115 (0.5), 17 Dec 2011, Columbia; 109 (3.4), 18 Dec 2017, Big Oak Tree; 86 (2.9), 21 Dec 1999, Big Oak Tree; 80 (3.6), 17 Dec 2007, Big Oak Tree.

\section{Spotted Sandpiper (Actitis macularius)}

Status: Common transient; uncommon summer resident; accidental winter visitant.

Documentation: Specimen: egg set, 7 May 1898, Wayland, Clark Co. (WFVZ 110262).

Habitat: Shoreline, flooded fields, mudflats.

Spring: Occasionally a bird is seen in Mar, but most years the first migrants are not seen until early Apr. Peak is in early May. Earliest dates: 1, 5 Mar 1992, Taney Co. (JHy); 1,7 Mar 1984, Loess Bluffs (FL); 1, 8 Mar 1972, East Prairie, Mississippi Co. (M. Southard). High counts: 125, 9 May 2000, Loess Bluffs (DE, JH); 62, 8 May 1997, Swan Lake (B. Olson); a few counts of $>50$ individuals/site in early May.

Summer: An uncommon summer resident with the smallest numbers observed in the Ozarks (BBA data). 
Fall: Migrants begin appearing during the latter half of Jul, with peak in Aug. Few are observed after mid-Oct. High counts: 110, 2 Aug 2010, Four Rivers (DW); 75, 25 Aug 2007, Schell-Osage (RF, G. Johnson). Latest dates: 1, 3 Dec 2017, Longview Lake, Jackson Co. (K. Davis); 1, photos, 2 Dec 2017, Perry County Community Lake (A. Gathman); 1, 29 Nov 1985, St. Louis Co. (CH, KH); 1, photos, 25 Nov 2007, Winfield, Lincoln Co. (JU); 1, 25 Nov 2011, Lake Wappapello, Wayne Co. (CB).

Winter: There are two records: 1, 5-15 Jan 2002, Smithville Lake (J. Eldridge, J. Harter, J. Zellmer); 1, 17 Dec - 26 Feb 2004-5, Winfield Dam, Lincoln Co. (SS, JU).

\section{Solitary Sandpiper (Tringa solitaria)}

Status: Common transient.

Documentation: Specimen: male, 3 May 1879, Charleston, Mississippi Co. (MCZ 42476).

Habitat: Marshes, flooded fields, shoreline.

Spring: Typically the first migrants do not appear until early Apr, with peak in late Apr/early May. An occasional bird lingers into early Jun. Earliest dates: 1, 22 Mar 2009, Coon Island CA, Butler Co. (CB); 1, 22 Mar 2007, Otter Slough (BL); 1, 24-31 Mar 2012, Columbia Bottom (JU, BR). High counts: 44, 20 Apr 2016, Dunklin Co. (TJ); 42, 24 Apr 2010, Duck Creek (CB); 28, 4 May 2011, Dexter (CB): 26, 29 Apr 2011, near Dexter (CB). Latest dates of presumed spring migrants: 1, 19 Jun 1999, Pershing SP (DE, E. Hueste); 1, photos, 19 Jun 2016, Ten Mile Pond (K. Poetzl); 1, 8 Jun 2008, Columbia Bottom (BR); 1, 8 Jun 2007, Eagle Bluffs (BJ).

Fall: Southbound birds begin to appear at the end of Jun, with large numbers seen by the end of Jul/Aug. Numbers are greatly reduced after the first week of Sep, with only a few records after the first week of Oct and only one Nov observation. Earliest dates: no.?, 29-30 Jun 1991, rice fields in Stoddard Co. (TB, PM, BRe); 2, 30 Jun 2006, Eagle Bluffs (JU, JM, CM); 1, 29 Jun 2008, Ten Mile Pond (JU). High counts: 125, 27 Jul 2009, Four Rivers (DW); 75, 4 Aug 2007, Winfield Dam (SS). Latest dates: 1, 6 Nov 2010, Confluence Point SP (G. Connette, DB et al.); 1, 29-30 Oct 2002, Columbia (BG).

Comments: Bennitt (1932) mentions that J.C. Salyer collected two specimens (CMC) in May 1919 and 1920 that were identified by H. Oberholser as the western subspecies, T. s. cinnamomea. That subspecies has been recorded on a few occasions in Kansas (KU 10416, 22949; juv., photos, 7 Aug 2014, Reno Co., J. Miller) and should be looked for and documented with photos. Leukering (2010) provides a summary on identification issues. In sum, western juveniles are distinct in having buffy/cinnamon spots on the dorsum vs. white of juvenile eastern birds. Adults of both species have white dorsal spotting.

\section{Lesser Yellowlegs (Tringa flavipes)}

Status: Common transient; rare winter resident in extreme southern Mississippi Lowlands, accidental winter visitant elsewhere. 
Documentation: Specimen: male, 20 Apr 1914, Jackson Co. (KU 39070).

Habitat: Marshes, mudflats, flooded fields, and shoreline.

Spring: Prior to 1996, there were no Feb records, but since then the species has become regular during the end of that month in the Mississippi Lowlands. Numbers gradually increase through Mar and the first half of Apr. In late Apr and early May this yellowlegs is widespread, and thousands may be seen at some marshes. A few individuals are encountered through the end of the period into early Jun. Earliest dates: from the onset of the period for several years. Northernmost Feb record: 2, 19 Feb 2000, Winfield Lock and Dam (PM, BG, BJ, BR). High counts during Feb, in Dunklin Co. by TJ: 284, 28 Feb 2011; 200, 25 Feb 2012. High counts during peak: 10,000, 13 May 2006, Loess Bluffs (DE); 9,100, 5 May 2011, Holt Co. (MR, M. Andersen); 7,160, 30 Apr 2007, Loess Bluffs (TR).

Fall: Southbound migrants begin to appear at the end of Jun, with numbers increasing dramatically during Jul. It is common from then into late Sep. Occasionally large numbers are seen in mid-Oct. It is rare during Nov and early Dec. Earliest date: 1, 20 Jun 2005, Riverlands (CM). High counts in Jun: 125, 30 Jun 1991, rice fields of Stoddard Co. (TB, PM, BRe). High counts: 1,000, 1 Sep 1963 (FL); 450, 20 Jul 1994, Loess Bluffs (DE); 330, 17 Oct 2011, Loess Bluffs (MR, JK). Latest dates: several observation through end of period.

Winter: Like the Greater Yellowlegs, it has been during only the past two decades that birds have lingered into Dec and returned early in Feb. Beginning in 2012, birds were observed during Jan in the extreme southern part of the bootheel. Records now span the entire period in southern Dunklin Co. High counts, in southern Dunklin Co. by TJ: 19, 29 Jan 2012; 19, 23 Dec 2012.

\section{Willet (Tringa semipalmata)}

Status: Uncommon transient in west, rare in east.

Documentation: Specimen: male, 6 May 1914, Jackson Co. (KU 39067).

Habitat: Mudflats, marshes, and shoreline.

Spring: Willets are rarely seen before the last ten days of Apr, but numbers increase rapidly with peak at the very end of Apr/first week of May. It is rarely observed the last week of May into the first week of Jun. Earliest dates: 1, 4 Apr 1976, Loess Bluffs (FL); 1, 5 Apr 2009, Riverlands (JE, JM). High counts: 107, 7 May 1967, Bigelow Marsh (DE); 100+, photos, 26 Apr 2009, Lake Jacomo (S. Wallace); 100, 22 Apr 2001, Cooley Lake (J. Bailey); 98, 9 May 2013, Eagle Bluffs (EW, PM). High count in east: 57, 25 Apr 2006, Riverlands (DR). Latest dates: 1, 7 Jun 1939, Lake of the Ozarks (H. Hedges); 6, 4 Jun 1981, Alton Dam (BRu, V. Bucholtz).

Fall: Although there are only two late Jun records, the largest numbers have been recorded in early Jul. This species is regularly observed in small numbers from mid-Jul through the first week of Sep, but thereafter it is rare, with only a few observations 
during the last half of Oct. Earliest dates: 1, 29 Jun 1995, Loess Bluffs (MR); 1, 30 Jun 1968, Loess Bluffs (FL). High counts, all at Thompson River Wetlands by SK: 15, 3 Jul 2011; 14, 5 Jul 2010; 10, 4 Jul 2005. Latest dates: 1, photo, 3-5 Dec 2016, Loess Bluffs (S. Hinds, D. Welchert); 4, 20 Oct 1963, Loess Bluffs (FL); 3, 13 Oct 2013, Schell-Osage (GSa).

Comments: Only the western subspecies inornatus has been recorded in Missouri.

\section{Greater Yellowlegs (Tringa melanoleuca)}

Status: Common transient; rare winter resident in extreme southern Mississippi Lowlands, casual winter visitant elsewhere.

Documentation: Specimen: female, 6 Nov 1949, Vernon Co. (KU 39068).

Habitat: Marshes, mudflats, flooded fields, and shoreline.

Spring: During the course of the past two decades this species has been arriving earlier, as there were no Feb records prior to then. There are now a number of records for Feb, and it is now regular in early Mar in the south. Peak is during the last two weeks of Apr. It is regularly observed through mid-May, but only the occasional individual is seen at the end of May into early Jun. Earliest dates: many observations from early to mid-Feb, especially in the southeast. High counts in Feb in Dunklin Co. by TJ: 80, 25 Feb 2012; 35, 15 Feb 2013. High counts during peak: 3,000, 19 Apr 2008, southern Dunklin Co. (CB); 1,000+, 12 Apr 1979, Loess Bluffs (TB). Latest dates: 1, 10 Jun 2015, Otter Slough (MH); 3 observations for 5 Jun.

Fall: Presumed southbound birds are regularly seen at the end of Jun. Earliest dates: 2, 21 Jun 2000, Swan Lake (SK). High count for Jun: 90, 29 Jun 1991, rice fields of Stoddard Co. (TB, PM, BRe). Numbers increase during Jul with peak in late Aug/early Sep. It remains relatively common through Sep and the first half of Oct, with scattered records from late Oct through early Dec. High counts: 200, 1-15 Sep 1963, Loess Bluffs (HB, FL); 75, 30 Aug 2008, St. Charles Co. (DR).

Winter: Since the first winter record in Dec 1997 on the Four Rivers CBC, this yellowlegs has been recorded almost annually in late Dec and late Feb, and since 2012 it has been overwintering in rice fields in extreme southern Dunklin Co. High counts, all from southern Dunklin Co. by TJ: 84, 21 Dec 2012; 74, 31 Jan 2012; 22, 6 Jan 2013.

\section{Wilson's Phalarope (Phalaropus tricolor)}

Status: Common transient in west, uncommon in east; accidental summer resident. Documentation: Specimen: female, 23 Apr 1914, Kansas City (KU 39073).

Habitat: Shallow pools in marshes, mudflats, flooded fields, and on ponds and lakes.

Spring: This phalarope is much more common in the western half of the state. The first birds appear at the beginning of Apr, with peak in early May. It is regularly seen through the end of the period into the first week of Jun. Earliest dates: 1, 18 Mar 2003, Loess Bluffs (D. Silverman); 1, 24 Mar 2007, BK Leach (T. Bormann, DR); two sight- 
ings for 25 Mar. High counts, all at Loess Bluffs: 2,011, 13 May 2006 (DE); 1,025, 10 May 2003 (DE); 1,000, 7 May 1967 (FL). High count in east: 160, 5 May 2010, southern Dunklin Co. (TJ).

Summer: Late migrants are routinely seen into the first week of Jun. There are two nesting reports. A nest with four eggs, located in the northwestern corner at Bob Brown on 22-27 May 1993 (Easterla 1994; KU 119180), was the first confirmed nesting record for the state. Widmann (1907) mentioned that Nehrling reported seeing young in Lawrence Co., in the southwestern corner of the state, during Jul 1884, but there is no confirmation of that extraordinary claim; see comments concerning other Nehrling reports under Western Kingbird and Savannah Sparrow accounts. There have been late May and Jun observations of pairs, but without any indication of breeding, e.g., two pairs, 20 Jun 1976, Maryville SL, with one male present until at least 23 Jun (DE, MR).

Fall: This phalarope is decidedly less common in fall statewide. The first migrants are usually not seen until mid-Jul, and it is seen only in small numbers (typically $<5 /$ day) through the first half of Oct. There are two Nov records. High counts: 30, 1 Sep 1963, Loess Bluffs (HB, FL); 18, 25 Aug 2011, near Corning, Holt Co. (DW); 17, 31 Aug 1974, Maryville SL (MR, DE). Earliest date: 1, photos, 9 Jul 2012, Riverlands (AS). Latest dates: 1, 17 Nov 1968, Loess Bluffs (FL); 2, 12 Nov 1984, St. Joseph (FL).

\section{Red-necked Phalarope (Phalaropus lobatus)}

Status: Rare transient; provisional winter visitant.

Documentation: Specimen: female, 16 May 1967, Bigelow Marsh (KU 117774).

Habitat: Shallow pools in marshes, mudflats, flooded fields, sewage lagoons, ponds and lakes.

Spring: This species has a narrow period when it passes through in spring. In most springs, it is seen during a two-week period in mid-May. There are a few records scattered through Jun that likely represent late migrants. Earliest dates: 1, basic plumage, photos, 21 Apr 2013, Loess Bluffs (MR, CH, SA); 1, 26 Apr 2017, Eagle Bluffs (PM, BJ, G. Leonard); female, 29 Apr 2012, Eagle Bluffs (RD). High counts, both at Loess Bluffs: 82, 19 May 1968 (DE, FL, JHam); 52, 23 May 2013 (MR).

Fall: This phalarope is not detected every fall. There are no July records, and when it is observed it is usually not seen until the third week of Aug, with the majority of records clustered at the end of Aug/early Sep. There are records throughout Oct. Earliest dates: 1, 4 Aug 1992, Mueller Pond, St. Louis (G. and T. Barker); 1, 10 Aug 2008, St. Charles Co (M. and D. Marjamaa). High counts: 14, 4 Sep 1974, Maryville SL (MR, DE); 9, 31 Aug 1963, Loess Bluffs (HB, FL). Latest and only Nov record: 1, 3 Nov 1968, Loess Bluffs (JHam).

Winter: An extraordinarily late bird was reported by a reliable observer on 1 Jan 1938, Iatan Marsh, Platte Co. (WC; Rising et al., 1978); however, no description or 
concrete documentation exists. It is unclear whether Red Phalarope was considered-a species that is more likely at this season than Red-necked. Thus this report is treated as provisional.

\section{Red Phalarope (Phalaropus fulicarius)}

Status: Casual spring and rare fall transient.

Documentation: Specimen: female, 25 Oct 1977, Maryville SL (KU 117987).

Habitat: Shallow pools in marshes, mudflats, sewage lagoons, ponds and lakes.

Spring: There are six spring records ranging from 10 May into early Jun. Earliest date: 1, transitional plumage, 10 May 2004, Loess Bluffs (MR, KG, A. Powell). High count: 3, 16 May 1954, Trimble (B. King, B. Tordoff et al.). Latest date: ad male, 1112 Jun 1997, Riverlands (CM et al.).

Fall: There are fifteen records of single individuals, with eight of the records during Oct. Earliest date: 1, 7 Sep 1986, Thomas Hill Reservoir (TB et al.). Latest dates: both of photographed juvs. at Montrose: 22 Nov 2015 (MR,CH); 4 Nov 2011 (MR, JK).

\section{Family Stercorariidae: jaegers}

\section{Pomarine Jaeger (Stercorarius pomarinus)}

Status: Accidental spring and casual fall transient.

Documentation: Specimen: sex?, 28 Nov 1915, Missouri River, Jackson Co. (Hoffman 1916; KU 47672).

Habitat: Large rivers, reservoirs, and lakes.

Spring: The sole record is of a very early spring migrant: $1^{\text {st }}$ cycle, 27 Feb 1991, Riverlands (B. Wetteroth, RG, J. Ziebol et al.).

Summer: A single observation: $3^{\text {rd }}$ cycle, 9-12 Jul 1981, Alton Dam (Y. Balsinger, M. Scudder, BRu et al.).

Fall: In addition to the specimen listed above, there are ten additional observations ranging from late Sep to mid-Dec. Earliest dates: $2^{\text {nd }}$ cycle, 24-29 Sep 1980, Lake Contrary (FL, TB, DE, I. Lawhon; photo in Robbins and Easterla (1992) was misidentified as a Parasitic); 1, 3 Oct 1979, Thomas Hill Reservoir (TB). High count: 2, 20 Nov 1996, Riverlands (K. Lannert et al.). Latest dates: A bird observed as late as 14 Dec 1996 at Riverlands (JVB et al.) was presumably one of two seen through November; 1, 14-25 Nov 1985, Smithville Lake (CH, MM, FL et al.).

Comments: The 27 Nov 1982, Alton Dam report listed in Robbins and Easterla (1992) has been retracted. See comments under Parasitic Jaeger. 


\section{Parasitic Jaeger (Stercorarius parasiticus)}

Status: Casual transient.

Documentation: Photograph; fig. 12.

Habitat: Large rivers, reservoirs, and lakes.

Spring: The only reports from this season are mentioned in an account by Harris (1919b), where he gave the extraordinary observation of 5 individuals on 23 Apr 1916 at the mouth of the Big Blue River in Jackson Co. He related that "there can be no question of the identification in the case, as the birds were close enough to show their distinctive characteristic, the sharp middle tail feathers a few inches longer than the others." Also intriguingly, he remarked: "The older river men state that this bird was not uncommon in the days when the river was filled with refuse from the packing houses."

Fall: There are the following records: bird collected (specimen apparently not extant), Aug 1905, near Billings, Christian Co. (J. Kastendieck; Widmann 1907); juv. (another jaeger was seen at the same time but not identified to species), photos, $16-22 \mathrm{Sep}$ 2016, Smithville Lake (M. Nemecek et al.; fig. 12); 1, 2 Nov 1991, Mel Price Dam (DB et al.); $1^{\text {st }}$ cycle, videotaped, 22 Nov - 10 Dec 1996, Smithville Lake (DE, JH, PM, TB et al.).

Comments: There are several observations where species identification was in question. These include: 1, 6 Sep 1971, Loess Bluffs (FL, MR, LG, R. Rowlett); 1, 3 Nov 1968, Swan Lake (JHam et al.); 1, 3 Nov 1972, Browning Lake (FL); 1, 10 Nov 1987, Smithville Lake (T. Schallberg); 1, 28 Dec 1991, Table Rock Lake (TB).

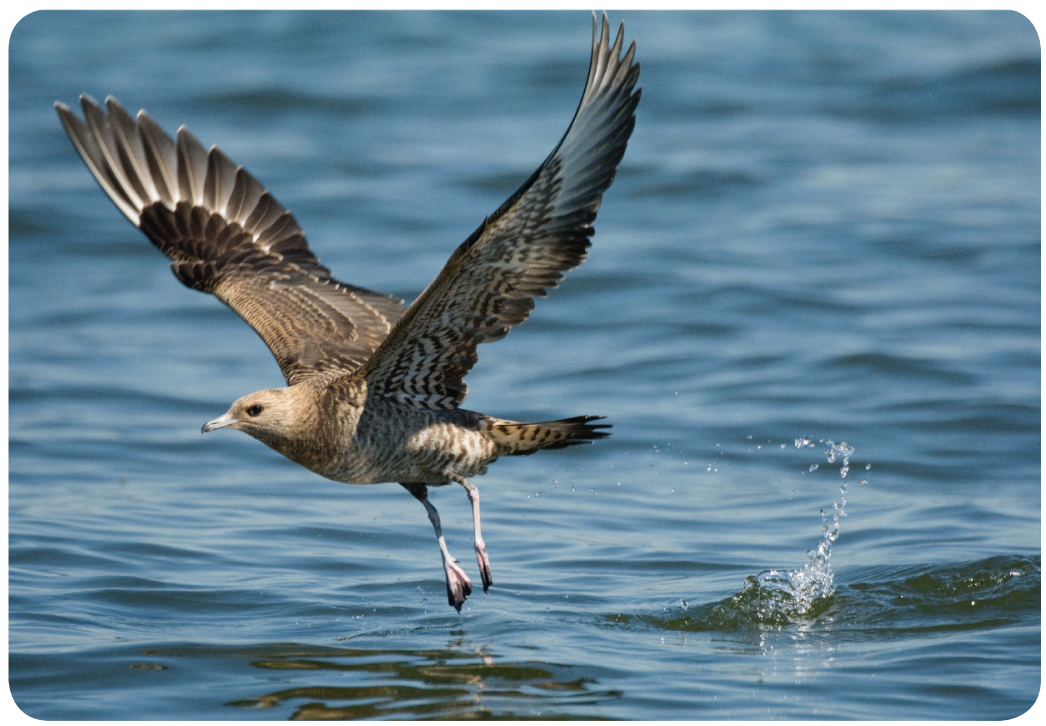

Fig. 12. A juvenile Parasitic Jaeger at Smithville Lake on 17 September 2016. Photo by Mary Nemecek. 


\section{Long-tailed Jaeger (Stercorarius longicaudus)}

Status: Casual transient.

Documentation: Photograph, see below.

Habitat: Large rivers, reservoirs, and lakes.

Spring: A single record: specimen (apparently no longer extant), spring 1910, Bean Lake (Harris 1919b).

Fall: Four records: ad, photos, 13 Aug 2016, Aldrich arm, Stockton Lake (DB1 and B. Blevins); ad, 12 Sep 1974, Maryville SL (MR, DE); $1^{\text {st }}$ cycle, photos, 16-20 Sep 2010, Smithville Lake (Mayo 2011); 2, 3 Oct 1916, Missouri River, Jackson Co. (B. Bush; Harris 1919b).

Comments: Most jaeger records through the interior of North America during Aug and Sep have proven to be Long-taileds.

\section{Family Laridae: gulls, terns, skimmer}

\section{Black-legged Kittiwake (Rissa tridactyla)}

Status: Casual transient; rare winter resident along Mississippi River at St. Louis, casual winter visitant elsewhere.

Documentation: Photograph: $1^{\text {st }}$ cycle, 7-8 Dec 1996, Fellows Lake, Greene Co. (GS et al.).

Habitat: Large, open rivers, reservoirs and lakes.

Spring: Most records during this period are birds that have overwintered at St. Louis (latest there $15 \mathrm{Apr}$ ). Latest dates elsewhere: $1^{\text {st }}$ cycle, probably same bird that was first detected on 24 Feb stayed until 26 Apr 2011, Smithville Lake (DW); $1^{\text {st }}$ cycle, 15 Apr 1984, Aldrich (C. Tyndall et al.); ad, videotaped, 7 Apr 1991, Schell-Osage (CH, G. Griffith, TB).

Fall: Records, all of single individuals, range from mid-Oct through the end of the period statewide. Most records are from late Nov to the end of the season. All but one observation have been $1^{\text {st }}$ cycle birds. Earliest dates: 12 Oct 1991, Lake Contrary (K. Jackson); 18-19 Oct 2000, Lake Jacomo (MB, RM, R. Simmons).

Winter: All but four records are from the Mississippi River at St. Louis, where it is observed only sporadically. The four non-St. Louis records, all single $1^{\text {st }}$ cycle birds, except one: 28 Dec 1989, Stockton Lake (MR); 20-21 Jan 1995, Blue Springs Lake, Jackson Co. (MB, L. Moore); 30-31 Dec 2007, Thomas Hill Reservoir (JE); ad, 17 Dec 2011, Maryville SL (DE).

Comments: The specimen mentioned by Widmann (1907) for Jackson Co. cannot be located. 


\section{Ivory Gull (Pagophila eburnea)}

Status: Accidental winter visitant.

Documentation: Photograph; fig. 13.

Records: An adult that was originally found on the Illinois side of the Mississippi River at Quincy was seen multiple times and photographed along the Missouri side of the river, Marion Co. It was present 2-9 Jan 2015 (J. Mullins et al.).

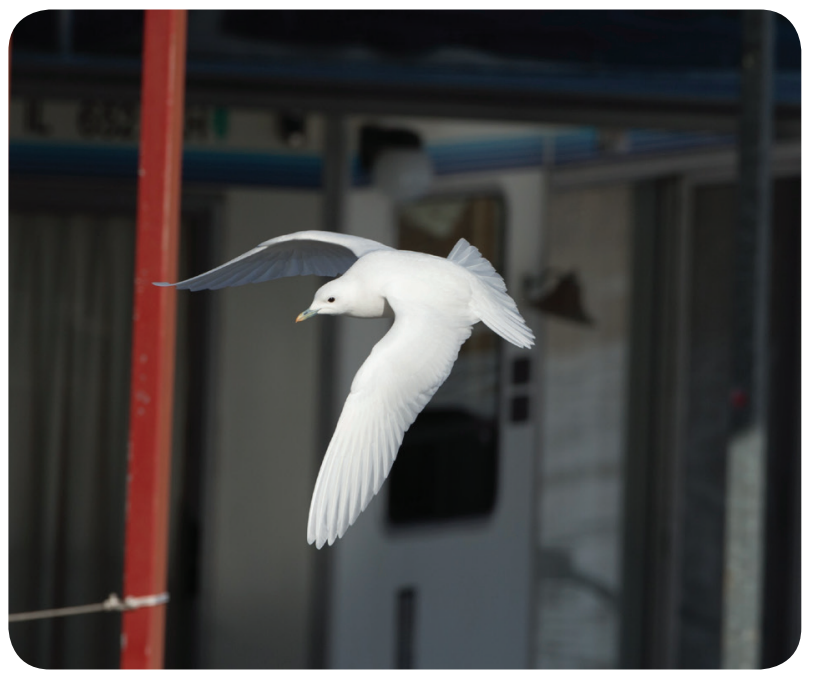

Fig. 13. The only Missouri record of Ivory Gull, 9 January 2015, Mississippi River. Photo by Linda Williams.

\section{Sabine's Gull (Xema sabini)}

Status: Rare transient in fall.

Documentation: Specimen: male, 15 Sep 1900, near Fox Island, Mississippi River, Clark Co. (Royal Ontario Museum of Natural History 39588).

Habitat: Reservoirs, lakes, and large rivers.

Fall: Recorded virtually every fall, between mid-Sep and mid-Oct, at the large reservoirs. With the exception of one individual, all have been juveniles. Earliest dates: 1, 1-14 Sep 2005, Thomas Hill Reservoir (EW, JE); 1, 6 Sep 2008, Table Rock Lake (JE, GS). High counts: 4 (ad, 3 juvs.), 24 Sep to 16 Oct 2000, Riverlands (L. Lundt, BR et al.); two records of 3 individuals during different years in late Sep. Latest dates: all of single juvs.: 27 Oct 2007, Thomas Hill Reservoir (JE); 13 Oct 1995, Smithville Lake (MR, CH); photos, 13 Oct 2013, Smithville Lake (DW).

\section{Bonaparte's Gull (Chroicocephalus philadelphia)}

Status: Common transient; accidental summer visitant; locally uncommon winter resident in south, rare winter visitant in north. 
Documentation: Specimen: male, 27 Nov 1964, 10 miles south of Gravois Mills, Morgan Co. (KU 117662).

Habitat: Reservoirs, lakes, and large rivers.

Spring: Migrants begin augmenting the wintering population during the latter half of Mar, with migrants widespread across the state during Apr. It is regularly observed through the first two weeks of May, with a number of observations through the third week of May. High counts, all at Table Rock SP: 2,100+, 22 Mar 2008 (MR); 550, 15 Mar 2014 (m. ob.); 250-300, 19 Mar 2009 (MR). Latest dates: 3 observations for 25 May.

Fall: This small gull is more common and widespread in fall than spring. Although a few are occasionally observed in late Aug, typically the first individuals are not seen until the end of Sep. Thousands/day may be seen at the larger reservoirs during Oct through Nov. During mild late falls, hundreds are still present on southern reservoirs at the end of the period. Earliest dates: ad, basic plumage, 29-31 Jul 1971, Loess Bluffs (MR, FL, CH, SP); 2 juvs., 11 Aug 1991, Riverlands (BR); ad, basic plumage, 13 Aug 1983, Mississippi River, St. Charles Co. (RG). High counts: 10,000+, 3 Nov 1991, Thomas Hill Reservoir (PM, TB); 3,000, 11 Oct 1992, Swan Lake (I. Adams); 1,000+, 27 Nov 2004, Bagnell Dam, Miller Co. (DE, JE).

Winter: For the past twenty-five years the winter population has been increasing. During mild winters this gull can now be seen in relatively large concentrations at large southern reservoirs, with much smaller numbers at unfrozen northern reservoirs. Concentrations are higher during the early and late part of this season. High counts: 1,225, photo, 2 Jan 2016, Bagnell Dam, Miller Co. (CB); 550, 19 Dec 1998, Oronogo Water Treatment Plant, Jasper Co. (LH); 420, 3 Jan 2009, Taney Co. CBC; 365, 23 Dec 2006, Stockton Lake (MR). High count in north: 60, 17 Dec 2012, Smithville Lake (DW, L. Owens).

\section{Black-headed Gull (Chroicocephalus ridibundus)}

Status: Accidental transient.

Documentation: Specimen: ad male, 30 Oct 1976, Maryville SL (DE; KU 117869).

Habitat: Reservoirs, lakes, and large open rivers.

Records: In addition to the above record there are two others: ad, 10-25 Sep 1988, Alton Dam (DB, RG et al.); ad, 12-27 Feb 1991, Gravois Mills, Morgan Co. (Contreras 1991).

\section{Little Gull (Hydrocoloeus minutus)}

Status: Rare transient, accidental winter visitant.

Documentation: Photograph: 2 ads, 12 Feb - 2 Mar 1991, Gravois Mills, Morgan Co (Contreras 1991; photos in article).

Habitat: Reservoirs, lakes, and large open rivers. 
Spring: Less frequently recorded in spring, with only six records: ad, basic plumage, 5-6 Apr 1987, north of Gravois Mills, Lake of the Ozarks (W. Leitner, TB); $1^{\text {st }}$ cycle, 4 Apr 1991, Riverlands (RA, JVB); ad, basic plumage, 5 Mar 1994, Table Rock Lake (M. Mlodinow, D. Chapman); alternate plumage, 12 Apr 2006, Riverlands (JU); ad, photos, 11 May 2009, Riverlands (D. Kassebaum, JE, AS et al.); ad and $1^{\text {st }}$ cycle, photos, 28-30 Mar 2015, Aldrich Arm, Stockton Lake (P. Hostetler et al.).

Fall: A rare migrant, with records of both adults and juveniles ranging from late Sep into early Dec. Most records are between late Oct and mid-Nov. Earliest dates: 2 juvs, 29 Sep into Oct 2000, Riverlands (DB, BR et al.); 1 juv., 23 Oct 2005, Thomas Hill Reservoir (JE). High counts: besides the above two other records involving two birds. Latest date: juv., 4 Dec 2011, Thomas Hill Reservoir (RD).

Winter: Two other observations besides the above Gravois Mills record: ad, 30 Dec 2007, Thomas Hill Reservoir (JE); $1^{\text {st }}$ cycle, 16 Dec 2012, Smithville Lake (DW).

\section{Ross's Gull (Rhodostethia rosea)}

Status: Accidental winter visitant.

Documentation: Photograph: fig. 14.

Habitat: Reservoirs, lakes and large, open rivers.

Records: Single record: ad, 31 Dec - 9 Jan 1991-92, Riverlands (Barksdale 1992; photo in article).

\section{Laughing Gull (Leucophaeus atricilla)}

Status: Rare transient, with most records from the Mississippi River; rare summer visitant along Mississippi River, accidental elsewhere; casual winter visitant.

Documentation: Specimen: $1^{\text {st }}$ cycle male, 28 May 1977, Thomas Hill Reservoir (J. Rathert; MDC B0128).

Habitat: Large open rivers, reservoirs, lakes, and mudflats.

Spring: Typically not observed until May, with the majority of records along the Mississippi River at St. Louis. Earliest dates: 1, 13-17 Mar 1997, Riverlands (JVB); 1, 29 Mar - 1 Apr 1969, Alton Dam (P. Snetsinger, TB). High counts: 9, 26 May 2008, Riverlands (DR, JM, CM); 5, 28 May 2011, Riverlands (JU, DB).

Summer: Like spring, most observations are from along the Mississippi River at St. Louis and are principally during Jun to the beginning of Jul; there are no observations for the last three weeks of Jul. Records away from that region include: subadult, 6 Jun 1981, Lake Viking, Gallatin, Daviess Co. (DE); 1, $2^{\text {nd }}$ cycle, 27 Jun 2009, Thousand Hills SP (PK); $1^{\text {st }}$ cycle, photos, 16 Jun 2013, Smithville Lake (DW, N. Varvel). Only Jul record: 2 ad, 4 Jul 1999, Riverlands (CM, JM). High count: 4, alternate plumage, 23 Jun 1991, Riverlands (G. and T. Barker). 


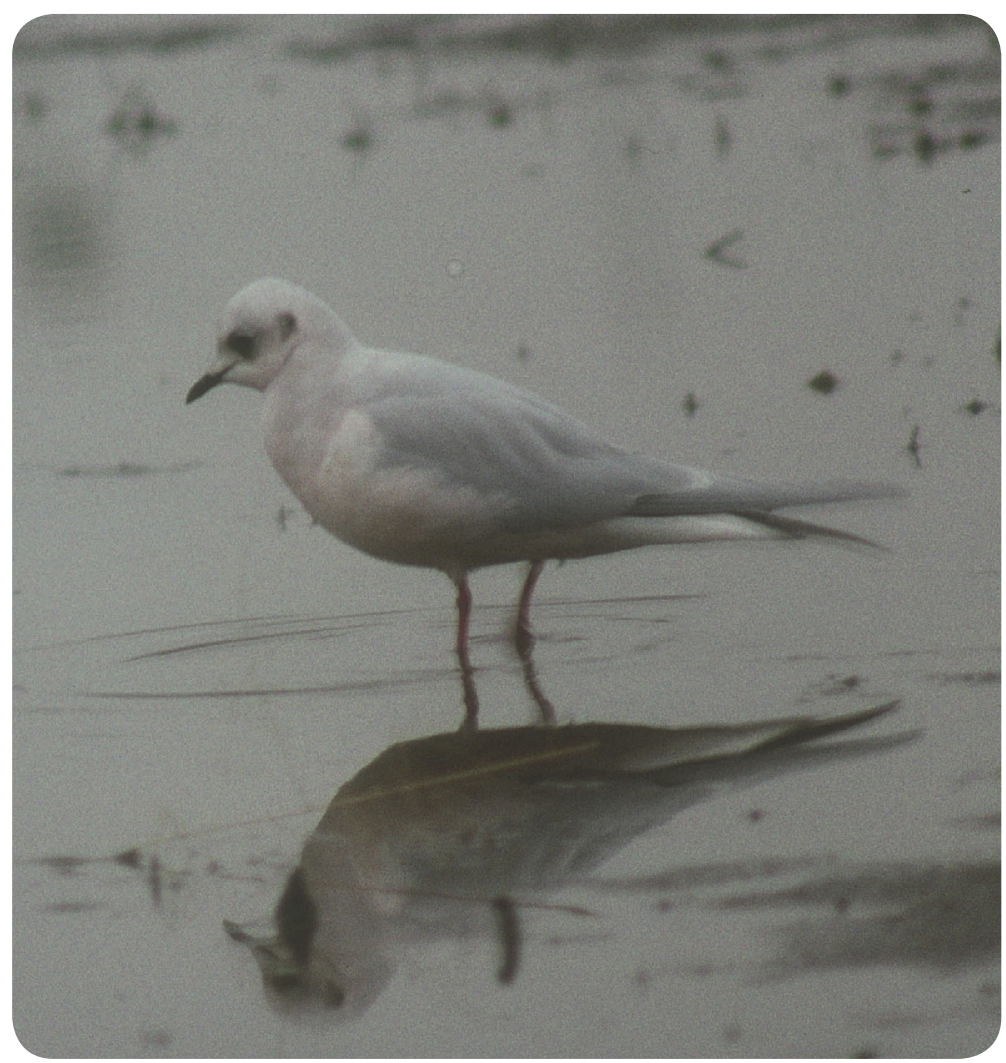

Fig. 14. Adult Ross's Gull at Riverlands on 31 December 1991. Photo by Dennis Bozzay.

Fall: Records span from the first week of Aug through mid-Nov statewide, with most during Aug and the first half of Sep. Earliest dates, all at Riverlands: 2, photos, 1-5 Aug 2015 (CM, JM, BR); 1, 10 Aug 2002 (D. Clark); ad, 11 Aug 1990 (R. Coles). Latest dates: ad, 15-16 Nov 1985, Alton Dam (BRu, P. Snetsinger, RA); $1^{\text {st }}$ cycle, 16 Nov 1986, Riverlands (RA). High count away from Mississippi River: 3 (2 ad, 1, $1^{\text {st }}$ cycle), photos, 29-31 Aug 2016, Stoutsville Recreation Area, Mark Twain Reservoir, Monroe Co. (A. Casey, C. Gregory).

Winter: There are now six records, with four from along the Mississippi River. The two records away from the Mississippi: $1^{\text {st }}$ cycle, 19 Dec 1976, Fountain Grove (Goodge 1977); ad, 4 Jan 2009, Long Branch Lake, Macon Co. (PK).

\section{Franklin's Gull (Leucophaeus pipixcan)}

Status: Common transient in west, uncommon in east; rare summer and winter visitant. Documentation: Specimen: male, 3 Nov 1925, Jackson Co. (KU 39075).

Habitat: Reservoirs, lakes, large rivers, recently plowed fields, and marshes. 
Spring: Although it is common in the west at this season, it is not seen in such immense numbers as during fall. It is much less frequently seen in the eastern half of the state. The first arrivals appear by mid-Mar, and by the end of the month hundreds may be seen. Peak is in late Apr/early May when flocks with high hundreds or low thousands of individuals may be encountered. Small flocks may still be seen passing through the west in early Jun. Earliest dates: 1, 3 Mar 2013, Smithville Lake (J. Phillips et al.); 1, 6 Mar 1956, St. Joseph (FL). High counts, in west: 2,500, 15 May 1966, near St. Joseph (JHam); 2,000, late Apr 1965, Loess Bluffs (FL, HB). High count in east: 30, 10 May 2003, Riverlands (JU).

Summer: Late migrants are regularly seen into early Jun and there are multiple records of individuals and small flocks spanning all of Jun and Jul.

Fall: Apparent southbound migrants begin to appear in Aug, but it remains uncommon until the end of Sep when relatively large flocks, numbering in the hundreds and low thousands of individuals, are seen. The impressive peak, when tens of thousands of birds may be concentrated at large reservoirs in the western and central part of the state, is during Oct. Large concentrations are seen through mid-Nov. High counts: 150,000, 23 Oct 1968, Swan Lake (L. Kline); 50,000, 17 Oct 2011, Smithville Lake (JK); 30,000+, 4 Oct 1991, Smithville Lake (PM, CH, TB, MR).

Winter: A rare and irregular winter visitant. Records of both adults and immatures span the entire period statewide. Adults observed during this season often have complete black hoods and pink suffusion on the breast. High counts: 4, 9 Feb 1998, Franklin Island CA (C. Royall); 3, ads in full alternate plumage, 23-27 Dec 1988, Big Lake SP (MR et al.); 3, 22 Feb 1998, Lake Contrary (LL).

\section{Mew Gull (Larus canus)}

Status: Accidental spring transient.

Documentation: Photograph; fig. 15.

Habitat: Large, open rivers and reservoirs.

Records: A single observation of a $1^{\text {st }}$-cycle individual of the western North American subspecies brachyrhynchus, Smithville Lake, 18-21 Apr 2008 (DW, LW et al.; fig. 15).

\section{Ring-billed Gull (Larus delawarensis)}

Status: Common transient; uncommon summer visitant along Mississippi River, rare elsewhere; common winter resident in south, uncommon across most of the north except along the Mississippi River where it can be common.

Documentation: Specimen: female, 29 Oct 1925, Kansas City (KU 39074).

Habitat: Virtually every body of water and recently plowed fields.

Spring: Migrants begin augmenting the winter population by the end of Feb. Peak along the Mississippi River is in early Mar, whereas in the west it typically is not until early Apr. It is commonly observed through early May statewide. By the end of 


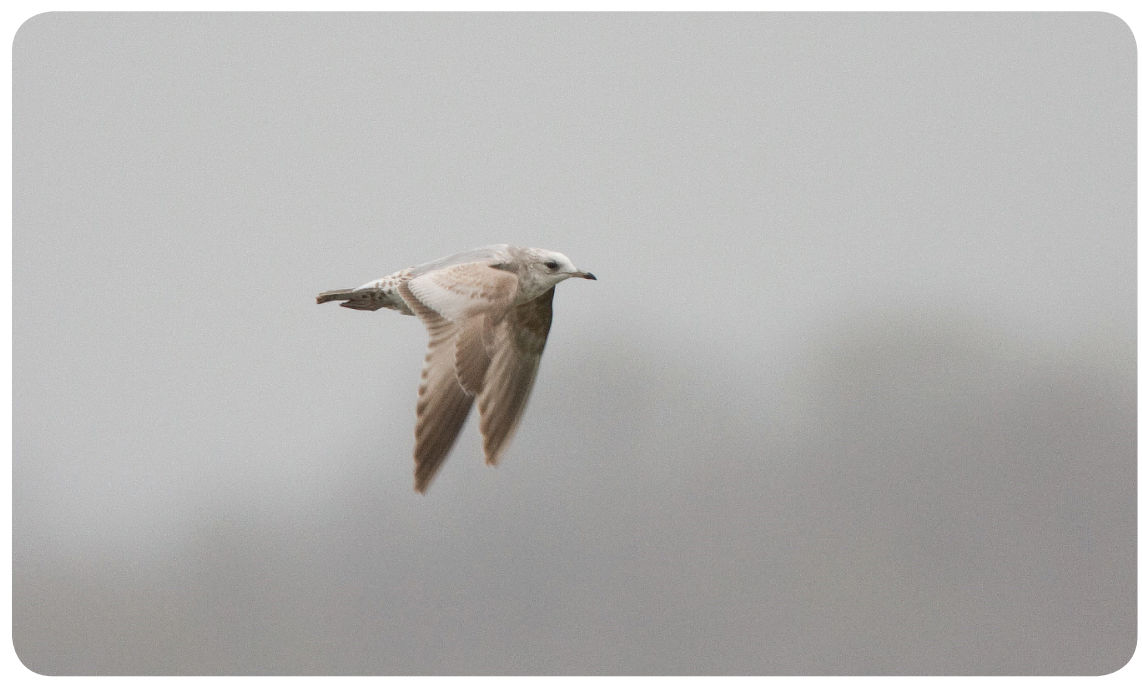

Fig. 15. The only record of Mew Gull in Missouri, 18 April 2008, Smithville Lake. Photo by Linda Williams.

the period only individuals and small groups are seen. High counts: several counts of 5,000 along the Mississippi River in the St. Louis area during early Mar. High count in west: 3,500, 8 Apr 1996, Smithville Lake (CH). High count at end of season: 137, 31 May 2008, Riverlands (JE).

Summer: It is a rare but regular visitor during this period at marshes, reservoirs, and the large rivers. High counts: 690, 31 Jul 2016, Columbia Bottom (MT); several reports of over 100 during the latter part of Jul.

Fall: Numbers across the state begin increasing by the latter half of Jul. There is a gradual increase during Aug and the first half of Sep, with larger numbers seen during the latter half of Sep. The largest concentrations are seen during Nov into early Dec. High counts: several estimates of 10,000 along the Mississippi River in the St. Louis area during late Nov. Much smaller numbers, still numbering in the high hundreds and low thousands, are seen at reservoirs in other parts of the state.

Winter: Very common along the Mississippi River at St. Louis and at reservoirs where there are nearby refuse dumps. High counts: 19,200, 1 Jan 2009, Confluence CBC; several estimates of 10,000 individuals along the Mississippi River in the St. Louis area.

\section{California Gull (Larus californicus)}

Status: Rare transient; casual winter visitant.

Documentation: Photograph: $2^{\text {nd }}$ cycle, 6-13 Nov 1981, Alton Dam (BRu, RK, TB; VIREO x08/7/001).

Habitat: Large rivers, reservoirs, and lakes. 
Spring: There are seven records, six of which are from the Alton Dam/Riverlands area. All observations are of single individuals, ranging in age from $1^{\text {st }}$ cycle to adults. Earliest dates: ad, 7 Mar 1976, Alton Dam (TB); ad, 29 Mar 1987, Alton Dam (RA). Latest date: $3^{\text {rd }}$ cycle, 18 May 1986, Alton Dam (RG et al.). The only non-Mississippi River record: ad, 7 May 1989, Smithville Lake (MR, DE, TE).

Fall: There are ten records, with six from the Alton Dam/Riverlands area. All observations are of single birds that range from early Oct through early Dec. Earliest date: 1, 4 Oct 1986, Alton Dam (RA). Latest date: ad, 2-8 Dec 2004, Riverlands (JE, DR, JU, JM, CM).

Winter: There are six records: ad, 10 Feb 1991, Stockton Lake (TB); 1, 28 Dec - 3 Jan 1991-2, Table Rock Lake (PMa, TB); ad, 18 Jan 1999, Stockton Lake (MR); $1^{\text {st }}$ cycle, 18 Jan 2009, Riverlands (DR); ad, 14 Feb 2012, Columbia Bottom (CA, C. Kirmaier); ad, 28-31 Jan 2015, Smithville Lake (KM, DW et al.).

Comments: The preponderance of records during migration from the Mississippi River in the St. Louis area is likely due to a combination of factors, ranging from favorable sites for concentrating and retaining gulls to more intense observer coverage. Given that this gull is western in distribution it would be expected to be detected as or more frequently in the western than the eastern half of the state. Subspecific determination of adults has been minimal. Most are likely of the nominate subspecies, however, the adult observed on 18 Jan 1999 had a very pale mantle and may have been attributable to the more northern albertaensis.

\section{Herring Gull (Larus argentatus)}

Status: Common transient and winter resident along the Mississippi River at St. Louis; uncommon transient elsewhere; uncommon winter resident south of St. Louis along the Mississippi River, rare elsewhere; rare summer visitant along Mississippi River, casual elsewhere.

Documentation: Specimen: female, 25 Dec 1968, 10 miles south of Gravois Mills, Morgan Co. (KU 117550).

Habitat: Large rivers, reservoirs, and lakes.

Spring: By mid-Feb the large wintering concentrations along the Mississippi River are already headed north. This gull remains common in that area until early Apr, e.g., 500, 1 Mar 2014, St. Charles Co. (BR, CM, JM), but few are still present by the end of the month. A few linger through the end of the period. Away from the Mississippi River, it is much more uncommon, with usually under five birds/site. High count away from the Mississippi River: 160, 7 Mar 2011, Smithville Lake (DW).

Summer: Typically non-adults are occasionally seen during the summer along the Mississippi River. It is much less frequently encountered elsewhere at this season. All records are of 1-2 individuals/day and span the period. 
Fall: There is a gradual increase in sightings from Aug through Oct, but relatively large numbers are not observed until mid-Nov. As in all other seasons, it is most frequently encountered along the Mississippi River in the St. Louis area. High counts, both at Riverlands: 325, 28 Nov 2013 (JM, CM); 100, 24 Nov 2011 (JM, CM). High counts elsewhere are usually $<10$ individuals/day.

Winter: Huge concentrations are seen along the Mississippi after very cold weather to the north forces birds down to the state. High counts: 10,000 (estimated 500-600 in $1^{\text {st }}$ cycle), Jan 1994, Mississippi River at St. Louis (m. ob.); 4,000, 9 Feb 1991, Mel Price Dam (PM, TB, RG). High counts elsewhere: 250, 19 Dec 2013, Smithville Lake (DW). The high count of 227, 23 Dec 1990, Trimble CBC was likely a transcriptional error, as only 72 Ring-billeds were reported.

\section{Iceland Gull (Larus glaucoides)}

Status: Rare winter resident, most frequent along the Mississippi River.

Documentation: thayeri, male, 8 January 1978, Chain of Rocks, Mississippi River, St. Louis (KU 117548).

Habitat: Large rivers, reservoirs, and lakes.

Comments: Although considerable doubt has existed for over a century about the validity of Thayer's Gull (Larus thayeri) as a species (Dwight 1917, Snell 1991), it was not until 2017 that it was treated as a subspecies of Iceland Gull (L. glaucoides; Chesser et al. 2017). Birds referred to as thayeri breed across the Canadian Arctic east to Baffin Island and primarily winter along the west coast of North America, whereas birds that breed on eastern Baffin Island and winter primarily along the northwestern Atlantic coast are referred to as kumlieni, at present considered a subspecies of Iceland Gull. However, birds referred to as kumlieni appear to be hybrids between thayeri and nominate Iceland Gull, with Weir et al. (2000) concluding that kumlieni is an unstable, hybrid population. Indeed, birds that are often identified as kumlieni are highly variable with wingtips ranging from nearly pure white to nearly as dark as those of thayeri. Nominate glaucoides, now restricted as a breeder to Greenland (Weir et al. 2000), has not been recorded in Missouri and is considered quite rare in winter in the northeastern continental United States (Weir et al. 2000). Both thayeri and kumlieni phenotypes occur in Missouri and observations for the two are given separately below. It should be emphasized that some of these identifications to one or the other form may be problematic. Moreover, for birds with darker wingtips, observers should exercise great care in attempting to separate these two forms. In many cases subspecific identification should not be attempted and birds should simply be identified at the level of Iceland Gull.

Spring: Wintering birds start leaving in Feb, with a few lingering into Mar. Latest dates: 1 (thayeri), 27 Mar 1993, Smithville Lake (RF); 1, 1st cycle (kumlieni), photos, 14 Mar 2010, Smithville Lake (DW, KM).

Fall: There are two records for thayeri during the second week of October, but no additional observations until the end of Nov, when thayeri is regularly seen along the 
Mississippi River at St. Louis. Earliest dates for thayeri: 1, $1^{\text {st }}$ cycle, 10 Oct 2001, Horseshoe Lake (MR); 1, photos, 11 Oct 1975, Alton Dam (TB). The earliest kumlieni: ad, photos, 20 Nov 2017, Riverlands (BJ).

Winter: Thayeri appears to be a regular winter resident along the Mississippi River at St. Louis. One to four birds/day are noted almost annually, mainly during the coldest part of the winter. During some winters as many as $10+$ individuals have been reported in a day. There are a number of records from elsewhere, especially Smithville Lake. High counts: 11, 19 Feb 1985, Alton Dam (C. Patterson); 6, 17 Jan 2001, Riverlands (C. Wood, B. and S. Hengeveld). Larger numbers were reported during very severe winters in the late 1970s and early 1980s (TB).

Kumlieni is rarer and an irregular winter resident along the Mississippi River at St. Louis. In some winters none are detected there. There are a few accepted records of kumlieni from outside the St. Louis area. High counts, both at Riverlands: 3, $24 \mathrm{Feb}$ 2007 (JU, CM et al.); 3, 22 Feb 2015 (JU, BR).

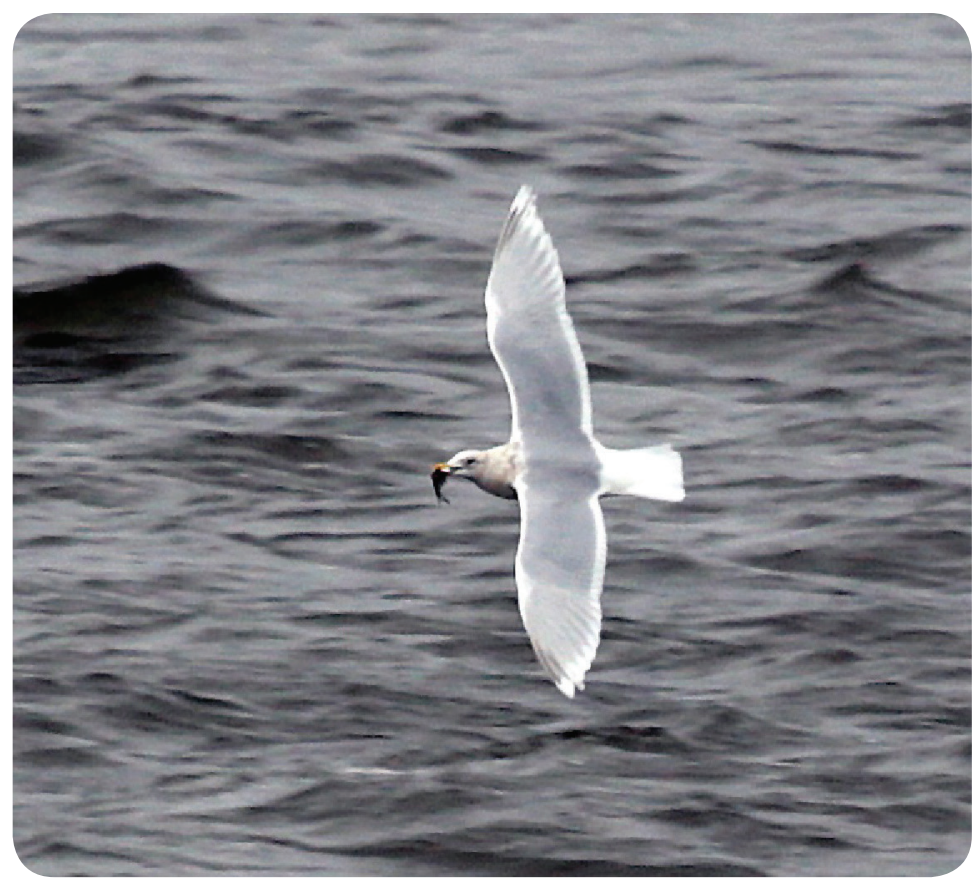

Fig. 16. Adult Iceland Gull at Mel Price Dam, Riverlands, 11 January 2014. Photo by Douglas Hommert.

\section{Lesser Black-backed Gull (Larus fuscus)}

Status: Rare transient and winter resident, with most records from along Mississippi River at St. Louis; accidental summer visitant. 
Documentation: Specimen: male, 22 Sep 2004, Smithville Lake (KU 110064).

Habitat: Large rivers, reservoirs, and lakes

Spring: As with the other gulls that are primarily found in the state during winter, this species also begins to leave in Feb from along the Mississippi River in the St. Louis area. Individuals are regularly seen until mid-Mar, with two May records. Latest dates: $1^{\text {st }}$ cycle, 18 May 2014, Riverlands (BR); $3^{\text {rd }}$ cycle, 2-4 May 2007, Riverlands (JU, CM, F. Holmes); $2^{\text {nd }}$ cycle, 27-30 Apr 2013, Lake Contrary (JK, J. Phillips).

Summer: Three records: $2^{\text {nd }}$ or $3^{\text {rd }}$ cycle, 30 Jul 1992, Riverlands (RA); ad, photos, 31 Jul 2016, Eagle Bluffs (BJ); photos, apparent $3^{\text {rd }}$ cycle, 26 July 2017, Columbia Bottom CA (MT).

Fall: This species continues to be more frequently encountered. There are now several early Sep records with infrequent observations throughout the rest of the season. Earliest dates, all at Riverlands: ad, photos, 1 Sep 2012 (JM, CM, AR); $2^{\text {nd }}$ cycle, 9 Sep 2011 (JU); ad, 11 Sep 2006 (CM, CA).

Winter: It is recorded in small numbers every winter along the Mississippi River in the St. Louis area and at the larger reservoirs such as Smithville and Long Branch. High counts: 5-6, mid-Jan 2001, Riverlands (m. ob.); 6, 24 Feb 2007, Riverlands (JU, $\mathrm{CM}$ et al.).

Comments: The first record for the state was obtained in Dec 1980 at Chain of Rocks, St. Louis (BRu, P. Snetsinger et al.). By the early 1990s, it began to be recorded on a regular basis in the St. Louis area. While this species does appear in greater numbers in winter, its occurrence is less tied to cold weather than that of the other large white-headed gulls. The only subspecies recorded in Missouri is L. f. graellsii, which breeds in Britain, Iceland, and Greenland.

\section{Slaty-backed Gull (Larus schistisagus)}

Status: Accidental winter resident.

Documentation: Photograph: ad, 20 Dec-29 Jan 1983-84, Mississippi River, St. Louis (photos by D. Ulmer; Goetz et al. 1986).

Comments: The above record was meticulously documented in the Goetz et al. 1986 paper. Since this record there have been a number of records in the lower 48 states, including one at Carlyle Lake in Illinois near St. Louis.

Glaucous-winged Gull (Larus glaucescens)

Status: Accidental winter visitant.

Documentation: Photograph; MBRC files, see below.

Habitat: Large rivers, reservoirs, and lakes.

Record: A single record: $1^{\text {st }}$ cycle, photos, 6 Feb - 23 Mar 1997, Riverlands (JVB et al.). 
Comments: As a regular western vagrant, with two records in Illinois near St. Louis, this species can be expected to occur again in Missouri.

\section{Glaucous Gull (Larus hyperboreus)}

Status: Rare winter resident.

Documentation: Specimen: male, 30 Jan 1978, near Trimble (KU 117648).

Habitat: Large rivers, reservoirs, and lakes.

Spring: Wintering birds primarily leave in Feb, but it is regularly seen during Mar. There are at least four Apr records and one May observation. High count in Mar: 4, 9 Mar 1963, Alton Dam (JEC). Latest dates: 1, 27 May 1978, St. Charles Co. (RA, P. Bauer); $2^{\text {nd }}$ cycle, 16-18 Apr 1977, Chain of Rocks (JE et al.).

Fall: Typically this gull is not detected until the end of the season in late Nov/early Dec. Earliest dates: $1^{\text {st }}$ cycle, 28 Oct 1982, Schell-Osage (J. Wilson); 1, 13-18 Nov 1980, Alton Dam (BRu, C. Patterson, C. Spener).

Winter: The Glaucous Gull is primarily observed along the Mississippi River in the St. Louis area, but there are records, a few involving two individuals, scattered throughout the state during this season. High counts: 9, 24 Jan 1994, Riverlands (JVB); 8, Jan 1984, Alton Dam area (m. ob.).

\section{Great Black-backed Gull (Larus marinus)}

Status: Rare winter resident along Mississippi River at St. Louis, accidental elsewhere. Documentation: Photograph: ad, 12 Feb 1984, Alton Dam (B. Rose; VIREO x08/5/001). Habitat: Large rivers and reservoirs.

Spring: Birds that wintered are typically gone by the end of Feb; however, there are three Mar records: ad, 17 Mar 1978, Alton Dam (BR, M. Schaeffer); $1^{\text {st }}$ cycle, 3-4 Mar 2007, Riverlands (JM, CM et al.); $1^{\text {st }}$ cycle, photos, 23-24 Mar 2014, Riverlands (JM, CM).

Fall: There are only two Nov records, both of $1^{\text {st }}$ cycle individuals: 7-8 Nov 1985, Mississippi River, St. Louis Co. (C. Patterson, BRu); 15-19 Nov 1992, Riverlands (JVB, RA et al.).

Winter: Typically only one or two individuals are observed during this season in the St. Louis area, and it is not recorded every winter. There are only four records away from that area: ad, 1 Jan 1945, Cape Girardeau (Mrs. Findley, Mrs. Harris): 1, 16-24 Jan 2004, Long Branch Reservoir (m. ob.); $3^{\text {rd }}$ cycle, photos, 31 Jan 2010, Truman Reservoir, Benton Co. (MR, M. Andersen, JK); ad, photos, 29 Jan - 17 Feb 2015, Smithville Lake (DW et al.). High counts: minimum of 5, various ages, 4-24 Feb 2007, Riverlands (JE, JU et al.); two additional years where three birds were observed. 
Sooty Tern (Onychoprion fuscatus)

Status: Accidental vagrant.

Documentation: Specimen: see below.

Record: An adult male was picked up in the Osage River, Osage Co., on 5 August 1995, after the passage of the remnants of Hurricane Erin (B. Bax; KU 86618).

\section{Least Tern (Sternula antillarum)}

Status: Rare transient and summer visitant; locally common summer resident along lower Mississippi River; formerly bred along the Missouri River.

Documentation: Specimen: female, 26 May 1968, Bigelow Marsh (KU 117997).

Habitat: Large rivers with sandbars, reservoirs, lakes, and marshes.

Spring: Typically, this tern does not appear until the second week of May. At breeding sites along the lower Mississippi River it can be locally common by late May. Away from that area only a few individuals are observed at this season. Earliest dates: 1, 21 Apr 2001, Schell-Osage (CH); 1, 25 Apr 1998, Schell-Osage (CH, C. Litterst).

Summer: Prior to 1900, the Least Tern was apparently an uncommon breeder on sandbars of both the Mississippi and Missouri rivers (Widmann 1907). Breeding still occurred along the Missouri and adjacent shallow pools through the mid-1950s: 23, 4 young being fed by adults, 17 Aug 1941, Big Lake SP (WC); 15-20 pairs, 4 nests with 2 eggs each, 23 Jul 1952, Mud Lake, Buchanan Co. (B. King); 6 nests, 9-23 Jul 1955, Missouri River near Dundee, Franklin Co. (Jackson 1955).

Since the 1950s, the principal breeding area in the state has been along the Mississippi River from the Missouri/Arkansas state line up to Cape Girardeau. Numbers vary considerably with availability of sandbars. Beginning in 1985, the MDC conducted a long-term study of the species; early results of that were presented by Smith (1987). Subsequent surveys in this area documented as many as 1,200 nests on fourteen islands during the summer 1991, and on 14 Jun 1999, 968 nests were located in ten colonies (R. Renken). In 2002, the first nesting attempt in about 50 years was documented at Riverlands when a nest with two eggs was located (DR). Nesting barges were placed there, and in Jul 2009, 2 nests with 20 chicks were documented (S. Miller, V. Giammaria et al.). At this site in 2017, close to 60 adults were present that resulted in 56 birds hatching (L. Richter).

Fall: Away from breeding sites, mostly small numbers are sporadically seen through mid-Sep. High counts away from breeding area: 35, 5 Sep 1986, Stockton Lake (PMa et al.); 35, 19 Aug 1965, Lake Springfield (N. Fay). Latest dates: 1, 27 Sep 1984, Alton Dam (C. Patterson); 10, 26 Sep 2005, Caruthersville (JE).

\section{Caspian Tern (Hydroprogne caspia)}

Status: Uncommon transient, provisional winter visitant.

Documentation: Specimen: female, 29 Oct 1972, Alton Dam (KU 117674). 
Habitat: Large rivers, reservoirs, lakes, and marshes.

Spring: Usually the first individuals appear by mid-Apr, and by the end of the month small numbers are seen across the state. Peak is during mid-May. It is regularly seen into the first week of Jun. Earliest dates, all of single birds at Riverlands: photos, 29 Mar 2006 (JU); 31 Mar 2007 (JE); 31 Mar 2017 (BR); 4 Apr 2004 (JM, CM). High counts: an extraordinary event occurred on 14 May 1978, when 3,000+ were seen in the St. Joseph and Loess Bluffs area (FL) and 247 were present at Columbia (J. Rathert). High counts under more normal circumstances: 80, 17 May 2014, Swan Lake (BJ, PM, et al.); 75, 9 May 2012, Smithville Lake (K. Brink).

Summer: Individuals and small flocks are regularly seen during the first two weeks of Jun, but observations span the entire period. High counts: 24+, 10 Jun 1993, Riverlands (BL); 17, 26 June 1966, Loess Bluffs (FL).

Fall: Small numbers are observed through Aug, and by early Sep it is seen in larger numbers. Peak is in mid-Sep with numbers tapering off until mid-Oct. There are two early Nov records. High counts: 250, 14 Sep 1977, Missouri River, Jefferson City (fide BG); 105, 25 Sep 1998, Truman Dam (MR); 95, 11 Sep 1999, Swan Lake (SK). Latest dates, all at St. Louis: 1, 8 Nov 1981 (BRu, JE); 1, 3-5 Nov 2005 (CM, JE); 1, 30 Oct - 4 Nov 2003 (JU).

Winter: There is a single report of 1, 2 Jan 2017, St. Joseph, by a reliable observer, but characters were not noted that would distinguish the bird from a Royal Tern; hence this is treated as provisional.

\section{Black Tern (Chlidonias niger)}

Status: Common transient in west, uncommon in east; former summer resident.

Documentation: Specimen: female, 15 May 1857, St. Louis (USNM A7073).

Habitat: Marshes, lakes, reservoirs, and large rivers.

Spring: This tern is rarely seen before the very end of Apr. Peak is usually in mid-May when hundreds can be seen at prime marsh sites in the western and central part of the state. Earliest dates: 4, 15 Apr 2013, Loess Bluffs (DW); 1, 23 Apr 2001, Lake Wappapello (BRe, SD). High counts: 3,000, 14 May 1978, Loess Bluffs/Lake Contrary (FL); 1,765, 14 May 2005, Holt Co. (DE et al.); several observations of about 1,000/day.

Summer: Relatively large numbers are regularly seen headed north through mid-Jun. By mid-Jul southbound migrants appear when flocks of up to 50 individuals may be seen. High counts: 400+, 13 Jun 1996, Clarence Cannon (B. Treiterer); 125, 18 Jun 1966, Loess Bluffs (FL).

Formerly, this tern was a "fairly common" breeder in marshes, but by about 1900 it was already considered rare (Widmann 1907). The last definite nesting records occurred at Marais Temps Clair in Jun 1940 and 1950 (JEC). 
Fall: As mentioned above, southbound migrants are detected by mid-Jul. Peak is usually at the end of Aug/early Sep. By mid-Sep it is much less common and there are very few Oct records. High counts: 500, 31 Aug 1963, Loess Bluffs (FL); 500, 1 Sep 2013, Smithville Lake (DW); "several hundred", 19 Aug 1963, Schell-Osage (S. Hilty). High count late in season: 80, 24 Sep 2003, Riverlands (JE). Latest dates, both at Smithville Lake: 6, 18 Oct 2013 (DW); 1, 13-14 Oct 1995 (CH, MR, RF). Widmann (1907) lists a 21 Oct record without year or locality (presumably St. Louis).

\section{Common Tern (Sterna hirundo)}

Status: Uncommon transient.

Documentation: Specimen: female, 17 May 1974, Maryville SL (KU 117667).

Habitat: Reservoirs, lakes, rivers, and marshes.

Spring: This tern is usually not observed until early May with peak during the second or third week of that month. Late northbound migrants are seen through early Jun, although see comments below. Earliest dates: 1, 18 Apr 1999, Riverlands (JM, E. Alexander); 1, 20 Apr 2008, Smithville Lake (RF). High counts: 100+, 16 May 1993, Riverlands (DB); 55, 24 May 2008, Riverlands (JE); 50, 23 May 1970, Loess Bluffs (DE); 40, 6 May 2004, Smithville Lake (KM).

Fall: Presumed southbound birds are observed as early as late Jun, with a clear increase in numbers during the latter half of Jul. There are observations spanning the early to mid-Jun period that may represent birds that never went north to breed. Numbers increase during Aug and early Sep with the highest counts in late Sep/early Oct. It is rarely observed during the last two weeks of Oct. High counts: 60, 15 Sep 1977, Alton Dam (JE et al.); 24, 13 Sep 2017, Little River CA, Dunklin Co. (BJ); 23, 5 Oct 2013, Smithville Lake (MR, CH, J. Cooper). Latest dates, all of single birds: alternate plumage, 25 Nov 2017, Thomas Hill Reservoir, Macon Co. (BJ); 30 Oct - 1 Nov 1991, Smithville Lake (CH, TB, L. Moore); 29 Oct 2009, Riverlands (CA); 24 Oct 2005, Riverlands (JU).

Comments: Many spring reports, especially during the latter half of May into early Jun, may have involved $2^{\text {nd }}$ cycle Forster's Terns, as birds in that plumage stage often have worn primaries that appear dark, not unlike Common Tern. Birds in that plumage can have entirely black caps, long tail streamers, and breeding soft-part colors. All observations of birds in alternate plumage should note not only the primary wing pattern but the color of underparts: gray in Common, white in Forster's.

\section{Forster's Tern (Sterna forsteri)}

Status: Common transient; accidental winter visitant.

Documentation: Specimen: male, 19 Apr 1965, 10 miles south of Gravois Mills, Morgan Co. (KU 117867).

Habitat: Reservoirs, lakes, rivers, and marshes.

Spring: This species is more common at all seasons than the Common Tern. The first arrivals are usually seen by the second week of Apr. Peak is in early May, with some 
individuals seen through end of the season. Earliest dates: 2, 15 Mar 2016, Riverlands (CM); 1, photos, 23 Mar 2012, Smithville Lake (DW); 1, photos, 24 Mar 1995, Little Blue River, Jackson Co. (MB). High counts: 109, 7 May 1994, Loess Bluffs (DE); 100, 5 May 1991, Loess Bluffs (DE, MR, TE).

Fall: There are observations throughout Jun, presumably a combination of late spring and early fall migrants. The frequency of observations increases during the latter half of Jul and continues through late Sep. Since the end of the 1990s, it has been regularly seen until mid-Oct and there are now several records for the last week of Oct. High counts: 63, 4 Sep 2011, Thomas Hill Reservoir (RD); 40, 7 Aug 2012, Swan Lake (SK); 35, 20 Jul 1965, Loess Bluffs (FL); 30, 3 Oct 1965, Loess Bluffs (FL). Latest dates: $1^{\text {st }}$ cycle, 10 Dec 2015, Riverlands (PK); 8 (1 lingering until $19^{\text {th }}$ ), photos, 8-19 Nov 2017, Stoutsville Recreation Area, Mark Twain Reservoir, Monroe Co. (A. Casey, BJ); ad, photos, 7 Nov 2015, Aldrich Arm, Stockton Lake (MR, CH, P. Hostetler); $1^{\text {st }}$ cycle, 1-6 Nov 2011, Smithville Lake (MR, JK); 1, 5 Nov 2003, Big Lake SP (TR).

Winter: A single observation: 1 in basic plumage, 9 Feb 1991, Portage Des Sioux, Mississippi River, St. Charles Co (PM, TB).

\section{Black Skimmer (Rhynchops niger)}

Status: Accidental.

Documentation: Photograph; fig. 17.

Habitat: Rivers.

Record: 1, photos, 25 Sep 2004, Riverlands (DB, JU, JM, CM).

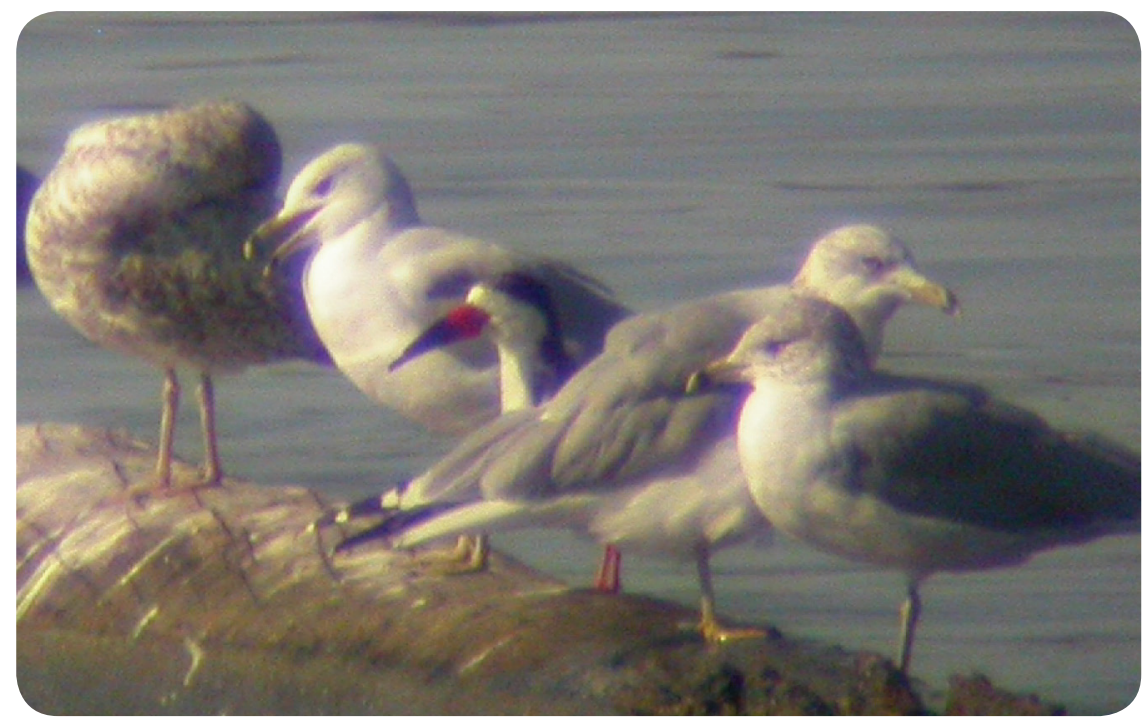

Fig. 17. The only Black Skimmer record for the state, 25 September 2004, Riverlands. Photo by Josh Uffman. 


\section{Order Gaviiformes Family Gaviidae: loons}

\section{Red-throated Loon (Gavia stellata)}

Status: Rare fall, casual spring transient; accidental winter visitant/resident.

Documentation: Specimen: sex?, Dec 1937, Laclede Co. (Southeast Missouri State University 32).

Habitat: Reservoirs, lakes, and large rivers.

Spring: Occurs much less frequently at this season than in fall, with only eight records spanning nearly the entire period: 1, 26 Feb 1994, Riverlands (DB et al.); 1, 7 Mar 1981, Thomas Hill Reservoir (S. Sherman, TB); 2, photos, 25-26 Mar 2016, Stockton Lake (AK et al.); 1, alternate plumage, 30 Mar 1958, Sugar Lake (WC; Rising et al. 1978); 1, 31 Mar - 1 Apr 2015, Riverlands (B. Schindewolf, L. Richter, et al.); 1, 4-6 Apr 2004, Lake Springfield (J. Leonatti, KM);1, alternate plumage, 9 May 2001, Loess Bluffs (DE, B. Thomas); 1, alternate plumage, 16 May 1971, Kirksville (M. Luker).

Fall: Because of increased observer coverage at large reservoirs, this loon is now recorded almost annually, with as many as five in a single fall (2006). Records span from early Oct through the period, with a peak in late Oct/early Nov. Earliest dates: 1, 2 Oct 2004, Riverlands (CA, T. Bormann); 1, 1-2 Oct 2006, Smithville Lake (JH). High counts: several of two individuals.

Winter: Three observations: 2, 16 Dec 2001, Smithville Lake (MG); imm, 21 Jan late Feb 1991, Table Rock Lake (PM, TB et al.); 1, 23-26 Jan 2013, Table Rock Lake (PM, BJ).

\section{Pacific Loon (Gavia pacifica)}

Status: Rare fall, casual spring transient; accidental summer visitant; casual winter visitant/resident.

Documentation: Specimen: male, 23 Oct 1969, Browning Lake, Buchanan Co. (Easterla and Lawhon 1971; KU 117712).

Habitat: Reservoirs, lakes, and large rivers.

Spring: Like the Red-throated Loon, this species is much less frequently recorded in spring than fall. There are only five records that span most of the period: imm, 23 Feb - 9 May 1990, Table Rock Lake (Lundberg 1990); 1, in basic plumage, 13 Mar 1999, Fellows Lake (GS, CBu); 1, 15 Apr 2006, Stockton Lake (B. Bailey); 2, 16 Mar 2008, Table Rock Lake (MT); 1, alternate plumage, photos, 3 May 2010, Smithville Lake (DW, KM).

Summer: There are two records: a bird in alternate plumage, photos, 10 Jul 1998, Table Rock Lake (K. Lee), and one in basic plumage, photos, 15-18 Jun 2014, Stockton Lake, Dade Co. (TB, J. and S. Martin et al.). 
Fall: With increased knowledge and coverage of the larger reservoirs and rivers, this species is now recorded annually at this season, with several observations involving more than one bird. Records span from early Oct through the end of the season, with peak in late Oct to mid-Nov. Earliest dates: 1, 2 Oct - 25 Nov 2006, Smithville Lake (JH, DW, RF); 2, photos, 18 Oct 2013, Smithville Lake (DW). High counts: 8, 27-29 Nov 1964, south of Gravois Mills, Lake of the Ozarks (Easterla 1965a); 6, photos, 11 Nov 2013, Smithville Lake (DW).

Winter: There are six records: 2, ad and imm, 18 Jan - late Feb 1991, Table Rock Lake (J. Day, PM, TB et al.); 1, 2 Jan-16 Feb 1992, Lake Springfield (J. Confer, D. Rising); 1, 19 Dec 1999, Smithville Lake (CH, MG); 2, 23-26 Jan 2013, Table Rock Lake (PM, BJ); 1, photos, 16 Jan 2016, Smithville Lake (M. Nemecek); 1, Dec thru Feb 2016-7, Stockton Lake (R. and L. Hostetler et al.).

Comments: The Arctic Loon (Gavia arctica) should be looked for in fall as it has been recorded twice along the Front Range in Colorado (2002, H. Kingery et al.; 2005, A. Spencer, G. Walbek; Colorado Bird Records Committee).

\section{Common Loon (Gavia immer)}

Status: Uncommon transient, rare summer visitant; locally uncommon winter resident in the south.

Documentation: Specimen: male, Nov 1965, near Big Lake, Holt Co. (KU 117540). Habitat: Reservoirs, lakes, and large rivers.

Spring: Migrants begin augmenting the wintering population by late Feb, with the majority of observations during Apr. Peak is typically the last half of Apr, but relatively large concentrations have been seen in early May. High counts: 87, 4 Apr 2015, Stockton Lake (CB); 78 (wintering birds?, see below), 28 Feb 2010, Stockton Lake (MR); 61, 15 Mar 2014, Table Rock Lake SP (m. ob.); 50, 4 May 1937, Mississippi River, St. Charles Co. (W. Short).

Summer: Non-breeding birds, typically in basic plumage, are recorded virtually every summer in small numbers at the large reservoirs and lakes. It has been recorded at as many as seven locations (2 individuals at 3 sites) during a summer (1998). High counts: 4, 21 Jun - 31 Jul 1976, Fellows Lake (C. Bonner, N. Fay); 4, all summer 2006, Smithville Lake (m. ob.); 3, 28 Jul 2007, Fellows Lake (D. Ringer, LB, CBu); multiple sightings of two individuals.

Fall: Migrants begin to appear by mid-Oct, with peak in early Nov. Birds observed in Aug and Sep may have oversummered. Earliest record of bird not oversummering: 1, 10 Sep 1977, Maryville SL (DE). High counts: 133, 11 Nov 2009, Stockton Lake (BJ, AF); 114, 4 Nov 2007, Stockton Lake (JE); 110, 11 Nov 2013, Smithville Lake (DW).

Winter: During at least mild winters, this loon now winters in relatively large numbers at southern reservoirs. High counts, both at Stockton Lake: 135, 16 Jan 2011 (MR, M. Andersen, JK); 74, 28 Dec 2014 (PL). 
Comments: Prior to the construction of large reservoirs and lakes, loons were primarily recorded along the major rivers, but now they are routinely observed in relatively large numbers during migration and winter.

\section{Yellow-billed Loon (Gavia adamsii)}

Status: Accidental transient and winter resident.

Documentation: Photograph; see below.

Habitat: Large reservoirs.

Records: The first record was obtained when a bird was found at Table Rock Lake on $14 \mathrm{Feb} 1990$ (Lundberg 1990). What was presumed to be the same individual was present during the winters of 90-91 through 1997-8. During that period the earliest it was detected was 22 Nov 1991, in alternate plumage (J. Fitzgerald), and the latest 9 May 1990 (C. Lundberg). The only other record: 1, 25 Nov 2005, Thomas Hill Reservoir (Uffman 2006).

\section{Order Procellariiformes}

\section{Family Hydrobatidae: storm-petrel}

\section{Band-rumped Storm-Petrel (Oceanodroma castro)}

Status: Accidental vagrant.

Documentation: Specimen, see below.

Comments: Likely as a result of Hurricane Baker, which made landfall in Mobile, Alabama, on 30 August 1950, this storm-petrel was found injured beneath a farm windmill near Defiance, St. Charles Co., on 2 Sep (K. Wesseling; Anderson 1994). Fortunately, it was preserved and mounted as a specimen (STCS). Although the whereabouts of the specimen were unknown for a few decades, it was relocated and reexamined in 1994 at the St. Louis Science Center (Anderson 1994, with photos of mount therein). Plumage pattern and measurements procured in 1994 confirm the original identification, which was made by a curator at USNM shortly after it was discovered.

The Band-rumped Storm-Petrel, which breeds in both the Atlantic and Pacific oceans, may represent a complex of multiple species (Smith et al. 2007). If more than one species is eventually recognized, the Missouri specimen may need to be reexamined.

\section{Order Ciconiiformes Family Ciconiidae: stork}

\section{Wood Stork (Mycteria americana)}

Status: Casual summer visitant; formerly recorded annually, sometimes in large numbers, in the Mississippi Lowlands.

Documentation: Photograph; see below.

Habitat: Marshes and wetlands. 
Records and Comments: With the exception of two observations, all postbreeding dispersers have been recorded between mid-Jul and early Sep. During the past 25 years there have been eight records, all of immatures: 2, 10 - 17 Aug 1996, Riverlands (P. Bauer, DE); 1, photos, 21-22 Nov 2004, near Schell-Osage (S. Robertson); 1, photos, 28 Jul - 12 Aug 2007, Four Rivers (N. Johnson, J. Garrett, N. Leo); 1, 15-21 Jul 2010, Thompson River Wetlands (TM, SK); 4, photos, 10-23 Jul 2012, Swan Lake (SK et al.); 2, photos, 8 Jun - 1 Aug 2014, Four Rivers (C. Daniel et al.); 1, photos, 29 July 2017, Schell-Osage (R. Hostetler); 1, photos, 4 Sep 2017, Hornersville Swamp CA (TJ).

Widmann (1907) considered it a regular summer visitor to the Mississippi Lowlands. In August 1932 there was a major influx into the state with 130 at St. Louis (G. Foster, R. Zahn) and 44 near Cape Girardeau (R. Dede). The last report of a large group was of 35-40 on 14 Aug 1937 at Cape Girardeau (H. Bolen), although 23 were present in Illinois just southeast of St. Louis in 1963 (W. George). Between the 1937 record and the mid-1990s, this stork was recorded on only two occasions: 1, 16-26 Jul 1952, near Seckman, Jefferson Co. (B. Tanner) and an adult, 14 Sep 1975, SchellOsage (G. Seek). The paucity of records during the latter period is likely a reflection of the scarity of observers in the Mississippi Lowlands coupled with a decline in the species (Coulter et al. 2013).

As mentioned in Robbins and Easterla (1992), the report of 4 at Mingo on 23 Jun 1956 is an error, as the birds were photographed in Florida (R. Nolf, pers. comm.).

\section{Order Suliformes \\ Family Fregatidae: frigatebird}

\section{Magnificent Frigatebird (Fregata magnificens)}

Status: Accidental vagrant.

Documentation: Photograph: adult female, 28 Sep 1988, Longview Lake, Jackson Co. (CH, RF et al.; Robbins and Easterla 1992).

Habitat: Expected at large bodies of water and rivers.

Records: The above record occurred about three weeks after a storm system, remnants of hurricane Gilbert, passed through the state. During this same time frame, several additional observations occurred across the interior of North America (Lehman 1989).

Two other frigatebird species, Greater and Lesser, have been recorded in North America; thus it cannot be assumed that a frigatebird appearing in Missouri is a Magnificent. Attempts should be made to photograph every individual extensively. There are the following additional Missouri records, all occurring after storms, where the identity of the frigatebird species could not be determined: immature or adult female, 2 Apr 1982, Marshfield, Webster Co. (J. Sowers); 1, 27 Apr 1983, near DeSoto, Jefferson Co. (M. Wiese); 1, 13 Oct 1995, Mississippi River, St. Charles Co. (M. and R. Huber). The record mentioned in Bennitt (1932) is considered erroneous given that the observer had a plethora of unreliable observations that Bennitt included in his compilation. 


\section{Family Phalacrocoracidae: cormorants}

\section{Neotropic Cormorant (Phalacrocorax brasilianus)}

Status: Transient and summer visitant rare west, casual east.

Documentation: Photograph: see below.

Habitat: Lakes, marshes, and rivers.

Spring: The status of this species has changed dramatically since the first record in early Jun 1990 at Loess Bluffs. It is now regular in spring in the western half of the state, with records spanning from early Apr through the end of the period. Observations include both adults and birds less than a year old. Earliest dates: ad, photos, 31 Mar - 16 Apr 2016, Schell-Osage (M. Mutchler et al.); ad, photos, 18 Mar into May 2017, Schell-Osage (LB, CBu, D. and S. Martin et al.); ad, photos, 28 Mar 2017, Four Rivers (M. Nemecek). There are only three eastern records with one also the spring high count for the state: 3, 22 Apr 2011, Delaney Lake CA, Mississippi Co. (CB); imm, photos, 28 Apr - 19 May 2016, Ten Mile Pond (CB, MH et al.); imm, photos, 29 Apr - 1 May 2016, Duck Creek (CB, A. Gathman).

Summer: Adults and immatures are now regularly found in the western half of the state during the latter half of Jul into fall. There is a single record for the eastern half of the state during this period: 1-2 ad, 8 Jul - 24 Aug 2017, Grand Tower Island, Perry Co. (BJ et al.). The only other Jun record: ad, 27 Jun 2008, Swan Lake (PM, P. Herman). High count: 3, photos, 26 Jul 2012, upper Smithville Lake (DW et al.).

Fall: The only eastern records for this period: ad, 30 Aug - 12 Sep 1992, Riverlands (BR, P. Snetsinger, P. Bauer et al.); imm, photos, 2-9 Sep 2016, Eagle Bluffs (BJ, PM); and the above Grand Tower record. Latest dates: 1, 15-18 Nov 2013, Lake Springfield (m. ob.); ad, photos, 23 Sep 2013, Smithville Lake (DW).

\section{Double-crested Cormorant (Phalacrocorax auritus)}

Status: Common transient; rare summer resident; uncommon summer visitant; rare winter resident, primarily in southern reservoirs.

Documentation: Specimen: 4 May 1879, Charleston, Mississippi Co. (MCZ 42917).

Habitat: All bodies of water.

Spring: Migrants begin supplementing the winter population as early as late Feb, with a gradual increase during Mar. The bulk of the migrants appear in Apr, with a decrease by the end of Apr. Small numbers are still regularly seen through May. High counts: 4,000, 12 Apr 2007, Eagle Bluffs (RF); 3,100, 25 Mar 2015, Smithville Lake (DW); 3,000, 10 Apr 2004, Riverlands (B. Schindewolf).

Summer: The first definite breeding record in almost 40 years was obtained when 25-30 young, still in nests (total of ca. 46 nests), were found at a rookery just south of Clarksville, Pike Co., on the late date of 27 Oct 1993 (M. Christensen and M. Greenwell). About 50 nests, photos, were located in Pike Co. on 26 Aug 1996 (B. Treiterer), 
and a nest was found on $20 \mathrm{Jul}$ 2001, Clarence Cannon (SK). The only St. Louis nesting record occurred in 2011 at Confluence Point: 80 birds and at least 15 nests, 27 Aug, with 125 birds including young on 29 Aug (m. ob.). The following colonies were found in the western half of the state: 24 nests, 17 May - 1 Jun 2006, Deepwater arm of Truman Lake, Henry Co. (BJ, MR); 40 nests, 31 Jul 2007, Four Rivers (SK); 25+ nests, Settle's Ford CA (SS, PW, BJ).

Fall: Migrants first appear by late Aug with larger numbers appearing during the latter half of Sep. Peak is during Oct, when thousands may be seen at a single locality. Large numbers are now regularly seen at the end of Nov at some of the larger reservoirs, e.g., 900, 1 Dec 2011, Montrose (MR). High counts, all at Montrose: 4,500, 5 Oct 1996 (SA, E. Preston); 3,500, 7 Nov 2015 (MR); 3,000, 11 Oct 1998 (EW).

Winter: This species regularly overwinters in the south in small numbers, especially during mild years. The highest concentrations at this season are routinely observed at Montrose Reservoir, where there is a power plant that releases warm water. High counts, both on the Montrose CBC: 2,733, 15 Dec 2001; 501, 18 Dec 2004.

Comments: Populations have rebounded from the low of the 1960s-1970s as a result of reduction in chemical contaminants (Dorr et al. 2014).

\section{Family Anhingidae: anhinga}

\section{Anhinga (Anhinga anhinga)}

Status: Rare transient and summer visitant in Mississippi Lowlands, accidental elsewhere; former summer resident in the Mississippi Lowlands.

Documentation: Photograph: female, 23 Jun 1956, Mingo (R. Coy, D. Reynolds; Robbins and Easterla 1992).

Habitat: Heavily wooded swamps, sloughs, and rivers.

Spring: The first arrivals typically are not seen until the third week of Apr. Most records are in late Apr and May. The only record outside the bootheel: male, 3 May 2003, Weston Bend (RM, C. Andersen, M. Rader). Earliest dates: female, photos, 30 Mar 2014, near Ben Cash (TJ); pair, same locality on 1 Apr 2014. High counts: 15+, photos, 25 Apr 2009, Big Oak Tree (Gyllenhaal family); 13, photos, 21-22 May 2011, Otter Slough (JU, JE, CB).

Summer: Prior to the draining and deforestation of the Mississippi Lowlands in the late 1800s/early 1900s, the Anhinga was a common summer resident in that region of the state (Widmann 1907). There have been a number of records during the past few decades of multiple individuals, but there is still no evidence that the species has returned as a breeder. The Anhinga breeds as close as Reelfoot Lake in adjacent Tennessee and that locality may be the source of a number of the summer sightings. There are three records outside the bootheel during this season, two at Four Rivers: ad, 19 Jun 2007 (AF); male, 26 Jul 2009 (DW). The third is of 1-3 birds, photos, mid-Jul - 3 
Sep 2017, Grand Tower Island, Perry Co. (A. Gathman et al.). Modern high count: 5, 2 Jun 2009, Otter Slough (R. Meade).

Fall: Single birds continue to be seen in the bootheel into mid-Sep. Latest dates, both at Otter Slough: male, 21 Sep 1994 (M. and L. Lashley); 12 Sep 2011 (CB).

Comments: Likely as an indication that the Anhinga was more common prior to largescale habitat destruction in the late $19^{\text {th }}$ century were the following extralimital records: small flock in 1882 along the Missouri River at Kansas City and a specimen (apparently no longer extant), taken at Parkville, Platte Co. in 1898 by J. Bryant (Harris 1919b).

\section{Order Pelecaniformes}

Family Pelecanidae: pelicans

\section{American White Pelican (Pelecanus erythrorhynchos)}

Status: Common transient; uncommon summer visitant and winter resident (local).

Documentation: Specimen: male, 8 Apr 1975, west of Big Lake, Holt Co. (KU 71273).

Habitat: Reservoirs, lakes, rivers, marshes with open water.

Spring: The status has changed considerably during the past two decades, as the species has become much more regular and common in the eastern half of the state. Small flocks now begin to reappear even in late Feb on both sides of the state, and thousands are present by the third week of Mar. Peak is generally in early Apr, with flocks consisting of a few hundred non-breeding individuals (immatures from previous year) seen through the end of the period. High count for early in season, both at Riverlands: 1,200, 25 Feb 2001 (R. Bodman); 1,200, 23 Feb 2008 (B. Duncan). During peak there are several high counts consisting of 5,000 birds from both sides of the state. Highest count: 7,500, 13 Mar 2009, BK Leach (DR).

Summer: Now regularly seen in summer, at times in large flocks of a few hundred birds, on both sides of the state. Large flocks seen in early Jun are often late migrants, whereas summering flocks are composed of immatures from the previous breeding season. Highest counts: 1,595, photos, 26 Jul 2013, Clarence Cannon (JM, CM); 500, 28 Jul 2009, Four Rivers (KM).

Fall: Migrant flocks appear during the latter half of Aug, with numbers increasing to a peak in mid- to late Sep. Large flocks are still encountered into early Nov, but thereafter are rarely encountered: High counts: ca. 8,000, 11 Sep 1960, Loess Bluffs (FL); 6,000, mid-Sep 1962 (HB); 5,000+, 24 Sep 2000, Schell-Osage (G. Baggins); 4,000, 3 Sept 2007, Riverlands (JE).

Winter: Most records for this period are of late lingering individuals or early spring arrivals, but increasingly large flocks are overwintering along the Mississippi River and large reservoirs. High counts: 700, 18 Feb 2005, Riverlands (JU); 423, 1 Jan 2012, Confluence CBC. 


\section{Brown Pelican (Pelecanus occidentalis)}

Status: Casual transient and summer visitant; accidental winter visitant.

Documentation: Photograph: 1, 18 May - 25 Oct 1991, Lake Wapappello (S. and J. Brown et al.).

Habitat: Lakes and reservoirs.

Comments: Prior to 1991, there were only three records, but since then there have been ten additional records, all of single birds. Most of the recent records have been in May, with some birds lingering for months. Earliest dates: imm, photos, 18 Feb - 3 Mar 2009, Niangua arm, Lake of the Ozarks, Camden Co. (A. Kline, C. Turek, J. Stavropolis); 3, 1 Apr 1929, Parkville, Platte Co. (J. Jackson et al.; Bennitt 1932). Aside from birds that lingered for months, there are one Jun, one Jul, two Aug, and one Sep records. The following bird lingered into the winter season: photos, 29 May - 19 Dec 2012, Binder Lake, Cole Co. (R. George et al.). In addition to the three Parkville birds in 1929, an amazing five were present on 28 Jun of that same year near Hollister, Lake Taneycomo (G. Greenwell); there were no records for adjacent states that year.

The increase of observations in the interior of North America undoubtedly is related to the increase in the North American population following the population lows of the late 1950s through 1970s as a result of the overuse of pesticides (Shields 2014).

\section{Family Ardeidae: herons}

\section{American Bittern (Botaurus lentiginosus)}

Status: Uncommon transient; rare summer resident; casual winter visitant/resident.

Documentation: Specimen: male, 8 Apr 1907, McDonald Co. (Yale Peabody Museum of Natural History 218).

Habitat: Primarily in marshes, but occasionally in wet meadows and prairie swales.

Spring: The first birds appear at the end of Mar, with an increase in numbers through Apr, peaking in early May. Earliest dates: 1, photos, 12-16 Mar 2016, Riverlands (CMc, AR); 1, photos, 13 Mar 2013, Dunklin Co. (TJ); 1, 18 Mar 2011, Dunklin Co. (TJ). High counts: 17, 15 May 1979, Loess Bluffs (MR, DE, TB); 14, 7 May 1976, Loess Bluffs (N. Johnson); 14, 19 Apr 2007, Clarence Cannon (DR).

Summer: A rare breeder primarily in marshes north of the Missouri River. The following is one of the few records south of that river during the past three decades: 1,8 Jun 1993, Mingo (K. Adams, BL, BRe). Not surprisingly, given that most of the wetlands have been drained and converted to agriculture, this bittern was once "a fairly common summer resident" (Widmann 1907).

Fall: Migrants begin to appear by mid-Aug, with peak in late Sep/early Oct. It is regularly observed through mid-Nov, but thereafter it is rare. There are four early Dec records. Earliest date away from breeding sites: 1, 18 Aug 1980, Springfield (W. Holloway). High counts: 15, 5 Oct 2003, near Dexter, Stoddard Co. (JE); 7, 10 Sep 1973, Loess Bluffs (FL). 
Winter: There are eight records of single birds, all from the northern half of the state where there is prime habitat: 27 Dec 1959, Loess Bluffs CBC; 28 Jan 1971, St. Charles Co. (JEC et al.); early Feb 1966, Loess Bluffs (HB); 1 Jan 1992, Riverlands (JVB et al.); 13 Feb 2000, Eagle Bluffs (S. Elbert et al.); 12 Dec through Feb 2016-17, near Pershing SP (SK); 20 Dec 2016, Clarence Cannon (J. Wilson); 30 Dec - 1 Jan 201617, Riverlands (PL et al.).

\section{Least Bittern (Ixobrychus exilis)}

Status: Uncommon transient and summer resident.

Documentation: Specimen: egg set, 4 Jun 1889, Wayland, Clark Co. (WFVZ 96699). Habitat: Cattail-dominated marshes.

Spring: This secretive species is rarely seen during migration and is usually not encountered until the end of Apr/early May. Earliest dates: 1, 16 Apr 1977, near Alton Dam (JE et al.); 1, 20 Apr 2010, Otter Slough (CB); 1, 20 Apr 2015, Otter Slough (J. Bergmann). High counts: see summer.

Summer: Because it is restricted to cattail-dominated marshes, this bittern is very local in distribution and is primarily found at northern refuges, although it does breed at appropriate sites in the south, e.g., Mingo. When not in a drought the highest concentrations are found at Loess Bluffs where over 100 nests have been located in a single season. Hilsabeck and Bell (1999) summarize Loess Bluffs totals from 1992-7. The following are high counts from Loess Bluffs: 118 individuals, including 17 nests, 5 Jun 1992; 59 nests, 31 May 1994; 185 nests (476 individuals), summer 1996 (JH); 135 nests, Jun 1997; 188 nests, summer 1999. High counts elsewhere: 45 nests, summer 2003, Clarence Cannon; 19 nests, 7 Jul 1993, Mingo.

Fall: Relatively large numbers are still present at breeding sites until mid-Sep. However, by the second week of Oct very few birds are present. There are three Nov records. High count late in season: 34, 22 Sep 2001, Swan Lake (SK). Latest dates: 1, 29 Nov 2005, Riverlands (DR); 1, 15 Nov 2001, Swan Lake (SK); 1, 11 Nov 1986, Lake Contrary (FL).

Comments: A bird that was banded as a nestling on 21 June 2001 at Loess Bluffs was recaptured there on 13 Jun 2006 (Durbian et al. 2007).

\section{Great Blue Heron (Ardea herodias)}

Status: Common transient and postbreeding summer visitant; locally common summer resident; locally uncommon winter resident in south, rarer in north.

Documentation: Specimen: egg set, 14 Apr 1894, near Carthage, Jasper Co. (MVZ 1659).

Habitat: Most common in marshes, but found at virtually every type of shallow water.

Spring: Migrants begin augmenting the winter residents in the south by late Feb and about a week later in the north. Peak is typically in mid-Apr, when numbers at heron- 
ries can number in the hundreds of individuals. High count: 335, 26 Apr 2014, Loess Bluffs (MR, JB, M. Mutchler, N. Varvel).

Summer: Surveys by the MDC, initiated in 1978, have demonstrated that this heron is common and widespread, with the vast majority of the rookeries in the southern half of the state. In 1982 and 1983 there were 103 known rookeries, with only four north of the Missouri River. By the early 1990s, over 200 colonies were being recorded. The largest rookery in 1997, along the Osage River below Bagnell Dam, contained over 300 nests. During the summer of 2000, 283 colonies were identified. Rookeries have not been tracked since then.

Fall: Postbreeding concentrations across the state often consist of over 200 individuals at a single site. This heron remains common statewide until water freezes. Highest counts: 500, 7 Aug 2007, Four Rivers (SS); 413, 9 Sep 2010, Eagle Bluffs (KA et al.).

Winter: With warmer than average winters during the past two decades, this heron is now wintering further north and in larger numbers. Only in severe winters is it absent during the core of the winter in the north. High counts: 125 (1.3), 29 Dec 2007, Taney Co. CBC; 100+, at heronry site, 10 Feb 1990, Taney Co. (JHy, PMa).

\section{Great Egret (Ardea alba)}

Status: Uncommon transient and summer resident; common summer visitant; rare winter visitant.

Documentation: Specimen: female, 11 May 1973, near Maryville (KU 117683).

Habitat: Most common in marshes, but found at virtually every type of shallow water.

Spring: This heron typically does not appear until the end of Mar in the south. By late Apr it is relatively common, with peak in May. Numbers observed during May are much smaller than are seen in summer through Oct. Earliest dates: 4, 4 Mar 1951, Alton Dam (RA); 1, 10 Mar 2004, St. Louis (S. McCown); 1, 16 Mar 2008, Stoddard Co. (CB). High counts: about 200, 17 May 1959, Loess Bluffs (K. Krum); several counts of 100 along the Mississippi River during the latter half of May.

Summer: The number of colonies has increased both in number and size since the MDC initiated surveys in the early 1980s, when 4-7 colonies were located in the Mississippi Lowlands. By 1992, a few pairs were located in a Great Blue Heron colony on an island in the Mississippi River, Pike Co., and in 1993, 4 nests, also in a Great Blue Heron colony, at Yellow Creek CA, Chariton Co. (SK), with 2-3 nests at Sunshine Lake, Ray Co. (MM). In 1995, 50-60 nests were located along the Marmaton River in Vernon Co. High counts of postbreeding birds: 1,500+, 24 Aug 2008, Clarence Cannon (BR); 1,192, 6 Aug 2013, Clarence Cannon (CM, JM); 1,000, 19 Jun 2011, Fountain Grove (SK, LL); 1,000+, 7 Aug 2007, Four Rivers (SS, BJ, PW).

Fall: The postbreeding concentrations are present through Aug. Numbers decrease in early Sep, but concentrations of a few hundred birds/site can be seen in the southern 
part of the state through mid-Oct. By early Nov only widely scattered, small numbers are encountered. By the end of Nov it is rare statewide.

Winter: As a result of the warmer late falls and winters, a few individuals are now observed in early winter with a few overwintering. With the exception of two observations, all records are of single individuals, with the vast majority from the south. Prior to 1990, there was only a single winter record: 1, 26 Dec 1973, Gray Summit CBC. Northernmost record: 1, photos, 17-24 Dec 2015, Loess Bluffs (m. ob.). High counts: 2, 15 Dec - 3 Feb 2001-2, Springfield CBC (LB, D. Rising); 3, 20 Dec 2008, Mingo CBC; 3, photos, 16 Dec 2015, Riverlands (C. Stapleton et al.).

\section{Snowy Egret (Egretta thula)}

Status: Uncommon transient; uncommon to locally common summer visitant; rare summer resident in southeast.

Documentation: Photographic.

Habitat: Mostly marshes, flooded fields and the edge of ponds and lakes.

Spring: Single birds begin appearing at the beginning of Apr, with a gradual increase to a peak in May. Earliest dates: 1, 21 Mar 2011, Forest Park (C. Feree); 3, 22 Mar 1989, Caruthersville (BRe); 1, 28 Mar 1962, Kansas City (J. Rising).

Summer: There have been 2-3 colonies, consisting of a few up to an estimated 40-60 nests/rookery, in the Mississippi Lowlands (Caruthersville and Charleston areas) for decades. At least 125 individuals were observed at the Caruthersville rookery on 29 Jun 1991 (TB, PM). There were about 50 nests in summer 2001 near Sikeston. Postbreeding concentrations begin appearing by mid-Jul and continue through early Sep. High counts: 840, 28 Jun 1998, south of Hayti, Pemiscot Co. (J. Howland); 220, 7 Sep 2008, Columbia Bottom CA (BR).

Fall: After early Sep numbers begin to decrease, and by the second week of Oct it is rare. Beginning in 1994, this egret began to be observed regularly until mid-Oct. High counts: see above. Latest dates: 1, 2 Nov 2003, Montrose (JE); 3, 31 Oct 2004, Thompson River Wetlands (SK); 1, 31 Oct 2011, Eagle Bluffs (E. Wood).

\section{Little Blue Heron (Egretta caerulea)}

Status: Uncommon transient and summer visitant; common summer resident in southeast, accidental elsewhere.

Documentation: Specimen: male, 9 Apr 1964, Bertrand, Mississippi Co. (SEMSU 224). Habitat: Mostly marshes, flooded fields, and the edges of ponds and lakes.

Spring: The first migrants begin to appear at the end of Mar in the Mississippi Lowlands, with a rapid increase there in early Apr. By mid-Apr, a few thousand can be seen at the traditional heronries. It is much less common away from the Mississippi River, with only small numbers, typically only a few individuals/day, observed. Oddly, the earliest spring record is of a bird that was initially banded on 6 Jun 1937 in Glen 
Allan, Mississippi, and found dead about 10 Mar 1944, ca. 3 miles south of Dudley, Stoddard Co. (Cooke 1950). Other early dates: 1, 19 Mar 2012, Jasper Co. (LH); ad, 24 Mar 1996, Prairie Lee Lake, Jackson Co. (RF). High count: 1,200, 20 May 2007, Pine Ridge, Scott Co. (JE).

Summer: Historically, this heron has been primarily restricted as a breeder to the bootheel, with up to three known heronries/summer. However, there are two old records of breeding at St. Louis: adults with six young, 12 Jul 1936, Dardenne Island, Missouri River, St. Charles Co. (W. Short), and "small numbers bred", summer 1962, Marais Temps Clair (RA). In 2016, several hundred birds were at rookery within the St. Louis city limits (A. Schuhmann); also note large concentrations below that may have involved local breeding birds. Other recent extralimital breeding events include: 150 individuals, includes some non-breeders, 17 Jun 1993, Horseshoe Lake (JH, DE); 450, includes some non-breeders, 15 Jun 1995, eastern Jasper Co. (LH; apparently the species also bred at this locality in 1994); 8-10 nests, May-Jul 1999, residential Kansas City (D. Arney). High counts: about 900 and 1,000 nests, May-Jun 1985, at two separate colonies near Miner and Caruthersville (J. Wilson); 3,000 individuals, 9 Aug 1986, Caruthersville (DE, FL, LG); 2,000 individuals, 8 Jul 2007, Sikeston heronry, Scott Co. (SS, JE, PW). The largest concentrations reported outside the southeastern corner occurred for three straight years near Lambert Field, St. Louis: 1,017, 11 Aug 2000 (MT); 1,500, 16 Jul 2001 (J. Farm); 1,400, 1 Aug 2002 (J. Farm); these may have involved some local breeding birds.

Fall: Large postbreeding concentrations are seen from mid-Jul into early Sep in the southeastern corner with smaller numbers elsewhere. By mid-Sep numbers have dropped off considerably, but a few linger into the first week of Oct. Like the Snowy Egret, it appears that birds are now lingering later in the fall as compared to 25 years earlier. Latest dates: 2, 19 Oct 2010, Hazel Hill Lake, Johnson Co. (L. Olpin); 1, 18 Oct 2006, Missouri River, Boone Co. (EW, B. Clark); 1, 14 Oct 1972, Busch (BR); 2 imm, 13 Oct 2013, Schell-Osage (GSa).

\section{Tricolored Heron (Egretta tricolor)}

Status: Rare transient and summer visitant.

Documentation: Photograph: adult, 15-16 May 1978, Lake Springfield (M. Goodman; VIREO x08/11/001).

Habitat: Marshes, flooded fields, and lake edge.

Spring: Although this heron is rare, it is recorded almost annually with records from all regions of the state. All records pertain to singletons. Earliest dates: 13 Apr 1890, near Sand Ridge, Clark Co. (E. Currier; Widmann 1907); 14 Apr 2017, Loess Bluffs (M. Mutchler et al.); 15 Apr 2000, Swan Lake (TM, SK); 16 Apr 1998, Mingo (BRe, $\mathrm{SD})$.

Summer and Fall: There are observations statewide of single adults and immatures that span Jun through early Sep. Latest dates: 1, 12-19 Sep 1948, Iatan Marsh, Platte 
Co. (J. Bishop, E. Cole, H. Hedges); 1, 6 Sep 2012, Swan Lake (A. Fournier); first week of Sep 1961, near Portageville, New Madrid Co. (L. Jenkins).

Comments: This heron may eventually be found breeding in the Missouri bootheel, as it has been documented breeding on a few occasions in Mississippi County, Arkansas (James and Neal 1986), which is adjacent to Dunklin County, Missouri.

\section{[Reddish Egret (Egretta rufescens)]}

Status: Provisional fall transient.

Documentation: Sight record only; see below.

Habitat: Marshes and flooded fields.

Comments: There is a single sight record: 1, 30 Sep 1951, Marais Temps Clair (JEC, A. Bolinger). There is little doubt that this is a valid record, as both experienced observers independently identified the bird and noted "unusual feeding behavior." This distinctive egret has been documented in virtually every state that borders Missouri. Efforts should be made to look for the species in the bootheel between mid-Jul and early Sep.

\section{Cattle Egret (Bubulcus ibis)}

Status: Generally uncommon transient and summer visitant, although at times locally common. Locally common summer resident in Mississippi Lowlands; casual breeder elsewhere. Accidental winter visitant.

Documentation: Specimen: male, 9 Jun 1965, near Charleston, Mississippi Co. (KU 117652).

Habitat: Often observed foraging among cattle in pastures, but also in wet meadows, marshes, and flooded fields.

Spring: The first migrants appear at the end of Mar, with a gradual increase peaking in late Apr in the bootheel. Much smaller numbers are seen elsewhere, and peak in the north is usually in early May. Earliest dates: 1, 5 Mar 1996, Schell-Osage (LL); 1, 16 Mar 1990, Duck Creek (SD, BL). Earliest in north: 14, 23 Mar 2006, Loess Bluffs (TR).

Summer: Considerably more common in the southeastern corner, where breeding pairs can reach the low thousands at one of the heronries, e.g, 2,500-3,000 individuals, summer 1995, Sikeston heronry; 4,500 individuals, 26 Jun 2007, Sikeston heronry (JE, SS, PW); 12,000 individuals, 28 Jun 1998, south of Hayti, Pemiscot Co. (J. Howland). Cattle Egrets were found first breeding in the northwest during 1993: "several hundred, with some nesting" were observed from mid-May through the summer at Horseshoe Lake (LL, LG). In 1994, 200 nests were found near Carthage (LH), and the following year 3,000 (includes non-nesting birds) were estimated on 15 Jun, in eastern Jasper Co. (LH). Finally, about 20 nests were found at Loess Bluffs in Jun 2008 (TR, B. Lomas, F. Durbian). 
Fall: Postbreeding numbers increase during Aug, e.g., 8,000, 9 Aug 1986, Caruthersville (DE, FL, LG), into early Sep and gradually taper off during the latter half of Sep. Typically, only small flocks are seen through Oct into early Nov. There are a number of late Nov records: 7, 2-30 Nov 1973, near Columbia (J. Kare); 2, 30 Nov 2011, Loess Bluffs (m. ob.); 1, 27 Nov 2011, Riverlands (m. ob.). There are two early Dec records of single birds with photos: 1-2 Dec 2011, Loess Bluffs (m. ob.); 13 Dec 2012, Dunklin Co. (TJ). High count late in season: 27, 18 Nov 2016, Loess Bluffs (M. Nemecek et al.).

Winter: One record: adult, photos, 16 Jan 2016, Otter Slough (D. Swofford).

Comments: Following natural immigration into eastern South America in the 1930s, the Cattle Egret was first encountered in the United States in Florida in the early 1940s (Crosby 1972). It was first detected in Missouri on 19 Apr 1955, St. Charles Co. (V. Balsevic). The first nesting record was documented in May 1963, when 4-5 pairs were detected breeding at the heronry at Bertrand, Mississippi Co. (P. Heye), and shortly thereafter the breeding population increased dramatically. By the late 1970s it had replaced the Little Blue Heron as the most numerous species in the Bertrand/Miner heronry. Like other herons, the Cattle Egret is now lingering much later in fall than in prior decades.

\section{Green Heron (Butorides virescens)}

Status: Common transient and summer resident; casual winter visitant.

Documentation: Specimen: egg set, 11 May 1894, near Carthage, Jasper Co. (MVZ 1660).

Habitat: Marshes, streams, edge of ponds and lakes.

Spring: The first migrants are detected in mid-Apr, but the species is not widespread until early May. Earliest dates: 1, 1 Apr 1988, Duck Creek (BRe); 1, 2 Apr 2011, Castor River, Bollinger Co. (A. Brant); two records at separate localities for 3 Apr 2010. An indication that migration of this species continues until at least the last week of May was a group of seven migrating on 22 May 2009, Bigelow Marsh (MR, BJ, PM). High counts: 25, 22 May 2012, Elk River (24 miles; D. English); 20, 8 May 1989, Schell-Osage (MR, TE).

Summer: This is a low-density, widespread species throughout the state. There are no reliable data to indicate if there are differences in abundance across the physiogeographic regions of the state. Presumably it is least widespread in the Ozarks, although it is not uncommon along Ozark rivers. High counts: 35, 7 Aug 2011, Eagle Bluffs (K. McCommis); 26, 15 Jul 2012, Columbia (PM).

Fall: Migrants begin augmenting summer residents in late Aug, and limited observations at night indicated that the species remains common in passage through at least early Oct: e.g., 50+, heard at night, 1-3 Oct 1989, Taney Co. (JHy); large movement of undetermined numbers heard migrating at night, 3 Oct 1986, Lake of the Ozarks, Mill- 
er Co. (PMa, JHy). There are very few records after the first week of Nov. Latest dates: 1, 5 Dec 1978, Springfield (B. Dyer); imm, photos, 15-26 Nov 2016, Forum Nature Area, Boone Co. (C. Weston, M. Dodds); 1, 24 Nov 2015, Otter Slough (N. Koch).

Winter: There are five records for early in the season: 1, 19-25 Dec 1980, Orchard Farm CBC; 1, 2 Jan 1983, Orchard Farm CBC; 1, 20 Dec 2003, Meramec River, Crawford Co. (L. Frederick); 1, 15 Dec 2015, Kenzora CA, Platte Co. (S. Leonardo); 1, 19 Dec 2015, Smithville Lake CBC.

\section{Black-crowned Night-Heron (Nycticorax nycticorax)}

Status: Uncommon transient and summer visitant; locally common summer resident in Mississippi Lowlands, casual elsewhere; casual winter visitant/resident, with a few records of birds overwintering in the south.

Documentation: Specimen: imm male, 8 Oct 1926, St. Joseph, Buchanan Co. (USNM 299199).

Habitat: Primarily in marshes, less frequently edges of rivers, ponds, and lakes.

Spring: The initial migrants appear at the end of Mar, with a peak in late Apr. This night-heron is much more common in the bootheel than in other regions of the state. Earliest dates: 1, 2 Mar 2013, southern Dunklin Co. (TJ); in northern Missouri: 1, 24 Mar 1963, Beverly Lake (Rising et al. 1964). High counts away from heronries in the bootheel: 65, 2 May 2005, Loess Bluffs (TR); 57, 13 Apr 1980, Loess Bluffs (FL).

Summer: This night-heron is less common than Little Blue Heron and Cattle Egret in the bootheel heronries. There were 100 and 150 nests located in Caruthersville and Miner heronries, respectively, in 1985 (J. Wilson). Over 100 individuals were observed on 28 Jun 1998, south of Hayti, Pemiscot Co. (J. Howland). Breeding is more sporadic in other parts of the state. Over 500 nests were estimated during the summer of 1937 at Marais Temps Clair (W. Short), and sixty individuals (at least 3 ground-level nests located) were breeding at Loess Bluffs in Jun 1990 (R. Bell). Two-three nests were located at the latter locality in Jun-Jul 2008 (TR, B. Lomas, F. Durbian). Over 25 individuals were present and breeding at Horseshoe Lake on 17 Jun 1993 (DE, JH).

Fall: Like other herons and egrets, there is an increase in numbers from postbreeding dispersal, but numbers are much lower than for other species. This species continues to be relatively common and widespread through Oct. It is regularly seen in small numbers, usually 1-2 individuals, during Nov; the vast majority of these are immatures. There are several early Dec records from across the state. High counts: 280, 10 Aug 2013, Columbia Bottom (B. Duncan); 76 (over half immatures), 21 August 1988, Chain of Rocks, St. Louis (RA).

Winter: As a result of the warm late falls and winters during the past two decades, birds, primarily immatures, are lingering into this season with a few overwintering in the south. There are twice as many records for the south as the north, and those in the north are from early in the season. High counts: 8 imm, 19 Dec 1998, near Columbia 
(B. and K. Palmer); 6, throughout 2012-3 winter, Dunklin Co. (TJ); 4 adults, photos, entire winter 2013-4, St. Louis Zoo (E. Jelters).

\section{Yellow-crowned Night-Heron (Nyctanassa violacea)}

Status: Uncommon transient and summer resident.

Documentation: Specimen: female, 13 Jul 1934, Independence (KU 21235).

Habitat: Marshes, sloughs, wooded streams and rivers, edge of ponds and lakes.

Spring: The initial migrants are now appearing as early as mid-Mar in the south, but most do not appear across the state until early May. Earliest dates, all of adults: 1, 10 Mar 2013, Springfield (CBu); 1, photos, 13 Mar 2016, Springfield (CBu); 1, 17 Mar 2001, Mingo (B. Beck); 1, 18 Mar 2011, Springfield (D. Thurman). Earliest date in north: ad, 2 Apr 1967, Loess Bluffs (JHam). High count: 18, 30 May 2000, Swan Lake (SK).

Summer: This is a relatively low-density breeder throughout the state. Small colonies, $<$ 10 nests/site, have been found in all physiogeographic regions in a variety of sites, ranging from suburbia to Ozark streams and floodplain wooded swamps. All high counts are of fewer than 20 individuals; these have consisted of both adults and immatures. River-based surveys demonstrate low densities, with the highest detections in the Ozarks, e.g., 10 (0.8; 9 ad, 1 imm), 2 Jun 2004, Eleven Point River (MR, B. Barber; Table 6).

Fall: This night-heron is regularly seen in small numbers through Sep. With the exception of one record, all Oct and Nov observations are of single birds, and there still is no Dec record. High count: 29 (2 ad, 27 imm), 7 Sep 1947, near Parkville, Platte Co. (J. Bishop). Latest dates: 1, 24 Nov 1962, Lake Contrary (FL); 2 ad, 24 Nov 2002, Eagle Bluffs (L. and F. Schiffel); 1, 16 Nov 1992, Riverlands (JVB).

\section{Family Threskiornithidae: ibises, spoonbill}

\section{White Ibis (Eudocimus albus)}

Status: Rare transient and summer visitant in south, casual in north.

Documentation: Photograph; fig. 18.

Habitat: Marshes, swamps, and flooded fields.

Spring: The status of this species has changed dramatically during the past two decades. Prior to 1992, there was only a single spring record, whereas now 1-2 individuals are observed almost annually. Most records are in late Apr and May. Earliest dates: $1^{\text {st }}$ year, 13 Apr 1998, Big Oak Tree (D. Kluza, T. Ryan). An astounding 226 were photographed on 26 May 2011, along St. Francis River levee road, Dunklin Co. (TJ; fig. 18). On that same day, just to the south, > 6,000 were estimated at Bald Knob NWR, White Co., Arkansas!

Summer: As in spring, small numbers are observed almost annually. Formerly, this species may have been more common as two adults were taken from a flock of "about 
one hundred" on 10 Jul 1910 at Old Monroe, Lincoln Co. (Williams 1913). High counts: 7, 24 Jul 2010, Otter Slough (CB); 5, Jun 2005, near Sikeston, Scott Co. (CM, JU, JE).

Fall: Some birds from summer linger until the end of Aug, but there is only one Sep and one Oct record, both from southern Dunklin Co. by TJ: 5, 8 Sep 2009; ad, photos, 25 Oct 2010.

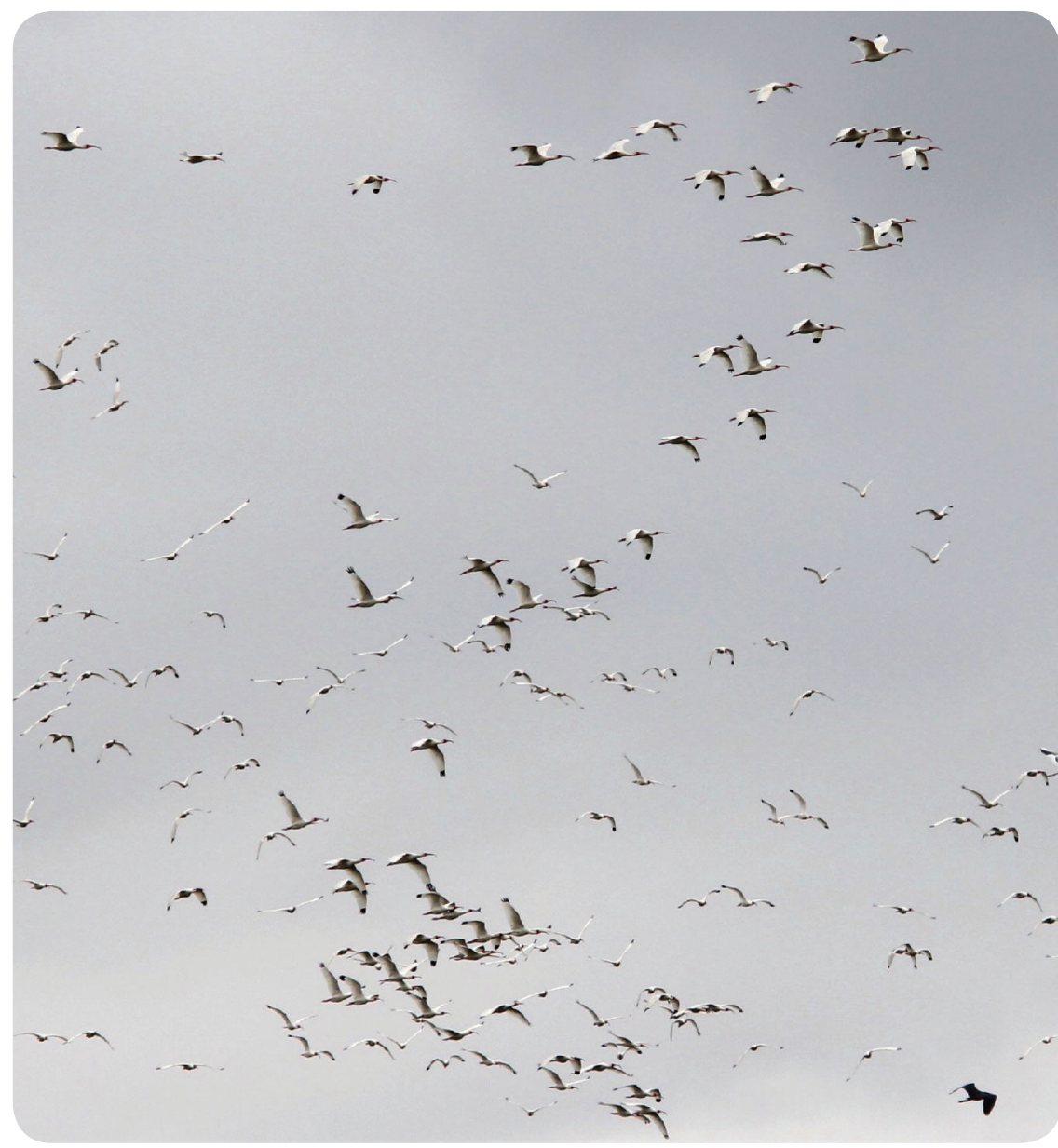

Fig. 18. Unprecedented concentration of White Ibis in Missouri, 26 May 2011, Dunklin County. Photo by Tim Jones.

Glossy Ibis (Plegadis falcinellus)

Status: Rare transient and summer visitant; accidental summer resident.

Documentation: Specimen: male, 30 Apr 1975, Bigelow Marsh (KU 11765).

Habitat: Marshes, swamps, and flooded fields. 
Spring: This ibis is seen throughout the state, e.g., nearly 20 records for the northwestern corner, in small numbers. It is quite rare prior to mid-Apr, with most records during May. Earliest dates: 2, photos, 5 Apr 2011, Otter Slough (TJ); 1, photos, 10-11 Apr 2011, Loess Bluffs (DW, K. Brink); 1, 15 Apr 2006, Bean Lake (KM, DW). High count: 7, 19 or 21 May 1968, Bertrand heronry (P. Heye).

Summer: There is a single nesting record: pair with 3 young that were about 2-3 weeks old, 1 Jul 1968, Bertrand heronry (P. Heye; photos, VIREO x05/2/007-009; in Robbins and Easterla 1992). This species likely will be found breeding again, as a few pairs have been found nesting adjacent to the bootheel in Mississippi County, Arkansas (James and Neal 1986). There are fewer sightings during this period than in spring, but records span the entire period statewide.

Fall: Primarily because of the difficulty in distinguishing this species from Whitefaced Ibis at this time of year, there are no definitive records for this season.

Comments: Hybridization between Glossy and White-faced Ibises is well documented and may be much more frequent then generally appreciated (Arterburn and Grzybowski 2003); thus observers should carefully scrutinize all ibis. A well-photographed bird that appeared to be a hybrid was present 11-15 Apr 2013, Loess Bluffs (DW), and another apparent hybrid was seen there in May 2014 (JK, JU).

\section{White-faced Ibis (Plegadis chihi)}

Status: Uncommon transient in northwest; rare elsewhere; casual summer and winter visitant/resident.

Documentation: Specimen: female, 26 Apr 1975, Bigelow Marsh (KU 117608).

Habitat: Marshes, swamps, and flooded fields.

Spring: Typically, the first individuals do not appear until mid-Apr, with peak in late Apr/early May. It is much more common in the northwestern corner, and larger numbers have been observed there over the past two decades. Earliest dates: 1, 26 Mar - 5 Apr 2003, Clarence Cannon (SS, JU); 16, 7 Apr 2013, Loess Bluffs (JB); 10, 7 Apr 2016, Eagle Bluffs (J. Leonatti et al.). High counts in west: 137, 2 May 2006, Loess Bluffs (TR, MR, BJ, AF); 124, 1 May 2014, Loess Bluffs (Dan Cowell); 100, 2 May 2014, Four Rivers (Ronda Sherrill, Linda Childers). High counts in east: 75, 21 Apr 2014, Eagle Bluffs (J. Leonatti, Lori Turner); 30, 25 Apr - 13 May 1999, Riverlands (m. ob.); 30, 18 Apr 2013, Duck Creek (BJ).

Summer: Observations have been increasing for this period, and even large flocks of non-breeding birds are now seen in the northwestern corner. Given the current trend, this ibis is likely to be found soon breeding in cattails there. It is accidental outside the northwestern corner at this season. High counts: 43, 2 -20 Jun 2013, Loess Bluffs (MR, L. Olpin, D. Welchert); 16, 2-3 Jun 2011, Lewis and Clark SP (R. Anderson). 
Fall: There are many records for early fall through Oct that likely pertain to this species, but only a few times were critical distinguishing field marks noted to eliminate Glossy Ibis. High counts for Plegadis sp., all at Loess Bluffs: 25 until 3 Dec 2016, with 2 still present 8 Dec (m. ob.); 20, 28 Oct 2000 (M and K. Fain); 13, 30 Oct 2013 (D. Cowell). Latest dates: see above and 1, 5 Dec 2013, near Clarence Cannon (D. Driemeyer). During the past decade there are several other records across the state through Nov. High count of unequivocal White-faced: 7+ (of a group of 11), photos, 19 Oct through Nov 2014, Eagle Bluffs (AK et al.).

Winter: Six records of Plegadis sp.: 1, 14 Dec 2001, Four Rivers CBC (RM, MR); 1, winter 2002-3, south of Swan Lake (seen repeatedly by duck hunters fide SK); 1 , 20 Dec 2014, St. Joseph CBC; 7 (at least two were White-faced), 15 Dec 2015, Loess Bluffs (m. ob.); imm, photos, 2 Jan 2016, Iatan Marsh, Platte Co. (JB); imm, photos, 1-16 Jan 2016, Otter Slough (D. Swofford).

Comments: See remarks under Glossy Ibis account concerning hybridization with Glossy Ibis.

\section{Roseate Spoonbill (Platalea ajaja)}

Status: Casual transient and summer visitant.

Documentation: Photograph: immature, 1-19 Aug 1986, Schell-Osage (J. Shatford; Wilson 1986; photo in reference and VIREO x05/3/018; x05/3/001).

Habitat: Marshes and flooded fields.

Spring: A single record: adult, photos, 10 Apr 2011, Duck Creek (RD, CB, EW).

Summer and Fall: Since the above 1986 record there have been thirteen additional observations that span Jun into early Oct. Most are from the Mississippi Lowlands, and a number of observations are of birds that appeared in Jun or Jul and lingered into Sep. The vast majority of the birds that have been aged have been immatures, with a single definitive observation of an adult. Latest date: 2 imm, photo, 10 Oct 2017, east of Hayti, Mississippi River, Pemiscot Co. (M. Greene, TJ). High counts: 4 imm, 7-28 Sep 2008, Grand Tower Island, Perry Co. (P. Moxon, J. Smith, R. Rothrock, M. McCarthy); 4 imm, photos, 2 Sep 2012, Eagle Bluffs (RD, S. Elbert, KA).

\section{Order Cathartiformes}

\section{Family Cathartidae: New World vultures}

\section{Black Vulture (Coragyps atratus)}

Status: Locally common permanent resident in extreme south, uncommon and more local in northern Ozarks; accidental transient in north and the two western tiers of counties in the Osage Plains.

Documentation: Specimen: sex?, 7 May 2015, Isabella, Ozark Co. (KU 131152).

Habitat: Primarily found in forest that borders marshes, lakes, and rivers; often found roosting on electronical substations and at dam and reservoir facilities. 
Spring and Summer: Because there is now such a large winter population, with birds overwintering farther north, it is difficult to determine when migrants appear. In areas where this vulture does not regularly winter, the first migrants appear in late Feb/early Mar. Until the past decade, this vulture was extralimital beyond the southern tier of counties, but it has spread dramatically northward. High count for spring that likely included wintering birds: 250, 30 Mar 2013, below Table Rock Lake dam (J. Kurtz); 200, 1 Mar 2014, kettling near the Springfield Nature Center, Greene Co. (A. Liles, S. Martin, D. Martin, m. obs.). Relatively large numbers, in the double digits, may be seen even during May.

Prior to 2004, this species was not known to breed north of Mingo in the southeast and the southern tier of counties in the south-central and southwest. However, in 2004 it was suspected of breeding in St. Genevieve Co. (JE), and a single bird was noted far to the north on 23 Jul 2006 at Maple Leaf Lake CA, Lafayette Co. (L. Gilcrist). In 2009, there were the following observations: 2, Lake of the Ozarks, Camden Co. (JE); 1, Lead Mine CA, Dallas Co (P. Sensenig); 7, Magnolia Hollow CA, St. Genevieve (JU, JM, JE), and there were two separate sightings in St. Louis Co. On 9 Mar 2017, a kettle of 25 was seen over Cedar Hill, Jefferson Co. (W. George). In addition to the above records, the northernmost observations were: 1, 23 Apr 1994, Busch (G. Koppel); 1, 25 Jul 1998, Linn Co. (D. and N. Witten); 1, photos, 16 May 2009, Klondike Park, St. Charles Co. (MT); 1, 21 Apr 2012, Columbia (RD); 1, 3 Sep 2016, Fountain Grove CA (K. Mortensen).

Fall and Winter: Birds observed away from breeding areas are noted moving south from late Sep through mid-Nov. Large concentrations occur below Table Rock Lake dam beginning in Nov, e.g., 230, 21 Nov 2001 (MR). Through the 1980s and 1990s, $<200$ birds wintered at this locality, but now high hundreds/day may be observed. This vulture was first detected in winter at Ha Ha Tonka SP, Camden Co. in Jan 2010 (S. Hazelwood), and previously unimaginable numbers were observed to the north at Bagnell Dam by late fall of 2011: 34, 3 Dec 2011 (DE, TE); 55, 29 Nov 2012 (CB). By 2012 they were routinely being recorded in small numbers around Stockton Lake and the species is now regularly wintering as far north as Bagnell and Truman dams. High counts, all on the Taney Co. CBC: 1,261 (15.3), 27 Dec 2014; 1,350 (14.9), 28 Dec 2013; 772, 1 Jan 2000; 750, 31 Dec 2011; 715, 3 Jan 2004. Extralimital sightings: 1, 16 Sep 2000, Schell-Osage (B. Ball); 3, 28 Nov 2007, Columbia (TM); 1, 11 Oct 2014, Little Blue River, Jackson Co. (LR); 2, 23 Dec 2015, Columbia (G. Leonard, J. Besser); 1, 3 Sep 2016, Fountain Grove (K. Mortensen).

\section{Turkey Vulture (Cathartes aura)}

Status: Common transient and summer resident; uncommon winter resident in south and central; accidental winter visitant in north.

Documentation: Specimen: male, 15 May 1879, Charleston, Mississippi Co. (MCZ 42921).

Habitat: Found in a wide range of habitats, but especially in forest and woodland. 
Spring: Recently, the first migrants are appearing in late Feb even in the northern half of the state. In the past, peak was in late Mar/early Apr in the south and mid-Apr in the north, but now this may be advanced. Relatively large flocks (>50 birds/flock) are seen through the end of the period. High counts: 600, 1 Mar 2014, Springfield (A. Liles et al.).

Summer: This vulture breeds statewide, but it is far more abundant in the Ozarks. Relatively large flocks can be seen at this season. BBS data indicate it has dramatically increased throughout the duration of the BBS; for the 2003-2013 period there has been $7.16 \%$ annual increase.

Fall: By early Sep birds are migrating through the state. Peak is typically at the end of Sep/early Oct when hundreds may be seen. There are several high counts of $>200$ individuals/day in early Oct. Even larger numbers can be seen at roost sites that now span the entire period. High count at single roost site: 500, 3 Dec 2011, Bagnell Dam (DE, TE); 377, 12 Nov 2011, below Table Rock dam (m. ob.).

Winter: The winter distribution has shifted considerably north during the past two decades. Prior to about 1990, large roosts were confined to the southern tier of counties, mostly individual birds were observed further north, and there was no winter record for the northern quarter of the state. However, in the early 1990s numbers at southern roost sites increased dramatically, and by the mid-1990s small numbers were observed throughout the winter in central Missouri. The first record for the northern quarter of the state was obtained at St. Joseph on 24 Dec 1990 (P. and J. Voltz, B. Roberts, J. Rushin) with a single bird at Kansas City on 1 Feb 1991 (RF). By 1995 small numbers were being seen during Jan and early Feb in Benton and Camden counties. By 1999, it was a regular winter resident as far north as Boone County. High counts in the north: 30, 2 Jan 2011, Busch (PL); 16, 27 Dec 2013, Clarence Cannon CBC; 10, 16 Dec 2011, Monkey Mountain CA, Andrew Co. (JH). High counts on the Taney Co. CBC: 1,308 (20.1), 3 Jan 2004; 750 (11.5), 2 Jan 2005.

\section{Order Accipitriformes}

\section{Family Pandionidae: Osprey}

\section{Osprey (Pandion haliaetus)}

Status: Uncommon transient; rare summer visitant and summer resident; rare winter visitant/resident.

Documentation: Specimen: female, 16 Oct 1938, Bethany, Harrison Co. (MU 464). Habitat: Reservoirs, lakes, and rivers.

Spring: The first migrants typically appear at the end of Mar, with an increase to peak during the last two weeks of Apr. A few individuals are still seen through May. Earliest dates: 1, 28 Feb 1987, Rockaway Beach, Taney Co. (PMa); 2, 8 Mar 2002, St. Charles Co. (EW). High counts: 7, 11 Apr 1987, Busch (J. Ziebol); 7, 22 Apr 1990, Busch (J. Ziebol); 7, 18 Apr 2007, Smithville Lake (DW). 
Summer: A reintroduction program, with chicks from Minnesota, was begun in 1995 at Thomas Hill and Mark Twain reservoirs. As a result of this program, Ospreys nested on Truman Lake south of Clinton in 2000, with a nest there again in 2001 as well as one at Stockton Lake. In 2003 the species bred at Jacksonville, Randolph Co. (T. Skinner). A few pairs now breed at a few reservoirs across the state. Until this reintroduction program, Ospreys had not bred in the state in over a century. Widmann (1907) lamented that just ten years prior to his compilation the Osprey was still considered an uncommon breeder in the southeastern part of the state and also bred along the larger rivers. By 1900, the species was either extirpated or on the verge of extirpation as a breeder in the state. Harris (1919b) mentioned that the last breeding record for Kansas City was on the bluffs just north of Independence in 1884. Prior to the reintroduction program, there were numerous sightings of mostly single birds during the summer without evidence of breeding. High count: 7, 4 Jun 2015, Stockton Lake (CBu, GW).

Fall: By the end of Aug migrants begin to appear. Peak is typically late Sep/early Oct. Numbers continue to decrease through Oct and Nov, with only an occasional single individual seen by the end of Nov. Earliest date: 4 Aug 1963, Lake of the Ozarks, Camden Co. (K. Stewart). High counts: 40, 14-19 Sep 1943, along Current River (R. Bennitt); 21, 4-5 Oct 1986, Lake of the Ozarks SP (m. ob.). Single-day high counts during Sep for the past decade at Smithville Lake have been of 10-12 individuals (m. ob.).

Winter: Most records are of single individuals in southern Missouri during the latter two weeks of Dec. There are a few records of birds that overwintered near the dam at Table Rock Lake. Northernmost records: 1, 10 Feb 1980, Winfield Dam, Lincoln Co. (C. Spener); 1, 18 Dec 1993, St. Joseph (LL, F. Cramer); 1, 25 Jan - 13 Feb 2005, near Edina, Knox Co. (CM).

\section{Family Accipitridae: kites, eagles, hawks}

\section{Swallow-tailed Kite (Elanoides forficatus)}

Status: Casual transient and summer visitant; former summer resident statewide.

Documentation: Specimen: male, 7 Aug 1872, St. Louis (Hurter 1884; STSC).

Habitat: Typically swamps bordered by forest.

Spring: Up until the early 1900s this kite was of regular occurrence throughout the state, with the highest abundance in the Mississippi Lowland cypress/tupelo swamps and along the large rivers. Since that period, there have been four modern spring observations: 1, 11 Apr 1992, between Reeds Spring and Galena, Stone Co. (J. Bair); 1, 29 Apr 1996, Webster Co. (B. Dyer); 1, 8 May 1996, Trail of Tears SP (NY); 1, 21 April 2013, Weldon Spring (C. Kirmaier).

Summer and Fall: Apparently the last nesting record for the state was in 1912 at Courtney, Jackson County (B. Bush in Harris 1919b). In addition to the southeastern swamps and along the major rivers, Widmann (1907) mentioned that it also bred in 
Clark County in the northeastern corner of the state. The largest concentration ever reported was of 40 that were present for over a week in early Aug 1872 in the St. Louis area (Hurter 1884; see above specimen record). The disappearance of the species from the state as a breeder and regular migrant coincided with the virtually complete elimination of forest in those regions.

There has been a minimum of ten modern records, all of single individuals, for the summer and early fall period, with most records from along the Mississippi River. Only one of these is in Jun: 1, 13-14 Jun 2005, El Dorado Springs, Cedar Co. (B. and J. Neal, N. Gant), whereas all others are from late Jul into early Sep. Latest dates: ad, photos, 5 Sep 2008, along Mississippi River, Mississippi Co. (M. Monroe, B. Palmer-Ball, E. Huber); 1, 4 Sep 1906, Courtney (B. Bush; Harris 1919b).

Comments: The increase in Missouri observations coincides with those in Arkansas, as breeding attempts have occurred during the past two decades at the White River NWR in east-central Arkansas (Chiavacci et al. 2011).

\section{White-tailed Kite (Elanus leucurus)}

Status: Accidental transient and summer visitant.

Documentation: Sight records only, see below.

Habitat: Prefers open country; pastures and grasslands.

Records: There are four observations of single adults: 3 May 2008, Columbia Bottom CA (R. Coles, BR, J. Solodar); 7 May 2004, near Columbia, Boone Co. (BJ); 15 May 1983, Springfield (G. Dobbs); 14 Jun 1976, near Pumpkin Center, Nodaway Co. (Easterla 1976).

\section{Mississippi Kite (Ictinia mississippiensis)}

Status: Uncommon to locally common transient in the Mississippi Lowlands; uncommon breeder from Mississippi Lowlands north along the Mississippi River to at least Pike county; rare summer resident elsewhere, but no known breeding records north of Kansas City; rare transient elsewhere.

Documentation: Specimen: juv. female, 12 Sep 1909, Monteer, Shannon Co. (AMNH 352054).

Habitat: Primarily in mature, bottomland forests, especially bordering rivers, streams, and swamps, but also towns, suburbs, and parks with large trees.

Spring: Typically the first migrants do not appear until the very end of Apr, with peak in mid-May. Earliest dates: at least three reports during the latter half of Mar, but none verified, as is the case with Mar reports in Kansas (Thompson et al. 2011, M. Thompson pers. comm., July 2016). Earliest Apr observations: ad, 14-15 Apr 2017, Cape Girardeau (BE); 1, 17 Apr 1996, St. Louis (RK); two separate reports on 19 Apr 1996, Springfield (B. Dyer, J. Cook, AK); 1, 20 Apr 2012, Castlewood SP (JM). High counts: 300, 16 May 1991, between Donaldson Point and Wolf Island, New Madrid/ Mississippi cos. (J. Wilson, L. Burger); 115, 5 May 2006, along Mississippi River (op- 
posite from Cape Rock to Chester, Illinois; M. Boyer, S. Ballard, M. Guetersloh). High count for the northwestern corner: 6, 18 May 1996, Loess Bluffs (RF, SA, G. Griffith).

Summer: Prior to the early 1990s, the breeding range was restricted to the southeastern corner of the state. During the past three decades this kite has dramatically expanded its breeding range within the state. In 1992, 4 adults, 16 Jul at Prairie Slough CA, Pike Co. (T. LaRue), in Aug at Schell-Osage (CH), and a pair attempted nesting in Swope Park, Kansas City (RF, B. House). The following year breeding likely occurred at a quarry in Lake of the Ozarks SP, Miller Co. (T. Nagel), and nesting was confirmed for the first time at Joplin (Herbert 1994a). In 1994, pairs were detected along the Marmaton River, east of Horton, Vernon Co. (RF), and along the Grand River, near Hartwell, Henry Co. (MR), and it bred at Gladstone, Clay Co. (RF). By 2001, the species had been recorded breeding at Eagle Bluffs, and during mid-Jun 2012 adults were observed at Swan Lake (SK). It has become fairly numerous in many parts of suburban St. Louis County, often nesting in well-treed yards. The increase in Missouri corresponds with range expansion in Kansas (Thompson et al. 2011).

Historically, the southeastern corner of the state was the primary area where the species bred; however, based on information included in Widmann (1907), the species may have been more widespread, with breeding records as far north as St. Louis. Apparently Nehrling found the species "pretty numerous" in Lawrence Co., and in 1906 Widmann observed pairs in Webster and Howell cos. There was a hiatus in breeding records outside the southeastern corner from that time until the above early 1990s records.

Fall: Birds begin leaving the state by mid-Aug, and relatively few remain by the second week of Sep. There still is no Oct record. High count: 80, photo, 8 Aug 2014, Cape Girardeau (A. Gathman). Latest dates: 1, 28 Sep 2004, St. Louis (JU, M. Paradise); 8, 24 Sep 2001, St. Louis Co. (MBr); 1, 23 Sep 2006, Lake of the Ozarks SP (EW).

\section{Bald Eagle (Haliaeetus leucocephalus)}

Status: Common transient and winter resident along large rivers and reservoirs, uncommon elsewhere; uncommon summer resident.

Documentation: Specimen: female, 6 Dec 1907, Monteer, Shannon Co. (AMNH 352772).

Habitat: Primarily along major rivers, reservoirs, and lakes.

Spring and summer: During most springs, the majority of the wintering population has left the state by the end of Feb/early Mar. By early Apr mostly breeding birds are present. Nest construction is typically initiated during the early part of this season.

Prior to 1850 , the species bred in Missouri along several rivers and in the southeastern swamps, but by 1900 it was on the verge of extirpation as a breeder because of deforestation and persecution (Widmann 1907). There were occasional nesting reports from Widmann's time up to the present (Griffin and Elder 1980). The species went 
through a dramatic population decline as a result of the overuse of pesticides (primarily DDT) from the 1950s through the 1970s. Since the banning of the pesticides, the species has made a dramatic comeback. In the 1980s, 5-6 nests were known in Missouri, and 10 nests were documented during the summer of 1993. By 2000, 48 nests were located across 34 counties; in the spring/summer of 2007 there were greater than 150 nests in the state; and in 2015 greater than 260 nests were known (MDC data).

Fall and winter: The first migrants, typically immatures, begin appearing from the north by the end of Sep. Numbers gradually increase through fall, with the largest concentrations occurring after water to the north of the state has frozen. The winter population varies considerably from year to year depending on the severity of the winter to the north, i.e., when reservoirs and large rivers become frozen/ice-bound to the north, there is an influx of birds into Missouri. Usually from late Dec through Jan, when shallow water is frozen, most of the population is found along the major rivers. Data for wintering, color-marked immatures during the 1970s indicted that the majority of the birds originated from Minnesota and Saskatchewan (Griffin et al. 1980).

Midwinter counts sponsored by the MDC and the USWFS have been conducted during the first week of Jan. The latest complete survey, in 2013, recorded 2,693 individuals. The highest count was in 2011 when 2,901 were recorded, with a low count in 1976 when only 763 individuals were recorded. High counts: 476, 27 Dec 2001, Loess Bluffs (refuge data); 450, 30 Jan 2007, Clarksville (K. Spahn); 417 (291 ad, 126 imm), 19 Dec 1978, Loess Bluffs CBC; 391, 22 Dec 2003, Loess Bluffs (refuge data); 295, 3 Jan 2007, Loess Bluffs (refuge data).

Comments: The Bald Eagle was taken off the Endangered Species list in 2007 but remains protected under the Bald and Golden Eagle and the Migratory Bird Treaty acts. In Missouri, it became essentially extirpated as a breeding bird for much of the twentieth century (see above), but there was always a substantial wintering population that originated much farther north. Thus it is inaccurate to say that the Bald Eagle was ever "almost extinct," as the media sometimes report.

\section{Northern Harrier (Circus hudsonius)}

Status: Common transient and winter resident; rare summer resident.

Documentation: Specimen: egg set, 21 May 1925, Kansas City (KU 74145).

Habitat: Marshes, prairies, and pastures.

Spring: Migrants begin supplementing the winter population in late Feb/early Mar. Peak is in mid- to late Mar, but relatively large numbers are seen through the third week of Apr. Apparent late migrants are seen at non-breeding sites into May. High counts: 100, 14 Mar 1998, Taberville Prairie (D. Arney); 75, 29 Mar 1964, Loess Bluffs (FL).

Summer: The harrier is a rare and very local breeder, with most recent nestings on native prairies. During the past few decades, the highest concentrations have been found 
at Prairie SP, where 7 pairs were present in 1984. The BBA survey (1986-1992; Jacobs and Wilson 1997) confirmed breeding in 6 blocks, with 5 other blocks as probable; these occurred in all physiogeographic areas except the Ozarks. There have been recent summer observations in rice fields in the bootheel, so the species may breed there. Presumably this species was more common and widespread in the prairie region of the state prior to European settlement, but by 1900 it already had declined considerably (Widmann 1907).

Fall: Obvious migrants begin appearing by late Aug, with a gradual increase in numbers through Sep, culminating in a mid-to-late Oct peak. High counts: 53, all age and sex classes, foraging late afternoon, minimum count in air at same time, 22 Nov 2015, Taberville Prairie (MR, CH, CBu, LB, R. Grant); 50, 29 Nov 2009, Prairie SP (D. Rising); 25, migrating in $1 \mathrm{hr}, 16$ Oct 1976, St. Charles Co. (JE).

Winter: This species is locally common at the remaining prairies and wetlands, but it is found in low densities elsewhere. As one would expect, because of the largely forested landscape, it is least abundant in the Ozarks. High counts: 65, 12 Jan 2015 and 29 Jan 2016, Penn-Sylvania Prairie, Dade Co. (m. ob.); 54, 18 Feb 1994, northwest Livingston Co. (D. Fitchett); 54, 1 Jan 2013, Dunklin Co. (TJ); 52, 20 Jan 2014, Taberville Prairie (MR, M. Andersen).

High counts on CBCs may be greatly inflated as a result of double-counting individuals, as often harriers that have been counted earlier in the day in outlying areas come, often from miles away, to forage and roost at prime areas in the evening and get recounted. Thus the following high $C B C$ counts should be viewed with some skepticism: 105, 29 Dec 2009, Liberal; 102, 14 Dec 2003, Four Rivers; 90, 15 Dec 2001, Grand River; 90, 18 Dec 1998, Four Rivers.

\section{Sharp-shinned Hawk (Accipiter striatus)}

Status: Common transient; uncommon winter resident; rare summer resident in Ozarks, and Ozark Border, accidental elsewhere.

Documentation: Specimen: imm male, 3 Oct 1892, Willow Springs, Howell Co. (USNM 141092).

Habitat: All woodland and forest habitats during migration and winter; for breeding prefers relatively large tracts of forest, especially with Shortleaf Pine (Pinus echinata) stands.

Spring: The spring migration is inconspicuous compared to fall. Migration commences in early Mar, with peak in Apr. Late migrants are regularly seen into early May. Nesting is often initiated in Apr. High count: 41, 24 Apr 1987, Imperial, Jefferson Co. (MP).

Summer: The breeding status of this species was poorly understood until Kritz's (1989) study located 17 nests during 1985-6 in an eleven county area of the eastern Ozarks and Ozark border. All but one of the nests were located in Shortleaf Pine (Pi- 
nus echinata). Breeding has subsequently been documented or suspected in additional counties in the Ozarks as well as possible breeding in other areas, including north of the Missouri River. Confirmed or suspected breeding has occurred in the following counties not listed by Kritz (1989): Boone, Crawford, Grundy, Montgomery, Holt, Taney, Webster, and Chariton.

Fall: The first migrants appear at the end of Aug with a gradual increase in numbers until the end of Sep when, usually following a cold front, relatively large numbers pass through the state. Numbers drop off dramatically by mid-Oct. Thereafter, typically only 1-2 individuals may be seen in a day. High counts: 125, 4-5 Oct 1986, Lake of the Ozarks SP (m. ob.); 32 (9 hrs), 7 Oct 2017, Eagle Bluffs (PM, BJ, E. Wood et al.); 22, 22 Sep 1995, Rockbridge SP (PM).

Winter: This accipiter is an uncommon winter resident statewide, although it is more common in the Ozarks and Ozark Border. Both Sharp-shinned and Cooper's hawks are now recorded at all-time highs on CBCs. Sharp-shinneds are frequently seen predating birds at feeders throughout the state at this season. High CBC counts: $13(0.0), 18$ Dec 2010, Columbia; 13 (0.1), 20 Dec 2012, Springfield; 13 (0.2), 14 Dec 2013, Columbia.

Comments: Both the Sharp-shinned and Cooper's hawks have increased dramatically during the past 50 years (BBS and $\mathrm{CBC}$ data).

\section{Cooper's Hawk (Accipiter cooperi)}

Status: Uncommon permanent resident; most common during migration, least common in summer.

Documentation: Specimen: male, 8 Sep 1909, Monteer, Shannon Co. (AMNH 352301).

Habitat: All woodland and forest habitats during migration and winter; for breeding prefers relatively large tracts of forest, especially with Shortleaf Pine (Pinus echinata) stands. At all seasons, much more frequent in towns and suburbs than formerly.

Spring: Chronology of migration is very similar to Sharp-shinned Hawk, but Cooper's is less common. Even during peak migration in Apr, rarely are more than 1-2 individuals seen/day.

Summer: Much more widespread and in higher densities than Sharp-shinned Hawk; during the past two decades it has dramatically increased and now has been found breeding in most counties, including residential areas in mid-sized to large cities. Like Sharp-shinned, it is far more prevalent in the Ozarks and Ozark border. Because of the lack of woodland and forest, the species is least common in the Mississippi Lowlands. Kritz (1989) located 43 nests (67\% in Shortleaf Pine), with the majority of those in the Ozarks and Ozark Border. Widmann (1907) considered this accipiter to be a fairly common breeder throughout the state, although presumably it was much more common in the forested regions. 
Fall: The temporal pattern is very similar to Sharp-shinned, and, as with that species, more are observed at this season than during spring migration. Typically, $<5$ birds/day are seen even during the peak of migration in late Sep/early Oct. High counts: 31, 4-5 Oct 1986, Lake of the Ozarks SP (m. ob.); 16, 11 Oct 2014, Bradford Farm, Columbia (BJ et al.).

Winter: Widespread throughout the entire state in low densities. It is most common in the Ozarks and Ozark border. Both Sharp-shinned and Cooper's hawks are now recorded at all-time highs on CBCs and like Sharp-shinned, Cooper's frequent bird feeding stations. High CBC counts: 12 (0.1), 18 Dec 2012, Springfield; 11 (0.0), 17 Dec 2005, Columbia; 11 (0.0), 17 Dec 2011, Columbia; several counts of 10 individuals.

\section{Northern Goshawk (Accipiter gentilis)}

Status: A rare and sporadic migrant and winter resident.

Documentation: Specimen: female, 5 Dec 1916, Kansas City (KU 39039).

Habitat: Forest and forest edge.

Spring: Typically, there are at most one or two reports of single individuals during this season, and some years not a single bird is reported. Following the occasional irruptive fall and winter movements, some individuals may be encountered as late as the end of Apr and into May. There are at least six May records, and, underscoring just how major the irruption was in the fall of 1972, an extraordinary five individuals were seen at Taberville Prairie on 21 Apr 1973 (KH et. al.). Latest dates: 1, 19 May 1973, Swope Park, Kansas City (N. Johnson, J. Garrett); 1, 15 May 1999, Castlewood SP (DB, MBr).

Fall: More frequently seen at this season than in spring, although, as in spring, most years a total of only 1-2 individuals are detected, and during some falls not a single bird is reported. Typically, the goshawk is not seen until the very end of Sep or in early Oct, with most observations at the end of Oct through the end of the period. The falls and winters of 1972, 1982, and 1983 are three notable years when relatively large numbers were detected in the state. The earliest documented major irruption into the state was in 1906, when five adults were shot between mid-Nov and mid-Dec (Widmann (1907). Since the fall of 1983, there have not been any impressive irruptions into the state; the highest number reported since then was of six individuals during the fall of 2001. Earliest dates: ad, 26 Sep 1984, Tyson Valley RC, St. Louis (MP, J. Ziebol, S. Russell); 1, 27 Sep 2005, Eagle Bluffs (AF).

Winter: During most winters a maximum of 1-2 individuals are detected, and most years none are reported on CBCs. The most reported during the past three decades is a total of four individuals during winter 1991-2. High counts: 3, 16 Dec 1972, Kansas City Southeast CBC; 3, 19 Dec 1982, Trimble CBC.

\section{Harris's Hawk (Parabuteo unicinctus)}

Status: Accidental; single record. 
Documentation: Photograph, see below.

Habitat: Non-forested, upland grassland.

Record: An adult was photographed, 8 - 22 Feb 1995, Columbia (S. Heying, PM, BJ, J. Wallace). It was reported in Columbia several months prior to the February photographic documentation and may have been present as late as 11 Mar. This record occurred during a major extralimital movement of this species during the fall and winter of 1994-5. In addition to the Missouri record there were records in Wisconsin, eastern Kansas, Louisiana, and eastern Colorado, with unprecedented numbers north of the species' normal range in Texas (Kaufman 1995a,b).

\section{Red-shouldered Hawk (Buteo lineatus)}

Status: Common permanent resident in south; generally rare, but locally uncommon in the north.

Documentation: Specimen: male, 5 Mar 1879, Charleston, Mississippi Co. (MCZ 43061).

Habitat: Riparian forest and wooded swamps.

Spring: Although there is a sizable winter population in the southern half of the state, migrants are discernible in early to mid-Mar, e.g., 7, 1 Mar 1992, near Imperial (MP). Nesting is well advanced by mid-Mar.

Summer: This species has increased dramatically during the past two decades. It is more widespread and common at this season than in winter and is most common along Ozark streams and rivers and in wooded swamps, such as Mingo. For example, 22 nests, summer 1984, along Shoal Creek, Newton Co. (W. Perkins); 13 nests, summer 1983, Mingo (T. Humphrey). See Table 6 for numbers recorded on float surveys. Although it is more local and rare in the Osage and Glaciated Plains, it has been increasing in those regions, e.g., in the north-central part of the state (Swan Lake, Fountain Grove, Pershing SP), where the increase was noted starting in 2001 (SK). Along with the increase in numbers, this hawk has expanded from strictly rural areas into well-wooded towns and suburbs, e.g., in St. Louis County.

Within the Glaciated Plains it is rarest in the northwestern corner where only a few scattered pairs have bred. In that region, breeding was noted along the 102 River southeast of Maryville in 1970 (MR) and along the lower Nodaway River at Honey Creek CA, Andrew/Holt cos. until 1970 (FL); however, both those areas lost riparian habitat that likely led to its disappearance. Recently, a pair bred at Brickyard Hill from 2000-2007 (DE, TR; Easterla 2000) and in 2010 a few birds were detected in southern Andrew Co. (LL, JH et al.). It is now least common in the largely denuded Mississippi Lowlands, where it almost certainly was most abundant prior to European settlement.

Fall: Based on birds away from known nesting areas, it appears that migrants from north of Missouri and a large percentage of the Missouri breeding population primarily passes through and leaves the state from late Aug through mid-Nov. Although data 
are sparse, peak of movements appears to be from late Sep to mid-Oct. All high counts are $<10$ individuals/day.

Winter: During the past decade this hawk has increased dramatically statewide, and it now winters farther north. Increases were noted in the St. Louis area during the winter of 2000-2001, and the following year in the Swan Lake region (SK). It was not recorded on the Columbia CBC until 1996-7, but by 2002-3 double-digit numbers were recorded. Based on $\mathrm{CBC}$ data for the entire state, the species went from about 5 individuals/100 pa hrs in 2002 to 20 individuals/100 pa hrs in 2011. High CBC counts, all on Mingo: 42 (0.6), 28 Dec 1996; 37 (0.6), 28 Dec 2013; 36 (0.5), 30 Dec 1995; 31 (0.4), 27 Dec 2003. More information is needed to ascertain whether wintering individuals are from breeding populations from north of Missouri or represent permanent residents.

\section{Broad-winged Hawk (Buteo platypterus)}

Status: Common transient; uncommon summer resident in the Ozarks and Ozark Border; rare elsewhere.

Documentation: Specimen: egg set, 17 May 1891, Kansas City (FMNH 6668).

Habitat: Prefers mature, continuous forest for nesting.

Spring: In contrast to fall, migration is less dramatic and more diffuse, with the species more frequently observed in larger numbers in the eastern portion of the state. The initial migrants are typically detected in early Apr, with peak at the end of the month. Migrants, especially first-year birds, are regularly seen migrating in small flocks through the end of the period. Earliest dates: 1, 10 Mar 1980, (P. Snetsinger, M. Wiese); 1, 15 Mar 1969, Busch (JEC). High counts: 572, 22 Apr 1990, Busch (J. Ziebol); 571, 18 Apr 1992, near Loutre River, Montgomery Co. (TB, PM).

Summer: Occasionally, late migrants in small groups, primarily composed of firstyear birds, are seen passing through the state the first week of Jun, e.g., 7, 4 Jun 1981, near Asburn, Pike Co. (MR, DE). This buteo is most common in heavily wooded sections of the state, the Ozarks and Ozark Border. It is very local in the Osage Plains and is largely absent from the Mississippi Lowlands. Within the Glaciated Plains it is most common in the more heavily-wooded eastern portion; in the western half it is very local and primarily found in the wooded bluffs along the Missouri River floodplain.

Fall: Large kettles, involving up to a few thousand individuals, are regularly observed in all parts of the state except the extreme western portion (roughly the 2-3 westernmost tiers of counties). The first migrants begin to appear in Aug, e.g., 3, 9 Aug 1987, St. Louis (MP); 3, 21 Aug 1986, Loess Bluffs (FL). Peak occurs following a cold front during the last two weeks of Sep. Large concentrations are still observed through the first week of Oct, but by mid-Oct only a few individuals are seen, with no verified records for the last week of Oct and Nov. High counts: 6,000, 24 Sep 2017, Columbia (A. Lambert, P. Monacell); 5,419, 4 Oct 1986, Jefferson Co.; this unusually late high count was the result of weather conditions (MP); 3,700, in $1 \mathrm{hr}$ and 20 minutes, 21 Sep 
1992, eastern Taney Co. (Myers and Myers 1992); 3,500, 22 Sep 1990, Tyson Valley RC, St. Louis (MP). Latest date: 1, 24 Oct 2014, St. Louis (JE).

Comments: The rarely-encountered dark morph has been reported on at least four occasions, all in spring: 23 Apr 1969, Loess Bluffs (FL, DE et al.); 17 Apr 1994, Roaring River (PM); 27-29 Apr 1995, Loess Bluffs (DE, JH, CH, PM), and once, without date, at St. Louis (MP, pers. comm.). This morph is primarily found in the central and western parts of the breeding range (Burns 1911).

\section{Swainson's Hawk (Buteo swainsoni)}

Status: Uncommon transient in west, rare in east; rare summer resident in west; accidental summer visitant in east.

Documentation: Specimen: female, 12 Apr 1969, near Skidmore, Nodaway Co. (KU 117542).

Habitat: Open country; pastures, prairies, and harvested fields.

Spring: Much more common in the western half, especially the western two tiers of counties. The first migrants appear at the beginning of Apr, with peak during mid- to late Apr. Late migrants during the latter half of May are typically non-adults. Earliest dates: 1, 14 Mar 1987, Kansas City, Clay Co. (T. Schallberg); 1, 18 Mar 1989, Jefferson Co. (MP); 1, 22 Mar 2011, Springfield (CBu). High counts: 200+, 18 Apr 2006, Bigelow Marsh (McKenzie et al. 2006); 65, 20 Apr 2013, Horseshoe Lake (JB, JK); 45+, 20 Apr 2013, Loess Bluffs (m. ob.). High count in east: 9, 18 Apr 1992, near Loutre River, Montgomery Co. (TB, PM).

Summer: Late migrants, typically non-adults, are seen well into Jun: 24, 12 Jun 1964, near Forbes, Holt Co. (FL); 7, 21 Jun 1964, near St. Joseph (JHam). The Swainson's Hawk is a very low density breeder in the prairie region of the western quarter of the state. The highest density is in the Springfield area, the easternmost documented breeding in the state, where as many as four nests have been found in a summer (2011; $\mathrm{JBu}$ et al.). However, more pairs may actually be located in Barton and adjacent counties in the west-central part of the state. A single pair has continually bred, since at least 1994, at the Kansas City International Airport, Platte Co. (MR, CH, RM et al.). A few birds are occasionally seen in mid-summer in the Missouri River floodplain from Kansas City north to the Iowa border, but to date there is no nesting verification for that region. There is a single eastern record for this season: ad, photos, 22 June 2015, Franklin Co. (J. Foreman).

Fall: The first migrants appear at the very end of Aug. Numbers increase until peak in late Sep/early Oct. During peak, large flocks may be observed foraging and resting in harvested soybean fields along the western border. A few individuals are seen until the end of Oct, but it becomes quite rare by the first week of Nov. There are no verified records for mid-to-late Nov; however, note the recent Dec record below. High counts: 284 (267 in one flock), 1 Oct 1991, Missouri River valley in Atchison and Holt cos. (MR); 125, 5 Oct 1990, near Bolckow, Andrew Co. (JH; Robbins and Hilsabeck 
1991); 114, 5 Oct 1990, Cass Co. (J. Jefferson). Highest count in east: 5, 18-24 Sep 1974, St. Louis area (RA, JC). Latest dates: imm, photos, 1-12 Dec 2015, Clarence Cannon (C. Alger, R. Mustell; fig. 19); 1, 6 Nov 1982, near Springfield (A. Banfield); 1, 4 Nov 1995, Busch, St. Charles Co. (JVB); imm, photos, 31 Oct 2009, south of St. Joseph, Buchanan Co. (M. Nemecek).

Comments: The winter distribution of this hawk has changed dramatically in the past three decades; now multiple individuals are seen each winter in southern Louisiana (V. Remsen, pers. comm.; eBird), and it is regular as far north as east-central Texas (eBird). Juveniles could easily be overlooked and passed off as heavily marked Redtailed Hawks. In view of this and the above recent December record, this raptor should be looked for during the latter half of Nov and early winter. All such records should be documented with photographs.

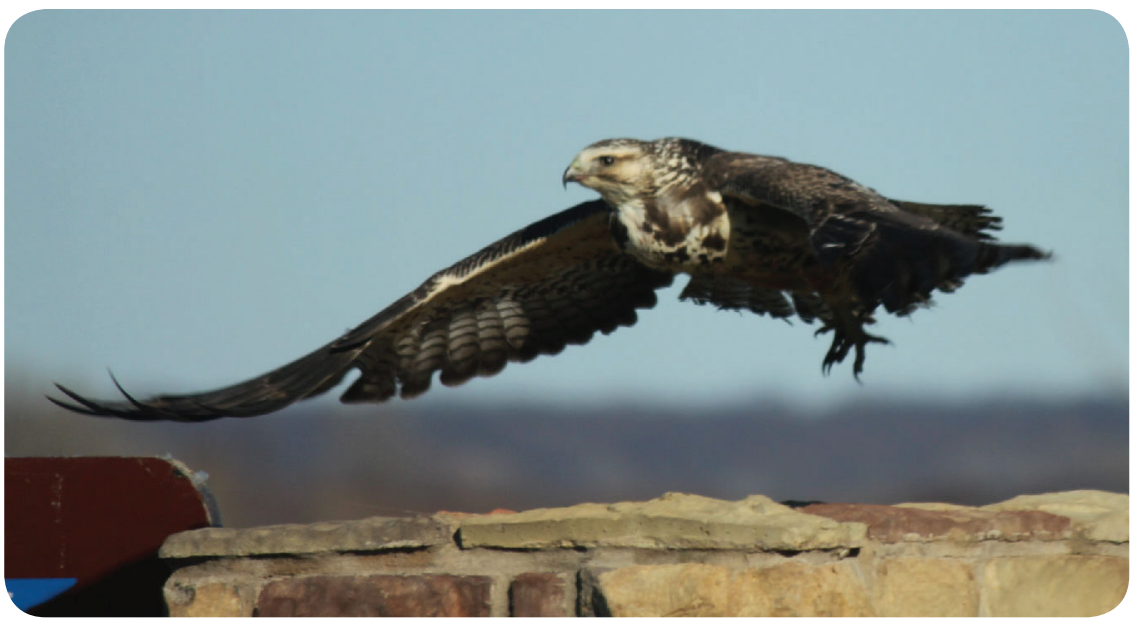

Fig. 19. The only December record of Swainson's Hawk in Missouri; present 1-12 December 2015, Clarence Cannon N.W.R. Photo by Cody Alger.

\section{Red-tailed Hawk (Buteo jamaicensis)}

Status: Common permanent resident.

Documentation: Specimen: male, 20 Jun 1818, Barton Co. (MVZ 57189).

Habitat: A wide variety of open habitats. Nesting is typically at the edge of woodlots and forest. At all seasons, frequently encountered in towns and suburbs.

Spring: Movement of all subspecies begins in late Feb/early Mar. Peak is usually in mid-to late Mar. The majority of non-resident individuals have left the state by mid-Mar. However, some individuals of all subspecies are regularly seen through Apr, with an occasional bird, usually an immature, being seen into the first week of May. High counts: 82, 23 Mar 1984, Jefferson Co. (MP). Latest dates, harlani: imm, 4 May 2013, Loess Bluffs (JU, M. Paradise); male, 25 Apr 1968, near Loess Bluffs (DE; KU 117875); kriderii: 19 May 1963, Loess Bluffs (FL); 11 May 2013, Boone Co. (RD et 
al.); calurus: single, dark-rufous morphs: 18 May 2013, Bob Brown(JK); 8 May 1989, Schell-Osage (MR, TE).

Summer: This buteo is most common in the open areas of the state; thus it is most abundant in the Glaciated and Osage Plains and least common in the Ozarks. The density is also lower in the agriculture-dominated Mississippi Lowlands. All breeding birds are referable to the eastern subspecies $B . j$. borealis.

Fall: A few migrants appear as early as late Aug; however, non-resident subspecies do not appear until the very end of Sep/early Oct. All western subspecies are more common in the western half of the state. Peak of all subspecies is in late Oct to mid-Nov. Earliest dates by subspecies, all single individuals: harlani, 25 Sep 1966, Loess Bluffs (FL); 29 Sep 2005, Loess Bluffs (MR); calurus: ad, dark morph, 29 Sep 2005, Bob Brown (MR); ad, dark morph, 30 Sep 1992, near Forest City, Holt Co. (MR); 3 Oct 1968, Busch (K. Arhos et al.); kriderii: 3 Oct 1994, Bilby Ranch (KG); 5 Oct 1994, Taberville Prairie (MR); 5 Oct - 25 Nov 2000, Riverlands (CM, BR). Hawk watch high count: 136, 1 Nov 1984, Webster Groves, St. Louis (MP).

Winter: As in other seasons, this ubiquitous hawk is most common in open areas of the state. In contrast to summer, when the species is in lower densities, it is relatively common during the winter in the Mississippi Lowlands, e.g., ave. one individual/mile, along Interstate 55 from the Arkansas border to Sikeston, 31 Dec 1993 (M. Goodman); ave. one individual/mile, along Interstate 55 from the Arkansas border to Benton (80 miles), 1 Jan 2011 (McKenzie 2011).

Five subspecies of Red-tailed Hawk have been reported during winter in Missouri: Alaskan-breeding B. j. harlani, western B. j. calurus, northern Great Plains-breeding B. j. kriderii, taiga-breeding B. j. abieticola, and eastern B. j. borealis. Throughout eastern and Ozark sections of the state, the primary wintering subspecies is $B . j$. borealis. If Liguori and Sullivan (2014) are correct in their assessment of B. j. abieticola, this subspecies outnumbers harlani, calurus, and kriderii in at least the western half of Missouri during winter. However, distinguishing abieticola from light morphs of calurus, harlani, and borealis can be extremely difficult. Apparently a dark morph of abieticola is unknown, but birds that have long been reported as dark morph calurus in Missouri may indeed be attributable to abieticola (Liguori and Sullivan 2014; B. Sullivan, pers. comm.). Intergradation among several of the subspecies further complicates identification.

High counts, with a large portion of the individuals of the eastern subspecies borealis: 293 (5.2), 14 Dec 2010, Four Rivers CBC; 205 (2.4), 18 Dec 1998, Four Rivers CBC; 203 (3.0), 14 Dec 2003, Four Rivers CBC; 198, 30 Dec 1988, Barton and Vernon cos. (145 miles; MR). A high count of 25 harlani on the 20 Dec 1981, Loess Bluffs CBC is suspect as it may have involved both double counting and confusion with other subspecies. Typically, a maximum of a few individuals/day of harlani may be observed in the western two tiers of counties of the state during winter (MR). Indi- 
viduals of both dark-morph harlani and calurus with distinctive markings have been noted returning to the same wintering site for multiple years, e.g., ad. dark-morph calurus, Dec 2007-2012 at Columbia Bottom (BR).

Comments: As mentioned above, apparently there is extensive intergradation among the various subspecies where their ranges meet. Both the upper Great Plains breeding kriderii and the taiga breeding abieticola are controversial subspecies. Because of the loss of grassland coupled with the expansion of both borealis and calurus (abieticola as well?) into kriderii's range that has resulted in intergradation, it is thought that kriderii may now be much less common and widespread (Liguori and Sullivan 2010). There is no indication of a reduction in kriderii numbers in Missouri as multiple individuals are seen each winter, including the most recent: Nov through Jan 2015-16 (MR, CH, JB et al.). Liguori and Sullivan (2010) provide photos and characters for identifying kriderii and suspected hybrids. Also see comments above under winter.

\section{Rough-legged Hawk (Buteo lagopus)}

Status: Uncommon, sporadic transient and winter resident.

Documentation: Specimen: female, 26 Dec 1894, Carthage, Jasper Co. (BM 5464).

Habitats: Open country, especially prairie and pastures.

Spring: Most wintering individuals have left the state by the third week of Mar, but a few are regularly seen into the beginning of the second week of Apr. Latest dates, all of single birds: 29 Apr 1956, Loess Bluffs (FL); 28 Apr 2006, Hi Lonesome Prairie (JU); 27 Apr 2013, Eagle Bluffs (R. Stanton); ad male, 23 Apr 2011, Fountain Grove (TM et al.). High counts: 20+, 14 Mar 1975, Hi Lonesome Prairie and surrounding area (DE, MR); 6, migrating, 22 Mar 1997, Thomas Hill Reservoir (SK, TM).

Fall: The first migrants typically appear about the second week of Oct, with larger numbers not observed until the end of the period. Earliest dates: 1, 22 Sep 1975, Creve Coeur Lake (JC); 1, 27 Sep 1965, Kansas City (T. Anderson); 1, 7 Oct 1979, Loess Bluffs (FL); 1, 7 Oct 2010, Bilby Ranch (TM).

Winter: The number of individuals wintering varies considerably from year to year. Virtually every winter there are at least a few individuals observed at prime prairie habitat across the Glaciated and Osage Plains, with fewer individuals wintering as far south as the Mississippi Lowlands. During rare irruption events, extraordinary concentrations have reached the state; the winter of 1970-1 was an example. During that year 30 individuals were observed in one field (ca. 60 acres [24.3 hectares]), 20 Dec 1970, 11 miles north of Maryville (MR) and just to the south, on 24 Dec 1970, 25 were recorded on the Maryville CBC. High counts at a single locality during non-major irruptive years: 10+, 12 Feb 2010, Poosey CA (SK); 8, hovering over same field, 28 Dec 2005, Liberal CBC (JCa, K. Badgley, AK). Recent high count for Mississippi Lowlands: 3, between Arkansas border and Benton, Missouri (80 miles of I-55), 1 Jan 2012 (McKenzie 2012). 


\section{Ferruginous Hawk (Buteo regalis)}

Status: Casual transient and winter visitant in west, accidental east.

Documentation: Photograph, see below.

Habitat: Open country with short grass.

Spring: A single record from a reliable observer on the late date of 24 Apr 1949, at Sugar Lake, Buchanan Co. (J. Bishop).

Fall: There are only seven observations that are considered reliable. All but two reports involve single, light-morph adults: imm light morph, photos, 30 Sep - 1 Oct 2017, Norris, Henry Co. and adjacent Johnson Co. (TB, BJ); 1 Oct 1972, Maryville SL (DE); 2 Oct 1970, Missouri River bottoms, near Amazonia, Andrew Co. (FL); 11 Oct 1981, Schell-Osage (TB); 19 Oct 1979, El Dorado Springs, Cedar Co. (TB); dark morph, 8 Nov 1953, Missouri River bottoms near Kansas City (J. Bishop); and 24 Nov 1960, St. Louis (RA).

Winter: There are seven records, all involving single light-morph individuals, with all but one from the western half of the state: ad, photos, 16 Dec 1994, Prairie SP (MR); ad, photos, 12 Feb 1995, south of Montrose, Henry Co. (CH, SA); imm, 28 Dec - 8 Jan 1998-9, Loess Bluffs (MR et al.); ad, 16 Dec 1999, Prairie SP (MR, B. Barber); imm, photos, 16 Feb 2009, Prairie Home CA, Cooper Co. (J. Pons); imm, photos, 29 Feb 2014, along Mississippi R., New Madrid Co. (M. Greene); imm, photos, 6 Feb 2016, Shawnee Trails CA (MR, JB).

Comments: Other buteos are often misidentified as this species, especially kriderii-like individuals of the upper Great Plains Red-tailed Hawk; so there have been a number of unverified observations. All reports of the declining Ferruginous Hawk should be documented with photographs.

\section{Golden Eagle (Aquila chrysaetos)}

Status: Rare transient and winter resident.

Documentation: Specimen: sex?, 10 Mar 1887, Cainsville, Harrison Co. (CAS 35549).

Habitat: Open country, especially areas with short grass.

Spring: Most winter residents and migrants have left the state by mid-Mar; however, a few individuals have been reported during Apr. High counts: 3, 27 Mar 1997, Swan Lake (B. Olson); 3, 2 Mar 2008, Pike Co. (JE). Latest dates: 1, 1 May 1980, Glade Top Trail, Douglas/Ozark cos. (N. Fay); ad, 27 Apr 1991, Lake of the Ozarks SP, Camden Co. (C. Tyndall, J. Vickery). A subadult male, first trapped and tagged with a GLP tracking device in Tennessee, was noted to make visits to Texas, Dent, Warren, and St. Charles counties in Missouri, 25 Mar-9 Apr 2014 (S. Somershoe).

Fall: The first migrants are typically not detected until the end of Oct. Earliest dates: 1, 16 Aug 1981, Aldrich (N. Fay); ad, 29 Sep 1987, Tyson Valley RC (JZ; Peters 1988); 
1, 8 Oct 2000, Eagle Bluffs (J. Leonatti). High counts: 5 (4 ad, 1 imm), 20 Oct 1974, Swan Lake (BG).

Winter: A very low-density species, primarily seen in open country. The vast majority of records are of single individuals. High count: 3, 21 Dec 1968, Loess Bluffs CBC.

\section{Order Strigiformes \\ Family Tytonidae: Barn owl}

\section{Barn Owl (Tyto alba)}

Status: Rare permanent resident; smaller numbers are encountered during the winter, especially in the northern half of the state.

Documentation: Specimen: female, 1 Apr 1891, Clinton, Henry Co. (USNM 119956). Habitat: Open country; nests and roosts in abandoned or infrequently used buildings in both rural areas and cities.

Comments: The highest densities are found in the agriculture-dominated landscapes of the state. Prior to the draining and deforestation of Mississippi Lowlands in the late 1800 s/early 1900s, the species was either very rare or absent in that area (Widmann 1907). Today, however, the largest numbers may be found in that region. It is rarest in the heavily-forested sections of the Ozarks.

The species is partially migratory, as birds that breed in an area often disappear during fall/early winter. At least in the northern part of the state, the species is less prevalent in winter than in summer; however, even there the species has been documented breeding in early winter, e.g., 4 not fledged young, photos, second week of Dec 2015, near Plattsburg, Clinton Co. (LW et al.). High counts of adults on CBCs: 3, 18 Dec 1982, Mingo; 3, 29 Dec 1997, Four Rivers.

\section{Family Strigidae: owls}

\section{Eastern Screech-Owl (Megascops asio)}

Status: Common permanent resident.

Documentation: Specimen: female, 6 Jul 1892, Marvel Cave, Stone Co. (USNM 142339).

Habitat: A wide variety of wooded habitats, including in cities and towns.

Comments: Because of being nocturnal, BBS data are not appropriate for assessing the status of the species. Based on BBA and eBird data, not surprisingly, it is least common in the agriculture-dominated sections of the state. As an indication of how abundant this species can be in prime habitat are the results from two recent Columbia CBCs, where special efforts were made to detect the species: 52, 17 Dec 2011; 44, 18 Dec 2010. 


\section{Great Horned Owl (Bubo virginianus)}

Status: Common permanent resident.

Documentation: Specimen: egg set, 20 Jan 1890, Wayland, Clark Co. (WFVZ 70039).

Habitat: Wide range of habitats, but most common in open areas with scattered woods.

Comments: Although this species is widespread and common statewide, it is presumed to be most common in areas where there is a mixture of open habitats that interdigitate with woodland and forest edge. Based on BBA data, it is least common in the Mississippi Lowlands region. High counts on CBCs: 37, 15 Dec 1990, Grand River; several counts with a total of 33.

Only the nominate subspecies has been documented in the state, but the pale northern subspecies subarcticus might occur as a vagrant in winter, as it has been documented in Iowa (Kent and Dinsmore 1996). There have been a couple of reports of pale birds from the northwestern corner of the state during winter, but there are no detailed descriptions or photos associated with those observations.

\section{Snowy Owl (Bubo scandiacus)}

Status: An irregular, rare winter resident.

Documentation: Specimen: male, 3 Dec 1949, Callaway Co. (MU 1517).

Habitat: Bare open country; often seen sitting on fence posts, telephone poles, and hay bales.

Comments: Most years a maximum of only one or two individuals are reported in the northern part of the state, with no reports during some winters. Occasionally major irruptions occur, with the most recent during the winter of 2011-2. The 2011-2012 event was a very well-documented irruption with a minimum of 67 individuals reported. The vast majority were hatch-year birds (Robbins and Otte 2013). The first individuals appeared 22 Nov with peak in reports in late Dec, e.g., as many as three were seen on a single irrigation rig in Holt Co. (K. Goslee), and at least five were present at Smithville Lake (m. ob.). The latest during that event was a hatch-year male that was hit by a car on 13 Mar south of Cameron, Clinton Co.

As this book was going to press, another major irruption was ongoing, with about 20 between 9 Nov 2017 and mid-Jan 2018. Other major irruptions occurred in 1976-7 (8+ reports) and 1980-1 (13+ reports). With few observers in the state, earlier irruptions were poorly documented. From 1882-83 through 1945-6, seventeen irruptions were documented in North America, at intervals of 3 to 5 years (mean 3.9 yrs; Gross 1947).

Earliest fall dates: hatch-year, 19 Oct 1983, Ted Shanks (M. Bates); 1, 24 Oct 1996, near Brookfield, Linn Co. (T. Hoyt, J. Roe). Latest spring dates: male, struck by car, 24 Apr 1977, near Craig, Holt Co. (fide DE; KU 117688); 1, 12 Mar 1963, St. Joseph (m. ob.); 1, 19 Mar 1985, near Lake Contrary (FL). 


\section{Burrowing Owl (Athene cunicularia)}

Status: Rare transient in west, accidental in east; accidental summer resident in northwest; accidental winter resident and visitant.

Documentation: Specimen, see below.

Habitat: Pastures, edge of cultivated fields, and mowed or heavily-grazed prairie/ pasture.

Spring: There is a minimum of eleven modern (since 1965) observations for this season, ranging from early Mar through the end of May. Only two records from the eastern part of the state: 1, photos, 5 Apr 1991, Columbia (TB, BG); 1, photos, 20 Apr 2011, Dunklin Co. (TJ). Earliest date: 1, 3-9 Mar 2011, Willard, Greene Co. (CBu, LB et al.).

Summer: There is a single documented nesting record: $5+$ young were raised in an old badger hole east of Loess Bluffs during May and Jun 1974 (FL et al; Robbins et al. 1986b; photo in Robbins and Easterla 1992). Intriguingly, four birds, including an adult female that was collected (no longer extant) were observed at a hole in Sep 1934 near Lee's Summit, Jackson Co. (Teachenor 1940); it is possible that those bred there.

Fall: There are seven records, six from the western half of the state, with most in late Sep to mid-Oct. Earliest date: 1, 22 Sep 1980, Cass Co. (J. Jefferson). Latest dates: female, hit by car, 19 Oct 2013, southwest of Peculiar, Cass Co. (K. Todd; KU 122775); 1, photos, 17 Oct 1995, Kansas City, Jackson Co. (K. Hogan et al.). A bird that appeared in the fall of 1960 remained until Feb 1962, south of Sikeston, Mississippi Co. (W. Pollock; photos).

Winter: Only two records: the above Sikeston bird and 1, 19 Dec 1987, Montrose CBC (M. Taylor).

\section{Barred Owl (Strix varia)}

Status: Common permanent resident.

Documentation: Specimen: egg set, 14 Apr 1881, Maryville, Nodaway Co. (WFVZ 120709).

Habitat: Primarily found in mature forest, especially river bottom and wooded swamps.

Comments: This riparian and swamp-inhabiting owl was presumably most common in the swamps of the Mississippi Lowlands and along the two major rivers prior to the deforestation of these areas. Based on BBA data and habitat coverage, it appears to be least common in the Mississippi Lowlands region (Jacobs and Wilson 1997). High counts on CBCs: 40 (0.1), 17 Dec 2011, Columbia; 30 (0.7), 5 Jan 2007, Swan Lake; 25 (0.1), 18 Dec 2010, Columbia.

\section{Long-eared Owl (Asio otus)}

Status: Uncommon winter resident; rare and very local summer resident in north. Documentation: Specimen: egg set, 29 Mar 1897, Kansas City (FMNH 21531). 
Habitat: Most often encountered in conifers and cedars during migration and winter, but also roosts on the ground in dense thickets in riparian areas. Breeding documented in dense riparian forest and pine plantations.

Spring and Summer: Migrants and presumed lingering winter residents are regularly seen until mid-Apr. Birds seen from Apr through the end of the period may represent breeders. Because of its secretive nature and habit of breeding in thick woods associated with water or in pine plantations, it is often overlooked. There are about 20 nesting records scattered across the northern part of the state, with the most recent, 2006-2010, in separate pine plantations in Livingston Co., where as many as two nests were located in a single grove (SK). High count in spring that does not include birds at nests: 15, 6 Mar 1949, Marais Temps Clair (J. Ziervogel et al.); 11, 28 Feb 2009, Henry Sever Lake CA, Knox Co. (P. Harrison).

Fall: This owl is rarely detected prior to mid-Nov, and no large concentrations have been reported for this season. Earliest dates and only Oct records: 2 Oct 1933, Grand Glaize, Camden Co. (MU 454); 1, 10-12 Oct 1975, Independence (KH et al.).

Winter: Not surprisingly, most observations are during CBCs, and when it is detected on CBCs it is usually only a total of one or two individuals. However, large concentrations are occasionally encountered during this period, involving birds roosting either in pine plantations or on the ground in dense woods, usually associated with riparian habitat. High counts: 60, no specific date mentioned, near Courtney, Jackson Co. (B. Bush; Harris 1919b); 30+, 8 Feb 1990, pine/cedar grove at Dorsett Hill Prairie, Cass Co. (D. Myers et al.); 30, 30 Jan 1873, Mississippi River, near St. Louis (J. Hurter; Widmann 1907).

\section{Short-eared Owl (Asio flammeus)}

Status: Uncommon transient and winter resident; rare summer resident in prairies and marshes in north and west, accidental in Mississippi Lowlands.

Documentation: Specimen: egg set, 14 Apr 1883, Maryville, Nodaway Co. (MVZ 5976).

Habitat: Grasslands and marshes.

Spring: The largest concentrations, likely a combination of winter residents and migrants, are observed in Mar with smaller numbers ( $<5$ birds/site) regularly seen into early Apr. Stragglers are seen until the end of Apr. Latest date of late migrant seen away from breeding area: 1, 28 Apr 1974, Maryville SL (DE). High counts: estimated 60, 29 Mar 1970, Loess Bluffs (FL); 30, 8 Mar 2010, northeast of Carthage, Jasper Co. (R. Heth).

Summer: As a result of the loss of prairie and marshes, this owl is now a very rare breeder in the state, with most recent records from remnant prairies in the Osage Plains. Widmann (1907) listed a few counties where the species bred, all in the Glaciated and Osage plains regions. The first nesting record for the Mississippi Lowlands was ob- 
tained when a nest with 3 young was photographed, 10-13 Jun 1995, south of East Prairie, Mississippi Co. (S. and S. Barker). During the BBA, four confirmed breeding records were obtained, with two nests in Putnam Co. (Jacobs and Wilson 1997). In 2002 there were two separate reports of summering birds in Daviess Co. (TM).

Fall: Typically, the first arrivals are detected during the third week of Oct with an increase in observations during the latter half of Nov. Earliest dates: 1, 3 Sep 1992, Greene Co. (JHy); 1, 10 Oct 1994, near Maryville (KG). High counts: 22, 25 Oct 1970, north of Maryville (MR); 19, 7 Dec 1961, Callaway Co. (DE).

Winter: Abundance can vary considerably from year to year. Some winters very few individuals are observed across the state (e.g., 2013-4), whereas in years such as 20092010 it can be widespread and locally common. The 2009-2010 winter was extraordinary: 125, 31 Jan 2010, Dade Co. (CBu et al.), and 34 recorded on each of the following CBC counts: 30 Dec 2009, Cole Camp; 29 Dec 2009, Liberal.

\section{Northern Saw-whet Owl (Aegolius acadicus)}

Status: Rare to uncommon transient and winter resident; accidental summer resident. Documentation: Specimen: female, 9 Mar 1969, near Mound City (KU 117946).

Habitat: Most frequently encountered in dense cedar and conifers, but occasionally found in dense growth in deciduous woods.

Spring: Wintering birds and presumed migrants are regularly encountered until midto late Mar. There are only three Apr records: 1, 11 Apr 1976, Maryville (fide DE); 1, 14 Apr 1996, St. Louis (J. Cook et al.); 1, 16 Apr 1893, St. Louis (Currier; Widmann 1907). High counts: no more than two birds have been detected in a day.

Summer: There is a single breeding record: nest with 3 young, spring 1904, Bluffton, Montgomery Co. (J. Muller; Widmann 1907). However, there is a nesting record from a few miles west of the border in Wyandotte Co., Kansas, in 1951 (J. Bishop; Tordoff 1956). Presumably, the species occasionally breeds in Missouri and is undetected.

Fall: As a result of banding efforts by the Missouri River Bird Observatory (D. Ripper, E. Duke) and the World Bird Sanctuary, the status of this diminutive owl is being clarified. Based on those data, this owl is much more common than incidental observations indicate. Birds arrive by mid-Oct and appear to be at least uncommon from late Oct through mid-Nov. All the following numbers are of individuals captured and banded (D. Ripper, E. Duke, PL): 9, 13 Nov 2010, Benton Co.; 26, Oct-Nov 2011, with single-night high of 5, 4 Nov, Saline Co.; 34, 26 Oct - 8 Nov 2012, Saline Co.; 6, 12-13 Nov 2012, St. Louis; 13, 23 Oct - 18 Nov 2013, Saline Co.; 15, 15 Oct - 1 Dec 2013, St. Louis; 8, 21 Oct - 30 Nov 2014, St. Louis. There are no Sep records, and the earliest Oct record is of 1, 3 Oct 1951, St. Louis (G. Moore).

A banded bird that was hit by a car and recovered on 20 Oct 2001 in Adair Co. (fide E. Hooper) had been banded on 28 Sep 2000, near Arnold, Minnesota. At the time 
it was banded it was estimated to have hatched in 1998. Another bird, banded on 1 Nov 2012, Marshall, Saline Co., was found alive and released on 18 Oct 2013, Sandhill State Wildlife Area, Babock, Wisconsin (D. Ripper, pers. comm.).

Winter: Based on the above banding data this owl is presumed to be a much more common winter resident than the records indicate, especially in the extensive cedar and pine stands in the Ozarks, e.g., 2, banded, 10 Dec 2011, 8 miles south of Rolla, Phelps Co. (D. Ripper). There are only three records for the southern tier of counties, 1, 28 Dec 1991, Taney Co. CBC; 1, 16 Jan 2012, near Rogersville, Webster Co. (D. Ripper, AK); ad female, 21 December 2012, Drury-Mincy CA, Taney Co. (J. Green). As many as 20, however, have been captured in a single fall (2015) in northwestern Arkansas (M. Pruitt), so it undoubtedly occurs regularly in the extreme southern Ozarks.

\section{Order Coraciiformes Family Alcedinidae: kingfisher}

\section{Belted Kingfisher (Megaceryle alcyon)}

Status: Uncommon summer resident; uncommon winter resident in south, rare in north.

Documentation: Specimen: egg set, 22 Apr 1894, Kansas City (KU 74512).

Habitat: Virtually any body of water; nests are placed in riverbanks.

Spring: Migrants begin augmenting the winter population as frozen water begins to thaw, usually at the end of Feb. Peak is in early to mid-Apr. High counts: see under Summer for late season numbers: early season: 15, 5 Mar 2014, Montauk SP (L. Wilkinson).

Summer: Prior to the large-scale conversion to agriculture throughout the Midwest that has caused extensive siltation, coupled with channelization, it is presumed this kingfisher was most common along the two large rivers, where there were abundant nesting sites in banks. Today, even though nest sites are much less prevalent in the Ozarks than along northern rivers, the highest densities appear to be along clear-flowing Ozark streams and rivers, with lowest detections in the Glaciated and Osage Plains (Table 6). High counts: 40 (2.2), undoubtedly included fledged young, 18 Jul 2013, Eleven Point River, Oregon Co. (B. Nelson); 23 (2.5), 21 May 2003, Aker's Ferry, Current River; 21 (1.9), 3 Jun 2005, upper St. Francis River (Table 6).

Fall: Presumed migrants (birds seen in non-breeding areas) are seen by at least early Sep. Peak appears to be in late Sep/early Oct. Numbers gradually decrease through the remainder of the period. High counts: 25+, 3 Oct 1977, along Niangua River, Dallas Co. (S. Yeskie); 21 (1.7), 9 Oct 2004, Waymeyer Access to Big Spring, Current River (12 miles; MR); 21 (2.2), 29 Sep 2017, Pulltite to Round Spring, Current River (9.5 miles; MR). 
Winter: Densities vary considerably from year to year reflecting the severity of a winter. A few individuals are regularly seen in the north until virtually every body of water is frozen. During the past two decades of record-breaking warm winters, the species has been present in small numbers even in the north throughout the winter. Highest densities are in the south. CBC high counts: 33 (0.3), 29 Dec 2007, Taney Co.; 30 (0.4), 1 Jan 2006, Taney Co.; 30 (0.3), 17 Dec 2005, Springfield.

\section{Order Piciformes Family Picidae: woodpeckers}

\section{Lewis's Woodpecker (Melanerpes lewis)}

Status: Accidental transient and winter resident.

Documentation: Photograph; see below.

Habitat: Open woodland, especially riparian areas with cottonwoods.

Records: There are three records, two of birds overwintering and one of a presumed spring migrant: 1, photos, 23 Dec - 24 Mar 1962-3, near Rolla, Phelps Co. (Mrs. Ollar, F. Frame et al.; photo in Robbins and Easterla 1992); ad, photos, 20 Oct - 4 May 2001-2, Schell-Osage (J. and E. Zellmer et al.); 1, photos, 6 May 1989, northeast of Gainesville, Ozark Co. (Jacobs 1989). The May record coincides with extralimital records from adjacent states.

\section{Red-headed Woodpecker (Melanerpes erythrocephalus)}

Status: Common transient and summer resident statewide; sporadic and locally uncommon to common winter resident in south, much more local and in smaller numbers during winter in the north.

Documentation: Specimen: egg set, 29 May 1890, Kansas City (FMNH 21540).

Habitat: During migration may be seen anywhere; in summer in open woodland, often in high densities in riparian woodland with cottonwoods, in woodlots, and in open forest.

Spring: The first migrants appear in early Apr, but peak is not until the end of Apr/ early May. High counts: 43, 8 May 1999, Knox Co. (P. Harrison); 36, 11 May 1996, Holt Co. (DE et al.).

Summer: The Red-headed Woodpecker reaches its highest densities in woodlots and along riparian woodland with large cottonwoods in the Glaciated Plains. The lowest densities are in the Ozarks and the Mississippi Lowlands. As a breeder is has been on a long-term decline in Missouri and surrounding areas. BBS data indicate an annual decline, both long-term (1967-2013) and more recent (2003-2013), of 4.41\%.

Fall: Movement of this species is apparent by the end of Aug, with large numbers seen in a single day during the first half of Sep after the passage of a cold front. By mid-Oct, most migrants have passed through the state. High counts: 684 (3.5 hrs), 10 Sep 2016, Weston Bend (MR); 290+, 2 Sep 1942, Fairfax, Atchison Co. (A. White); 284, in one 
hour, 15 Sep 1884, along Mississippi River, St. Louis (Widmann 1907); 202 (2 hrs), 4 Sep 2011, Weston Bend (MR).

Winter: Depending on mast crop abundance, such as oaks, hickories, and pecans, the abundance of this woodpecker can vary considerably from region to region within a winter and among years (Smith 1986). Some of the highest tallies on North American CBCs regularly occur in Missouri. CBC high counts: 639 (10.4), 18 Dec 2017, Four Rivers; 592 (10.5), 2 Jan 1989, Mingo; 521 (10.0), 17 Dec 2013, Four Rivers; 483 (11.2), 15 Dec 2014, Four Rivers.

\section{Red-bellied Woodpecker (Melanerpes carolinus)}

Status: Common permanent resident.

Documentation: Specimen: male, 22 Apr 1856, St. Joseph (UMMZ 20396).

Habitat: Most abundant in open woodland and forest, but also in lightly wooded areas in towns and cities.

Summer: Based primarily on BBS data and the distribution of woodland, this species is most common in the Ozarks and Ozark Border. It is least common in the Mississippi Lowlands. BBS data indicate there has been an increase in the species throughout the duration of that protocol; for the 2003-2013 period the average annual increase has been $1.49 \%$.

Winter: Given that this species is non-migratory, the relative abundance in the natural divisions is presumed to be the same as other times of year. CBC high counts: 265 (1.6), 17 Dec 2005, Columbia; 238 (4.1), 29 Dec 1957, Weldon Spring; 229 (4.4), 17 Dec 2013, Four Rivers.

Comments: Occasionally, atypical plumaged, female Red-bellied Woodpeckers can be extremely similar to female Golden-fronted Woodpeckers (Melanerpes aurifrons) that have led to extralimital reports of the latter species (Gerber 1986). Indeed, such an event occurred in Missouri, when an apparent, atypical plumaged, female was photographed at a feeder 5-24 Apr 2009, New Franklin, Howard Co. (W., D., and E. Baldridge, P. and D. Porneluzi; fig. 20). One of the diagnostic characters for separating females of these woodpeckers is the pattern of the central pair of rectrices, which are entirely black in female Golden-fronted and mostly white in female Red-bellied (Gerber 1986). Unfortunately, the central rectrices were missing from the New Franklin bird and thus further complicated the original identification (fig. 20). Another stunning example of an atypical plumaged, female Red-bellied Woodpecker is one that frequented feeders from late Jan to mid-Mar 2017 in Clinton Co. (W. Blackledge; fig. 21; note the mostly white central rectrices).

\section{Yellow-bellied Sapsucker (Sphyrapicus varius)}

Status: Uncommon transient; uncommon winter resident in south, rare in north; formerly bred in northeastern corner of the state.

Documentation: Specimen: male, 5 Oct 1887, Hannibal, Marion Co. (SDNHM 520). Habitat: Found in both strictly deciduous forest and in conifers. 


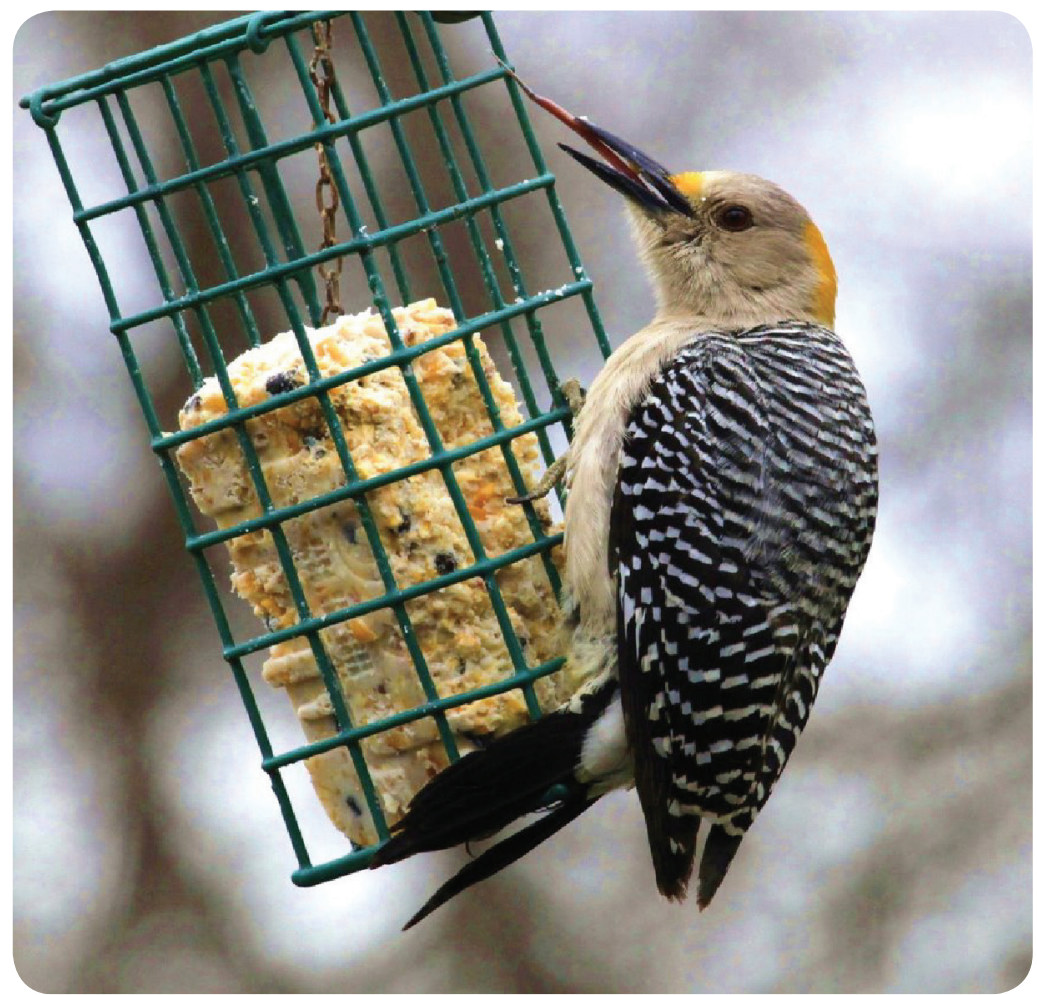

Fig. 20. Aberrant plumaged, female Red-bellied Woodpecker, 5 Apr 2009, New Franklin, Howard County. Photo by Don Baldridge.

Spring: Obvious migrants begin augmenting the winter resident population during Mar, with peak in late Mar/early Apr. Relatively large numbers are seen through the third week of Apr, but by early May few are encountered. High counts: 20, 2 Apr 2017, Tower Grove (T. Bailey); 15, 1 Apr 2015, Tower Grove (PL); 14, 2 Apr 2014, St. Louis (AR, CMc). Latest dates: 1, 29 May 1979, Springfield (fide C. Bonner); female, photos, 24 May 2014, Tower Grove (CM, JM); female, 20-21 May 1997, Pulltite Access, Current R., Shannon Co. (MR, K. Zyskowski, B. Barber).

Summer: Formerly, this sapsucker bred in the Mississippi River floodplain from St. Louis northward (Widmann 1907). Breeding populations have apparently declined in Iowa since about 1900 (Kent and Dinsmore 1996), and there have been few recent Illinois records (Bohlen and Zimmerman 1989). The only summer observation since Widmann (1907) is of a male, 18 Jul 1992, Univ. of Missouri campus, Columbia (G. Perrigo).

Fall: The initial arrivals are seen at the end of the third week of Sep, with a dramatic increase in observations during the last week of Sep. Peak is typically the second 


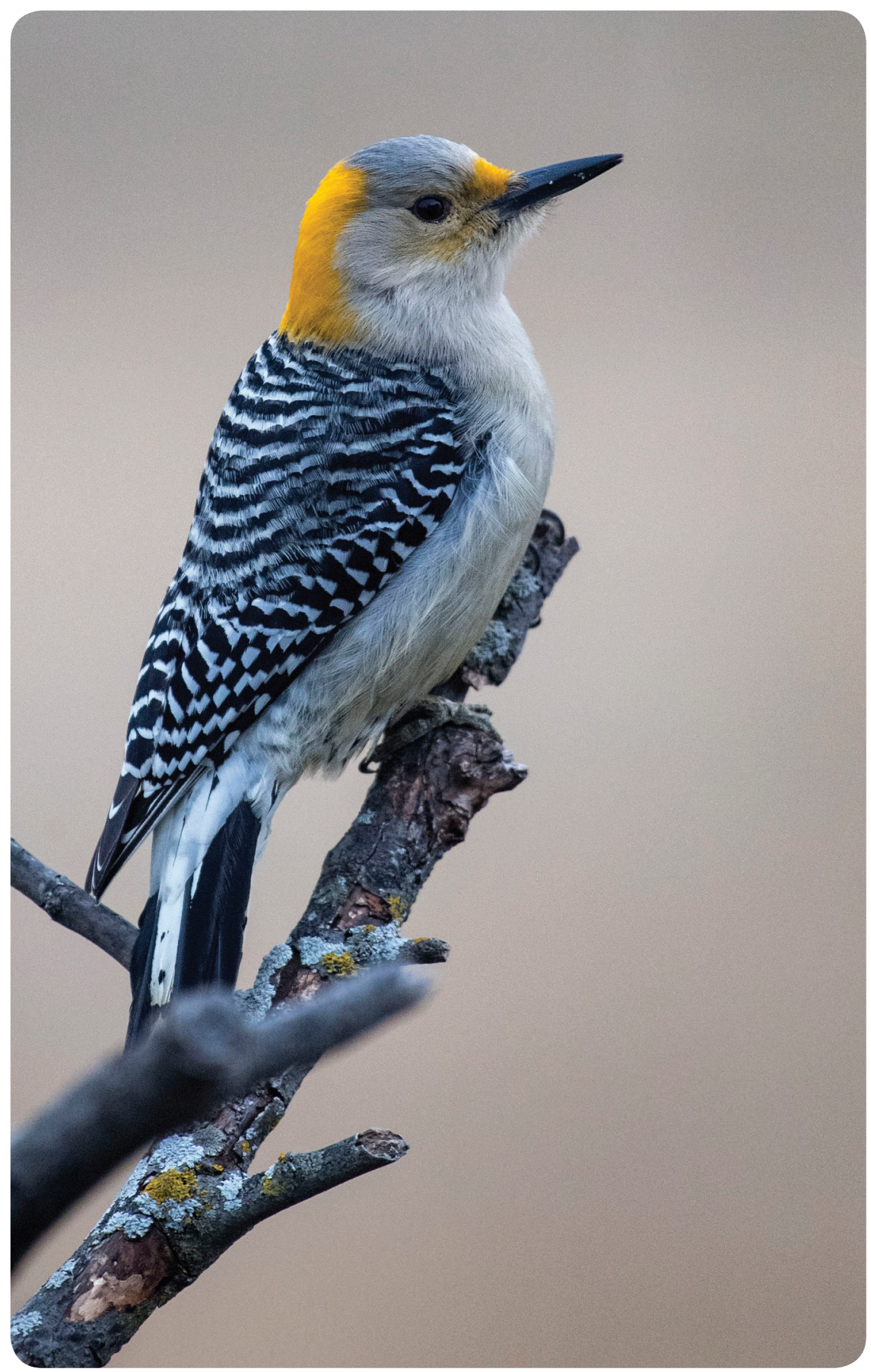

Fig. 21. Aberrant plumaged, female Red-bellied Woodpecker, 31 January 2017, northwest side of Smithville Lake, Clinton County. Photo by William Blackledge. 
week of Oct. High count: 23, 20 Oct 2016, Tower Grove (AR, CMc). Earliest dates: 1, 6 Sep 2014, Platte Co. (AK); ad female, 10 Sep 2015, Rock Bridge SP, Boone Co. (EW); ad male, 12 Sep 1992, Weston Bend (CH); 1, 12 Sep 2010, Three Creeks CA, Boone Co. (RD).

Winter: Based primarily on $\mathrm{CBC}$ data, the highest densities are near the southern border. However, as illustrated by the following Columbia CBC, when there is a large observer effort the species is not uncommon in some winters at that latitude. CBC high counts: 45 (0.6), 3 Jan 2009, Taney Co.; 38 (0.6), 2 Jan 1988, Taney Co.; 35 (0.3); 31 (0.1), 17 Dec 2005, Columbia; 29 (0.4), 27 Dec 2003, Mingo.

Comments: There are two records of presumed hybrids between Yellow-bellied and Red-naped (S. nuchalis) sapsuckers documented for the state: male, photos, 13-17 Apr 1993, Blue Springs, Jackson Co. (M. McKellar et al.; Robbins et al. 2005); male, photos, 22-23 Mar 2012, Tower Grove (BRu). There are a number of reports of hybrids for the Great Plains (Robbins et al. 2005).

\section{Downy Woodpecker (Picoides pubescens)}

Status: Common permanent resident.

Documentation: Specimen: egg set, 18 May 1887, Clay Co. (USNM 482497.4170631).

Habitat: Found in every habitat with trees.

Comments: Because woodpeckers generally vocalize relatively little during the period when BBS is conducted, that technique is poor for determining the relative abundance for this group. The Downy is ubiquitous and much more common than the Hairy in all regions. It is least abundant in the Mississippi Lowlands. Although high counts from $\mathrm{CBC}$ data for this species are directly correlated with the number of participants, the following high counts underscore just how common this woodpecker is: 243 (2.0), 15 Dec 2012, Columbia; 229 (1.2), 14 Dec 2002, Columbia. The highest CBC birds/ pa hour was 2.0 , which has been recorded on several counts, but generally just under one $\mathrm{bird} / \mathrm{pa} \mathrm{hr}$ is recorded.

\section{Hairy Woodpecker (Picoides villosus)}

Status: Uncommon permanent resident.

Documentation: Specimen: egg set, 1 May 1890, Kansas City (FMNH 7346).

Habitat: Prefers more extensive woodland and forest than Downy.

Comments: This woodpecker, while widespread in all forest types, is much less common than the Downy in all regions, and, as with the Downy, the lowest densities are in the Mississippi Lowlands region. CBC high counts: 46 (0.2), 18 Dec 1999, Columbia; 44 (0.2), 18 Dec 2010, Columbia; 44 (0.2), 17 Dec 2011, Columbia. The highest birds/ pa hr for a Missouri CBC is 0.7 . 


\section{Red-cockaded Woodpecker (Picoides borealis)}

Status: Extirpated; formerly a local, uncommon permanent resident in southeastern Ozarks.

Documentation: Specimen; see below.

Habitat: Open forest dominated by shortleaf pine (Pinus echinata).

Comments: In 1907, Woodruff found the species in Shannon and Carter cos., but even then it was predicted it would soon disappear from the state because of the relentless lumber industry. The last colony disappeared shortly after the remaining large stand of shortleaf pine was reduced to a narrow strip along highway 19, south of Round Spring, Shannon Co. in the spring of 1946. Apparently, the last observation at that site was of 5 birds on 16 Jun 1946 (WC). Although the only definite records were from Shannon and Carter cos. (Woodruff 1907, 1908; AMNH 229479-229483), it likely occurred in pine stands prior to the early 1900s in Butler, Reynolds, Ripley, Oregon, Texas, and Wayne counties (Eddleman and Clawson 1987).

The species has suffered severe declines and extirpations throughout its range and has been on the U.S. Fish and Wildlife Service Endangered Species List since 1968.

\section{[Black-backed Woodpecker (Picoides arcticus)]}

Status: Provisional.

Documentation: Single sight record.

Record: The inclusion of this species is based on a seemingly reliable sighting of a male, 9 Apr 1946, in Kansas City (Williamson 1946). Apparently the bird was quite tame, and the observer was able to note the all-black back and yellow "head patch" at a distance of three feet as it fed in an apple tree.

\section{Northern Flicker (Colaptes auratus)}

Status: Common permanent resident.

Documentation: Specimen: male, 20 Mar 1899, Independence (KU 67594).

Habitat: Woodland and forest edge, open areas with scattered trees.

Spring: By mid-Mar obvious migrants are observed, and peak is from the end of Mar through early Apr. High counts: 100 seen flying northeast in ca. 1.5 hrs, 23 Mar 1895, St. Louis (Widmann 1907); 100, on burned prairie, 14 Mar 1998, Taberville Prairie (D. Arney); 80, 19 Mar 2016, Wah'kon-tah Prairie, St. Clair Co. (CBu); 75, 5 Apr 1964, Trimble/Loess Bluffs (FL); 65+, 12 Apr 1975, Bigelow Marsh (MR, DE).

Summer: Based on BBS data, this flicker is about twice as common in the Glaciated Plains as in the Ozarks, Ozark Border, and Osage Plains. It is least common in the heavily-forested part of the Ozarks and the agriculture-dominated Mississippi Lowlands. BBS data indicate a dramatic decline in this woodpecker, $3.73 \% / \mathrm{yr}$ for the period, 2003-2013. 
Fall: By early Sep migrants begin appearing. Peak is in late Sep/early Oct. High counts: 522 (3 hrs), 27 Sep 2017, Weston Bend (MR, JB); 496, during hawk watch, 5 Oct 1983, Forest Park (MP); 100, 25 Sep 2003, Tower Grove (JE).

Winter: $\mathrm{CBC}$ data indicate it is most common in the open areas of the state, with the lowest densities in the heavily-forested part of the Ozarks. CBC high counts: 215 (12.1), 2 Jan 1993, Big Oak Tree; 214 (4.9), 1 Jan 2011, Swan Lake; 197 (2.9), 3 Jan 2004, Weldon Spring.

Comments: The western red-shafted subspecies (C. a. cafer) is a rare migrant and winter resident. It is more prevalent in open areas of the western part of the state. The vast majority (perhaps all?), of the "red-shafted" have proven to be hybrids. Earliest dates for fall "red-shafted": 1, 20 Sep 1968, St. Joseph (FL); 1, 21 Sep 1976, St. Louis (K. Boldt). High counts: 5, 26 Dec 2004, Trimble CBC; 4, 21 Dec 1969, Loess Bluffs CBC. There is only one record after the third week of Apr for this subspecies: 1, 25 May 1971, Busch (K. Boldt, JEC et al.).

Recently, orange to red coloration has been detected in the flight feathers of pure yellow-shafted flickers as a result of foraging on berries of introduced honeysuckle species (Lonicera spp.; Hudon et al. 2017), as also been documented in the terminal tail band in some individuals of Cedar Waxwing. Thus individuals with reddish flight feathers observed out of season, mid-Apr through mid-Sep, should be carefully scrutinized.

\section{Pileated Woodpecker (Dryocopus pileatus)}

Status: Uncommon to common permanent resident in Ozarks and Ozark Border, rare in northern and western Glaciated Plains, Osage Plains, and most of the Mississippi Lowlands.

Documentation: Specimen: male, 5 May 1879, Charleston, Mississippi Co. (MCZ 43411).

Habitat: Usually in mature woodland and forest, especially in bottomlands.

Records: BBA data indicate it is most widespread and common in the Ozarks and Ozark Border. The lowest densities are in the northern and western Glaciated Plains, the Osage Plains, and the Mississippi Lowlands. During the past few decades it has spread and become more common throughout the state, especially in the northwest corner, where the first observations north of the St. Joseph area began in the late 1980s.

A study of 16 sites in eastern, central, and southern Missouri found that this woodpecker was most abundant in mature bottomland forest. An average density of 1.8 birds/ 100 hectares, with a range of 0.5 to 4.1 territories/ 100 hectares, was found across those 16 sites (Renken and Wiggers 1993).

At the time of European settlement, the species occurred statewide, but then with widespread deforestation and hunting the species likely reached population lows in the early 1900s. In what is now Atchison Co., Audubon encountered the species on 7 May 
1843. Widmann (1907) stated that it was most common in the Mississippi Lowlands, an area that is largely denuded now. Apparently it was a regular breeder along the Missouri River bottoms at Kansas City until the early 1890s (Harris 1919b).

CBC high counts: 64 (0.8), 27 Dec 2003, Mingo CBC; 45 (0.9), 22 Dec 2012, Mingo CBC: 45 (0.5), 27 Dec 2014 Taney Co. CBC; 36, 21 Dec 2005, Cuivre River SP (BS).

\section{Ivory-billed Woodpecker (Campephilus principalis)}

Status: Extinct; formerly an uncommon permanent resident in the Mississippi Lowlands north to at least St. Louis.

Documentation: Specimen: female, 8 May 1886, near Forest Park (Denven Museum of Natural History 27343).

Habitat: Mature bottomland and swamp forest.

Comments: This magnificent woodpecker was still uncommon in the 1820s along the Mississippi River bottomland at least north to the mouth of the Missouri River (Hasbrouck 1891). The last record for the state was of a male that was shot 8 miles southwest of Morley, Scott Co., on 8 Nov 1895 (Widmann 1907). The disappearance of this species in the state resulted from logging of the southeastern lowlands and hunting.

Reports that the species existed in Arkansas in 2004 and Florida in 2005 are erroneous (Jackson 2006, Sibley et al. 2006, Robbins 2007), as the last definite record was in Apr 1944 in northeastern Louisiana.

\section{Order Falconiformes Family Falconidae: falcons}

\section{Crested Caracara (Caracara cheriway)}

Status: Accidental transient.

Documentation: Photograph; fig. 22.

Habitat: Open country.

Records: Two records. An adult was photographed 7 Dec 2015, near Neosho, Newton Co. (T and S. Cook, J. and B. Wylie, J. Hughes). Apparently the bird was present about two weeks prior to the day it was photographed. Another bird was photographed and seen to enter Pemiscot Co., Missouri from a Mississippi River sandbar in Tennessee on 20 Sep 2017 (M. Greene, M. Todd). The number of post-breeding wanderers has increased dramatically in the past decade, with the Texas population being the most likely source of birds appearing in the interior of the United States (Brinkley 2016).

\section{American Kestrel (Falco sparverius)}

Status: Common winter resident; common summer resident except in the Ozarks where it is uncommon.

Documentation: Specimen: male, 7 May 1879, Charleston, Mississippi Co. (MCZ 43132).

Habitat: Open country, but also in towns and cities. 


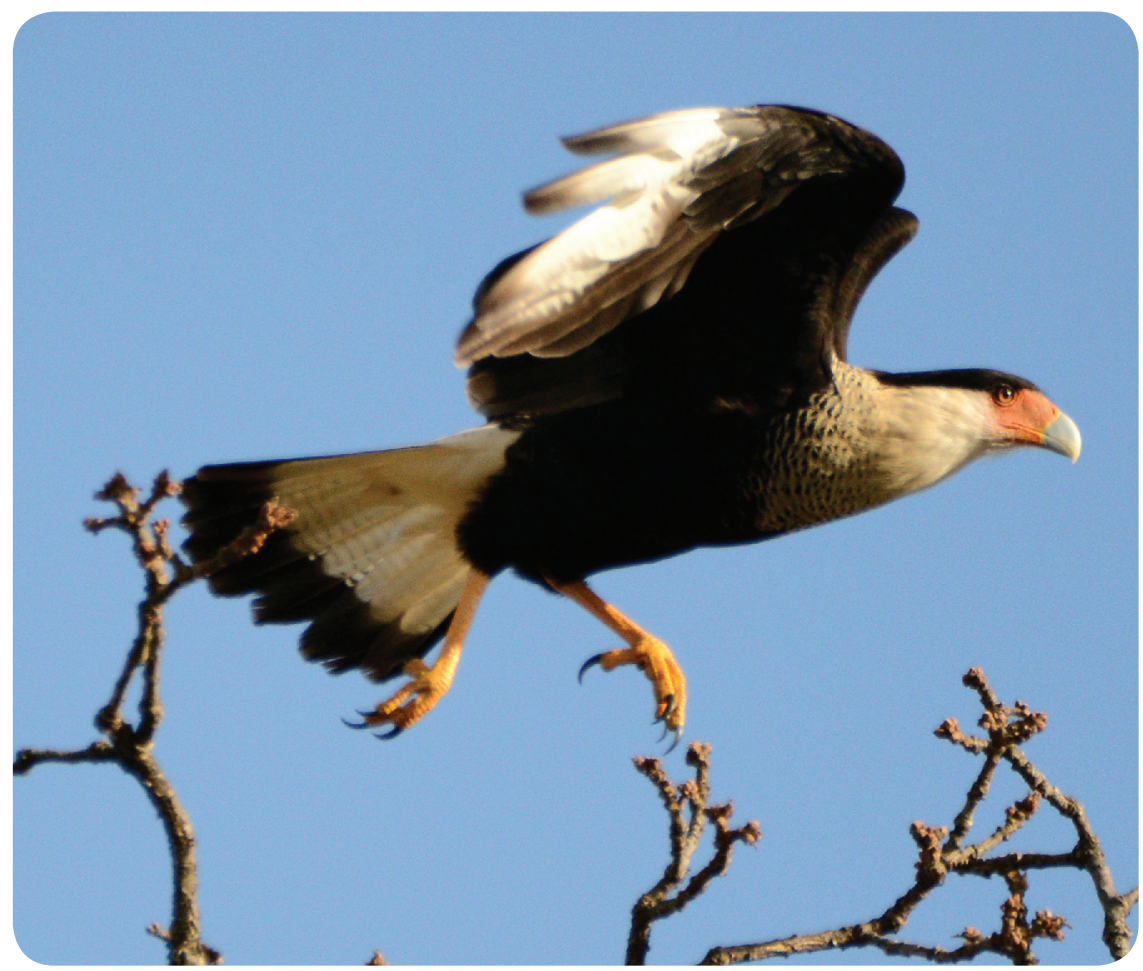

Fig. 22. The first Missouri record of Crested Caracara, 7 December 2015, near Neosho, Newton County. Photo by Becky Wylie.

Spring: Migrants begin augmenting the winter population in late Feb/early Mar with peak in late Mar/early Apr. High counts: 44, 17 Apr 1983, St. Joseph/Loess Bluffs area, ca. 80 miles (FL); 65, 22 Mar 1971, St. Joseph/Unionville, ca. 280 miles (FL).

Summer: The kestrel is much less common at this season than at any other. Based on BBS data it is most prevalent in the Mississippi Lowlands and least common in the Ozarks. High count: 15, 11 Jul 1986, St. Louis Co. (RG).

Fall: Migration begins in late Aug, with a gradual increase in numbers reaching a peak at the very end of Sep/early Oct. By early Nov much fewer are observed. High counts: 58, 4-5 Oct 1986, Lake of the Ozarks SP (m. ob.); 15, within 0.5 mile, 30 Sep 1971, near Rosendale, Andrew Co. (JH).

Winter: This falcon is more common at this season than in summer, but the largest numbers are still found in the Mississippi Lowlands and the fewest are in the Ozarks and Ozark Border. At least in the Glaciated, Ozark Border, and Osage Plains regions (data are not available for other regions), males outnumber females during this season. For example, 14 (13 males, 1 undetermined), 28 Dec 2011, Alexandria to Lucerne, 
97.5 miles, (MR, JB); 18 (14 males, 2 females, 2 undetermined), 29 Dec 2011, from near Eaglesville south to Cameron, 135 miles (MR, JB); 11 (10 males, 1 female), 5 Feb 2016, primarily Boone Co., 117 miles (BJ, S. Kendrick); 16 (13 males, 3 females), 6 Feb 2016, western Barton, western Vernon, and southern Bates cos., 76 miles (MR, JB). CBC high counts: 86 (1.5), 17 Dec 1995, North Cass Co. CBC; 76 (1.5), 17 Dec 1994, St. Joseph CBC; 75 (0.8), 15 Dec 1990, Springfield; 72 (0.7), 18 Dec 1999, Springfield CBC.

\section{Merlin (Falco columbarius)}

Status: Uncommon transient; rare winter resident.

Documentation: Specimen: subspecies richardsonii, 5 Sep 2002, Parkville, Platte Co. (KU 94617; Robbins 2004).

Habitat: Wide range of open habitats at all seasons.

Spring: Migrants begin to supplement wintering birds as early as late Feb, but peak is not until early Apr, with the species regularly seen in small numbers through midMay. Latest dates: 3 sightings for 18 May; 1 for 17 May; 3 sightings for 14 May. High counts: 7 (photos; 3 richardsonii, 2 nominate subspecies, 2 undetermined), of wintering birds that remained into this season, 3 Mar 2017, Penn-Sylvania Prairie, Dade Co. (R. Locke er al.); other high counts of 4 birds/day.

Fall: A few individuals regularly appear by the end of Aug, with numbers increasing through Sep. The nominate (taiga) subspecies dominates numerically during peak at the end of Sep/early Oct. The status of the prairie subspecies richardsonii is still being worked out (Robbins 2004), but records for that subspecies span the entire period. Merlin numbers decrease though Oct and Nov. Earliest dates: imm or female, probable richardsonii, 3 Aug 2004, Mud Lake, Buchanan Co. (LL, SK, T. Vawter); imm richardsonii, 20 Aug 2012, Loess Bluffs (DW). High counts, both at Lake of the Ozarks SP: 9, 4-5 Oct 1986 (m. ob.); 4, 30 Sep 1978 (RA et al.).

Winter: A regular, low-density resident, with the largest concentrations seen in the evening at native prairies, where they forage on blackbirds coming to roost (Robbins 2004). The prairie subspecies richardsonii is much more common in the western half of the state, but it has been recorded in the east, e.g., female, 1 Jan 2004, Orchard Farm CBC, St. Charles Co. (RK et al.). The prairie subspecies outnumbers nominate subspecies in areas such as Taberville Prairie and Loess Bluffs, e.g., 4 (3 richardsonii, 1 nominate), 29 Dec 2003, Taberville Prairie (Robbins 2004). Other high counts: 5 (4 richardsonii, 1 nominate), 16 Dec 2010, Loess Bluffs CBC; 4 (3 richardsonii, 1 nominate), 17 Dec 2008, Loess Bluffs CBC; 4 (3 richardsonii, 1 nominate), 14 Dec 2009, Loess Bluffs CBC.

\section{Gyrfalcon (Falco rusticolus)}

Status: Casual transient and winter resident.

Documentation: Photograph; fig. 23.

Habitat: Open country. 
Spring: A single record: ad, white morph, 9 Mar 1996, Fountain Grove (MB, J. Rambo, et al.).

Fall: Single record: imm, captured by falconer, 22 Nov 2000, Holt Co. (D. Scarbrough; photos in Easterla and Scarbrough 2001).

Winter: Only three documented records: 1, 18 Dec 1977, Loess Bluffs (Barksdale and Rowlett 1981, see comments therein on earlier, unsubstantiated sight observations); ad gray morph, 26 Dec 1994, Mark Twain SP, Monroe Co. (PM); imm, gray morph, photos, 26 Feb 2005, Chariton Co. (N. and K. March).

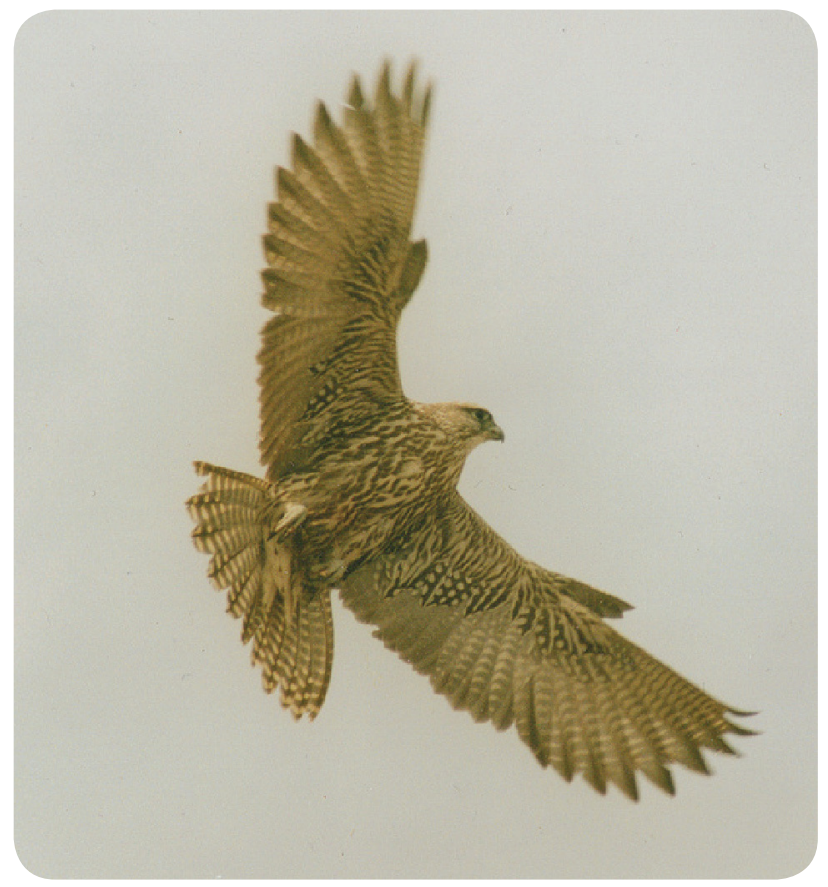

Fig. 23. An immature, gray morph Gyrfalcon in Chariton County on 26 February 2005. Photo by Nicholas March.

\section{Peregrine Falcon (Falco peregrinus)}

Status: Uncommon transient; very rare winter resident, except for hacked birds in cities. Documentation: Specimen: imm, 21 Sep 1964, Independence (CMSU 172).

Habitat: Most often seen in migration at shorebird concentrations, but can be seen in virtually any open habitat, including city buildings.

Spring: The first migrants appear at the beginning of Mar, but it is seen in small numbers until late Apr/early May, when multiple individuals can be seen at the same time foraging on shorebirds and small waterfowl (teal). Migrants are quite rare by the end of May. Latest date of migrant: 1, 31 May 1971, Creve Coeur Lake (P. Snetsinger). 
High counts: 6, 30 Apr 2017, Palmetto area, Greene Co. (JB1, GSa); 6, 4 May 2013, Loess Bluffs (DE, TE, PK; Easterla 2013); multiple reports of 3 and 4 birds observed simultaneously at shorebird concentrations in early May at Loess Bluffs.

Summer: There are no Jun records of late migrants. There are a number of sightings of presumed migrants, away from cities where the species has been reintroduced, for the entire month of Jul across several decades. Beginning in 1991, birds were hacked at tall buildings in downtown Kansas City and St. Louis. By at least 2000, birds were breeding at those sites.

Formerly, this species bred along the cliffs of the Missouri and Mississippi Rivers. Widmann (1907) accumulated information that indicated that "many" nested along the cliffs up until the 1850 s, but by 1880 and the early 1890s only a few pairs were known to breed. An adult male mounted specimen that was taken about 1885 along the Missouri River bluffs between Portland and Bluffton, Callaway Co., resides in the MU collection. An adult observed during Jul 1911 along a cliff face on the Meramec River, Crawford Co., may represent one of the last breeding records in the wild for the state (Baldwin 1911). This population represented the southern breeding distribution of the continental subspecies anatum, which became extirpated from North America south of the arctic by the overuse of pesticides (including DDT) during the 1950s through early 1970s. Reintroduced eastern North American populations involved individuals bred in captivity of seven subspecies from four continents (Tordoff and Redig 2001). The majority of migrants seen in Missouri involve individuals of the tundra breeding population, tundrius.

Fall: Presumed migrants from the arctic population, tundrius, begin to reappear in Aug. Numbers increase with a peak in late Sep/early Oct. Earliest dates of birds away from potential nest sites: three observations for 2 Aug. High count: 18 (9 hrs), 7 Oct 2017, Eagle Bluffs (PM, BJ, E. Wood, J. Besser; McKenzie et al. 2017).

Winter: This is a very low-density winter resident, as it is much less common than Merlin and Prairie Falcon during this period, especially in the western half of the state. Birds are most frequently observed at introduced breeding sites in Kansas City and St. Louis; however, not all of these birds are from the reintroduced population, as a banded female from Yukon wintered in downtown Kansas City for four consecutive winters in the late 1990s (D. Stinnet).

\section{Prairie Falcon (Falco mexicanus)}

Status: Rare transient and winter resident; provisional summer resident.

Documentation: Photograph: 28 Nov 1978, south of Mound City, Holt Co. (B. Heck; Robbins and Easterla 1992).

Habitat: Open areas, pastures, prairies and cropland.

Spring: At least some winter residents begin leaving by the end of Feb/early Mar, but birds are regularly seen through Mar. Latest dates: 1, 14 May 1994, St. Charles Co. 
(RK, JVB, CA); 1, 5 May 1996, Diamond Grove Prairie CA (MB); 1, 22 Apr 2000, Tower Grove (CA, K. Lannert).

Summer: Surprisingly, there is an old breeding report of a nest with two eggs in a tree near Maryville, Nodaway County, on 28 Apr 1880 (Goss 1891, Widmann 1907). Given that the eggs have not been located, the atypical nest site, and the distance from the nearest breeding population (western Nebraska; Sharpe et al. 2001), this record is treated as provisional.

Fall: The first migrants appear in late Sep, with an obvious peak in late Oct/early Nov. Almost all records during this period are of single individuals and the majority are from the western half of the state. Earliest dates: 1, 23 Sep 1983, northwest of Maryville (DE, TE); 1, 23 Sep 2011, Bob Brown (D. Morris); 1, 27 Sep 1995, near Osborn, DeKalb Co. (LG).

Winter: As in all seasons, this falcon is encountered more often in the western part of the state, but there are a number of records for the easternmost counties. Multiple individuals have been seen at the same time foraging on blackbirds coming to roost in the evening at prairies. High counts: several observations of three individuals observed simultaneously at prairies in west-central part of the state (MR).

Comments: There was a dramatic increase in observations across the state beginning in the mid-1970s (see comments in Robbins and Easterla 1992). A similar increase was noted in Iowa beginning in the early 1980s (Kent and Dinsmore 1996).

\section{Order Psittaciformes Family Psittacidae: parrot}

\section{Carolina Parakeet (Conuropsis carolinensis)}

Status: Extinct; formerly common permanent resident.

Documentation: Specimen: 4 May 1843, along Missouri River, below St. Joseph (J. Audubon and E. Harris; ANSP 136786; see below).

Habitat: Apparently a wide variety of habitats, but most prevalent in river-bottom forest.

Comments: McKinley (1960c) provided an overview of the status of the species in the state; highlights are presented below. Most of the information for this parakeet is from people who navigated the Mississippi and Missouri rivers in the 1800s; those accounts indicated that it was common in forest along the rivers. The few remarks about the species away from those rivers indicate that it was widespread and common in at least the forested part of the state. It was still common through the $1850 \mathrm{~s}$, but there were very few records thereafter (Widmann 1907). The last parakeet collected in Missouri may have been one taken by J. Bryant in 1894 in Kansas City (Harris 1919b). The specimen had no additional data and has since been stolen (McKinley 1960c). The following represent the last reports for the state: 1, 18 Jul 1905, Notch, Stone Co. (T. Powell; 
Widmann 1907); 1, present for several weeks in 1912 along the Missouri River near Courtney, Jackson Co. (B. Bush; Harris 1919b).

Audubon and Harris "shot a number of Parroquets today" along the "Missouri R. below blacksnake Hills" on 4 May 1843 (Street 1948; also see Cooke 1910). It is unclear, and really unimportant, which side of the river they were on when the specimens were collected between Fort Leavenworth, Kansas, and St. Joseph, Missouri, on that day. McKinley (1964) mentions another extant specimen, deposited at St. Benedict's College, Atchison, Kansas, that was purported to have been taken in Platte Co., Missouri, around the turn of the century. Finally, there is a specimen in the Central Methodist College (CMC 689) that was taken in Franklin Co. in 1875.

\section{Order Passeriformes}

\section{Family Tyrannidae: flycatchers}

\section{Olive-sided Flycatcher (Contopus cooperi)}

Status: Uncommon transient.

Documentation: Specimen: female, 3 Sep 1933, near Sarcoxie, Jasper Co. (KU 21174).

Habitat: Typically seen in the top of leafless tree branches in woodland and forest edge.

Spring: Detected much less frequently at this season than in fall. Usually this late migrant is not seen until the second week of May with peak during the last ten days of May. Late migrants are routinely seen through the first week of Jun. Earliest dates: 1, 19 Apr 1992, Taney Co. (PMa, D. Rising). High counts: 8, 19 May 2016, Ben Cash (TJ); several observations of 4/day. Latest dates: 1, 22 Jun 1989, Higginsville, Lafayette Co. (F. Young); 1, 13 Jun 2007, Springfield (D. Rising).

Fall: Usually the first southbound birds are not seen until the last week of Jul. Peak is in late Aug/early Sep. By late Sep virtually all have passed through. Earliest dates: 1, 5 Jul 2004, Henning CA (B. Ball et al); 1, 11 Jul 1987, Hermitage, Hickory Co. (H. John); 1, 19 Jul 2001, Swan Lake (H. Lambert-Doherty). High counts: 9, 25 Aug 2016, Dunklin Co. (TJ); 6, 9 Sep 2008, Brickyard Hill (TR); several observations of 4/day in late Aug/ early Sep. Latest dates: 1, 11-12 Oct 1974, Brickyard Hill (DE, MR); 1, 4 Oct 2001, Watkins Mill SP, Clay Co. (KM); 1, 3 Oct 2012, St. Louis Co. (J. Solodar).

\section{Western Wood-Pewee (Contopus sordidulus)}

Status: Accidental summer visitant.

Documentation: Photograph and audio recordings: see below.

Record: A single record: male, 10 Jun - 3 Jul 2012, Lake Lotawana, Jackson Co. (CH, N. Hobbs et al.; ML 516400). 


\section{Eastern Wood-Pewee (Contopus virens)}

Status: Common summer resident.

Documentation: Specimen: female, 15 May 1879, Charleston, Mississippi Co. (MCZ 43668).

Habitat: Woodland and forest edge.

Spring: The first arrivals are not until mid-Apr with peak in mid-May. Earliest dates: 1, 17 Apr 2000, Castlewood SP, St. Louis Co. (MBr); 1, photos, 17 Apr 2014, near Fremont, Carter Co. (J. Kutylowski). High counts: 49, 9 May 2009, Mingo (V. Harp); 28, 16 May 2015, Babler SP (JM, CM).

Summer: Although it is widespread and common across the entire state in areas with open woodland and forest, it is most common in the Ozarks and Ozark Border and least widespread in the Mississippi Lowlands.

Fall: Migrants are obvious from at least mid-Aug, with peak during the first half of Sep. By the beginning of the second week of Oct it is scarce. High count during migration:

37, 9 Sep 2007, Otter Slough (CB); 15, 25 Sep 2003, Tower Grove (JE). Latest dates: 1, 11 Nov 1987, Busch (BRe, BL); 1, 27 Oct 2007, Columbia Bottom (BR).

\section{Yellow-bellied Flycatcher (Empidonax flaviventris)}

Status: Uncommon transient in east, rare in west.

Documentation: Specimen: male, 16 May 1907, Grandin, Carter Co. (AMNH 229528).

Habitat: Typically in moist, shady areas in the lower story of woodland and forest; often encountered in conifers.

Spring: This inconspicuous flycatcher appears to be more common in the eastern half of the state. It is rarely encountered before the second week of May, with peak during the beginning of the fourth week of May. It is regularly seen through the first week of Jun. Earliest dates: male, 2 May 1883, St. Louis Co. (CAS 35328); 1, heard calling and seen, 3 May 2008, near Providence, Boone Co. (PM); two records for 6 May. High counts: 6, 26 May 2008, Columbia Bottom (BR, RM); 5, 30 May 2005, Rock Bridge SP (PM); other counts of 4/day in late May, including one in extreme west: 4, 27 May 1973, Trimble (S. Patti). Latest dates: 1, 16 Jun 2010, McClure CA, Mercer Co. (EW); 1, 8 Jun 2007, Tower Grove (JE).

Fall: There are very few records prior to the third week of Aug. It is regularly seen into early Oct, but it is accidental by mid-Oct. Earliest dates: 1, 1 Aug 1970, Maryville (MR); 1, netted, 5 Aug 2012, Andrew Co. (N. Komar); 2, 9 Aug 1993, Tower Grove (BR). High counts: 4, 30 Aug 1992, Schell-Osage (RF); all other high counts are of two individuals. Latest dates: 1, photos, 14-25 Oct 2012, Tower Grove (AR, CMc et al.); 1, 13 Oct 2017, Tower Grove (AR, CMc); 1, 11 Oct 1973, Busch (P. Snetsinger, JEC). 


\section{Acadian Flycatcher (Empidonax virescens)}

Status: Common summer resident in Ozarks and Ozark Border, uncommon to locally common in the remaining regions of the state.

Documentation: Specimen: male, 9 May 1879, Charleston, Mississippi Co. (MCZ 43698).

Habitat: Prefers moist, shady woodland and forest in riparian areas and swamps.

Spring: Typically not seen until the very end of Apr in the south with peak in midMay. Earliest dates: several records for 22-23 Apr in the southern part of the state. High counts: 60+, 20 May 1978, along 13-mile stretch of Niangua River, Dallas Co. (MR, FL); see Table 6.

Summer: Despite the Mississippi Lowlands having been almost entirely deforested by the early 1900s, today the highest densities are found in remnant, swampy forest there, e.g., it is abundant at Mingo and along rivers in this region (see below). One can only imagine how abundant this flycatcher must have once been in that region and in floodplain forest along the Mississippi and Missouri Rivers.

It is common along streams and rivers in the Ozarks and Ozark Border (Table 6). It is least widespread and more local in the Glaciated and Osage plains regions, where riparian woodland and forest is spotty in distribution; but even there, relatively high densities are found in prime habitat (see below). High counts: 130 (10.5), 2 Jun 1999, Marmaton River, Vernon Co. (Table 6); 110 (9.6), 1 Jun 2005, Castor River, Bollinger Co. (Table 6); 72 (13.3), 4 Jun 2005, lower Black River (Table 6); 47, 9 Jun 2011, Mingo (CB).

Fall: Most apparently leave in Aug, but birds are routinely recorded in small numbers until mid-Sep, e.g., 6, 15 Sep 1994, near Blairstown, Henry Co. (MR). By the last few days of Sep it is very rare, and there is no confirmed Oct record. Latest dates: 1, $30 \mathrm{Sep}$ 2013, Dunklin Co. (TJ); three observations for 28 Sep.

\section{Alder Flycatcher (Empidonax alnorum)}

Status: Common transient in west, uncommon in east.

Documentation: Specimen: male, 26 May 1985, 10 miles north of Maryville (ANSP 178011).

Habitat: Most frequently encountered in willows in riparian areas, but also in hedgerows, thickets, and edge of woodland away from water.

Spring: This is one of the latest migrants, with the first individuals typically not appearing until the second week of May. Peak is at the end of the third week or the beginning of the fourth week of May. Relatively large numbers may be seen through the first week of Jun, and it is routinely observed into the second week. Earliest dates: 1, 2 May 2013, Eagle Bluffs (PM); three observations for 3 May across three different years in central. High counts, in west: 41, along 16.5 mile stretch of Nodaway River, 2 Jun 1995 (MR, D. Mead, K. Zyskowski); 32, 23 May 2013, Weston Bend (MR); in 
east: 8, 19 May 2014, Ben Cash (TJ); 5, 28 May 2011, Weldon Spring (MT). Latest dates: 1, 12 Jun 1993, BBS route, Lewis Co. (H. Ward); 1, 10 Jun 1994, Jefferson City (BJ, J. Wilson, J. Rathert); 1, 10 Jun 2007, BBS route, Pike Co (JM).

Fall: The first individuals are detected during the second week of Aug, with peak from the middle to the third week of Aug. After early Sep, numbers are greatly reduced, and there is only one definite Oct record (see below). Earliest dates: 4, 4 Aug 2006, Bob Brown and Dupree CA, Holt and Buchanan cos., respectively (MR); 4, 6 Aug 2010, Bob Brown (MR). High counts, both at Bob Brown by MR: 16, 15 Aug 2006; 11, 11 Aug 2005. Latest dates: 1, 3 October 2014, St. Joseph (KU 123589); female, 29 September 2002, St. Joseph (KU 94626); identifications confirmed with genetic data.

\section{Willow Flycatcher (Empidonax traillii)}

Status: Uncommon summer resident.

Documentation: Specimen: male, 26 May 1986, Bigelow Marsh (ANSP 178064).

Habitat: Breeds in willow stands in riparian areas, but also found in hedgerows, thickets, and edge of woodland away from water during migration.

Spring: This flycatcher arrives about the same time as the Alder, typically in early May. Peak is during the third week of May. Earliest dates: four observations for 1 May. High counts, both along 16.5 miles along Nodaway River (Robbins et al. 1992, 1993): 22, 26 May 1993; 14, 22 May 1992.

Summer: An inconspicuous, locally uncommon breeder in willow stands statewide, although much of its habitat is inaccessible. Densities are lowest in the Ozarks and Ozark Border. Only a single bird was recorded in 263.6 miles (each segment of river tallied only once even though some sections were run multiple years) of river-based surveys in the Ozarks (Table 6); however, a few were recorded in the Ozarks during the BBA (Jacobs and Wilson 1997). High counts: all counts along 16.5 miles of Nodaway River; some may have been migrants, although all were singing: 22, 26 May 1993 (Robbins et al. 1993); 14, 22 May 1992 (Robbins et al. 1992); 13, 26 May 1994 (MR, D. Mead, DE); 12, 2 Jun 1995 (MR, D. Mead, K. Zyskowski).

Fall: Most observations for this period are of breeding birds that are still on territory until early Aug. Interestingly, territorial birds often leave the same night that Alders arrive, often associated with mild cold fronts in early Aug (MR, data from Bob Brown). Small numbers are recorded through mid-Sep, but definite observations after then are lacking.

\section{Least Flycatcher (Empidonax minimus)}

Status: Common transient; accidental summer resident.

Documentation: Specimen: male, 23 May 1879, Charleston, Mississippi Co. (MCZ 47245).

Habitat: A wide variety of edge habitats during migration, ranging from hedgerows and riparian vegetation to suburban backyards. Breeds in hedgerows and edge of scrubby woodland. 
Spring: This is the most common Empidonax during migration; it typically arrives in late Apr, almost two weeks before all but the Acadian Flycatcher. Peak is in mid-May with individuals routinely seen through the first week of Jun. Earliest dates: 1, photos, 16 Apr 2014, Hornersvillle Swamp, Dunklin Co. (TJ); 1, 21 Apr 1964, St. Joseph (FL); 1, 21 Apr 2014, Eagle Bluffs (PM). High counts: 45, 13 May 1995, Weston Bend (CH); 37, 11 May 1996, Longview Lake, Jackson Co. (MB); 35+, 14 May 2000, Weston Bend (MR). See Summer for late migrants.

Summer: There are at least three documented nesting records, all in the northern half of the state. However, this inconspicuous flycatcher is undoubtedly overlooked at this season. The breeding records: nest with 3 eggs, 16 Jun 1891, Jackson Co. (Harris 1919b); nest, 27 Jun - 5 July 1992, near Americas, Montgomery Co. (McKenzie and Jacobs 1992); pair building nest that was later abandoned, photos, 4-5 Jun 1999, near Clifton Hill, Randolph Co. (C. Smith). Intriguingly, a singing bird was present 29 Jun - 9 Jul 2001, Swan Lake (H. Lambert-Doherty), and another singing bird was recorded on a Sullivan Co. BBS route on 11 Jun 1993 (S. Hein). A late migrant that was not breeding (small gonads): 11 Jun 1965, along Current River, near Eminence, Shannon Co. (DE; KU 118893). There are at least four nesting records for Iowa (Kent and Dinsmore 1996).

Fall: Much less conspicuous in fall than in spring. Returning birds are detected as early as mid-Jul. Peak is in Aug, but the species is frequently observed through the second week of Sep. It is rare by late Sep, but there are several records for the first week of Oct. Earliest dates: 1, banded and photographed, 15 Jul 2010, Fort Leonard Wood, Pulaski Co. (M. McCloy); 1, 16 Jul 1996, near Aldrich (JHy); 2, 17 Jul 2001, Hamburg Bend CA (LL, SK). Latest dates: 1, 19 Oct 2013, Big Spring, Carter Co. (MR); 1, 11 Oct 2014, Ritter Springs Park, Greene Co. (DB1); 1, 11 Oct 2016, Red Bridge Road, Christian Co. (M. Linz).

Comments: There is one very late observation of a bird thought to be a Least Flycatcher, but the identification was not confirmed: 1, 7 Dec 2010, Pershing SP.

\section{Eastern Phoebe (Sayornis phoebe)}

Status: Common summer resident, except in the Mississippi Lowlands where it is rare; rare winter resident in south, casual winter visitant in north.

Documentation: Specimen: egg set, 19 Apr 1881, St. Louis (FMNH 9252).

Habitat: Usually associated with water. Nests are placed in cliff faces, under bridges, in abandoned buildings, and at cave entrances.

Spring: Migrants begin augmenting wintering birds in the south by early Mar and usually a few days later in the north. Peak is in early to mid-Apr. High counts: 34, 5 Apr 2008, Forest Park (C. Ferree et al.); 30, 30 Mar 2010, Grand Gulf SP, Oregon Co. (K. Burciaga). 
Summer: All data sets indicate it is most common along streams and rivers in the Ozark and Ozark Border and least abundant and most sparsely distributed in the Mississippi Lowlands region. River-based surveys indicate it is most abundant along Ozark rivers that have eroded, rock-based cliffs for nesting, e.g., high counts, all by MR, B. Benz, and A. Nyari: 31 (3.3), 31 May 2002, Jack's Fork River; 30 (3.1), 22 May 2003, Pulltite, Current River; 30 (2.8), 29 May 2003, Logyard, Current River.

Fall: Birds are seen away from nesting areas beginning in late Aug, but peak does not occur until the latter half of Sep. It remains common through mid-Oct. High counts: 34, 13 Oct 2015, Ben Cash (TJ); 30, 9 Sep 2007, Riverlands (DR).

Winter: There has been a dramatic increase in numbers wintering in the state since the mid-1990s. It is now routinely found wintering across the southern two tiers of counties, although it is most common in the southeast. There are now a number of records of birds lingering into the early part of this period in the north. High counts, all on Mingo CBCs: 39 (0.4), 14 Dec 2017; 29 (0.6), 22 Dec 2012; 25 (0.4), 20 Dec 2008.

\section{Say's Phoebe (Sayornis saya)}

Status: Rare transient and winter visitant/resident.

Documentation: Specimen: imm, 2-3 Dec 1983, Maryville SL (KU 117956; photo in Robbins and Easterla 1992).

Habitat: Open areas; often seen perched on fences.

Spring: There are the following observations of single individuals: photos, 17 Mar -1 Apr 2012, Capital View Access, Cole Co. (B. Clark, KA, BJ, PM, EW et al.); photos, 5 Apr 2015, Dunklin Co. (TJ); photos, 21 Apr 2013, Loess Bluffs (D. Grisson, C. Kline, C. Ross); 6 May 1984, Loess Bluffs (B. Clark); photo, 20 Feb - 15 Mar 2016, Willow Springs (D. and S. White).

Fall: In addition to the above specimen record there are at least eight records of single birds that span from early Sep through the end of the period. All of these are from the western half of the state. Earliest date: photos, 6 Sep 2004, Chillicothe (M. Carlton, SK). The 27 Sep 1981, Washington Co. record in Robbins and Easterla (1992) has been retracted.

Winter: There are the following records, all of single individuals: 28 Dec 1952, Busch (E. Atkins et al.); photos, 9-28 Dec 1994, Schell-Osage (E. Johnson, L. Abraham); photos, 14 Dec 2002, Four Rivers CBC (MR, RM); 26 Dec - 1 Jan 2011-2, Swan Lake (SK); photos, 1-9 Jan 2013, Elsberry, Lincoln Co. (JU et al.); photos, 24 Jan - 6 Feb 2016, Perry Co. (JE, BE, R. Francis et al.); photos, 15-17 Jan 2017, near Ash Grove, Greene Co. (DB1, B. Blevins); photos, 9-13 Jan 2018, northeast of Lamar, Barton Co. (D. and S. Martin et al.).

\section{Vermilion Flycatcher (Pyrocephalus rubinus)}

Status: Casual transient and accidental winter resident. 
Documentation: Specimen: imm male, 13 Nov 1967, Busch (Easterla and Anderson 1969; KU 118846).

Habitat: Open areas; often associated with water such as ponds and lakes, where it typically perches atop small trees and bushes.

Spring: There are three records for this season: male, 13 Mar 1955, Gasconade River, near Hartville, Wright Co. (H. Hedges, O. Hawksley); 1, 5 May 1958, Forest Hill Cemetery, Jackson Co. (Tatum et al.); and ad male, photos, 2 May 2013, Cass Co. (C. Carr, B. Davis).

Fall: Five records from Sep through mid-Nov as follows: 1, Sep 1958, Portageville, New Madrid Co. (C. Moody); male, 28 Sep 1972, Busch (m. ob.); 4 (3 females, 1 male; females disappeared after a few days, male stayed until 13 Nov), 30 Sep - 13 Nov 1967, Busch (M. Schaeffer et al.; Easterla and Anderson 1969); ad male, 27 Oct 1945, Pleasant Hill, Cass Co. (A. Shirling); imm male, 11-23 Nov 1952, Busch (A. Bennitt).

Winter: Single record: male, photos, 19 Dec - 11 Jan 2011-2, Perry Co. (N. Thompson et al.).

\section{Great Crested Flycatcher (Myiarchus crinitus)}

Status: Common summer resident.

Documentation: Specimen: male, 7 May 1879, Charleston, Mississippi Co. (MCZ 43609).

Habitat: Most common in woodland and forest clearings and edge, but also in parks and other relatively open areas with trees.

Spring: The first arrivals in the south appear by mid-Apr with peak in mid-May. Earliest dates: 2, 5 Apr 2011, Holly Ridge CA, Stoddard Co. (CB); 1, 7 Apr 1977, Big Oak Tree (JHa); 3, 10 Apr 2011, Wallace SP (KM).

Summer: Most common in the Ozarks and Ozark Border region and least common in the Mississippi Lowlands region. BBS data indicate a $1.44 \% / y r$ decline for the 20032013 period.

Fall: Birds begin leaving the state by the latter half of Aug. It is still common through mid-Sep, but it is rare by the end of that month. Latest dates: 1, 13 Nov 1999, Weston Bend (RM); 1, 6 Nov 1965, Little Dixie Lake, Callaway Co. (J. Roller); 1, 15 Oct 1971, Columbia (L. and J. Falch).

Comments: Any Myiarchus observed after early Oct should be carefully scrutinized and photographed, as there is a good possibility that it might be Ash-throated Flycatcher (M. cinerascens). 


\section{Tropical Kingbird (Tyrannus melancholicus)}

Status: Accidental transient.

Documentation: Photos and audio recordings; see below.

Habitat: Open areas, where it often perches in the tops of bushes and trees.

Records: A single record of a bird that was photographed and audio recorded, 30 Oct - 10 Nov 2004, Sunshine Lake, Lafayette Co. (KM et al.; ML 126497).

\section{Western Kingbird (Tyrannus verticalis)}

Status: Uncommon but local summer resident in northwest and west-central; rare elsewhere.

Documentation: Specimen: female, 16 May 1964, Mud Lake, Buchanan Co. (KU 117957).

Habitat: During migration, typically seen perched on fences and utility wires in open country. Most frequently nests on telephone poles, utility power stations, in parks, and in small groves of trees.

Spring: This kingbird is usually not seen until the very end of Apr. It is common at breeding sites by mid-May. Earliest dates: 1, 15 Apr 1894, Stotesburg, Vernon Co. (T. Surber; Widmann 1907); 1, 18 Apr 2011, Greene Co. (CBu et al.); 1, 21 Apr 2007, Joplin, Jasper Co. (LH); 1, 21 Apr 2011, Jasper Co. (LH). All high counts of migrants are $<10$ birds/day.

Summer: The breeding distribution of this kingbird continues to expand in the state. Prior to the early 1980 s, it was primarily known to breed along the western border, especially from Kansas City northward to the Iowa border. It was first noted nesting in Columbia in 1981, and by 1986 one to a few pairs were detected breeding in the St. Louis area (Robbins and Easterla 1992 for summary). By 1992, it was noted nesting in Nevada, near Sedalia, and at Montrose. The first breeding record for the bootheel was obtained in Jun 1991 at Kennett, Dunklin Co. (H. and N. Schanda), with nesting documented at Charleston in 2001 (JHa). By 2006 breeding was noted in Livingston Co. (JK), and during the summer of 2008 nesting was noted in Perry and Scott cos. (JE) and for the first time in the northeastern corner of the state at Kirksville (D. Nichols). At the current rate of expansion it will soon be breeding locally in open areas across the entire state.

Widmann (1907) provided little information on the status of Western Kingbird. In addition to the early Apr record mentioned above, he related that H. Nehrling considered the species to be fairly common in the early 1880s at Freistatt, Lawrence Co., in the southwestern corner of the state, but this Lawrence Co. report is at odds with information from both Oklahoma and Kansas for that period. The species was clearly expanding its distribution, but during the late 1800s it apparently was restricted to the panhandle of Oklahoma (Nice 1924), and Goss (1891) stated that it was a common summer resident in western and central Kansas; so the Nehrling report, if accurate, was an outlier in both date and location. 
Early historical documentation of breeding in Missouri is based on a 3-egg clutch on 17 Jun 1898 at Tarkio, Atchison Co. (CM E1155). Harris (1919b) did not mention any records for the Kansas City area, but noted that it was present to the northwest in Holt Co. during that period. The arrival of Europeans, who provided an increase in nesting sites by planting trees and erecting telephone poles and other structures, greatly enhanced the spread of the species across the Great Plains (Honig 2001).

Fall: The majority of the breeders leave the state during Aug, with few remaining in early Sep. It is quite rare during the latter half of Sep. Latest dates: 1, 16 Oct 2000, Macon Co. (EW); 1, 12 Oct 1938, Fairfax, Atchison Co.; 1, 10 Oct 1992, Taberville Prairie $(\mathrm{CH})$.

Comments: Hybrids between Western and Eastern Kingbirds have been noted on at least two occasions during summer at Mound City (SK, LL). A yellow-bellied kingbird, species undetermined, was observed on the 17 Dec 2005 Mingo CBC (BE, W. Mueller).

\section{Eastern Kingbird (Tyrannus tyrannus)}

Status: Common summer resident.

Documentation: Specimen: male, 16 May 1879, Charleston, Mississippi Co. (MCZ 43566).

Habitat: Prefers open country; often observed perched atop bushes, fences, and telephone wires.

Spring: The first arrivals appear by the end of the second week of Apr with peak in early to mid-May. Earliest dates: 1, 28 Mar 1983, St. Francois Co. (BL); 1, 28 Mar 1998, near Golden City, Barton Co. (CBu et al.); 1, 1 Apr 2001, Van Meter SP (M. Mills). High counts: 112, 1 May 2016, Hornersville Swamp area (TJ); 44, 11 May 2013, Roaring River (JCa, AK).

Summer: The highest densities are in the open country of the Glaciated and Osage plains regions, with the lowest densities in the Mississippi Lowlands region. Apparently it is now much more common in the Ozarks than it was before that region was logged in the late 1800s and early 1900s, as Widmann (1907) related that it was "much less common in the Ozarks" before it was "opened up". Nonetheless, BBS data indicate a $2.25 \% / \mathrm{yr}$ decline of this kingbird for the period of 2003-2013; this may be related to the large-scale conversion of pasture/fields to cropland, especially in the western and central sections of the Glaciated Plains.

Fall: By the second week of Aug, migration is apparent as flocks are widespread. Peak is generally at the end of Aug/early Sep when flocks numbering over a hundred individuals may be encountered. It is rare by the end of Sep and only casually observed after the first few days of Oct. High counts: 300, 11 Sep 1983, Cooley Lake (CH, KH, MM); 200, 29 Aug 2003, Bluffwoods CA (LL); several observations of over 100 indi- 
viduals. Latest dates: 1, 26 Oct 2005, Lambert Airport, St. Louis Co. (MT); 1, 24 Oct 1964, near St. Joseph (FL); two reports for 12 Oct.

Comments: see remarks under Western Kingbird regarding hybrids.

\section{Gray Kingbird (Tyrannus dominicensis)}

Status: Accidental transient.

Documentation: Sight record only; see below.

Habitat: Open areas; often observed perched on utility lines.

Record: A single record of a bird that was carefully observed and sketched at the time of the observation by two independent observers on 23-24 May 2006, Salem, Dent Co. (D. Plank, L. McClure; fig. 24). There are numerous extralimital records for the eastern United States away from its principal United States breeding distribution in Florida and adjacent Gulf Coast states (Armistead and Iliff 2003).

\section{Scissor-tailed Flycatcher (Tyrannus forficatus)}

Status: Common transient in Osage Plains, rare elsewhere; uncommon summer resident in Osage Plains, rare elsewhere, except extreme north and northeast where it is a casual breeder; accidental winter visitant.

Documentation: Specimen: male, 16 May 1964, near Forest City, Holt Co. (KU 117730).

Habitat: Prefers prairies and pastures with isolated trees, and utility stations in towns and cities.

Spring: Concentrations at this season never approach the large numbers observed in fall. It is much more common in the Osage Plains than in any other region of the state. The earliest arrivals appear at the end of Mar/early Apr. Peak is in late Apr/early May. Earliest dates: 1, 22 Feb 1980, Springfield (W. Carras); 1, 12 Mar 1986, Springfield (B. Dyer); 1, 18 Mar 2009, Jasper Co. (JCa). High counts: several of 12 individuals/ day from mid-Apr to early May with high counts of 20+ breeders during late May. Unlike fall, no large migratory groups have been observed at this season.

Summer: It is much more prevalent in the Osage Plains region than in any other part of the state, but as a result of a major range expansion since at least the 1940s it is now rare and local throughout the state, except the most northern and northeastern counties.

There was considerable confusion about the status of the species in Missouri for about 100 years from the 1860s through the 1960s (see details in Robbins and Easterla 1992). The first unequivocal breeding record was not obtained until 29 Jun 1940, Garden City, Cass Co. (E. Markward et al.), and it was noted breeding near Lowry City, St. Clair Co. in 1946 (B. Hilty, A. Haverland, fide S. Hilty). Presumably it was breeding in the state well prior to those definitive records; nonetheless, since the 1940s the breeding distribution has considerably expanded. 


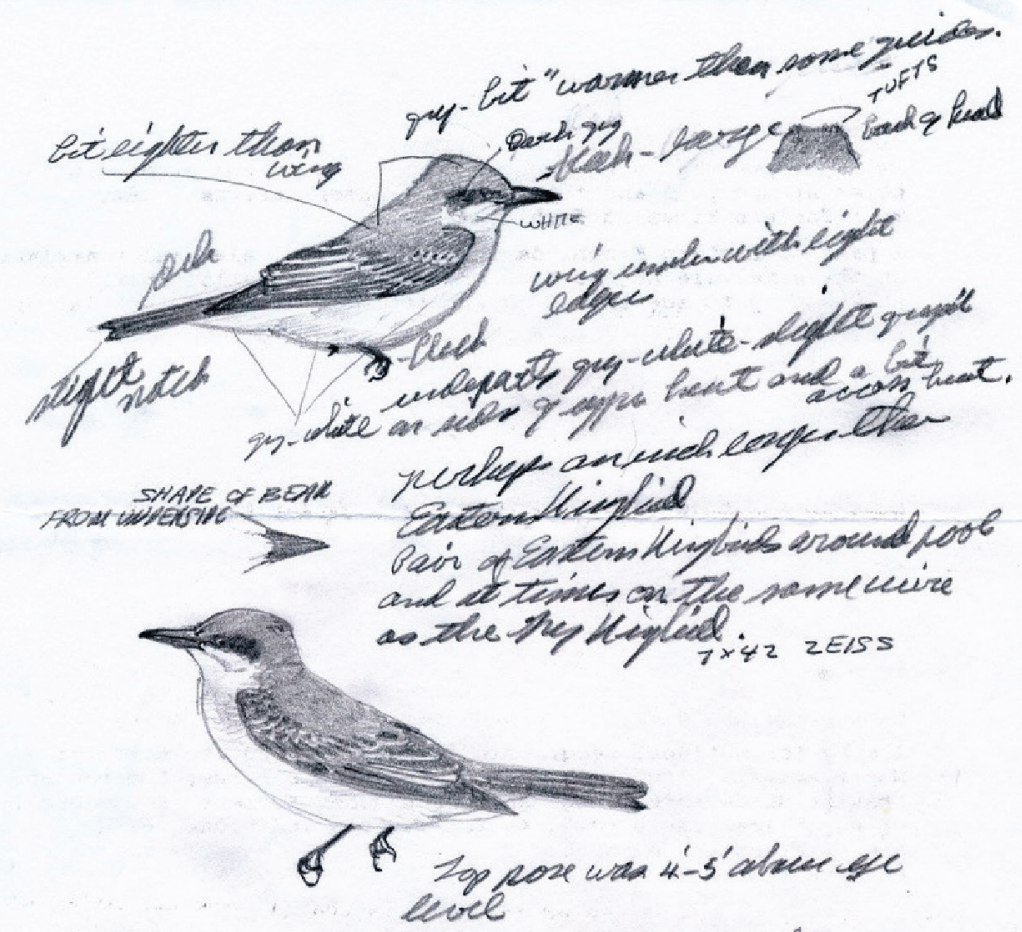

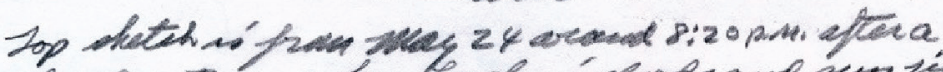

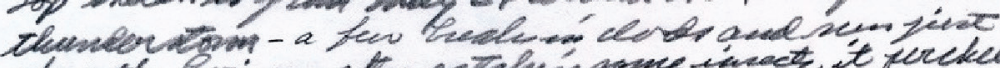
atrue the Roinger. efter ceteler pone inect, it jercked

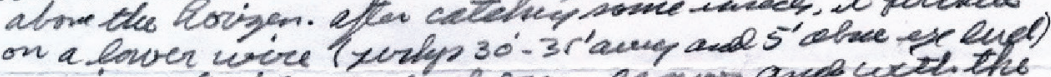

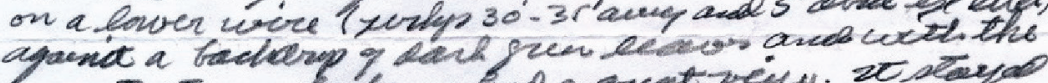

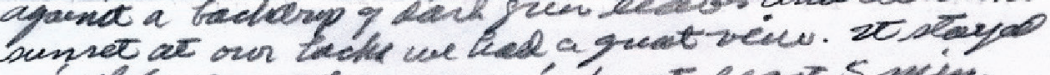

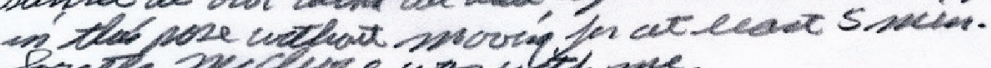
brete medere ua vith m.

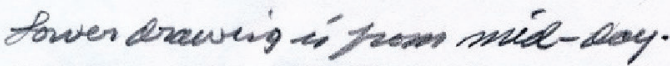

HABITAT: TREES AHONES ACONG EAST SIDE OF CITY SWIMHIN POOL I A FEW TRES ABOUT POYD WNW BUT MOST QF THE ANEA CUEST IS OPEN WITA

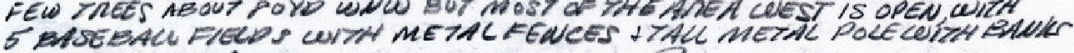
o HGHT an 70 .

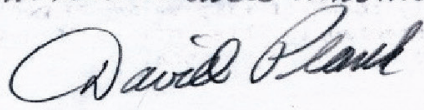

Fig. 24. Drawing made by David Plank of Gray Kingbird on 24 May 2006, Salem, Dent County.

The first nesting record for the eastern half of the state was obtained at Salem, Dent Co. in 1976 (D. Plank), and breeding was documented in 1980-2 near Belgrade, Washington Co. (SD, BL, BRe). However, the first nesting in the St. Louis area was not observed until 1991 near Eureka (A. Shock et al.) and the following year in Clinton Co. (M. Hoover). By 1999, breeding was confirmed in eastern Callaway Co. (R. 
Windsor), and in 2000 it nested at Union, Franklin Co. (R. and C. Delashmit) and at the Kansas City International Airport, Platte Co. (LL). In 2001, a number of new localities were documented across the state. The first for the southeastern corner of the state was obtained in 2004 in Scott Co. (L. Koller, K. Crammer), and it has subsequently been noted at several localities in that region of the state. Breeding records were confirmed in the northwestern region during the following years and counties: 2006 and 2007, two sites in Livingston Co. (SK); 2013, Gentry Co. (TM); 2014, Worth Co. (KU 131185); 2015, Atchison (R. Evans). Like the Western Kingbird, the Scissor-tail's breeding distribution continues to expand.

Fall: The migration of Scissor-tails is later than that of other kingbirds. Migration is apparent by late Aug, when relatively large groups ( $>40$ individuals) may be observed. The spectacular peak does not occur until the end of Sep/early Oct when over 100 birds may be seen at a single site in the Osage Plains. Although smaller in numbers, relatively large groups may be seen through the third week of Oct. By early Nov it is quite rare. High counts: several observations involving 100 birds; a high count north of the breeding range that involved migrants: 15, 27 Sep 2012, Smithville Lake (DW). Latest dates: 1, 2 Dec 1985, Springfield (B. Dyer); 1, 21 Nov 1991, Urbana, Dade Co. (JHy); 1, 20 Nov 1986, Jasper Co. (G. Dobbs, W. Holloway).

Winter: A single record of a very late migrant: 1, 29 Dec 1992, near Jameson, Daviess Co. (TM, B. Ritter).

\section{Fork-tailed Flycatcher (Tyrannus savanna)}

Status: Accidental transient.

Documentation: Photograph; fig 25.

Habitat: Open areas with scattered trees.

Record: An immature was present 26-28 Apr 2009, near Muskrat Lake, Buchanan Co. (C. and G. Thompson et al.). Detailed photos of this vagrant demonstrated that the primaries were emarginated, which indicated that it was of the southern South American nominate subspecies that is migratory and has been documented from several other eastern states.

\section{Family Laniidae: shrikes}

\section{Loggerhead Shrike (Lanius ludovicianus)}

Status: Rare to uncommon permanent resident in the western Glaciated and Osage plains and the Mississippi Lowlands, increasingly rare elsewhere.

Documentation: Specimen: male, 26 May 1883, St. Louis (CAS 36484).

Habitat: Open areas with scattered hedgerows, bushes, and trees.

Spring: Migration is inconspicuous as a result of the wintering population, but there clearly is an influx of birds during Mar into early Apr. Most breeders have established territories by late Mar. High counts such as 25, 5 Apr 1964, Trimble/Loess Bluffs, ca. 


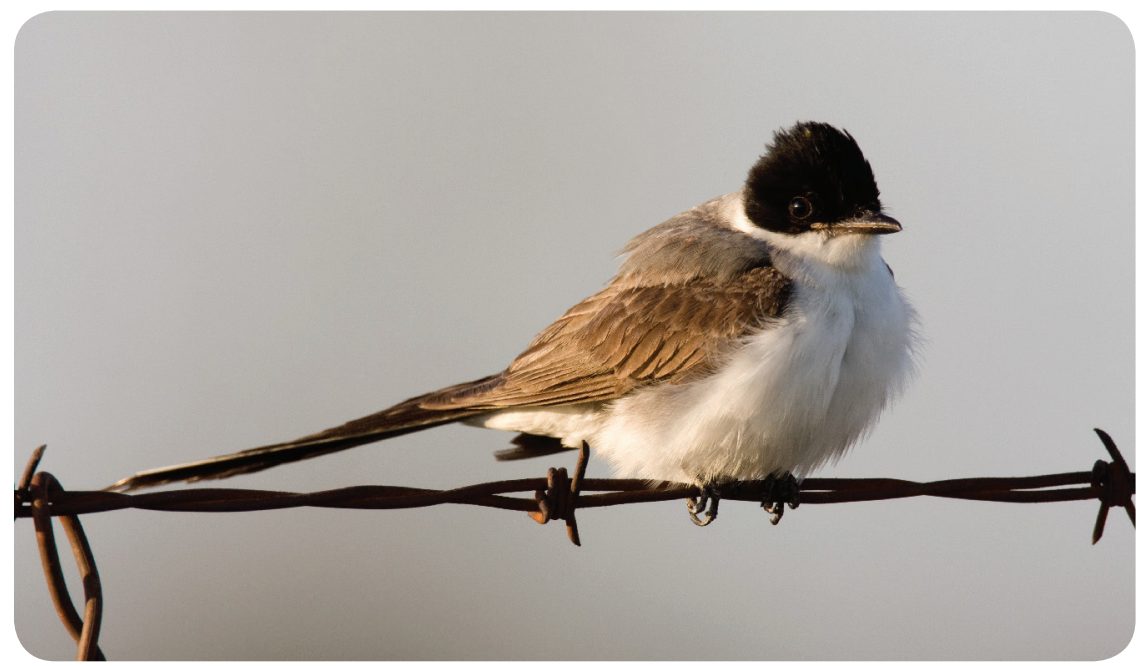

Fig. 25. The only Missouri record of Fork-tailed Flycatcher. Photo by Linda Williams on 28 April 2009.

175 miles, (FL) and 22, 30 May 1969, St. Joseph/Honey Creek CA, ca. 90 miles (FL) have not been observed since the mid-1970s as a result of dramatic declines in the species. High count, post-1980: 12, 15 Apr 2007, Dunn Ranch, Harrison Co. (SK).

Summer: The western Glaciated Plains, the Osage Plains, and the Mississippi Lowlands continue to be the stronghold for this declining species, although it is now local even in those regions (eBird). The highest densities are in the heavily-managed Dunn Ranch, Harrison Co., area where relatively large numbers can still be observed, e.g., 25 (included family groups), 19 Jun 1994 (DE), and 21 (included family group of 7), 4 Jul 2007 (JE). Smaller numbers are primarily seen around remnant prairies in the Osage Plains and where the Osage Plains and western Ozarks regions interface. Lower densities occur in the Mississippi Lowlands region. Predictably, this shrike is absent from the heavily forested regions of the Ozarks and Ozark Border.

The Loggerhead Shrike has declined dramatically during the past 50 years as a result of habitat loss via conversion of prairie, pastures, and hedgerows to agriculture, and of pesticide use (Arbib 1977). Kridelbaugh (1981) documented the decline in Missouri and BBS data indicate the decline continues (8.9\%/yr; 2003-2013). Widmann (1907) considered the species "fairly common summer resident... in the prairie and Ozark border region, scarce in the Ozarks and the southeast." Harris (1919b) also considered it fairly common in the Kansas City region. Presumably it was very rare and local in the Mississippi Lowlands before this region was largely deforested in the late 1800 s and early 1900 s.

Fall: Migration is apparent from late Sep through mid-Nov with peak in Oct. 
Winter: The highest densities are in the Osage Plains and Mississippi Lowlands. During severe winters fewer are present in the north. Kridelbaugh (1981) demonstrated that the winter population had also declined, with the most precipitous decline in the western Glaciated Plains. CBC data demonstrate that the decline continues statewide despite greater observer effort and milder winters during the past two decades. In the $1960 \mathrm{~s}$, an average of $0.11-0.24 \mathrm{birds} / \mathrm{pa}$ hour were recorded statewide, whereas during the 2000s the average was more than a magnitude lower $(0.02-0.08 \mathrm{birds} / \mathrm{pa}$ hr). CBC high counts: 26 (0.4), 19 Dec 1982, Trimble; 24 (0.6), 28 Dec 1965, Mingo; 22 (0.7), 30 Dec 1974, Mingo.

Comments: Breeding birds and the vast majority of migrants and winter residents are referable to the subspecies migrans. However, a bird that was banded as a juvenile in Saskastachewan on 31 Jul 1953 was recovered later that same year on 23 Sep at Cross Timbers, Hickory Co.; a distance of 1,953 miles (Burnside 1987). That individual would be referable to the excubitorides subspecies. The latter subspecies supposedly breeds throughout the Great Plains south to Texas, but it is unclear if and where the range interface is with the western limit of migrans.

\section{Northern Shrike (Lanius borealis)}

Status: Rare winter resident in north, casual southwest, accidental Ozarks and Mississippi Lowlands.

Documentation: Specimen: female, 1 Feb 1977, southwest of Maryville (KU 117992). Habitat: Open country with scattered bushes and trees.

Spring: Wintering birds typically remain until late Feb/early Mar. Latest dates: 1, 8 Apr 2009, near Amity, DeKalb Co. (C. Merkord); 1, 7 Apr 1896, St. Joseph (Widmann 1907); imm, photos, 31 Mar 1995, near Bigelow, Holt Co. (KG); 1, 26 Mar 2008, Whetstone Creek CA, Warren Co. (B. Clark). High count: 3, 13 Mar 2009, Daviess, Livingston, and Clay cos. (MR).

Fall and Winter: The first individuals are detected at the end of Oct, with numbers continuing to increase through Nov. In non-irruption years it is found annually in low densities across the Glaciated Plains and casually south to Barton County in the southwest. During two recent major irruptions, 2007-8 (Eades 2008) and 2008-9, this shrike was observed in larger numbers and farther south. During the 2007-8 irruption birds were recorded for the first time as far south as 1, late Nov 2007, south of Dorena, Mississippi Co. (J. Brunjes); 1, 16 Jan 2008, Stoddard Co. (S. Hasse); imm, 29 Dec 2007, near Trail of the Tears SP, Cape Girardeau Co. (K. Fothergill, H. and T. Winkleblack); and ad, 17 Jan 2008, near Farmington, St. Francois Co. (BL; KU 111504). The southernmost record for the state is during a non-irruptive year: 1, 6 Jan - 18 Feb 2012, near Pineville, McDonald Co. (LH). Earliest dates: juv., 24 Oct 2011, Providence Prairie, Lawrence Co. (B. Clark, B. Mees); ad, 25 Oct 1995, Bilby Ranch (KG); 1, photos, 26 Oct 2013, Cass Co. (G. Culver). High counts: 5, 21 Dec 2007, Grand River CBC; 4 ad, 29 Dec 2011, Harrison and Daviess cos. (MR, JB). 
Comments: Widmann (1907) considered this shrike "a rather common winter resident", whereas Harris (1919b) remarked that it was "never numerous and in some winters is not seen." The lack of records between that period and when the species started to be detected on an annual basis in 1969 was almost certainly due to the paucity of observers in the northern part of the state.

\section{Family Vireonidae: vireos}

\section{White-eyed Vireo (Vireo griseus)}

Status: Locally common summer resident in Ozarks and Ozark Border, uncommon to rare elsewhere; accidental winter visitant.

Documentation: Specimen: sex?, 26 May 1882, Independence (KU 39274).

Habitat: Brushy areas, thickets, and dense second growth at edge of woodland and forest.

Spring: The initial migrants arrive in early Apr in the south and about a week later in the north. Peak is the last week of Apr in the south and early May in the north. Earliest dates: 1, 21 Mar 2012, Wyatt, Mississippi Co. (MH); 1, 29 Mar 1980, near Collins, St.Clair Co. (MR, M. Braun); two records for 31 Mar. High count: 28, 9 May 2013, Busch (CM); several high counts in south of 25+. High count in northwest: 9, 15 May 1998, Weston Bend (m. ob.).

Summer: This vireo is most common in the Ozarks and Ozark Border regions and it is much less widespread and in lower densities in the Osage Plains and Mississippi Lowlands. It is quite local in the Glaciated Plains, especially the northern three tiers of counties. Although it went unrecorded in the northeastern county of Adair during the BBA, it was "observed at multiple locations" there during the summer of 2008 (PW).

Fall: Summer residents are still present and common through Sep. After the first week of Oct it is rare with only a few records after mid-Oct. High counts during Sep: 40+, 10 Sep 1977, Roaring River (N. Johnson, J. Garrett); 32, 13 Sep 2011, Meramec SP (MH). High count in Oct: 9, 6 Oct 2013, near Ben Cash (TJ). Latest dates: 1, photos, 7 Nov 2016, Ben Cash (TJ); 1, 4 Nov 2007, Kimberling City, Stone Co. (D. Gagne); 1, 4 Nov 2009, Ben Cash (TJ); 1, 29 Oct 2014, near Ben Cash (TJ).

Winter: A single winter record: 1, photos, 2 Jan 1995, Mingo CBC, Wayne Co. (S. Hazelwood, K. and B. Palmer).

\section{Bell's Vireo (Vireo bellii)}

Status: Uncommon summer resident in Glaciated and Osage plains and locally in Ozark Border, rare elsewhere.

Documentation: Specimen: male, 22 May 1885, St. Louis (California Academy of Sciences 36548).

Habitat: Thickets, brushy hedgerows, and young, dense willow stands. 
Spring: Typically not seen prior to early May, especially in north. Peak is in mid-May. Earliest dates: 1, 19 Apr 2011, Jefferson City (B. Moyer); 1, 23 Apr 1964, St. Joseph (FL); 1, 23 Apr 2016, near Ben Cash (TJ). High counts: 56, 26 May 1993, 16.5 miles of Nodaway River (Robbins et al. 1993); 32, 17 May 2008, Prairie SP (LH).

Summer: Bell's Vireo is uncommon in the Glaciated and Osage plains regions and least widespread and in the lowest densities in the heavily forested central and eastern Ozarks and the Mississippi Lowlands. Populations in open areas with scattered shrubs are relatively conspicuous compared to populations occupying mostly inaccessible dense stands of willows in riparian areas. In the latter habitat, an average of 27.5 birds was recorded along 16.5 miles of the Nodaway River ( $\mathrm{n}=6$ years; 1992-97; Table 6). High count in open/mixed shrub habitat: 33, 12 Jun 2010, Prairie SP (LH). BBS data lack precision to determine trends by region or at the statewide level. Demography was studied at two grassland/shrub sites in central Missouri for the period of 1996-98 (Budnik et al. 2000).

Fall: Territorial birds are still heard singing through the second week of Sep, but virtually all have left by the end of the third week of Sep. Latest dates: male, singing, 2 Oct 2016, Springfield (LB, J. Hays et al.); male, 1 Oct 1919, Lexington, Lafayette Co. (CMC 452).

Comments: The type specimen from which this species was described was taken on 6 May 1843 at St. Joseph (USNM A01926; Cooke 1910). This vireo and Lark and Harris's sparrows were the only species that were first made known to science from specimens collected in Missouri.

\section{Yellow-throated Vireo (Vireo flavifrons)}

Status: Uncommon summer resident.

Documentation: Specimen: male, 2 May 1879, Charleston, Mississippi Co. (MCZ 45152).

Habitat: Mature woodland and forest, especially in bottomland.

Spring: The first arrivals are in early Apr in the south, a week or so later in the north. Peak is in late Apr/early May. Earliest dates: 1, 28 Mar 2012, Rockwoods Reservation CA, St. Louis Co. (CM); 30 Mar 1896, Mississippi Lowlands (Widmann 1907); at least two observations for 1 Apr. High counts: 23, 16 Apr 2016, Sugar Camp Scenic Drive (CBu, LB); 18, 26 Apr 2014, Red Bridge Road, Christian Co. (AK).

Summer: Although this vireo is found statewide in appropriate habitat, it is most common in the southeastern Ozarks and Ozark Border. As expected, the lowest densities are in the Mississippi Lowlands region.

Fall: Most of the summer residents leave the state in late Aug and during Sep with only a few lingering into early Oct. Latest dates: 17 Oct 1903, Monteer, Shannon Co. 
(W. Savage; Widmann 1907); 1, 16 Oct 2013, Martha Lafite Thompson Nature Sanctuary, Clay Co. (K. Brink et al.); 1, 14 Oct 1956, Lake of the Ozarks SP (FL).

\section{Blue-headed Vireo (Vireo solitarius)}

Status: Uncommon transient; accidental winter visitant.

Documentation: Specimen: female, 3 Oct 1892, Willow Springs, Howell Co. (USNM 137771).

Habitat: Wide range of woodland and forest habitat, even small patches in residential areas.

Spring: Typically the first arrivals are not seen until the last week of Apr with peak in early May. Occasionally, late individuals are seen in late May into the first week of Jun. Earliest dates: three observations for 9 Apr; 1, 10 Apr 1992, Mingo (BL). High counts: 11, 11 May 1996, Jackson Co. (MB). Latest dates, all of single birds: 8 Jun 1985, Cass Co. (J. Garrett); 5 Jun 1993, Cooley Lake (MM); 29 May 1983, Wallace SP, Clinton Co. (CH, MM); 29 May 2017, Longview Lake, Jackson Co. (S. Leonardo).

Fall: The first southbound birds are usually not seen until the beginning of Sep with peak in late Sep. It is regularly observed through mid-Oct when multiple individuals may be observed, e.g, 8, 13 Oct 2007, Tower Grove (D. Scheu). It is casual during Nov. Earliest dates: 1, 28 Aug 1964, St. Joseph (FL); 1, 28 Aug 2007, Tower Grove (JE). High counts: 11, 29 Sep 2012, Tower Grove (AR, CMc); a few observations of 8 individuals/day. Latest dates: 1, photos, 13 Dec 2017, east of Winona, Shannon Co. (MR, JB); 1, 28 Nov 2008, east of Puxico, Stoddard Co. (CB); 1, 26 Nov 1963, Columbia (W. George); 1, at suet feeder, 25 Nov 1981, Jefferson City (J. Wilson).

Winter: There are four observations: 1, 15 Dec 1962, St. Joseph (FL); 1, 17 Dec 2004, Ten Mile Pond (BE); 1, photos, 8 Feb 2014, Ben Cash (TJ); 1, photos, 1 Dec - 24 Jan 2016-7, Ben Cash (TJ).

\section{Philadelphia Vireo (Vireo philadelphicus)}

Status: Uncommon transient.

Documentation: Specimen: female, 21 May 1883, St. Louis (CAS).

Habitat: Woodland and forest, but also seen in small woodlots in residential areas.

Spring: The first arrivals typically appear at the end of the last week of Apr with peak in at the end of the first week of May in the south, second week of May in the north. Earliest dates: 2, 18 Apr 1965, Big Oak Tree (JH); 1, 21 Apr 1983, Busch (S. Russell). High counts: 12, 6 May 2007, Busiek SF (GS); 10-12, 5 May 1990, Mingo/Duck Creek (BRe, R. Brundage). Latest date: 1, 1 Jun 1988, St. Louis Co. (RK).

Fall: Usually not detected until early Sep with peak not until the end of the third week or beginning of the last week of Sep. A few are seen into the second week of Oct, but it is accidental after mid-Oct. Earliest dates: 1, 24 Aug 1979, Busch (F. Hallett); 1, 26 Aug 2003, Greene Co. (D. Thurman). High count: 15, tower kill, 24 Sep 1960, Co- 
lumbia. Latest dates: male, 24 Nov 1984, Maryville (MR, DE; KU 118747); 1, 24 Oct 2014, Ben Cash (TJ); 1, photos, 18-19 Oct 2013, Ben Cash (TJ).

\section{Warbling Vireo (Vireo gilvus)}

Status: Common summer resident, except the Ozarks and Mississippi Lowlands where it is local and uncommon; accidental winter visitant.

Documentation: Specimen: male, 8 May 1879, Charleston, Mississippi Co. (MCZ 45111).

Habitat: Riparian woodland and forest, especially with cottonwoods.

Spring: The first birds arrive at the beginning of the second week of Apr, with peak in late Apr in the south, early May in the north. Earliest dates: 1, 26 Mar 2007, Shaw Nature Reserve, Franklin Co. (M. Terpstra); 1, 4 Apr 2009, Roaring River (J. Williams); four observations for $6 \mathrm{Apr}$ in the southeast. High counts, both during surveys of 16.5 miles of Nodaway River: 90, 26 May 1993 (Robbins et al. 1993); 87, 22 May 1992 (Robbins et al. 1992); see summer.

Summer: This is a very common summer resident wherever there are cottonwoods, especially along the two major rivers in the state. In the Ozarks it is found in small numbers and is spotty in distribution, found primarily in the broader and more open floodplains. It is also very local in the Mississippi Lowlands. An average of 83.5 birds were recorded along 16.5 miles of the Nodaway River ( $n=6$ years; 1992-97; Table 6); in contrast, no birds were recorded on several Ozark rivers (Table 6).

Fall: Most of the summer residents and northern migrants have left by mid-Sep. A few individuals are seen through the last two weeks of Sep. Latest dates: 1, 20 Oct 2013, Big Spring SP, Carter Co. (MR); 2, photos, 7-8 Oct 2013, Ben Cash (TJ); a few observations for 1-2 Oct.

Winter: An extraordinary record is of a bird at a suet feeder that was eventually found dead, 20 Jan 1936, Kansas City (A. Shirling). Apparently the specimen was not preserved, thus precluding subspecific determination.

Comments: Only the eastern, nominate subspecies has been recorded in the state, but the western $V$. g. swainsoni might occur as a fall vagrant.

\section{Red-eyed Vireo (Vireo olivaceus)}

Status: Common summer resident.

Documentation: Specimen: female, 5 May 1879, Charleston, Mississippi Co. (MCZ 45105).

Habitat: Mature woodland and forest.

Spring: The first arrivals appear near the southern border at the beginning of Apr, but not until the last week of Apr in the north. Earliest dates: 1, 28 Mar 2007, Boone Co. (PM); 1, audio recording (ML 210176), 29 Mar 1980, near Collins, St. Clair Co. (MR, 
M. Braun); a few observations for 3 Apr. High counts. Both along Sugar Camp Scenic Drive: 229, 9 May 2014, May 2014 (MR, JB); 172, 9 May 2013 (MR, CH, JB).

Summer: This species reaches its highest densities in the eastern Ozarks and the Ozark Border regions. As a result of the lack of larger blocks of woodland and forest habitat, it is least common in the Glaciated and Osage plains and Mississippi Lowlands regions.

Shirling (1920) recorded 84 males at Swope Park, Kansas City in 1916, whereas a re-survey of this site in 1973 resulted in only 34 males (Branan and Burdick 1981). Between the two surveys there was over a $50 \%$ decrease in the upland forest, whereas there was similar acreage of riparian forest.

Fall: Migrants begin supplementing resident birds by the end of Aug, with peak of migrants during the third and fourth weeks of Sep. It is regularly recorded through the first week of Oct, e.g., 12, tower kill, 6 Oct 1962, Cape Girardeau (Heye 1963), but there are no records after the middle of the month. High counts, both at Columbia tower kills: 185, 20-21 Sep 1963 (George 1963); 126, 19 Sep 1966 (Elder and Hansen 1967). Latest dates: 1, photos, 24 Oct 2015, Cedar Hill, Jefferson Co. (W. George); 1, photos, 17 Oct 2015, St. Louis (CMc, AR); 1, 15 Oct 2011, Dunklin Co. (TJ).

\section{Family Corvidae: jays, nutcracker, magpie, crows, raven}

\section{[Gray Jay (Perisoreus canadensis)]}

Status: Provisional.

Documentation: Sight record only; see below.

Habitat: In normal range, associated with coniferous forest.

Record: There is a single record of a bird feeding at a deer carcass near Craig, Holt Co., on 21 Nov 1985 (T. Bell, M. Hoover). Unfortunately, no photographs were secured, nor was the description detailed enough to determine subspecific identification; thus the provenance of the bird was unknown, i.e., whether it belonged to the boreal Canadian population (P. c. canadensis) or was from the Rocky Mountains (P. c. capitalis). There were no extralimital movements of either of those populations that winter; it is possible that the bird was an escapee.

\section{Blue Jay (Cyanocitta cristata)}

Status: Common permanent resident; migrant populations involved.

Documentation: Specimen: male, 16 May 1870, Charleston, Mississippi Co. (MCZ 42782).

Habitat: Virtually anywhere that has at least a small grove of trees.

Spring: In addition to birds that appear to be year-round residents, there is a large migratory population that winters south of the state. A conspicuous movement through the entire state occurs from mid-Apr into the third week of May. These migrants, rang- 
ing from small groups to relatively large flocks ( $>50$ individuals), often move at or just above tree top level. High counts: "several hundred migrating", 26 Apr 1961, Table Rock Lake area (FL); 185, 28 Apr 2015, Canton, Lewis Co. (R. DeCoster).

Summer: A widespread and common species statewide, with the highest densities in the Ozarks and the lowest densities in the Mississippi Lowlands. Although there is no obvious, dramatic change in the status and distribution of the species during historical times, it is presumed that it was least prevalent in the prairie region of the state prior to European settlement. Between 1916 ( $n=73$ individuals; Shirling 1920) and 1973 ( $n=199$ individuals) this species increased by 273\% in Swope Park, Kansas City (Branan and Burdick 1981).

Fall: Southbound movement is apparent as early as late Aug, e.g, 38 (29 in one string), 30 Aug 1984, St. Joseph (FL); numbers increase to a peak in late Sep/early Oct, when numerous large groups may be seen/day. By late Oct/early Nov migration is greatly reduced. High counts: 1,000+, during hawk watch, 30 Sep 1978, Lake of the Ozarks SP (m. ob.); 819 (2.6 hrs), 28 Sep 2016, Weston Bend (MR, JB); 761 (3 hrs), 27 Sept 2017, Weston Bend (MR, JB).

Winter: It is most common in the Ozarks and Ozark Border and least prevalent in the Mississippi Lowlands. Smith (1986) showed that winter abundance is positively correlated with mast production. Both Widmann (1907) and Harris (1919b) mention that it was much less common during severe winters, presumably when some birds move further south; however, the widespread feeding of birds and planting of trees likely has ameliorated this to some extent.

Comments: The spread of West Nile virus into the region had dramatic negative effects on many species, but it was particularily notable in corvids (LaDeau et al. 2007). Declines on Missouri CBCs were apparent as early as the 2001-2002 CBCs.

\section{Clark's Nutcracker (Nucifraga columbiana)}

Status: Casual fall transient and winter resident.

Documentation: Photograph: 3, 5 Nov - late Dec 1972, north Kansas City, Clay Co. (W. Rodgers et al; Robbins and Easterla 1992).

Habitat: In normal range, associated with coniferous forest.

Fall: The above record and a single bird in Independence on 16-28 Nov 1972 (fide $\mathrm{CH})$ were part of a major irruption of nutcrackers from the Rocky Mountains to the Great Plains that reached as far east as Illinois (Williams 1973; Kleen and Bush 1973). There are two other fall records: 1, shot, 12 Oct 1907, near Louisiana, Pike Co. (Widmann 1908); 1, shot, 28 Oct 1894, Kansas City (Bryant 1895); it appears that neither of these two specimens is extant.

Winter: Three winter records: 1, 14 Feb 1962, near Nevada, Vernon Co. (T. Pucci); 1, at suet feeder, 10 Jan - 31 Mar 1969, Pleasant Hill, Cass Co. (H. Williams, L. Warner); 
1, photos, 21-23 Dec 2002, Busch (R. Kostecke et al.). Other extralimital records in the Great Plains also were recorded during the same winters as the latter two Missouri records.

\section{Black-billed Magpie (Pica hudsonia)}

Status: Accidental fall transient and winter resident; accidental summer resident.

Documentation: Specimen: female, 5 Dec 1925, Jackson Co. (KU 39167).

Habitat: Open country with scattered trees, especially in riparian areas in the Great Plains.

Summer: After an unprecedented irruption during the fall and winter of 1921-2, at least two pairs bred within 3 miles of Corning, Holt Co., in the summer of 1922 (C. Dankers; see comments below).

Fall: There are three additional old records besides the above specimen: 4, 1 Nov 1890, Saline Co. (L. Corder; Widmann 1907); 1, 12 Nov 1927, Adair Co. (J. Peeler; Bennitt 1932); 1, collected in late fall of 1913 in Holt Co. (Harris 1919b).

Winter: Formerly more frequently reported at this season. An extraordinary 50+ birds were recorded during the winter of 1921-2 in Holt Co., part of a major irruption across the Great Plains and upper Midwest during the fall of 1921 (Kent and Dinsmore 1996). Another major irruption occurred in the winter of 1936-7, as there were at least three magpies recorded in Missouri during Jan 1937: two separate birds, 1 killed in a trap, the other shot, in early Jan 1937, Lewis Co. (Musselman 1937), and an unpublished record of a bird that was seen in Jan 1937, 2 miles east of Skidmore, Nodaway Co. (Q. Goslee, fide KG). Another unpublished record is of one seen near Cosby, Andrew Co., along the Platte River in the 1930s (G. Kephart, fide FL, DE). There is one recent record: 1, 8 Dec 2005, Maryville (J. Dawson). All other reports likely involved escapees and birds that were intentionally introduced (Robbins and Easterla 1992).

Comments: Thompson et al. (2011) suggested that magpie distribution in Kansas during the 19th and the $20^{\text {th }}$ centuries may have been an expansion onto the plains from the foothills of the Rockies. This may have been related to the reduction of fire and grazers (bison), enabling the expansion of vegetation, especially in riparian areas. However, with the spread of West Nile virus across the country (LaDeau et al. 2007), conspicuously reaching the interior of the United States by the summer of 2001, the magpie population was decimated; it completely disappeared or was drastically reduced in numbers across most of its Great Plains distribution (Thompson et al. 2011, eBird data). For example, just prior to the arrival of West Nile a total of nearly one thousand magpies was recorded on Kansas CBCs, but on the 2013-4 counts a total of only 24 individuals was observed (Young and Whiles 2016).

\section{American Crow (Corvus brachyrhynchos)}

Status: Common permanent resident. 
Documentation: Specimen: male, 1 Jan 1880, Carthage, Jasper Co. (Denver Museum of Natural History 1272).

Habitat: Wide range of habitats when foraging, but needs at least small woodlots for roosting and nesting.

Spring: Winter roosts have mostly dissipated by the beginning of Mar. Obvious migrants are seen through Mar. High counts: 2,373, 4 Mar 2014, Kansas City (MG); 600, 25 Feb 1977, St. Joseph (FL).

Summer: This species is far more abundant in the Ozarks and Ozark Border than in any other region. It is also quite common along large rivers, but data are lacking for those rivers. It is least common in the western Glaciated Plains and Mississippi Lowlands.

Fall: Migrants are apparent in Sep with an increase during Oct. By Nov impressive roosts may be seen, especially in cities along the large rivers. High counts: 5,000, 25 Nov 1965, St. Joseph (FL); 1,053, 26 Nov 2013, Riverlands (CM, JM).

Winter: Relative abundance varies considerably among regions and annually. Among the natural regions, $\mathrm{CBC}$ data indicate it is most common in the Mississippi Lowlands and least common across the Glaciated Plains. However, the largest concentrations are observed along the Missouri and Mississippi rivers, where thousands may be seen at roost sites in areas such as St. Louis, Kansas City, and St. Joseph. Although these huge concentrations may still be seen today, apparently they are relatively small compared to when cities routinely dumped refuse into the rivers. For example, Widmann (1907) stated "hundreds of thousands" congregated along the Mississippi River, primarily in Nov and Dec, at St. Louis. Recent, but pre-West Nile virus, CBC high counts: 13,361 (366.0), 20 Dec 1980, St. Joseph; 11,000 (1,100.0), 27 Dec 1969, Big Oak Tree; 10,798 (189.4), 21 Dec 1988, St. Joseph. Post-West Nile virus high count: 6,200, 13 Feb 2003, Kansas City (MG).

Comments: Like magpies and Blue Jays, American Crows suffered major declines as a result of West Nile virus. Based on BBS data, a $45 \%$ decline was documented regionally in the eastern United States (LaDeau et al. 2007). Missouri CBC data show a decline with the arrival of West Nile virus, but that was not reflected in the BBS data.

Fish Crow (Corvus ossifragus)

Status: Locally common summer resident in Mississippi Lowlands region, along the Mississippi River to at least Pike County, and along southern Ozark rivers north to riparian areas in the Osage Plains; rare winter resident in Mississippi Lowlands, casual elsewhere.

Documentation: Specimen: male, 9 Jun 1965, near Big Oak Tree (Easterla 1965b; KU 117876).

Habitat: Very closely associated with river habitats, but also observed foraging in cultivated fields. 
Spring and Summer: The first migrants are typically detected during the first week of Mar with migration continuing through Apr. This crow has gone through a major range expansion in the state during the past quarter of a century. From the time of its first discovery in the state, 22 Apr 1954, along the Mississippi River in Pemiscot Co. (B. King; Robbins and Easterla 1992), until the late 1980s, it was primarily found in the Mississippi Lowlands and northward along the Mississippi River to St. Louis. In 1989, it was first found at Ted Shanks; then in 1994 it was first detected in the southwestern corner at Roaring River (PM) and near Joplin, Newton Co. (Herbert 1994b). In the spring of 1997 it was observed in the central part of the state in Cole Co. (E. Young) and farther upriver at Eagle Bluffs in May 1999 (PM, BJ). The first observation for the west-central section was at Four Rivers in 1998 (RM), with the first for Kansas City in May 2000 (D. Arney). In May 2003 it was noted as far up the Missouri River as Weston Bend (MG). The first observation for the north-central region was in May 2008 at Pershing SP (P. Harrison, EW, SK, M. McNeely et al.). By 2006, it was considered "very common" in Newton and Jasper cos in the southwest (LH). High counts: 130, 19 Apr 2008, Busch and Weldon Spring (BR); 59, 11 Apr 2017, Big Sugar Creek SP, McDonald Co. (DBl); 56, 20 Apr 2013, Sam Baker SP (D. Sheets).

Fall: Fish Crows primarily leave the state during Sep, but relatively large numbers may be locally seen into early Oct in the Mississippi Lowlands. It is rare everywhere by the latter half of Oct. High counts: 83, 2 Oct 2011, Lake Wappapello (CB); 67, most imm, 29 Sep 2015, Montrose (MR); 50+, 29 Sep 1994, near Neelyville, Butler Co. (MR); 50, 5 Sep 2001, St. Louis (S. Eaton). Latest dates outside the Mississippi River corridor: 1, 12 Nov 2008, Montrose (MR); 1, 14 Oct 2012, Swan Lake (SK).

Winter: A local and very low-density winter resident in the Mississippi Lowlands, as it is rarely recorded on the Mingo and Big Oak Tree CBCs with all-time high counts of only 4 individuals for either count. By 2007 it was considered to be year-round, except during Jan, at Castlewood, St. Louis Co. (MBr). Single individuals have been recorded on the Four Rivers CBC on two occasions, the first in 2004. High counts on the Poplar Bluff CBC: 81, 17 Dec 2010; 8, 18 Dec 2009.

\section{Common Raven (Corvus corax)}

Status: Extirpated; former permanent resident.

Documentation: Specimen; see below.

Habitat: Primarily along rivers that had cliffs for nesting and roosting.

Comments: Apparently this raven was uncommon until the 1870s along Ozark rivers and the big rivers where there were cliff nesting and roosting sites, but it disappeared from much of the state shortly thereafter (Widmann 1907, Harris 1919b). The last definite nesting record was of a clutch of 5 eggs that were collected (apparently no longer extant), 5 Apr 1901, at Ha Ha Tonka, Camden Co. (P. Smith; Widmann 1907), where about 6 pairs were present. Smith also related that "a few years earlier" a colony, perhaps the same birds that were at Ha Ha Tonka, nested near Vienna, along the Gasconade River. There are no substantiated records since then. It is conceivable that this 
species might reappear in the state, as it is recolonizing areas such as the Appalachian Mountains and the western Great Plains.

\section{Family Alaudidae: lark}

\section{Horned Lark (Eremophila alpestris)}

Status: Common permanent resident in the non-forested sections of the state; observed in much larger numbers during fall and winter.

Documentation: Specimen: male, 15 Dec 1888, St. Louis (USNM 206028).

Habitat: Pastures, harvested and cultivated fields, and on roads, especially after snowfall.

Spring: Most winter residents and migrants have left by the end of Mar, but individuals of non-breeding subspecies have been recorded into early Apr (see below). Breeding birds are displaying as early as late Feb, with eggs often laid by mid-Mar.

Summer: The highest densities are in the heavily-cultivated Mississippi Lowlands, followed by the Glaciated and Osage plains. It is quite local and in low densities in the Ozarks and Ozark Border. BBS data indicate both long-term (1967-2013) and shorter term (2003-2013) annual declines of $3.06 \%$ and $2.55 \%$, respectively. Undoubtedly, the large-scale conversion of pasture/short-grass fields to cropland has had a negative impact on this species.

Fall: By late Sep, migrants appear, e.g., 2, nominate (non-breeding) subspecies, on each of the following dates at Rosecrans Airport by MR: 27 Sep 1991 and 4 October 2015, with numbers increasing through Oct and Nov. Large flocks numbering in the hundreds and low thousands of individuals may be seen by the end of Nov.

Winter: As during the breeding season, the largest numbers are seen in the open areas of the state. High counts: 4,625 (159.4), 19 Dec 2000, Big Oak Tree CBC; 2,000, 19 Dec 2009, Montrose (K. Brink); 1,609 (48.7), 18 Dec 1983, Orchard Farm CBC; 1,300 (136.8), 27 Dec 1980, Big Oak Tree CBC.

Comments: The summer resident birds and the majority of the wintering birds are of the subspecies $E$. a. praticola. The nominate subspecies, E. a. alpestris, is a rare transient and winter resident, although it is likely much more prevalent than the records indicate, as few observers make subspecies determinations. The nominate subspecies has been recorded as early as late Sep (see above) and as late as 4 Apr 1896, St. Joseph (S. Wilson; Widmann 1907). Specimen confirmation or high-quality photographs are needed to confirm the presence of other subspecies.

\section{Family Hirundinidae: swallows}

Purple Martin (Progne subis)

Status: Locally common summer resident. 
Documentation: Specimen: egg set, 21 May 1889, St. Louis (USNM B23913).

Habitat: Mostly breeds in human constructed structures in residential areas; during migration typically associated with water.

Spring: During mild, early springs, males may arrive as early as late Feb in the south, but in most years males are not seen until early to mid-Mar. Peak is during the first half of Apr. Earliest dates: 1, killed by cat, 11 Feb 1937, near Springfield (P. Smith); 2, 16 Feb 2009, Peculiar, Cass Co. (B. Ballenger); 1, 19 Feb 1983, St. Louis (G. Dreyer); 3, 22 Feb 1986, near Forsyth, Taney Co. (PMa).

Summer: Because of nesting structures provided by humans, this species is common across the state in urban and rural residential areas. This was the case even in the late 1890s/early 1900s as Widmann (1907) remarked that it was "common and generally distributed ....in cities and towns and on many farms...; most abundant in old towns along rivers." BBS and BBA data indicate it is most widespread and in higher densities in the non-Glaciated Plains regions. By early Jul huge concentrations, numbering in the thousands of individuals, may be encountered along rivers and lakes. High counts: 30,000, 10 Jul 1965, roost on Missouri River at St. Louis (RA); 16,000, 24 Jul 1963, Busch (JC); 6,000 - 7,000, 11 Jul 1982, Springfield (C. Bonner).

Fall: The huge concentrations observed during Jul may still be present into the second week of Aug, but by late Aug most martins have left the state. Typically, after mid-Sep only a few individuals may be seen in a day, and by mid-Oct it is accidental. High counts: half million, 18 Aug 1981, Springfield (fide C. Bonner); the following are at the same site along the Missouri River at St. Louis by RA: 130,000+, 14 Aug 1965; 90,000 - 100,000, 8-10 Aug 1964. Latest dates: 1, 24 Oct 1983, Tyson Valley Recreation Area, St. Louis (R. Coles); 2, 12 Oct 2008, Swan Lake (SK, M. Carlton); 2, 11 Oct 1931, Forest Park (Barger).

Comments: Prior to European settlement this species would have been much less widespread and common. Presumably it would have been most abundant along the two large rivers, where it would have nested primarily in large, dead trees such as cottonwoods.

\section{Tree Swallow (Tachycineta bicolor)}

Status: Common transient; locally uncommon to common summer resident in the Glaciated, Osage Plains, Ozark Border and Mississippi Lowlands, absent or very local in the heavily-forested section of the Ozarks; accidental winter visitant.

Documentation: Specimen: female, 12 Jun 1926, Buchanan Co. (KU 39157)

Habitat: Usually associated with water. Breeds in holes of tree snags and nest boxes over water.

Spring: During mild early springs, a few individuals appear at the end of Feb, but in most years it is not seen across the state until late Mar. Peak is late Apr/early May. Earliest dates: 1, 10 Feb 1990, Clarence Cannon (N. Rattenborg); 1, 16 Feb 1975, 
Little Dixie Lake, Callaway Co. (L. Falch); several records for the last week of Feb. High counts: 8,827, 26 Apr 2011, Eagle Bluffs (J. Maschmann); 5,000, 30 Apr 2014, Eagle Bluffs (BJ).

Summer: A local breeder, usually in small numbers, in all regions of the state except the heavily-forested part of the Ozarks, where it is absent or very local (BBA, eBird). It can be locally common in such areas as Swan Lake, Fountain Grove, Duck Creek, and Mingo. High counts, both at Otter Slough: 800, 26 Jul 2008 (CB); 750, 31 Jul $2010(\mathrm{CB})$.

Fall: By late Jul/early Aug relatively large concentrations are seen that are composed of breeders and early migrants. Numbers continue to increase through Aug and Sep, e.g., 100,000, 27 Aug 2013, Livingston Co. (SK). Peak is at the end of Sep/early Oct when extraordinary concentrations may be observed. For example, for over a decade an immense annual concentration has been observed in the Pershing SP area. At this site, 9-11 Oct 1997, over a million swallows were estimated with ca. $85 \%$ of them Tree Swallows (m. ob.); 320,000, 18-23 Sep 1998, Pershing SP (SK, TB et al.). It is now regularly seen through the third week of Nov. Latest dates: ad, photos, 11 Dec 2015, Stewartsville sewage lagoon, Dekalb Co. (S. Fitzgerald); 13, 29 Nov 2013, Smithville Lake (MR); several other observations for late Nov.

Winter: In addition to early spring arrivals appearing during the latter half of Feb (see above) there are the following late-lingering fall migrants: ad, 2 Jan 2010, Otter Slough (CB); 2, 18 Dec 2011, Lake Wappapello (CB); 2, 26 Jan 2013, Mingo (CB); and most surprisingly, 2 ( 1 on 20 Dec 2014 at this same site on the Trimble CBC), photos, 5 Jan 2015, Smithville Lake (DW).

\section{[Violet-green Swallow (Tachycineta thalassina)]}

Status: Provisional; accidental fall transient.

Documentation: Sight records only.

Report: There is written documentation of three birds on 7 Oct 1974 at Lewis and Clark SP, Platte Co. (M. Myers). The above report was accompanied by convincing details, but only a single observer was involved, and hence it is treated as provisional. All other reports lack sufficient documentation.

\section{Northern Rough-winged Swallow (Stelgidopteryx serripennis)}

Status: Locally common summer resident.

Documentation: Specimen: male, 4 May 1879, Charleston, Mississippi Co. (MCZ 45035).

Habitat: Primarily nests in holes in banks along watercourses, roadside cuts, cliffs, and very rarely tree cavities. Can be seen anywhere during migration.

Spring: The first arrivals are during the third week of Mar in the south, a few days later in the north. By the end of Apr it is common statewide. Earliest dates: 1, 4 Mar 1991, 
Taney Co. (J. Fitzgerald); 10 Mar 1902, Festus, Jefferson Co. (Widmann 1907); 30, 12 Mar 1999, Four Rivers (A. Mitchell). High counts: 1,000, 28 Apr 2010, Eagle Bluffs (C. Darr); several counts of 500.

Summer: It is most widespread and common along the major rivers. Although it is more local in the Ozarks and Ozark Border, it nests on cliff faces and in trees along rivers in those regions, e.g., 80 (8.3), 26 May 2004, Pulltite, Current River; 80 (6.5), 23 May 2003, Round Spring, Current River (Table 6). It is least common in the Mississippi Lowlands, although presumably it has always been in low density and widely scattered there when this region was once covered with swampy forest prior to the early 1900s. Even in prime breeding sites, such as eroded banks along large rivers, colony size is much less than that of Bank Swallow.

Fall: By late Jul, hundreds to low thousands of individuals may be seen congregating at large pools of water and along rivers. The largest concentrations are observed during the latter half of Sep. Although greatly reduced in numbers, it is regularly seen through mid-Oct, but by the end of the month all have left the state. High counts: 80,000, 1823 Sep 1998, Pershing SP (SK, TB et al.); 7,500, 21 Sep 1985, St. Joseph (FL); 6,000, 21 Sep 1980, St. Joseph (FL). Latest dates: 1, 1 Dec 1963, Browning Lake, Buchanan Co. (FL); 1, 23 Nov 2011, Winfield Lock and Dam (SS); 1, 11 Nov 2017, Binder Lake, Cole Co. (CB et al.).

\section{Bank Swallow (Riparia riparia)}

Status: Locally common summer resident, except the Ozarks where it is rare and very local.

Documentation: Specimen: male, 4 May 1879, Charleston, Mississippi Co. (MCZ 45031).

Habitat: During migration may be seen anywhere, but, as its English name indicates, it nests in banks, whether along eroded river banks or road cuts.

Spring: This is a late-arriving swallow, with the first individuals typically not detected until the beginning of Apr. Peak is in early to mid-May. Earliest dates: 1, 25 Mar 2001, Busch (Y. Homeyer, CM, JM); 1, 30 Mar 1991, Montrose (TB). High counts: 3,000, 6 May 2004, Loess Bluffs (DE); 2,500, 15 May 1966, Loess Bluffs (FL).

Summer: A local colonial breeder along eroded banks of rivers, north of and including the Missouri River, where colony size may reach hundreds of pairs (Table 6). It is more local along the southern portion of the Mississippi River and is quite local in the Mississippi Lowlands. It is least common, and typically only found at recent road cuts, in the Ozarks (eBird; Table 6).

Fall: By mid-Jul large congregations may be seen around water, e.g., 2,000+, $20 \mathrm{Jul}$ 1991, Riverlands (P. Snetsinger, RA); 2,000+, 29 Jul 1973, Loess Bluffs (MR). Large concentrations are seen into early Sep, but by the third week of Sep numbers are drastically reduced and very few are seen during the last week of Sep. High count for late 
in season: 2,000, 21 Sep 1991, Thomas Hill Reservoir (PM, TB). Latest dates: 5, 7 Oct 1974, St. Joseph (FL); 2, 6 Oct 2012, Otter Slough (CB).

\section{Cliff Swallow (Petrochelidon pyrrhonota)}

Status: Locally common summer resident.

Documentation: Specimen: male, 6 May 1879, Charleston, Mississippi Co. (MCZ 44979).

Habitat: Most commonly breeds on bridges, but also on dams, cliffs, culverts, and the sides of buildings.

Spring: Typically the first arrivals are not seen until the second week of Apr, with peak at the end of Apr/early May. Earliest dates: 1, 16 Mar 1963, Rolla (F.Frame); 1, 21 Mar 2008, Table Rock Lake (MR); 2, photos, 23 Mar 2012, Eagle Bluffs (RD, JU). High counts: 8,000, 14 May 2011, Eagle Bluffs (RD); 7,500, 13 May 2006, BK Leach (SS); 5,000, 13 May 2006, Winfield Lock and Dam, Lincoln (SS).

Summer: This highly colonial species is locally common but sparsely distributed throughout all natural regions. Although Widmann (1907) lamented that it had declined as a result of nest destruction by humans, presumably it has increased dramatically from early European settlement via the use of manmade structures that are largely inaccessible, such as bridges and dams. During the Missouri BBA, hundreds of birds were observed at multiple colonies, and BBS data also indicate a dramatic increase.

Fall: By late Jul, large concentrations are seen at water impoundments and along larger rivers. The largest gatherings are observed during the latter half of Aug/early Sep, when thousands may be present at a single site. Most have left by the end of Sep, and it is casual in Oct. High counts: 5,000+, 2 Aug 1964, St. Joseph/Loess Bluffs (FL); 5,000, 10 Aug 1946, Sugar Lake, Buchanan Co. (E. Newton). Latest dates: ad, photos, 1 Nov 2009, Otter Slough (CB); 1, 21 Oct 2007, Ten Mile Pond (CB); 1, 19 Oct 1954, St. Joseph (FL).

\section{Cave Swallow (Petrochelidon fulva)}

Status: Accidental transient.

Documentation: Specimen; see below.

Comments: An ad female, potentially of the Caribbean nominate subspecies ( $P$. f. ful$v a$ ), was found at the Maryville SL, 7 Oct 1977 (Easterla 2008). This record is extraordinary, as the subspecies that is routinely found during summer and fall in the eastern half of the United States is the range-expanding population that breeds in central Texas and northern Mexico (P.f. pallida). The latter subspecies is likely to occur in the state any time from May through Nov. During the breeding season it should be looked for among Cliff Swallow colonies. 


\section{Barn Swallow (Hirundo rustica)}

Status: Common summer resident; accidental winter visitant.

Documentation: Specimen: male, 15 May 1879, Charleston, Mississippi Co. (MCZ 44990).

Habitat: Prefers open country, breeding primarily in buildings, bridges, and other man-made structures.

Spring: The first arrivals usually are not seen until the last week of Mar. Numbers increase with peak in early to mid-May. Earliest dates: 1, 1 Mar 1981, Ted Shanks (BG, S. Sutter); 1, 12 Mar 2016, Arcola, Dade Co. (DBl). High counts: 5,000, 14 May 1967, Loess Bluffs (FL); 5, 000, 14 May 2011, Eagle Bluffs (RD, K. McCommis).

Summer: This is one of the most ubiquitous birds at this season, as it is common and distributed statewide. Both presently and historically, it is least common in the Mississippi Lowlands region.

Fall: Although large concentrations (hundreds, low thousands) may be observed during late Aug/early Sep, extraordinary concentrations have been observed in the latter half of Sep/early Oct. Numbers continue to decrease through Oct, and after the first week of Nov it is casual. High counts: over one million, 2 Oct 2001, south of Pershing SP (m. ob.); 320,000, 18-23 Sep 1998, Pershing SP (SK, TB et al.); 20,000, 28 Sep 2010, south of Pershing SP (KA et al.); 10,000, 4 Oct 1978, with 5,000+ still present on 21 Oct, Loess Bluffs (MR, FL). Latest dates: 4, 19 Nov 2011, Loess Bluffs (LL); 1, 18 Nov 2002, Riverlands (JM, CM); 1, 16 Nov 2015, Smithville L. (SK); 1, 14 Nov 1985, Maryville SL (DE).

Winter: Only two records: 1, 17 Dec 1988, Poplar Bluff CBC (V. Moss); ad, 2 Jan 2010, Otter Slough (CB).

\section{Family Paridae: chickadees, titmouse}

\section{Carolina Chickadee (Poecile carolinensis)}

Status: Common permanent resident in the Ozarks, Ozark Border, Mississippi Lowlands and the southern part of the Osage Plains.

Documentation: Specimen: male, 14 May 1879, Charleston, Mississippi Co. (MCZ 47013).

Habitat: Found in virtually every habitat with trees.

Comments: This chickadee occurs in roughly the southern half of the state, entirely occupying the Ozarks and Mississippi Lowlands regions. In the Ozark Border, it is primarily found south of the Missouri River (see below and eBird). The distribution within the Osage Plains was delineated by Robbins et al. (1986a). As expected, it is least common in the Mississippi Lowlands where woodland and forest are sparse. BBS data are not a good indicator of the relative abundance of the two chickadee species, as chickadees, like a number of other birds such as titmice, nuthatches, Blue Jays, 
and woodpeckers, vocalize comparatively little during the period when those surveys are conducted. $\mathrm{CBC}$ data are a better indicator of how common this species is, and because the high counts on the $\mathrm{CBCs}$ are directly related to effort, the highest absolute counts are on those counts with many observers: 399 (5.4), 27 Dec 2003, Mingo; 364 (4.1), 1 Jan 1990, Springfield.

Data are needed to ascertain if climate change is influencing the distribution of this chickadee. In Apr and May 2007, a few individuals were reported from Cooper and Moniteau cos., away from the Missouri River at the northern edge of the species' distribution (EW); this coincides with a few reports in this area during the BBA. A bird that was north of the species' range was photographed, 16 Dec 2006, near Columbia, Boone Co. (C. Gerhardt, L. Hillman, R. Folgenlogen). There were no reports during the BBA for this county. In the St. Louis area the Missouri River has historically been considered the dividing line between the two chickadees; however, within the St. Louis city limits, south of the Missouri River, birds in Manchester, Forest Park, and Tower Grove have been heard singing intermediate songs (Anderson 1992). More work is needed in central and eastern Missouri to document the precise zone of contact between the two chickadees. Hybridization occurs at the range interface in Missouri (Robbins et al. 1986a, Braun and Robbins 1986).

\section{Black-capped Chickadee (Poecile atricapillus)}

Status: Common permanent resident in Glaciated and Osage plains regions, accidental winter visitant in south.

Documentation: Specimen: egg set, 18 Apr 1889, Kansas City (FMNH 21603).

Habitat: Like the Carolina Chickadee, found in virtually every habitat with trees.

Comments: The approximate location of the contact zone between this chickadee and the Carolina is indicated by eBird data. Delineation of this zone from the Kansas/Missouri border north and east to Henry County was documented in 1978-1980 (Robbins et al. 1986a, Braun and Robbins 1986). Demarcation of the zone east of Henry County is more poorly documented, but see the Carolina Chickadee account for Jefferson City/ Columbia and the St. Louis areas.

Unlike the Carolina Chickadee, which is considered to be largely sedentary, the Black-capped is known to make periodic southward movements during fall and winter. The following reports are of birds well south of the documented breeding area: 2 , at feeder, 29 Nov 1987, Farmington (SD); 2, 31 Dec 1973, Big Oak Tree CBC; 3 Feb 1973, near Springfield (N. Fay et al.). Because of the difficulty in detecting Black-cappeds at this time of year, when they are not singing, it is presumed that they occur more frequently in southern Missouri than the few records indicate. It should be emphasized that song is not a reliable character for species identification, as it is learned, and some individuals, including hybrids, may sing both chickadee song types. Naturally, for a species that is so ubiquitous and common, the highest CBC counts are on those that have more party-hours: 668 (6.61), 21 Dec 1991, Columbia; 624 (6.36), 27 Dec 1987, Columbia. 


\section{Tufted Titmouse (Baeolophus bicolor)}

Status: Common permanent resident.

Documentation: Specimen: female, 9 May 1879, Charleston, Mississippi Co. (MCZ 45794).

Habitat: Common in woodland and forest, less common in open areas with scattered trees.

Comments: The Tufted Titmouse is especially common in the wooded and forested regions of the state; BBS data indicate it is most common in the Ozarks and Ozark Border and least common in the Mississippi Lowlands. Presumably it was less common and more local in the prairie regions of the state prior to European settlement, as Widmann (1907) noted that prior to deforestation of the Mississippi Lowlands it was "much more numerous [in the] southeast than [the] northwest." As with the chickadees and White-breasted Nuthatch, highest totals are recorded on those CBCs with the greatest observer effort, e.g., 500 (4.5), 15 Dec 2012, Columbia; 464 (2.0), 17 Dec 2011, Columbia.

\section{Family Sittidae: nuthatches}

\section{Red-breasted Nuthatch (Sitta canadensis)}

Status: Sporadic, uncommon winter resident; accidental summer resident and summer visitant.

Documentation: Specimen: sex?, 24 Oct 1965, 10 miles west of Maryville (KU 118535).

Habitat: During migration may be seen in any type of woodland and forest, but it primarily inhabits coniferous trees.

Spring: Although there may be movement during Mar and the first half of Apr, it is not as evident as during late Apr through mid-May, when birds are observed even in strictly deciduous woods in areas where they did not winter. These movements are most obvious following winters when major irruptions have occurred. High counts: 19, 28 Apr 2008, Cane Ridge, Mark Twain NF, Butler Co. (MR); 5, 6 May 2000, Hawn SP (BL). Latest dates: 1, 31 May 2011, Columbia (R. Garrett); 1, 26 May 2013, Cape Girardeau (A. Gathman).

Summer: There are two definite breeding records of a pair feeding two young in Kansas City, Jackson Co.: 2-12 Jun 1955 (Schoen 1955); photos, 7-13 Jun 2006 (N. and T. Allen). Another possible breeding event was when two birds were observed from early Jul into Aug 1993 in a pine plantation northeast of Columbia, Boone Co. (O. Fajen et al.). There are the following observations of single birds: 8 Jun 1983, St. Louis (MP); 20 Jun 2006, Forest Park (S. McCowan); 21-22 Jun 1958, St. Joseph (B. Brown); 22 Jul 2000, Raymore, Cass Co. (J. Garrett).

Fall: During years when there is a major influx into the state (every 2-3 years) the first individuals are observed as early as late Aug. In non-irruptive years, birds are 
typically not seen until mid-to late Sep. Earliest dates: 1, 1 Aug 2000, St. Joseph (LL; note, under Summer, a bird seen on 22 Jul same year); 1, 23 Aug 1968, St. Louis (RA). Highest counts: 60+, 6 Nov 1975, St. Louis area (fide JEC); 51 (in 4 hr), 10 Nov 1993, Taney-Christian Cos. (PMa, J. Vickery); 50, 7 Nov 1999, Lake Jacomo (MG).

Winter: There is considerable year to year variation in numbers, ranging from winters when very few individuals are recorded to irruptive years when this nuthatch can be ubiquitous and common in even small pine stands across the entire state. Annual fluctuations in numbers are correlated with pine-cone production in the boreal forest (Bock and Lepthien 1972). High counts: 58, 19 Dec 1981, Kansas City Southeast CBC; 40, 25 Dec 2001, Lake Jacomo (MG); a number of observations of 20-25 birds at a single locality or during a CBC.

Comments: Based on chronology and locations of major fall and winter influxes, it appears that the source of Missouri birds is from the Canadian taiga and not from the Rocky Mountains.

\section{White-breasted Nuthatch (Sitta carolinensis)}

Status: Common permanent resident.

Documentation: Specimen: male, 15 May 1879, Charleston, Mississippi Co. (MCZ 45743).

Habitat: Woodland and forest, but also in sparsely wooded areas such as residential areas.

Comments: Both BBS and CBC data indicate that this nuthatch is most common in the Ozarks and Ozark Border and least common in the Mississippi Lowlands region. $\mathrm{CBC}$ data demonstrate that it has been increasing for the past 50 years, likely, in part, because of an increase in woodland. CBC high counts, all from Columbia: 220 (1.8), 15 Dec 2012; 208 (0.9), 17 Dec 2011; 186 (0.9), 14 Dec 2002.

\section{Brown-headed Nuthatch (Sitta pusilla)}

Status: Extirpated; former accidental transient and presumed permanent resident. Documentation: Specimen; see below.

Habitat: Shortleaf pine (Pinus echinata) stands in the southeastern Ozarks.

Comments: There are only two records of this southern, pine-inhabiting nuthatch in the state. Inexplicably, Woodruff (1908) found a pair at only one site, near Ink, Shannon Co. on 19 March 1907 (AMNH 230089-90). This was unexpected, given that he failed to find the nuthatch at other mature stands of shortleaf pine in Shannon and Carter cos. where he found Red-cockaded Woodpeckers and Bachman's Sparrows. Indeed, Red-cockaded Woodpeckers, which have more specific pine requirements than the nuthatch, persisted in the state until the 1940s. The only other observation is of a single bird observed in St. Louis on 6 May 1878 (Widmann 1907). 
There are other recent extralimital records from adjacent states, including a bird that was photographed and observed by dozens at a bird feeder, 25 Dec - 24 Jan 19978 , in Johnson Co., Kansas, less than a half block from the Missouri border (Thompson et al. 2011). In 2013, this nuthatch was documented breeding in western Kentucky (Renfrow 2013). It may again occur as a vagrant in some of the larger pine stands in Shannon and Carter cos. or even at Hawn State Park, St. Genevieve Co.

\section{Family Certhiidae: creeper}

\section{Brown Creeper (Certhia americana)}

Status: Common transient; uncommon winter resident; casual summer resident in Mississippi Lowlands, accidental in the Ozarks.

Documentation: Specimen: sex?, 3 Mar 1899, Kansas City (KU 39202).

Habitat: All woodland and forest types; recorded breeding in bald cypress (Taxodium distichum) swamps and river bottoms.

Spring: Migration is evident in Mar, with peak in late Mar/early Apr. Many fewer are encountered after mid-Apr, with a few observed into the first week of May. High counts: 20+, 25 Mar 1998, Lane Springs, Phelps Co. (L. Frederick); 20, 22 Mar 2000, Phelps Co. (L. Frederick). Latest dates of apparent migrants: 1, 27 May 1945, St. Louis (JEC); 1, 8 May 2013, Creve Coeur, St. Louis (M. Paradise, JU); 1, 8 May 2004, Excelsior Springs, Clay Co. (E. Stock).

Summer: An easily-overlooked species, especially in summer, that likely breeds annually in several areas of the state. However, there have been only two recent documented breeding records, one in the Mississippi Lowlands and the other in the Ozarks: 13-14 May 1985, Big Oak Tree (Robbins 1986); ad feeding young, 21 Jun 1994, Fort Leonard Wood, Phelps Co. (L. McFarland). In addition, there are the following observations that suggest possible breeding; singing male, 18 May 1987, Big Lake, Mississippi Co. (JHa); 1, 6 Jun 1987, along Meramec River near Pacific (E. Bever); 1, 22 Jun 1992, near Freeburg, Osage Co. (BBA); 1, 30 Jun 1995, Tebo Island, Benton Co. (L. McFarland); singing male in pine stand, 25-26 May 2004, along Current River, below Pulltite Access, Shannon Co. (MR, BB).

Widmann (1907) considered it a regular breeder in the cypress swamps of the Mississippi Lowlands; a testament to that was the collection of multiple egg sets in Stoddard Co. during 1893-5 (FMNH). A pair was found breeding in 1909 in the Missouri River floodplain at St. Louis (Betts 1909). It should be looked for in appropriate riparian habitat along both the Missouri and Mississippi rivers, especially on forested islands in the upper Mississippi above St. Louis.

Fall: Usually not detected until the last week of Sep; in early Oct several/day may be observed. Peak is in mid-Oct. Earliest dates: 2, 28 Aug 2005, BK Leach (JU, JE); 1, 1 Sep 1975, Montgomery Co. (R. Windsor); 1, hit side of house, 3 Sep 1996, Lebanon 
(L. Pannell). High counts: 50+, 27 Oct 1990, McGraws Ford, near Springfield (D. Thurman); 30, 9 Dec 2012, Drury-Mincy CA (JCa).

Winter: As expected, this creeper is most common in the more heavily-wooded parts of the state. There are a number of CBC high counts of 33-35 individuals, with all less than one bird/pa hr average.

\section{Family Troglodytidae: wrens}

Rock Wren (Salpinctes obsoletus)

Status: Casual transient; accidental summer and winter visitant/resident.

Documentation: Specimen: imm male, tower kill, 5 Oct 1972, Maryville (Easterla and Ball 1973; KU 118799).

Habitat: Rock quarries, rock and log piles.

Spring: Two records: 1, 28 Apr 1992, Columbia (T. Menard, M. Guzy, S. Hazelwood); 1, 23-26 Mar 2004, Rich Hill, Bates Co. (Herbert 2004a).

Summer: A single record: 1, singing, 16 Jul 1964, St. Joseph (JHam; Easterla and Ball 1973).

Fall: Including the above tower-kill specimen there are eight records, all involving single birds, between late Sep and early Dec. Earliest dates: 27 Sep 1992, near Diamond, Newton Co. (L. Childers); above tower kill bird; 1, 7 Oct 1984, near Owl's Bend, Shannon Co. (J. Greenberg).

Winter: Four records of single birds, including one of the fall records of a bird overwintering: 23 Jan 1966, near Cedar Creek, Bull Shoals Lake, Taney Co. (N. Fay et al.); videotaped, 18 Dec 1997, below Bagnell Dam on Osage River, Miller Co. (K. Muenks); photos, 23 Jan - 20 Feb 2016, Riverlands (N. Carson et al.); photos, 9 Nov - 30 Jan 2015-6, near Aldrich arm, Stockton Lake (S. and D. Martin et al.).

\section{House Wren (Troglodytes aedon)}

Status: Common summer resident except in the Mississippi Lowlands, where it is uncommon; rare winter resident in Mississippi Lowlands, casual elsewhere.

Documentation: Specimen: male, 4 Oct 1892, Willow Springs, Howell Co. (USNM 136734).

Habitat: Most common in residential areas where nest boxes have been erected, but also at forest and woodland edge.

Spring: Occasionally the first migrants arrive in late Mar, but more often they do not appear until the second week of Apr. Peak is in early May. Earliest dates: 1, 28 Feb 1962, near St. Louis (JEC); 1, 3-4 Mar 2012, Ben Cash (TJ); 1, 4 Mar 2000, St. Louis (K. Thompson, T. Berger). High counts: 78, 1 May 2010, Loess Bluffs (R. Reed); 68, 17 May 2014, Loess Bluffs (JK). 
Summer: The House Wren is much more common and widespread in the Glaciated Plains than in any other region, with the lowest densities in the Ozarks, especially the south-central portion, and the Mississippi Lowlands. It has increased and expanded southward, as Widmann (1907) related that it was common in the north, with its range extending southward along the Mississippi River to St. Genevieve county and on the western side of the state to Jasper Co. Thus, it was rare or absent in the Ozarks and the Mississippi Lowlands regions.

In the late 1930s it still had not been recorded in the Steelville, Crawford Co., or the Lebanon, Laclede Co., areas of the Ozarks (JEC). During the 1960s, however, observers began noting House Wrens in residential areas of the Ozarks, and there was a dramatic increase in that region during the 1970s. It was recorded on the initial (1967) BBS route in Cape Girardeau and Scott cos., where the Ozarks interface with the Mississippi Lowlands. This expansion was also noted at the same time in the Arkansas Ozarks (James and Neal 1986). The BBA effort, 1986-1992, demonstrated that large portions of the Ozarks, especially the south-central part, and the Mississippi Lowlands were still uninhabited by this wren.

Fall: It is quite common through the third week of Sep, and several individuals/day may still be encountered through mid-Oct, but by late Oct it is rare. It is casual during Nov outside the Mississippi Lowlands.

Winter: The vast majority of the records are from the Mississippi Lowlands, where it is a very low-density resident. There are only five records for the northern half of the state and all of those consisted of single day observations, i.e., the birds almost certainly did not overwinter. The maximum number recorded on $\mathrm{CBCs}$ is three individuals on three separate counts in the Mississippi Lowlands region.

\section{Winter Wren (Troglodytes hiemalis)}

Status: Uncommon transient; uncommon winter resident in south, rare in the north.

Documentation: Specimen: male, 3 Oct 1887, Hannibal, Marion Co. (SDNHM 1565). Habitat: Found in moist, dense vegetation, especially along wooded and forested ravines and streams.

Spring: Migrants are apparent by mid-Mar with an increase in numbers until the peak in early to mid-Apr. A few birds are encountered through the first week of May. High counts: estimated 50, 2 Apr 1994, 8-mile float trip, Current River (S. Hazelwood); 13, 1 Mar 2012, Ben Cash (TJ); 11, 24 Mar 2005, Roaring River (MR). Latest dates: 1, 11 May 1996, St. Louis (RK); 2, 9 May 2009, Rock Bridge SP, Boone Co. (PM); 1, 8 May 1993, Cass Co. (E. Johnson, J. Neale); 1 singing, 7 May 1995, Laclede Co. (LR).

Fall: Typically, this secretive wren is not detected until the final week of Sep, with peak usually in mid-Oct. High counts: 15, 26 Oct 2009, Otter Slough (CB); 11, 10 Oct 2016, Ben Cash (MR). Earliest dates: 1, 9 Sep 2005, Burr Oak Woods CA, Jackson Co. (J. Zellmer); 1, 8 Sep 2011, C. Davidson CA, St. Louis Co. (MH). 
Winter: Presumably this wren is most common in the southern third of the state, but the largest $\mathrm{CBC}$ counts are from Columbia, where there is greater observer effort. Not surprisingly, it is more local and in smaller densities in the more open regions of the state, i.e., the Glaciated and Osage plains. CBC high counts: 45 (0.5), 14 Dec 2017, Mingo; 28 (0.4), 31 Dec 2016, Mingo; 24 (0.4), 2 Jan 1988, Mingo; 22 (0.1), 17 Dec 2005, Columbia.

\section{Sedge Wren (Cistothorus platensis)}

Status: Uncommon transient; locally common summer resident in Glaciated and Osage plains, rare elsewhere; rare winter resident in southern Osage Plains and Mississippi Lowlands, casual elsewhere.

Documentation: Specimen: female, 14 May 1907, Spring Valley, Shannon Co. (AMNH 230077).

Habitat: Prairie, wet meadows, sedge dominated marshes, and weedy fields.

Spring: The first arrivals are typically not detected until the last week of Apr with peak during mid-May. Earliest dates in non-wintering areas: 3, 13 Apr 2102, Loess Bluffs (DW); 1, 16 Apr 1977, Loess Bluffs (TB). High count: 37, 12 May 2013, Webster Co. (GSa).

Summer: Two populations breed at different times of the summer. Most birds that are seen in migration breed to the north of the state, but a relatively small number remain and breed during May into early July in the northern tier of counties in the Glaciated Plains. Subsequently, and often associated with the arrival of a mild cold front, large numbers appear en masse beginning in mid-Jul and peaking in early Aug to breed across the Glaciated and Osage Plains as far south as Barton and Jasper cos. At that time, this wren is relatively widespread and can be locally common in prairies, wet meadows, weedy fields, and sedge-dominated marshes. The provenance of birds arriving from the north during Jul and Aug is still unknown (Hobson and Robbins 2009). High counts: 50-70, 16 Aug 1979, Marais Temps Clair (HB, V. Bucholtz); 66, 15 Aug 2017, Shell-Osage (DBl); 58, 15 Aug 2006, Bob Brown (MR); 56, 13 Aug 2003, Bob Brown and Nodaway Valley CAs (MR).

Birds have been heard singing during Jun well south of the normal breeding range, e.g., 2, 9 Jun 1994, north of Galena, along James River, Stone Co. (MR, D. Mead). It is unknown whether such birds are late migrants or extralimital breeders.

Fall: Migrants begin augmenting the late summer breeding population (which cease singing in early Sep) by mid-Sep. Peak of migration is in early Oct. By the end of Nov it is rarely encountered.

Winter: Prior to the mid-1990s there were fewer than ten winter observations for the state, but since that time the species has wintered annually in prime prairie habitat in the southern Osage Plains (Robbins 2008, eBird). During this same period, this secretive wren has been detected more frequently in other areas of the state, primarily in the 
Mississippi Lowlands. There are now seven records for north of the Missouri River, with the northernmost as follows: 1, 21 Dec 1941, Parkville, Platte Co. (H. Hedges); 1, 21 Dec 1980, Trimble CBC; 1, 5 Jan 2011, Lake Contrary (SK, LL); 4, 22 Dec 2016, Loess Bluffs (MR); 1, 24 Dec 2016, near Chillicothe (SK). High counts at Prairie SP: 42 (38 Prairie SP, 4 Osage Prairie CA), 28 Dec 2008 (MR); 29, 17 Dec 1998, Prairie SP (Robbins 2008); high count in Mississippi Lowlands: 8, 1-2 Jan 2009, Otter Slough (CB).

\section{Marsh Wren (Cistothorus palustris)}

Status: Uncommon transient; locally uncommon summer resident in north, accidental in south; rare winter resident and visitant.

Documentation: Specimen: male, May 1879, Charleston, Mississippi Co. (MCZ 45716).

Habitat: Cattail-dominated marshes; in migration may be seen in non-marsh habitat, such as grassy or weedy fields and brushpiles.

Spring: During "early" warm springs the first individuals may arrive as early as late Mar, but typically the first migrants are not encountered until mid-Apr. Peak is in early May. Earliest dates of presumed non-wintering birds: 1, 14 Mar 2007, Otter Slough (J. Bergmann); 2, 16 Mar 1990, Duck Creek (BRe). High counts: 35, 7 May 2017, Eagle Bluffs (CB); 23, 6 May 2013, Cooley Lake (J. Cole).

Summer: As with the Sedge Wren, there are two populations that breed at different times in the northern part of the state. During years when there is sufficient water associated with cattails, a small population breeds in appropriate areas north of the Missouri River during late May through early Jul. Then, often associated with a mild cold front during mid-Jul and early Aug, adults arrive en masse to breed in northern Missouri south to the Missouri River (Robbins 2015b). The only two records of birds breeding south of the Missouri River were documented in Vernon and Iron cos. during the BBA. High count during the late May - early July period: 7 (additional birds at Loess Bluffs on same day), 7 Jun 1976, Bigelow Marsh (MR, DE). High count for mid-Jul - Aug period: 39 singing males, 7-14 Jul 1995, Clarence Cannon (BJ); 34, 8 Aug 2013, Loess Bluffs (MR); 32, 30 Jul 2014, Loess Bluffs (MR).

Fall: Migrants begin augmenting the late summer breeding population (which ceases singing in early Sep) by mid-Sep. Peak of migration is at the end of Sep/early Oct. By the end of Nov it is rarely encountered. High counts: 67, 29 Sep 2007, BK Leach (DR); 45, 1 Oct 1992, Bigelow Marsh and Big Lake SP (MR); 45, 10 Oct 2013, BK Leach (A. Fournier).

Winter: During years when late fall and early winter have been mild, birds linger even as far north as Loess Bluffs. During severe winters, few, if any, overwinter even in the south with the exception of the McBaine water-treatment plant south of Columbia, where a few birds are present even during more severe winters. At this latter site, continual water movement prevents freezing. Six were present all winter at Fountain 
Grove during 2002-3 (SK). CBC high counts: 13, 22 Dec 2016, Loess Bluffs (MR); at least three counts of 11 individuals on the Loess Bluffs and Four Rivers, and 10 on two Columbia CBCs.

Comments: There is unequivocal data that two species of Marsh Wren should be recognized within the United States and Canada (Kroodsma 2005). During the breeding season the two taxa come into contact within the United States in east-central Nebraska (Kroodsma 1988; Robbins 2015a). Although only the Eastern Marsh Wren has been recorded in Missouri, it is highly likely that the Western Marsh Wren occasionally occurs during migration, especially in fall, in the western part of the state. However, because the two species are almost inseparable based on plumage, audio recordings of singing birds or genetic samples will be needed for confirmation.

\section{Carolina Wren (Thryothorus ludovicianus)}

Status: Common permanent resident.

Documentation: Specimen: male, 3 May 1879, Charleston, Mississippi Co. (MCZ 45676).

Habitat: A variety of habitats with woods and relatively dense undergrowth; also in residential areas.

Comments: Abundance varies considerably. Populations are greatly reduced following extended periods of ice and snow cover during the winter. For example, the state population was decimated during the harsh winters of 1976, 1978, and 1983 and again in the winter of 2000-2001 (BBS data). Densities are lowest in the Glaciated Plains, especially the northern half of that region. CBC high counts: 155 (1.1), 18 Dec 2004, Columbia; 154 (1.5), 17 Dec 2005, Springfield; 154 (1.6), 16 Dec 2006, Springfield; 147 (2.1), 3 Jan 2009, Taney Co.

\section{Bewick's Wren (Thryomanes bewickii)}

Status: Uncommon summer resident in the Ozarks and Ozark Border, rare to nonexistent elsewhere; rare winter resident in south.

Documentation: Specimen: female, 11 Jun 1892, Edge Hill, Reynolds Co. (CHAS 16087).

Habitat: Most common around abandoned farm equipment, old automobiles, sheds, etc., and in open, brushy areas at woodland edge.

Spring: Migrants begin to appear in early Mar with peak at the end of Mar/early Apr. Most of the northern Missouri records are between mid-Mar through mid-Apr.

Summer: The bulk of the breeding population is in the Ozarks and Ozark Border, as BBA data indicated that it was most frequently recorded in blocks in the south-central part of the Ozarks. It is local in the eastern part of the Osage Plains and the southern and central portion of the Glaciated Plains. There are no recent records from the northwestern corner, where it was always considered rare, and it is unknown in the Mississippi Lowlands region. Declines were noted in Dallas and Taney cos in the 
early 1990s (PMa, JHy). It was reported from 14, 10, 10, and 9 counties during the summers of 2013-2016, respectively. BBS data indicate both long and shorter term annual declines of $3.3 \%$.

Fall/winter: It appears most have left the state by late Sep/early Oct, and the few individuals that remain are found in the southern third of the state in winter. There are no winter records north of Columbia and St. Louis.

Comments: Prior to European settlement, this wren may have been most abundant in Ozark glades. During Widmann's time the species was considered common and more uniformly distributed across the Ozarks and Ozark Border. Harris (1919b) related that in the Ozarks and Ozark Border "there is hardly a farm house without its Bewick Wren, while in the towns there is one or more in every square." In the Steelville area, Crawford Co., it was "very numerous" in the late 1930s (JEC). Apparently this wren expanded its distribution and became more common when the eastern section of the country, including Missouri, was deforested between the mid-1800s and the early 1900s. Since then much of the forest has regenerated, and Bewick's Wren has disappeared entirely from a large area and has become scarce in other regions. It is on the verge of extirpation as a breeder in Arkansas (James and Green 2009), and, as mentioned above, it is declining in Missouri.

The nominate subspecies, which is redder dorsally than all other populations, is the one that occurs in Missouri. However, just to the west of Missouri, birds become grayish-brown, thus there may be a cline in dorsal coloration from more humid to drier conditions (MR, unpubl. data). Genetic work is needed to ascertain the validity of described subspecies.

\section{Family Polioptilidae: gnatcatcher}

\section{Blue-gray Gnatcatcher (Polioptila caerulea)}

Status: Common summer resident, although more local in the Glaciated Plains and Mississippi Lowlands regions; accidental winter visitant.

Documentation: Specimen: male, 11 May 1879, Charleston, Mississippi Co. (MCZ 47137).

Habitat: Deciduous woodland and forest edge.

Spring: The first are seen at the end of Mar in the south, but typically not until the beginning of the second week of Apr in the north. Peak migration is in late Apr in the south, early May in the north. Earliest dates: 3, 21 Mar 2012, Ben Cash (TJ); three observations for 23 Mar in southern part of state. High counts: 112, 9 May 1992, Taney Co. (PMa, JHy et al.); 60, 18 Apr 1987, along 18-mile stretch of Current River, Shannon Co. (RK).

Summer: Most common in the Ozarks and Ozark Border and least common in the Glaciated Plains and the Mississippi Lowlands. Presumably it was much more com- 
mon in the latter region prior to deforestation. At Swope Park in Kansas City, a comparison of a 1916 vs. 1973 survey revealed a significant decline, from 31 males to 1 (Shirling 1920, Branan and Burdick 1981). The major habitat change between the two surveys was the conversion of upland forest to parkland.

Fall: The majority of the summer residents and migrants leave the state during the last two weeks of Aug, as numbers are greatly reduced in the north even by early Sep. It is rarely encountered after the third week of Sep. Latest dates: 1, 12 Nov 1980, Loess Bluffs (FL); 1, 11 Nov 2015, Forest Park (T. Bailey); 1, 9 Nov 2011, Ben Cash (TJ); 1, photos, 23-24 Oct 2013, Dunklin Co. (TJ).

Winter: There are four records, all recent of single individuals: 30 Dec 1996, Big Oak Tree (NY, I. Domazlicky, D. Wheeler et al.); 29 Dec 2010, near Egypt Mills, Cape Girardeau Co. (B. Gillespie); photos, 5-26 Feb 2012, Mingo (CB, BE); photos, 23 Dec 2017, Shepard of the Hills Fish Hatchery, Taney Co. (GS, B. Brown).

\section{Family Regulidae: kinglets}

\section{Golden-crowned Kinglet (Regulus satrapa)}

Status: Common transient; uncommon winter resident.

Documentation: Specimen: male, 9 Mar 1907, Grandin, Carter Co. (AMNH 230120). Habitat: Primarily seen in evergreens, but also in strictly deciduous woods, especially during migration.

Spring: Migrants begin supplementing the winter population by mid-Mar with peak during the first week of Apr. Virtually all have left the state by the end of Apr. High counts: 29, 29 Mar 2008, St. Francis Co. (CB); several reports/site of 20+ birds in late Mar/early Apr. Latest dates: 1, 29 May 2017, Bois D’Arc CA, Greene Co. (DBl); 1, audio, also 29 May 2017, Reynolds Co. (D. Hollie); 1, 17 May 1983, Van Meter SP, Saline Co. (CH, KH); 1, 11 May 1998, St. Louis (RK).

Fall: The first individuals are seen during the last week of Sep with peak during the second and third weeks of Oct. Numbers remain relatively high through early Nov, but there is a marked drop-off thereafter. Earliest dates: 2, photos, 10 Sep 2016, Tower Grove (CMc, AR); 1, 15 Sep 2007, Platte Falls CA, Platte Co. (L. Gilchrist); 1, 16 Sep 1965, St. Louis (H. Hill). High counts: 200+, 20 Oct 1985, St. Louis (RA); 71, 26 Oct 2008, Otter Slough (CB).

Winter: This species is most common in the southern Ozarks and the Mississippi Lowlands and least abundant in the Glaciated and Osage plains regions. CBC high counts, all Mingo: 125 (2.0), 25 Dec 1995; 120 (2.0), 18 Dec 2010; 86 (1.8), 28 Dec 2002.

\section{Ruby-crowned Kinglet (Regulus calendula)}

Status: Common transient; uncommon winter resident in southern Ozarks and Mississippi Lowlands, rare elsewhere. 
Documentation: Specimen: female, 28 Apr 1907, Spring Valley, Shannon Co. (AMNH 230127).

Habitat: A wide variety of woodland and forest edge, but also in residential areas.

Spring: This is a later migrant than the Golden-crowned Kinglet, with the first migrants appearing in the south during the end of Mar and about a week later in the north. Peak is at the end of Apr. Only a few individuals are observed by mid-May and virtually all are gone by the beginning of the last week of May; there are no Jun records. High counts: 50+, 23 Apr 1993, Huzzah CA (M. Goodman); 48, 21 Apr 2017, St. Louis (CMc, AR); 45, 16 Apr 2008, St. Louis (C. Spahn). Latest dates: 1, 28 May 1986, Knob Noster SP, Johnson Co. (MR); 3, 23 May 1989, Big Lake SP (MR); 1, 23 May 2017, St. Louis (CMc, AR).

Fall: The earliest individuals are not detected until the beginning of Sep, with numbers increasing throughout that month and peaking in early Oct. It remains common through Oct into early Nov. Thereafter smaller numbers are observed through the rest of the season. Earliest dates: 1, 19 Aug 2006, Tower Grove (J. Chain, R. Bodman); 1, 26 Aug 1968, north of Maryville, Nodaway Co. (MR, D. Thate). High counts: 71, 31 Oct 2009, Duck Creek (CB); 49, 18 Oct 2012, Otter Slough (CB).

Winter: The highest densities are in the southern Ozarks and Mississippi Lowlands, with the fewest observed in the northern Glaciated Plains. CBC high counts: 49 (0.9), 17 Dec 2013, Four Rivers; 32 (0.4), 27 Dec 2003, Mingo; 29 (0.4), 2 Jan 2000, Mingo.

\section{Family Turdidae: bluebirds, solitaire, thrushes}

\section{Eastern Bluebird (Sialia sialis)}

Status: Common summer resident; uncommon to locally common winter resident in south, more local and rare in north.

Documentation: Specimen: egg set, 5 Jun 1887, Clay Co. (University of Florida Museum of Natural History 55321).

Habitat: Open areas with scattered trees.

Spring: Migrants begin amplifying the winter population at the end of Feb, when wintering males begin singing and displaying. The bulk of migration is during Mar, with smaller numbers still moving through in early Apr, e.g., 112 (several groups of up to 25 individuals/flock), 4 Apr 1993, near Forest City, Holt Co. (MR). Spring migration is more diffuse, and large flocks typically are not encountered as in fall.

Summer: Ubiquitous throughout the state except in the heavily-cultivated Mississippi Lowlands region. Presumably this species is much more common now as a result of nest- box programs than it was at the time of European settlement, e.g., 1,220 nestlings were banded, summer 2000, along "bluebird" trails in Franklin Co. (T. Winter). BBS data indicate both a long and a shorter-term increase. 
Fall: Migrants are apparent by the end of Sep, with peak during the second and third weeks of Oct. Relatively large flocks, sometimes numbering over a hundred individuals, may be encountered, e.g., 100, 5 Nov 1998, Rock Ridge SP (EW); 90, 19 Oct 2013, Jackson Co. (S. Leonardo). Numbers drop off dramatically by mid-Nov.

Winter: Much more common and widespread in the southern part of the state where fruit-bearing cedars are abundant. CBC high counts: 601 (9.7), 28 Dec 1991, Taney Co.; 577 (6.3), 28 Dec 2013, Taney Co.; 556 (2.8), 16 Dec 2006, Columbia.

\section{Mountain Bluebird (Sialia currucoides)}

Status: Casual transient and winter visitant.

Documentation: Specimen: male, died during ice storm, 2 Jan 1993, southeast of Jamesport, Livingston Co. (KU 86063)

Habitat: Open areas with scattered trees.

Spring: There are four records, all in the west between late Mar and mid-Apr: male, 23-24 Mar 1974, Loess Bluffs (FL et al.; photos, VIREO x08/15/001); male, 25 Mar 2003, Taberville Prairie (P. and J. Moroz); female, 2 Apr 1990, Prairie SP (J. Loomis et al.); male, photos, 10-14 Apr 1990, near Cedar Springs, Cedar Co. (J. Garrett, E. Johnson, I. and R. Rhorer).

Fall: There are only three records, all of single individuals: ad female, photos, 31 Oct 2011, Prairie SP (J. Newman); imm male, photos, 15-19 Nov 2012, east of Warrensburg, Johnson Co. (K. Dean et al.); 1, 13 Dec 1991, El Dorado Springs, Cedar Co (TB).

Winter: There are seven records, all but one first located during the latter half of Dec: male and female, 18 Dec - 13 Jan 1988-9, southwest of Peculiar, Cass Co. (J. Jefferson et al.; Garrett 1989); male, 20-29 Dec 1986, Jefferson City, Cole Co. (m. ob.); 1, 23 Dec 1950, near Independence (H. Hedges: Rising et al. 1978); male, 15 Dec 1990, McBaine, Boone Co. (R. Brundage, G. Perrigo); 1, photos, 17-19 Dec 2004, Big Oak Tree CBC (BE); female, 15 Dec 2012, Grand River CBC (M. McNeely); ad male, 27 Jan 2013, near Salem, Dent Co. (R. Francis).

Comments: Rising et al. (1978) mentioned that a bird was found dead, without date, along Shoal Creek, Clay Co., by Dr. Monahan.

\section{Townsend's Solitaire (Myadestes townsendi)}

Status: Rare and sporadic winter resident in northwest, accidental elsewhere.

Documentation: Specimen: male, 1 Dec 1963, Kansas City (KU 43407).

Habitat: Almost invariably seen at fruiting cedars.

Spring: Presumed wintering birds have typically left by late Feb/early Mar. Latest dates: 1, 18 Mar - 17 Apr 2001, Liberty, Clay Co. (A. Rights et al.); 1, 14 Mar 2006, Binder Lake, Cole Co. (J. Howland, R. George). 
Fall and Winter: There are about 20 records, ranging from late Nov through the end of the winter, with all but four of these from the northwestern corner. Inexplicably, it has not been found in late Oct and earlier in Nov, when surrounding states have a number of records. It also is surprising that it has never been recorded in the Ozarks, where there are extensive cedar groves; this is likely, in part, due to the abundance of habitat coupled with relatively few observers in the region. It is now routinely found at Magazine Mountain in the Arkansas River valley (D. Simmons, eBird). Earliest dates: 1, photo, 30 Nov 2017, Cass Co. (G. Culver); ad male, 1 Dec 1963, Mt. Washington Cemetery, Jackson Co. (Rising 1965; KU 43407). Only record of more than one individual: 2, 10 Dec 1972, Reed CA, Jackson Co. (CH, KH).

The only other records for outside the northwestern corner: 1, 28 Dec - 28 Feb 2005-6, Kirkwood, St. Louis Co. (A. McCormack et al.); 1, 21-23 Dec 2007, Cuivre River SP (SS, E. and B. Schuette); 1, photos, 2-10 Feb 2014, Young CA, Jefferson Co. (JU et al.), and the above Cass Co. record.

\section{Veery (Catharus fuscescens)}

Status: Uncommon transient in east, rare in west.

Documentation: Specimen: male, 9 May 1879, Charleston, Mississippi Co. (MCZ 46949).

Habitat: Woodland and forest, especially in moist valleys.

Spring: With the exception of one observation, there are no records prior to the last week of Apr; peak occurs during mid-May, and a few are seen during the last week of May. It is more frequently seen in the east. At the migrant trap, Forest Park, St. Louis, an average of $0.1 \mathrm{birds} / \mathrm{hr}$ was recorded during 25 Apr-20 May 1979-90 (RK; n=421 hrs). Earliest dates: 1, 16 Apr 1965, Big Lake, Mississippi Co. (JHa); 1, 23 Apr 2017, Hickory Co. (H. Winfrey); 1, 24 Apr 2015, Wire Road CA, Stone Co. (JCa); a few observations for 25 Apr. High counts: 14, 15 May 2014, Big Oak Tree (MR, JB); 11, 23 May 1985, Hayti, Pemiscot Co. (J. Wilson); 10, 13 May 1990, Fort Leonard Wood, Pulaski Co. (J. Keating). Latest dates: 1, 3 Jun 1984, Wallace SP (CH et al.); 1, 30 May 2007, Forest Park (JE).

Fall: As with all the Catharus thrushes, the Veery is much more inconspicuous in fall than in spring, with the majority of birds presumably making an overflight of the state at night. Nocturnal monitoring, using flight calls for identification, is needed during late Aug through Sep to determine the magnitude of birds that pass through the state, especially along the eastern border. A majority of the taiga-breeding birds migrate to the east of the state at this season (eBird).

Of the relatively few fall records, most are from the eastern part of the state from the end of Aug through the first two weeks of Sep, with only one Oct record. Earliest dates: a bird originally banded at St. Louis on 5 May 1929 was found dead there on 30 Jul 1931 (Cooke 1937); 1, photos, 18-19 Aug 2012, Tower Grove (AR); 2, netted and photographed, 23 Aug 2010, Grand Pass (D. Ripper). High count: see below; 3, 1 
Sep 2012, Little Dixie Lake, Callaway Co. (RD). Latest dates: 1, photos, 10-11 Nov 2015, St. Louis (CMc, AR); 4, 1 Oct 2017, Current River SP (MR); 2, 28 Sep 2002, Van Buren, Carter Co. (MR).

Comments: Of the few specimens that exist for the state, all but one can be assigned to the nominate subspecies. However, a tower-kill casualty, 4 Sep 2008, Columbia (WW; KU 116064) may be assignable to the less reddish, duller western subspecies C.f. salicicola.

\section{Gray-cheeked Thrush (Catharus minimus)}

Status: Uncommon transient.

Documentation: Specimen: female, 6 May 1879, Charleston, Mississippi Co. (MCZ 45831).

Habitat: Woodland and forest, but also encountered in residential areas.

Spring: Like the Veery, this thrush typically is not seen until the last week of Apr. Peak of migration is during mid-May, with a few seen through the end of the month. It is much less common than Swainson's, but decidedly more abundant than Veery even in the eastern part of the state. An average of $0.2 \mathrm{birds} / \mathrm{hr}(\mathrm{n}=421 \mathrm{hrs})$ were recorded by RK at Forest Park during 25 Apr-20 May 1979-90. Earliest dates: three observations across three years for $18 \mathrm{Apr}$. High counts: two counts of 15 individuals/site. Latest dates: 1, 11 Jun 2007, Big Oak Tree (WW); 1, 1 Jun 1983, Busch (S. Russell).

Fall: Presumably most pass over the state during the night, with very few encountered during the day on the ground. The majority of the boreal breeders pass to the east of Missouri at this season (eBird). Of the relatively few fall records, most occur during the first half of Sep. There are several observations for the first week of Oct. Reports later in the month have no details or concrete evidence, and some of these were clearly referable to Hermit Thrush. Earliest dates: 1, 30 Aug 2012, St. Louis (PL); 1, 31 Aug 2014, St. Louis (AR, CMc). High counts: 22, tower kill, 19 Sep 1966, Columbia (Elder and Hansen 1967); 10, tower kill, 20-21 Sep 1963, Columbia (George 1963). Latest dates: 1, 7-9 Oct 2015, St. Louis (AR, CMc); 2 records, one with photos, for 6 Oct.

\section{Swainson's Thrush (Catharus ustulatus)}

Status: Common transient.

Documentation: Specimen: male, 7 May 1879, Charleston, Mississippi Co. (MCZ 45841).

Habitat: A wide variety of areas with woods, including residential areas.

Spring: By far the most common Catharus thrush during migration. The first birds typically arrive the last week of Apr, with peak numbers observed in mid-May. A few individuals are routinely seen into early Jun. An average of $2.8 \mathrm{birds} / \mathrm{hr}$ ( $\mathrm{n}=421 \mathrm{hrs}$ ) were recorded by RK at Forest Park during 25 Apr-20 May 1979-90. Earliest dates: 1, photos, 10 Apr 2017, St. Louis (M. Terpstra); several observations for 13-14 Apr. High counts: 201, 9 May 2014, 8-mile stretch of Sugar Camp Scenic Drive (MR, JB); 
several counts of 100+/day during the second week of May from across the state. Latest dates: 1, 9 Jun 1945, Hannibal, Marion Co. (WC); 1, 9 Jun 1997, St. Louis (A. McCormack).

Fall: Although this thrush is encountered much more often at this season than either Veery or Gray-cheeked, it too is only observed in relatively small numbers on the ground during the day. Relatively large numbers may be heard passing overhead at night, associated with cold fronts, from late Aug through the end of Sep. It is routinely recorded into the first week of Oct, with an occasional bird recorded into the third week of Oct. There are no confirmed Nov records. Earliest dates: 1, photos, 21 Aug 2016, Sodalis Nature Preserve, Marion Co. (A. Casey); several records for the last three days of Aug. High counts 94, heard passing over from 5:50 to 6:30 a.m., 1 Oct 2017, Current River SP, Shannon Co. (MR); from tower kills at Columbia: 53, 19 Sep 1966; 53, 22 Sep 1965 (Elder and Hansen 1967). Latest dates: 1, 27 Oct 1975, Busch (JC); 1, 21 Oct 2014, St. Louis (PL, L. Richter).

Comments: Only the olive-backed, boreal-breeding subspecies, C. u. swainsoni, has been definitely recorded in the state, but it is conceivable that one or more of the western, russet-backed C. u. ustulatus subspecies group could occur as a vagrant. The specimen that was reported by Wayne (1926) from Dunklin Co. in May 1896 as representing a russet-backed form cannot be located.

\section{Hermit Thrush (Catharus guttatus)}

Status: Uncommon transient; uncommon winter resident in south and central, rare in north.

Documentation: Specimen: female, 16 Apr 1965, 10 miles south of Gravois Mills, Morgan Co. (KU 118583).

Habitat: A wide variety of areas with woods, including residential areas, but most common in bottomland woodland and forest. In winter it is often associated with various fruiting trees, shrubs, and vines.

Spring: Migrants begin augmenting the winter population by late Mar with peak in mid-Apr. A few are seen into the first week of May. There are no confirmed records after mid-May. High counts: 25, 14 Apr 2003, Tower Grove (J. Berger); 20+, 30 Apr 2006, Tower Grove (JE); 20, 13 Apr 2012, Tower Grove (AR, CMc). Latest dates, all of single birds: 12 May 1990, Tower Grove (BR); 12 May 2011, Tower Grove (DB et al.); 11 May 1988, Forest Park (RK).

Fall: There are a few observations for late Aug, but even throughout Sep it is rarely encountered. In most years, the first individuals are encountered at the beginning of Oct. Peak is during the second and third weeks of Oct. After early Nov it is rare in the northern part of the state. Earliest dates: 1, 18 Aug 2007, Long Ridge CA, Franklin Co. (BR); 1, 23 Aug 2012, St. Louis (PL). High counts: 43, 13 Oct 2012, Tower Grove (AR, CMc); 22, 2 Dec 1997, Davis Memorial Forest, Barton Co. (MR). 
Winter: As a result of relatively warm winters during the past fifteen years, this thrush has increased dramatically and has become more widespread in winter, with birds now overwintering to the northern border. Prior to the early to mid-1990s, the winter population was primarily restricted to the two southern tiers of counties, and during severe winters it was scarce or virtually absent. However, by the winter of 2000-1 birds were being detected at several sites in northern Missouri, such as Kansas City, St. Joseph, and Pike Co. CBC high counts: 37 (0.2), 17 Dec 2005, Columbia; 33 (1.0), 19 Dec 2000, Mingo. High count in north: 5 (0.0), 14 Dec 2009, Loess Bluffs.

Comments: With the exception of two specimens, all records pertain to the eastern $C$. g. nanus group. The only records of non-C. g. nanus group (C. g. guttatus subspecies group, "western lowlands", following Pyle 1997): 16 Dec 1994 and 18 Dec 2010, both at Davis Memorial Forest, Barton Co. (MR; KU 86378; 117243). Limited tracking data demonstrate that birds from as far west as Alberta pass through at least the western part of the state (Alvarado et al. 2014), and given the morphology (plumage and morphometrics) of the above Barton Co. birds, those may have come from that region.

\section{Wood Thrush (Hylocichla mustelina)}

Status: Common summer resident.

Documentation: Specimen: male, 5 May 1879, Charleston, Mississippi Co. (MCZ 45816).

Habitat: Mature, relatively continuous woodland and forest, and, at least for juveniles, also early and mid-succesional oak-hickory and pine forest and mature riparian forest.

Spring: The first arrivals are typically seen by mid-Apr in the south and about a week later in the north. It is common statewide after the first week of May. Earliest dates: 1, 17 Mar 1982, St. Louis (C. Patterson); 1, 3 Apr (no year given), Dunklin Co. (Widmann 1907); 1, 4 Apr 2001, St. Louis (RG). High counts: 26, 27 Apr 2016, Babler SP (CM); 22, 15 May 2015, Babler SP (JM).

Summer: Given this species' propensity for larger tracts of mature forest, it is most common in the eastern Ozarks and is reduced in abundance in the less-forested areas of the state, such as the Glaciated and Osage plains and the Mississippi Lowlands. However, even within the latter areas where there are large tracts of mature forest it is relatively common, e.g., 14 males, 7 Jun 2001, 2.8 miles of trail, Charlie Heath CA (Robbins et al. 2001). Anders et al. (1998) documented that post-natal dispersal by juveniles was into a variety of habitats, including early and mid-successional oak-hickory and pine forest, mature riparian forest, and forest and field edges.

Fall: Migrants are apparent by late Aug, with most appearing to leave then and early Sep. It is regularly recorded through the first week of Oct, but after the second week it is extremely rare. Latest dates: 1, 11 Nov 2010, Wildcat Grade, Newton Co. (JCa); 1, 29 Oct 1963, St. Joseph (FL); 1, 12-21 Oct 2009, Tower Grove (AR, CMc). 


\section{American Robin (Turdus migratorius)}

Status: Common summer resident; common but local winter resident in south, rare to locally uncommon in north.

Documentation: Specimen: sex?, 8 Feb 1883, Carthage, Jasper Co. (BM 2649).

Habitat: Parks, residential areas, edge of woodland and forest. During winter strongly associated with cedar groves.

Spring: Migrants begin arriving by as early as mid-Feb in the south and about a week later in the north. Between mid-Mar and early Apr large numbers, hundreds to thousands of individuals, arrive overnight. By the end of Apr mostly breeding birds are present.

Summer: During this season, the American Robin is one of the most widespread and abundant species in the state. It is ubiquitous in towns and cities and in rural areas. BBS data indicate it is most common in the Glaciated and Osage plains and least common in the Mississippi Lowlands region. An indication of the influence of parklike habitat on the abundance of this species is the comparison between $1916(\mathrm{n}=31$; Shirling 1920) and 1973 ( $\mathrm{n}=197$; Branan and Burdick 1981) at Swope Park, Jackson Co. Between those years, much of the upland woodland was converted to parkland, resulting in a $635 \%$ increase in the species. An overall increase in the abundance of this species is documented throughout the BBS data set.

Fall: Large flocks are observed as early as mid-Sep, but the species is especially numerous during Oct and Nov when immense flocks may be encountered statewide. High counts: 100,000-250,000, late Nov 1988, Taney Co. (PMa, JHy); several counts of $10,000+$ during Nov.

Winter: This species can be locally common anywhere in the state, but it is consistently encountered in huge numbers in the southern Ozarks where there is an abundance of cedar berries. It is much more local during this season, and in some years it can be quite scarce in the Glaciated and Osage plains. There have been a number of roosts that have been estimated into the millions. The estimated 5 million on the 1 Jan 2011 Taney Co. CBC was not only highest for Missouri but was the high for a North American $\mathrm{CBC}$ that winter. Large roosts are frequently encountered in that region. High counts in north: 3.5 million, late Dec-late Jan 1964-5, Washington SP, Washington Co. (Anderson 1965); 1.5 million, 18 Feb 2013, St. Joseph (B. Galliart, LL).

\section{Varied Thrush (Ixoreus naevius)}

Status: Rare transient and winter visitant/resident.

Documentation: Photograph: ad male, 21 Jan 1985, Maryville (Robbins and Easterla 1985; VIREO x05/2/001-2).

Habitat: Most frequently observed at feeders in urban areas, but also associated with conifers. 
Spring: Two records: ad male, 1 Apr 1995, Loess Bluffs (J. Garrent, E. Johnson); ad female, 7 Mar 2011, Kansas City (J. Bair, M. Kelly).

Fall: There are three fall records: sex unknown, 15 Oct 2005, Tower Grove (S. McCowan et al.); ad male, photos, 29 Oct 2007, Columbia (M. Cadwell); ad male, 10 Nov 2010, Springfield (B. and R. Ball).

Winter: There are a total of ten records, all of adult males, that span the entire period in all regions except the Mississippi Lowlands.

Comments: Although the first record for Missouri was not until Jan 1985 (Robbins and Easterla 1985), this species almost certainly occurred in the state long before then, as it was recorded in adjacent states much earlier (Bohlen and Zimmerman 1989, Kent and Dinsmore 1996, Thompson et al. 2011). It has been recorded almost annually in Iowa since 1975 (Kent and Dinsmore 1996). Presumably the preponderance of adult males reported may, in part, be related to how conspicuous and easily identifiable that sex is compared to females. Data have not been published on sex ratios of birds recorded in adjacent states.

\section{Family Mimidae: catbird, thrashers, mockingbird}

\section{Gray Catbird (Dumetella carolinensis)}

Status: Common summer resident; rare winter resident in central and south, casual in north.

Documentation: Specimen: female, 5 May 1879, Charleston, Mississippi Co. (MCZ 45629).

Habitat: Thickets, hedgerows, vine tangles, dense understory of woodland and forest edge.

Spring: At least some Mar records are of presumed wintering birds, with initial migrants typically arriving in mid-Apr in the south and a few days later in the north. High counts: 88, 12 May 2007, Livingston Co. (SK); 57, 14 May 2005, Fountain Grove (SK).

Summer: It is most common in the Glaciated Plains, with the lowest abundance in the Mississippi Lowlands and the southern portion of the Ozarks.

Fall: Migration is apparent beginning in late Aug, but peak is not until the last ten days of Sep and the first few days of Oct. By mid-Oct few are recorded, and it is rare from early Nov through the reminder of the period. High counts, all from tower kills: 300, 6 Oct 1954, Clinton, Henry Co. (M. James); 100, 24 Sep 2009, Morgan Co. (WW); 60, 22 Sep 1965, Columbia; 40, 19 Sep 1966, Columbia (Elder and Hansen 1967). Non-tower kill high count: 58, 21 Sep 2015, Ben Cash (TJ). 
Winter: More frequently recorded in winter during the past two decades. The preponderance of records is of single individuals recorded on CBCs throughout much of the state; however, because of observer effort on CBCs in metropolitan areas, there are as many records for the Kansas City, Columbia, and St. Louis areas as there are from the sparsely populated southern third of the state. Presumably it occurs more frequently in the south where there is a more reliable source of winter fruit.

\section{Brown Thrasher (Toxostoma rufum)}

Status: Common summer resident; uncommon winter resident in southeast, rare elsewhere.

Documentation: Specimen: egg set, 14 May 1883, St. Louis (WFVZ 136598).

Habitat: Thick brushy areas including hedgerows, vine tangles, and woodland and forest edge.

Spring: Migrants arrive by mid-Mar in the south and in late Mar/early Apr in the north. Peak is during mid-Apr in the south and late Apr/early May in the north. High counts: 50, 10 May 1964, St. Joseph/Loess Bluffs (FL); 40, 26 Apr 1964, St. Joseph/ Loess Bluffs (FL).

Summer: Like the Gray Catbird, this species is most common in the Glaciated and Osage Plains. Because of the lack of habitat, it is least abundant in the agriculture-dominated landscape of the Mississippi Lowlands. BBS data indicate both a long- and short-term annual decline of $>1 \%$.

Fall: Migration is evident throughout Sep, with peak during mid-to late Sep. In the north, few remain by early Oct. High counts: 86, 17 Sep 1953, Calvary Cemetery, St. Louis (JEC); 35, 8 Sep 2012, Burr Oak Woods CA (M. Stoakes).

Winter: This is a low-density winter resident in the southernmost counties, especially in the Mississippi Lowlands region. With the exception of extremely harsh winters, a few are also found scattered elsewhere. CBC high counts, both on Mingo: 21 (0.3), 27 Dec 1997; 19 (0.3), 30 Dec 1995.

\section{Sage Thrasher (Oreoscoptes montanus)}

Status: Accidental transient and winter visitant.

Documentation: Photograph; see below.

Records: There are only two records: 1, 2 May 2004, Newton Co. (Herbert 2004b), and a photographed bird that was present 28 Dec - 14 Jan 1966-7, Lampe, Stone Co. (B. Bright; photo in Robbins and Easterla 1992).

\section{Northern Mockingbird (Mimus polyglottos)}

Status: Common summer resident in all regions except the extreme northern tier of counties, where it is more local and uncommon; uncommon winter resident in the south, rare in the north, especially the northern third of the state. 
Documentation: Specimen: egg set, 17 May 1882, St. Louis (WFVZ 101379).

Habitat: Open areas with dense hedgerows, scattered shrubs, and thickets; also suburbia where planted fruiting shrubs are prevalent. Winter territories are centered around clumps of fruit.

Spring: Migration, both spring and fall, is difficult to detect because of the sizeable permanent resident population in the southern half of the state. Thus, movement is most obvious in the Glaciated Plains. Migrants begin to appear by the latter half of Mar and continue through Apr.

Summer: It is most common in the Osage Plains and Ozark Border, and open areas of the Ozarks. It is uncommon and least widespread in the heavily forested part of the southeastern Ozarks and the northern part of the Glaciated Plains. For the period of 2003-2013, BBS data indicate an annual increase of $2.56 \%$ in Missouri.

Fall: See comments under Spring. There is some movement in the first half of Sep, but migrants are most obvious from late Sep through Oct.

Winter: This is a common resident in the southern half of the state, but local and rare in the northern section of the Glaciated Plains at this season. Numbers are reduced statewide during severe winters, especially in years when there has been a poor fruit crop. For example, there was a significant decrease in numbers recorded on CBCs during the three consecutive severe winters in the late 1970s. This again occurred during the mid-1980s. CBC high counts: 108 (1.2), 18 Dec 2004, Springfield; 101 (1.1), 18 Dec 2010, Springfield; 100 (1.1), 28 Dec 2013, Taney Co.

\section{Family Sturnidae: starling}

\section{European Starling (Sturnus vulgaris)}

Status: Introduced; common permanent resident.

Documentation: Specimen: sex?, 27 Jan 1930, Independence (KU 39268).

Habitat: With the exception of heavily forested areas, found in virtually every habitat, but especially around human habitation: cities, suburbs, and farms.

Comments: This species became established in New York City in 1890-1; it was first recorded in Missouri on 28 Jan 1928 (Cooke 1928). The following Jan it was recorded at Patton, Bollinger Co. (A. Vaughn), and by Dec of that same year it was noted at Marionville, Lawrence Co., and West Plains, Howell Co. (Neff 1930). In 1931 it was seen at several additional sites, and in 1932 it bred at Columbia and Forest Park. By the fall of 1934, flocks of over 500 birds were observed at Lebanon, Laclede County. It became established statewide shortly thereafter.

Kessel (1953) documented from banding returns that birds in the Midwest tended to migrate northeastward in spring and southwestward in fall. For example, starlings marked at Independence, Missouri primarily migrated northeastward with returns in 
spring from Iowa, northern Illinois, and Wisconsin. Some birds banded in northeastern Illinois were recovered in Missouri in winter (Kessel 1953).

BBS data indicate that the starling is most common in the Mississippi Lowlands and least abundant in the heavily-forested areas of the Ozarks. Large variation in numbers recorded on $\mathrm{CBCs}$ is the result of the presence/absence of large roosts. High counts on CBCs: 157,184 (1,816.5), 18 Dec 2010, Springfield; 153,149 (3,224.1), 15 Dec 2012, St. Joe; 108,434 (570.7), 14 Dec 2002, Columbia.

\section{Family Bombycillidae: waxwings}

\section{Bohemian Waxwing (Bombycilla garrulus)}

Status: Casual, sporadic winter visitant.

Documentation: Specimen: male, 18 Dec 1976, Maryville (KU 117916).

Habitat: Cedars and fruiting bushes.

Records: This northern waxwing has not been recorded in the state since the winter of 1976-7 when the above specimen was taken and there were "several" observed during Dec and Jan at St. Louis (m. ob.). There have been two major, historical irruptions into the state, the first in the winter of 1919-20 when "flocks aggregating 600 birds" were observed in Holt Co. in the northwestern corner (C. Dankers) and 175 (4 collected) during Jan 1920 in eastern Jackson Co., Kansas City (H. Harris). The other major influx occurred during the winter of 1961-2, when birds were observed at several sites across the northern half of the state. The largest group reported for that flight was 40 at St. Joseph on 11 Feb (FL). However, just across the state line in Johnson Co., Kansas, up to 1,000 birds were seen during Jan 1962 (Rising et al. 1978).

The latest spring reports were after the 1961-2 irruption: 3, 15 Apr, Trimble (FL); 1, 25-26 Apr, St. Louis (G. Wilhelm et al.). The earliest fall/early winter report was of a single bird at Busch on 6 Dec 1973 (m. ob.).

\section{Cedar Waxwing (Bombycilla cedrorum)}

Status: Common transient; local, rare to uncommon summer resident, apparently rarest in the Mississippi Lowlands region; abundance varies considerably in winter depending on fruit availability, but invariably more common in the Ozarks and Ozark Border, where cedars and other fruit-bearing species are more common and widespread.

Documentation: Specimen: female, 28 May 1883, Independence (KU 39261).

Habitat: During migration may be observed virtually anywhere there are trees; in winter primarily seen at cedars and other fruiting trees and bushes.

Spring: Because of the presence of wintering birds and the general erratic nature of this frugivore, movements during the earlier part of the spring are not well defined; however, there is a predictable, well-defined movement during the last half of May into the second week of Jun. During that period a broad movement, at times involving 
hundreds of individuals at a single site, occurs across the entire state. The provenance of the May/Jun birds is unknown but might involve birds that have wintered farther south, such as Mexico and Central America. High counts: 2,100, 10 Mar 1986, Taney Co. (PMa); 2,000, 22 Feb 1948, Springfield (B. Eisenmeyer). High counts for late May/Jun: 1,000, 14 May 2004, along highway 54, Cedar Co. (MG); 250, 2 Jun 2013, Little Creve Coeur (DR).

Summer: A local, rare to uncommon breeder statewide. Pairs are widely scattered, and nowhere have multiple pairs been found breeding at a single locale. As mentioned above, late spring migrants are routinely observed statewide during the first two weeks of Jun; then in late Jul small groups are occasionally observed that likely represent family groups.

Fall: Small groups ( $<30$ individuals) observed during the latter half of Aug are presumed to be migrants. Numbers increase gradually until the end of Sep/early Oct when flocks composed of several hundred individuals are regularly encountered. Although relatively large flocks are observed during the remainder of the fall, they are unpredictable.

Winter: As a result of depending on relatively small fruit, such as cedar berries, this species is erratic and irregular in distribution. Because of the extensive distribution of cedars in the Ozarks and Ozark Border regions, it is more regular and seen in higher numbers there. CBC high counts: 3,469 (23.6), 20 Dec 2008, Columbia; 3,134 (38.2), 27 Dec 2014, Taney Co.; 2,918 (119.1), 3 Jan 1998, Dallas Co.

\section{Family Passeridae: Old World sparrows}

\section{House Sparrow (Passer domesticus)}

Status: Introduced; common permanent resident.

Documentation: Specimen: egg set, 2 May 1890, Kansas City (FMNH 21802).

Habitat: Open areas with scattered trees and bushes, especially in cultivated areas and in towns and cities.

Comments: This weaver finch was first introduced into the United States in 1850 at Brooklyn, New York (A.O.U. Check-list 1983). By 1870 it had reached St. Louis (Lever 1987). Widmann (1907) mentioned that it was present wherever there was human habitation. It continues to be common in open areas of the state, but it has declined across most of the United States, including Missouri, since the mid-1980s. BBS data indicate both long- and shorter-term declines: -5.85 \% (1967-2013), -4.14\% (20032013). CBC data also reflect the decline during the past 30 years.

Based on both BBS and CBC data, it is most abundant in the Mississippi Lowlands and least common in the heavily forested Ozarks. CBC high counts: 4,036 (44.3), 15 Dec 1973, Kansas City; 3,009 (24.0), 20 Dec 1975, Kansas City; 2,900 (96.6), 26 Dec 1965, St. Joseph; 2,727 (24.4), 17 Dec 1977, Kansas City; 2,597 (22.9), 16 Dec 1978, Kansas City. 


\section{Eurasian Tree Sparrow (Passer montanus)}

Status: Introduced; common permanent resident in the St. Louis area northward along the Mississippi River to the Iowa border; casual elsewhere.

Documentation: Specimen: female, 25 October 1875, St. Louis (MCZ 231126).

Habitat: Similar to House Sparrow, but less tied to human habitation than that species. In fall and winter, rural populations tend to gather in flocks in brushy areas and dense weeds.

Comments: In Apr 1870, between 20 and 34 birds were released in Lafayette Park, St. Louis (Widmann 1907; Jones 1934). Its expansion has been much slower and much more limited than that of House Sparrow. By the mid-1930s it had become established in isolated colonies along the Missouri River as far west as Washington, Franklin Co., and during the 1930s it colonized much of St. Louis and St. Charles counties. Along the Mississippi River it was first recorded breeding as far north as Hannibal, Marion Co., in 1946 (Musselman 1950), and the first Iowa record was obtained in 1987, with the first confirmed breeding record there obtained in 1993 (Kent and Dinsmore 1996). It has also spread north and east in Illinois. Along the Mississippi River south of St. Louis, fifteen were noted 27 Jul 2007, Flamm City Access, Jefferson Co. (P. McCaslin), and in 2009 single birds were documented with photos as far south as Jackson, Mississippi Co. (MH), and Bloomfield, Stoddard Co. (CB).

In addition to moving along the Mississippi River, the species was first noted to the west at Columbia, $28 \mathrm{Nov}-16 \mathrm{Dec} 1995$ (G. Ruhr et al.), and nesting was confirmed there in 2007 (M. West, BG). In 2013, it was documented farther west with 1, 13 Nov at Blind Pony CA, Saline Co. (EW), and two were photographed on 8 Mar 2013, Clay Co. (J. Gorski). Most recently, a bird was photographed and present from 28 Nov to 5 Mar 2014-15, in Peculiar, Cass Co. (G. Culver). High counts, all from the former Orchard Farm CBC (all birds were recorded in Missouri, fide RK): 727 (20.1), 3 Jan 2000; 672 (12.6), 1 Jan 2004: 620 (10.5), 1 Jan 2005; 619 (10.8), 1 Jan 2003.

\section{Family Motacillidae: pipits}

\section{American Pipit (Anthus rubescens)}

Status: Uncommon transient; rare winter visitant in south, casual in central and north. Documentation: Specimen: male, 3 May 1961, east of Columbia (KU 118840). Habitat: Flooded fields, mudflats, sod farms, and edges of ponds, lakes, and rivers.

Spring: The initial migrants typically do not appear in the south until early Mar and about a week later in the north. Peak is in early to mid-Apr when large flocks numbering in the low hundreds are observed. It is regularly seen in small numbers through the first week of May but is accidental after mid-May. High count early in season, not wintering birds: 75, 27 Feb 1997, Swan Lake (SK). High counts during peak: 250, 21 Apr 1994, Loess Bluffs (DE); 200+, 7 Apr 1991, Schell-Osage (RF, TB); 200+, 14 Apr 1991, Jasper Co. (TB). Latest dates: three reports across different years for 29 May. 
Fall: Typically the initial arrivals appear in mid-Sep, when most observations are of single birds. By early Oct relatively large flocks are seen, with peak in mid-Oct. During the past two decades relatively large numbers have been seen through the end of the season. Earliest dates: 2, 27 Aug 2006, BK Leach (M. and D. Marjamaa); 9, 4 Sep 2007, Eagle Bluffs (M. McKim-Louder); 1, 7 Sep 1964, Mississippi Co. (JHa). High counts: 375 at sod farm, 1 Nov 2016, Lincoln Co. (T. Parmeter, A. Smith); 250+ at sod farm, 30 Oct 2004, Lincoln Co. (JU); 250, 14 Nov 2009, near Loess Bluffs (SK, LL).

Winter: The early winter status of this pipit has changed dramatically during the past two decades. Prior to 1991, there were only six observations of late fall migrants; now the species is regularly recorded during the last two weeks of Dec into early Jan, with some birds overwintering near the southern border. High counts: 173 (4.5), 17 Dec 2010, Poplar Bluff CBC; 108 (1.2), 14 Dec 2017, Mingo; CBC; 85 (2.9), 16 Dec 2010, Big Oak Tree CBC; 84, 28 Jan 2010, Dunklin Co. (TJ).

\section{Sprague's Pipit (Anthus spragueii)}

Status: Uncommon transient in west, accidental in east; accidental winter visitant. Documentation: Specimen: female, 7 Oct 1893, Carthage, Jasper Co. (BM 5860).

Habitat: Dry, short-grass prairie, especially on hilltops and ridges; harvested soybean fields and pastures.

Spring: Less frequently encountered at this season than in fall in the west; it is accidental in the east. Although a few are seen during the latter half of Mar, most observations are from mid-to late Apr. It is accidental after the first week of May. Earliest dates: 1, 13 Mar 1982, Taberville Prairie (LG); 1, 20 Mar 2008, Prairie SP (MR). High counts, both at Rosecrans Airport by MR: 4, 23 Apr 1996; 4, 16 Apr 1997. Latest dates: 1, 13 May 1986, Taberville Prairie (S. Schoech); 3, 7 May 2005, Livingston Co. (SK). Only definitive record for the east at this season: 1, 3 May 2005, between Riverlands and Confluence SP, St. Charles Co. (S. Mitten).

Fall: Much more frequently observed at this season, with a preponderance of juveniles recorded (MR; KU, ANSP specimen data). The first arrivals appear in mid-Sep with peak in mid-Oct. Birds are regularly encountered through the first week of Nov. Earliest dates, both by MR at Rosecrans Airport: 1, 14 Sep 1999; 2, 18 Sep 2003. Only eastern record (there are records for Callaway and Cole cos.): 2, 19 Oct 1992, St. Charles airport, St. Charles Co. (JVB). High counts: 20, 4 Oct 1991, Rosecrans (MR); 10, 7 Oct 2000, south of Montrose (CH). Latest dates: 2, 2 Dec 2011, Joplin (LH); 1, 26 Nov 1979, Osage Prairie, Vernon Co. (TB); 2, 20 Nov 2001, Prairie SP (MR).

Winter: Only two records: 1, 29 Dec 1992, Monegaw Prairie, near El Dorado Springs, Cedar Co. (MR); 1, 13 Dec 2001, Prairie SP (MR).

Comments: Because juvenile Horned Larks are often misidentified as this species during late summer and fall, any suspected Sprague's Pipit prior to mid-September should be documented with photographs. 


\section{Family Fringillidae: fringillid finches}

\section{Evening Grosbeak (Coccothraustes vespertinus)}

Status: Rare and increasingly irregular winter resident; accidental summer visitant.

Documentation: Specimen: female, 15 Jan 1962, Columbia (MU 2102).

Habitat: Deciduous and coniferous woodland and forest; most frequently seen at feeders.

Spring: Until the 1990s, following winters when relatively large numbers were present, this grosbeak was regularly recorded at non-wintering locales, especially in the Ozarks, during the final two weeks of Apr and the first week of May, e.g., 60, late Apr 1981, Callaway Co. (R. Windsor); 12 (4 males, 8 females), 30 Apr 1978, Big Piney River, Texas Co. (MR). However, it now is recorded with much less frequency and in smaller numbers (see below). Other high counts, both in the first half of Mar 1996 at different sites in Iron Co.: 35 (C. Shannon); 12 (S. Young). Latest dates: 4, at feeder, 13 May 1984, Russellville, Cole Co. (J. Wilson); 11 May 1988, Forest Park (RK).

Summer: Three records of late lingering birds: 1, 13 Jun 1965, near Independence (J. Mitchell); 10+, summer 1986, Farmington; female until 15 Jul 1986, near Farmington (B. Dugal, BRe).

Fall: At least historically, the first arrivals were seen at the beginning of Nov with numbers increasing through the end of the season. Earliest dates: 3, 21 Sep-4 Oct 1903, New Haven, Franklin Co. (A. Eimbeck; Widmann 1907); 7, 7 Oct 1985, Jefferson Co. (MP). High counts: 15-20, 5 Nov 1977, Maryville (DE). The last relatively large movement into the state, small compared to other large flights, was in the fall and early winter of 1995, when small flocks, the largest composed of 13 birds, were reported across the state during the last two weeks of Nov through Dec.

Winter: At least formerly, Evening Grosbeaks were encountered most frequently in the Ozarks, e.g., the highest average number of birds/10 pa hrs on any CBC was the 1.5 on the Sullivan count (1971-89). Formerly, during major irruptions, hundreds of individuals appeared in the state. The following were major "flight" years: 1961-2, 1968-9, 1975-6, 1977-8, 1983-4, and 1985-6. Since 1990, the species has been recorded in the state during only six winters, and with the exception of 1995-6, usually only a total of one or two individuals were recorded during those years. High counts: 75, 13 Jan 1984, Forsyth, Taney Co. (PMa); 70, 20 Feb 1962, Columbia (DE, W. George).

Comments: Since about 1980, this species has suffered severe declines in the eastern portion of its distribution, likely the result of a combination of factors in the taiga such as budworm infestations, forest degradation, and perhaps diseases (Bolgiano 2004, Bonter and Harvey 2008). Based on the correlation of the overall decline of Evening Grosbeaks in eastern North America with that in Missouri, it is presumed that the source of most, if not all, grosbeaks in Missouri has been the taiga and not the Rocky Mountain populations. 


\section{Pine Grosbeak (Pinicola enucleator)}

Status: Casual winter visitant in north, accidental in south.

Documentation: Specimen: female, one of three present, 2 Dec 1962, Kansas City, Jackson Co. (Rising 1965; KU 41460).

Habitat: Usually seen at bird feeders; also at fruiting bushes and trees and in conifers.

Spring: Only two verified records: a late-lingering female in Feb at St. Joseph (see below) and an extraordinarily late record of 9 (3 males, 6 females), 24-25 Mar 1986, near Farmington, St. Genevieve Co. (G. Wylie, BRe, BL, K. Adams).

Fall: Five records, in chronological order: female, 3 Dec 1903, LaGrange, Lewis Co. (Johnson 1908); 1, 20 Nov 1938, between Steelville and Cuba (JEC, JC); the above Jackson Co. specimen record; female, 13-14 Nov 1965, Maryville (Easterla 1966a; KU 117915); male, 18-23 Nov 1972, St. Joseph (FL).

Winter: Six records, in chronological order: male, Dec 1947, Bourbon, Crawford Co. (E. Dunn); male, 18 Jan 1964, St. Louis (JVB); imm male, 8 Jan - 24 Feb 1978, Maryville (MR et al.; photo in Robbins and Easterla 1992); female, 25 Feb 1978, St. Joseph (FL); male, 14 Dec 1980, St. Joseph (FL et al.); male, photos, 20 Dec 1980, Maryville CBC (DE).

Comments: Based on plumage, the four Missouri specimens cannot be confidently identified to subspecies. As with crossbills, there is geographic variation in call notes among Pine Grosbeak populations (Adkisson 1981); thus audio recordings should be obtained. The last Missouri record was in Mar 1986, and since 1985 CBC data demonstrate fewer and much smaller irruptions have occurred; this may be attributed to boreal forest degradation following budworm infestation of the 1970s (Bolgiano 2004). Given that no records have occurred in the state since this decline, it may suggest that the source of Missouri birds is the taiga and not the Rocky Mountains.

\section{Black Rosy-Finch (Leucosticte atrata)}

Status: Accidental winter visitant.

Documentation: Video: ad male, 26 Dec 1989, Montgomery City, Montgomery Co. (G. Banfield; Jacobs 2017).

Habitat: Residential feeder.

Record: This extraordinary record, the easternmost with documentation, was noted at the time as something unusual by the homeowner and was videotaped. The tape was brought to the attention of the MBRC years later, and the location and date were eventually verified (image from video in Jacobs 2017).

\section{House Finch (Haemorhous mexicanus)}

Status: Uncommon permanent resident.

Documentation: Photograph: imm male, 1 Dec 1977 to 23 Apr 1978, St. Louis (B. Whitner; VIREO m0025-01). 
Habitat: Residential areas, open areas with scattered bushes and trees.

Comments: This species is now an uncommon resident in the open areas of the state, with the highest densities in towns and cities. It is least common in the heavily forested Ozarks.

Populations from California, H. m. frontalis, were released on Long Island, New York, about 1940 (Elliot and Arbib 1953). The introduced population initially spread slowly, with an estimated 280 birds observed in the Long Island area in 1951. Based on $\mathrm{CBC}$ data, the population in the eastern half of the United States was estimated to have increased tenfold between 1962 and 1971 (Bock and Lepthien 1976).

It was first detected in Missouri on 23 Nov 1974, when a single bird was photographed at a feeder in St. Louis (B. Erickson). The next record was not obtained until Dec 1977, when an immature remained at St. Louis until Jun 1978 (Jones 1978). In 1983, the first nesting record was established when an adult was observed feeding a fledged young at St. Louis. By the end of 1983, it was detected for the first time in the western half of the state on the Maryville CBC (DE, MR). Breeding was first documented in the Mississippi Lowlands at Cape Girardeau during Jul 1985 (J. Peerman, J. Wilson). By 1986, breeding was suspected or confirmed at Kennett, Charleston, and Columbia, and during the spring of 1988 the first nesting records for the northwestern corner, at St. Joseph and Maryville, were obtained (C. Fisher; DE). The first relatively large concentration was noted in Nov 1987 at St. Louis when a flock of 35 was observed (S. Russell). The first nesting record for Joplin was obtained in 1991, and that fall flocks of 100s were noted in several of the non-Ozark sections of the state. By the spring of 1992 it "exploded in Kansas City (CH) and St. Louis (m. ob.) where numbers are beyond estimating," and nesting reports occurred throughout the non-forested sections of the state that summer. Since the explosive expansion from the late 1980s to the mid-1990s, numbers have significantly decreased and the population appears to have stabilized, although numbers still vary considerably among years on CBCs.

The decline in the Missouri population, as across the entire introduced eastern North American population, may be attributed to the spread of the bacterium Mycoplasma gallisepticum in the early and mid-1990s that caused conjunctivitis (Dhondt et al. 1998). CBC high counts: 779 (8.7), 17 Dec 1994, Springfield; 715 (7.3), 15 Dec 2001, Springfield; 682 (7.5), 21 Dec 1996, Springfield; 546 (6.3), 1 Jan 2001, Springfield; 470 (3.6), 16 Dec 2000, Columbia; 450 (4.0), 16 Dec 1995, Columbia.

\section{Purple Finch (Haemorhous purpureus)}

Status: Common transient; uncommon winter resident.

Documentation: Specimen: male, 15 May 1857, St. Louis (USNM A7040).

Habitat: Woodland and forest, often at bird feeders.

Spring: The winter population begins to be augmented with migrants by the end of Feb, but numbers do not increase dramatically until mid-Mar. Peak is at the end of Mar 
in the south, early Apr in the north. Small flocks ( $<20$ birds $)$ are regularly encountered into early May, with an occasional bird observed into the third week of May. Latest dates, all at feeders: female, 30 May 2008, Rolla, Phelps Co. (L. Frederick); female, 2425 May 2008, Boaz, Christian Co. (M. Owens); female, 25 May 2013, Cole Co. (CB).

Summer: The only record for this season is of an injured bird attending a feeder, summer 2002, Livingston Co. (M. Carlton).

Fall: Initial arrivals are typically not detected until the second week of Oct, and it does not become numerous until the end of the third week of Oct. During most years, it remains fairly common through mid-Nov, but by the end of the month most non-wintering birds appear to have moved south. Earliest dates: imm, photos, 8-13 Sep 2014, Kirksville (PK); imm, 16 Sep 1990, Swan Lake (RF et al.); female, photos, 20 Sep 2014, Weldon Spring (D. and M. Marjamaa); 2, 24 Sep 1979, Cleveland, Cass Co. (C. Swink, M. Stephens).

Winter: Numbers vary considerably from year to year. During "flight" years, large numbers may be seen across the state starting in late Oct and continuing through Apr. In other years, this finch is encountered in much smaller numbers and can be quite patchy in distribution. For example, on the Columbia CBC in 2001 a total of 259 (1.4) were recorded, whereas only $8(0.0)$ were detected the following year on that count. High counts at a single locality: 112, 13 Jan 2004, Macon, Macon Co. (TR); 100+, 21 Jan 2008, Union Ridge CA, Sullivan and Adair Cos. (PW). CBC high counts: 315 (2.5), 15 Dec 2007, Columbia; 259 (1.4), 15 Dec 2001, Columbia; 257 (11.1), 19 Dec 1992, Poplar Bluff.

Comments: A number of high counts for Purple Finch on several CBCs during the 1990s were clearly misidentified House Finches. For example, one west-central CBC in 1995 reported 304 Purple and only 13 House finches. Some of the mid- to late May records may also pertain to House Finches. Bolgiano (2004) suggested that dramatic declines in Purple Finches from 1985 through at least 2002 in eastern North America coincided with the 1970s spruce budworm infestations.

\section{Common Redpoll (Acanthis flammea)}

Status: Rare and irregular winter resident, mainly in the northern half of the state.

Documentation: Specimen: female, 3 Mar 1875, Warrensburg, Johnson Co. (CMSU 34) Habitat: Open areas with scattered bushes and trees, particularly in fields with ragweed and sunflower. Most recent records during the past 25 years are at feeders.

Spring: Following falls and winters when there are relatively large irruptions into the state, some birds remain into Mar. High counts: 70+, 1 Mar 1970, Maryville (MR); 50-70, 4 Mar 1978, St. Charles Co. (F. Hallett et al.). Latest dates: ad female, photos, 21 Apr-8 May 2013, Ashland, Boone Co. (W. Palmer, K. Palmer); 1, 12 Apr 1903, Montgomery Co. (Widman 1907); 8 Apr 1886, Mt. Carmel, Audrain Co. (Mrs. Musick; Widmann 1907). 
Fall: Even during years when there are large influxes, this species is usually not encountered until mid-Nov. Earliest dates: 1, photos, 28-29 Oct 2017, Tower Grove (K. Leeker et al.); 1, at feeder, 2 Nov 1997, St. Joseph (JH); 4 Nov 1885, Mt. Carmel, Audrain Co. (Mrs. Musick; Widmann 1907); 1, photos, 7 Nov 2017, Platte Co. (N. Allen). The report of 300, 20 Nov 1981, Lake Jacomo (Bluebird 49[3]:15), was attributed to the wrong species in that report and should be discarded.

Winter: Most observations are during Jan and Feb. The irruption of 1969-70 was the most spectacular on record. This species continues to be sporadically recorded every few years in small numbers, e.g., eight reports during the winter of 2012-3, and at least ten for the late fall through mid-Jan of 2017-8. High counts: 100+, Dec-Jan 1969-70, 10 miles north of Maryville (MR); 50, 29 Jan 1987, Loess Bluffs (FL); 43, 30 Jan 1970, Maryville (Robbins 1969).

\section{Hoary Redpoll (Acanthis hornemanni)}

Status: Accidental winter visitant.

Documentation: Photographic: see below.

Habitat: Same as Common Redpoll; the three accepted records were all at feeders.

Comments: The winter of 2012-3 witnessed a major movement of redpolls that included two Hoary Redpoll taxa (Brinkley 2013). Two individuals of the $A$. $h$. exilipes subspecies reached Missouri and were documented with photos: 22 Dec 2012, Columbia (B. Mees, J. Mees, A. Robinson); 27 Dec 2012, St. Louis (CA). The third record is a bird photographed at a feeder 14 Feb-11 Mar 2015, Brashear, Adair Co. (Frankie Cuculich, Tony Elliott, PK et al.).

There are two earlier reports. A 1976 Kansas City report of 1-3 birds was revisited in 2013 with the revelation that a more extensive series of photos (at a feeder and in the hand) existed of one or more of those redpolls. The photos clearly indicated that the bird(s) was almost certainly a Common Redpoll. A 1978 St. Louis report lacked documentation.

The MBRC made the above determinations based on widely-accepted criteria for identification of Hoary Redpoll. Recent genetic work on redpolls, however, casts doubt on the validity of Hoary as a species (Mason and Taylor 2015), and it is possible that the Hoary will soon be lumped with Common Redpoll.

\section{Red Crossbill (Loxia curvirostra)}

Status: Rare, almost annual, transient and winter resident; casual summer visitant.

Documentation: Specimen: see below for documentation of various types.

Habitat: Typically associated with conifers, but often at bird feeders with sunflower seeds.

The Red Crossbill complex is one of the most fascinating avian groups in North America because it involves multiple forms (hereafter referred to as types) that are 
highly nomadic and may breed at any time of the year. Based on the landmark work by Groth (1993), our understanding of this complicated and intriguing group was greatly enhanced. Briefly, Groth demonstrated that this complex is likely composed of multiple species that have co-evolved bill size and shape with a pine-cone size. He recognized eight types (10 are now recognized, Benkman et al. 2009, Young and Spahr 2017), each with characteristic morphology (primarily bill size and shape) and vocalizations. All of the forms, except for the birds in southern Idaho (Benkman et al. 2009), appear to be highly nomadic as a result of their reliance on specific pine species. In years when pine seed production is low in a particular type's core area, birds may leave the core area en masse and wander to other parts of the continent in search of food. In 2017, the AOS (Chesser et al. 2017) recognized the resident birds in southern Idaho as a species, the Cassia Crossbill (L. sinesciuris).

Based on specimens and audio recordings, the following types have been documented in Missouri (type names follow Groth 1993, Young and Spahr 2017). Because vocalizations are unique to each type, observers should obtain audio recordings whenever possible.

Type 2. A ponderosa pine specialist with core breeding area in the Rocky Mountains, e.g., this species regularly breeds as close to Missouri as Colorado, Nebraska, Wyoming, and South Dakota; it also breeds in the central and northern Pacific Coast mountains. This is the most common type encountered in Missouri, as it is recorded almost annually. The vast majority of specimens are of this type, and to date all documented summer records are of this type.

Type 3. This is a hemlock/spruce specialist with core breeding area in the Pacific Northwest. It has been documented on the following occasions in Missouri: 3 Apr - 1 May 1907, Shannon Co. (Woodruff 1907: AMNH 229611-14; none in breeding condition); 8 Dec 1965, west of Maryville (DE; KU 118887-8); 30 Dec 1973, Maryville (DE; KU 118888); 26 Nov 1984, southwest of Maryville (MR; KU 86558, 86561, 86563); and several documented (audio recordings, specimens) records across the northern half of the state during Dec-Jan 2012-3 (eBird).

Type 4. Prefers douglas-fir with core breeding area in the Pacific Northwest. Definite proof of this type in the state did not come until November 2017, when a flock of 15 individuals were audio recorded on 10 Nov at Davis Memorial Forest, Barton County (MR; ML 76341401), and a single individual was audio recorded 25 Nov at Jamesport Community Lake, Daviess Co. (MR; ML 76342081, 76341811, 76341791). However, based on measurements, two specimens taken on 26 Nov 1984, southwest of Maryville, Nodaway Co. (MR; KU 86559, 86562) are very likely Type 4.

Type 5. Prefers lodgepole pine with core breeding area in the western United States and Canada. There is a single record, based on audio recording (ML 20363011), 2 Dec 2012, Rocky Ford CA, Boone Co. (RD, N. March). 
Spring: Especially after major irruptions into the state, Type 2 is often recorded into May. Note above that Type 3 has been documented as late as 1 May.

Summer: To date, all summer records are referable to Type 2. There is a minimum of a dozen records scattered across the state with no indication of breeding; most records involve single birds at feeders. However, crossbills should be carefully monitored for breeding, especially after major irruptions, as documented nesting has occurred at least twice in Shawnee Co., Kansas, during Mar 1917 and Feb 1943 (Thompson et al. 2011). High count: 9, type 2, 5 Jun 2013, Marshfield, Webster Co. (GS, L. Chamberlain); 7, at feeder, 28-30 Jul 1972, Kansas City (K. Wahl et al.).

Fall: During non-irruption years, it is typical for crossbills to appear initially in midOct, with peak during Nov and early Dec. During irruption years, birds may arrive as early as late Jul, as occurred across the Great Plains into Missouri in 1996. High counts: 125, 22 Nov 1981, Kansas City (KH); 61, 26 Nov 1969, 10 miles west of Maryville (DE); 54, 9 Nov 1996, Lake Jacomo (PM, BJ, TB).

Winter: Numbers vary considerably from year to year, with no reports during some years. The report in the Bluebird Winter Seasonal Survey of "up to 200", Dec 1981-2, was an error; it should have stated "up to 20 " birds.

\section{White-winged Crossbill (Loxia leucoptera)}

Status: Rare and irregular winter resident; accidental summer visitant.

Documentation: female, 18 Apr 1907, Shannon Co. (Woodruff 1908; AMNH 229633).

Habitat: Primarily found in conifers, especially hemlocks, but also at feeders.

Spring: Following fall and winter irruptions, individuals or small groups remain into the first half of Mar. There are at least five Apr records. Latest dates: imm male, $29 \mathrm{Apr}$ 2002, Excelsior Springs (E. Stock); imm male, present through winter until $20 \mathrm{Apr}$ 2002, Loess Bluffs (DE et al.); above specimen record; 1, caught by cat and released, 17 Apr 1981, Kansas City (M. Jackson; Rising et al. 1978).

Summer: A single record, but note Aug records below for the same year: male, apparently starved, 22 Jul 1969, Maryville (C. Bell; KU 63811).

Fall: With the exception of four records, all observations are from mid-Nov through the end of the period. Earliest dates: imm male, photos, 1-9 Aug 1989, Prathersville, Boone Co. (M. Gutsy, BJ et al.); male and female, 3 Aug 1969, Kansas City (J. Isenberger et al.); female, photos, 23 Aug 1969, Brickyard Hill (F. and H. Diggs); 5, 17 Oct 1972, Table Rock area, Stone Co. (JC). High counts: 14 (4 males, 10 females), 22 Nov 1981, St. Joseph (FL); 13, 30 Nov 1969, Maryville (DE). The fall and winter of 1969-70, 1975-6, and 1981-2 were especially notable for irruptions into the state, with individuals appearing as early as late Jul and Aug (see above) in the 1969 event. 
Winter: Although there are several reports during the past 25 years, there have been no relatively large irruptions since 1981-2. Highest counts during the past 25 years: 8 , 26 Nov 2012, St. Louis (A. Smith et al.); 10, Jan 2013, St. Joseph (m. ob)

\section{Pine Siskin (Spinus pinus)}

Status: Irregular, rare to locally common winter resident; casual summer resident; rare summer visitant.

Documentation: Specimen: female, 13 May 1907, Spring Valley, Shannon Co. (Woodruff 1908; AMNH 229646).

Habitat: Most frequently encountered at feeders and in conifers, but also in fields where observed feeding on seeds.

Spring: There is considerable variation from year to year in the number of birds present and how long they remain. Following winters when there has been a sizable population present, siskins are commonly observed into May. There are many records for the entire month of May, with relatively large numbers occasionally seen until mid-May. High counts for May: 300, 3 May 1970, St. Joseph/Loess Bluffs (FL); 148, 3 May 2013, Holt Co. (DE, TE); 50, 24 May 1966, Lowry City, St. Clair Co. (S. Hilty).

Summer: There are over thirty records, primarily during Jun, across the state. Although there are only seven confirmed nesting records, breeding has been suspected in several other instances. Nest building has been observed as early as the beginning of Apr. The first documented nesting records were at Mt. Washington Cemetery, Jackson Co. in 1960 and 1961 (J. Rising).

Fall: In non-irruptive years, the first individuals are usually encountered by early Oct, with larger numbers (30 birds/day) recorded at the end of Oct. In falls when there are major incursions, it can be abundant and ubitiquous by the end of Nov/early Dec. High count: 1,500, 8 Dec 1965, St. Louis (S. Hanselmann). High count for Sep: 45, 30 Sep 1992, Brickyard Hill (MR).

Winter: During some years the siskin may go unrecorded in the state, but during irruptive years the species may be ubitiquous and observed by the hundreds at a single locality. High counts: 2,000, Dec-Jan 1965-6, St. Louis (RA et al.); 2,000, winter of 1969-70, St. Louis (m. ob.). CBC high counts: 450 (25.0), 20 Dec 1969, Maryville; 330 (2.6), 20 Dec 1975, Kansas City: 324 (6.1), 20 Dec 1997, Kansas City.

\section{Lesser Goldfinch (Spinus psaltria)}

Status: Casual transient and winter visitant.

Documentation: Photograph; see below.

Habitat: All records are of birds at feeders.

Comments: Based primarily on back color in adult males, there are two subspecies recognized within the United States distribution, however, there is considerable variation and there is intergradation (Watt and Willoughby 2014). Adult birds from east- 
ern Colorado and Texas are generally black-backed, whereas birds west of Colorado and New Mexico are mostly green-backed (Watt and Willoughby 2014). Both blackbacked and green-backed birds have been recorded in Missouri.

There are the following nine records, all but one of males that were photographed: black-backed, 4-6 Apr 1971, Kansas City (C. Hicks, N. Edding et al.); black-backed, 18 May 2001, Jackson, Cape Girardeau Co. (C. Casteel); green-backed, 20 Dec 2010, Jackson Co. (R. Simmons); green-backed, 18 Jan - 20 Feb 2012, Humansville, Polk Co. (C. Borntrager et al.); green-backed, 28 Dec - 26 Jan 2012-3, Nixa, Christian Co. (M. Duzan et al.); black-backed, 6 Apr 2013, Peculiar, Cass Co. (G. Culver); greenbacked, 15 Feb - 23 Mar 2014, Stone Co. (E. Berg, GSa); black-backed, 2 Jun 2014, east of Miller, Lawrence Co. (L. Hostetler); imm, 18-20 Dec 2016, Kansas City (E. Walters).

Because all but one record are of the distinctive adult males, it is likely that some female and immature birds are going undetected. There are about 40 records for Kansas, with the majority of the records concentrated in the southwest and south-central portions of the state (Thompson et al. 2011).

\section{American Goldfinch (Spinus tristis)}

Status: Common permanent resident.

Documentation: Specimen: male, 8 May 1857, St. Louis (USNM A07042).

Habitat: Wide range of habitats, but generally open areas with scattered bushes and trees; very common at feeders.

Spring: During Mar and Apr relatively large flocks are seen throughout the state. Migration continues into early May, but thereafter usually only pairs or small groups are seen. High count: 500, 24 Mar 2013, near Winona (W. Wood).

Summer: A common and widespread breeder, with the highest densities in the Glaciated Plains (BBS) and the lowest in the Mississippi Lowlands, where it is much less common than elsewhere (BBS, BBA). This is one of the latest breeders, as most nesting occurs from mid-Jul through the end of the summer.

Fall: Migrants in relatively small flocks are apparent by the end of Sep/early Oct. By the end of Oct, much larger flocks are encountered, and it is common thereafter. High counts: 1,500, 23 Oct 2009, Lincoln Co (JE); 700+, 3 Nov 1991, near McBaine, Boone Co. (S. Hazelwood); 600, 11 Oct 2009, Clarence Cannon (MT).

Winter: Numbers vary considerably from year to year and among regions, with numbers consistently lowest in the Mississippi Lowlands. High counts: 1,000, 13 Jan 2008, Weldon Spring (JU); several reports of 500. CBC high counts: 2,249 (56.9), 1 Jan 2013, Swan Lake; 967 (6.5), 20 Dec 2008, Columbia; 962 (20.4), 29 Dec 1968, Weldon Spring. 


\section{Family Calcariidae: longspurs, Snow Bunting}

\section{Lapland Longspur (Calcarius lapponicus)}

Status: Common transient, uncommon and local winter resident, but rare in the Ozarks. Documentation: Specimen: male, March 1917, Kansas City (KU 39598).

Habitat: Harvested corn and soybean fields, short-grass fields and pastures.

Spring: In late Feb/early Mar, enormous flocks numbering in the thousands may be encountered. After the first few days of Apr only small groups are observed, and it is casual in early May. High counts: 50,000, 4 Mar 1962, Platte Co. (J. Rising, D. Cole); 10,000, 28 Mar 1965, Platte Co. (DE); 8,000+, 9 Mar 1999, Rosecrans Airport (MR, LL). Latest dates: ad male, 9 May 2000, Bradford Farm (PM); 8, 8 May 2010, near Lake Contrary (LL); 1, 6 May 1979, Taberville Prairie (CH, KH).

Fall: This longspur is usually not detected until mid-Oct, with occasional large flocks observed in early Nov. It is common through the remainder of the period. Earliest dates: 7, 2 Oct 2004, Dunn Ranch, Harrison Co. (MR); 1, 5 Oct 1988, near Forest City, Holt Co. (MR); 1, 9 Oct 1977, north of Maryville (MR). High counts: 8,000+, 28 Nov 1984, Bates and Jasper cos. (FL, MR); 5,000, 7 Dec 1991, Barton Co. (TB).

Winter: It is less common at this season than in late fall and early spring. It is most frequently observed in the heavily cultivated areas of the state. Numbers vary considerably from year to year. High counts: 6,000+, 25 Jan 2009, between Bloomfield and Dexter, Stoddard Co. (CB); 5,120, 22 Dec 2010, southern Dunklin Co. (TJ); 4,000, 27 Dec 2008, Liberal CBC.

\section{Chestnut-collared Longspur (Calcarius ornatus)}

Status: Rare transient in west, accidental in east; accidental winter visitant in east.

Documentation: Specimen: male, 26 Mar 1966, near Maryville (KU 118787).

Habitat: Short-grass prairie, pastures, and harvested, cultivated fields.

Spring: There are at least 15 records for this season ranging from late Feb into early May, with peak in late Mar/early Apr, often after strong west or southwest winds. Earliest dates: 1, 22-23 Feb 1957, St. Charles Co. (S. Springer et al.; only eastern record for the season); 1, 15 Mar 2009, Dunn Ranch, Harrison Co. (SK). High counts: 13, males and females, 16 Apr 1997, Rosecrans Airport (MR); two observations of two males. Latest dates: 1, 3 May 1991, Four Rivers (TB) and the above Apr record.

Scott (1879) reported this longspur to be "rather common" in Apr 1874 on prairies near Warrensburg, Johnson Co. Lending support to the species being more common during that period are the two males that were collected at St. Louis on 9 Mar 1875 (Hurter collection; STSC), and the relatively large numbers that were reported in Iowa during the late 1800s (Dinsmore et al. 1984). 
Fall: There are at least eight records, ranging from early Oct through mid-Nov, with most during the third week of Oct. Earliest date: 1, 9 Oct 1998, Rosecrans Airport (MR, CH, P. Dunne). High count: 4, 20 Oct 1994, Rosecrans Airport (P. Lehman). Latest date and only eastern record for this season: ad male, 16 Nov 1991, St. Charles Co. (JVB). Rising et al. (1978) listed two records for the Kansas City region, 3 Oct 1954 and 7 Nov 1953, without further details.

Winter: The only two winter records, unexpectedly, are from the St. Louis area: 1, 14 Feb 1959, St. Charles Co. (A. Bolinger, JEC); probable female, photos, 10 Jan 2010, Columbia Bottom (BRu).

\section{Smith's Longspur (Calcarius pictus)}

Status: Uncommon transient in west, rare in east; rare winter resident in southwest.

Documentation: Specimen: male, 14 Nov 1964, Platte Co. (KU 118311).

Habitat: Short-grass prairie, pastures, and harvested, cultivated fields; at times shows an affinity for patches of three-awn grass (Aristida).

Spring: Much more common in the western half of the state. The first migrants appear at the very end of Feb/early Mar. Peak is typically during the end of the third week and beginning of the final week of Mar, but small groups are seen regularly through mid-Apr. It is accidental in May. Earliest dates of birds observed away from known wintering sites: 1, 18 Feb 1994, Bilby Ranch (KG, BJ); 5, 13 Feb 1999, Maryville (KG). High counts: 5,000-6,000, 21 Mar 1978, east of Columbia (fide BG); 350, 3 Mar 2006, Rosecrans Airport (MR); several reports of 300 individuals/day. Latest dates: Harris (1919b) mentioned that three were collected, apparently no longer extant, on 1 May 1905 in the Kansas City area; 2 females, 1 May 1997, Rosecrans Airport (MR); female, 28 Apr 1984, near Camden, Ray Co. (KH, RF, MM).

Fall: This longspur is typically not recorded until the third week of Oct, with peak in early to mid-Nov. By the end of Nov it is rare, with most observations from prairies in the southern part of the Osage Plains. Earliest dates: 2, 7 Oct 2000, Montrose (CH); 1, 14 Oct 2001, Montrose (MG); 1, 18-19 Oct 1994, St. Charles airport (JVB, RA). High counts: 500+, 14 Nov 1999, near Clearmont, Nodaway Co. (DE); a few counts of 150 individuals during Nov into early Dec.

Winter: Prior to 1991, there were only five reliable observations for this period. However, since that time it has been found to be a regular, low-density winter resident on prairies in the southern part of the Osage Plains. High counts: 150, 15 Feb 1953, Windsor, Henry Co. (K. Miller, D. Jones, JC et al.); 55, 21 Dec 2012, Penn-Sylvania Prairie, Dade Co. (MR); 17, 21 Dec 2009, Taberville Prairie (MR).

\section{McCown's Longspur (Rhynchophanes mccownii)}

Status: Accidental transient and winter visitant.

Documentation: Specimen: female, 16 Mar 1975, Maryville SL (KU 118785).

Habitat: Short-grass fields and harvested, cultivated fields. 
Spring: The above is the only record.

Fall: Single record: 3, male and two unsexed birds, 15 Nov 1986, Taberville Prairie (W. Leitner).

Winter: Two sightings: 2, 28 Dec 1951, near Loess Bluffs (J. Bishop); 1, 11-16 Jan 1979, Busch (P. Snetsinger, C. Patterson, BRu; Rudden 1980).

\section{Snow Bunting (Plectrophenax nivalis)}

Status: Rare winter resident in north, accidental south.

Documentation: Specimen: male, 4 Nov 1974, Maryville SL (KU 118933).

Habitat: Rocky shoreline, such as dams, and harvested cultivated fields.

Spring: There are very few records for the latter half of Feb, with three Mar observations: no.?, 24 Mar 1885, Audrain Co. (Mrs. Musick; Widmann 1907); 6, 3 Mar 1978, near Clearmont, Nodaway Co. (TB); 4, 1-14 Mar 2006, Mozingo Lake, Nodaway County (DE).

Fall: The majority of the records are from early Nov to the end of the period at the Maryville SL. Earliest dates, both at the Maryville SL: 1, 20 Oct 1977 (DE, MR, TB); imm male, 20 Oct 1989 (DE, MR). High counts: 16, 8 Dec 1984, Maryville SL (DE); 12, 11 Nov 1991, Aldrich (JHy).

Winter: A rare and irregular winter resident throughout the Glaciated Plains, accidental elsewhere. During the past several decades, two years stand out with well above normal numbers reported: 1981-2 and 2007-8. Southernmost records: 2-6, 25-26 Jan 1982, Washington Co. (SD et al.); 1, 29 Dec 1958, Springfield CBC. A report in Bluebird for 16 Feb 1997 at Schell-Osage was actually at Riverlands. High counts: 70+, Feb 1982, St. Charles Co. (RK et al.); 60, 1 Feb 1982, near Columbia (TB).

\section{Family Passerellidae: towhees, sparrows}

\section{Green-tailed Towhee (Pipilo chlorurus)}

Status: Casual transient and winter resident.

Documentation: Specimen: 1, 12 Mar 1920, Lexington, Lafayette Co. (C. Salyer; CMC 121).

Habitat: Brushy areas and thickets.

Spring: Three records, including the one above: 1, 1 Mar 1975, Bennett Springs SP (J. Garrett); 1, 23 Mar 1947, near Liberty, Clay Co. (M. Diemer).

Late fall and winter: Five records: 1, 23 Nov - 26 Dec 1952, Busch (JC et al.); 1, at feeder, 18 Dec - 25 Jan 1976-7, Springfield (D. Hagewood et al.); 1, photographed, 3 Feb 1976, Busch (D. Jones et al.); 1, 17-18 Dec 1993, Loess Bluffs (CH et al.); 1, photographed; 9 Dec - 2 Jan 1994-5, Lake Jacomo (J. and E. Zellmer et al.). 
Comments: A bird reported at Busch in Apr 1957 was later retracted (Robbins and Easterla 1992).

\section{Spotted Towhee (Pipilo maculatus)}

Status: Uncommon transient in west, rare in east; rare winter resident (primarily in west).

Documentation: Specimen: male, 1 April 1967, Bigelow Marsh (KU 120841).

Habitat: Brushy areas, thickets, woodland and forest edge.

Spring: As in all seasons, this towhee is much more common in the western half of the state, especially along the western border. Migrants begin supplementing the winter population during the latter half of Mar. Peak is during mid- to late Apr with a few individuals seen into the beginning of the second week of May. Latest dates: female, 22-28 May 2007, Tower Grove (JE, MT); 1, 12 May 2013, Clinton (J. Mosley); 1, 10 May 1964, Cooley Lake (F. Bart).

Fall: The first arrivals appear at the end of Sep with peak in early to mid-Oct. Earliest dates: male and female, 24 Sep 1990, Brickyard Hill (MR); multiple observations for 28-30 Sep, all in the northwestern corner. High counts, both at Brickyard Hill by MR: 4, 30 Sep 1991; 3, 30 Sep 1992.

Winter: A regular, low-density resident in the western half of the state. Typically only single birds are seen in the eastern part of the state. High counts: 25, 26 Dec 1938, Parkville, Platte Co. (WC, H. Hedges et al.); 5, 31 Dec 1995, Farley, Platte Co. (MR).

Comments: There is extensive hybridization at the range interface of the Spotted and Eastern towhees in the central and northern Great Plains. Hybrids are occasionally seen in Missouri.

\section{Eastern Towhee (Pipilo erythrophthalmus)}

Status: Common summer resident except in the Mississippi Lowlands, where it is uncommon. Uncommon winter resident in southeast, rare elsewhere.

Documentation: Specimen: female, 18 Jun 1857, Independence (USNM 8350).

Habitat: Brushy areas, thickets, woodland and forest edge.

Spring: Migrants begin augmenting the winter population in the south by early Mar and in the north by mid-Mar. Peak is in early Apr in the south and about a week later in the north. High counts: 41, 27 Apr 2013, Busch (CM); several reports of ca. 30 from late Apr through the period.

Summer: BBS data indicate that it is considerably more common in the Ozarks and Ozark Border than in the other regions. It is very local and largely absent from the Mississippi Lowlands and in the Missouri River floodplain above the confluence with the Nodaway River. 
Fall: Although numbers are reduced from those present in mid-Sep, it remains fairly common across the northern half of the state until mid-Oct, and in the south until the beginning of Nov. Thereafter, primarily winter residents remain.

Winter: Generally a rare and irregular winter resident in the state except the southeastern section of the Ozarks where it is uncommon, but even in the latter area numbers vary considerably among years with fewer present during severe winters. CBC high counts, all on the Mingo count: 85 (1.4), 18 Dec 2010; 71 (1.2), 25 Dec 1997. Mingo $\mathrm{CBC}$ high counts during the early to mid-1960s are considered erroneous (fide BE).

\section{[Cassin's Sparrow (Peucaea cassinii)]}

Status: Provisional.

Documentation: Sight record only; see below.

Record: A non-displaying bird was observed on 9 May 1987, south of Camden, Ray Co. (RF). Although the bird was not photographed, extensive written details eliminate other sparrows. The MBRC has evaluated this record on two occasions (several years apart) and in both instances has concluded it is a valid observation meeting Provisional criteria.

\section{Bachman's Sparrow (Peucaea aestivalis)}

Status: Very rare summer resident in southern Ozarks, and at least formerly in the Ozark Border. On the verge of extirpation as a breeder.

Documentation: Specimen: see specimens listed below.

Habitat: Overgrown fields with ground cover of grass with scattered scrubs; glades and open pinewoods.

Spring: Now very rare. First migrants arrive at the very end of Mar/early Apr. Most are on the breeding grounds by the end of Apr. Earliest dates: male, 19 Mar 1907, Shannon Co. (Woodruff 1908; AMNH 229745); 1, singing, 29 Mar 1974, McCormack Lake, Oregon Co. (JC); 3, 29 Mar 1976, Caulfield, Howell Co. (R. Tweit). When this species was more common and bred farther north (see below), it was seen in areas where it is now considered a vagrant. For example, there was a minimum of five observations within the city limits of St. Louis up through the mid-1960s. There are two spring extralimital records north of the Missouri River: 1, 20 Apr 1941, near Ashland, Boone Co. (m. ob.); 2, 1-5 May 1889, along Mississippi River, Marion Co. (O. Poling; Widmann 1907).

Summer: Currently this sparrow is on the verge of extirpation as a breeder. Since 2000, almost all records, involving at most a few pairs, have been at glades in Ozark and Taney cos. One exception was of a single bird, 17-26 Jun 2002, Lichen Glade CA, St. Clair Co. (SK).

The following is from Robbins and Easterla (1992): Until relatively recently this sparrow occurred in the Ozarks from the southwestern corner (Lawrence and Barry 
cos.) east to Butler, Wayne, and St. Genevieve cos. and north into the Ozark Border (Morgan and St. Louis cos.). Apparently it underwent a retraction from the northern end of its range and decreased in the core Ozark area since the 1960s and 1970s. Up until the mid-1960s, it bred as far north as western St. Louis Co. (Anderson and Bauer 1968). In Morgan County, adults were observed feeding young on 4 Jun 1968, 10 miles south of Gravois Mills (DE), and it was recorded on BBS route 20 through 1981, but it has not been recorded there since. It appeared to decline during the latter part of the 1970s in the Salem, Dent Co., area (D. Plank, pers. comm.).

In 1976, 21 singing males were recorded in the Mark Twain NF of Taney and Ozark cos. (Hardin et al. 1982). These birds bred in glades with a relatively dense herbaceous cover, but since that time the species has been difficult to find in this habitat. Hardin et al. (1982) suggested that overgrazing and drought have a detrimental effect on the herbaceous growth in the glades, thus depressing sparrow densities. It was recorded in only six BBA blocks, 1986-1992 (Jacobs and Wilson 1997), although it was found at several additional sites in 1992 and 1993 (Chambers 1994). Succession of glades and savannas to woody vegetation has eliminated much potential habitat.

Prior to settlement, it was probably most common in the shortleaf pine area of the state, as Woodruff (1907; AMNH 229740-229747) found it "common throughout the mixed pine and oak woods" in Shannon Co. before this area was entirely logged. The prevention and containment of forest fires in the pine region has been detrimental to this sparrow, as very few mature stands of pine remain where there is not an extensive deciduous understory. Extralimital record during this season: 1, 18 Jun 1966, Cuivre River SP (RA). The virtual disappearance of this sparrow in Missouri is part of a broader pattern throughout the northern and central parts of its former range (Tucker et al. 2004, 2006).

Fall: There are only the following records for Sep: 1, 28 Sep 1996, Toronto Springs CA, Camden Co. (MB, S. Hazelwood, SK, LL, TM, J. Vickery et al.); imm male, 7 Sep 1964, near Salem, Dent Co. (D. Plank, DE; KU 118781); 4, 2 ad and 2 imm, 1 Sep 1947, Bourbon, Crawford Co. (JEC).

Comments: Because of the paucity of records during the past two decades, all observations should be thoroughly documented (photos/audio recordings).

\section{American Tree Sparrow (Spizelloides arborea)}

Status: Common winter resident in the Glaciated and Osage Plains and the Ozark Border; uncommon elsewhere.

Documentation: Specimen: male, 13 Jan 1909, Monteer, Shannon Co. (AMNH 403243).

Habitat: Open weedy fields, hedgerows, and edges of brushy areas.

Spring: The majority leave the state during the first half of Mar. However, it can still be common, even in the southwest, until the beginning of the second week of Apr. In 
most years, it is rare statewide by the beginning of the third week of Apr, and only single birds are casually observed at the end of Apr. Latest dates: 1, 1 May 1939, Webster Groves, St. Louis (JEC); 1, 30 Apr 1974, St. Louis (RA).

Fall: Normally, the first arrivals appear at the very end of Oct. It does not become common until mid-Nov, with numbers increasing into Dec. Earliest dates: 10 Oct 1894, St. Joseph (Widmann 1907); 3, 10 Oct 2013, Lake Jacomo (MB); 2, 11 Oct 2009, BK Leach (MT).

Winter: This is the common sparrow in open country in the Glaciated and Osage plains. It is much less common in the Ozarks and Mississippi Lowlands, where numbers vary considerably from year to year. CBC high counts: 5,018 (77.8), 2 Jan 1955, Weldon Spring; 3,587 (27.5), 17 Dec 1983, Kansas City Southeast; 3,452 (63.9), 30 Dec 1956, Weldon Spring; 2,500 (53.1), 29 Dec 1968, Kansas City Southeast; 2,479 (86.9), 30 Dec 1995, Swan Lake.

\section{Chipping Sparrow (Spizella passerina)}

Status: Common summer resident in Ozarks; more local but still common elsewhere; rare winter resident in Ozarks and Ozark Border, casual elsewhere.

Documentation: Specimen: male, 8 May 1879, Charleston, Mississippi Co. (MCZ 44593).

Habitat: Most common in open pine stands, but also found in entirely open deciduous areas; also common breeder in residential areas, especially with planted conifers.

Spring: Migrants begin supplementing the low-density winter population in the south by early Mar, but not until the end of Mar/early Apr in the north. Peak is in early Apr in the south, but not until late Apr in the north. Relatively large migrating flocks are seen through the second week of May. Earliest arrivals north of wintering areas: 10 Mar 1887, St. Louis (Widmann 1907); 27 Mar 1963, St. Joseph (FL; n=32 years, 19561987). High counts: 155, 3 May 2013, Loess Bluffs (DE, TE; Easterla 2013); 141, 8 May 2010, Fountain Grove (J. Newman); 125, 20 Apr 1988, Tower Grove (S. Russell).

Summer: It is most common in the Ozarks, especially in the shortleaf pine region (fig. 2), and Ozark Border. It is much less common in open country of the Glaciated and Osage plains, but even in those regions it is common in towns and cities, in part because of conifer plantings. It is rare and very local in the agriculture-dominated Mississippi Lowlands. Widmann (1907) related that it was common in the cypress swamps of the latter region. BBS data indicate an annual increase of $3.80 \%$ for the 2003-2013 period.

Fall: By early Oct relatively large flocks are not uncommon, and the peak of the migration is during the second and third weeks of Oct. By early Nov numbers are greatly reduced. High counts: 80, 21 Oct 1991, Truman Dam (PM, TB); 65, 31 Oct 2009, Duck Creek (CB); several observations of 50 individuals/day. 
Winter: The status of this sparrow has changed considerably since 1990, when there were only eight definitive winter records for the state (Robbins and Easterla 1992). Between the winters of 1992-3 and 2013-4, there were about 30 reports, many involving multiple individuals. Several of these records involved multiple individuals as far north as Columbia and St. Louis. The northernmost record for this period was a single bird on 11 Feb 2011, Buchanan Co. (LL). High counts: 17, 4 Feb 2012, Dexter, Stoddard Co. (CB); 9, 5 Jan 2009, Shrewsbury, St. Louis Co. (JE); 7, 26 Dec 2005, near Poplar Bluff (T. and L. Mills, A. Trombley).

\section{Clay-colored Sparrow (Spizella pallida)}

Status: Uncommon transient in west, rare in east; accidental winter visitant.

Documentation: Specimen: male, 21 April 1961, Columbia (KU 118792).

Habitat: Weedy fields, hedgerows, and open parkland.

Spring: This sparrow is much more common and regular in the western half of the state. It is not recorded every spring in the east, and nearly all the eastern observations are of single birds. In the west, it first appears during the final week of Apr and peaks during the second week of May. Earliest dates: 1, 4 Apr 2001, Columbia (EW); singing male, 6 Apr 2001, Ashland, Boone Co. (PM); 1, 11 Apr 1976, St. Joseph (FL). High counts: 137, 4 May 2013, Loess Bluffs (DE, TE, PK; Easterla 2013); 28, 11 May 1996, Loess Bluffs (DE et al.); 27, 5 May 2013, Loess Bluffs (C. Carr). Latest dates: 1, 22 May 2009, Bigelow Marsh (MR, BJ, PM); 2, 19 May 1965, Loess Bluffs (DE).

Fall: More frequently encountered in the eastern half of the state during this season, but seemingly encountered in smaller numbers in the west as compared to spring. Typically, the first individuals begin arriving during the last week of Sep. Peak is in mid-Oct. It is accidental after the first week of Nov. Earliest dates: 1, 4 Sep 2010, Chillicothe (SK); 1, 7 Sep 2016, Raytown, Jackson Co. (J. Mosley); 2, 9 Sep 2007, Riverlands (DR); 2, 9 Sep 2009, Thompson River Wetlands (SK). Highest counts: 10, 15 Oct 2010, Warrensburg (L. Olpin); several counts of 8 in the western half of the state. Latest dates: 1, 22 Nov 1997, Liberty, Clay Co. (MM); 1, 21 Nov 2007, Danville CA, Montgomery Co. (EW).

Winter: There are three winter records: 1, 22-26 Dec 1985, Loess Bluffs CBC (TB, MR, DE et al.); 1, 29 Dec 1963, Weldon Spring CBC; 1, 28 Feb 2008, Cedar Hill, Jefferson Co. (W. George).

\section{Field Sparrow (Spizella pusilla)}

Status: Common summer resident; uncommon winter resident in Ozarks, Ozark Border and Mississippi Lowlands, rare elsewhere, especially in the north.

Documentation: Specimen: male, 14 Jun 1892, Edge Hill, Reynolds Co. (CHAS 18466).

Habitat: Overgrown fields with scattered trees and hedgerows, and woodland and forest edge. 
Spring: Migrants begin supplementing the winter population in the south in early Mar, but birds do not appear in the north until the end of the month. Peak is during late Mar in the south and early to mid-Apr in the north. High counts: 52, 12 Apr 2012, Maintz Wildlife Preserve (MH); a few daily counts of 45.

Summer: This is the most common and widespread sparrow in the state at this season. It is most common in the Ozarks, Ozark Border, and Osage Plains, and least abundant in the Mississippi Lowlands (BBS data). Some of the highest densities are in the cedar glades of the White River section of the Ozarks. BBS data indicate a decline of $1.08 \%$ annually for the 2003-2013 period.

Fall: Territorial birds continue to sing through mid-Aug. Presumably there is movement from early Sep through at least early Nov, but data are too few to discern a migration peak.

Winter: Most wintering birds are found in the Mississippi Lowlands and the southern and eastern sections of the Ozarks and Ozark Border (eBird). It is quite rare north of southern Kansas City, Columbia, and St. Louis, with typically no more than a couple of individuals sparingly encountered. It is also rare and local in the northern and western portions of the Osage Plains (see Four Rivers CBC). CBC high counts: 378 (6.4), 2 Jan 1988, Taney County; 338 (5.7), 28 Dec 1991, Taney Co.; 240 (4.0), 27 Dec 1986, Taney Co. High count in north: 3, 28 Dec 1996, Swan Lake (SK, TM, D. Fitchett). Mingo CBC high counts during the early to mid-1960s are considered erroneous (fide $\mathrm{BE})$.

Comments: In winter, American Tree Sparrows are frequently misidentified as Field Sparrows; among other questionable reports, there routinely have been erroneous CBC Field Sparrow reports in the Osage Plains region.

\section{Vesper Sparrow (Pooecetes gramineus)}

Status: Uncommon transient; rare to locally uncommon summer resident in the Glaciated Plains, especially in the northern portion of this region; rare winter resident in south, casual in north.

Documentation: Specimen: female, 24 Mar 1926, Fayette, Howard Co. (UMMZ 106589).

Habitat: During migration found in bare and overgrown fields and along hedgerows. During the breeding season found in short-grass fields and pasture with scattered trees and at edge of cultivated fields.

Spring: The first arrivals appear by the second week of Mar at the southern border and by the final week of Mar in the north. Peak is during the first week of Apr. Typically, only breeding birds remain by the beginning of May. Earliest dates: 2, 7 Mar 2004, Eagle Bluffs (KM); 1, 7 Mar 2015, Castlewood SP (J. Lidgus). High counts: 65, 30 Mar 1991, Schell-Osage (PM, TB); 50, 4 Apr 1965, near Salem, Dent Co. (D. Plank); 50, 6 Apr 1980, St. Joseph/Loess Bluffs (FL). 
Summer: This is a low-density breeder north of the Missouri river, with the highest concentrations in the northern two tiers of counties. For example, it was recorded on 16 of 18 BBA blocks from Andrew east to Sullivan cos. (JH), and a dozen territorial males were found in a single Harrison Co. block (TM, pers. comm.).

At least formerly, it bred in the Ozark Border and the extreme northern edge of the Ozarks and Osage Plains. In 1874, it bred at Warrensburg (Scott 1879), and up until the late 1950s there were breeding records as far south as Crawford Co. (Bourbon, Steelville; JEC). In addition, breeding was documented in 1944 in St. Louis, Franklin, and Washington cos. (WC, E. Knapp). Since the mid-1970s, there have been several reports of singing birds south of the Missouri River (on BBS routes 3 and 21, and 3 sites during the BBA), but breeding has not been confirmed in those areas.

Fall: There are several late Aug/early Sep observations, but all are from areas where the species might have bred. Obvious migrants begin to appear at the end of Sep and peak during the last half of Oct. It remains relatively common through early Nov, with a sharp drop in numbers thereafter. It is rare but regular until the end of Nov. High counts: 14, 3 Nov 2013, Taberville Prairie (PK); 10, 4 Nov 2013, Prairie SP (S. Nixon).

Winter: Although not as dramatic as for the Chipping Sparrow, the increase in winter records for the Vesper Sparrow during the past twenty-five years has been significant. Prior to the winter of 1991, there were about eleven winter reports, all of single birds (Robbins and Easterla 1992). Since then there have been nearly 20 records, several involving more than a single bird, with the majority of records in the southern half of the state. High counts: 14, in two groups, 1 Jan - 27 Feb 2011, near Warbler Woods CA, Dunklin Co. (TJ); 9, 9 Dec 2009, southern Dunklin Co. (TJ); all other high counts are of 2 individuals.

\section{Lark Sparrow (Chondestes grammacus)}

Status: Uncommon summer resident; accidental winter visitant.

Documentation: Specimen: sex?, 22 May 1885, Cliff Cave, Scott Co. (FMNH 4902). Habitat: Cultivated fields, pastures, short-grass fields, and woodland edge.

Spring: It is casual during the last ten days of Mar and early Apr, with first arrivals typically appearing the second week of Apr. Peak is in early May. Earliest dates: 1, 12 Mar 2012, near Rogersville, Webster Co. (AK); 2, 16 Mar 2007, Pettis Co. (EW); 2, 17 Mar 2015, Webster Co. (GSa et al.). High counts: 400+, major fallout along road and adjacent fields, 16 Apr 2013, just off highway 6, near Gallatin, Daviess Co. (TM); 150, 10 May 2008, Livingston Co. (SK et al.); 60, 12 May 2005, Livingston Co. (SK); 58, 4 May 2013, Loess Bluffs (JU).

Summer: The Lark Sparrow is most common in the western half of the state, especially in the western Glaciated Plains, the Osage Plains, and the more open western Ozarks. It is least abundant in the heavily forested southern and eastern Ozarks and the Mississippi Lowlands. 
Fall: This sparrow is rarely seen after mid-Sep. It is casual after early Oct and accidental during Nov. Latest dates: 1, 27 Nov 2013, near Rogersville, Webster Co. (AK); 1, 3 Nov 2012, near Rogersville, Webster Co. (AK); 1, 2 Nov 1938, Lebanon, Laclede Co. (P. Draper).

Winter: Only two records: 1, 27 Dec 1986, northwest of Lowry City, St. Clair Co. (S. Hilty); 1, 24 Feb 2009, near Stella, Newton Co. (LH).

\section{Black-throated Sparrow (Amphispiza bilineata)}

Status: Accidental winter visitant/resident in northwest.

Documentation: Photograph; see below.

Winter: Both records are during late fall and winter in the northwest: ad, photos, 15-20 Jan 1993, west of Skidmore, Atchison Co. (K. Goslee, DE, et al.; Easterla and Goslee 1994); ad, photos, 3 Dec - 16 Jan 2009-10, near Savannah, Andrew Co. (D. and P. Rush et al.).

\section{Lark Bunting (Calamospiza melanocorys)}

Status: Casual transient with most records from the northwest; accidental summer resident in northwest; accidental winter resident.

Documentation: Specimen: male, 25 May 1971, west of Spickard, Grundy Co. (KU 65112).

Habitat: Stubble fields, lightly grazed pastures, and hedgerows.

Spring: There are nine records during this period, with six from the northwest corner. Most of the records are during late May. Records outside the northwest corner include: 1, 12 May 1950, near Clinton, Henry Co. (S. Hughes); female, 24 May 1993, near Salem, Dent Co. (D. Plank); male, photos, 1 Apr 2012, Taberville Prairie (C. Hensley, J. Rhoades).

Summer: The Lark Bunting is a sporadic breeder at the eastern edge of its range, with periodic expansions well outside its normal distribution. Such an event occurred in 1969, when two small colonies were detected in northwestern Missouri (Easterla 1970a). One colony, consisting of at least twelve birds (10 males, 2 females), nested near Lake Contrary. At that colony, birds were seen from at least 2 Jun through $1 \mathrm{Jul}$ (J. Farlie et al.). The other colony, consisting of about twelve birds, was located on 5 Jun north of Tarkio, Atchison Co. (9 males, 3 females; nest photographed; DE; KU $118710-1 ; 118872-3 ; 120838)$. A single male was also seen on that same day, about 2 miles east of the Tarkio colony (DE; KU 121526). The only other record for this period is of a female, 14 Jun 1964, northwest of St. Joseph (FL, S. Rositsky et al.).

Fall: Five of seven records for this season are during the first half of Sep. Earliest dates: male, 13 Aug 1920, Lexington, Lafayette Co. (J. Salyer; CMC 113); 2, one definite male, 10 Sep 1984, west of Forest City, Holt Co. (MR; KU 118913). Two of 
the fall records are from the eastern half of the state: 1, 5 Sep 1983, St. Charles Co. (C. Spener et al.); female or imm male, photos, 4 Dec 2004, Weldon Spring (BR et al.).

Winter: There are two records: male, 19 Jan - mid-Feb 1997, southern Daviess Co. (RM, P. Crisp, PM et al.); 1, 17 Jan - 8 Feb 2007, Oak Ridge CA, Stoddard Co. (BRe, BL; Reeves 2007).

\section{Savannah Sparrow (Passerculus sandwichensis)}

Status: Common transient; casual summer resident and visitor; uncommon to locally common winter resident in south, rare in north.

Documentation: Specimen: male, 9 Oct 1893, Carthage, Jasper Co. (BM 6161).

Habitat: Wide variety of grassland habitats.

Spring: Migrants begin augmenting the now-sizeable winter population by early Mar in the south and mid-Mar in the north. Peak is in mid- to late Apr, but it remains common through the first week of May. Small numbers are regularly seen into the last week of May. High counts, both at Rosecrans Airport: 250, 1 May 1997 (MR); 220, 1 May 2011 (MR, JK).

Summer: Although there are a number of reports of individuals during the summer, the breeding status of this sparrow is uncertain. Jacobs and Wilson (1997) listed three confirmed, six probable, and 24 possible records during the 1986-1992 BBA, but apparently none was actually confirmed and there was no follow up on any of the records (BJ, pers. comm, Jun 2014). Nevertheless, extraneous to the BBA effort, a pair was observed building a nest, 15-20 May 1992, Clarence Cannon NWR, by a reliable observer (JVB). Of the few other valid summer records during the past fifty years, almost all involve single individuals with no indication of breeding. For example, a male taken on 24 Jun 1976 at the Maryville SL had small testes (MR, DE; KU 118798).

Historically, the species may have been a more regular and widespread breeder in the prairie part of the state. It was reported breeding on 27 May 1874, near Warrensburg (W.E.D. Scott; Widmann 1907), and even more surprising is the claim that it bred at Pierce City, Lawrence/Barry cos. (Nehrling, no date given; Widmann 1907; see comments on other unexpected reports by Nehrling in the Wilson's Phalarope and Western Kingbird accounts). In addition to those two old reports, Harris (1919b) mentioned that there were "a few instances" of birds remaining through "the entire summer" in the Kansas City area, but he added that no nests had been found. All summer observations should be documented, and efforts should be made to ascertain whether breeding occurs.

Fall: Typically this sparrow is not encountered until the second week of Sep, with a gradual increase during the latter half of Sep and early Oct. By the second week of Oct it is common and widespread, with peak during the last ten days of Oct. Earliest dates: 1, 2 Aug 1999, near Horseshoe Lake (JH, LL); 1, 21 Aug 2006, Union Ridge CA (PW). 
High counts: 650, 22 Oct 2013, Eagle Bluffs (T. Johnson); 515, 20 Oct 1991, Bradford Farm (PM, TB); a few counts of 300-400 individuals/day in late Oct.

Winter: Since the mid- to late 1990s, this species has gone through a dramatic increase in the number of birds wintering in the state. The species is now not only locally common in the south but regular in relatively high numbers in the central part of the state. Small numbers may even be encountered in the extreme north, at least in early winter, e.g., 18, 14 Dec 2000, near Skidmore, Nodaway Co. (KG, DE), but a cold front arrived that night and only a couple could be found the next morning (fide $\mathrm{JH}$; also see LeConte's Sparrow account). CBC high counts: 370 (12.7), 19 Dec 2000, Big Oak Tree; 228 (3.1), 17 Dec 1999, Four Rivers; 189 (4.2), 17 Dec 2009, Four Rivers.

\section{Grasshopper Sparrow (Ammodramus savannarum)}

Status: Locally common summer resident in Glaciated and Osage Plains, and western and northern sections of the Ozark Border. More local in the western Ozarks and rare or absent from the forested Ozarks and the Mississippi Lowlands. Accidental winter visitant/resident.

Documentation: Specimen: sex?, 22 Jul 1897, Golden City, Barton Co. (ANSP 190697).

Habitat: Prairie, unhayed and lightly-grazed pasture, fallow fields.

Spring: Casually recorded in late Mar, but typically not seen until the second week of Apr, with the first individuals not encountered until the third week of Apr in the north. By late Apr it is common. Earliest dates: "several", one collected (specimen apparently no longer extant), 19 Mar 1907, Shannon Co. (Woodruff 1908); 1, 26 Mar 2009, Chillicothe (SK); 2, 29 Mar 2007, Hi Lonesome Prairie (NY); 1, 1 Apr 1994, Loess Bluffs (MR). High counts: "wave of hundreds", 21 Apr 1965, Platte Co. (DE); several reports of 40-50 birds/site in the southern half of the state from late Apr through the third week of May.

Summer: This sparrow is most common and widespread across the Glaciated and Osage Plains, and the open, less forested areas of the Ozark Border and western Ozarks. It is more local and less common in isolated fields in the rest of the Ozarks, and it is rare and very local, primarily in the northern section, in the Mississippi Lowlands. Not surprisingly, given the continued deterioration and disappearance of grassland across the Glaciated and Osage plains, this sparrow has exhibited both a long- and short-term annual decline of $>2 \%$ (BBS data). Prior to the arrival of Europeans, this sparrow was surely more common in the prairie regions, but it likely was absent or very local in the Mississippi Lowlands and the Ozarks.

Fall: It is still common through the third week of Sep, but thereafter numbers drop off considerably, with small numbers ( $<5$ individuals/day) seen through the first week of Oct. It is casually observed during the final ten days of Oct, with only three Nov records. Latest dates: 15 Nov 1902, Jasper Co. (Widmann 1907); imm female, 3 Nov 
1972, Maryville SL (Easterla 1975; KU 118834); 1, first week of Nov 1960, Tucker Prairie (Easterla 1962b); 1, 31 Oct 2005, Taberville Prairie (JE).

Winter: There is a single record: 2, 14-24 Jan 1961, Hi Lonesome Prairie (Easterla 1962b; KU 118826).

\section{[Baird's Sparrow (Ammodramus bairdii)]}

Status: Provisional; casual transient.

Documentation: Sight records only; see below.

Habitat: Short and mixed-grass prairie, fallow fields.

Spring: There are several reports, but of those only the following are considered likely valid: 1, 17 Apr 1954, St. Charles Co. (RA; Easterla 1967a); 1, singing, 1 May 1956, St. Joseph (FL); 1, 7 May 1959, Trimble (E. Cole et al.). Most spring records in Kansas are during late Apr/early May.

Fall: Only the following reports are considered reliable sightings: 1, 30 Oct 1971, Reed CA, Jackson Co. (CH, KH); 1, 19 Oct 1974, near Golden City, Barton Co. (m. ob.); 1, 29 Oct 1961, Busch (JC). Tower-kill data from northwestern Kansas indicate that most pass through during mid-Sep, but there is one specimen from a tower at Topeka on 11 Oct 1986 (KU 82948; Thompson et al. 2011).

Comments: Specimen or photographic confirmation is needed, as other sparrows are often confused with Baird's. See Robbins and Easterla 1992 for comments on earlier, questionable records. Harris (1919b) mentioned that there were two specimens (no date) from Buchanan County by S. Wilson; however, these cannot be located, and Wilson mentioned that "each spring I have seen a few....they seem to pass through just ahead of the common Savanna [sic] Sparrows" (Wilson 1896). Given the frequency of observations, timing, and the fact that he had not recorded Grasshopper and Henslow's sparrows prior to 1896, it seems likely that misidentifications were involved in Wilson's Baird's Sparrow reports.

\section{Henslow's Sparrow (Ammodramus henslowii)}

Status: Locally uncommon summer resident in the Glaciated and Osage Plains, scarcer and more local in the Ozark Border and the western Ozarks.

Documentation: Specimen: male, 17 Apr 1899, Durham, Lewis Co. (MCZ 306920). Habitat: Prairie, fallow fields with forbs.

Spring: The first arrivals appear at the end of Mar, and by mid-Apr it is uncommon at breeding localities. Birds continue to arrive at nesting sites and pass through the state through at least mid-May. Earliest dates: 1, 19 Mar 1907, Shannon Co. (Woodruff 1908; AMNH 229727); 2, 23 Mar 2007, Castlewood SP (MBr); three observations for 26 Mar.

High counts: both at Hi Lonesome Prairie: 58, 26 Apr 2012 (CB); 44, 24 Apr 2016 (M. Lumpe). 
Summer: Formerly much more common and widespread throughout much of the Osage and Glaciated plains and the Ozark Border (Widmann 1907). Today, because of the distribution of the little remaining prairie in the state, it is most common in the southern Osage Plains. It is very patchily distributed in the Glaciated Plains and in the more open areas of the western Ozarks (BBA, eBird data). Between 1961-66, an estimated two hundred pairs bred on Taberville Prairie (1680 acres; Easterla 1962a).

Fall: Most appear to leave the state during the latter half of Sep and early Oct. Small numbers are occasionally seen into the final week of Oct. Most migrants that are seen away from breeding localities are observed during Oct. Latest dates: 1, photos, 2 Dec 2012, Penn-Sylvania Prairie, Dade Co. (J. Wilson); 1, 8 Nov 2016, Liberty (M. Mutchler); 1, 31 Oct 1999, Bois D'Arc CA, Greene Co. (LB et al.); 3, 29 Oct 2000, Houf Ranch, Callaway Co. (BJ).

\section{LeConte's Sparrow (Ammodramus leconteii)}

Status: Common transient in west, uncommon in extreme east; locally uncommon winter resident in south, rare in north.

Documentation: Specimen: male, 29 Mar 1923, Lexington, Lafayette Co. (UMMZ 106600).

Habitat: Moist prairie, wet meadows, marshes, and fallow fields.

Spring: Migrants begin augmenting the winter population by early Mar. Peak is in late Mar/early Apr with birds commonly seen through Apr. Occasionally, relatively large numbers may be seen during the first week of May, e.g., 9, 7 May 1977, Bigelow Marsh (MR, DE). Latest dates: 1, 16 May 1979, Loess Bluffs (TB); 1, 12 May 2001, Busch (MT, BR et al.).

Fall: The first arrivals are typically detected during the last week of Sep, with numbers peaking in late Oct. Earliest dates: imm female, 9 Sep 1976, Maryville SL (DE; KU 118790); 1, 15 Sep 1968, Loess Bluffs (FL). High counts, all at Bradford Farm: 133 (90 by a single party), 30 Oct 1995 (BJ, PM; McKenzie 1996a); 94, 17 Oct 1992 (PM et al.); 82, 20 Oct 1991 (PM, TB).

Winter: Local, but at times present in relatively high numbers in prime habitat in the south. It is much more local and found in smaller numbers in the northern half of the state and may not overwinter in at least some areas there, e.g., 16, 14 Dec 2000, near Skidmore, Nodaway Co. (KG, DE), but a cold front arrived that night and no birds were found the next day (fide JH). High counts: 44, 2 Jan 1955, Busch (JEC); 42 (0.8), 30 Dec 1964, Mingo CBC; 40, 14 Jan 1966, Lowry City, St. Clair Co. (S. Hilty).

\section{Nelson's Sparrow (Ammodramus nelsoni)}

Status: Rare spring, uncommon fall transient.

Documentation: Specimen: male, 13 October 1956, 10 miles south of Gravois Mills, Morgan Co. (KU 118558).

Habitat: Marshes, wet meadows, and moist prairies. 
Spring: It is casually observed in late Apr, with most records during mid-May. Earliest dates: 1, 7 Apr 1957, Trimble (J. Rising: Rising et al. 1978); 1, 18 Apr 1953, Busch (JC, JEC); 1, 20 Apr 1996, Grand Pass (SK). High counts: 10+, 18-20 May 1968, Loess Bluffs (DE, FL, JHam); 10, 14 May 2002, Loess Bluffs (TR); 9, 17 May 1970, Bigelow Marsh (DE). Latest dates: 1, 29 May 2005, BK Leach (SS); 1, 25 May 2010, Columbia Bottom (M. and D. Marjamaa). Although this sparrow is typically overlooked, it is presumably more common in the western half of the state in spring.

Fall: More commonly encountered at this season than in spring statewide. The first arrivals are detected by mid-Sep, with peak during the last week of Sep/early Oct. It is regularly seen in small numbers through Oct. Earliest dates: 2, 11 Sep 1977, Thomas Hill Reservoir (J. Rathert); "several", 11 Sep 2003, Swan Lake (SK). High counts: 12, 12 Oct 2013, Riverlands (JM); 10, 19 Oct 2013, Eagle Bluffs (J. Besser); 9, 29 Sep 2007, BK Leach (DR). Latest dates: 3, 10 Nov 2001, Swan Lake (SK); 1, 7 Nov 2005, Little Creve Coeur L. (J. Solodar); 1, 6 Nov 2006, Thompson River Wetlands (LL).

\section{Fox Sparrow (Passerella iliaca)}

Status: Common transient east, uncommon west; uncommon winter resident in south and central, rare in north.

Documentation: Specimen: male, 26 Nov 1908, New Madrid, New Madrid Co. (CHAS 18541).

Habitat: Thickets, brush piles, second growth at woodland and forest edge.

Spring: Migrants begin supplementing the winter population by early Mar, with numbers gradually increasing to a peak in late Mar in the south and early Apr in the north. It is regularly seen in small numbers until the beginning of the final week of Apr. It is accidental in May. High counts: 100, 14 Mar 1975, Bennett Spring SP, Dallas Co. (FL, MR, DE); 98, 2 Apr 1979, Loess Bluffs (TB). Latest dates: 1, 11 May 1988, Forest Park (RK); 1, 6 May 1993, Pershing SP (CH).

Fall: The first arrivals appear at the very end of Sep. Peak is during the last week of Oct and early Nov. By the end of Nov numbers have dropped off considerably. Earliest dates: 1, 24 Sep 1990, Brickyard Hill (MR); 1, 25 Sep 1988, Big Lake SP (MR); 1, 26 Sep 2007, Saline Valley, Miller Co. (TM). High counts: 225, 12 Nov 2008, Crowley's Ridge CA (CB); 200, 25 Oct 1941, Missouri River bottoms, near Parkville, Platte Co. (WC); 94, 30 Nov 2010, Crowley's Ridge CA (CB).

Winter: This sparrow is locally uncommon in the southern and central sections of the state, especially the Mississippi Lowlands. It is much more local and rare in the northern third of the state. CBC high counts: 117 (1.9), 28 Dec 2012, Clarence Cannon; 116 (1.3), 21 Dec 1980, Columbia; 97 (0.7), 15 Dec 2007, Columbia; 93 (0.5), 1 Jan 2011, Taney Co; 81 (1.4), 18 Dec 2010, Mingo. 
Comments: Only the nominate subspecies has been recorded in the state, but birds of the "Slate-colored" Fox Sparrow group, with breeding range in the Rockies, could occur as vagrants.

\section{Song Sparrow (Melospiza melodia)}

Status: Common summer resident from the Missouri River valley northward, uncommon along the Mississippi River, rare elsewhere; common winter resident statewide.

Documentation: Specimen: female, 6 Apr 1895, near St. Joseph (University of Colorado Museum of Natural History 13707).

Habitat: During migration and winter found in a wide range of relatively open habitats; in summer, along streams, rivers, thickets, second-growth woods at edge of marshes and swamps, and urban and suburban residential settings wherever there is adequate shrubby cover.

Spring: Migrants begin supplementing the winter population as early as late Feb. Peak is during mid-Mar in the south and at the end of Mar in the north. Few are seen away from nesting localities by the end of Apr. High counts: 200, 11 Mar 2006, Weaubleau Creek Wetland, St. Clair Co. (H. John); 121, 9 Mar 2016, Eagle Bluffs (CB, S. Garr).

Summer: This sparrow is a common breeder from the Missouri River northward and along the entire Mississippi River floodplain. Although populations are much more local, it is common in wetland areas in the Osage Plains, such as Four Rivers and Schell-Osage. It is least common and widespread in the Ozarks, where it is very local. BBS data indicate a dramatic decline of 5.14 \% annually for the 2003-2013 period. Presumably, this decline may in part be due to the conversion of much of the Glaciated Plains to cropland, especially the western half, where even hedgerows have been greatly reduced. Global climate change may also result in retraction of the breeding grounds from the southern portion of this sparrow's breeding distribution.

Fall: Migrants began to appear by mid-Sep, with peak in late Oct and early Nov. It is common statewide thereafter. High counts: 500, 25 Oct 1941, Missouri River bottoms, near Parkville, Platte Co. (WC); 225, 12 Nov 2008, Crowley's Ridge CA(CB): 123, 11 Nov 1991, Aldrich arm of Stockton Lake (JHy); 100+, 31 Oct 2011, Pershing SP (SK).

Winter: A common resident statewide; based on $\mathrm{CBC}$ data, it is most common in the Mississippi Lowlands and Ozark Border and least common in the forested regions of the Ozarks. CBC high counts: 550 (9.5), 18 Dec 2010, Mingo; 471 (5.4), 14 Dec 2017, Mingo; 352 (2.1), 17 Dec 2005, Columbia; 347 (1.7), 16 Dec 2006, Columbia.

\section{Lincoln's Sparrow (Melospiza lincolnii)}

Status: Uncommon to common in transient in west, uncommon in east; rare winter resident.

Documentation: Specimen: male, 7 May 1879, Charleston, Mississippi Co. (MCZ 44711). 
Habitat: Thickets, brushpiles, hedgerows, weedy fields, and edge of woodland and forest.

Spring: By the end of Mar the first migrants are observed with numbers building to a peak at the end of Apr and early May. It is regularly seen into the last week of May. It is more common in the west than the extreme east. High counts: 53, 4 May 2013, Loess Bluffs (DE, TE, PK; Easterla 2013); 50, 2 May 1997, Mark Youngdahl Urban CA (LL); 27, 8 May 2007, Cooley Lake (K. Driggers). Latest dates: 1, 6 Jun 1996, Taberville Prairie (MR); 1, 30 May 2009, Riverlands (BR, JE); 1, 29 May 1996, Bilby Ranch (KG).

Fall: The first arrivals are usually not detected until mid-Sep, with relatively large numbers (20+/day) in the north by the final week of Sep. Peak is during early Oct. By the beginning of Nov, most have left the state. It is rare thereafter. Earliest dates: 1, 31 Aug 2006, Bigelow Marsh (TR); 1, 10 Sep 1977, Maryville (DE); 1, 12 Sep 2012, Thompson River Wetlands (SK). High counts: 65 (50, Clarence Cannon and 15 BK Leach), 30 Sep 2006 (JE); 55, 6 Oct 2001, Overton Bottoms (McKenzie and Wade 2001); several observations of ca. 25 individuals/day.

Winter: A low-density sparrow that fluctuates considerably from year to year. During severe winters it can be scarce. During mild winters, especially during the last two weeks of Dec, 1-3 individuals/day may be recorded even in the north. $C B C$ high counts: 17 (0.2/ pa hr), 19 Dec 1982, Trimble; 16 (0.1/pa hr), 18 Dec 1982, Kansas City Southeast; 11 (0.2/pa hr), 14 Dec 2001, Four Rivers.

\section{Swamp Sparrow (Melospiza georgiana)}

Status: Common transient; formerly summer resident in north; uncommon to locally common winter resident.

Documentation: Specimen: male, 23 Apr 1907, Spring Valley, Shannon Co. (AMNH 229757).

Habitat: Swamps, marshes with scattered bushes, wet meadows, and weedy fields with brush piles.

Spring: Migrants begin augmenting the winter population by early Mar in the south and about a week later in the north. Peak is early Apr in the south and mid-Apr in the north. By early May, usually only 1-2/day are observed and after mid-May virtually none remain. High count late in season: 221, 29 Apr 2015, near Hornesville Swamp (TJ). Latest dates: singing male, audio recorded, 29 May 2017, Eagle Bluffs (BJ); 25 May 1874, Warrensburg (Scott 1879); 1, 25 May 2013, Webster Co. (GSa); 1, 24 May 2010, Grindstone Nature Area, Boone Co. (T. Luhring); singing male, 23 May 2015, Eagle Bluffs (BJ).

Summer: There have been no definite nesting records since those listed by Widmann (1907): nest with young, 2 Jun 1905, St. Charles Co. (P. Smith); "nesting near Montgomery City" (no date given; E. Parker); and at Sand Ridge, near Wayland, Clark Co. 
(no date given; E. Currier). The only summer report during the last century was of two birds at Smithville Lake, 3 Jun 1984, but there was no evidence of breeding (N. Johnson). Seemingly appropriate habitat is present at a few sites in the northern half of the state and breeding was documented as far south as Pike Co., Illinois (opposite Ralls and Pike cos. in Missouri), in 1979 (Bohlen and Zimmerman 1989). In Iowa, all confirmed breeding records are from the northern half of the state (Kent and Dinsmore 1996).

Fall: By mid-Sep the first individuals begin to appear, with relatively large numbers occasionally observed during the final week of Sep. Peak is usually at the end of Oct, with relatively large numbers typically present into early Dec. Earliest dates: 1, photos, 31 Aug 2015, St. Charles Co. (J. Stahl); 1, 16 Sep 2000, Swan Lake (SK); 1, 16 Sep 2005, Thompson River Wetlands (SK); 1, 17 Sep 1980, Lake Contrary (FL). High counts: 170, 22 Oct 2013, Eagle Bluffs (T. Johnson); several counts of 100-125/day from end of Sep into Nov.

Winter: The number of birds wintering depends on the severity of the winter and perhaps on whether there has been a drought, e.g., the range in the number of individuals on the Loess Bluffs and Mingo CBCs has been from 1-2 to nearly 500/count (see below). Generally, it is encountered in small numbers, but it can be locally common in prime marsh habitat such as Loess Bluffs, Swan Lake, Eagle Bluffs, and Mingo. It is least common in the northern Glaciated Plains and in the heavily-forested sections of the Ozarks, with the highest abundances typically along the lower Mississippi River. $C B C$ high counts: 671 (4.1), 18 Dec 2010, Columbia; 655 (15.6), 30 Dec 2009, Clarence Cannon; 480 (8.3), 18 Dec 2010, Mingo; 470 (14.2), 19 Dec 1978, Loess Bluffs.

\section{White-throated Sparrow (Zonotrichia albicollis)}

Status: Common winter resident; casual summer visitant.

Documentation: Specimen: male, 9 May 1879, Charleston, Mississippi Co. (MCZ 44572).

Habitat: Woodland and forest edge, thickets, brushy areas, and urban and suburban residential settings wherever there is adequate shrubby cover.

Spring: Migrants from farther south begin augmenting the winter population in the south by early Mar with a large increase in numbers in early Apr. Peak is in mid-Apr in the south, but not until the end of Apr/early May in the northern third of the state. Few birds remain after mid-May. High counts, all at the migratory "trap" at Tower Grove: 500+, 23 Apr 1990 (J. Ziebol); 500+, 26 Apr 1991 (B. Boyce, B. Kleiger); 300, 27 Apr 2014 (G. Sheets).

Summer: There are at least eleven observations of birds during the summer, with all but three from the northern half of the state. None of these were considered injured and two of these involved individuals that were present for several days. The only record involving more than one individual: 2, 10 Jul 1982, Springfield (G. Dobbs et al.). 
Fall: The first for this season typically appear the third week of Sep and by the second week of Oct it is common. Peak is during the last two weeks of Oct. Numbers are reduced considerably in the north by the second week of Nov. Earliest dates: ad, photos, 26 Aug - 11 Sep 2015, Tower Grove (B. Prather, CMc); 1, 15 Sep 2002, Castlewood SP (MBr); 1, 18 Sep 2003, Buchanan Co. (MR). High counts: 185, 5 Nov 2011, Ben Cash (TJ); 122, 26 Nov 2010, Holly Ridge CA (CB); 180, 22 Oct 2013, Ben Cash (TJ).

Winter: As with several other species of sparrows, the abundance of this species varies considerably among years, with smaller numbers present during severe winters. Regardless of the winter, it is most common in the Mississippi Lowlands. CBC high counts: 1,216 (13.9), 14 Dec 2017, Mingo; 862 (15.5), 27 Dec 1997, Mingo; 850 (5.1), 18 Dec 2010, Columbia; 774 (8.9), 18 Dec 2010, Springfield.

\section{Harris's Sparrow (Zonotrichia querula)}

Status: Common transient in the western third of the state, rare eastward; uncommon winter resident in western third of the state, rare eastward; accidental summer visitant. Documentation: Specimen: male, 18 Oct 1873, Kansas City (University of Colorado Museum of Natural History 13871).

Habitat: Brushy areas in fields.

Spring: This sparrow is much more common in the western third of the state, especially along the two western tiers of counties. Typically only individuals or small groups ( $<5$ birds) are sparingly encountered in the eastern two-thirds of the state. By midMar, the wintering population begins to be augmented by migrants, with peak during the last week of Apr and the first few days of May. After the first week of May it is encountered in much smaller numbers, but it is regularly observed through the third week of May. High counts: "thousands", 22 Apr 1922, Kansas City (H. Hedges); 100, 6 May 1962, St. Joseph/Loess Bluffs (FL). High count for eastern third of state: 12, 8 Apr 2001, St. Charles Co. (MT, MBr, et al.). Latest dates: 1, 25 May 1968, northern Atchison Co. (JHam); 1, 23 May 1970, Bigelow Marsh (DE); 1, 23 May 2014, Weston Bend (MR).

Summer: Only two records: 1, at bird feeder, 3 Jun 1996, Harrisville (J. Garrett) and an ad, with missing tail, 10 Jul - Oct 2003, Nodaway Co. (D. Heflin; Easterla 2004).

Fall: More frequently seen in the eastern half of the state at this season than in spring. The first individuals are encountered at the end of the first week of Oct in the north. It does not become numerous until mid-Oct. Peak is at the end of Oct/early Nov. Few migrants remain by late Nov. Earliest dates, all at Brickyard Hill by MR: ad, 26 Sep 1990; 5, 30 Sep 1991; 2, 30 Sep 1992. High count: 60+, 2 Nov 1974, east of Maryville (MR).

Winter: It is most prevalent in the western two tiers of counties in the Glaciated and Osage plains. There is considerable variation in number of birds wintering, presumably related to the severity of the winter and to drought conditions, which negatively 
affect seed production (compare CBC counts across years in the extreme western part of the state). For example, during CBCs in the years 2000-2001 and 2012-2013, comparatively large numbers were encountered not only in the western CBCs, but eastern counts as well. CBC high counts: 319 (12.5), 15 Dec 1991, Maryville; 266 (6.1), 18 Dec 1977, Trimble; 243 (3.7), 14 Dec 2012, Four Rivers.

Comments: Like the Bell's Vireo and Lark Sparrow, the Harris's Sparrow was first made known to science by its discovery in Missouri. Thomas Nuttall collected a specimen on 28 Apr 1834 a few miles west of Independence (Harris 1919a).

\section{White-crowned Sparrow (Zonotrichia leucophrys)}

Status: Common winter resident; accidental summer visitant.

Documentation: Specimen: female, 7 May 1879, Charleston, Mississippi Co. (MCZ 44534).

Habitat: Brushy areas in fields and along edges of scrubby woodland.

Spring: Migrants are obvious by mid-Mar, but it does not become common until midApr with peak during late Apr/early May. After mid-May it is only casually observed. High count: 200, 22 Mar 2006, Bois D’Arc CA, Greene Co. (DB1). Latest dates: 1, 3 Jun 2014, Lawrence Co. (m. ob); 1, 21-30 May 2010, Columbia (RD); three observations for 27 May 2005.

Summer: There are two observations of birds that appeared injured and thus likely could not migrate: 1, probably present since spring migration, 8 Aug 1994, Springfield (D. Baker); ad, photos, 20 Jun 2008, St. Louis (D. Eisenhart).

Fall: By the beginning of Oct a few birds begin to appear, with relatively large numbers present by mid-Oct. Peak is in late Oct and early Nov. Typically, after the end of Nov numbers are greatly reduced in the north. Earliest dates, all single imm.: 22 Sep 2013, Riverlands (BR); 24 Sep 2007, Pilot Knob, Stone Co. (D. Gagne); 25 Sep 1988, Big Lake SP (MR), 25 Sep 2008, Forest Park (E. Miller).

Winter: This sparrow is most common in the western Osage Plains and the Mississippi Lowlands, with the lowest densities in the Glaciated Plains and the heavily forested sections of the Ozarks. CBC high counts: 627 (11.0), 29 Dec 2010, Cole Camp; 594 (19.6), 27 Dec 2008, Liberal; 515 (7.8), 14 Dec 2003, Four Rivers; 453 (8.0), 14 Dec 2010, Four Rivers. Non-CBC high count: 275+, 20 Feb 1991, Diehlstadt, Scott Co. (PM, J. Hazelman).

Comments: The northwestern subspecies, Z. l. gambellii, is an uncommon transient and winter resident in the western half of the state; it is much less frequently encountered in the eastern part, although few observers make subspecific determinations. At times during migration and winter in the extreme western part of the state, it can locally outnumber the nominate subspecies (MR). Earliest date: 10 Oct 1920, Kansas 
City (D. Teachenor). Latest date: 2, 14 May 2010, Bigelow Marsh (MR, M. Andersen, L. Sanchez-Gonzalez).

\section{Golden-crowned Sparrow (Zonotrichia atricapilla)}

Status: Accidental transient and winter resident.

Documentation: Photograph; see below.

Habitat: Brushy areas.

Records: There are now four records for this Pacific Coast sparrow: ad, photos, 1622 Apr 1992, south of Stover, Morgan Co. (R. Lorance et al.); $2 \mathrm{imm}$ that molted to definitive plumage, photos, 27 Nov - 21 Apr 1992-3, east of Columbia, Boone Co. (B. and C. Terry, PM, TB et al.); ad, 19 Dec 1998, Montrose, Henry Co. (R. Edmunds); 1, photos, 9 Jan - 16 Mar 2011, Linn, Osage Co (SD et al.).

\section{Dark-eyed Junco (Junco hyemalis)}

Status: Common transient and winter resident; accidental summer visitant.

Documentation: Specimen: sex?, 18 Oct 1873, Kansas City (University of Colorado Museum of Natural History 13275).

Habitat: Generally, open areas with shrubs and trees and at edge of woodland and forest; also urban and suburban residential settings with feeders.

Spring: The greatest numbers are present during the last two weeks of Mar, when presumed migrants and winter residents are present. Considerably fewer birds are present by the beginning of the second week of Apr. After the first few days of May it is only casually observed. Latest dates: 1, 20 May - 3 Jun 2006, Kearney, Clay Co. (J. Eldridge); 1, 31 May 1990, Loess Bluffs (TB); 1, 29 May 1882, St. Louis (Widmann 1907).

Summer: There are three records; it is likely that these birds were injured or sick: 1, 10 Jun 1987, near Bennett Springs SP (B. Handy); 1, photos, 20 Jun 1978, 10 miles east of Salem, Dent Co. (D. Wallan); probable female, 8 Jul 2004, Shaw Nature Reserve, Franklin Co. (C. Brown).

Fall: The first arrivals appear during the last week of Sep in the north. Numbers increase dramatically by mid-Oct and peak is at the end of Oct/early Nov. It is common for the remainder of the period. Earliest dates: 1, 2 Sep 1972, St. Louis (A. Bromet); 1, photos, 3 Sep 2011, St. Louis (A. Smith); 1, 17 Sep 1956, St. Louis (O. Peterson).

Winter: This is one of the most common winter residents. $\mathrm{CBC}$ data indicate that it is least abundant in the Mississippi Lowlands region and the extensively forested part of the Ozarks. CBC high counts: 3,881 (56.2), 16 Dec 1973, Weldon Spring; 2,892 (22.2), 17 Dec 1983, Kansas City; 2,234 (18.0), 15 Dec 2007, Columbia; 2,247 (15.3), 20 Dec 2008, Columbia; 1,976 (26.8), 1 Jan 2011, Taney Co. 
Comments: The "Oregon" subspecies group (J.h. montanus) of the Dark-eyed Junco is routinely recorded in small numbers throughout the state during winter, e.g., a high count: 10 (but see comments below concerning cismontanus), 20 Dec 2008, Columbia CBC. There are two definite records of the distinctive, "Gray-headed" Junco, $J . h$. caniceps. Photos of both birds establish that they are referable to the more northern caniceps: 6 Dec into Apr 2001, Polk Co. (C. Foster; fig. 26); 13-18 Feb 2011, Rolla, Phelps Co. (L. Frederick).

The "Pink-sided" subspecies, $J$. h. mearnsi, has been reported on a few occasions, but confirmation is needed, and there is considerable confusion with intergrades between the "Oregon" subspecies and the nominate subspecies. These intergrades are from the so-called $J$. h. cismontanus, which is now often referred to as the Cassiar Junco. In fact, probably the majority of the "Oregon" type juncos that are reported in Missouri may be from that population. Although there are reports of the Black Hills "White-winged" subspecies, $J$. h. aikeni, all have proved to be aberrant examples of the nominate subspecies that had variable amounts of white wing-bars (e.g., photo in Robbins and Easterla 1992). Care should be exercised with subspecific identifications, as intergradation is frequent among several subspecies.

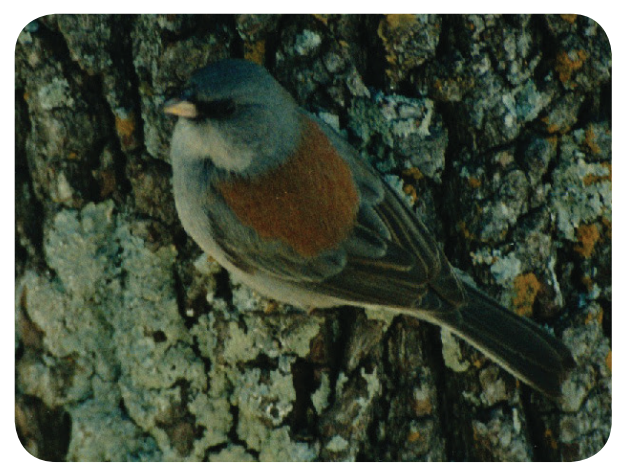

Fig. 26. One of only two records of "Gray-headed" Junco in Missouri. This individual was present from 6 December into April 2001, Polk County. Photo by Cathie Foster.

\section{Family Icteriidae: Yellow-breasted Chat}

Yellow-breasted Chat (Icteria virens)

Status: Common summer resident in Ozarks, Ozark Border; more local and uncommon elsewhere; accidental winter visitant.

Documentation: Specimen: male, 12 May 1879, Charleston, Mississippi Co. (MCZ 45498).

Habitat: Dense brushy areas, thickets, and young second-growth woodland. 
Spring: The first chats typically arrive the third week of Apr in the south and a few days later in the north. By the second week of May it is common in the Ozarks and Ozark Border. Earliest dates: 1, 12 Apr 2014, Roaring River (JCa); 1, 13 Apr 2001, Butler Co. (B. Beck); 1, 14 Apr 1981, Farmington (BRe); 1, 16 Apr 2012, Holly Ridge CA, Stoddard Co. (CB); 1, 17 Apr 1971, Loess Bluffs (MR). High counts: 25, 16 May 2014, Cane Ridge, Butler Co. (MR, JB); 20, 31 May 2007, Mora CA, Benton Co. (SS, PW).

Summer: Chats are most common in the Ozarks and Ozark Border. It is far less widespread and in much lower densities in the northern section of the Glaciated Plains (BBA, BBS, eBird data). Naturally, it is also much more local in the agriculture- dominated Mississippi Lowlands. Shirling (1920) reported a total of 18 singing males at Swope Park, Jackson Co. in 1916, but a survey in 1973 detected none (Branan and Burdick 1981). BBS data indicate that the Missouri population is stable.

Fall: Most breeders and migrants have left the state by late Aug. It is rare during the latter half of Sep into early Oct. There is only one record after mid-Oct. Latest dates: 1, 5 Dec 2015, Shaw Nature Reserve, Franklin Co. (B. and P. Johnson); 1, photos, 16 Oct 2013, Ben Cash (TJ); 1, 12 Oct 1999, Eagle Bluffs (EW, B. Heidy); 1, 12 Oct 2011, Reform CA, Callaway Co. (J. Fone).

Winter: Single record of a late-lingering individual: 19 Dec 2015, Little Prairie CA, Phelps Co. (D. Hatch et al.).

Comments: The taxonomy of this species has long been debated and recent genetic data indicate that it is not closely related to the wood-warblers (Parulidae; Barker et al. 2013). As a result, the AOS (Chesser et al. 2017) erected a new family for this enigmatic species.

\section{Family Icteridae: blackbirds, meadowlarks, orioles, cowbirds, grackles}

\section{Yellow-headed Blackbird (Xanthocephalus xanthocephalus)}

Status: Locally common summer resident in northwestern counties bordering the Missouri River from Platte Co. northward; very rare and local elsewhere in the Glaciated Plains; formerly nested in the Osage Plains; uncommon transient in west, rare east; rare winter resident in northwest, casual elsewhere.

Documentation: Specimen: egg set, 3 Jun 1888, Wayland, Clark Co. (WFVZ 111766). Habitat: Nests in cattail marshes; during migration and winter can often be observed in feedlots and cultivated fields.

Spring: This stunning blackbird is locally common in the Missouri River valley in the northwest and uncommon in other parts of the western tier of counties, but it is rare and not recorded annually in the eastern third of the state. The earliest arrivals appear at the end of Mar with numbers increasing during Apr. By the end of Apr it can be 
locally common, with peak during early to mid-May. High counts, both in the Loess Bluffs area: 300+, 29 Apr 1990 (DE); 229, 7 May 1989 (DE). High counts in east: 30, 15 Apr 2014, Eagle Bluffs (G. Leonard); 25, 21 Apr 2002, Eagle Bluffs (NY); all records in the eastern third of the state are fewer than 10 individuals/day.

Summer: The primary breeding area is in cattail marshes in the Missouri River valley from Platte Co. north to the Iowa border. Almost invariably, the largest populations are at Loess Bluffs. As a result of water levels, abundance varies considerably among years, with the greatest numbers during years with above average spring rainfall. Formerly, it was documented breeding in Jasper, Johnson, Saline, Franklin, and Clark (egg set taken 4 Jun 1895 by E. Currier) counties during the late 1800s and the very early 1900s (Widmann 1907). No nesting was documented outside the northwest Missouri River floodplain during the BBA, 1986-1992 (Jacobs and Wilson 1997). However, nesting occurred at Grand Pass, in 1993 and 1997 (R. Leonard). Presumed postbreeding individuals are occasionally seen as early as mid-Jul in nonbreeding regions of the state.

Fall: Most have left breeding areas by late Aug/early Sep. It is rare statewide after mid-Sep with only individuals or small flocks ( $<5$ individuals) observed. Individuals are regularly encountered with other blackbirds in cultivated fields and feedlots throughout the season in the extreme western Glaciated and Osage plains.

Winter: A rare resident in small numbers; not recorded annually. Most records are during $\mathrm{CBCs}$ in the westernmost tier of counties of the Glaciated and Osage plains. It is casually recorded outside that region. High counts, both on the Trimble CBC: 50, 18 Dec 1977; 7, 27 Dec 1986; high count in east: 7, 30 Jan - 1 Feb 2016, Weldon Spring (AR, CMc, BR).

\section{Bobolink (Dolichonyx oryzivorus)}

Status: Uncommon transient; rare to locally uncommon summer resident in the Glaciated Plains, and rare and local in the northern section of Osage Plains and Ozark Border.

Documentation: Specimen: male, 14 May 1923, Lexington, Lafayette Co. (UMMZ 106598).

Habitat: Fallow fields, clover fields, wet meadows, and prairie.

Spring: The first individuals typically appear in the south during the last week of Apr, increasing in number with a peak during mid-May. Migrant flocks are regularly encountered through the end of May. Earliest dates: 1, 20 Apr 1980, Marais Temps Clair (G. and T. Barker); 15, 20 Apr 2010, near Rogersville (AK). High counts: several reports of ca. 300 individuals, with most during the second week of May.

Summer: The Bobolink is a rare to locally uncommon summer resident across the Glaciated Plains north of the Missouri River. It is most prevalent along the northern half of that region. It is very local south of the Missouri River in the northern Osage 
Plains as far south as Vernon (BBA), Bates (BBA), and St. Clair (2003, SK) counties and in the northwestern portion of the Ozark Border in Boone County (colonies at different sites in 1992, R. Nutall, J. Rathert). High counts, all at Dunn Ranch, Harrison Co.: 90, 5 Jun 2016 (LW et al.); 75, 19 Jun 1994 (DE); 73, 4 Jul 2007 (JE).

Although BBS data indicate an annual increase of 2.18\% between 2003 and 2013, this may not reflect the status of this species statewide during this period due to the conversion of grassland to cropland in some areas and the lack of BBS routes in some regions. Moreover, nesting success rate in those regions is likely low, as haying typically occurs in early Jun, when Bobolinks are in the egg/nestling stage (MR, pers. obs.).

Fall: Birds begin to leave nesting areas as early as the second week of Jul. Presumed migrants from farther north, consisting of flocks numbering in the hundreds of individuals, are seen during the last week of Aug through mid-Sep. Individuals and small flocks are regularly seen into early Oct. Latest dates: 1, 28 Oct 2000, Clarence Cannon (BR); 1, 23 Oct 2015, Chillicothe (SK); ad, banded, 22 Oct 2014, St. Louis (L. Tossing). High count late in fall: 45, 10 Oct 2010, Confluence Point SP (BR). High counts: 500, 2 Sep 1968, Loess Bluffs (FL); 500, 10 Sep 1967, near Loess Bluffs (FL); 195, 3 Sep 2013, Pershing SP (SK).

\section{Eastern Meadowlark (Sturnella magna)}

Status: Common permanent resident.

Documentation: Specimen: female, 13 Jul 1892, Golden City, Barton Co. (USNM 139430).

Habitat: Fallow fields, pastures, prairies, and harvested cultivated fields.

Spring: There is a pronounced movement statewide of this meadowlark during Mar into at least mid-Apr. In the northwestern corner, where Eastern Meadowlark is less common than Western between Nov and Mar, Easterns begin to reappear in late Feb/ early Mar but do not outnumber Westerns until the end of Mar/early Apr. Migration continues into at least mid-Apr. In the bootheel, Easterns are observed in larger numbers in winter than summer, but it is unclear whether this represents local birds that are in relatively large flocks or an influx of meadowlarks to that area from other regions.

Summer: Based on BBS data, this meadowlark is much more common in the Osage Plains than in any other region. These data also indicate that it is more common in the eastern than the western half of the Glaciated Plains, although with continued cultivation of the little remaining grassland, especially since the early 1990s, it continues to decline in that region as a whole. It is least common in the forested sections of the Ozarks and in the Mississippi Lowlands. On the other hand, it undoubtedly has increased dramatically in those two regions following deforestation after the arrival of Europeans. Widmann (1907) stated that it was "scarce" in both these regions. BBS data for both the long and short term indicate an annual decline of $2 \%$. 
Fall: Migration is most obvious during Oct and into early Nov, but movements continue through the end of the period. After early Nov, it is outnumbered by Western Meadowlark in the northwestern corner of the state.

Winter: Because meadowlarks only occasionally sing during winter, and field identification can be difficult, the relative abundance of the two meadowlarks is poorly understood in some regions of the state, especially the central and eastern sections of the Glaciated Plains. Moreover, numbers can vary considerably depending on the severity of the winter, especially in the Glaciated Plains (CBC data). What is certain is that Eastern outnumbers Western in all regions of the state except the northwest. $\mathrm{CBC}$ data (average individuals/party hour) indicate that Eastern is most common in the Mississippi Lowlands, but when both species are pooled (including individuals unidentified to species), meadowlarks are most common in the Glaciated and Osage plains, especially the southern part of the latter region (see Liberal CBC results). $C B C$ high counts: 463 (7.1/pa hr), 28 Dec 1975, Columbia; 350 (5.8/pa hr), 1 Jan 1972, Columbia. High counts based on single-party effort: 250, 17 Jan 2013, Dunklin Co. (TJ); 224, 29 Dec 2009, Prairie SP (R. Mangile).

Comments: See remarks concerning hybridization under Western Meadowlark account.

\section{Western Meadowlark (Sturnella neglecta)}

Status: At least formerly, common permanent resident in northwest; rare summer resident elsewhere; in winter, locally common in Osage Plains and rare to uncommon elsewhere.

Documentation: Specimen: sex?, 18 March 1900, Independence (KU 39334).

Habitat: Prefers drier, shorter grass areas than the Eastern Meadowlark, especially on slopes and hilltops. In migration and winter, often in open fields with corn stubble and other short or sparse cover.

Spring: Migration is primarily during Mar into early Apr with some movement still occurring in mid-Apr. Until at least mid-Mar, this is the more common meadowlark in the northwest, and this species is routinely present as far east as the Mississippi River at St. Louis until late Mar/early Apr. Latest dates for sites where the species is not considered a breeder: 1 singing, photos, 15-25 May 2011, Otter Slough (CB, JU); 1, 19 May 2001, Riverlands (JM, CM); 1, 3 May 1964, St. Charles Co. (S. Hanselmann, J. Willet); 1, 28 Mar 1975, Mississippi Co. (JHa).

Summer: In the early 1900s, this meadowlark bred in the northwest, as B. Stigall found it during the summer of 1906 in Atchison and Nodaway cos. (Widmann 1907). Lanyon's (1956) work in the mid-1950s demonstrated that the distribution of the species had not changed since the early 1900s; he documented that the principal nesting area was limited to the extreme northwestern corner, with isolated pockets of breeding birds farther east in the Glaciated Plains. In 1986, a transect across the northern two tiers of counties did not produce any Westerns east of Harrison Co., and it was quite 
local in that county; but it was locally common from the western half of Worth Co. westward (MR). The BBA effort, 1986-1992, also determined that the main breeding area was from Harrison, Daviess, and Caldwell cos. westward with isolated, confirmed breeding east to Schuyler and Adair cos (Jacobs and Wilson 1997). Within the Glaciated Plains, there are still no documented breeding records for the easternmost two tiers of counties or for the southern two tiers of counties east of Carroll Co. Into the early 1990s, this meadowlark was still considered a common breeder throughout the northwest, but with the unprecedented conversion of pasture to crops (corn, soybeans) during the subsequent two decades, much habitat has been lost and this species, along with several other grassland-inhabiting species, has suffered yet further substantial declines. BBS data for 2003-2013 indicate an annual decline of 5.62\%.

There are small, local populations in the Osage Plains as far south as Jasper Co. and in the extreme western section of the unforested Ozark Plateau. Occasional singing males are noted in other areas of the Ozarks, and it is accidental in the Mississippi Lowlands; breeding confirmation, however, is lacking for those two areas. Extralimital records, all of single singing males: 3 Jun 1977, Scott Co. (JHa, BE); 16 Jul 1994, Riverlands (D. Crow et al.); 13 Jun 2001, Jefferson City airport (EW); 6 Jun 2007, near Montgomery City, Montgomery Co. (PM); 28 Jun 2010, Laclede Co. (M. Stoakes, S. Laurent).

Fall: Obvious migrants begin appearing by early Oct, and the influx of birds continues into Dec. For example, in 2006 at Rosecrans Airport, St. Joseph, this species increased from about 20 on 22 Sep to greater than 130 individuals on 13 Oct (MR). It becomes the dominant meadowlark in the northwestern section of the state from midOct through winter, and it is regularly recorded in small numbers by the last week of Oct in the St. Louis and Columbia areas. Earliest dates for the east, both at Busch, of single, singing males: 3 Oct 1981 (T. Parmeter et al.); 19 Oct 1967 (K. Arhos).

Winter: Westerns are much more common and widespread at this season statewide, but it is more common than the Eastern only in the northwest. Because of identification difficulties at this time of year, the ratio of Western to Eastern meadowlarks in the central section of the Glaciated Plains, Osage Plains, and Ozark Border is poorly understood. Nonetheless, Westerns are less common than Easterns in the Osage Plains and the eastern portion of the Glaciated Plains. Westerns are considerably less common in the other regions. In the Ozarks, it occasionally reaches the Arkansas border, e.g., 4 heard, 16 Dec 1990, Exeter, Barry Co. (JHy); 2 singing, 4 Jan 1992, Barry Co. (JHy). There are very few records for the Mississippi Lowlands, but it may be overlooked there, as it has been found in small numbers in adjacent Kentucky and Tennessee (eBird). High counts: at St. Louis: 60, 16 Feb 2013, Weldon Spring (BR); 30, 10 Feb 2008, Columbia Bottom (BR); in the Mississippi Lowlands: 3, 22 Dec 1012, Mingo CBC; in Osage Plains: 125, most singing, 6 Feb 2016, near Prairie SP (MR, JB). High counts on Loess Bluffs CBC: 115 (2.6), 21 Dec 2011; 68 (1.4), 18 Dec 2007. Numbers vary considerably from year to year. 
Comments: Hybridization occasionally occurs, with some individuals singing intermediate songs. This was first reported by Baskett (1896), who heard birds singing intermediate songs about 15 miles southwest of Mexico, Audrain Co., Missouri on 9 Mar 1896.

\section{Orchard Oriole (Icterus spurius)}

Status: Common summer resident.

Documentation: Specimen: male, 14 May 1879, Charleston, Mississippi Co. (MCZ 44102).

Habitat: Open, brushy areas and the edge of young secondary forest.

Spring: It is seen by the third week of Apr in the south, and by the final days of Apr in the north. Peak is in early and mid-May in the south and north, respectively. Earliest dates: 5 Apr 1988, Farmington (BL, SD); three reports for 15 Apr across different years. High counts: 65, 22 May 1992, 16.5 miles of Nodaway River (Robbins et al. 1992); 65, 24 May 2014, Loess Bluffs (D. Merz); 63, 24 May 2016, Loess Bluffs (MR).

Summer: Most common along the Missouri and Mississippi rivers floodplains, e.g., one of the highest population densities is at Loess Bluffs. It is also common in the Ozark Border, the more open areas of the Ozarks, and the Osage Plains. Prior to 1992, BBS data indicated that it was most common in the western half of the Glaciated Plains, but because of the extensive conversion of brush, hedge rows, and woodland edge to crops, it may now be least widespread and common in that area. It is also more local and less common in the agriculture-dominated Mississippi Lowlands.

Fall: This is an early migrant, with family groups seen moving south as early as the latter half of Jul. Peak in migration appears to be during mid-Aug, with very few remaining after the first week of Sep. There are no verified records after the third week of Sep. High count of presumed migrants: 25, 24 Aug 2007, Lake Contrary (LL). Latest dates: 1, 24 Sep 1990, Brickyard Hill (MR); 2, 16 Sep 2012, Webster Co. (AK); 1, 16 Sep 2014, Bois D’Arc CA, Greene Co. (DBl).

\section{Hooded Oriole (Icterus cucullatus)}

Status: Accidental spring transient.

Documentation: Photograph; fig. 27.

Record: An adult male from the south Texas/east Mexican cucullatus subspecies group was photographed at a nectar (oranges) feeder in Columbia on 20 May 2016 (L. and G. Flenner). There have been several recent records in surrounding states, all in May, of the nominate subspecies. In large part the recent detection of this species is likely due to the increase in nectar feeders for attracting birds. Presumably females are going undetected, given how similar they are to female Orchard and Baltimore orioles. 


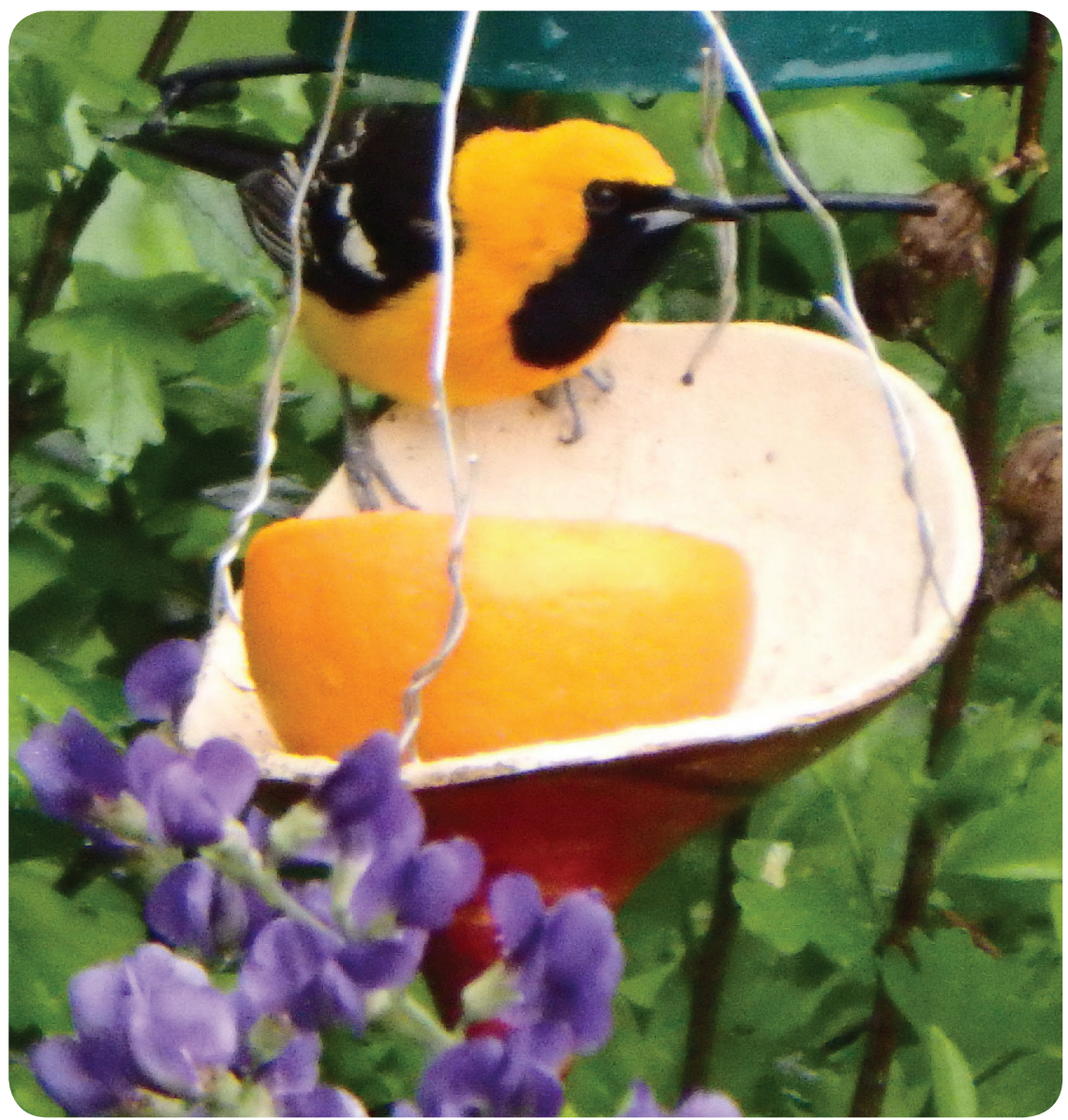

Fig. 27. Adult male Hooded Oriole on 20 May 2016, Columbia, Boone Co. Photo by George Flenner.

\section{Bullock's Oriole (Icterus bullockii)}

Status: Accidental winter visitant.

Documentation: Photograph; see below.

Record: There is a single verified record: a female at a bird feeder: 19 Dec -1 Jan 2009-10, Savannah, Andrew Co. (C. Oldenburger). The record of a photographed female at a feeder in St. Louis, 20 Nov-1 Feb 1978-79 (D. Jones et al.; VIREO $\mathrm{x} 08 / 16 / 001)$ was evaluated by the MBRC and thought to be a Baltimore. Other reports lack evidence. See remarks under Baltimore Oriole.

\section{Baltimore Oriole (Icterus galbula)}

Status: Common summer resident in Glaciated and Osage plains and Ozark Border; locally uncommon in other regions; rare winter visitant. 
Documentation: Specimen: male, 4 May 1879, Charleston, Mississippi Co. (MCZ 44116).

Habitat: Open woodland and forest, parks and residential areas.

Spring: The first arrivals appear by mid-Apr at the southern border and at the beginning of the final week of Apr in the north. Peak is in early May in the south, mid-May in the north. Migrants are routinely seen into early Jun. An average of $0.5 \mathrm{birds} / \mathrm{hr}$ was recorded at Forest Park between 29 Apr-18 May 1979-90 (RK; n=343 hrs). Earliest dates: 1, 3 Apr 2011, Webster Co. (AK); 1, 7 Apr 2011, Busiek SF (CBu et al.); 1,7 Apr 2012, Roaring River (D. Williams). High counts: see Table 6; 51, 4 May 2007, Galena area, Stone Co. (D. Gagne).

Summer: This oriole is decidedly more widespread and common in the Glaciated and Osage Plains, in the Ozark Border, and along the entire Mississippi River floodplain, although it is much more local in the Mississippi Lowlands because that area is largely treeless away from the river. It is very local and much less common in the Ozarks, especially in the heavily-forested sections, where it is primarily found in towns and cities and along Ozark streams with a broad, more open floodplain (BBS, BBA, Table x). High counts: an average of 70.3 birds were recorded along 16.5 miles of the Nodaway River ( $\mathrm{n}=6$ years; 1992-97; Table 6); in contrast, no birds were recorded on several Ozark rivers (Table 6).

Fall: As with the Orchard Oriole, migration commences early, with obvious migrants (often family groups) observed in late Jul. Peak is during Aug. By early Sep numbers are greatly reduced, but unlike the Orchard Oriole it is regularly seen in small numbers until the end of Sep. It is rare after mid-Oct and casual in Nov; see Winter season. High count: 20, 24 Aug 2007, Lake Contrary (LL); all other high counts $<20 /$ day.

Winter: There are now about 20 records statewide, all involving single birds that include all age and sex classes, with the majority at bird feeders. Prior to 1990, there were only about five records for this period.

Comments: Hybridization between Bullock's and Baltimore orioles is frequent, and thus hybrids are likely to appear in Missouri. To date, however, no unequivocal hybrid has been recorded.

\section{Red-winged Blackbird (Agelaius phoeniceus)}

Status: Common summer resident and transient; locally common winter resident. Documentation: Specimen: male, 4 May 1879, Charleston, Mississippi Co. (MCZ 46579).

Habitat: Breeds in marshes, swamps, and wet meadows, and along roadside ditches. During migration and winter seen in a wide variety of habitats, but not in continuous forest. 
Spring: This is one of the most abundant birds at all seasons. By late Feb large flocks are already seen returning north, and some individuals establish territories. Enormous flocks are observed during the last two weeks of Mar into early Apr. By mid-Apr smaller groups are observed, but migration continues into May. High counts: several estimates of millions/day in March.

Summer: BBS data indicate it is the most widespread and abundant species in the state at this season. However, BBS data are poor at estimating small woodland species, such as chickadees and titmice, that likely surpass this blackbird in numbers. Based on BBS data it is most common in the Mississippi Lowlands and least common in the forested Ozarks. Presumably it was much less numerous and local in the former region prior to deforestation.

Fall: The inception of migration is difficult to determine, as relatively large flocks are seen moving at least locally as early as mid-Jul. Flocks that are certainly southbound are observed by mid-Sep. Large concentrations, in the millions of individuals, are typically observed at the end of Nov/early Dec at prime roosting sites, such as Loess Bluffs, Swan Lake, and Mingo.

Winter: At this season the species is considerably more local; nonetheless it can be quite abundant at some areas, especially early and late in the season. High count: 8,019,000, 19 Dec 1978, Loess Bluffs CBC. A very similar, independent estimate was made during the same week by a blackbird biologist (fide B. Heck, Loess Bluffs manager).

\section{Bronzed Cowbird (Molothrus aeneus)}

Status: Accidental winter visitant.

Documentation: Specimen; see below.

Record: A single record of a male at a bird feeder at the Loess Bluffs headquarters on 5 Jan 1979 (B. Heck et al.; photo in Robbins and Easterla 1981; KU 117922).

\section{Brown-headed Cowbird (Molothrus ater)}

Status: Common summer resident; locally uncommon winter resident.

Documentation: Specimen: egg in Yellow-breasted Chat nest, 3 Jun 1897, Golden City, Barton Co. (WFVZ 116426).

Habitat: Open areas, especially grassland, pastures, harvested cultivated fields, woodland and forest edge.

Spring: As with other blackbirds, migrants are apparent by the end of Feb. Numbers increase until a peak in early Apr in the south and about a week later in the north. High counts: 3,000, 1 Apr 1999, Little Creve Coeur Lake, St. Louis (JM); 1,800, 16 Mar 2012, Columbia Bottom (D. Gochfeld, S. Whittle, S. Galick); 1,500, 21 Mar 1984, St. Joseph (FL). 
Summer: Formerly most common in the western half of the Glaciated Plains (BBS data, Robbins and Easterla 1992), but with the continued conversion of pastureland to crops in that area, this cowbird may no longer be most abundant there. It is less ubiquitous in the Mississippi Lowlands and in the more contiguous, heavily-forested parts of the Ozarks than in other regions (BBS). During the course of the BBS data set, 1968-2013, this cowbird has shown a slight decline in most areas of the state.

Fall: Flocks numbering in the thousands are regularly seen from Sep through the end of the period. Peak appears to be during Oct into early Nov. High counts: 100,000, 13 Nov 2014, Dunklin Co. (TJ); 75,000, 5 Nov 2011, Dunklin Co. (TJ).

Winter: Much more local at this season, especially in the northern half of the state, but during mild winters large flocks may be encountered even there, e.g., 1,100, 8 Feb 2003, Bilby Ranch (M. Stoakes). During the heart of the winter, it is typically least widespread and rarest in the Glaciated Plains and in the heavily-forested sections of the Ozarks. CBC high counts, both at Springfield: 165,000, 19 Dec 1981; 150,000, 15 Dec 1979.

\section{Rusty Blackbird (Euphagus carolinus)}

Status: Locally common transient; locally uncommon winter resident in south, rare in north.

Documentation: Specimen: male, 3 Mar 1894, Bryds Mill, Dunklin Co. (CHAS 17803).

Habitat: Woodland, flooded forest, cultivated fields and feedlots.

Spring: Migrants begin supplementing the winter population as early as late Feb. By early Mar it can be common and remain in high numbers through early Apr. After the second week of Apr it is rare. High counts: 10,000, 1 Mar 2008, Mingo (BL); 2,000+, 21 Feb 1916, Kansas City (Harris 1919b). Latest dates: 1, 27 Apr 2013, Creve Coeur (C. Brown); 23 Apr 1874, Johnson Co. (Widmann 1907); female, 23 Apr 1977, Bigelow Marsh (DE).

Fall: Typically not encountered until the second week of Oct, but from late Oct into mid-Nov it is common. In the north, it is typically rare by late Nov. Earliest dates: 28 Sep 1896, Clark Co. (E. Currier in Widmann 1907); 1, 2 Oct 2004, Dunn Ranch, Harrison Co. (MR); 10, 5 Oct 2013, Montrose (MR, CH, J. Cooper). High counts, both at Loess Bluffs by FL: 500, 13 Nov 1966; 500, 15 Nov 1981.

Winter: This blackbird is locally uncommon in the southern half of the state in wooded wetlands; during mid-winter it is perhaps most consistently encountered in larger numbers in the Mississippi Lowlands, but early in the period large concentrations may be present even in the north, such as Loess Bluffs. CBC high counts: 20,250, 19 Dec 1978, Loess Bluffs; 14,682, 19 Dec 1982, Loess Bluffs; 10,000, 23 Dec 1995, Taney Co. 
Comments: Both BBS and CBC data in North America have shown significant declines in this blackbird, especially since about 1980, as a result of degradation of boreal breeding habitat, loss in bottomland hardwood forest on the wintering grounds, large- scale blackbird control measures, and perhaps climate change (Greenberg and Droege 1999; Niven et al. 2004, Greenberg and Matsuoka 2010). Within Missouri most of the wintering habitat was lost between the late 1800s and the early 1900s, when most of the state was deforested, especially in the Mississippi Lowlands region.

\section{Brewer's Blackbird (Euphagus cyanocephalus)}

Status: Uncommon transient; rare winter resident.

Documentation: Specimen: female, 28 March 1937, near Chillicothe, Livingston Co. (KU 22514).

Habitat: Cultivated fields, pastures, and prairie. In winter, typically observed foraging in feedlots and cultivated fields and roosting at native prairie.

Spring: Migrants are observed as early as late Feb, with numbers increasing to a peak in early to mid-Apr. Although there are several records for the last week of Apr, there is only one May observation. High counts: 2,000, mid-Apr 1974, Busch (JC); 650, 26 Mar 2017, Taberville Prairie (E. Hough); 600, 27 Feb 2010, Otter Slough (CB, B. Beck); 525, 28 Mar 2011, Dade Co. (CBu, GS). Latest dates: 5, 10 May 2008, Fountain Grove (SK); 8, 29 Apr 1979, St. Joseph (FL); 3, 29 Apr 2007, near St. Joseph (JE).

Fall: The first arrivals are typically seen during the second week of Oct. Peak is during mid-Nov. Relatively large numbers may be encountered into the winter period. Earliest dates: 1, 22 Sep 1965, Busch (K. Arhos, S. Hanselmann); 4, 2 males and 2 females, 6 Oct 1987, Langdon, Atchison Co. (MR). High counts: 500, 9 Nov 1969, near St. Joseph (FL); three reports of 400+ birds in mid-Nov/early Dec.

Winter: Locally common in the Osage Plains prairies and in cultivated fields in the Mississippi Lowlands, rare to locally uncommon elsewhere. High counts: 700, 29 Jan 2016, Dade Co. (DBl and B. Blevins); 350, 27 Dec 1975, Kansas City North CBC; 300, males and females, 29 Dec 2001, Mingo CBC; 250, 1 Jan 2009, Otter Slough (CB).

Comments: Other blackbird species, especially Common Grackles, are frequently misidentified as Brewer's Blackbirds. Published reports of thousands on CBCs undoubtedly involved misidentifications.

\section{Common Grackle (Quiscalus quiscula)}

Status: Common summer resident; locally common winter resident in south, locally uncommon in north.

Documentation: Specimen: male, 3 May 1879, Charleston, Mississippi Co. (MCZ 44182). 
Habitat: For nesting, open areas with scattered trees, in towns and cities as well as agriculture-dominated landscapes. During migration and winter, also found in cultivated fields and at feedlots.

Spring: By the end of Feb large numbers are evident statewide. During late Mar/early Apr it is common statewide when flocks numbering in the thousands may be observed. Mostly summer residents remain by the latter half of Apr.

Summer: Currently this species is most common in the Mississippi Lowlands and least common in the heavily-forested sections of the Ozarks (BBS data). Prior to deforestation, it was much less common in both areas, especially the former. Widmann (1907) considered it "rare as a breeder" in the Ozarks. With the conversion of upland forest and prairie to parkland and residential areas, this grackle was documented to have dramatically increased at Swope Park, Jackson Co. between 1916 ( $n=9$ territorial males; Shirling 1920) and 1973 ( $\mathrm{n}=149$ territorial males; Branan and Burdick 1981). In contrast, BBS data indicate a significant decline of $3.53 \%$ for the $2003-2013$ period.

Fall: Flocks numbering in the thousands, sometimes hundreds of thousands, are encountered statewide throughout the period. Peak appears to be in late Oct/early Nov. High count: one million, 26 Oct 1966, St. Joseph (FL).

Winter: A locally common resident that can be seen in huge numbers, even in the millions, at roost sites. It is least widespread and common in the heart of winter in the northern Glaciated Plains. CBC high counts: 3,550,530, 17 Dec 2011, Columbia CBC; 1 million, 17 Dec 2005, Meramec CBC.

\section{Great-tailed Grackle (Quiscalus mexicanus)}

Status: Locally common transient in west and central; locally uncommon summer and winter resident in west and central; rare transient and winter visitant, and accidental summer resident in east.

Documentation: Specimen: female, 8 May 1976, Bigelow Marsh (KU 117998).

Habitat: During migration and winter most often in cultivated fields and feedlots; typically breeds in cattail-dominated marshes.

Spring: Along the western border, migrants begin augmenting the winter population in late Feb. Numbers increase through Mar and peak in early to mid-Apr. It is rare in the eastern half of the state at this season. One of only two nesting records for the east was of a single pair, $1 \mathrm{Apr}-31$ May 2012, eastern Adair Co. (F. Cuculich). High counts: 4,200, in 25 minutes, 22 Mar 2004, Kansas City, Jackson Co. (MG); 547, 6 Mar 2009, Buckner, Jackson Co. (MB).

Summer: Breeding is primarily concentrated in the western third of the state in cattail-dominated marshes and farm ponds with cattails. In drought years the species can be greatly reduced in numbers. In addition to the above Adair Co. nesting record there are the following breeding records for the central part of the state: Jun 1986, Macon 
Co.; 16 (ad and juvs.), 1 Jun - 21 Jul 1996, Eagle Bluffs (McKenzie 1996b); male, 3 females, farm pond, 7 Jun 1996, north of Versailles, Morgan Co. (J. Wilson); small colonies, summer 2003, in St. Clair Co. (SK); farm pond, summer 2007, Dunn Ranch, Harrison Co, summer 2007 (SK); adult with begging young, 27 Jul 2010, Swan Lake (SK). One of the largest colonies was an estimated 200+, 24 Jun 1993, Horseshoe Lake (DE).

Nesting was first documented in the state in 1979 in a cattail marsh at Big Lake SP (Robbins and Easterla 1986). Breeding was not noted away from Holt Co. until 1986, when a small colony was found in Cass Co. (J. Jefferson); the following year small colonies were noted in Buchanan (DE), Johnson (G. Gremaud), Newton (J. Wilson) and Ray (L. Burgess) cos. In 1990, the first Harrison Co. breeding record was documented (M. McNeely).

Fall: As at other times of the year, this grackle is most common along the two western tiers of counties, with relatively large flocks encountered in that area throughout the period, e.g., estimated 1,000, 4 Dec 2002, Boone Co. (NY); 500-700, 31 Oct - 14 Nov 1990, near Merwin, Bates Co. (J. Jefferson). There are now a number of records involving individuals and small flocks as far east as St. Louis.

Winter: Numbers vary considerably from year to year, but it is decidedly more regular and at times locally common in the western half of the state. The species is now regular but localized in the St. Louis area with high counts of up to 80 individuals. High counts: 3,000, 21 Jan 1999, downtown Kansas City (MG); 2,400, 18 Dec 2001, Loess Bluffs CBC; 1,060, 19 Dec 2009, St. Joseph CBC.

Comments: The first record of this species was on 4 Jan 1958, St. Charles Co. (JEC; Anderson and Bauer 1968). Inexplicably, the second record did not occur until Dec 1972, when a single bird was located in a large blackbird flock at Springfield (N. Fay).

\section{Family Parulidae: wood-warblers}

\section{Ovenbird (Seiurus aurocapilla)}

Status: Common transient; locally common summer resident in central and eastern Ozarks and Ozark Border, rare to locally uncommon in the Glaciated and Osage plains, absent from the Mississippi Lowlands.

Documentation: Specimen: female, 20 Jun 1857, Independence (USNM A08387).

Habitat: Breeds in relatively large tracts of upland woodland and forest; during migration can be found in most wooded areas including residential areas.

Spring: The initial migrants are seen during the second week of Apr in the south, but not until the final week of Apr in the north. Peak is in early May in the south, a few days later in the north. An average of 0.8 birds/hr was recorded 30 Apr-22 May 197990 at Forest Park (n=379 hrs; RK). Earliest dates: 1, 8 Apr 2001, Tower Grove (N. Barber); 12, photos, 10 Apr 2017, Sugar Camp Scenic Drive (DBl). High counts: 44, 8 
May 2014, Sugar Camp Scenic Drive (MR, JB); 39, 11 May 2013, Red Bridge Road, Christian Co. (DBl).

Summer: Most common in the continuous tracts of forest in the central and southeastern Ozarks. It is local in the Glaciated and Osage plains and apparently does not breed in the Mississippi Lowlands region. Within the northeastern section of the Glaciated Plains, relatively large concentrations may occur in extensive forest: 48 territorial males, 7 Jun 2001, 2.8 miles of trail, Charlie Heath CA (Robbins et al. 2001); 22 territorial males, 14 Jun 2008, Union Ridge CA, Adair/Sullivan/Putnam cos (PW). Area requirements and population densities were estimated for Ovenbirds in north-central and central Missouri (Van Horn et al. 1995, Wenny et al. 1993).

Fall: Migrants begin appearing by late Aug, with numbers increasing to a peak during the third week of Sep. It is rare but regular during the first half of Oct and only casually observed thereafter. Earliest date away from breeding areas: 1, 19 Aug 2001, Tower Grove (T. Berger). High counts from tower kills: 197, 20-21 Sep 1963, Columbia (George 1963); 87, 24 Sep 1960, Columbia; 84, 24 Sep 2009, Morgan Co. (WW). Latest dates: 1, window kill, 13 Dec 2003, Ashland, Boone Co. (K. Palmer; KU 93084); 1, 27 Nov 1993, Columbia (B. Elder); 1, 8 Nov 1975, St. Louis (JE); 1, 25 Oct 2007, Salem, Dent Co. (L. McClure).

\section{Worm-eating Warbler (Helmitheros vermivorum)}

Status: Locally uncommon summer resident in Ozarks and Ozark Border, rare elsewhere.

Documentation: Specimen: sex?, 27 May 1857, Independence (USNM A08309).

Habitat: Typically, mature woodland on steep slopes.

Spring: Typically this warbler is not seen until the final week of Apr in the south and a few days later in the north. Earliest dates: 1, 12 Apr 2014, Roaring River (JCa); 7, 13 Apr 2017, Sugar Camp Scenic Drive (DBl); four observations across different years for 14 Apr. High counts for Apr: 15, 29 Apr 2004, Onondaga Cave SP (A. Nisbett); 13, 25 Apr 2014, south of Columbia (PM). See Summer for high counts in May.

Summer: Very few are found breeding outside the central and southeastern Ozarks and Ozark Border. In the Glaciated Plains it is known to breed only along steep, wooded ravines as far north as Bluffwoods SF, Platte Co. (FL) and Weston Bend. Because of the very flat terrain, it is extremely local in the Osage Plains, and it is absent from the Mississippi Lowlands region. Floating rivers has provided access to birds in otherwise inaccessible areas, with the Jack's Fork River having the highest densities (Table 6): 29 (3.1), 31 May 2002, Highway 16 access, Jack's Fork; 15 (1.6), 1 Jun 2002, Rymer's Access, Jack's Fork; 16, 6 Jun 2010, Meramec SP (JU). Area requirements and population densities were estimated for this species in central Missouri (Wenny et al. 1993). 
In at least some areas of the Glaciated Plains, it was once more common, as Shirling (1920) recorded 21 singing males at Swope Park, Kansas City, in Jun 1916, but it had "mostly vanished" as a breeder there by the late 1920s (WC; Rising et al. 1978).

Fall: Very few are seen after late Aug and it is only casually observed during the latter half of Sep. Latest dates: 1, 2 Oct 1955, south of Gravois Mills, Morgan Co. (DE); 1, 1 Oct 1995, Lake of the Ozarks SP (CH, MR et al.); 1, photos, 1 Oct 2013, Ben Cash (TJ).

\section{Louisiana Waterthrush (Parkesia motacilla)}

Status: Common summer resident along Ozark and Ozark Border rivers and streams; rare to locally uncommon elsewhere.

Documentation: Specimen: male, 10 May 1879, Charleston, Mississippi Co. (MCZ 45440).

Habitat: During breeding season prefers clear flowing creeks, streams, and rivers.

Spring: This is one of the earliest warblers to arrive, with the first detected in the south by the second week of Mar. By late Mar large numbers may be encountered along Ozark streams and rivers. Peak is during mid-Apr in the south. Earliest dates: 1, photos, 8 Mar 2009, Castlewood SP, St. Louis Co. (D. and M. Marjamaa); two observations for 12 Mar. High counts: several counts of 60-65 on Ozark rivers (Table 6). High count early in season: 26, 25 Mar 2007, Busiek SF, Christian Co. (DB1 and B. Blevins).

Summer: It is common and widespread along clear running streams and rivers of the Ozarks and Ozark Border. It is quite local and much less common in the Glaciated and Osage Plains and virtually absent from the Mississippi Lowlands. See Table 6 for results from river-based surveys. High counts (from Table 6): 65 (5.9), 3 Jun 2005, upper St. Francis River; 65 (5.5), 3 Jun 2004, Turner's Mill, Eleven Point River; 63 (6.0), 29 May 2003, Logyard, Current River.

Fall: This species leaves the breeding grounds very early: birds are heading south during the first half of Jul, and numbers are greatly reduced by early Aug. It is rare after the first week of Sep. Birds encountered after mid-Sep should be documented, as tower-kill data have erroneously reported this species as occurring in late Sep/early Oct (George 1963, Heye 1963); reexamination of the few extant specimens from those reports has proved them to be Northern Waterthrush (MR). Widmann's (1907) comment of "still common and in song in early Oct 1896" in Dunklin Co. is hard to reconcile. Latest dates: 1, seen and heard, 21 Sep 1997, Tower Grove (JVB); 1, 12 Sep 2010, Otter Slough (CB).

\section{Northern Waterthrush (Parkesia noveboracensis)}

Status: Common transient.

Documentation: Specimen: female, 8 May 1878, Charleston, Mississippi Co. (MCZ 47217). 
Habitat: Primarily seen in wet thickets, edges of flooded woodland and forest, and along streams.

Spring: This waterthrush arrives two to three weeks after the first Louisiana Waterthrush. The first appear during the second week of Apr in the south (late Mar reports are suspect) and a few days later in the north. Peak is typically during the first week of May with a few individuals seen through the remainder of the month. An average of 0.7 birds/hr was recorded at Forest Park, 23 Apr-15 May 1979-90 (RK; n=390 hrs). Earliest dates: 1, 4 Apr 2016, Graham Cave SP, Montgomery Co. (PM et al.); 1, 8 Apr 1987, St. Louis (S. Russell); 1, 14 Apr 2014, J. A. Reed CA (MB). High counts: 49, 3 May 2013, Loess Bluffs (DE, TE; Easterla 2013); 29, 29 Apr 2017, Eagle Bluffs (BJ, PM, E. Wood); 17, 1 May 2011, Duck Creek (CB). Latest dates: male, 12 Jun 2010, Little Dixie Lake, Callaway Co. (RD); 1, 3 Jun 1984, Clinton Co. (CH).

Fall: The first migrants appear by the second week of Aug with numbers increasing to a peak during the second or third week of Sep. It is regularly encountered through the first week of Oct. Earliest dates: 1, 6 Aug 2012, Pershing SP (SK); 1, window kill, 8 Aug 1972, Kansas City (S. Patti); two reports for 12 Aug. High counts from tower kills: 113 (Northern plus erroneously identified Louisianas), 20-21 Sep 1963 (George 1963; see comments under Louisiana Waterthrush); 9, 19 Sep 1966 (Elder and Hansen 1967). Latest dates: 1, 12 Nov 2006, St. Louis Co. (M-J. Voss); 1, 29 Oct 2017, Rocky Ridge, Franklin Co. (J. and S. Foreman); 1, photos, 22 Oct 2016, Ben Cash (TJ).

\section{Bachman's Warbler (Vermivora bachmanii)}

Status: Extinct; formerly a common summer resident along the St. Francois River drainage in Dunklin Co; accidental in southeastern Ozarks.

Documentation: Specimens; see below.

Habitat: Dense growth in understory of swampy woodland and forest; perhaps in cane (Arundinaria gigantea) stands as postulated by Remsen (1986).

Spring: Along the St. Francois River in Dunklin Co., Widmann (1907) found singing males as early as 17 Apr 1898. He discovered and described the first nest and eggs for the species when on 13 May 1897 he located a nest that was in the final stages of construction; three eggs were eventually laid (Widmann 1897). In the same area, Howell (1911) found it "rather numerous" from 25 Apr to 5 May 1909. He collected six males during that period (USNM 204985-204990).

Presumably this warbler was more widespread, as Woodruff (1907) collected two males during May 1907 in the southeastern Ozarks. One (AMNH 229845) was taken near Ink, Shannon Co., on 2 May and the other near Grandin, Carter Co., on 23 May (AMNH 229846). At the latter locality Woodruff was certain that he heard another male singing. Apparently the species persisted in the St. Francois drainage through the late 1940s, as W. Cunningham found it west of Cardwell, Dunklin Co., in 1934 and again in the spring of 1948. The latter report is apparently the last for the state; it was 
of a male "in second growth gum and cypress." The last verified record of this species was in 1962, in South Carolina (Hamel 2011).

\section{Golden-winged Warbler (Vermivora chrysoptera)}

Status: Uncommon transient, formerly accidental summer resident.

Documentation: Specimen: male, 13 May 1857, St. Louis (USNM A6982).

Habitat: Secondary and mature woodland and forest edge.

Spring: Larger numbers are reported from the eastern half of the state, spring and fall. Typically birds are first seen at the end of Apr with peak during the second week of May. Late migrants are seen through the end of May, with two early Jun observations. An average of 0.6/hr ( $\mathrm{n}=359 \mathrm{hrs}$ ) were observed, 27 Apr-17 May 1979-90, at Forest Park (RK). Earliest dates: 1, 13 Apr 2008, Weldon Spring (D. and M. Marjamaa); 1, 17 Apr 2012, Eagle Bluffs (N. and J. March). High counts: 20, 5 May 1990, Mingo/ Duck Creek (BRe, R. Brundage); in west: 10, 13 May 1995, Knob Noster SP (D. Fisher, T. Liston). Latest dates: singing male, mid-Jun 1984, Tyson Valley RC (R. Coles); 1, 8 Jun 1980, Bluffwoods SF (FL); 1, 5 Jun 2011, Otter Slough (CB).

Summer: There is a single, definitive record breeding record, quite surprisingly from Mississippi Co. in the bootheel. Two eggs were taken from a nest on 29 May 1890 (M. Crawford; WFVZ 73393). That record represents the southernmost for the species. In addition, Widmann (1907) related that it was reported as a breeder in Audrain Co. in 1884 by Mrs. Musick. During that same period the species was recorded breeding nearby in Lee Co., Iowa (opposite Clark Co., Missouri), and in Richland Co., Illinois (opposite St. Louis). These records coincide with an increase and range extension of the species in the northeastern United States (Connecticut, New York) in the late 1880s through the turn of the century (Gill 1980). The Missouri records are consistent with the supposition that the expansion during that period was related to deforestation across the entire eastern part of the country, which temporarily provided prime breeding habitat for Golden-wings, i.e., early stages of old field succession (Gill 1980).

Fall: There are no other definitive records until the third week of Aug. Peak appears to be in mid-Sep with birds regularly seen through Sep. Earliest dates: 1, photos, 19-21 Aug 2012, Tower Grove (AR, CMc); 1, 21 Aug 2012, Tower Grove (D. and M. Marjamaa). High counts, both at Ben Cash by TJ: 10, 21 Sep 2013; 9 , 9 Sep 2011. Latest dates: 1, 10-13 Oct 2011, Ben Cash (TJ); 1, 12 Oct 2003, Big Oak Tree (JE); 1, 11 Oct 2017, Tower Grove (BJ, CMc).

\section{Blue-winged Warbler (Vermivora cyanoptera)}

Status: Uncommon summer resident in the Ozarks and Ozark Border, rare elsewhere. Documentation: Specimen: female, 21 May 1883, St. Louis (Michigan State University OR.631).

Habitat: Open fields with scattered shrubs and trees, and bushy areas at edge of woodland and forest. 
Spring: By the second week of Apr birds have begun to arrive in the south. Peak is in early May. It is regularly seen in small numbers in the north, but it is rare in the northern counties, especially the north-central and northwestern sections. An average of 0.3 birds/hr ( $\mathrm{n}=246 \mathrm{hrs}$ ) were observed at Forest Park, 25 Apr-8 May 1979-90 (RK). Earliest dates: 1, 1 Apr 1988, Farmington, St. Francois Co. (BRe); 1, 2 Apr 2007, Wayne Co. (J. Bergmann); 3 Apr 1896, "southern border" (Widmann 1907). High count: 29, 5 May 2006, Busiek SF (E. Schuette).

Summer: This warbler is most common in the Ozarks and the Ozark Border, with more local breeding populations in the eastern Glaciated and eastern Osage plains. It is rarest in the western Glaciated Plains and Mississippi Lowlands. Localized populations in the western part of the state appear to be ephemeral based on available habitat. For example, Shirling (1920) recorded as many as 17 singing males in Swope Park in Jun 1916 and it was "regular" in Jackson Co. until the 1940s (WC; Rising et al. 1978). Just to the north of Jackson Co., at Weston Bend, several pairs, including hybrids with the "Brewster's" phenotype, were first noted breeding in 2000 . However, with vegetational succession the species is on the verge of extirpation at that site. Widmann (1907) related that it was "common" at Chillicothe, Livingston Co., on 16 May 1854. In the extreme north, this warbler has consistently bred at Rebel's Cove, Schuyler/Putnam cos., where 10 territorial males were recorded on 31 May 1986 (MR), and 4 territorial males were noted there on 7 Jun 2001 (Robbins et al. 2001).

Fall: Very few remain in the state by early Sep. It is quite rare during the latter half of Sep and there are only a few Oct records. Latest dates: 1, 17 Oct 2014, Hornersville Swamp area (TJ); 1, 6 Oct 1996, Springfield (D. Rising); 2, photos, 4-6 Oct 2013, Ben Cash (TJ); 1, 4 Oct 1998, Tower Grove (D. Bozzay).

Comments: Hybrids between Blue-winged and Golden-winged warblers are infrequently observed both during migration and in the breeding season (see above). For example, during migration six "Brewster's-type" phenotypes were observed in eleven springs at Forest Park (1979-89; Korotev 1990). The earliest hybrid documented for the state was of a male, 12 May 1907, Spring Valley, Shannon Co. (AMNH 229871). Extraordinarily, a probable hybrid between a Blue-winged/Golden-winged and an American Redstart was carefully scrutinized and described on 5 May 1991, in southern Taney Co. (JHy, PMa, Mr. and Mrs.Van der Mehden).

\section{Black-and-White Warbler (Mniotilta varia)}

Status: Common transient; uncommon summer resident in the Ozarks, rare to very rare elsewhere.

Documentation: Specimen: female, 6 May 1879, Charleston, Mississippi Co. (MCZ 45169).

Habitat: Woods and forest during migration; during the breeding season, primarily mature bottomland forest. 
Spring: The first arrivals typically do not appear in the south until the beginning of the final week of Mar and in early Apr in the north. Peak is during the last week of Apr in the south and the second week of May in the north. Earliest dates: 10 Mar 1894, Dunklin Co. (Widmann 1907); 1, 10 Mar 2001, Lee's Summit (S. Reese). High counts, both by DB1, Sugar Camp Scenic Drive: 53, 11 Apr 2015; 53, 14 Apr 2016.

Summer: This warbler is far more widespread and common in the Ozarks than any other region (BBS, BBA, eBird). It is in particularly low densities in the Glaciated Plains and Mississippi Lowlands regions. Habitat for this species has declined considerably since European settlement, as it was a common breeder in the Mississippi Lowlands and in forests along the Missouri and Mississippi Rivers that are now either denuded or reduced to a thin forested strip along the banks (Widmann 1907).

Fall: The first migrants begin to appear during the latter two weeks of Aug and increase to a peak in mid-Sep. It is regularly encountered in small numbers through the first week of Oct. It is only casually seen during the last half of Oct. Earliest dates at non-breeding sites: 1, 13 Aug 2015, Columbia Bottom (BR); 1, 15 Aug 2001, Tower Grove (S. McCowan). High counts, all from tower kills: 45, 24 Sep 2009, Morgan Co. (WW); 22, 24 Sep 1960, Columbia; 18, 19 Sep 1966, Columbia (Elder and Hansen 1967). Latest dates: 1, 9 Dec 2004, Hawn SP, St. Genevieve Co. (DW); 1, 1-2 Nov 1969, Maryville (MR); 1, 2 Nov 1981, Busch (M. Richardson).

\section{Prothonotary Warbler (Protonotaria citrea)}

Status: Locally common summer resident across all regions, but it is rare and local in the northern Glaciated Plains.

Documentation: Specimen: male, 6 May 1879, Charleston, Mississippi Co. (MCZ 45177).

Habitat: Bottomland woodland and forest, especially river oxbows and wooded swamps and marshes; reservoirs with dead trees along the periphery.

Spring: The initial migrants appear at the beginning of Apr in the south with peak in late Apr. Birds are not seen in the north until late Apr. Earliest dates: three separate sightings for 31 Mar in the Mississippi Lowlands. High counts: 100+, 9 May 1946, Big Oak Tree (WC); 53, 16 Apr 2015, Ben Cash (TJ); 39, 8 May 2009, Mingo (V. Harp).

Summer: The highest densities are in oxbows, wooded swamps and marshes, and reservoirs with dead trees along the periphery throughout the non-Ozark part of the state. Even in the north-central Glaciated Plains, densities can be relatively high in prime river bottom habitat, e.g., 21, 2 Jul 2002, Pershing SP (SK); nonetheless, it is least widespread and in lowest densities in the northernmost part of the Glaciated Plains. Within the Ozarks it is in lower densities and more local along the narrow, fast-flowing streams and rivers than in the broader floodplains (Table 6). Although most of its habitat has been removed, it is still locally common in the few remaining tracts of wooded swamps in the Mississippi Lowlands, where it was once widespread and quite common (Widmann 1907), e.g., 48 (8.8), 4 Jun 2005, Coon Island, lower 
Black River. Other high counts: 113 (8.6), 26-27 May 1999, contiguous stretches (total of 13.1 river miles) of lower St. Francis River; 58 (4.8), 2 Jun 1999, Marmaton River, Vernon Co. (Table 6).

Fall: Most have left the state by late Aug, although they remain common right up until that time, e.g., 14, 26-27 Aug 1976, Bennett Springs SP, Dallas Co. (J. Garrett); 14, 2 Sep 2007, Pershing SP (PK). Very few are seen during the final three weeks of Sep. Latest dates: 1, banded and photographed, 10 Oct 2011, Van Meter SP, Saline Co. (D. Ripper); 1, 7 Oct 1958, St. Joseph (FL); 1, 29 Sep 1994, Alfred Lake Natural Area, Butler Co. (MR, BJ).

\section{Swainson's Warbler (Limnothlypis swainsonii)}

Status: Rare and local summer resident along river floodplains in the southern two tiers of counties; casual transient and summer visitant elsewhere.

Documentation: Specimen: sex?, 14 Jun 1892, Edge Hill, Reynolds Co. (CHAS 16610).

Habitat: Primarily associated with cane (Arundinaria gigantea) along southern Ozark streams and rivers, but also in dense thickets.

Spring: The first arrivals are heard at the end of the third week of Apr. Peak appears to be in mid-May. Earliest dates: 2, 16 Apr 1986, below Greer Springs, Eleven Point River, Oregon Co. (J. Wilson); 1, 18 Apr 1974, Big Oak Tree (JHa). High counts: 10 individuals on three different sections of Current and Eleven Point rivers (Table 6).

There are several extralimital records, all but two south of the Missouri River in the eastern edge of the Ozarks and Ozark Border. The northernmost are as follows: 1, 22 Apr 1950, St. Louis (M. Tuttle); 1, 23 Apr 1973, St. Louis (P. Snetsinger); 1, 3 May 1981, south of Westphalia, Osage Co. (J. Garrett, J. Warner); 1, 22 May 1977, Gray Summit, Franklin Co. (RG); 1, photos, 27 May - 3 Jun 2015, Hidden Valley Nature Reserve, Clay Co. (LR, S. Buback, LW, M. Mutchler et al.). Rising et al. (1978) listed three May records for Johnson Co., Kansas, adjacent to Kansas City, Missouri.

Summer: Surveys along Ozark streams and rivers have documented that this species is a low-density inhabitant of cane stands along the southern two tiers of counties as far west as Roaring River. The highest densities are along the Current and Eleven Point rivers. Field work sponsored by the Missouri Department of Conservation documented 26 sites where the species was present in 1992 (B. Thomas). High counts from more recent river-based surveys are in Table 6.

Widmann (1907) recognized the importance of cane to this species when he found it in Dunklin Co. in 1894, and subsequent studies have confirmed this within Missouri (Eddleman 1978, Thomas et al. 1996). Presumably, it was most common in the Mississippi Lowlands prior to the draining and deforestation of this area. There is one extralimital record for this season: 1, photos, 10-11 Jul (possibly present in Jun) 2005, Liberty, Clay Co. (DW, C. Hensley, T. Swope, LW et al). 
Fall: Presumably this species leaves the state during Aug, but data are scant. At least some birds remain on breeding grounds into early Sep, e.g. 3, 3 Sep 1968, Big Oak Tree (JHa). Latest dates, two of which are extralimital records: 1, 16-17 Sep 1972, Busch (J. and N. Strickling); 1, 17 Sep 1996, Springfield (D. Rising); 1, 12 Sep 1989, western Taney Co. (BJ).

\section{Tennessee Warbler (Oreothlypis peregrina)}

Status: Common transient.

Documentation: Specimen: male, 5 May 1879, Charleston, Mississippi Co. (MCZ 45219).

Habitat: Prefers woodland and forest, but can be numerous wherever there are trees.

Spring: Typically not observed until the third week of Apr in the south, about a week later in the north. During peak, usually second week of May, this is one of the most conspicuous and abundant passerine migrants, as it is often heard persistently singing anywhere there is at least a small clump of trees. A few individuals are occasionally seen into the first week of Jun. An average of $5.8 \mathrm{birds} / \mathrm{hr}$ was recorded at Forest Park, 20 Apr-25 May 1979-90 (RK; n=521 hrs). Earliest dates: male, 6 Apr 2010, near Rogersville, Webster Co. (AK); three records for 9 Apr. High counts: 362, 9 May 2014, Sugar Camp Scenic Drive (MR, JB); 233, 9 May 2013, Sugar Camp Scenic Drive (MR, CH, JB); 205, major fallout event, 10 May 2004, Big Lake SP and Loess Bluffs (MR, A. Powell). Latest dates: 1, singing, 28 Jun 1980, Providence, Boon Co. (BG); 1 singing, 20 Jun 1956, south of Gravois Mills (DE).

Fall: Usually this warbler does not appear until the beginning of Sep with peak during the third week of that month. Individuals are regularly encountered through the first half of Oct, e.g., 6, 18 Oct 2008, Big Spring SP, Carter Co. (MR), and it is casual during Nov. Earliest dates: 1, 9 or 10 Aug 1985, St. Louis (M. Wiese); several sightings for 25 Aug. High counts, tower-kill data from Columbia: 92, 19-20 Sep 1966 (Elder and Hansen 1967); 66, 20-21 Sep 1963 (George 1963). Latest dates: 1, 27 Nov - 4 Dec 1988, St. Louis (L. Hepler, RG et al.); 1, 27 Nov 1997, Chillicothe (SK); 1, 24 Nov 1985, St. Louis (RA).

\section{Orange-crowned Warbler (Oreothlypis celata)}

Status: Common transient in west, uncommon in east; rare winter visitant/resident in south, casual in north.

Documentation: Specimen: male, 2 May 1965, Beverly Lake, Platte Co. (KU 118174). Habitat: Brushy areas, weedy fields with small trees and shrubs, forest and woodland edge.

Spring: Much less conspicuous at this season than in fall. More common in the west than in the east both spring and fall. Aside from the occasional wintering bird, the initial migrants typically do not appear until the beginning of the third week of Apr. Peak is usually during the final days of Apr or the first few days of May. It is absent after mid-May. An average of 0.3 birds/hr was recorded at Forest Park, 20 Apr-10 May 
1979-90 (RK; 331 hrs). Earliest dates: 3, 27 Mar 1998, Trail of Tears SP (NY); 1, 1 Apr 2012, Jefferson Co. (JU); 1, 9 Apr 1982, Big Oak Tree (JHa). High counts: 30, 4 May 2008, Weston Bend (MR, M. Andersen); 24, 3 May 2014, Weston Bend (M. Stewart); 20, 7 May 1998, Weston Bend (CH, M. Clark). Latest dates: 1, 27 May 1982, Missouri River, Atchison Co. (MR).

Fall: Usually not observed until mid-Sep, with a notable increase by the last week of Sep. Peak is normally during the first week of Oct. It remains fairly common through mid-Oct and is seen in small numbers through early Nov. Thereafter observations are of single, widely scattered birds. Earliest dates: 1, 6 Sep 2001, Smithville Lake (RF); 1, 8 Sep 1987, St. Louis (E. Larson); 1, 8 Sep 2012, Little Dixie Lake, Callaway Co. (RD). High counts: 37+, 28 Sep 1974, east of Maryville (MR); 29, 6 Oct 1987, Brickyard Hill (MR).

Winter: Prior to 1990 there were only four observations for this period. Now it is a rare but regular winter visitant/resident, primarily in the southern part of the state. Records in the northern half of the state are mostly from the last two weeks of Dec and typically represent birds that do not overwinter, whereas some birds in the southern half of state overwintered. The are two only two records of more than one bird: 2, 17 Dec 1997, Mingo (NY, BE et al.); 2, photos, 1 Jan 2018, Dresser Island CA, St. Charles Co. (MT; Confluence CBC).

Comment: Some fall Tennessee Warblers are easily mistaken for Orange-crowns; they may even have a wash of yellow on the undertail coverts. Any suspected Orange-crowned before mid-Sep should be examined very carefully and photographed, as Tennessee is far more likely at such an early date.

Potentially, western subspecies $O$. c. lutescens/orestera might occur as a vagrant, but field identification is difficult. An example is of a bird well photographed at a feeder from 20 Jan - 21 Mar 2009, St. Louis Co. (F. Zottorella; MBRC 2009-43), that was much brighter yellow both ventrally and dorsally than the eastern subspecies celata that migrates through and now occasionally winters in Missouri; however, definite subspecific identification could not be made even by parulid experts.

\section{Nashville Warbler (Oreothlypis ruficapilla)}

Status: Common transient; accidental winter visitant.

Documentation: Specimen: male, 9 May 1877, Charleston, Mississippi Co. (MCZ 45201).

Habitat: Brushy areas, woodland and forest edge.

Spring: Typically not seen until the beginning of the third week of Apr in the south and about a week later in the north. Peak is at the end of the first week/beginning of the second week of May. It is rarely seen through the last week of May. At Forest Park, an average of $4.5 \mathrm{birds} / \mathrm{hr}$ was recorded between $20 \mathrm{Apr}$ and 15 May 1979-90 (RK; n=419 hrs). Earliest dates: 1, 5 Apr 2012, Creve Coeur (JU); 1, 7 Apr 2012, Columbia 
Bottom (JU). High counts: 65+, 8 May 2010, Weston Bend (MR); 50, 5 May 1963, St. Louis (Hanselmann 1963); 50, 8 May 2009, Watkins Mill SP (L. Gilchrist, LW). Latest dates: 1, singing, 30 May 1986, northeastern corner of Clark Co. (MR); 1, 28 May 2012, Pickle Spring NA, St. Genevieve Co. (MH).

Fall: The initial migrants appear at the end of Aug. By the second week of Sep it is common with peak during the third or early part of the fourth week of Sep. It remains common through the first week of Oct. It is casual during Nov. Earliest dates: 1, 16 Aug 2002, Castlewood SP (MBr); 1, 17 Aug 2012, Platte Co. (L. Owens); 2 reports for 18 Aug. High counts: 120, 1 Oct 2000, Weston Bend (MG); 48, 20 Sep 2015, Liberty (M. Mutchler); 32, 15 Oct 2014, Dunklin Co. (TJ). Latest dates: 1, 5 Dec 2013, Reeds Spring, Stone Co. (J. Fitzgerald); 1, 15-27 Nov 1990, St. Louis (M. Richardson); 1, 13 Nov 1994, Springfield (D. Catlin).

Winter: Two records: 1, 28 Dec 1975, Weldon Spring CBC; 1, photos, at residential feeder, 7-25 Dec 2017, Columbia (B. Mees et al.).

\section{Connecticut Warbler (Oporornis agilis)}

Status: Rare transient in spring; much less frequent in fall.

Documentation: Specimen: male, 18 May 1974, southeast of Maryville (KU 118752).

Habitat: Woodland and forest understory, especially in moist areas.

Spring: A very low density, inconspicuous late migrant. Occasionally, a very early individual may appear at the end of Apr, but most years it is not detected until the end of the second week of May with peak at the end of the third or the beginning of the final week. Some individuals are observed through the first week of Jun. Most records are from the eastern half of the state. Earliest dates: 1, 24 Apr 1987, Farmington (BB); 1, 25 Apr 1979, St. Louis (C. Patterson); singing male, 26 Apr 2003, Springfield (PM). High counts: 4, 24 May 1997, Columbia (PM et al.); several observations of two/ site. Latest dates: 1, 5 Jun 2003, Tower Grove (JU); male, 5 Jun 2007, Castlewood SP (MBr).

Fall: As with the Blackpoll Warbler, the primary fall migration route of the Connecticut Warbler is to the east of Missouri, and thus it is much less frequently detected at this season; indeed, it is not recorded annually. Most records, all of single individuals, are from the end of Aug through the first half of Sep. Tower-kill reports from Kansas City during 1964 have proved, upon reexamination, to be Mourning Warblers. Earliest date: 1, 14 or 15 Aug 1974, St. Louis (JE); 1, 21 Aug 2006, Weston Bend (D. Willis, K. Driggers); 1, banded, 26 Aug 1971, Rosendale, Andrew Co. (JH). Latest dates: 1, 13 Oct 1983, Marais Temps Clair (M. Scudder, F. Ruegsegger); 1, 9 Oct 1938, St. Charles Co. (W. Short); 1, 8 Oct 2002, St. Louis (M. Terpstra).

Comments: Fall tower kill specimens mentioned in Robbins and Easterla (1992) have proved to be Mourning Warblers (MR). 


\section{MacGillivray's Warbler (Geothlypis tolmiei)}

Status: Accidental spring transient.

Documentation: Photograph; see below.

Habitat: Dense thickets and vegetation at edge of woodland and forest.

Record: A mist-netted male was photographed on 1 May 1974, in extreme northern Atchison Co. (F. and H. Diggs; VIREO x05/1/020; photo in Robbins and Easterla 1992).

\section{Mourning Warbler (Geothlypis philadelphia)}

Status: Uncommon transient.

Documentation: Specimen: sex?, 25 May 1882, Independence (KU 39311).

Habitat: Dense thickets and vegetation at edge of woodland and forest.

Spring: Like the Connecticut Warbler, this is a late migrant, but Mourning is much more numerous than that species. There are only two late Apr records, with the first birds typically seen during the second week of May. Peak is during the last two weeks of the month, and the last individuals are routinely seen during the first week of Jun. An average of 0.2 birds was recorded at Forest Park, 8-25 May 1979-90 (RK; n=243 hrs). Earliest dates: 1, 27 Apr 1981, St. Louis (B. Hely); 1, 28 Apr 1935, Hahatonka SP, Camden Co. (I. Adams). High counts: 18, 19 May 1999, Weston Bend (CH, J. Harter); 15, 30 May 1963, St. Louis (Hanselmann 1963); 14, 21 May 1997, Pulltite to Round Spring (9.6 river miles), Current River (MR, B. Barber, K. Zyskowski). Latest dates: 1, 11 Jun 1996, Springfield (LR); three observations of single birds for 9 Jun.

Fall: There are no records until mid-Aug. Based on tower-kill data, peak apparently is in mid-Sep with an occasional bird seen in early Oct. Earliest dates: 1, 14 Aug 2012, Tower Grove (AR, CMc); 1, 16 Aug 1979, Big Oak Tree (JHa). High counts, from tower kills, 9, 20-21 Sep 1963, Columbia (George 1963); 7 (see comments under Connecticut Warbler), 10-11 Sep 1964, Kansas City. Latest dates: 1, 10 Oct 1991, Tower Grove (m.ob.); 1, 7 Oct 1980, Springfield (C. Bonner); 1, tower kill, 6 Oct 1962, Cape Girardeau (Heye 1963).

\section{Kentucky Warbler (Geothlypis formosa)}

Status: Common summer resident in Ozarks and Ozark Border, local and uncommon in Glaciated and Osage plains, very local in Mississippi Lowlands.

Documentation: Specimen: male, 9 May 1879, Charleston, Mississippi Co. (MCZ 45449).

Habitat: Prefers understory of large tracts of mature woodland and forest.

Spring: The first migrants appear in the south during the second week of Apr, but typically not until the final week of Apr in the north. Peak is in early to mid-May. An average of 0.2 birds/hr was recorded at Forest Park, 23 Apr-15 May 1979-90 (RK; n=390 hrs). Earliest dates: 1, 30 Mar 1975, Charleston, Mississippi Co. (JHa); 1, 5 Apr 2008, 
Busiek SF (CBu); two reports for 9 Apr. High counts: 28, 11 May 2013, Red Bridge Road, Christian Co. (DBl); 23, 27 Apr 2012, floating Big Piney River, Texas Co. (RD).

Summer: BBA and BBS data demonstrate that this is a common breeder in the Ozarks and Ozark Border and much less common and more local in the other regions, although it can be locally common in continuous forest near the northern border, e.g., 9 territorial males, 7 Jun 2001, 2.8 miles of trail, Charlie Heath CA (Robbins et al. 2001). Area requirements and population densities were estimated for this species in central Missouri (Wenny et al. 1993).

Presumably it was much more common in the Mississippi Lowlands and Ozarks prior to European settlement. At Swope Park, Shirling (1920) counted 74 singing males in Jun 1916, whereas only a single male was encountered there in 1973 (Branan and Burdick 1981). Over $50 \%$ of the upland forest at Swope Park had been removed in the interval between those two surveys.

Fall: This warbler leaves early, primarily in Aug, with relatively few still present in early Sep. It is rare after mid-Sep, but there are several records for early Oct. Latest dates: ad male, 18 Oct 1977, Busch (P. Snetsinger); 1, tower kill, 8-9 Oct 1967, Cape Girardeau (P. Heye); two observations for 7 Oct.

\section{Common Yellowthroat (Geothlypis trichas)}

Status: Common summer resident; rare winter visitant.

Documentation: Specimen: male, 12 May 1879, Charleston, Mississippi Co. (MCZ 45487).

Habitat: Marshes, wet meadows with tall vegetation, weedy fields, and thickets bordering water.

Spring: In the Mississippi Lowlands the first migrants are seen during the second week of Apr, but not until the beginning of the final week in the north. Peak is at the end of Apr in the southeast, the second week of May in the north. There are a few midMar records that may represent winter residents. High counts: 136, 29 Apr 2012, Otter Slough (CB); 95, 26 Apr 2008, Otter Slough (CB); 81, 1 May 2011, Duck Creek (CB).

Summer: This is the most abundant warbler in the nonforested regions of the state. BBS data indicate the highest densities are in the Mississippi Lowlands, followed by the Glaciated Plains. Presumably it was only a local breeder in the Mississippi Lowlands prior to deforestation. As expected, the lowest densities today are in the forested Ozarks. High count: 88, 16 Jun 2012, Otter Slough (CB).

Fall: It remains common through Sep with peak during the third or early part of the fourth week of the month. Relatively few birds remain after the first week of Oct. However, small numbers linger statewide through the end of the period, especially during mild late falls. High counts: 284, tower kill, 24 Sep 1960, Columbia; 131, tower 
kill, 19 Sep 1966, Columbia (Elder and Hansen 1967); 60+, 29 Sep 2007, BK Leach (DR).

Winter: Most records are of late-lingering birds on CBCs that probably do not overwinter. The few birds that may overwinter are likely only in the extreme south. High counts: 3, 17 Dec 1993, Loess Bluffs CBC; several records involving two individuals.

\section{Hooded Warbler (Setophaga citrina)}

Status: Locally uncommon summer resident in southern Ozarks, rare elsewhere.

Documentation: Specimen: male, 11 May 1896, Dunklin Co. (MCZ 257065).

Habitat: Dense understory of relatively large tracts of woodland and forest; clearcuts several years old that have relatively tall, dense vegetation surrounded by mature forest; and cane along Ozark rivers and streams.

Spring: The first individuals appear at the southern border by the second week of Apr, with peak there in early May. It is a rare migrant elsewhere, especially in the northern section of the Glaciated Plains and the western part of the Osage Plains. Earliest dates: male, photos, 22 Mar 2008, Tywappity Community Lake, Scott Co. (CB); male, 24 Mar 2008, Forest Park (R. Haeseler); 1, 28 or 29 Mar 2008, Jackson, Cape Girardeau Co. (T. Draper); male, 31 Mar - 4 Apr 1991, Forest Park (K. Cohen et al.). High counts, all Sugar Camp Scenic Drive: 29, 13 May 2016 (MR, CH, JB); three records of 25, 7-8 May 1995, 2013, 2014.

Summer: A locally uncommon breeder in dense understory, often with stands of cane, along eastern and southern Ozark streams and rivers. Also within the southeastern Ozarks, it is not uncommon in areas that have been clearcut, with several years of subsequent vegetation succession, surrounded by mature forest. There have been scattered pairs in other regions of the state, but these are often ephemeral. For example, as many as 4 males (females were also observed), Weston Bend, ca. 2005-2012; nested at Busch in 2000; and a pair, 8 Jul 2003, Brickyard Hill (Easterla and Rodgers 2003). High counts: 27 (2.3), 3 Jun 2004, Turner's Mill, Eleven Point River (Table 6); ca. 15, 26 Jun 1988, Eleven Point River, below Greer Crossing, Oregon Co. (R. Brundage). See Table 6 for other results from river-based surveys.

Not surprisingly the species was once common in the Mississippi Lowlands before the area was denuded. Widmann (1907) also mentioned that it was "fairly common in the Ozarks, Ozark Border and in the bluff as well as the bottom lands of the Mississippi and Missouri Rivers." He found the species breeding as far north as Platte Co.

Fall: Most have left the state by the end of Aug, although some presumed summer residents are still present into early Sep. Obvious migrants, birds seen away from breeding areas, are primarily observed from late Aug through the first half of Sep. Latest dates and the only Oct observations: 1, 20 Oct 1984, Columbia (I. Adams); female or imm male, photos, 2-4 Oct 2012, Tower Grove (CMc, AR). 


\section{American Redstart (Setophaga ruticilla)}

Status: Common transient; locally common summer resident in Glaciated and Osage plains, Ozark Border, Ozark streams and rivers, and along the Missouri and upper part of the Mississippi rivers; rare summer resident in the Mississippi Lowlands. Accidental winter visitant.

Documentation: Specimen: female, 8 May 1879, Charleston, Mississippi Co. (MCZ 45546).

Habitat: During migration found in virtually any woodland or forest patch, but primarily breeds in riparian forest.

Spring: The first birds appear by mid-Apr in the extreme south, but not until the final days of Apr in the north. Peak is in early May in the south, mid-May in the north. Earliest dates: 1, 9 Apr 2000, Castlewood SP (MBr); 11 Apr 1893, bootheel (Widmann 1907); 1, 11 Apr 2001, Rolla (S. Juhlin); 1, 13 Apr 2012, Loess Bluffs (DW). High counts: for riparian survey results see Table 6; 51, 17 May 2014, Loess Bluffs (JK).

Summer: Common to abundant locally in bottomland woodland and forest in the Glaciated and Osage plains, Ozark Border, Ozark streams and rivers, and the Missouri and upper Mississippi rivers. It is rare to non-existent in the Mississippi Lowlands, as the BBA effort did not confirm any, and float-based surveys documented very few in that region (Table 6). High counts, both on Round Spring section of Current River (Table 6): 132 (10.7), 28 May 2004; 130 (10.5), 23 May 2003. Although the dates for these high counts are in May they represent breeding birds.

Fall: Relatively large numbers of migrants are seen during the latter half of Aug and early Sep, but by mid-Sep numbers are greatly reduced, with usually only 1-2 individuals seen into the second week of Oct. High counts: 50, 30 Aug 1978, St. Louis (S. Hosler); 15, 25 Sep 2003, Tower Grove (JE). Latest dates: imm, photos, 24 Oct 2015, St. Louis (RK); imm male, photos, 21 Oct 2016, St. Joseph (JH, S. Brown); imm, 19 Oct 2016, Ben Cash (TJ); imm, photos, 18 Oct 2013, Ben Cash (TJ).

Winter: A single record: imm, photos, 27 Dec 2003, Mingo, Stoddard Co. (J. and C. Vickery, J. Kelly, BRE, D. Reeves).

\section{Kirtland's Warbler (Setophaga kirtlandii)}

Status: Accidental transient.

Documentation: Specimen; see below.

Comments: Widmann (1907) collected a male on 8 May 1885 at St. Louis; unfortunately, that specimen is apparently no longer extant. That record occurred when the Kirtland's Warbler population was much greater, as there were a number of what are now considered extralimital records during the same period (Walkinshaw 1983).

There is an observation by two reliable observers of a bird at Busch on 30 Sep 1950 (JEC, JC). The bird was observed foraging 3-4 $\mathrm{m}$ above the ground in a semi- 
open area. The observers noted that it "continually wagged its tail" as it foraged ( $\mathrm{Na}$ ture Notes 22:46).

\section{Cape May Warbler (Setophaga tigrina)}

Status: Uncommon transient extreme east, rare west; casual winter visitant/resident. Documentation: Specimen: male, 10 May 1907, Shannon Co. (AMNH 229892).

Habitat: Woodland and forest; often conifers; sometimes residential feeders in winter.

Spring: Numbers vary considerably from year to year, as this warbler's populations are positively correlated with spruce budworm "outbreaks" on the breeding grounds. Thus, springs following above-average breeding production are when this species is observed in relatively high numbers. During above-average years such as 1966, 1968, and 1982, as many as twenty birds have been observed during May in the St. Louis area. However, in most years a total of $<5$ individuals may be observed during spring there. Korotev recorded a total of 73 birds, 28 Apr-11 May 1979-90 (n=252 hrs) at Forest Park.

The first individuals appear at the end of Apr with peak in early May. Earliest dates: male, photos, 5-6 Apr 2016, St. Louis (CMc, AR); 1, 21 Apr 1989, Schell-Osage (J. Garrett, E. Johnson); 1, 23 Apr 2007, Tower Grove (D. Garcia). High counts: 8, 8 May 2010, Tower Grove (PL et al.); 6, 4-5 May 1988, Forest Park (RK). Latest dates: 28 May 1907, St. Louis (Widmann 1907); 1, 26 May 1997, Forest Park (SD, BRe); 1, 26 May 2001, Roaring River (RM).

Fall: Although it is still more frequently reported from the eastern half of the state, there are more observed in western Missouri at this season. There are only two late Aug records, with the majority of observations during Sep. It is casual from mid-Oct to the end of the period. Earliest dates: 1, 23 Aug 1986, St. Joseph, Andrew Co. (LG); 1, 28 Aug 1994, Burr Oak CA (RF). High counts: 4, 28 Sep 2002, Winfield Lock and Dam, Lincoln Co. (JU); all other reports are of no more than two individuals. Latest dates: 1, 1-12 Dec 1963, St. Louis (S. Hanselmann); imm female, 31 Oct-11 Dec 1970, Maryville (MR et al.); imm female, 24 Nov 1984, Maryville (MR, DE; KU 118750); 1, 20 Nov 1993, Busch (BR).

Winter: There are six records of birds lingering into this period: imm, 20 Dec 1992, O'Fallon, St. Charles Co. (BR); imm female, 23-29 Dec 1993, St. Louis (A. McCormack); imm male (?), 1 Jan 1994, Sunset Park, St. Louis Co. (BR); 1, 7 Jan - 28 Mar 1995, Kansas City, Clay Co. (J. and C. Weir, M. McKellar); 1, 28 Dec-15 Jan 1997-8, Chillicothe (SK); imm, photos, 1-10 Jan 2015, St. Louis (CA).

\section{Cerulean Warbler (Setophaga cerulea)}

Status: Locally common summer resident in southeastern and southern Ozarks, locally uncommon in Osage Plains and Ozark Border, rare and very local in Glaciated Plains and Mississippi Lowlands. 
Documentation: Specimen: female, 10 May 1879, Charleston, Mississippi Co. (MCZ 45328).

Habitat: Mature, relatively large tracts of bottomland and upland woodland and forest.

Spring: At the southern border the first arrivals appear during the second week of Apr, but they do not arrive in the north until the final week of Apr. Peak in the south is in early May. Earliest dates: 1, 6 Apr 1958, south of Gravois Mills (DE); 1, 6 Apr 1986, Gray Summit, Franklin Co. (RG). High counts: for riparian survey results (Table 6); 50, 9 May 1946, Big Oak Tree (WC).

Summer: Locally common along streams and rivers of the eastern and southern Ozarks. Densities are lower in the upland areas of that same region (Robbins et al. 1998). It is locally uncommon in riparian areas of the Ozark Border and Osage Plains but quite rare in the Glaciated Plains and Mississippi Lowlands. Within the Glaciated Plains, birds were present, with a maximum of 4 territorial males, from 1999 through at least 2008 at Weston Bend; and 3 males were at Charlie Heath Memorial CA, Clark Co. in the northeastern corner (Robbins et al. 2001). High counts, all from along the upper Current River (Table 6): 63 (5.1), 23 May 2003, Round Spring; 59 (4.7), 28 May 2003, Jerktail; 58 (4.7), 27 May 2004, Round Spring.

This warbler was most common in the Mississippi Lowlands prior to the early 1900 's, when this region was forested (Widmann 1907), and in May 1871 it was considered common as far north as Platte Co. (J. Allen; Widmann 1907). In nearby Jackson Co., at Swope Park, Shirling (1920) recorded 34 singing males in June 1916, but it had virtually disappeared as a breeder there by about 1940 (WC; Rising et al. 1978). In Jul 1953, "fair numbers" were present along ca. 20 river miles of the Niangua River (Hedges 1953), but a survey of 13 miles along that river on 20 May 1978 failed to record a single individual (MR, FL).

Fall: This species leaves early, with few breeders observed after mid-Aug. Migrants, birds seen away from breeding areas, are seen during late Aug and into early Sep. Latest dates: 28 Sep 1897, Dunklin Co. (Widmann 1907); 1, 26 Sep 1968, Busch (JEC).

\section{Northern Parula (Setophaga americana)}

Status: Common summer resident in the Ozarks, Ozark Border, and Osage Plains, and along the large rivers; much more local in the Glaciated Plains and Mississippi Lowlands.

Documentation: Specimen: sex?, 10 May 1896, Dunklin Co. (Illinois State Museum 603285).

Habitat: Most common in mature bottomland woodland and forest.

Spring: The first individuals are now recorded during the last week of Mar in the extreme south, but it is typically not encountered in the north until mid-Apr. Peak is in late Apr in the south and early May in the north. An ave. of $0.4 \mathrm{birds} / \mathrm{hr}$ was recorded 
at Forest Park, 20 Apr-10 May 1979-90 (RK; n=331 hrs). Earliest dates: 1, 22 Mar 2008, Tywappity Community Lake, Scott Co. (CB); 1, 24 Mar 2012, Webster Co. (AK); several observations for $25 \mathrm{Mar}$ in the south. High count for early in season: 50, 7 Apr 2012, Roaring River SP (D. Williams); 50, 11 Apr 2015, Mingo (GSa, D. Martin et al.). High counts: see below and Table 6.

Summer: It is widespread and abundant along rivers and streams in the Ozarks, Ozark Border, and Osage Plains. It is also locally common in areas that are forested along the Missouri and Mississippi rivers. It is least widespread and abundant in the largely non-forested Glaciated Plains and Mississippi Lowlands, but prior to the latter region's deforestation, the species was more abundant there than in any other region (Widmann 1907). A decline was also noted in Swope Park, Jackson Co. between 1916 $(\mathrm{n}=32$ males; Shirling 1920) and 1973 ( $\mathrm{n}=11$; Branan and Burdick 1981). High counts from river-based surveys (Table 6): 115 (9.2), 28 May 2003, Jerktail, Current River; 109 (9.3), 3 Jun 2004, Turner's Mill, Eleven Point River; 94 (8.9), 29 May 2003, Logyard, Current River.

Fall: By mid-August, summer residents become quiet and inconspicuous; presumably many leave at that time. Migrants are routinely observed into early Oct, and relatively large concentrations have been noted into the second week of Oct in the Mississippi Lowlands, e.g., 35, 7 Oct 2007, Lake Wappapello (CB); 17, 7 Oct 2011, Otter Slough (CB); 12, 8 Oct 2008, Lake Wappapello (EW). However, by mid-Oct it is rare. Latest dates: 1, 5 Nov 2011, Ben Cash (TJ); 1, 25 Oct 2015, Columbia Bottom (BR); 1, 22 Oct 1983, Duck Creek (SD).

Winter: There is a single record for this season: male, 18 Dec 2001, Big Oak Tree $\mathrm{CBC}(\mathrm{NY})$.

\section{Magnolia Warbler (Setophaga magnolia)}

Status: Common transient, more so in eastern half of state.

Documentation: Specimen: 10 May 1879, Charleston, Mississippi Co. (MCZ 45315).

Habitat: Primarily in woodland and forest, often in cedars.

Spring: Typically not seen until the end of Apr, with peak during the second week of May. A few individuals are seen through the end of May. An average of 1.6 birds/ hr were recorded at Forest Park, 4-15 May 1979-90 ( $\mathrm{n}=327$ hrs: RK). Earliest dates: 1, 13 Apr 1986, Taney Co. (G. Dobbs); 1, 17 Apr 2011, General Mills CA, Scott Co (CB). High counts in east: 20, 2 May 2009, Eagle Bluffs (BJ); 20, 13 May 2010, Tower Grove (CMc, AR); 18, 19-20 May 1983, Forest Park (RK). High counts in west: 11, 14 May 2000, Weston Bend (MR); three reports across three years of 10. Latest dates: 1, 6 Jun 1988, near Farmington (BRe); 1, 4 Jun 2004, Tower Grove (JU); 2, 3 Jun 1975, Springfield (N. Fay).

Fall: The first arrivals are detected at the end of Aug, with peak at the end of the second or during the third week of Sep. It is regularly seen in small numbers into the 
second week of Oct. Earliest dates: 1, 19 Aug 2012, Tower Grove (JM, AR, CMc); 1, 19 Aug 2013, Martha Lafite Thompson Nature Sanctuary, Clay Co. (C. Ross). High counts: 25, 16 Sep 2012, Tower Grove (CMc, AR); 21, 21 Sep 2015, Ben Cash (TJ). Latest dates: 1, 7 Nov 1999, Busch (J. Moe); 1, 1 Nov 1975, Columbia (BG); 1, photos, 20-27 Oct 2013, Ben Cash (TJ); 1, 21-24 Oct 2014, Ben Cash (TJ).

\section{Bay-breasted Warbler (Setophaga castanea)}

Status: Uncommon transient, more frequently encountered in eastern half of state.

Documentation: Specimen: male, 10 May 1879, Charleston, Mississippi Co. (MCZ 45345).

Habitat: Woodland and forest.

Spring: As with the Cape May Warbler, numbers vary considerably from year to year, since this warbler's populations are positively correlated with spruce budworm "outbreaks" on the breeding grounds. Thus, springs following above-average breeding production are when this species is observed in relatively high numbers.

The first arrivals are not seen until the very end of Apr, with peak statewide between 10 and 16 May. Occasionally individuals are observed through the end of May. Korotev recorded an average of 1.2 birds/hr at Forest Park, 4-25 May 1979-90 (n=327 hrs). Earliest dates: three observations across three years for $26 \mathrm{Apr}$. High counts for east, both at Forest Park by RK: 18, 13 May 1981; 17, 19 May 1983; High counts in west: 5, 6 May 1962, St. Clair Co. (S. Hilty); 5-6, 15 May 1979, near Maryville (MR, DE, TB). There are two Jun observations: 1 (same bird?), 10 and 23 Jun 1984, St. Louis (R. Edwards); 1, 2 Jun 1907, St. Louis (Widmann 1907).

Fall: More common statewide at this season than in spring. See remarks under spring migration concerning large fluctuations in numbers observed. The first individuals are seen at the very end of Aug. It is regularly seen through the second week of Oct, but it is accidental after the third week. Earliest dates: 1, 28 Aug 2007, Tower Grove (JE); 1, 29 Aug 2010, Tower Grove (CMc, AR). High counts: 40, 12 Sep 1964, St. Louis (S. Hanselmann); 17, tower kill, 20-21 Sep 1963, Columbia (George 1963). Latest dates: 1, 1 Nov 1975, Columbia (BG); 1, 22 Oct 1955, Creve Coeur Lake (JEC).

\section{Blackburnian Warbler (Setophaga fusca)}

Status: Uncommon transient.

Documentation: Specimen: male, 3 Oct 1892, Willow Springs, Howell Co. (USNM 141782).

Habitat: Woodland and forest.

Spring: The first individuals appear at the very end of Apr in the south. Peak is during mid-May, with a few individuals occasionally encountered through the end of the month. Earliest dates: male, 9 Apr 1989, Roaring River (LG); 1, 11 Apr 1991, St. Louis (RG). High counts: 13, 7 May 1983, Forest Park (RK); 12, 6 May 2007, Buisek 
SF (GS, LB, CBu). Latest dates: ad male, 8 Jun 2000, along St. Francois R., Madison Co. (P. Wilson); 1, 6 Jun 1998, Tower Grove (B. Wetteroth).

Fall: Individuals are typically noted by the third week of Aug, with peak in mid-Sep. It is regularly observed into the second week of Oct. Earliest dates, both at Tower Grove: 1, photos, 18 Aug 2012 (CMc, AR); 1, 19 Aug 2000 (BR). High counts: 100, "an amazing flight", 3 Sep 1938, St. Charles Co. (W. Short); several of 7-8 individuals/ day in early Sep. Latest dates: 2, 15 Oct 2008, Forest Park (C. Ferree); a few observations of single birds for 11 Oct.

\section{Yellow Warbler (Setophaga petechia)}

Status: Common transient; locally common summer resident in wetlands in the western and central Glaciated Plains, Osage Plains, and along the large rivers. It is more local and less abundant along the larger floodplains of the Ozarks and the Mississippi Lowlands.

Documentation: Specimen: sex?, 1 Sep 1873, New Haven, Franklin Co. (MCZ 23103).

Habitat: Most common in riparian thickets, especially with willows, and in second-growth woodland edge.

Spring: The first arrivals typically appear in the south during mid-Apr, with peak in late Apr there and in early to mid-May in the north. Earliest dates: 2, 1 Apr 2009, Dexter, Stoddard Co. (CB); 1, 3 Apr 2010, Binder Lake (CB); 1, 6 Apr 2008, Montauk SP (S. Hunter). High counts: 122, 17 May 2014, Loess Bluffs (JK); 80 (4.8), 22 May 1992, Nodaway River (16.5 miles; Robbins et al. 1992); 72, 15 May 2012, Loess Bluffs (MR, JB, JK); 71, 24 May 2016, Loess Bluffs (MR).

Summer: The highest densities are found in riparian areas in the western and central sections of the Glaciated Plains (e.g., see above Nodaway River surveys; Table 6). It is more local in the remainder of the state, but it can be locally common in wetlands in the southern sections of the state, such as Four Rivers and Schell-Osage in the southern Osage Plains, and at Mingo and Duck Creek in the northern Mississippi Lowlands.

Fall: Many of the breeding birds appear to start leaving by late Jul. Obvious migrants, observed away from breeding sites, appear by early to mid-Aug. Relatively few birds are seen by the second week of Sep. Tower-kill data from Columbia: 3, 19-20 Sep 1966 (Elder and Hansen 1967); 3, 20-21 Sep 1963 (George 1963). Latest dates: 1, 8 Nov 1969, Maryville (DE); 1, 2 Nov 2008, Columbia Bottom CA (BR); 1, 4 Oct 2010, St. Louis (JU).

\section{Chestnut-sided Warbler (Setophaga pensylvanica)}

Status: Common transient, more abundant in eastern half of state; casual summer resident in eastern Ozarks and Ozark Border.

Documentation: Specimen: 2 nests with eggs, 27 May and 7 Jun 1893, St. Louis Co. (USNM B26552, B26553). 
Habitat: Woodland and forest; breeds in brushy second growth at woodland/forest edge.

Spring: The first individuals appear by the end of Apr, with peak the second week of May. An average of 1.9 birds/hr was recorded at Forest Park, 2-23 May 1979-90 (RK; n=349 hrs). Migrants are infrequently seen into early Jun that are presumed non-breeders, e.g., singing male, 21 Jun 1997, St. Louis (A. McCormack); three observations at Springfield at the beginning of the second week of Jun. Earliest date: 1, 16 Apr 2009, Big Buffalo Creek CA (LW). High counts: in east, 40, 18 May 1963, St. Louis (Hanselmann 1963); 26, 8 May 1983, Forest Park (RK); in west, 12, 6 May 2007, Buisek SF (GS, CBu, LB).

Summer: This warbler has periodically been documented breeding in the state, with all definite records from the eastern Ozarks and eastern Ozark Border (Fig. 1). Although no definite breeding was documented during the BBA, 1986-1992, two mid-summer records of singing males may have indicated breeding in western Chariton and northern Jefferson counties (Jacobs and Wilson 1997). In addition, there are the following recent records of singing males: 28 Jun 1993, near Laurie, Morgan Co. (J. Wilson) and 11-30 Jul 1995, Reeds Spring, Stone Co. (J. Fitzgerald). Presumably it is a more regular breeder in the eastern section of Ozarks and Ozark Border than the few records indicate.

Widmann (1907) stated that it "has repeatedly been found breeding in eastern Missouri in places grown with hazel, blackberry and scrub-oak." Indeed, it seems likely that it was more common and widespread as a breeder during the period when much of the Ozarks was logged followed by succession in the late 1800s and early 1900s. Today, it should be looked for in powerline rights-of-way and other areas that have been clear-cut followed by several years of vegetation regeneration.

Fall: Obvious migrants appearing at non-breeding sites have been detected as early as mid-Aug. Birds are regularly observed by the end of Aug/early Sep. Peak is in midSep. Individuals are routinely seen into the second week of Oct. Earliest dates: 1, 15 Aug 2004, Little Creve Coeur Lake (MBr); 1, 16 Aug 1964, Kansas City (E. Cole). High counts: 35, 16 Sep 2012, Tower Grove (CMc, AR); 30, 12 Sep 1964, St. Louis (S. Hanselmann); 20, 18 Sep 2005, Confluence SP (DR); 15, tower kill, 24 Sep 1960, Columbia; 15, tower kill, 20-21 Sep 1963, Columbia (George 1963). Latest dates: 1, 16-28 Nov 1980, St. Louis (MP); 1, 29 Oct 2015, Dunklin Co. (TJ); 1, 25 Oct 2006, Busch (PL); 1, 25 Oct 2012, Tower Grove (R. Spahn).

\section{Blackpoll Warbler (Setophaga striata)}

Status: Common transient in spring; accidental in fall.

Documentation: Specimen: male, 2 May 1879, Charleston, Mississippi Co. (MCZ 45357).

Habitat: Woodland, forest, and forest edge; often seen in cottonwoods and willows. 
Spring: Like the Bay-breasted Warbler, this boreal breeding warbler is a relatively late migrant. Typically, the earliest individuals appear in the south at the end of Apr. During the peak in mid-May it is one of the more common migrant warblers, but like Bay-breasted it is often overlooked because its song is high pitched. An average of 2.6 birds/hr was recorded at Forest Park, 30 Apr-26 May 1979-90 (RK; n=395 hrs). Late individuals are occasionally seen through the first week of Jun. Earliest dates: 1, 16 Apr 2012, Stone Co. (J. Fitzgerald); 1, 19 Apr 1982, Forest Park (RK); 1, 19 Apr 2002, Kansas City (RM). High counts: 60, 11 May 1975, St. Joseph/Loess Bluffs (FL); 50, 15 May 2004, Tower Grove (JE); 20 in a single tree, 18 May 2004, Tower Grove (DR). Latest dates: 1, 9 Jun 1945, Hannibal, Marion Co. (WC); male, 6 Jun 1964, west of Cardwell, Dunklin Co. (DE; KU 118769).

Fall: The primary migration route for the species is well to the north and east of Missouri. Only the following have been documented: probable imm, 2 Oct 2005, Tower Grove (JE); probable imm, photos, 23 Oct 2006, Forest Park (S. McCowan); 1, photos, 4 Oct 2013, St. Louis (M. Terpstra); 1, 24 Sep 2017, Lake of the Ozarks, Miller Co. (K. McKay, A. Hartley).

Comments: In fall other warbler species, especially imm female Bay-breasted and Pine warblers, are frequently misidentified as Blackpoll Warblers. Fall observations should include photographic documentation.

\section{Black-throated Blue Warbler (Setophaga caerulescens)}

Status: Rare transient, more regular and frequently observed in the east.

Documentation: Specimen: male, 7 May 1879, Charleston, Mississippi Co. (MCZ 45267).

Habitat: Typically, understory of woodland and forest.

Spring: A regular but rare transient in the east with an average total of 1-2/year. At St. Louis, where observer effort is greatest, the maximum total in a spring was four individuals in 1972. Most springs this warbler goes unrecorded in the west. Most observations are during the first two weeks of May. Earliest dates: 1, 26 Apr 2001, Columbia (EW, S. Hazelwood); 1, 27 Apr 1904, Iberia, Miller Co. (Widmann 1907); 1, 27 Apr 1974, Sullivan, Franklin Co. (J. Irving). High counts: a few observations of 2/day from both sides of the state. Latest dates: male, 29 May 1972, LaBenite Park, Jackson Co. (S. Patti); male, 26 May 2011, Forest Park (L. Garrett).

Summer: A single record of a presumed late migrant: male, 24 Jun 1992, Big Oak Tree (I. Domizlicky, B. and J. Scheibe).

Fall: More frequently recorded at this season than in spring, but still rare. Records range from late Aug into early Nov, with most during the last two weeks of Sep and the first week of Oct. Earliest dates: female, 30 Aug 2007, Tower Grove (fide JU); 1 Sep 1887, St. Louis (Widmann 1907). High count and only observation involving more than one bird: 2, 10-12 Oct 2008, Tower Grove (BRu, DR et al.). Latest dates: female, 
5 Nov 1978, Busch (G. and T. Barker); female, 3 Nov 2015, Springfield (D. Thurman); imm male, window kill, 1 Nov 1980, Maryville (DE; KU 118768).

\section{Palm Warbler (Setophaga palmarum)}

Status: Common transient in east, uncommon in west; rare winter resident in south.

Documentation: Specimen: female, 2 May 1879, Charleston, Mississippi Co. (MCZ 45409).

Habitat: Typically, open situations such as tall hedgerows, brushy fields, and edge of woodland and forest.

Spring: The first arrivals appear by the second week of Apr in the south and about a week later in the north. Peak is in late Apr/early May. There are very few reliable records after mid-May. It is considerably more common in the eastern half of the state, e.g., 20 Apr-10 May 1979-90 (n=331 hrs; RK), an average of $1.8 \mathrm{birds} / \mathrm{hr}$ was recorded at Forest Park. Earliest dates: 1, 2 Apr 2012, Tower Grove (PL); 1, 7 Apr 1978, Charleston, Mississippi Co. (JHa); High counts in east: 38, 29 Apr 2015, Hornersville Swamp area (TJ); 35, 30 Apr 2014, Eagle Bluffs (BJ); 33, 2 May 2009, Otter Slough (CB); 32, 1 May 2016, Hornersville Swamp area (TJ); 31, 27 Apr 1995, Forest Park (RK). High counts in west: 3 observations of 10 individuals/day. Latest dates: 1, nominate subspecies, photos, 27-28 May 2014, St. Louis (JU); 1, 25 May 2016, Lamine River CA, Cooper Co. (EW).

Fall: Accidental prior to the second week of Sep, with peak at the end of Sep/early Oct. During the past two decades it has been reported increasingly in late fall through Dec. Earliest dates: 1, 12 Aug 1977, Trimble CA (S. Patti, M. Myers); 1, 21 Aug 1977, Independence (CH). High counts: 38, 30 Sep 2015, St. Louis (AR, CMc); 24, 10 Oct 2010, Confluence Point SP (BR).

Winter: Prior to 1994, there were only four observations for this season; now there are about 15 records, with all from roughly the southern half of the state. The northernmost record is the Kansas City CBC record listed below. All but a couple of these are of birds that did not overwinter. High counts: 5, 4 Dec - 1 Jan 2010-11, Otter Slough (CB); 3, 8 Feb 2012, Ten Mile Pond (CB).

Comments: The nominate subspecies is the predominant one recorded in the state; however, there are at least six records, all but one in December, of the eastern hypochrysea: imm male, 21 Dec 1965, south of Clinton, Henry Co. (Easterla 1966b; KU 118776); 1, 15 Dec 1973, Kansas City Southeast CBC; 1, 27 Dec 1979, Big Oak Tree CBC; 1, until 26 Dec 1982, Busch (T. Barker); 1, 21 Sep 1991, Thomas Hill Reservoir (PM, TB); 1, 28 Dec 2002, Mingo CBC (BE et al.).

\section{Pine Warbler (Setophaga pinus)}

Status: Locally common summer resident in shortleaf pine in south, rare at scattered planted pine plantations elsewhere; rare transient in east, casual in west; rare winter resident in south. 
Documentation: Specimen: female, 16 Mar 1907, Spring Valley, Shannon Co. (FMNH 308218).

Habitat: Shortleaf pine in south, planted pine stands elsewhere; sometimes residential feeders in winter.

Spring: Early migrants augment the small wintering population beginning in late Feb. By early Mar the species can be common in shortleaf pine stands in the south, e.g., 25+, 7 Mar 2000, Chadwick area, Mark Twain NF, Christian Co. (CBu). The following observation also likely includes mostly early spring migrants: 34, 29 Feb 1992, 17 locations in Taney and Christian cos. (JHy, PMa). Presumed northbound migrants are observed through the northern half of the state during the last two weeks of Apr and the first few days of May. At that time it is a rare but regular migrant through the St. Louis area but only casually encountered elsewhere. High counts: 32, 16 May 2014, 10.6 miles along Cane Ridge, Mark Twain NF, Butler Co. (MR, JB); 30, 28 Apr 2008, Cane Ridge (MR).

Summer: The breeding distribution in the southern part of state coincides with the distribution of shortleaf pine (Fig. 2); thus, the species is most widespread and common in the southeastern Ozarks. There are a few small, isolated breeding pockets elsewhere. For example, the species was first noted breeding in 1992 at Baskett Research Area, Boone Co. (BG, K. Palmer) and Knob Noster SP, Johnson Co. (BBA), and in 2007 at Thousand Hills SP, Adair Co. (PK). A singing male was documented at Wallace SP, Clinton Co. beginning in 2012 (EW). Breeding may have occurred along the western border at Davis Memorial Forest, Barton Co., at least as early as 1999 and still persisted in 2016 (MR).

Fall: Most of the breeding population appears to leave in Sep through mid-Oct. Presumed resident birds are regularly heard singing through at least mid-Oct. Migrants from populations north of the state are primarily observed at non-breeding sites in the northern half of the state during the same time frame, e.g., 3, 14 Sep 1978, St. Louis (m. ob.); 4, 26 Sep 1978, Springfield (C. Bonner et al.); several sightings from midSep into early Oct in Linn Co. (SK et al.). Widmann (1907) lists three Aug records for St. Louis, the earliest on 20 Aug 1905. High counts: 24 (17 singing males), 8 Oct 2016, Pioneer Forest, south of Round Spring, Shannon Co. (MR); 14, 19 Sep 2015, Red Bridge Road, Christian Co. (DBl); 14 (7 singing males), 29-30 Sep 2017, Pioneer Forest (MR).

Winter: This hardy warbler is a low-density winter resident in the shortleaf pine region. There also have been a few records in the north of single birds attending feeders. Although Widmann (1907) did not mention any winter records, almost certainly as a result of the lack of observers in appropriate habitat, it surely wintered in the state then and long before. The first definitive winter record was of 4, 27 Dec 1965, west of Winona, Shannon Co. (Easterla 1966b; KU 118808). High counts, all on the Mingo CBC: 14, 30 Dec 1995; 12, 29 Dec 1990; 12, 18 Dec 2010. 
Comments: As with other species that are primarily restricted to shortleaf pine in the state, this warbler is now less common and less widely distributed than it was prior to the clearcutting of the area in the late 1800s and early 1900s.

\section{Yellow-rumped Warbler (Setophaga coronata)}

Status: Common transient; locally common winter resident in extreme south, locally uncommon in central, and rare in north.

Documentation: Specimen: female, 8 May 1907, Monteer, Shannon Co. (AMNH 381724).

Habitat: In a wide array of habitats during migration; primarily in woodland and forest edge, especially with cedars and poison ivy berries, during winter.

Spring: This is the most common warbler that does not breed in the state. By mid-Mar, birds begin to appear at non-winter localities. Although there is considerable variation among years, peak is typically during the third week of Apr in the south and the last week of Apr/early May in the north. During that period, a few hundred birds may be seen in a day. By the beginning of the third week of May it is rare, and by the final week of May it is casual, with only two Jun records. High counts: 2,000+, 17 Apr 1993, Duck Creek (BL); a number of counts of 200+ individuals/day during the final week of Apr. Latest dates: singing male, 21 Jun 1897, St. Louis (Widmann 1907); female/imm male, 8 Jun 2003, Jasper Co. (RM); 1, 28 May 2013, Perry County Community Lake (MH); 1, window kill, 26 May 1998, Maryville (DE).

Fall: Usually not encountered until the third week of Sep and does not become common until the final days of Sep/early Oct. Most pass through during the last half of Oct. By mid-Nov very few are seen in the northern third of the state. Earliest dates: 1, 15 Aug 1964, Kansas City (E. Cole); 1, 27 Aug 1975, Montgomery City (R. Windsor); 1, 27 Aug 2008, Forest Park (C. Feree). High counts: 250, 29 Sep 2005, Tower Grove (JU); 230, 12 Oct 2010, Tower Grove (CMc, AR); 150-200, 24 Oct 2015, St. Clair Co. (S. Hilty).

Winter: This warbler is locally common in the southern tier of counties, especially in the Ozarks where there is an abundance of cedar and poison ivy berries. It is less common northward and is very local and in low densities in the northern three tiers of counties. CBC high counts: 788 (12.3), 1 Jan 2005, Taney Co; 631 (7.6), 27 Dec 2014, Taney Co.; 443 (4.8), 28 Dec 2013; 404 (5.4), 1 Jan 2011, Taney Co.

Comments: The western "Audubon's" Yellow-rumped Warbler, S. c. auduboni, is casually recorded in the state. There are at least a dozen records, all of single birds, from across the state, ranging from mid-Oct through mid-May. Earliest fall dates: 14 Oct 1973, St. Louis (RA); 16 Oct 2011, Davis CA, Andrew Co. (EW). Latest spring: 11 May 1980, western Macon Co. (S. Hein); 11 May 1997, Warrenton, Warren Co. (W. Roehrs). 


\section{Yellow-throated Warbler (Setophaga dominica)}

Status: Common summer resident south, rare north; accidental winter visitant.

Documentation: Specimen: male, 8 Jun 1905, Dunklin Co. (AMNH 229965).

Habitat: Found in three distinct habitats: cypress-tupelo bottomland, sycamore-dominated floodplain, and shortleaf pine.

Spring: Typically the first birds are not seen until the end of the third week of Mar; by mid-Apr it can be common throughout its breeding range. Earliest dates: 1, 17 Mar 2012, Rockwoods Reservation (CM); 1, 18 Mar 2006, Phelps Co. (A. Wethington); 1, 18 Mar 2012, Roaring River SP (M. and J. Williams); two reports for 20 Mar 2011 in the south. High counts: 27, migrating north along stream, 1 Apr 1990, Bee Creek CA, Taney Co. (JHy, PMa); 22, 16 Apr 2016, Castlewood SP (JM); other high counts of breeding birds: see below and Table 6 .

Summer: It is most common in riparian areas with sycamores and along ridges with shortleaf pine in the Ozarks and Ozark Border. Prior to the early 1900s, it was most abundant in the cypress-tupelo swamps of the Mississippi Lowlands (Widmann 1907), but today it is rare in that region (BBA, eBird data). It is very local north of the Missouri River; in the western and northern Osage Plains it is primarily found along the Osage, Grand, and Marmaton rivers (see Table 6). It is rarest in the northwestern corner of the state, where it is not known to breed north of Andrew Co. or west of Crowder SP, and at both of these sites only a couple of pairs have been present. In the Kansas City area it had been considered a low-density and infrequent breeder until 17 May 2002, when 15 territorial males were located by floating 5 miles of the Blue River between Martin City and Minor Park, Jackson Co. (RM, LR). Further east in the Glaciated Plains it is also local and in low densities (see Chariton and Fox rivers in Table 6; Robbins et al. 2001). High counts from river-based surveys (Table 6): 35 (2.3), 28 May 1998, James River; 30 (3.2), 2 Jun 2000, Gasconade River.

Fall: Summer residents linger into Sep, but by the middle of the month most are gone. A few individuals are regularly seen into the second week of Oct in the south, but it is accidental after mid-Oct. Latest dates, all of single birds: 29-31 Oct 1991, Tower Grove (J. Ziebol, B. Wetteroth); photos, 18 Oct 2013, Ben Cash (TJ); 16 Oct 2009, Duck Creek (CB); 15 Oct 2015, Ben Cash (TJ).

Winter: A single record: 1, 22 Dec 2012, Puxico, Stoddard Co. (BE, M. Malin).

\section{Prairie Warbler (Setophaga discolor)}

Status: Uncommon summer resident in Ozarks and Ozark Border, especially the eastern parts of those regions; rare in the Osage Plains, casual in the Glaciated Plains, and virtually absent as a breeder in the Mississippi Lowlands.

Documentation: Specimen: male, 20 May 1885, St. Louis (CAS 36924).

Habitat: Most common in fields with scattered cedars; young, brushy successional growth; and open shortleaf pine stands. 
Spring: The first migrants typically appear by the third week of Apr, and by early May it is uncommon at breeding sites. Earliest dates: 1, 6-7 Apr 2013, Roaring River (C. Carr, JCa); three reports across different years for $13 \mathrm{Apr}$ in the south. High counts: 25 , 16 May 2014, 10.6 miles along Cane Ridge, Mark Twain NF, Butler Co. (MR, JB); 25, 15 May 2017, Caney Mountain CA, Ozark Co. (J. Jedlicka); 20, 24 May 2007, Peck Ranch, Carter Co. (SS, PW); 15+, 28 Apr 2008, Cane Ridge (MR).

Summer: BBA data (Jacobs and Wilson 1997) demonstrated that this warbler is most prevalent in the eastern Ozarks and Ozark Border, with a few scattered pairs in the Osage Plains and the southernmost part of the Glaciated Plains. Other than a few pairs that were documented along the northern edge of the Mississippi Lowlands, it was absent from that region. Although Dierker (1979) did not record this warbler at Hannibal during the ten- year period 1966-75. Singing males have occasionally been encountered in the northeastern part of the Glaciated Plains, but breeding has not been confirmed there. There are the following observations from that region of the state: male, 8 Jun 2001, Rebel's Cove CA (Robbins et al. 2001); male, 18 May - 18 Jun 2010, Sugar Creek CA, Adair Co. (PK); 1, 1 Jul 2011, northwestern Lincoln Co. (PW); 1, 6-16 Jun 2012, Thousand Hills SP, Adair Co. (PK). Nonetheless, it was recorded breeding near Keokuk, in southeastern Iowa, as early as Jun 1886 (DuMont 1936).

Just across the border from Jackson County, Missouri, at Lake Quivira and surrounding areas in Johnson and Wyandotte cos., Kansas, Hedges (1953) documented a breeding population from at least 1941 to 1953. In 1941 a minimum of 13 territorial males as well as females were observed feeding fledged young. Despite the Kansas population, the species has never been documented breeding in Jackson or the surrounding Missouri counties. The northwesternmost Missouri records, all of single, singing males: 18 May 1975, Pigeon Hill CA, Buchanan Co. (FL, D. Reynolds); early May for three consecutive years, 2003-5, Watkins Mill SP (KM).

Fall: Apparently, most birds leave the state in Aug, as few are recorded in even early Sep. Latest dates: 1, 24 Sep 1995, Shaw Nature Reserve, Franklin Co. (BR); 1, 21 Sep 2013, Ben Cash (TJ).

Comments: Presumably, with the clearing of the Ozarks and the subsequent vegetation succession during the end of the 1800s and the first two decades of the 1900s, the Prairie Warbler, like a number of other species (e.g., Bewick's Wren, Golden-winged and Chestnut-sided warblers), increased in numbers and distribution. Unfortunately, there were too few observers in suitable habitat to document that response to the major landscape changes.

\section{Townsend's Warbler (Setophaga townsendi)}

Status: Accidental fall transient.

Documentation: Photograph; see below. 
Record: Only a single record: 1, photos and banded, 9 Oct 2015, St. Joseph (JH, LL, D. Roberton et al.; Hilsabeck et al. 2016).

Comments: Hybrids between Townsend's and Hermit warblers are not uncommon; thus any observations of Townsend's and/or Hermit should be carefully scrutinized.

\section{Hermit Warbler (Setophaga occidentalis)}

Status: Accidental winter visitant.

Documentation: Specimen, see below.

Record: An imm male was obtained from a mixed-species flock in a large, isolated pine grove on 20 Dec 1969, 10 miles W of Maryville, Nodaway Co. (Easterla 1970b; KU 118771). This represents one of the few winter records for the United States outside of coastal California (eBird).

\section{Golden-cheeked Warbler (Setophaga chrysoparia)}

Status: Accidental transient.

Documentation: Photograph; see below.

Record: An extraordinary record of a singing male, videotaped, 19-22 Apr 2013, Creve Coeur, St. Louis (JU et al.). This is one of the few extralimital records for this endangered species outside its restricted breeding range in central Texas.

\section{Black-throated Green Warbler (Setophaga virens)}

Status: Common transient in east, uncommon in west; casual summer resident in southeastern Ozarks.

Documentation: Specimen: female, 15 May 1907, Monteer, Shannon Co. (AMNH 382233).

Habitat: Woodland and forest.

Spring: Typically this species is not encountered until mid-Apr, with peak in early May in the south and a few days later in the north. Migrants are occasionally seen into early Jun. Earliest dates: 1, 23 Mar 2007, near Hillsboro, Jefferson Co. (T. and L. Mills); 1, 28 Mar 2012, Washington Co. (L. Mills); 1, 30 Mar 2006, St. Louis (S. McCowan). An average of 1.1 birds/hr was recorded at Forest Park between 20 Apr and 20 May 1979-90 ( $\mathrm{n}=474$ hrs; RK). High counts: 13, 6 May 1983, Forest Park (RK); 12, 6 May 2014, Babler SP (CM); 10, 7 May 1996, Forest Park (RK); 9, 9 May 2014, Sugar Camp Scenic Drive (MR, JB). Latest dates of migrants: singing male, 28 Jun 2009 , Lead Mine CA, Dallas Co. (P. Sensenig); male, 13 Jun 1992, NW Centralia, Audrain Co. (PM, K. Werner); 1, 11 Jun 1993, near Otterville, Cooper Co. (S. Hazelwood).

Summer: There are at least six mid-Jun to early Jul records of singing males in non-breeding areas. The species was finally documented breeding for the first time in the state in late May to mid-Jul 2010, when multiple individuals were observed at six separate locations in three counties (Shannon, Carter, Reynolds; Burke et al. 2011). As 
many as three counter-singing males were present at one of the Shannon County sites with a fledged young observed begging to one of the males. Because intensive coverage at those sites had occurred since 1991, it was thought the 2010 event was novel. Another intriguing observation was of a male singing along the Eleven Point River on 12 Jul 1991 (TB). The species has been documented breeding in the Arkansas Ozarks since 1993 (Rodewald 1997).

Fall: Birds begin appearing by the end of Aug, with peak in late Sep/early Oct. It is regularly seen through the third week of Oct, but it is only casually observed thereafter. Earliest dates: female or imm, 4 Aug 2001, Polk Co. (C. Foster); 1, 17 Aug 2001, Castlewood Park (MBr); 1, 20 Aug 1980, St. Louis (MP). High counts, all at Tower Grove: 80-100, 10 Oct 1994 (JVB); 50+, 11 Oct 1999 (m.ob.); 48, 5 Oct 2015 (AR, CMc); 48, 4 Oct 2017 (AR, CMc). Latest dates: 1, 16 Nov 1972, Maryville (DE); 1, photos, 31 Oct - 1 Nov 2017, St. Louis (CMc); 1, photos, 31 Oct 2015, St. Louis (CMc, AR); 2, photos, 28 Oct 2013, Ben Cash (TJ); 1, photos, 28 Oct 2016, Ben Cash (TJ).

Comments: Hybrids between Black-throated Green and Townsend's warblers have been documented in Johnson Co., Kansas, and Colorado.

\section{Canada Warbler (Cardellina canadensis)}

Status: Uncommon transient; accidental summer visitant in southwest.

Documentation: Specimen: male, 13 May 1879, Charleston, Mississippi Co. (MCZ 45537).

Habitat: Thickets, brushy areas, woodland and forest edge.

Spring: An inconspicuous, late migrant that is rarely seen before the end of Apr in the extreme south and usually not until a week to ten days later in the north. Peak is between 18 and 25 May. Earliest dates, both by Widmann (1907): 10 Apr 1893, New Madrid Co; 28 Apr 1888, St. Louis. High counts: 31, 20 May 1997, Aker's Ferry to Pulltite Access (9.1 miles), Current River (MR, K. Zyskowski, B. Barber); 24, 21 May 1997, Pulltite Access to Round Spring (9.7 miles), Current River (MR, K. Zyskowski, B. Barber). The above high counts demonstrate the value of floating a river through prime habitat during peak. Other high counts are a maximum of 5 individuals/day. Latest dates: singing male, 13 Jun 1984, Big Oak Tree (JHa); 1, 4 Jun 2003, Tower Grove (JU).

Summer: Quite unexpectedly, a territorial adult male was photographed at Drury CA, Taney Co., during mid- to late Jun for four consecutive years, 1993-6 (Bo Brown). It is presumed the same bird was involved, but no mate was ever observed.

Fall: The first migrants are seen at the beginning of the third week of Aug. Peak is during Sep. It is rare during Oct. Earliest dates: 1, photos, 14 Aug 2012, Tower Grove (AR, CMc); 1, 16 Aug 1991, Columbia (B. Noble); 1, photos, 16 Aug 2016, Tower Grove (AR, CMc). High counts: 8, tower kill, 20-21 Sep 1963, Columbia (George 
1963); 7, 5 Sep 1969, Big Oak Tree (JHa). Latest dates: 1, 19-21 Oct 1944, Clay Co. (N. Fay); 1, photos, 19 Oct 2013, Ben Cash (TJ); 1, 11 Oct 1977, Cass Co. (J. Garrett).

\section{Wilson's Warbler (Cardellina pusilla)}

Status: Common transient.

Documentation: Specimen: female, 14 May 1879, Charleston, Mississippi Co. (MCZ 45516).

Habitat: Thickets, brushy areas, woodland and forest edge.

Spring: The first arrivals typically are not seen until the end of Apr in the south and a few days later in the north. Peak is usually between 10 and 18 May. Individuals are routinely encountered through May and occasionally into the first week of Jun. An average of 0.9 birds/hr was recorded at Forest Park, 8-25 May 1979-90 ( $\mathrm{n}=243 \mathrm{hrs}$; RK). Earliest dates: 1, 16 Apr 2012, Rock Bridge SP (G. Connette); 1, 17 Apr 1990, Tower Grove (J. Ziebol et al.); 1, 20 Apr 1979, St. Louis (M. Scudder). High counts: 16, 10 May 2014, Eagle Bluffs (BJ, RD); 13, 13 May 2015, Jefferson City (BJ). Latest date: 1, 18 Jun 1979, Jackson Co. (KH).

Fall: Birds begin to reappear by mid-Aug with peak at the very end of Aug/early Sep. By mid-Sep only 1-2 individuals/day are observed, and it is accidental after mid-Oct. Earliest dates: 1, 9 Aug 2012, Roaring River (C. Carr); 1, 15 Aug 1996, St. Joseph (LL); 1, 17 Aug 2012, Chillicothe (SK). High counts: 18, 30 Aug 2003, Nodaway Valley CA (MR); 15-20, 3 Sep 1977, Maryville/Loess Bluffs (MR, TB). Latest dates: 1, 17 Nov 1970, near Bourbon, Crawford Co. (D. Reger, S. Phillips); 1, 1 Nov 2010, Saline Valley CA, Miller Co. (EW); 1, 20 Oct 1985, St. Louis (RA).

Comments: The nominate subspecies is the one that is routinely recorded in the state. Ridgway (1902) reported the western $C$. p. pileolata from Independence, but that needs confirmation.

\section{Family Cardinalidae: Piranga, cardinal, grosbeaks, buntings, Dickcissel}

\section{Summer Tanager (Piranga rubra)}

Status: Common summer resident in the Ozarks and Ozark Border, uncommon in Osage Plains and more local in the Glaciated Plains and Mississippi Lowlands; accidental winter visitant.

Documentation: Specimen: female, 11 May 1879, Charleston, Mississippi Co. (MCZ 44959).

Habitat: During migration, virtually any woodland and forest; during the breeding season, typically mature oak-hickory forest.

Spring: The first arrivals typically appear at the southern border during the third week of Apr, but it usually is not seen in the north until the final days of Apr or even the beginning of May. Peak is in early May in the south, mid-May in the north. Earliest 
dates: female, photos, 11-12 Apr 2014, Peculiar (G. Culver); 1, audio recording, 13 Apr 2015, Carter Co. (M. Roach); three observations for 14 Apr. High counts: 37, 9 May 2009, Mingo (V. Harp); 36, 9 May 2014, Sugar Camp Scenic Drive (MR, JB); 31, 9 May 2013, Sugar Camp Scenic Drive (MR, CH, JB).

Summer: Most common in the Ozarks and Ozark Border and the eastern section of the Osage Plains (BBS, BBA, eBird). It is much more local and uncommon in the agriculture-dominated Glaciated Plains and Mississippi Lowlands. Shirling (1920) recorded 22 males at Swope Park in 1916, whereas Branan and Burdick (1981) observed none in 1973 . Over $50 \%$ of the upland forest had been lost at Swope Park in the intervening period between those two surveys. In contrast, BBS data indicate an increase throughout the duration of that protocol, with a $1.15 \%$ annual increase during the 2003-2013 period.

Fall and early winter: Migration is apparent as early as the last ten days of Aug. This Piranga remains common through Sep and is regularly observed in smaller numbers (1-2/day) into the second week of Oct. It is casually seen after mid-Oct. Although there is only one Nov observation, there are four well documented records for Dec: ad female, 5-6 Dec 2002, St. Louis (N. Barber); female, photos, 5-9 Dec 2009, Independence (L. Byrd); female, photos, 12 Dec 2003, near Republic, Greene Co. (D. Thurman); female, photos, 25 Dec - 1 Jan 2009-10, St. Louis (C. and S. Kennedy). High counts: 12, 24 Sep 2011, Big Spring SP (MR); 11, 16 Sep 2012, Duck Creek (CB).

Comments: Recent genetic analyses have shown that our "tanagers" of the genus $\mathrm{Pi}$ ranga are not true tanagers but are most closely related to a clade that includes Northern Cardinal (Klicka et al. 2007).

\section{Scarlet Tanager (Piranga olivacea)}

Status: Common transient, although more abundant in the eastern half of state; common summer resident in forested sections of the eastern and southern Ozarks and portions of the Ozark Border; uncommon and more local elsewhere; accidental winter visitant.

Documentation: Specimen: male, 2 May 1879, Charleston, Mississippi Co. (MCZ 44949).

Habitat: During migration, virtually any woodland and forest; during the breeding season, most common in mature oak-hickory forest.

Spring: As with the Summer Tanager, the first migrants appear in the south during the third week of Apr, with the first birds reaching the north at the end of the month. Peak is in early May in the south, mid-May in the north. An ave. of 0.5 birds/hr was recorded at Forest Park, 1-20 May 1979-90 (RK; n=333 hrs). Earliest dates: 1, 5 Apr 2007, Springfield (M. Snider); 2, 9 Apr 2015, Red Bridge Road, Christian Co. (DBl); 1, 10 Apr 2005, Tower Grove (DB). High counts: 20, 29 Apr 2016, Babler SP (JM); a few reports of $15+/$ day. 
Summer: This Piranga is most common and widespread in larger forested tracts of the Ozarks. It is more local and uncommon in all other regions. However, even in the largely unforested Glaciated Plains, it can be locally common, e.g., 13 territorial males, 7 Jun 2001, 2.8 miles of trail, Charlie Heath CA (Robbins et al. 2001). Not surprisingly, it is quite local and rare in the largely deforested Mississippi Lowlands (BBS, BBA, eBird).

Fall: Migration is apparent by the last ten days of Aug, with peak of birds moving through the state from more northern breeding grounds in Sep. By early Oct numbers are greatly reduced, although a few individuals/day may be observed into the second week of Oct, e.g., 4, 10 Oct 2004, Big Spring SP (MR); 2, 13 Oct 2009, St. Louis (JU). High counts: 14, 18 Sep 2012, Tower Grove (AR); 12, 24 Sep 2011, Big Spring SP (MR). Latest dates, single birds, both on 18 Oct: 2009, Tower Grove (B. Soloman); 2010, near Columbia (KA).

Winter: Although there are no Nov or early Dec records, there are three well documented mid-Dec/early Jan records: male, photos, 19 Dec - 7 Jan 2003-4, near Savannah, Andrew Co. (R. Claxton); female, photos, 14-17 Dec 2008, Chesterfield, St. Louis (P. Ross); imm male, photos, 13 Dec - 25 Jan 2010-1, Imperial, Jefferson Co. (C. Pilcher).

\section{Western Tanager (Piranga ludoviciana)}

Status: Casual spring transient, accidental fall transient and winter visitant.

Documentation: Photograph; fig. 28.

Habitat: Several records at feeders; should be looked for in conifers.

Spring: There are a total of eight spring records, all from 4 to 21 May, scattered across the state. Seven of the eight records were of males; presumably females are being overlooked.

Fall: Oddly, there is only a single fall record: male, 21 Aug 1966, St. Louis (F. Erb).

Winter: A single record of a male, photos, 17-28 Jan 2007, St. Louis (W. Burns et al.; fig. 28).

\section{Northern Cardinal (Cardinalis cardinalis)}

Status: Common permanent resident.

Documentation: Specimen: egg set, 27 May 1888, Kansas City (FMNH 21673).

Habitat: Brushy areas, edges of woodand and forest, and residential areas.

Summer: This is one of the most widespread and abundant birds in the state. BBS data indicate it is most common in the Osage Plains, the Ozark Border, and the less heavily- forested areas of the Ozarks. It is least abundant and widespread in the Mississippi Lowlands. 


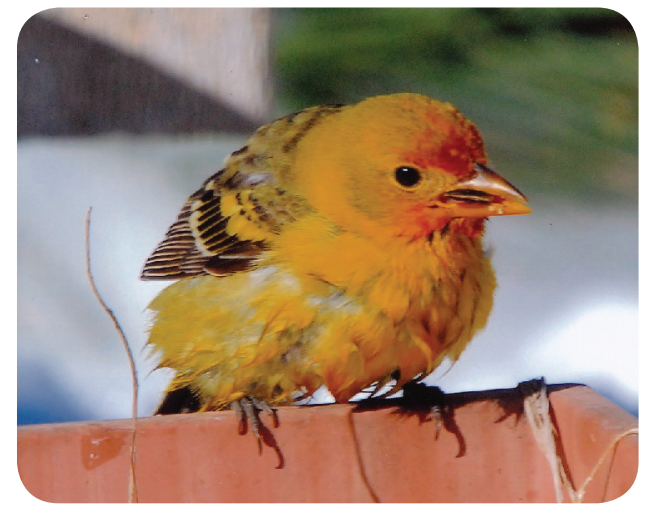

Fig. 28. The only winter record of Western Tanager for Missouri. This male was present at St. Louis from 17-28 January 2007. Photo by Paul Bauer.

Winter: Common and widespread statewide: CBC high counts: 1,117 (8.5), 17 Dec 1983, Kansas City; 985 (11.2), 19 Dec 2009, Springfield; 965 (9.8), 27 Dec 1987, Columbia; 932 (10.6), 19 Dec 1981, Kansas City.

Comments: European settlement that brought large-scale deforestation to the Mississippi Lowlands and Ozarks, coupled with the encroachment of second-growth/woodland edge into the former prairie regions of the state, has likely led to this species' becoming much more abundant and widespread. A significant increase of the species at Swope Park between $1916(n=70$ territorial males; Shirling 1920) and $1973(n=110$ males; Branan and Burdick 1981) was attributed to the conversion of forest and prairie to parkland and residential areas.

\section{Rose-breasted Grosbeak (Pheucticus ludovicianus)}

Status: Common transient; common summer resident in Glaciated Plains, rare breeder in northern Osage Plains and northern Ozark Border regions; casual to accidental breeder farther south; casual winter visitant and resident.

Documentation: Specimen: male, 15 May 1857, St. Louis (MCZ 16849).

Habitat: Openings and edge of woodland and forest, especially in riparian areas.

Spring: A common migrant statewide. The initial migrants typically appear at the beginning of the third week of Apr in the south but not until the very end of Apr in the north. Peak is during the first week of May in the south and the second week in the north. An average of 0.9 birds/hr was recorded at Forest Park, 27 Apr-17 May 197990 (RK; n=359 hrs). Earliest dates of non-wintering birds: male, 6 Apr 2001, along Meramec River, near Eureka, St. Louis Co. (D. Rabenau); 1, photos, 9 Apr 2013, Stringtown, Butler Co. (L. Holst). High counts: 100+, 6-7 May 1978, Roaring River 
(J. Garrett); 45, at feeder, 5 May 2007, Macon, Macon Co. (K. Mar); 46, at feeder, 2 May 2013, Kirksville (PK).

Summer: The breeding distribution coincides very closely with the Glaciated Plains region, although it is less widespread south of the Missouri river in that region. It is rare in the northern Osage Plains and very spotty in distribution farther south in that region. It is also quite rare south of the Missouri River in the Ozark Border. It is casual in the Ozarks, and there are no breeding records for the Mississippi Lowlands. Many observations south of the Missouri River, including as far south as the Mississippi Lowlands, involve singing, unpaired males (often first-year birds). The southernmost report of breeding include the following: ads feeding young, 6 Jul 1885, near Freistatt, Lawrence Co. (Nehrling; Widmann 1907, but see remarks concerning Nehrling reports under Wilson's Phalarope, Western Kingbird, and Savannah Sparrow accounts); ad male and fledged juv., photos, Jun 1986, Springfield (C. Tyndall).

Fall: Migrants begin appearing in non-breeding areas at the end of Aug. Peak is usually during the third week of Sep; however, recent observations by TJ in the bootheel indicate peak there may be in early Oct. Except for the bootheel region, numbers are greatly reduced by the beginning of Oct. After mid-Oct it is only casually encountered. High counts away from the bootheel: 50+, 16 Sep 1971, near the Iowa border, Nodaway Co. (MR). High counts at Ben Cash by TJ: 280, 8 Oct 2015; 58, 19 Sep 2012. Latest record: imm male, 27 Nov-3 Dec 1991, near Moberly, Randolph Co (S. and D. Vasse).

Winter: There are at least five records for this period: male at feeder, $18 \mathrm{Dec}-$ Mar 1973-4, Columbia (BG); 1, 19 Dec 1982, Weldon Spring CBC; male, 29 Dec 2004, Thompson River Wetlands (SK); 1, 18 Dec 2011, Grand River CBC (M. McNeely); ad and imm male, photos, 13 Jan - 26 Feb 2014, Jackson, Cape Girardeau Co. (MH, M. Goodman).

\section{Black-headed Grosbeak (Pheucticus melanocephalus)}

Status: Rare transient; accidental winter visitant.

Documentation: Photograph: imm male at feeder, 28 Nov-3 Dec 1984, Roaring River (J. Baugardt et al; photo by M. Rodgers; in VIREO r18/1/0001, reproduced in Robbins and Easterla 1992).

Habitat: Openings and edge of woodland and forest, especially in riparian areas.

Spring: There are at least fourteen spring observations with all but three from the western half of the state. All observations are of single individuals, with the majority from late Apr through mid-May. Earliest dates: male, videotaped, 20-26 Apr 1993, Country Club Village, Andrew Co. (D. Shoemaker); female, 21 Apr 1985, St. Louis (RK). Latest date: $2^{\text {nd }}$ year male, at feeder, 20 May - 11 Jun 2010, near Skidmore, Nodaway Co. (KG). 
Fall: There are at least a dozen observations distributed across the state. They span from early Sep through the end of the period. Earliest dates: imm male, 6 Sep 1962, St. Charles Co. (K. Arhos, RA); 1, 8-9 Sep 1973, James Reed CA (RF et al.). Latest dates: 1, early Nov - 13 Dec 1996, Springfield (S. Herring); above photographic record.

Winter: There are two observations: 1, 24 Feb 1986, Kansas City (KH); imm male, photos, 24 Dec - 2 May 2009-10, Kansas City, Platte Co. (L. Owens).

Comments: Female plumaged Black-headed Grosbeaks must be separated with care from female and imm male Rose-breasteds, and preferably photographed. Moreover, hybrids between Black-headed and Rose-breasted are not uncommon and should be considered in all observations of Black-headeds.

\section{Blue Grosbeak (Passerina caerulea)}

Status: Common summer resident in Ozarks, Ozark Border, and Osage Plains; uncommon and less widespread in the southern Glaciated Plains, with lower densities in the northern section of that region. It is rare and very local within the Mississippi Lowlands.

Documentation: Specimen: male, 8 Jul 1893, Carthage, Jasper Co. (BM 2914).

Habitat: Fields and prairie with brushy areas, hedgerows, and edge of young secondary woodland.

Spring: The first males appear in the south during the third week of Apr and about a week later in the north. Peak is in mid-May, with obvious migrants still arriving into early Jun. Earliest dates: male, 24 Mar 1993, Schell-Osage (E. Johnson, J. Garrett et al.); 1, photos, 11 Apr 2014, Hornesville Swamp CA, Dunklin Co. (TJ); 1, photos, 12 Apr 2013, Washington Co. (SD). High counts: 20+, 8 May 1989, St. Clair and Cedar cos. (MR, TE); 18, 28 Apr 2015, Ben Cash (TJ).

Summer: The Blue Grosbeak is a common breeder throughout the open areas of the Ozarks, Ozark Border, and Osage Plains. It is uncommon in the southern portion of the Glaciated Plains; in the northern section of this region it is less widespread and found in much lower densities. It is rare and quite local in the Mississippi Lowlands (BBS, BBA data).

At least along the western border and perhaps in general north of the Missouri River, this species appears to have increased since the end of the $19^{\text {th }}$ century. Widmann (1907) remarked, based on breeding in adjacent Miami Co., Kansas, that the northern limit of distribution along the western border was roughly in Cass Co. Just to the north in Jackson Co., Harris (1919b) remarked that the earliest breeding record was in 1917. Nonetheless, the lack of observations north of that area likely was, in part, due to relatively few qualified observers.

Fall: Most leave the state during late Aug through the first half of Sep. A few are still encountered at the end of Sep into early Oct, e.g., 6 imm, 1 Oct 1992, Bigelow Marsh 
(MR). It is accidental after the first week of Oct. Latest dates: male, 4 Dec 1952, Baden, St. Louis (RA); female/imm, photos, 16-25 Nov 2017, Loess Bluffs (LW, S. Leonardo, K. Stair, K. Gooby); 1, 22 Oct 1992, Smithville Lake (MM); male, 21 Oct 1987, Kansas City (KH, K. Brobisky).

\section{Lazuli Bunting (Passerina amoena)}

Status: Rare spring transient in western tier of counties, casual elsewhere; accidental fall transient, winter visitant, and summer resident.

Documentation: Photograph; see below.

Habitat: Brushy areas in fields, edge of woodland and forest.

Spring: With the exception of a single very early individual, all observations are from the end of Apr through May, with most during the second and third weeks of May. Prior to 1996 this bunting was considered a casual transient in the west, but since then it has been recorded almost annually, with multiple individuals observed during some springs in the western tier of counties. It is casual in the eastern third of the state. Earliest dates: ad male, photos, 3 Mar - 27 Apr 1995, Purcell, Jasper Co. (C. and M. Biggers); male, 28 Apr 1959, Mt. Washington Cemetery, Jackson Co. (F. Bart); male, 1 May 2001, south of Fairfax (E. Wright). High counts: 2 males, 6 May 2002, near Fairfax (E. Wright); 2 males, 17-18 May 1996, Springfield (T. Knapp, LR, CBu). Latest date: 27 May 2002, Amazonia, Andrew Co. (LL).

Summer: There are two reports: a male and female were observed (no nest found) twice during Jun 1939, Jackson Co. (Walters 1939); and a male was observed 5 July 2004, near Kingsville, Johnson Co. (D. Arney). See comments below concerning hybrids. There are a few records for this bunting as far east as central Kansas during summer (Thompson et al. 2011).

Fall: There is a single reliable record: 1, photos, 4 Oct 2010, Marshall CA, Platte Co (CB). Presumably, this species occurs more frequently than this single record indicates. See comments under Lazuli Bunting in Robbins and Easterla (1992) for questionable records in Widmann (1907).

Winter: A single record of an adult male at a feeder, photos, 31 Jan - 1 Feb 2016, Cape Girardeau (MH et al.).

Comments: Hybrids are common between Lazuli and Indigo buntings, and there are at least two sightings of hybrid males for the state: 14 Jun 1980, Marais Temps Clair (D. Jones); 10 May 2007, south of Fairfax, Atchison Co. (E. and W. Wright, TR).

\section{Indigo Bunting (Passerina cyanea)}

Status: Common summer resident; rare winter visitant in south, accidental in north.

Documentation: Specimen: male, 12 May 1857, St. Louis (USNM A7024).

Habitat: Brushy areas in fields, edge of woodland and forest. 
Spring: A very common migrant. Typically, the first individuals appear by the third week of Apr in the south, the last week in the north. Peak is early May in the south, mid-May in the north. Earliest dates: male, 11-14 Mar 1996 (perhaps a bird that overwintered?), Springfield (C. Noble); 2, 1 Apr 1980, Mississippi Co. (JHa). High counts: 620, 8 May 2015, near Hornersville Swamp, Dunklin Co. (TJ); 254, 19 May 2014, Ben Cash (TJ); 200, 14 May 1995, Stockton Lake (C. and B. Noble).

Summer: A very common summer resident that is most abundant in the Ozarks and Ozark Border and least common in the Glaciated Plains.

Fall: This bunting remains common through mid-Oct, but by the end of the month only single birds/day are encountered; it is rare thereafter. High counts: 220, 9 Oct 2015, Ben Cash (TJ); 150+, 19 Oct 2013, Ben Cash (TJ); 100, 10 Oct 2003, Chillicothe Wetlands, Linn Co. (SK).

Winter: Prior to 1990 there were only two records for this period; now it is recorded almost annually. All records involve single individuals that are detected for only a short period during the winter. With the exception of two records, all observations are from the southern half of the state. Northernmost records: 1, 2 Feb 1993, Excelsior Springs, Clay Co. (J. Davis et al.); 1, 20 Dec 2009, Chillicothe, Livingston Co. (SK).

\section{Painted Bunting (Passerina ciris)}

Status: Rare to locally uncommon summer resident in the southwest, casual summer resident elsewhere; casual transient outside southwestern Ozarks.

Documentation: Specimen: male, 23 Jun 1928, Vernon Co. (CMC 129).

Habitat: Open cedar glades, fallow fields with scattered trees borded by woodland and forest.

Spring: The first arrivals appear at the beginning of May, with peak in mid-May. Earliest dates: male, 19 Apr 1986, Hornersville, Dunklin Co. (H. Schanda); 1, 25 Apr 2014, Wells Hollow, Ozark Co. (B. and E. Fullen). High counts: 13 (10 males, 3 females), 17 May 1977, Protem, Taney Co. (W. West).

There are a number of extralimital records north of the Missouri River, e.g., there are at least eight records for the northwest and a few observations as far north as the St. Louis area. There are no records during this period for the northeastern corner of the state.

Summer: The primary breeding range is in the White River Glades section of the southwestern Ozarks, from the Oklahoma border east to at least Oregon Co. and north to Dade and Greene cos. Along the southern border in this region it can be locally uncommon, e.g., 8 and 11 territories near Protem, Taney Co., in 1979 and 1980 (Norris and Elder 1982b). Although there are no definite breeding records east of Oregon Co., it may sparingly breed as far east as the Mississippi Lowlands, since it is apparently common in the Mississippi River valley in Arkansas (James and Neal 1986, eBird). 
Isolated pairs have been documented as far north as Clay (at Gladstone in 1956; Rising et al. 1978), St. Clair (in 1973; Norris and Elder 1982b), St. Charles (Weldon Spring; for several years beginning in 2002), and Cole (Jefferson City; for a few years beginning in 2006) counties. In addition, there are a number of sightings of single birds as far north as the Missouri River and east to the Mississippi River during this season.

This bunting has expanded its breeding distribution northward during the past few decades. Harris (1919b) did not mention it at all for the Kansas City region and Rising et al. (1978) included only the 1956 Gladstone, Clay Co. record.

Fall: Most observations for this period are during Aug at breeding sites. Latest dates: female/imm male, 18 Oct 2005, Riverlands (J. Bergmann); female/imm male, 29 Sep 1994, Alred Pond Natural Area, Butler Co. (MR, BJ); ad male, 28 Sep 2000, Prairie SP (C. Evans); ad male, 21 Sep 1995, Moreau River, Jefferson City (K. Lohraff). The only record for the northeastern corner of the state is during this period: 1 , photo, 5 Aug 1982, Hannibal, Marion Co. (A. Allmon).

\section{Dickcissel (Spiza americana)}

Status: Common summer resident except in heavily forested sections of the Ozarks; rare winter resident.

Documentation: Specimen: male, 22 May 1883, St. Louis (CAS 36376).

Habitat: Fallow fields with scattered bushes, prairie, hedgerows.

Spring: A very common migrant that usually arrives in the south by the beginning of the third week of Apr and a few days later in the north. Peak is in mid-May. Because of birds that overwinter, the earliest migrants are difficult to ascertain; there are several Mar observations. High counts: both by TJ in the Hornersville Swamp area: 260, 1 May 2016; 186, 6 May 2012.

Summer: This ubiquitous bird of open country is most common in the Osage Plains and least abundant in the heavily-forested Ozarks. With the accelerated conversion of grassland to crops, this species has declined considerably in the Glaciated and Osage Plains. On the other hand, it is now fairly common and widespread in the Ozarks and Mississippi Lowlands, where it was likely absent or very local prior to deforestation of these regions. By the late 1800s it had already moved into those two regions, as Widmann (1907) remarked: "rare in the Ozarks where only in open, long settled localities; sparingly on the cultivated ridges of the southeast [Mississippi Lowlands]". High counts: 226, 22 Jun 2002, Prairie SP (RM); 203, 4 Jun 2011, Lockwood area, Dade Co. (CBu et al.).

Fall: A relatively large portion of the breeding population apparently departs as early as late Jul. However, relatively large numbers may be seen until mid-Sep, e.g., 92, 31 Aug 2006, Bigelow (TR); 91, 12 Sep 2003, Bradford Farm (PM). Smaller flocks, consisting of 10-20 birds, are seen from the latter half of Sep into early Oct, but after mid-Oct only solitary individuals are sparingly encountered. 
Winter: There are now about 20 records (ca. 7 prior to 1990, the remainder since then) that span the entire period and state. Birds often appear at feeders. There are two records that involved more than one individual: 2, at feeder, 18 Dec 1971, Springfield (R. Matthews); 2, 8 Jan 2012, Ten Mile Pond (CB).

\section{Acknowledgments}

I am especially indebted to Bill Rowe and Paul McKenzie, both of the Missouri Bird Records Committee (MBRC), who provided innumerable constructive comments on the entire manuscript. Other members of the MBRC and Missouri eBird reviewers continually brought to my attention important records: Lisa Berger, Ryan Douglas, Joe Eades, Brad Jacobs, Mary Nemecek, and Josh Uffman. Darrin Welchert of U.S. Fish and Wildlife Service provided unpublished data for Loess Bluffs National Wildlife Refuge. The following provided comments and information for selected species accounts: Tim Barksdale, Steve Cardiff, Donna Dittmann, Jon Dunn, Gary Graves, Chris Hobbs, John Hubbard, Jon King, Randy Korotev, Van Remsen, and Josh Uffman. The following were indispensable in obtaining the unique data set on riparian birds: Brian Barber, Brett Benz, David Easterla, David Mead, Arpi Nyari, Monica Papes, and Kristof Zyskowski. The following people answered my queries and confirmed the identification and presence of specimens under their care: Keith Barker (BM), Carla Cicero (MVZ), Andrew Kratter (Florida Museum of Natural History), Ben Marks (FMNH), Chris Milensky (USNM), Dana Morris (CMC), Nate Rice (ANSP), Dawn Roberts (CHAS), Stephen Rogers (CM), Paul Sweet (AMNH), Jeremiah Trimble (MCZ), Laura Wilkinson (CAS), and Kristof Zyskowski (Yale Peabody Museum). Ron Piva and Dale Gormanson provided the forest cover map. Kate Ingenloff and Chris Hensz kindly helped with producing figures and photographs. I thank all the photographers who contributed to this work.

My indefatigable friend and colleague Town Peterson provided help and advice on several facets of this work. In typical forward thinking, Town led me to publishing this work as an open access document with the unflagging effort and advice of University of Kansas Librarians, Pam LeRow and Marianne Reed. Pam did the monumental task of formatting this work. Finally, I want to thank my dear wife Kathy, who has been supportive in every way possible.

\section{Literature Cited}

Adkisson, C.S. 1981. Geographic variation in vocalizations and evolution of North American Pine Grosbeaks. Condor 83:277-288.

Alvarado, A.H., T.L. Fuller, and T.B. Smith. 2014. Integrative tracking methods elucidate the evolutionary dynamics of a migratory divide. Ecology and Evolution 4:3456-3469.

American Ornithologists' Union. 1983. Check-list of North American birds. $6^{\text {th }}$ ed. 
Anders, A.D., J. Faaborg, and F.R. Thompson, III. 1998. Postfledging dispersal, habitat use, and home-range size of juvenile Wood Thrushes. Auk 115:349-358.

Anderson, D. 1965. Winter robin roost in Missouri. Nature Notes 36:86-87.

Anderson, D. 1992. St. Louis area chickadees. Bluebird 59:65-68.

Anderson, D. 1994. Missing petrel specimen found. Bluebird 61:13-14.

Anderson, R. and P. Bauer. 1968. A guide to finding birds in the St. Louis Area. Webster Groves Nature Society, St. Louis.

Arbib, R. 1977. Bluelist 1978. American Birds 31:1093-1094.

Armistead, G.L. and M.J. Iliff. 2003. The vagrancy of Gray Kingbird in North America. North American Birds 57:148-161.

Arterburn, J.W. and J.A. Grzybowski. 2003. Hybridization between Glossy and Whitefaced Ibises. North American Birds 57:136-139.

Baldwin, R.N. 1911. Notes on rare species in eastern Missouri. Auk 28:490-492.

Banks, R.C, C. Cicero, J.L. Dunn, A.W. Kratter, P.C. Rasmussen, J.V. Remsen, Jr., J.D. Rising, and D.F. Stotz. 2004. Forty-fifth supplement to the American Ornithologists' Union Check-list of North American Birds. Auk 121:985-995.

Barker, F.K., K.J. Burns, J. Klicka, S.M. Lanyon, and I.J. Lovette. 2013. Going to extremes: contrasting rates of diversification in a recent radiation of New World passerine birds. Systematic Biology 62:298-320.

Barksdale, T.R. 1992. First Missouri record for Ross' Gull (Rhodostethia rosea). Bluebird 59:98-104.

Barksdale, T.R. and R.A. Rowlett. 1981. Status of the Gyrfalcon in Missouri, with notes on field identification. Continental Birdlife 2:154-157.

Baskett, J.N. 1896. Intergradation in song of Sturnella magna and S. m. neglecta in Missouri. Auk 13:258-259.

Bell, R.L. and F.E. Durbian. 2004. Ruddy Duck nest on Squaw Creek National Wildlife Refuge, Holt County, Missouri. Bluebird 71:38-39.

Benkman, C.W., J.W. Smith, P.C. Keena, T.L. Parchman, and L. Santisteban. 2009. A new species of Red Crossbill (Fringillidae: Loxia) from Idaho. Condor 111:169176.

Bennitt, R. 1932. Check-list of the birds of Missouri. Univ. of Missouri-Columbia.

Bennitt, R. and W.O. Nagel 1937. A survey of the resident game and furbearers of Missouri. Univ. of Missouri Studies 12:1-125.

Betts, N de W. 1909. Brown Creeper's nest in Missouri. Bluebird 53:32-34.

Bock, C.E. and L.W. Lepthien. 1972. Winter eruptions of Red-breasted Nuthatches in North America. American Birds 26:558-561.

Bock, C.E. and L.W. Lepthien. 1976. Growth in the eastern House Finch population, 1962-1971. American Birds 30:791-92.

Bohlen, H.D. and W. Zimmerman. 1989. The birds of Illinois. Bloomington and Indianapolis: Indiana University Press.

Bolgiano, N.C. 2004. Cause and effect: changes in boreal bird irruptions in Eastern North America relative to the 1970s spruce budworm infestation. American Birds 58:26-33.

Bonter, D.N. and M.G. Harvey. 2008. Winter survey data reveal rangewide decline in Evening Grosbeak populations. Condor 11:376-381. 
Branan, W.V. and H.C. Burdick. 1981. Bird species composition in a Missouri Park, 1916 vs. 1973. Kansas Ornithological Society Bulletin 32:41-45.

Braun, M.J. and M.B. Robbins. 1986. Extensive protein similarity of the hybridizing chickadees Parus atricapillus and P. carolinensis. Auk 103: 667-75.

Brennan, L.A. 1999. Northern Bobwhite (Colinus virginianus). The Birds of North America Online (A. Poole, Ed.). Ithaca: Cornell Lab of Ornithology. http://bna. birds.cornell.edu.bnaproxy.birds.cornell.edu/bna/species/397 doi:10.2173/bna.397

Brinkley, E.S. 2013. Changing Seasons: Strangers in a strange land. North American Birds 67:216-238.

Brinkley, E.S. 2016. Changing Seasons: Retrospect. North American Birds 69:342356.

Brown, N.L. 1963. Status of the Roadrunner in Missouri. Condor 65:242-3.

Budnik, J.M., M.R. Ryan, and F.R. Thompson, III. 2000. Demography of Bell's Vireos in Missouri grassland-shrub habitats. Auk: 117:925-935.

Burgess, H. 1981. The Trumpeters may again return. Bluebird 48:12

Burke, A.D., A.R. Forbes, P.A. Porneluzi, and J. Faaborg. 2011. Breeding Black-throated Green Warblers discovered in Missouri. Bluebird 78:54:58.

Burns, F.L. 1911. A monograph of the Broad-winged Hawk (Buteo platypterus). Wilson Bulletin 23:1-320.

Burns, L., J. Zellmer and M. Stoakes. 2010. First nesting record of Black-bellied Whistling Duck in Missouri. Bluebird 78:48-53.

Burnside, F.L. 1987. Long-distance movements by Loggerhead Shrikes. Journal of Field Ornithology 58:62-5.

Butcher, G.S., and D.K. Niven. 2007. Combining data from the Christmas Bird Count and the Breeding Bird Survey to determine the continental status and trends of North America birds. National Audubon Society, New York, NY.

Bryant, J.A. 1895. Clark's Nutcracker in eastern Missouri. Auk 12:82.

Cannon, R.W. and D.M. Christisen. 1984. 1983 breeding range and population status of the greater prairie-chicken in Missouri. Missouri Academy of Science 18:33-40.

Cardiff, S.W. 2008. The Winter Season, Arkansas and Louisiana. North American Birds 62: 256-261.

Cary, D.L. 1984. A stronghold for pheasants. Nature Notes 56:37-38.

Chambers, R.J. 1994. Habitat relations of Bachman's Sparrows and other birds on Missouri glades. M.S. thesis. University of Missouri-Columbia, $60 \mathrm{pp}$.

Chesser, R.T., K.J. Burns, C. Cicero, J.L. Dunn, A.W. Kratter, I.J. Lovette, P.C. Rasmussen, J.V. Remsen, Jr., J.D. Rising, D.F. Stotz, and K. Winker. 2017. Checklist of North and Middle American Birds. American Ornithological Society. Online. http://checklist.aou.org/taxa/

Chiavacci, S.J., T.J. Bader, A.M. St. Pierre, J.C. Bednarz, and K.L. Rowe. 2011. Reproductive status of the Swallow-tailed Kite in east-central Arkansas. Wilson Journal of Ornithology 123:97-101.

Christisen, D.M. 1985. The Greater Prairie-Chicken and Missouri's land-use Patterns. Missouri Department of Conservation Terrestrial Series, no. 15.

Collier, J.E. 1955. Agricultural Atlas of Missouri. University of Missouri Press. Bulletin 645 . 
Comfort, J. 1952. Resume for St. Louis area, 1951. Bluebird 19:3-4.

Comfort, J.F. 1972. Otto Widmann's bracketed species. Bluebird 39:2-5.

Cooke, W.W. 1910. The type locality of Vireo bellii. Auk 27:342-343.

Cooke, M.T. 1928. The spread of the European Starling in North America (to 1928).

U.S. Department of Agriculture. Circulation 40.

Cooke, M.T. 1937. Some returns of banded birds. Bird-Banding 8:144-155.

Cooke, M.T. 1950. Returns of banded birds. Bird-Banding 21:1-18.

Cooper, T.R. 2008. King Rail Conservation Plan, Version 1. U.S. Fish and Wildlife Service, Fort Snelling, Minnesota. 121 pp.

Coulter, M.C., J.A. Rodgers, J.C. Ogden, and F.C. Depkin. 1999. Wood Stork (Mycteria americana). The Birds of North America Online (A. Poole, Ed.). Ithaca: Cornell Lab of Ornithology. http://bna.birds.cornell.edu.bnaproxy.birds.cornell. edu/ban/species/409 doi:10.2173/bna.409

Contreras, A. 1991. Common Black-headed Gull and Little Gull in Morgan County. Bluebird 58:53-55.

Crosby, G.T. 1972. Spread of the Cattle Egret in the Western Hemisphere. Bird-banding 42:205-212.

Dahl, T.E. 1990. Wetland losses in the United States 1780's to 1980's. U.S. Department of the Interior. U.S. Fish and Wildlife Service, Washington, D.C. 13 pp.

Dhondt, A.A., D.L. Tessaglia, and R.L. Slothower. 1998. Epidemic myocoplasmal conjunctivitis in House Finches from eastern North America. Journal of Wildlife Diseases 41:54-59.

Dierker, W.W. 1979. Birds of the Hannibal, Missouri area. Transactions of the Missouri Academy of Science 13:41-51.

Dinsmore, J.J., T.H. Kent, D. Koenig, P.C. Petersen, and D.M. Roosa. 1984. Iowa Birds. Iowa State University Press, Ames.

Dorr, B.S., J.J. Hatch, and D.V. Weseloh. 2014. Double-crested Cormorant. (Phalacrocorax auritus). The Birds of North America Online (A. Poole, Ed.). http:// bna.birds.cornell.edu.bnaproxy.birds.cornell.edu/ban/species/441 doi:10.2173/ bna.441

Dumont, P.A. 1936. Old nesting records of rare birds in Iowa. Oologist 14:64-8.

Durbian, F.E., A.D. Griffin, B.N. Lomas, and N. Petersen. 2007. Least Bittern band return from Squaw Creek National Wildlife Refuge. Bluebird 74:3-4.

Dwight, J.D., Jr. 1917. The status of 'Thayer's Gull Larus thayeri'. Auk 34:413-414.

Eades, J. 2008. A historic Northern Shrike winter invasion; 2007-2008. Bluebird 75:41-49.

Eades, J., III, M. Jones, and D. Symes. 1978. First field identification of a female Barrow's Goldeneye in the St. Louis area. Bluebird 45:9-10.

Easterla, D.A. 1962a. Avifauna of Tucker Prairie. Master's thesis. University of Missouri, Columbia.

Easterla, D.A. 1962b. Grasshopper Sparrow wintering in central Missouri. Wilson Bulletin 74:288.

Easterla, D.A. 1965a. Arctic Loons invade Missouri. Condor 67:544.

Easterla, D.A. 1965b. Range extension of the Fish Crow in Missouri. Wilson Bulletin 77:297-298. 
Easterla, D.A. 1966a. Northern fringillids invade northwestern Missouri. Bluebird 33:3-5.

Easterla, D.A. 1966b. Short-billed Marsh Wren, Pine Warbler, Palm Warbler and Savannah Sparrow wintering in Missouri. Bluebird 33:26-28.

Easterla, D.A. 1967a. The Baird's Sparrow and Burrowing Owl in Missouri. Condor 69:88-89.

Easterla, D.A. 1967b. A breeding population of Henslow's Sparrow in southwestern Missouri. Bluebird 34:18-19.

Easterla, D.A. 1969. The Snowy Plover in Missouri. Auk 86:146.

Easterla, D.A. 1970a. First nesting colonies of Lark Bunting in Missouri. Wilson Bulletin 82:465-66.

Easterla, D.A. 1970b. Hermit Warbler in Missouri. Wilson Bulletin 82:464.

Easterla, D.A. 1975. Grasshopper Sparrow with crossed mandibles. Kansas Ornithological Society 26:21.

Easterla, D.A. 1976. First record of the Little Gull and the White-tailed Kite in Missouri. Bluebird 43:14-16.

Easterla, D.A. 1994. The Wilson's Phalarope rediscovered nesting in Missouri after 109 years. Bluebird 61:102-105.

Easterla, D.A. 2000. The Red-shouldered Hawk (Buteo lineatus). Rediscovered nesting in northwest Missouri after 30 years. Bluebird 67:44-48.

Easterla, D.A. 2004. What is a Harris' Sparrow doing in Missouri during summer? Bluebird 71:3-5.

Easterla, D.A. 2008. A specimen of the Caribbean Cave Swallow (Petrochelidon fulva cf. fulva) from Missouri. North American Birds 62:200-203.

Easterla, D.A. 2013. The great bird "fall-out" in northwest Missouri during the first weekend of May 2013. Bluebird 80:90-92.

Easterla, D.A. and R.A. Anderson. 1969. First Vermilion Flycatcher specimen for Missouri. Auk 86:750.

Easterla, D.A. and R.E. Ball. 1973. The Rock Wren in Missouri. Wilson Bulletin 85:479-80.

Easterla, D.A. and K.R. Goslee. 1994. First record of the Black-throated Sparrow for Missouri. Bluebird 61:106-108.

Easterla, D.A. and F. Lawhon. 1971. First specimen of Arctic Loon from Missouri. Auk 88:175.

Easterla, D.A. and T.L. Rodgers. 2003. First record of Hooded Warbler nesting in northwest Missouri. Bluebird 70:6-11.

Easterla, D.A. and D.L. Scarbrough. 2001. First documentation of the Gyrfalcon (Falco rusticolus) in Missouri. The World's largest falcon. Bluebird 68:23-27.

Eddleman, W.R. 1978. Selection and management of Swainson's warbler habitat. M.S. Thesis, Univ. Missouri-Columbia. 75pp.

Eddleman, W.R. and R.L. Clawson. 1987. Population status and habitat conditions of the Red-cockaded Woodpecker in Missouri. Transactions of the Missouri Academy of Science 21:105-117.

Elder, H.H. and J. Hansen. 1967. Bird mortality at KOMU-TV tower, Columbia, Missouri. Fall 1965 and 1966. Bluebird 34:3-6. 
Elliot, J.J. and R.S. Arbib. 1953. Origin and status of the House Finch in the eastern United States. Auk 70:31-37.

Fournier, A.M.V., D.C. Mengel, E.E.Gbur, and D.G. Krementz. 2017. Timing of autumn migration of Sora (Porzana carolina) in Missouri. Wilson Journal of Ornithology 129:765-770.

Funk, J.L. and J.W. Robinson. 1974. Changes in the channel of the lower Missouri River and effects on fish and wildlife. Missouri Department of Conservation Aquatic Series, no. 11.

Garrett, J. 1989. A male and female Mountain Bluebird in Cass County. Bluebird $56: 70$.

George, W. 1963. Columbia tower fatalities. Bluebird 30:5.

Gerber, B.D., J.F. Dwyer, S.A. Nesbitt, R.C. Drewien, C.D. Littlefield, T.C. Tacha, and P.A. Vohs. 2014. Sandhill Crane (Antigone canadensis), version 1.0. The Birds of North America Online (P.G. Rodewald, Ed.). Cornell Lab of Ornithology, Ithaca, New York, USA. http://doi:10.2173/bna.31

Gerber, D.T. 1986. Female Golden-fronted Woodpecker or mutant female Red-bellied Woodpecker? American Birds 40:203-204.

Gill, F.B. 1980. Historical aspects of hybridization between Blue-winged and Golden-winged warblers. Auk 97:1-18.

Gill, R.E., Jr., P. Canevari, and E.H. Iversen. 1998. Eskimo Curlew (Numenius borealis). Birds of North American Online (A. Poole, Ed.). Ithaca: Cornell Lab of Ornithology; retrieved from Birds of North America Online. http://bna.birds.cornell. edu.bnaproxy.birds.cornell.edu/bna/species/347 doi:10.2173/bna.347

Goetz, R.E., W.M. Rudden, and P.B. Snetsinger. 1986. Slaty-backed Gull winters on the Mississippi River. American Birds 40:207-16.

Goodge, B. 1972. Groove-billed Ani at Columbia. Bluebird 39:11.

Goodge, W. 1977. Laughing Gull at Fountain Grove waterfowl area. Bluebird 44:5.

Goss, N.S. 1891. History of birds of Kansas. Topeka: G.W. Crane and Co.

Graves, G.R. 2004. Avian commensals in Colonial America: when did the Chaetura pelagica become the chimney swift? Archives of natural History 31:300-307.

Greenberg, R. and S. Droege. 1999. On the decline of the Rusty Blackbird and the use of ornithological literature to document long-term population trend. Conservation Biology 13:553-559.

Greenberg, R. and S.M. Matsuoka. 2010. Rangewide ecology of the declining Rusty Blackbird. Condor 112:770-777.

Griffin, C.R. and W.H. Elder. 1980. Nesting records for the Bald Eagle in Missouri and the lower Mississippi River. Transactions of the Missouri Academy of Science $14: 5-7$.

Griffin, C.R., J.M. Southern, and L.D. Frenzel. 1980. Origins and migratory movements of Bald Eagles wintering in Missouri. Journal of Field Ornithology 51:161167.

Groth, J.G. 1993. Evolutionary differentiation in morphology, vocalizations, and allozymes among nomadic sibling species in the North American Red Crossbill (Loxia curvirostra) complex. Univ. of California Press, Berkeley. 
Gross, A.O. 1947. Cyclic invasions of the Snowy Owl and the migration of 19451946. Auk 64:584-601.

Hallet, D.L. 1988. Statewide Ring-necked Pheasant surveys. Study no. 29. Jefferson City: Missouri Department of Conservation.

Hamel, P.B. 2011. Bachman's Warbler (Vermivora bachmanii), version 2.0 In the Birds of North America (P.G. Rodewald, editor). Cornell Lab of Ornithology, Ithaca, New York, USA. https://doi.org/10.2173/bna.150

Hanselmann, S. 1963. The warbler and vireo migration in the St. Louis area. Bluebird 30:9-12.

Hardin, K.I., T.S. Baskett, and K.E. Evans. 1982. Habitat of Bachman's Sparrows breeding on Missouri glades. Wilson Bulletin 94:208-212.

Harford, H. 1959. A flamingo in Missouri. Bluebird 26:1.

Harris, H. 1919a. Historical notes on Harris's Sparrow (Zonotrichia querula). Auk 36:180-190.

Harris, H. 1919b. Birds of the Kansas City region. Transactions of the Academy of Sciences, St. Louis. Vol. 23, no 8.

Harris, H. 1921. The season. Kansas City Region. Bird Lore 23:254-255.

Hasbrouck, E.M. 1891. The present status of the Ivory-billed Woodpecker (Campephilus principalis). Auk 8:174-186.

Hedges, H.C. 1953. The Prairie Warbler in eastern Kansas. Kansas Ornithological Bulletin 4:30-31.

Hedges, M. 1953. Birding on Missouri's Niangua River. Kansas Ornithological Bulletin 4:24.

Herbert, L. 1994a. First nesting record of the Mississippi Kite in southwestern Missouri. Bluebird 61:10-12.

Herbert, L. 1994b. A sight record for the Fish Crow in southwestern Missouri. Bluebird 61:154-155.

Herbert, L. 2004a. A spring record for the Rock Wren (Salpinctes obsoletus) in Missouri. Bluebird 71:21-23.

Herbert, L. 2004b. A second record for the Sage Thrasher in southwestern Missouri. Bluebird 71:43-45.

Heye, P. 1963. Tower fatalities. Bluebird 30:7.

Hilsabeck, J. and R. Bell. 1999. Marsh and water bird nesting at Squaw Creek National Wildlife Refuge 1992-1997. Bluebird 66:24-32.

Hilsabeck, J., L. Lade, and D. Roberton. 2016. Missouri's first record of Townsend's Warbler (Setophaga townsendi). Bluebird 83:92

Hobson, K.A. and M.B. Robbins. 2009. Origins of late-breeding nomadic Sedge Wrens in North America: limitations and potential of hydrogen-isotope analyses of soft tissue. Condor 111:188-192.

Hoffman, P. 1916. The Pomarine Jaeger and the Purple Gallinule in western Missouri. Auk 33:196.

Homer, C.G., J.A. Dewitz, L. Yang, S. Jin, P. Danielson, P., G. Xian, J. Coulston, N.D. Herold, J.D. Wickham, and K. Megown. 2015. Completion of the 2011 National Land Cover Database for the conterminous United States-representing A decade 
of land cover change information. Photogrammetric Engineering and Remote Sensing 81:345-354.

Honig, R. 2001. Western Kingbird. The Texas Breeding Bird Atlas. Texas A \& M University System, College Station and Corpus Christi, Texas. http://txtbba.tamu. edu (25 August 2016).

Houston, C.S. C.R. Jackson, and D.E. Bowen, Jr. 2011. Upland Sandpiper (Bartramia longicauda). The Birds of North America Online (A. Poole, ed.). Ithaca: Cornell Lab of Ornithology. http://bna.birds.cornell.edu.bnaproxy.birds.cornell.edu/bna/ species/580 doi:10.2173/bna.580

Howell, A.H. 1911. Birds of Arkansas. Biological Survey Bulletin no. 38, Washington, D.C

Howell, S.N.G. 2002. Hummingbirds of North America. The Photographic Guide. Academic Press Natural World, San Diego.

Hoy, P.R. 1865. Journal of an exploration of western Missouri in 1854, under the auspices of the Smithsonian Institution. Nineteenth Annual Report Smithsonian Institution.

Hudon, J., R.J. Driver, N.H. Rice, T.L. Loyd-Evans, J.A. Craves, and D.P. Shustack. 2017. Diet explains red flight feathers in Yellow-shafted Flickers in eastern North America. Auk 134:22-33.

Hurter, J. 1884. List of birds collected in the neighborhood of St. Louis. Ornithologist and Oologist 9:85-87, 95-97.

Iliff, M.J., B.L. Sullivan, C.L. Wood. 2011. The Changing Seasons: The eBird Era. North American Birds 65: 394-405.

Jackson, J. 1955. The Least Tern in Missouri. Bluebird 22:2-3.

Jackson, J.A. 2006. The public perception of science and reported confirmation of the Ivory-billed Woodpecker in Arkansas. Auk 123:1185-1189.

Jacobs, B. 1989. I brake for birds: Missouri's second Lewis' Woodpecker. Bluebird 56:85-87.

Jacobs, B. 1991. First state nesting record for Black-necked Stilts, Himantopus mexicanus. Bluebird 58:7-11.

Jacobs, B. 2017. Black Rosy-finch (Leucosticte atrata) in Montgomery County: a first state record. Bluebird 84:169-171.

Jacobs, B. and J.D. Wilson 1997. Missouri breeding bird Atlas. 1986-1992. Natural History Series, No. 6. Missouri Department of Conservation, Jefferson City.

James, D.A. and A.R. Green. 2009. A status assessment of the eastern subspecies of Bewick's Wren (Thryomanes bewickii bewickii and Thryomanes bewickii altus). Univ. of Arkansas, Fayetteville.

James, D.A. and J.C. Neal. 1986. Arkansas birds: their status and distribution. Fayetteville: Univ. of Arkansas.

Jenner, W. 1934. Some bird observations in Howard County, Missouri. Wilson Bulletin 46:258-259.

Johnson, M. 1975. Maximas on the rocks. Missouri Conservationist 36:8-9.

Johnson, M.E. 1908. Notes on Missouri birds. Auk 25:324.

Johnston, R.F. 1960. Distributional history of the Chuck-will's-widow in Kansas. Kansas Ornithological Society Bulletin 11:18. 
Jones, D. 1978. The House Finch winter invasion reaches Missouri. Bluebird 46:2930.

Jones, S.P. 1934. The European Tree Sparrow: a bird of Missouri and Illinois. Bluebird 1:9.

Jonsson, J.E., J.P. Ryder and R.T. Alisauskas. 2013. Ross's Goose (Chen rossii), Birds of North American Online (A. Poole, Ed.). Ithaca: Cornell Lab of Ornithology. http://bna.birds.cornell.edu.bnaproxy.birds.cornell.edu/bna/species/162 doi:10.2173/bna. 162

Kaufman, K. 1995a. Changing Seasons (fall). National Audubon Society Field Notes 49:8-11.

Kaufman, K. 1995b. Changing Seasons (winter). National Audubon Society Field Notes 49:116-119.

Kent, T.H. and J.J. Dinsmore. 1996. Birds in Iowa. Published by the authors, Iowa City and Ames.

Kessel, B. 1953. Distribution and migration of the European Starling in North America. Condor 55:49-67.

Kleen, V.M. and L. Bush. 1973. Middlewestern Prairie Region. American Birds 27:622-625.

Klicka, J., K. Burns, and G.M. Spellman. 2007. Defining a monophyletic Cardinalini: a molecular perspective. Molecular Phylogenetics and Evolution 45:1014-1032.

Korotev, R. 1990. A timetable for the bird spring migration through Forest Park, St. Louis. Supplement to Nature Notes 60:1-40.

Kridelbaugh, A.L. 1981. Population trend, breeding and wintering distribution of Loggerhead Shrikes (Lanius ludovicianus) in Missouri. Transactions of the Missouri Academy of Science 15:111-119.

Kritz, K.J. 1989. Nesting ecology and nest site habitat of Sharp-shinned and Cooper's hawks in Missouri. Master's Thesis, Univ. of Missouri-Columbia.

Kroodsma, D. 1988. Two species of Marsh Wren (Cistothorus palustris) in Nebraska. Nebraska Bird Review 56:40-42.

Kroodsma, D. 2005. The singing life of birds. Houghton Mifflin Co., New York, New York.

Kucera, C.L. 1961. The grasses of Missouri. University of Missouri Studies, University of Missouri Press.

LaDeau, S.L., A.M. Kilpatrick, and P.P. Marra. 2007. West Nile emergence and large scale declines of North American bird populations. Nature 447:710-714.

Lade, L. 2002. Rare find for Missouri: Red-necked Stilt. Bluebird 69:26-29.

Lanyon, W.E. 1956. Ecological aspects of the sympatric distribution of meadowlarks in the north-central states. Ecology 37:98-108.

Lasley, G.W. and C. Sexton. 1988. The spring season. Texas region. American Birds 42:456-462.

Lawrence, G.N. 1877. A note on Cupidonia cupido var. pallidicintus, Ridgway. Bulletin of the Nuttall Club 2:52.

Lehman, P. 1989. The changing seasons. American Birds 43:50-54.

Leukering, T. 2010. Identifying Solitary Sandpiper subspecies: why and how. Colorado Birds 44:203-206. 
Lever, P. 1987. Naturalized birds of the world. New York: J. Wiley and sons.

Lewis, J.B. 1961. Wild Turkeys in Missouri. 1940-1960. Transactions of the North American Wildlife and Natural Resources Conference 32:17-28.

Liguori, J. and B.L. Sullivan. 2010. A study of Krider's Red-tailed Hawk. Birding 42:38-45.

Liguori, J. and B.L. Sullivan. 2014. Northern Red-tailed Hawk (Buteo jamaicensis abieticola) revisited. North American Birds 67:374-383.

Liming, F.G. 1946. The range and distribution of shortleaf pine in Missouri. Technical paper no. 106. U.S. Department of Agriculture, Forest Service, Central States, Columbus, Ohio. Pdf map at: www.fs.usda.gov/treesearch/pubs/48080

Lomas, B.N., F.E. Durbian, R.L. Bell, and A. Cunningham. 2006. Second confirmed nesting attempt by Sandhill Crane in Missouri. Bluebird 73:7-11.

Lowery, G.H. 1939. Vaux Swift in Louisiana. Wilson Bulletin 51:199-201.

Lundberg, C. 1990. Rare loons at Table Rock Lake. Western Ozark Birders Newsletter 5:11-12.

Martin, P.R. and B. M. Di Labio. 1994. Identification of Common x Barrow's Goldeneye hybrids in the field. Birding 26:104-105.

Mason, N.A. and S.A. Taylor. 2015. Differentially expressed genes match bill morphology and plumage despite largely undifferentiated genomes in a Holarctic songbird. Molecular Ecology 24:3009-3025.

Mayes, E.A. 1937. Forest restoration in Missouri. Univ. of Missouri-Columbia, College of Agriculture Research Bull. 392. Agricultural Experimental Station.

Mayo, K. 2011. Jaeger: an account of the effort to document and identify Missouri's fourth Long-tailed Jaeger. Bluebird 78:4-9.

McKenzie, P.M. 1996a. Notes on the fall migration of LeConte's Sparrow (Ammodramus leconteii) in east-central Missouri. Bluebird 63:26-29.

McKenzie, P.M. 1996b. First breeding record of Great-tailed Grackle (Quiscalus mexicanus) east of western Missouri. Bluebird 63:33-35.

McKenzie, P.M. 2000. Highlights of Boone County, Missouri Migration Count of May 13, 2000. Bluebird 67:6-8.

McKenzie, P.M. 2011. Winter raptor survey along interstate highways 55 and 70, 1-2 January 2011. Bluebird 78:13-15.

McKenzie, P.M. 2012. Repeat of Winter Raptor Survey along Interstates I-55 and I-70, 1-2 Jan. 2012. Bluebird 79:42-44.

McKenzie, P.M. and B. Jacobs. 1992. First recorded nesting attempt of Least Flycatcher (Empidonax minimus) in Missouri since 1891. Bluebird 59:158-160.

McKenzie, P.M. and L.J. Rizzo. 1994. Band recovery of a Rufous Hummingbird (Selasphorus rufus) in Missouri. Bluebird 61:6-9.

McKenzie, P.M. and M.B. Robbins. 1999. Identification of adult male Rufous and Allen's hummingbirds, with specific comments on dorsal coloration. Western Birds 30:86-93.

McKenzie, P.M. and E. Wade. 2001. New all-time state high for one-day count of Lincoln's Sparrow in Missouri and observations on a noteworthy movement of raptors. Bluebird 68:53-55. 
McKenzie, P.M., F.E. Durbian, T. Nagel, J. Briggler, and B. Lomas. 2006. A new high count for Swainson's Hawk in Missouri. Bluebird 73:39-40.

McKenzie, P.M., R.B. Jacobs, E. Wood, and J. Besser. 2017. Record 18 Peregrines in a single day. Bluebird 84:172-175.

McKinley, D. 1960a. History of the Ruffed Grouse in Missouri. Bluebird 27:3-11.

McKinley, D. 1960b. A history of the Passenger Pigeon in Missouri. Auk 77:399-419.

McKinley, D. 1960c. The Carolina Parakeet in pioneer Missouri. Wilson Bulletin 72:274-287.

McKinley, D. 1961. History of the Canada Goose as a breeding bird in Missouri. Bluebird 28:6-12.

McKinley, D. 1962. The Trumpeter Swan in Missouri. Bluebird 29:6-11.

McKinley, D. 1964. History of the Carolina Parakeet in its southwestern range. Wilson Bulletin 76:68-93.

Mlodinow, S.G., P.F. Springer, B. Deuel, L.S. Semo, T. Leukering, T. Doug Schonewald, W. Tweit, and J.H. Barry. 2008. Distribution and identification of Cackling Goose (Branta hutchinsii) subspecies. North American Birds 62: 344-360.

Mowbray, T.B., C.R. Ely, J.S. Sedinger and R.E. Trost. 2002. Canada Goose (Branta canadensis), The Birds of North America online (A. Poole, Ed.). Ithaca: Cornell Lab of Ornithology; retrieved from Birds of North America online. http://bna.birds. cornell.edu.bnaproxy.birds.cornell.edu/bna/species/682 doi:10.2173/bna.682

Musher, L. 2013. Reversing the Common Nighthawk population declines. Birding 45:30-36.

Musselman, T.E. 1935. New record for Fulvous Tree Duck in Missouri. Auk 53:444.

Musselman, T.E. 1937. American Magpie in Missouri and Illinois. Auk 54:393

Musselman, T.E. 1950. European Tree Sparrow at Hannibal, Missouri. Auk 67:105.

Myers, D. and E. Myers. 1992. Broad-winged Hawk migration. Bluebird 59:155-157.

Neff, J.A. 1930. The starling in the Missouri Ozarks. Wilson Bulletin 35:202-215.

Nelson, P.W. 2005. The terrestrial natural communities of Missouri. Jefferson City: Missouri Natural Areas Committee.

Newton, E.T. 1942. Western Sandpipers in western Missouri and eastern Kansas. Auk 59:109-110.

Nice, M.N. 1924. Extension of range of the robin and Arkansas Kingbird in Oklahoma. Condor 41:565-568.

Nigh, T.A. and W.A. Schroeder. 2002. Atlas of Missouri ecoregions. Missouri Department of Conservation.

Niven, D.K., J.R. Sauer, G.S. Butcher, and W.A. Link. 2004. Christmas bird count provides insights into population change in land birds that breed in the boreal forest. American Birds 58:10-20.

Norris, D.J. and W.H. Elder. 1982a. Decline of the Roadrunner in Missouri. Wilson Bulletin 94:354-356.

Norris, D.J. and W.H. Elder. 1982b. Distribution and habitat characteristics of the Painted Bunting in Missouri. Transactions of the Missouri Academy of Science $16: 77-83$.

Peters, M. 1988. Fall 1987 hawk migration - St. Louis area. Nature Notes 60:55-56. 
Pyle, P. 1997. Identification guide to North American birds. Part 1. Columbidae to Ploceidae. Slate Creek Press, Point Reyes Station, California.

Rafferty, M.D. 1982. Historical Atlas of Missouri. University of Oklahoma Press, Norman.

Reeves, B. 2007. First winter record of Lark Bunting from southeastern Missouri. Bluebird 74:26-28.

Remsen, J.V., Jr. 1986. Was the Bachman's Warbler a bamboo specialist? Auk 103: 216-219.

Renfrow, F. 2013. Brown-headed Nuthatchers in Marshall County: a first nesting record for Kentucky. Kentucky Warbler 89:82-86.

Renken, R.B. and E.P. Wiggers. 1993. Habitat characteristics related to Pileated Woodpecker densities in Missouri. Wilson Bulletin 105:77-83.

Ridgway, R. 1902. Birds of North and Middle America. U.S. National Museum. No. 50. 2:712.

Rising, J.D. 1965. Townsend's Solitaire and Pine Grosbeak in Missouri. Auk 82:275.

Rising, J.D., T.R. Anderson, M.L. Myers, and S.R. Leffler. 1964. Extreme dates of occurrence of birds in northeastern Kansas and adjacent Missouri. Kansas Ornithological Society Bulletin 15:17-18.

Rising, J.D., T. Pucci, N. Johnson, and R. Dawson. 1978. Birds of the Kansas City area. Burroughs Audubon Society and Shawnee Mission High School. Kansas City, Kansas.

Robbins, M.B. 1969. Common Redpolls this winter in Missouri? Bluebird 36:22.

Robbins, M.B. 1986. Rediscovery of nesting Brown Creepers in Missouri. Bluebird 53:32-34.

Robbins, M.B. 1989. Avian riparian censuses: a need for statewide surveys. Bluebird $56: 23-24$.

Robbins, M.B. 2004. Status and distribution of Merlin (Falco columbarius) subspecies in Missouri, with comments on subspecific identification. Bluebird 71:7-11.

Robbins, M.B. 2007. Review of Ivorybill hunters: the search for proof in a flooded wilderness, G.E. Hill, 2007. Birding 39:88-92.

Robbins, M.B. 2008. Sedge Wren (Cistothorus platensis) early winter status at Prairie State Park, Barton County, Missouri. Bluebird 75:26-29.

Robbins, M.B. 2010. First nesting of Black-necked Stilt (Himantopus mexicanus) away from the lower Mississippi River in Missouri. Bluebird 77:143-144.

Robbins, M.B. 2015a. Contact zone of the Eastern and Western Marsh Wrens in Nebraska revisited. Nebraska Bird Review 82:128-130.

Robbins, M.B. 2015b. Intra-summer movement and probable dual breeding sites of the eastern Marsh Wren (Cistothorus p. palustris); a Cistothorus ancestral trait? Wilson Journal of Ornithology 127:494-498.

Robbins, M.B. 2016. Historical first breeding records in Missouri of Eared Grebe (Podiceps nigricollis). Bluebird 83:158-159.

Robbins, M.B. and D.A. Easterla. 1985. First Missouri record of the Varied Thrush. Bluebird 52:30-31.

Robbins, M.B. and D.A. Easterla. 1986. Range expansion of the Great-tailed Grackle into Missouri, with details of the first nesting colony. Bluebird 53:24-27. 
Robbins, M.B. and D.A. Easterla. 1992. Birds of Missouri: their distribution and abundance. Univ. of Missouri Press, Columbia.

Robbins, M.B. and J.L. Hilsabeck. 1991. Fall 1990 observations on Swainson's Hawk migration through northwestern Missouri. Bluebird 58:12-14.

Robbins, M.B. and C. Otte. 2013. The irruptive movement of Snowy Owls (Bubo scandiacus) into Kansas and Missouri during the winter of 2011-2012. Kansas Ornithological Society Bulletin 64:41-44.

Robbins, M.B., B.R. Barber, and B.W. Benz. 2001. Breeding birds of northeastern Missouri. Bluebird 68:7-21.

Robbins, M.B., B.R. Barber, and K. Zyskowski. 1998. Census of Cerulean Warblers along the upper Current River, with comments on the status of other riparian species. Bluebird 65:10-16.

Robbins, M.B., M.J. Braun, and E.A. Tobey. 1986a. Morphological and vocal variation across a contact zone between the chickadees Parus atricapillus and P. carolinensis. Auk 103:655-656.

Robbins, M.B., D.A. Easterla, and F. Lawhon. 1986b. Notes on Missouri's first breeding record of the Burrowing Owl (Athene cunicularia). Bluebird 53:21-22.

Robbins, M.B., D.A. Easterla, and D. Mead. 1992. Avian census of the Nodaway River, northwestern Missouri. Bluebird 59:105-107.

Robbins, M.B., D.A. Easterla, and D. Mead. 1993. 1993 avian census of the Nodaway River, northwestern Missouri. Bluebird 60:110-111.

Robbins, M.B., P. McKenzie, and B. Jacobs. 2010a. A review of Mottled Duck (Anas fulvigula) in the North American interior, with comments on historical records of dark Anas ducks. North American Birds 64:518-522.

Robbins, M.B., A.S. Nyári, M. Papes, B.W. Benz, and B.R. Barber. 2010b. River-based surveys for assessing riparian birds populations: Cerulean Warbler as a test case. Southeastern Naturalist 9:95-104.

Robbins, M.B., D.E. Seibel, and C. Cicero. 2005. Probable Yellow-bellied (Sphyrapicus varius) x Red-breasted Sapsucker (S. ruber) hybrid from eastern Kansas, with comments on the field identification of adult sapsuckers. North American Birds 59:360-363.

Rodewald, P.G. 1997. Two new breeding species of wood-warblers (Parulidae) in Arkansas. Southwestern Naturalist 42:106-107.

Rowe, B. 2009. Twenty-first annual report of the Missouri Bird Records Committee Bluebird 76:517.

Rudden, B. 1980. First St. Louis area sighting of a McCown's Longspur. Nature Notes 52:1-2.

Say, T. 1823. Fringilla grammaca. In Account of an expedition [S. Long Expedition] from Pittsburgh to the Rocky Mountains, ed. E. James, 1:139-140. Philadelphia edition.

Schoen, E. 1955. Red-breasted Nuthatch nesting. Bluebird 22:3.

Schwartz, C.W. 1945. The ecology of the prairie-chicken in Missouri. Univ. of Missouri Studies 20:1-99.

Schroeder, W.A. 1981. Presettlement Prairie of Missouri. Natural History Series, no. 2. Missouri Department of Conservation. 
Scott, W.E.D. 1879. Notes on birds observed during the spring migration in western Missouri. Bulletin of the Nuttall Ornithological Club 4:139-147.

Sharpe, R.S., W.R. Silcock, and J.G. Jorgensen. 2001. Birds of Nebraska. Their distribution and temporal occurrence. University of Nebraska Press, Lincoln.

Sherony, D.F. 2008. Greenland geese in North America. Birding 40:46-56.

Shields, M. 2014. Brown Pelican (Pelecanus occidentalis). The Birds of North America Online (A. Poole, Ed.). Ithaca: Cornell Lab of Ornithology. http://bna.birds. cornell.edu.bnaproxy.birds.cornell.edu/bna/species/609 doi:10.2173/bna.609

Shirling, A. 1920. Birds of Swope Park. Kansas City, MO. McIndoo Publ. Co.

Sibley, D.A., L.R. Bevier, M.A. Patten and C.S. Elphick. 2006. Comment on "Ivory-billed Woodpecker (Campephilus principalis) persists in continental North America". Science 311:1555.

Smith, A.L., L. Monteiro, O. Hasegawa, V.L. Friesen. 2007. Global phylogeography of the band-rumped storm-petrel (Oceanodroma castro; Procellariiformes: Hydrobatidae). Molecular Phylogenetics and Evolution 43:755-773.

Smith, J.W. 1987. Improving the status of the endangered species in Missouri (Interior Least Tern habitat and nest survey). Endangered species project SE-01-12. Jefferson City: Missouri Department of Conservation.

Smith, K.G. 1986. Winter population dynamics of Blue Jays, Red-headed Woodpeckers, and Northern Mockingbirds in the Ozarks. American Midland Naturalist 115:52-62.

Smith, P.W. 1987. The Eurasian Collared-Dove arrives in the Americas. American Birds. 41:1371-1379.

Snell, R.R. 1991. Conflation of the observed and the hypothesized: Smith's 1961 research in Home Bay, Baffin Island. Colonial Waterbirds 14:196-202.

Sparks, F.W. 1891. Fulvous Tree Duck in Missouri. Forest and Stream 36:476.

Stewart, O.C. 2002. Forgotten Fires, Native Americans and the transient wilderness. University of Oklahoma Press, Norman.

Street, P.B. 1948. The Edward Harris collection of birds. Wilson Bulletin 60:167-84.

Tate, J. Jr. 1966. An early record of the Ross' Goose in Nebraska. Nebraska Bird Review 34:46-47.

Teachenor, D. 1940. Western Burrowing Owl in western Missouri. Auk 57:573.

Thom, R.H. and J.H. Wilson. 1980. The natural divisions of Missouri. Transactions of the Missouri Academy of Science 14:9-23.

Thomas, B.G., E.P. Wiggers, and R.L. Clawson. 1996. Habitat selection and breeding status of Swainson's Warblers in Southern Missouri. Journal of Wildlife Management 60:611-616.

Thompson, M.C., C.A. Ely, B. Gress, C. Otte, S.T. Patti, D. Seibel, and E.A. Young. 2011. Birds of Kansas. Univ. of Kansas Press, Lawrence.

Tordoff, H.B. 1956. Check-list of the birds of Kansas. Univ. of Kansas Publications, Museum of Natural History 8:307-359.

Tordoff, H.B. and P.T. Redig. 2001. The role of genetic background in the success of reintroduced Peregrine Falcons. Conservation Biology 15:528-532. 
Tucker, J.W. Jr., W.D. Robinson, and J.B. Grand. 2004. Influence of fire on Bachman's Sparrow, an endemic North American songbird. Journal of Wildlife Management 68:1114-1123.

Tucker, J.W. Jr., W.D. Robinson, and J.B. Grand. 2006. Breeding productivity of Bachman's Sparrows in fire-managed longleaf pine forests. Wilson Journal of Ornithology 118:131-137.

Tulenko, P.Q. 1950. Avis rara. Bluebird 17:1.

Uffman, J. 2006. Fifth state record, Yellow-billed Loon, Thomas Hill Reservoir. Bluebird 73:14-16.

Van Horn, M.A., R.M. Gentry, and J. Faaborg. 1995. Patterns of pairing success of the Ovenbird (Seiurus aurocapillus) within Missouri forest fragments. Auk 112:98106.

Veit, R.R. and L. Jonsson. 1984. Field identification of smaller sandpipers within the genus Calidris. American Birds 38:853-876.

Wade, E. 2003. Ruffed Grouse in Missouri - past, present and future. Bluebird 70:617.

Walker, B.M., N.R. Senner, C.S. Elphick, and J. Klima. 2011. Hudsonian Godwit (Limosa haemastica). The Birds of North America (P.G. Rodewald, Ed.). Ithaca: Cornell Lab of Ornithology. https://birdsna-org.bnaproxy.birds.cornell.edu

Walkinshaw, L. 1983. Kirtland's Warbler, the natural history of an endangered species. Bloomfield Hills: Cranbrook Institute of Science.

Walters, D.L. 1939. Lazuli Bunting in Missouri. Oologist 56:117.

Watt, D.J. and E.J. Willoughby. 2014. Lesser Goldfinch (Spinus psaltria), version 2.0. In The Birds of North America (P.G. Rodewald, Ed.). Cornell Lab of Ornithology, Ithaca, New York, USA. https://doi.org/10.2173/bna.392

Wayne, A.T. 1926. The Russet-backed Thrush in Missouri. Auk 43:102.

Webster Groves Nature Study Society. 1995. Birds of the St. Louis area, where and when to find them. Webster Groves Nature Study Society, Missouri.

Weir, D.N., A.C. Kitchener and R.Y. McGowan. 2000. Hybridization and changes in the distribution of Iceland Gulls (Larus glaucoides/kumlieni/thayeri). Journal of the Zoological Society of London 252:517-530.

Wenny, D.G., R.L. Clawson, S.L. Sheriff, and J. Faaborg. 1993. Population variation, habitat selection, and minimum area requirements of three forest interior warblers in central Missouri. Condor 95:968-979.

Widmann, O. 1897. The summer home of the Bachman's Warbler no longer unknown. Auk 14:305-310.

Widmann, O. 1907. A preliminary catalog of the birds of Missouri. Academy of Science, St. Louis.

Widmann, O. 1908. Another Clark's Crow taken in Missouri. Auk 25:222.

Widmann, O. 1928. Chimney Swifts in November, 1925. Wilson Bulletin 40:151-154.

Wilhelm, E.J. 1958. Birds of the St. Louis area. St. Louis Audubon Society.

Williams, F. 1973. Southern Great Plains. American Birds 27:633-637.

Williams, H.C. 1913. White Ibis (Guara alba) in Missouri. Auk 30:268.

Williamson, V. 1946. Arctic 3-toed Woodpecker in Missouri. Bluebird 13:1.

Wilson, J.D. 1986. Missouri’s first record of Roseate Spoonbill. Bluebird 53:16-18. 
Wilson, J.D. 1989. First record of White-throated Swift in Missouri. Bluebird 56:8284.

Wilson, S. 1896. Notes from Missouri. Wilson Bulletin 8:8.

Woodruff, E.S. 1907. Some interesting records from southern Missouri. Auk 24:348349.

Woodruff, E.S. 1908. A preliminary list of the birds of Shannon and Carter Counties, Missouri. Auk 25:191-214.

Wywialowski, A. 1988. Long-term trends in Missouri's Greater Prairie-Chicken Population. Missouri Prairie Journal 10:3-5.

Wywialowski, A. and D.M. Christisen. 1989. Greater Prairie-chicken population of Missouri: an overview. Missouri Prairie Journal 11:8-11.

Young, E.A. and A. Whiles. 2016. Black-billed Magpie (Pica hudsonia) winter populations in Kansas from 1949 to 2015 based on Christmas Bird Count data. Kansas Ornithological Society Bulletin 67:36-46.

Young, M.A. and T. Spahr 2017. Crossbills of North American: species and Red Crossbill call types. eBird online 17 October 2017. 


\section{Index of English bird names in Species Accounts}

Anhinga, 126

Ani, Groove-billed, 61

Avocet, American, 77

Bittern

American, 128

Least, 129

Blackbird

Brewer's, 271

Red-winged, 268

Rusty, 270

Yellow-headed, 261

Bluebird

Eastern, 215

Mountain, 216

Bobolink, 262

Bobwhite, Northern, 48

Brant, 24

Bunting

Indigo, 308

Lark, 248

Lazuli, 308

Painted, 309

Snow, 240

Canvasback, 37

Caracara, Crested, 169

Cardinal, Northern, 304

Catbird, Gray, 222

Chat, Yellow-breasted, 260

Chickadee

Black-capped, 204

Carolina, 203

Chuck-will's-widow, 63

Collared-Dove, Eurasian, 56

Coot, American, 73

Cormorant

Double-crested, 125

Neotropic, 125

Cowbird

Bronzed, 269

Brown-headed, 269

Crane

Sandhill, 74

Whooping, 75
Creeper, Brown, 207

Crossbill

Red, 233

White-winged, 235

Crow

American, 195

Fish, 196

Cuckoo

Black-billed, 60

Yellow-billed, 59

Curlew

Eskimo, 84

Long-billed, 84

Dickcissel, 310

Dove

Inca, 57

Mourning, 58

White-winged, 58

Dowitcher

Long-billed, 96

Short-billed, 95

Duck

American Black, 34

Harlequin, 40

Long-tailed, 42

Mottled, 35

Ring-necked, 38

Ruddy, 47

Wood, 29

Dunlin, 89

Eagle

Bald, 144

Golden, 155

Egret

Cattle, 133

Great, 130

Reddish, 133

Snowy, 131

Falcon

Peregrine, 172

Prairie, 173 
Finch

House, 230

Purple, 231

Flamingo, American, 52

Flicker, Northern, 167

Flycatcher

Acadian, 177

Alder, 177

Fork-tailed, 186

Great Crested, 181

Least, 178

Olive-sided, 175

Scissor-tailed, 184

Vermilion, 180

Willow, 178

Yellow-bellied, 176

Frigatebird, Magnificent, 124

Gadwall, 32

Gallinule

Common, 73

Purple, 72

Garganey, 29

Gnatcatcher, Blue-gray, 213

Godwit

Hudsonian, 84

Marbled, 85

Goldeneye

Barrow's, 44

Common, 43

Goldfinch

American, 237

Lesser, 236

Goshawk, Northern, 148

Goose

Barnacle, 25

Canada, 26

Cackling, 25

Greater White-fronted, 23

Ross's, 23

Snow, 22

Grackle

Common, 271

Great-tailed, 272

Grebe

Clark's, 55

Eared, 54
Horned, 53

Pied-billed, 52

Red-necked, 53

Western, 55

Grosbeak

Black-headed, 306

Blue, 307

Evening, 229

Pine, 230

Rose-breasted, 305

Ground-Dove, Common, 57

Grouse, Ruffed, 49

Gull

Black-headed, 107

Bonaparte's, 106

California, 111

Franklin's, 109

Glaucous, 116

Glaucous-winged, 115

Great Black-backed, 116

Herring, 112

Iceland, 113

Ivory, 106

Laughing, 108

Lesser Black-backed, 114

Little, 107

Mew, 110

Ring-billed, 110

Ross's, 108

Sabine's, 106

Slaty-backed, 115

Gyrfalcon, 171

Harrier, Northern, 145

Hawk

Broad-winged, 150

Cooper's, 147

Ferruginous, 155

Harris's, 148

Red-tailed, 152

Red-shouldered, 149

Rough-legged, 154

Sharp-shinned, 146

Swainson's, 151

Heron

Great Blue, 129

Green, 134 
Little Blue, 131

Tricolored, 132

Hummingbird

Allen's, 68

Anna's, 66

Black-chinned, 66

Broad-tailed, 67

Calliope, 68

Ruby-throated, 65

Rufous, 68

Ibis

Glossy, 137

White, 136

White-faced, 138

Jaeger

Long-tailed, 105

Parasitic, 104

Pomarine, 103

Jay

Blue, 193

Gray, 193

Junco, Dark-eyed, 259

Kestrel, American, 169

Killdeer, 81

Kingbird

Eastern, 183

Gray, 184

Tropical, 182

Western, 182

Kingfisher, Belted, 161

Kinglet

Golden-crowned, 214

Ruby-crowned, 214

Kite

Mississippi, 143

Swallow-tailed, 142

White-tailed, 143

Kittiwake, Black-legged, 105

Knot, Red, 86

Lark, Horned, 198

Longspur

Chestnut-collared, 238

Lapland, 238

McCown's, 239

Smith's, 239
Loon

Common, 122

Pacific, 121

Red-throated, 121

Yellow-billed, 123

Magpie, Black-billed, 195

Mallad, 34

Martin, Purple, 198

Meadowlark

Eastern, 263

Western, 264

Merganser

Common, 46

Hooded, 45

Red-breasted, 46

Merlin, 171

Mockingbird, Northern, 223

Nighthawk, Common, 61

Night-Heron

Black-crowned, 135

Yellow-crowned, 136

Nutcracker, Clark's, 194

Nuthatch

Brown-headed, 206

Red-breasted, 205

White-breasted, 206

Oriole

Baltimore, 267

Bullock's, 267

Hooded, 266

Orchard, 266

Osprey, 141

Ovenbird, 273

Owl

Barn, 156

Barred, 158

Burrowing, 158

Eastern Screech-, 156

Great Horned, 157

Long-eared, 158

Northern Saw-whet, 160

Short-eared, 159

Snowy, 157

Parakeet, Carolina, 174

Parula, Northern, 289 
Pelican

American White, 127

Brown, 128

Phalarope

Wilson's, 101

Red, 103

Red-necked, 102

Pheasant, Ring-necked, 48

Phoebe

Eastern, 179

Say's, 180

Pigeon

Band-tailed, 56

Passenger, 56

Rock, 56

Pintail, Northern, 35

Pipit

American, 227

Sprague's, 228

Plover

American Golden-, 79

Black-bellied, 78

Mountain, 82

Piping, 81

Semipalmated, 80

Snowy, 79

Wilson's, 80

Poorwill, Common, 62

Prairie-Chicken

Greater, 49

Lesser, 50

Rail

Black, 69

King, 70

Yellow, 69

Virginia, 70

Raven, Common, 197

Redhead, 37

Redpoll

Common, 232

Hoary, 233

Redstart, American, 287

Roadrunner, Greater, 60

Robin, American, 221

Rosy-Finch, Black, 230

Ruff, 87
Sanderling, 89

Sandpiper

Baird's, 90

Buff-breasted, 92

Curlew, 88

Least, 91

Pectoral, 94

Semipalmated, 94

Sharp-tailed, 87

Solitary, 99

Spotted, 98

Stilt, 88

Upland, 82

Western, 95

White-rumped, 92

Sapsucker, Yellow-bellied, 163

Scaup

Greater, 39

Lesser, 39

Scoter

Black, 41

Surf, 40

White-winged, 41

Shoveler, Northern, 31

Shrike

Loggerhead, 186

Northern, 188

Siskin, Pine, 236

Skimmer, Black, 120

Smew, 45

Snipe, Wilson's, 97

Solitaire, Townsend's, 216

Sora, 71

Sparrow

American Tree, 243

Bachman's, 242

Baird's, 251

Black-throated, 248

Cassin's, 242

Chipping, 244

Clay-colored, 245

Eurasian Tree, 227

Field, 245

Fox, 253

Golden-crowned, 259

Grasshopper, 250 
Harris's, 257

Henslow's, 251

House, 226

Lark, 247

LeConte's, 252

Lincoln's, 254

Nelson's, 252

Savannah, 249

Song, 254

Swamp, 255

Vesper, 246

White-crowned, 258

White-throated, 256

Spoonbill, Roseate, 139

Starling, European, 224

Stilt, Black-necked, 77

Stint, Red-necked/Little, 88

Stork, Wood, 123

Storm-Petrel, Band-rumped, 123

Swallow

Bank, 201

Barn, 203

Cave, 202

Cliff, 202

Northern Rough-winged, 200

Tree, 199

Violet-green, 200

Swan

Mute, 27

Trumpeter, 27

Tundra, 28

Swift

Chimney, 64

White-throated, 65

Tanager

Scarlet, 303

Summer, 302

Western, 304

Teal

Blue-winged, 30

Cinnamon, 30

Green-winged, 36

Tern

Black, 118

Caspian, 117

Common, 119
Forster's, 119

Least, 117

Sooty, 117

Thrasher

Brown, 223

Sage, 223

Thrush

Gray-cheeked, 218

Hermit, 219

Swainson's, 218

Varied, 221

Wood, 220

Titmouse, Tufted, 205

Towhee

Eastern, 241

Green-tailed, 240

Spotted, 241

Turkey, Wild, 51

Turnstone, Ruddy, 86

Veery, 217

Violetear, Mexican, 65

Vireo

Bell's, 189

Blue-headed, 191

Philadelphia, 191

Red-eyed, 192

Warbling, 192

White-eyed, 189

Yellow-throated, 190

Vulture

Black, 139

Turkey, 140

Warbler

Bachman's, 276

Bay-breasted, 291

Blackburnian, 291

Blackpoll, 293

Black-and-white, 278

Black-throated Blue, 294

Black-throated Green, 300

Blue-winged, 277

Canada, 301

Cape May, 288

Cerulean, 288

Chestnut-sided, 292

Connecticut, 283 
Golden-cheeked, 300

Golden-winged, 277

Hermit, 300

Hooded, 286

Kentucky, 284

Kirtland's, 287

MacGillivray's, 284

Magnolia, 290

Mourning, 284

Nashville, 282

Orange-crowned, 281

Palm, 295

Pine, 295

Prairie, 298

Prothonotary, 279

Swainson's, 280

Tennessee, 281

Townsend's, 299

Wilson's, 302

Worm-eating, 274

Yellow, 292

Yellow-rumped, 297

Yellow-throated, 298

Waterthrush

Louisiana, 275

Northern, 275

Waxwing

Bohemian, 225

Cedar, 225

Whimbrel, 83

Whip-poor-will, Eastern, 63

Whistling-Duck

Black-bellied, 21

Fulvous, 21
Wigeon

American, 33

Eurasian, 32

Willet, 100

Woodcock, American, 97

Woodpecker

Black-backed, 167

Downy, 166

Hairy, 166

Ivory-billed, 169

Lewis's, 162

Pileated, 168

Red-bellied, 163

Red-cockaded, 167

Red-headed, 162

Wood-Pewee

Eastern, 176

Western, 175

Wren

Bewick's, 212

Carolina, 212

House, 208

Marsh, 211

Rock, 208

Sedge, 210

Winter, 209

Yellowlegs

Greater, 101

Lesser, 99

Yellowthroat, Common, 285 


\section{About the author}

The author started birdwatching at thirteen and subsequently spent an inordinate amount of time at Loess Bluffs National Wildlife Refuge. While an undergraduate at the University of Arizona, he got his first taste of the Neotropics with forays into Mexico. Graduate work at Louisiana State University sent him even deeper into the Neotropics. He was ornithology collection manager at the Academy of Natural Sciences, Philadelphia for eleven years before filling the same position at the University of Kansas Biodiversity Institute, where he has been for twentyfive years. He has led or co-led over 50 expeditions to foreign countries documenting avian diversity. Nearly 11,000 of his audio recordings are deposited at the Macaulay Library, Cornell Laboratory of Ornithology. 